UNIVERSIDADE DE SÃO PAULO

FACULDADE DE FILOSOFIA, LETRAS E CIÊNCIAS HUMANAS DEPARTAMENTO DE HISTÓRIA PROGRAMA DE PÓS-GRADUAÇÃO EM HISTÓRIA SOCIAL

ROGÉRIO RICCILUCA MATIELLO FÉLIX

OS MÓVEIS DA TERRA

Dinâmicas sociais a partir da produção e circulação do mobiliário em São Paulo (1700-1830)

VERSÃO CORRIGIDA

São Paulo 


\author{
UNIVERSIDADE DE SÃO PAULO \\ FACULDADE DE FILOSOFIA, LETRAS E CIÊNCIAS HUMANAS \\ DEPARTAMENTO DE HISTÓRIA \\ PROGRAMA DE PÓS-GRADUAÇÃO EM HISTÓRIA SOCIAL
}

\title{
OS MÓVEIS DA TERRA \\ Dinâmicas sociais a partir da produção e circulação do mobiliário em São \\ Paulo (1700-1830)
}

Rogério Ricciluca Matiello Félix

Dissertação apresentada ao Programa de Pós-Graduação em História Social da Faculdade de Filosofia, Letras e Ciências Humanas da Universidade de São Paulo, para a obtenção do título de Mestre.

Orientadora: Prof..‥ Dr. ${ }^{\mathrm{a}}$ Maria Aparecida de Menezes Borrego

VERSÃO CORRIGIDA

SÃO PAULO 
Autorizo a reprodução e divulgação total ou parcial deste trabalho, por qualquer meio convencional ou eletrônico, para fins de estudo e pesquisa, desde que citada a fonte.

Catalogação na Publicação

Serviço de Biblioteca e Documentação

Faculdade de Filosofia, Letras e Ciências Humanas da Universidade de São Paulo

Félix, Rogério Ricciluca Matiello

OS MÓVEIS DA TERRA Dinâmicas sociais a partir da produção e circulação do mobiliário em São Paulo (17001830) / Rogério Ricciluca Matiello Félix ; orientadora Maria Aparecida de Menezes Borrego. São Paulo, 2018 .

$313 \mathrm{f}$.

Dissertação (Mestrado) - Faculdade de Filosofia, Letras e Ciências Humanas da Universidade de São Paulo. Departamento de História. Área de concentração: História Social.

1. São Paulo. 2. Cultura Material. 3. Mobiliário. 4. Artífices. 5. Consumo. I. Borrego, Maria Aparecida de Menezes, orient. II. Título. 
Nome: FÉLIX, Rogério Ricciluca Matiello.

Título: "Os móveis da terra: Dinâmicas sociais a partir da produção e circulação do mobiliário em São Paulo (1700-1830)"

Dissertação apresentada ao Programa de Pós-Graduação em História Social da Faculdade de Filosofia, Letras e Ciências Humanas da Universidade de São Paulo, para a obtenção do título de Mestre.

Aprovado em:

\section{BANCA EXAMINADORA}

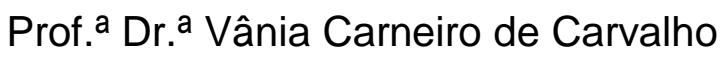
Julgamento:

Prof. . Dr. . Angela Brandão

Julgamento:

Dr. Paulo Eduardo Zanettini

Julgamento:

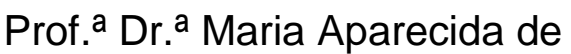
Menezes Borrego (presidente)

Julgamento:
Instituição: Museu Paulista-USP

Assinatura:

Instituição: UNIFESP

Assinatura:

Instituição: Zanettini Arqueologia Assinatura:

Instituição: Museu Paulista-USP

Assinatura: 
A todos nós que somos carpinteiros do Universo. 
Agradecimentos

Sou grato a todas as pessoas que contribuíram nesta jornada de pesquisa. $E$ muito emocionado escrevo, agradecendo e dedicando este trabalho à numerosa famiglia.

Agradeço e dedico este trabalho ao meus queridos pais, Edson e Conceição pelo seu sacrifício, sustento, compreensão e amor.

Sem nomear meus parentes até o Ötzi, agradeço e dedico este meu trabalho a meus irmãos Rodrigo e Carol, Marcella e Leandro, a Roberta e Piero, ao Toninho e ao Antoninho, Angelo, Tide e Penha, Wania e Daniela, André e Lígia, Marinho e Márcio, meu padrinho Tiago e todos os meus outros familiares espalhados pelo Brasil, distantes no espaço, mas perto nos sentimentos.

Igualmente faço homenagem aos meus antepassados, alguns dos quais foram carpinteiros em Socorro, Itapira e Águas de Lindóia. Dedico igualmente este trabalho os meus saudosos avós, Antônio, Cida, Waldemar e, de modo afetuoso à minha Avó Amélia; pois se hoje escrevo este trabalho letrado, deve-se e muito ao grande sacrifício desta, que pouco sabia ler. E que este trabalho também sirva para muitos aprenderem!

Agradeço especialmente a Prof. ${ }^{\text {a }}$ Dr. ${ }^{\text {a }}$ Maria Aparecida de Menezes Borrego, mais do que orientadora é uma verdadeira amiga. Pela sua vasta erudição, simpatia e generosidade desde a minha graduação. Desdobrando-se este mestrado das suas pesquisas anteriores de Pós-Doutorado, nas quais tomamos parte em nossa iniciação científica, somos sempre gratos pela generosidade no aceite e incentivo ao alargamento do estudo. Buscamos assim fazer jus a esta tarefa como quem recebe talentos e não os guarda, mas os multiplica com honra.

Ao Me. Daniel Polleti, colega com quem partilhamos a orientação na iniciação científica, de quem recebemos generoso apoio e de cuja pesquisa e penosas transcrições também partimos neste alargamento da temática.

A Me. Fabiola Zambrano pela sua amizade e solicitude em nos auxiliar e estimular nos exames de dendrologia dos móveis, trabalho que já rende bons frutos.

A Prof. ㅁ Dr. a Márcia Rizzutto - bem como seus orientandos do LAMFI-IF - pela sua solicitude, apoio e generosidade em realizar os exames arqueométricos nos 
móveis, que já renderam excelentes resultados e tem ainda muitos dados intrigantes a serem avaliados em futuros projetos.

A Prof. ${ }^{a}$. Dr. ${ }^{a}$ Vânia Carneiro de Carvalho e a Prof. ${ }^{a}$ Dr. ${ }^{a}$ Angela Brandão pelas excelentes dicas e referências em nossa banca de qualificação, bem como aos Drs. Paulo Eduardo Zanettini, Jaelson Bitran Trindade e Eudes Campos que nos passaram importantes informações no decurso do mestrado. Seus trabalhos são de grande inspiração para nossas pesquisas, as quais buscaremos sempre ampliar.

Também agradeço muitíssimo ao Prof. Dr. Luis Frederico Dias Antunes que nos recebeu em Lisboa durante o breve, mas intenso, mês de pesquisa em museus e arquivos. Pelas excelentes referências, livros e ensinamentos que nos passou, pelo contato com os mestres da FRESS, bem como pelos maravilhosos almoços da típica culinária portuguesa e suas saborosas histórias.

À Sra. Margarida Serra e à Dr. ․ Conceição Amaral da Fundação Ricardo Espírito Santo de Lisboa que nos receberam nesta maravilhosa instituição e permitiram visitar as preciosas oficinas de mobiliário. Serei sempre grato aos mestres artesãos desta fundação, em especial aos mestres Arthur de Souza, David Cruz e Miguel Alonso Duarte e Beatriz Canha, com quem muito aprendi, apesar da brevidade das visitas e a cujo exímio trabalho procuramos fazer jus nessas breves páginas.

Agradecemos também a todos os arquivistas, guias e amigos e amigas pesquisadores que nos ajudaram nas várias instituições nas quais pesquisamos, no Brasil e em Portugal, recordando especialmente as Me. Rafaela Basso e Angélica Brito pelas excelentes dicas sobre documentação e também de modo muito carinhoso a querida arqueóloga Juliana Freitas, não só pelas conversas "fora da estratosfera" sobre cultura material, mas também pelas lições de vida e história e pela esperança de ver em sua trajetória concretizando-se o Brasil que queremos para o futuro.

A todos os funcionários do Museu Paulista, entre eles ao Dr. Adilson José de Almeida, Vagner Gusmão, Maria da Glória dos Santos, Tatiana de Oliveira e a Dr. ạ Yara Petrella pelo apoio durante as oportunidades de consulta ao acervo. De modo especial ao Sr. José Rosael, que fez as belíssimas fotografias em Ultra-Violeta para nossa pesquisa. 
Ao Sr. Jair Mongeli do Arquivo da Cúria Metropolitana de São Paulo, pelas preciosas dicas, auxílios durante a pesquisa e as boas conversas com o gentil cafezinho.

Às Sras. Tomico e Vera do Arquivo Histórico Municipal, que deram preciosas dicas durante a longa pesquisa.

Ao Dr. Marcelo Chaves do Arquivo Público do Estado de São Paulo, pelas preciosas dicas sobre o gigantesco acervo.

À direção e às funcionárias do Centro de Apoio à Pesquisa em História Sérgio Buarque de Holanda e ao Me. José Francisco Guelfi Campos, com quem muito aprendi sobre História e Arquivologia, dando-me não só maravilhosas oportunidades de estágios, mas também ótimos conselhos antes de ser aprovado no mestrado.

Também agradeço a todos os professores com que tive aula desde a mais tenra idade, me inspirando no gosto e dedicação à História e à educação. Em especial ao muito caro Paulo Marcos da Silva.

Agradeço ainda, de modo especial, a Sofia e Marta Moreiras, que me hospedaram durante a passagem em Lisboa, pela afetuosa acolhida, as excelentes refeições à gran chef, as boas dicas de filmes e passeios, as lições de vida, pelas boas risadas e as peripécias com as gatas.

Ao André, a Márcia e seus funcionários da Copiadora L\&M, que imprimiram esta dissertação, sempre me atendendo gentilmente e dentro dos prazos de entrega.

À CAPES/CNPq, pela concessão da bolsa de mestrado e pelo apoio financeiro para a realização desta pesquisa, dinheiro que buscamos honrar e fazer gerar frutos, mostrando a importância do ensino, pesquisa e tecnologia para o desenvolvimento do Brasil.

Por fim agradeço também aos meus leitores e que lhes possa ser prazerosa, proveitosa e enriquecedora a leitura. Sendo agora "obra aberta", estejam sempre convidados a fazer correções, adições e sugestões. 
GAZETILHA

Dos LLOYD GEORGES da Babilônia

Não reza a história nada.

Dos Briands da Assíria ou do Egito,

Dos Trotskys de qualquer colônia

Grega ou romana já passada,

O nome é morto, inda que escrito.

Só o parvo dum poeta, ou um louco

Que fazia filosofia,

Ou um geômetra maduro,

Sobrevive a esse tanto pouco

Que está lá para trás no escuro

E nem a história já historia.

Ó grandes homens do Momento!

Ó grandes glórias a ferver

De quem a obscuridade foge!

Aproveitem sem pensamento!

Tratem da fama e do comer,

Que amanhã é dos loucos de hoje!

Álvaro de Campos. Publicado em Presença, n.ำ 18, janeiro de 1929. 


\section{RESUMO}

FÉLIX, R. R. M. Os móveis da terra: dinâmicas sociais a partir da produção e circulação do mobiliário em São Paulo (1700-1830). 2018. 306f. Dissertação (mestrado) - FFLCH-USP, São Paulo. 2018.

O objetivo geral da dissertação é compreender a vida social na cidade de São Paulo ao longo do século XVIIII e inícios do XIX em suas dinâmicas históricas, tomando as fontes de cultura material como disparadoras das problematizações, especificamente o mobiliário doméstico. Para tanto usamos exames formais e da Arqueometria balizando suas potencialidades com outras categorias de documentos. Considerando o mobiliário como produto e vetor de relações sociais, buscamos informações sobre a sua produção, consumo e circulação, de maneira a compreender o status social de seus artífices, o perfil dos consumidores e as transformações dos espaços domésticos, das sociabilidades e das formas de distinção pelo uso social dos objetos. Desta maneira agregamos informações multidisciplinares à historiografia no esforço de reavaliar visões consolidadas sobre a cidade.

Palavras-chave: São Paulo. Cultura material. Mobiliário. Artífices. Consumo.

\section{ABSTRACT}

FÉLIX, R. R. M. Os móveis da terra: social dynamics by the production and circulation of furniture in São Paulo (1700-1830). 2018. 306f. Dissertation (Master) Faculdade de Filosofia, Letras e Ciências Humanas, Universidade de São Paulo, São Paulo. 2018.

The general objective of this dissertation is to understand the social life in the city of São Paulo through the $18^{\text {th }}$ and the beginnings of the $19^{\text {th }}$ centuries by its historical dynamics, using the material culture resources as the trigger of the problematizations, more specifically the domestic furniture. Therefore we used formal examination and the Archaeometry balancing its potentialities together with other categories of sources. Considering the furniture as products and vectors of social relations, we searched for information about its production, consuming and 
circulation, comprehending the social status of the artisans, the consumer profiles and the transformation of the domestic environments, of the sociabilities and the distinction by the social use of the objects. In this way we added multidisciplinary information to the historiography in our effort to reevaluate consolidated visions about the city.

Keywords: São Paulo. Material culture. Furniture. Artisans. Consumption. 


\section{SUMÁRIO}

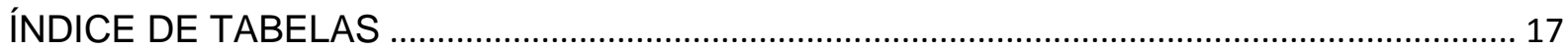

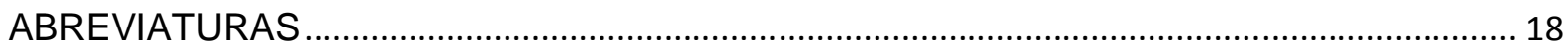

INTRODUÇÃO - Peças em um museu ...................................................................................... 19

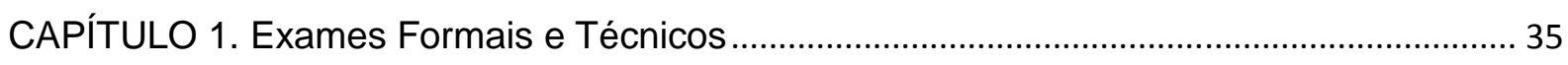

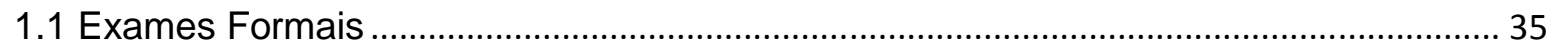

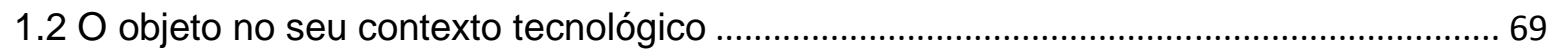

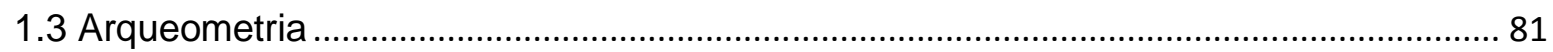

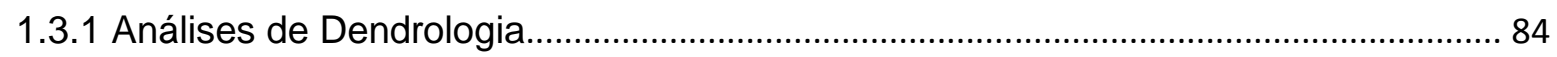

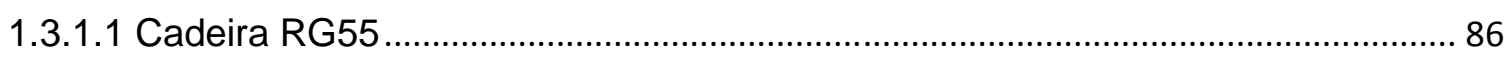

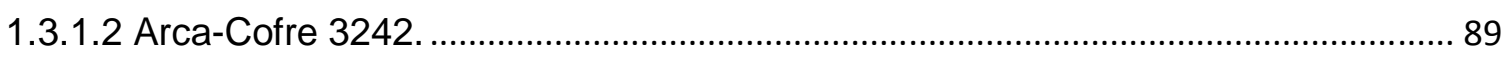

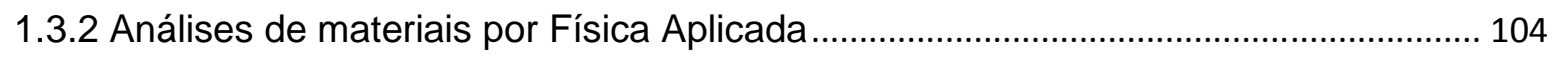

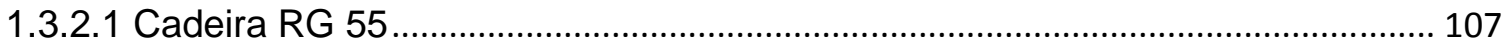

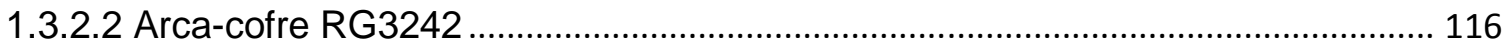

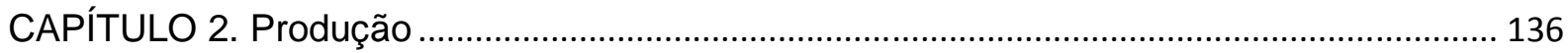

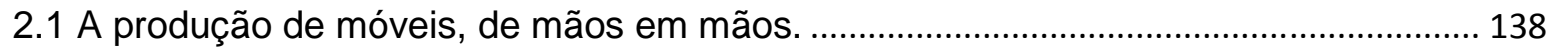

2.2 Remendões e Oficiais: a produção de mobiliário compreendida de maneira ampla.. 161

2.3 Fim dos códigos e continuidade das práticas. ................................................................. 186

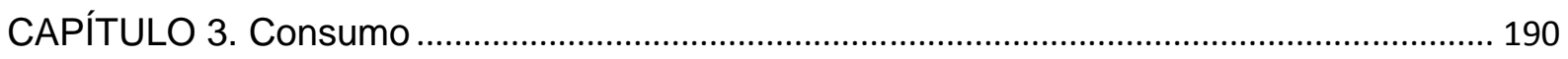

3.1 Formas de aquisição e circulação do mobiliário............................................................ 190

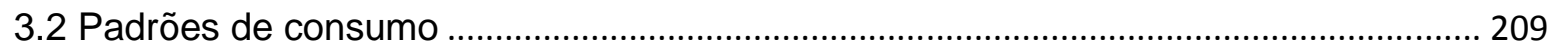

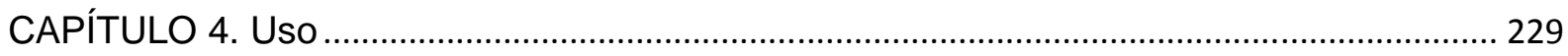

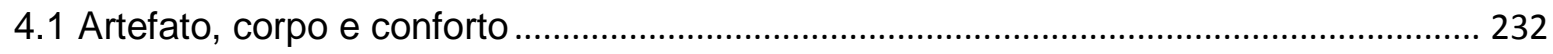

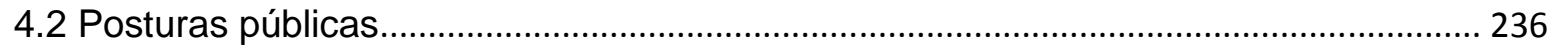

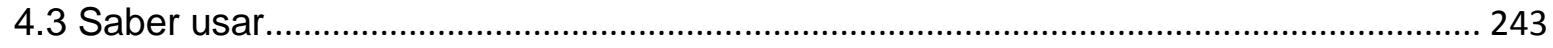

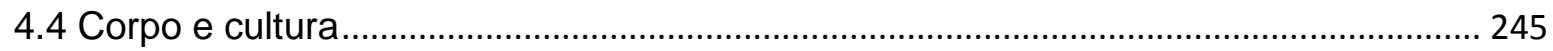

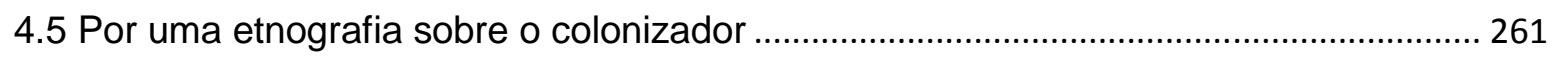

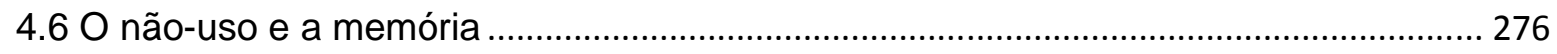

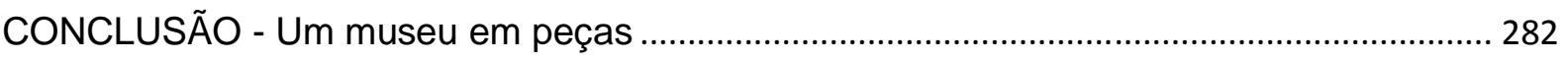

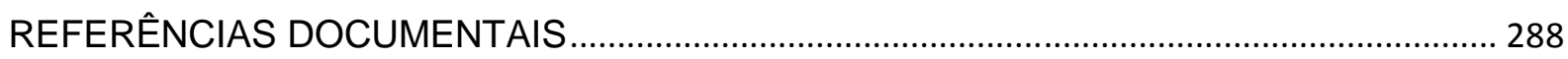

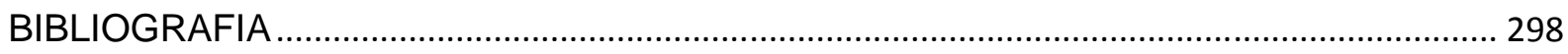




\section{ÍNDICE DE FIGURAS}

FIGURA 1: ÉdiPO E A ESFINGE. KYLIX, C. 470 A.C. MuSEU do VATICANO .......................... 19

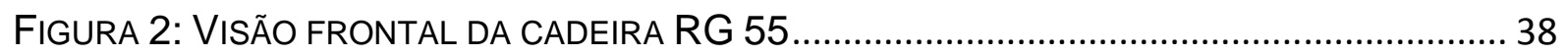

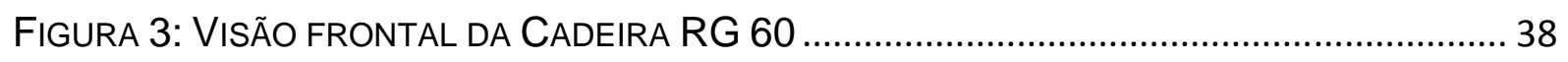

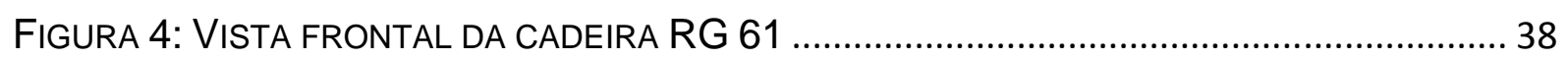

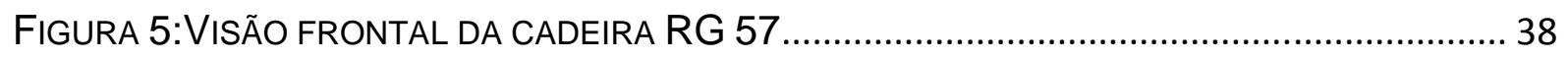

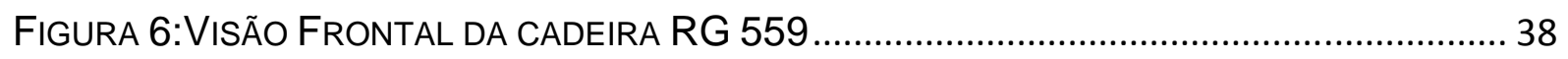

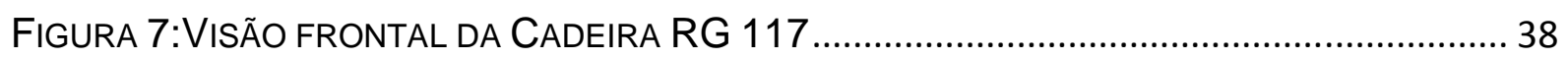

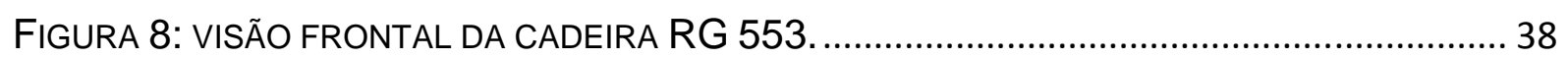

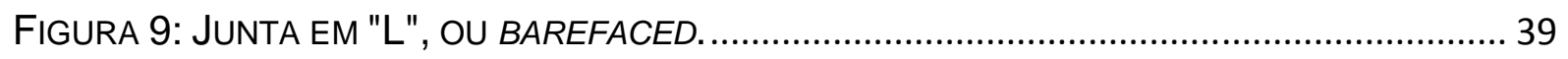

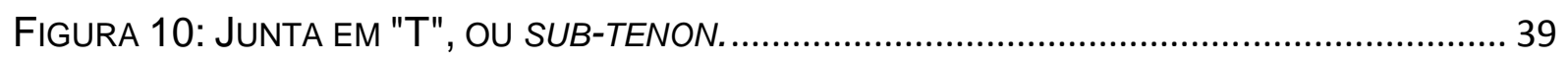

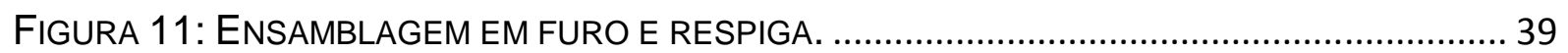

Figura 12: Cadeira de Sola. RG 61. Acervo Museu Paulista. Foto do AUtOR.......... 41

FIGURA 13: A) COM O COURO AINDA ÚMIDO O DESENHO, ELABORADO EM PAPEL FINO, É

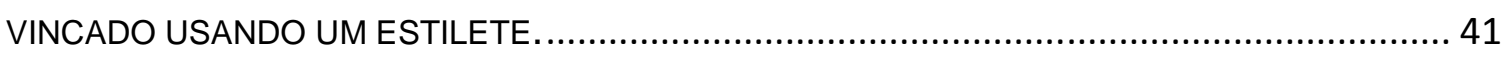

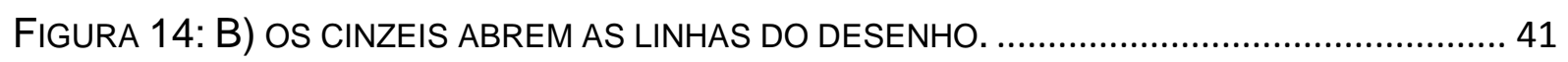

FIGURA 15: C) O REBAIXADOR INCLINADO E OS CALCADORES DÃO ÊNFASE AO MOTIVO. ..... 42

FIGURA 16: D) UM FERRO “FOSCO” DÁ TEXTURA AO FUNDO ATRAVÉS DE PUNÇÕES QUE GRANULAM O COURO, JUNTO COM ARREMATE POR CINZÉIS E MODELADORES. ............... 42

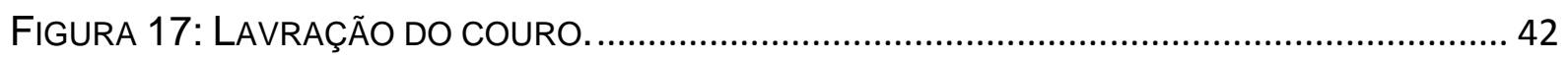

FIGURA 18: A MESTRA BEATRIZ LEITÃO CANHA MOSTRA ALGUNS DOS FERROS DE LAVRAR

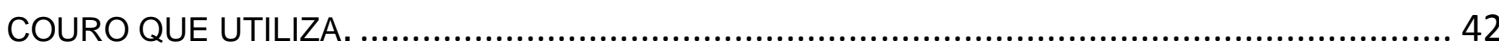

FIGURA 19: MESTRE ARTHUR DE SOUZA REALIZANDO A CINZELAGEM. FOTOGRAFIA DO

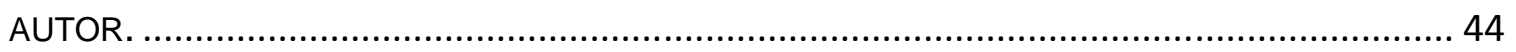

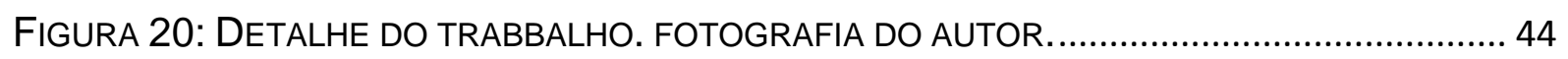

FIGURA 21: LATERAL DA CADEIRA DE SOLA RG 55, ONDE SE PODE VER OS PREGOS DE

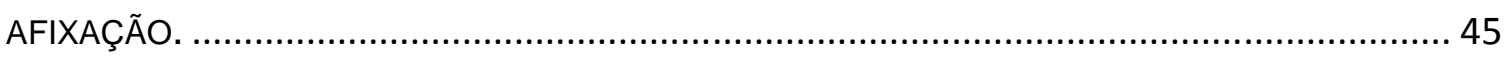

FIGURA 22: PREGOS ANTIGOS E IRREGULARES. FIGURA 23: PREGOS MODERNOS.................. 46

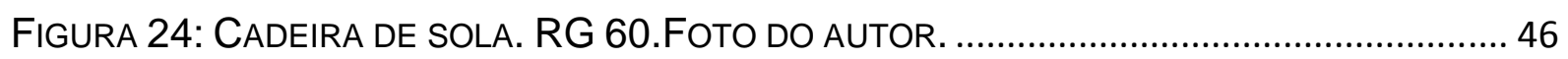

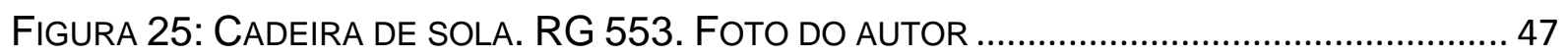

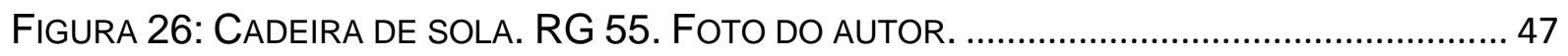

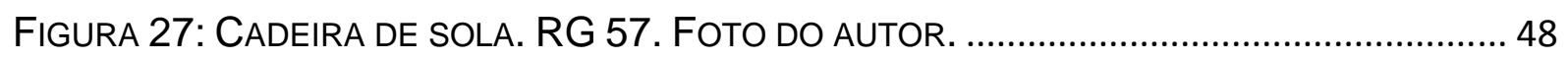

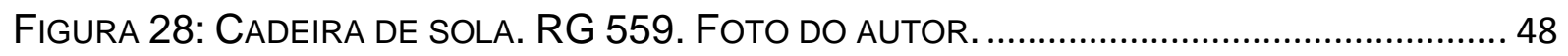

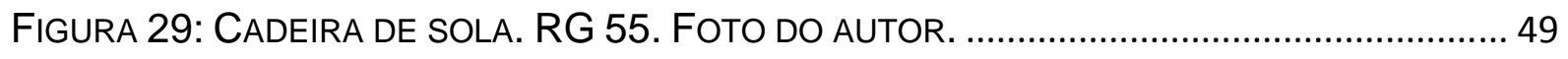

FIGURA 30: ENXÓ. S.D. MUSEU DA CIDADE DE SÃo PAULO. EXIBIDA DURANTE A EXPOSIÇÃO

"A MÃo dO POVO BRASILEIRO" (2016-2017) NO MASP. FOTOGRAFIA DO AUTOR. ..... 49

FIGURA 31: CADEIRA DE SOLA. RG 117. FOTO DO AUTOR................................................. 50

Figura 32 CadeIRA de SOLA. RG 117. DETALHE do ÍMÃ SOBRE A PREGARIA. Foto dO AUTOR ..... 
Figura 33: CADEIRA DE SOLA. RG 117. DetALHE do ÍMÃ NA LATERAL DA PREGARIA, SEM

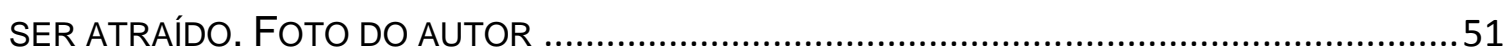

FIGURA 34: CHAPA DE METAL SENDO MOLDADA PELAS MARTELADAS.................................51

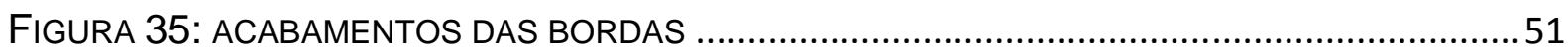

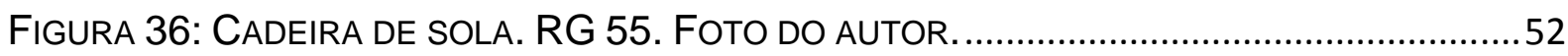

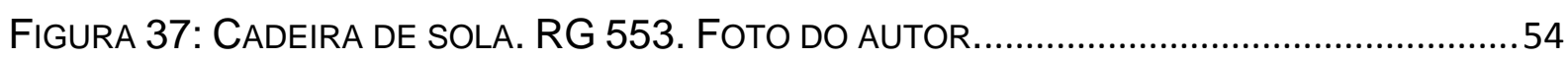

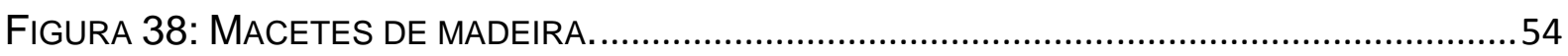

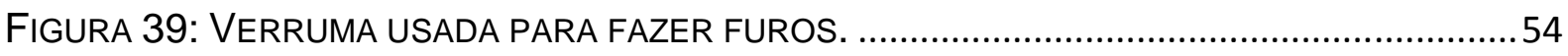

FIGURA 40: FERRAMENTAS DE EBANISTA E MARCENEIRO ESQUEMATIZADAS NA

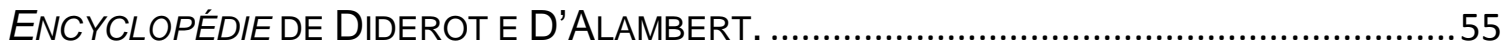

Figura 41: Plainas SÉc. XIX Coleção Emanoel Araújo. Fotografada duRANTE a EXPOSIÇÃO “A MÃO dO POVO BRASILEIRO” (2016-2017) NO MASP ...........................56

FIGURA 42: EXEMPLOS DE BOXEQUIM OU SPOKESHAVES, ONDE PODEMOS NOTAR A VARIEDADE DE FORMAS DE APOIOS PARA AS MÃOS VARIANDO CONFORME O SEU EMPREGO. 57

FIGURA 43: EXEMPLO DO USO CONTEMPORÂNEO DO BOXEQUIM. .........................................57

FIGURA 44: ILUSTRAÇÃO DA ENCYCLOPĖDIE DE DIDEROT E D'ALEMBERT REPRESENTANDO O

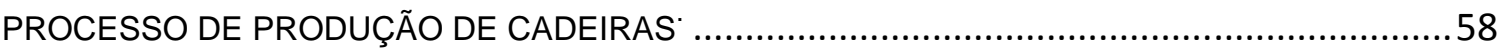

FIGURA 45: ESQUEMA DA PRODUÇÃO DE UMA CADEIRA EM ROCALHA NA .............................59

FIGURA 46: EXEMPLO DE PERNAS DE MESA ESTILO D. JOSÉ SENDO REPRODUZIDA NA OFICINA

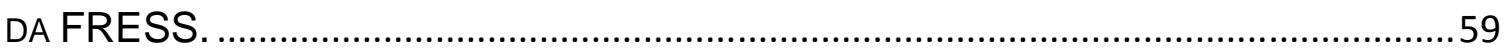

FIGURA 47: PONTA DE GOIVA NA OFICINA DA FRESS. FOTOGRAFIA DO AUTOR..................60 FIGURA 48 EXEMPLAR DE ORNATO ESTILO D. JOSÉ I SERVINDO DE RASCUNHO PARA OS

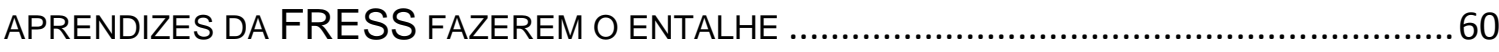

Figura 49: observa-SE NO detalhe como o Mestre Miguel Alonso Duarte sinalizou

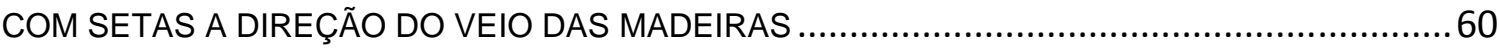

FIGURA 50: CADEIRA DE SOLA. RG 559. FOTO DO AUTOR.................................................61

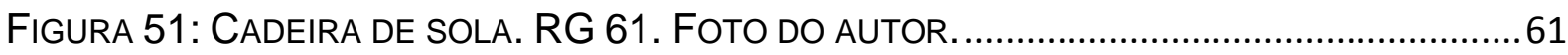

FIGURA 52: DEBRET, JEAN-BAPTISTE. NEGROS SERRADORES DE TÁBUAS. ......................62

FIGURA 53 SERRAÇÃO BRAÇAL NA REGIÃO dE MAFRA, AGUEIRA C. 1930 ...........................62

Figura 54 AbATE dE UMA ÁRVORE NA REGIÃo do PoRTO, C. 1930. PROCESSO dE CORTE

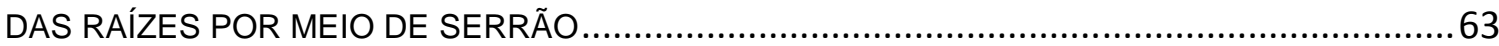

Figura 55 SERRÕES. S.D. ColeçÃo EMANOEl ARAúJo. Fotografada duRANTE A EXPOSIÇÃO “A MÃO DO POVO BRASILEIRO” (2016-2017) NO MASP 63

Figura 56 SerRote de ArmaçÃo ou de SÃo José. S.d. ColeÇão Museu CASA do ANHANGUERA EM SANTANA DE PARNAÍBA. FOTOGRAFADA DURANTE A EXPOSIÇÃO PERMANENTE.

FIGURA 57: VISÃO FRONTAL DA CADEIRA EM ROCALHA RG 469 ........................................64

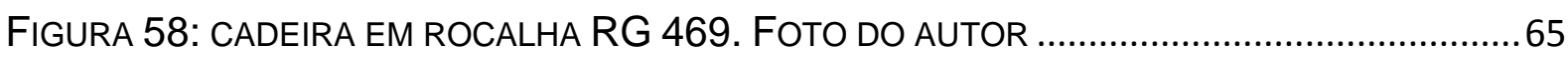

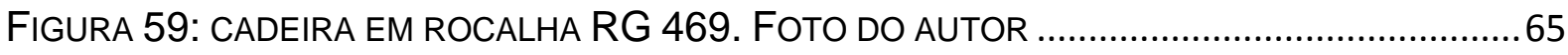

FIGURA 60: MESA DE JOGO DA FRESS FOTO DO AUTOR. ...............................................66

FIGURA 61: MESA DE JOGO DA FRESS. FOTO DO AUTOR.................................................66 
FIGURA 62: MESA DE JOGO DA FRESS E ENTREPANO A SER USADO NA REPRODUÇÃP. FOTO DO AUTOR.

FIGURA 63: PARTE LATERAL DE REPRODUÇÃO DE MESA DE JOGO DO SÉCULO XVIII SENDO

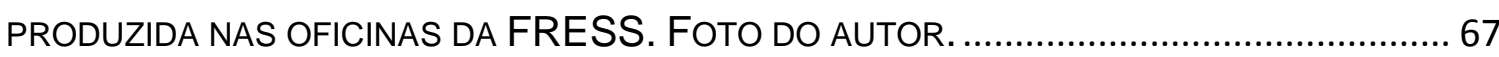

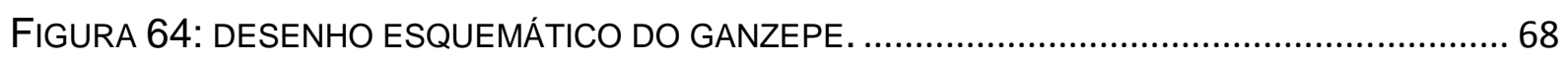

FIGURA 65: LATERAL DA GAVETA DA PEÇA ORIGINAL COM UMA REPRODUÇÃO DE ENCAIXES EM RABO DE ANDORINHA. 68

FIGURA 66: VISTA INTERNA DA MESA DE JOGO, ONDE SE OBSERVA A GUIA PARA A GAVETA INSERIDA A POSTERIORI. FOTO DO AUTOR. 68

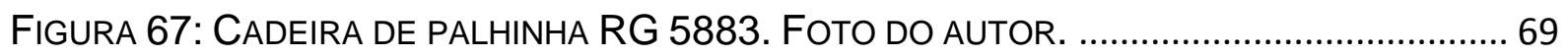

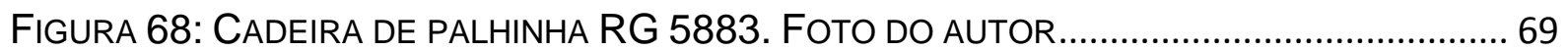

FIGURA 69: FOTOGRAFIA DOS MACHADOS FABRICADOS PARA O EXPERIMENTO, POSSUINDO O MENOR (№3) 8X5 CM E PESO DE 240 GRAMAS, O INTERMEDIÁRIO 10X7 CM, COM GROSSURA DE 3,5 CM E PESO DE 500 GRAMAS, E O MAIOR CERCA DE 30 CM DE COMPRIMENTO.

FIGURA 70: DETALHES DAS ÁRVORES DERRUBADAS POR IHERING. A FOTO INFERIOR É UMA

TIUNA, MADEIRA DE LEI, COM 30 CM DE DIÂMETRO, CORTADA EM 4 HORAS, CONTRA MEIA HORA COM MACHADO DE AÇO E 9 MINUTOS COM SERRA BRAÇAL DE DUPLA. A FIGURA

SUPERIOR É UMA CANELA DE 12 CENTÍMETROS DE DIÂMETRO. 73

FIGURA 71: DESENHO ESQUEMÁTICO DE CADEIRAS (DETALHE). A. DMERSAY E F. SORRIEU.

ARQUIVO HISTÓRICO DO ITAMARATY. 75

FIGURA 72: PROJETO DE ENGENHO DE CORTE DE MADEIRA DE IGNÁCIO DE VASCONCELOS 76 FIGURA 73: FORNO DE TIPO CATALÃO NAS OFICINAS DA FRESS. FOTO DO AUTOR............. 78

FIGURA 74: EXEMPLO DE LUPA "CONTA FIO" COM AUMENTO DE 10X .................................... 85

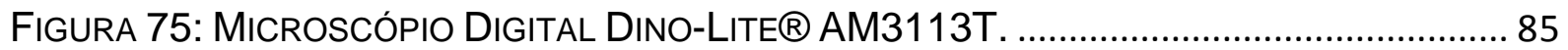

FIGURA 76: CADEIRA RG 55. A SETA INDICA O PONTO DE ANÁLISE, NO CASO NA FACE

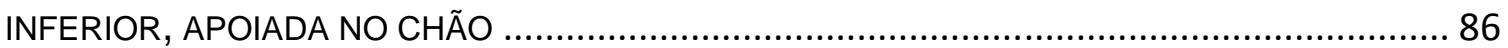

FIGURA 77: REPRODUÇÃO DA FICHA DO JACARANDÁ PAULISTA (MACHAERIUM VILLOSUM). . 87

FIGURA 78: REPRODUÇÃO DA FICHA DO JACARANDÁ PAULISTA (MACHAERIUM VILLOSUM). . 87

FIGURA 79: REPRODUÇÃO DA FICHA DO JACARANDÁ DA BAHIA (DALBERGIA NIGRA).......... 88

FIGURA 80: AMPLIAÇÃO DE 10X DA MADEIRA DE JACARANDÁ (DALBERGIA SP.) DA CADEIRA

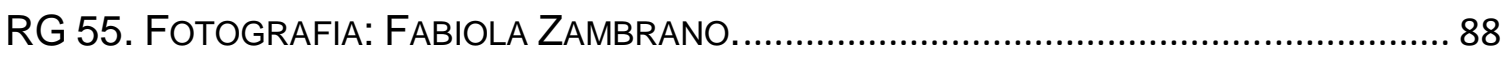

FIGURA 81: AMPLIAÇÃO DE 100X DA MADEIRA DE JACARANDÁ (DALBERGIA SP.) DA CADEIRA

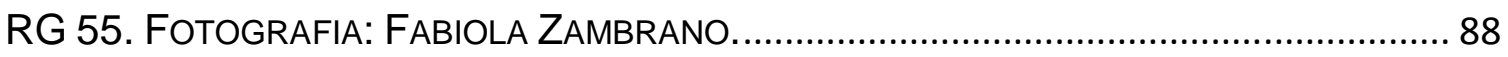

FIGURA 82: ARCA RG 3242. A SETA INDICA O PONTO DE ANÁLISE. ACERVO MUSEU

PAULISTA. FOTOGRAFIA: HTTP://WWW.ACERVO.MP.USP.BR/ACERVO.ASPX. 89

FIGURA 83: AMPLIAÇÃO DE 10X DA MADEIRA DE IMBUIA (OCOTEA SP.) DO TAMPO DA ARCA

RG 3242. FOTOGRAFIA: FABIOLA ZAMBRANO.

FIGURA 84: AMPLIAÇÃO DE 100X DA IMBUIA DA ARCA 3242. FOTOGRAFIA: FABIOLA

ZAMBRANO. 90

FIGURA 85:REPRODUÇÃO DA FICHA DA IMBÚIA (OCOTEA POROSA). 90 
FIGURA 86: DISTRIBUIÇÃO DO JACARANDÁ DA BAHIA. CORRE RISCO DE EXTINÇÃO. ESTIMASE QUE 30\% DA POPULAÇÃO FOI DESTRUÍDA.

FIGURA 87: DISTRIBUIÇÃO ATUAL DO JACARANDÁ PAULISTA. NÃO CORRE RISCO DE EXTINÇÃO.

FIGURA 88: DISTRIBUIÇÃO DA IMBUÍA (OCOTEA POROSA).

FIGURA 89: IMAGEM: CARTA COROGRAPHICA E HYDROGRAPHICA DE TODA COSTA DO MAR DA CAPITANIA DE S. PAULO. (1789). DIMENSÕES 0,980M X 1,42M. 95

FIGURA 90: DETALHE DA CARTA COROGRAPHICA E HYDROGRAPHICA, ONDE SE VÊ O RIO CUBATÃO E DESTAQUE.

FIGURA 91: FotOGRAFIA DO SISTEMA PORTÁTIL DE XRF: A) DETECTOR; B) TUBO DE RAIOS $X$ COM ANODO DE PRATA (AMPTEK®). 105

FIGURA 92: REPRESENTAÇÃO ESQUEMÁTICA DA EXCITAÇÃO POR RAIOS-X DOS ELÉTRONS E A SUA ALTERAÇÃO DE CAMADA ENERGÉTICA, FLUORESCENDO RAIOS X CARACTERÍSTICOS.

FIGURA 93: SESSÃO DE FOTOGRAFIAS COM FLUORESCÊNCIA DE RAIOS UV SOBRE OS MÓVEIS (NO CASO O LEITO RG 4996) FEITA POR JOSÉ ROSAEL. FOTOGRAFIA DO AUTOR.

FIGURA 94: EXEMPLO DE FOTOGRAFIA COM FLUORESCÊNCIA DE LUZ UV NA ARCA RG 3242 MOSTRANDO SINAIS DE RESTAURO, COMO TRÊS LINHAS VERTICAIS NA PARTE INTERNA DO TAMPO QUE REVELAM OUTROS TIPOS DE TINTAS. FOTOGRAFIA DE JOSÉ ROSAEL. .......107

FIGURA 95 E FIGURA 96: IMAGEM DE FLUORESCÊNCIA DE UV DA CADEIRA RG55 DO ACERVO DO MuSEU PAULISTA. ENCOSTO VISTO DA PARTE FRONTAL E DO VERSO, EVIDENCIANDO A MARCA DE RESTAURO NO COURO. FOTOGRAFIA DE JOSÉ ROSAEL. 108

FIGURA 97: IMAGEM A LUZ VISÍVEL DA CADEIRA RG55 DO ACERVO DO MUSEU PAULISTA COM A IDENTIFICAÇÃO DOS DIFERENTES PONTOS MEDIDOS PELA TÉCNICA DE FLUORESCÊNCIA DE RAIOS $X$. 109

FIGURA 98: FOTOGRAFIA DA CADEIRA RG55 ONDE SE VÊ O EMISSOR DE RAIOS X E O DETECTOR ACOPLADOS INCIDINDO NO PONTO P15, TOMANDO-SE O CUIDADO PARA NÃO REALIZAR CONTATO COM O MÓVEL.

FIGURA 99: DETALHE DA INCIDÊNCIA DAS MEDIÇÕES NOS PONTOS P7 E P8 PREGARIA GRAÚDA E MIÚDA, RESPECTIVAMENTE. FOTOGRAFIA DO AUTOR.

FIGURA 100: PARTE INFERIOR DO ASSENTO DA CADEIRA RG55 ONDE AINDA HÁ PELOS DO ANIMAL. FOTOGRAFIA DO AUTOR.

FIGURA 101: FOTOGRAFIA COM A LUZ UV ONDE SE PERCEBE A INCIDÊNCIA DE PONTOS DE RESTAURO NA ARCA, ESPECIALMENTE EM UMA FAIXA VERTICAL AO CENTRO DO BRASÃO, NO TOM AZULADOS. HÁ TAMBÉM PEQUENOS PONTOS ESPALHADOS PELA SUPERFÍCIE.

FOTOGRAFIA DE JOSÉ ROSAEL.

FIGURA 102: FOTOGRAFIA DA ARCA-COFRE RG3242 COM OS PONTOS DAS MEDIDAS DE EDXRF IDENTIFICADOS: FOTO DA PROF. a DR. a MÁRCIA RIZZUTO.

FIGURA 103: INTERIOR DA ARCA RG3242. FOTOGRAFIA DO AUTOR. 117

FIGURA 104: FOTOGRAFIA NO MOMENTO DE MEDIÇÃO DO PONTO P4, INCIDINDO NA TINTA VERMELHA DO BRASÃO DA ARCA-COFRE RG3242.

FIGURA 105: ASSINATURA DE NiCOLAU FRANCISCO ROSAL. 
FiguRA 106: RETÁBulo dEDICADO A N. S. DA CONCEIÇÃO, FEITO POR LUís ROdRIGUES

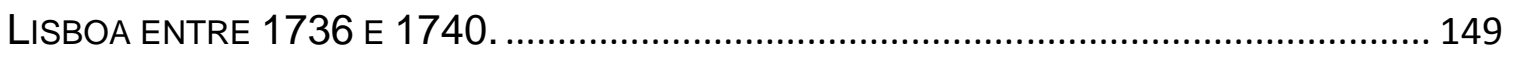

FIGURA 107: ASSINATURA DE LUIZ RODRIGUES LISBOA ………...................................... 150

FIGURA 108: FOTOGRAFIA FEITA EM 1911 DA NAVE E CAPELA MOR DA ANTIGA IGREJA DA SÉ,

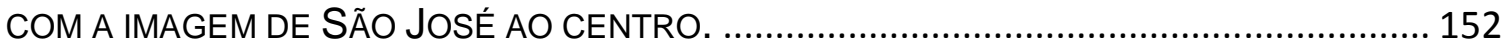

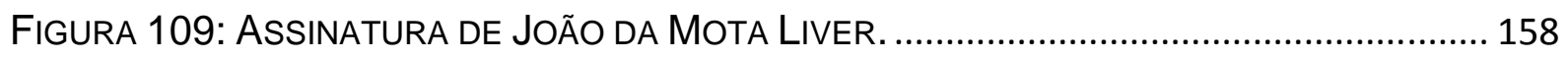

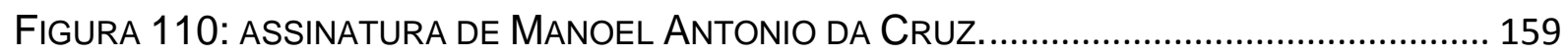

FIGURA 111: DEBRET, JEAN-BAPTISTE. "CARPINTEIRO INDO PARA A OBRA" (DETALHE), EM

VIAGEM PITORESCA E HISTÓRICA AO BRASIL, 1834-39 …………………………..... 166

FiguRA 112: HISTÓRIA DO CHAPELEIRO ANTÓNIO JOAQUIM CARNEIRO. C. 1790. MUSEU DO

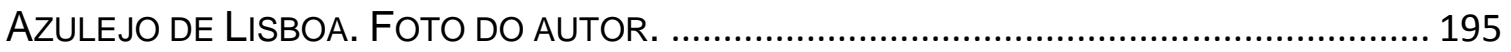

Figura 113: PINK, EdMUND. VISTA DA CIDADE - PALÁCIO DA SOLA. (DETALHE). C. 1820. 196

FIGURA 114: MUZZI, JOÃO FRANCISCO. INCÊNDIO DO RECOLHIMENTO DE NOSSA

SenHORA do PARTO. ACERVO: Museus CAStro MAYA - IPHAN/MINC................... 202

FIGURA 115: LEITO FEITO POR ALEXANDRE-LOUIS BELLANGÉ E PERTENCENTE À MARQUESA

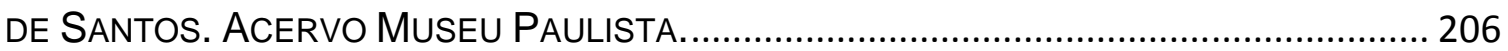

FIGURA 116: GRÁFICO DE PROPORÇÃO ENTRE CATEGORIAS DE MÓVEIS, EM 15 INVENTÁRIOS DO INTERVALO ENTRE 1700-1740. NÚMEROS ABSOLUTOS DA QUANTIDADE DOS MÓVEIS E PORCENTAGENS DIVIDIDAS POR VÍRGULAS. 210

FIGURA 117: GRÁFICO DE PROPORÇÃO ENTRE CATEGORIAS DE MÓVEIS, EM 23 INVENTÁRIOS DO INTERVALO ENTRE 1801-1840. NÚMEROS ABSOLUTOS DA QUANTIDADE DOS MÓVEIS E PORCENTAGENS DIVIDIDAS POR VÍRGULAS. 211

FIGURA 118: Nicolas II DE LARMESSIN (1632-1694), HABIT de MENIUSIER ÉBENISTE. LES COSTUMES GROTESQUES ET LES MÉTIERS, 229

FIGURA 119: BUFETE COM PÉS DE BOLACHA - SÉCULO XVIII - ACERVO DO MUSEU

PAULISTA/ USP. FotogRAFIA dE HÉLIO NOBRE. 235

FiguRA 120: MESA CONSOLE, CADEIRAS E SOFÁ DO BRIGADEIRO LUÍS ANTONIO. SÉCULO

XIX. ACERVO do MUSEU PAULISTA/ USP. FotogRAFIA de RÔMULO FIELDINI. ......... 235

FIGURA 121: BIARD, FRANÇOIS. CARREGADORES DE PIANO, 1859................................ 241

FIGURA 122: FIGURAS ESQUEMÁTICAS DE ALGUMAS DAS POSTURAS CATALOGADAS PARA $O$

ESTUDO COMPARATIVO. PRODUZIDAS A PARTIR DE FOTOGRAFIAS DA LITERATURA

ETNOGRÁFICA. EXTRAídO DE HEWES, GORDON. WORLD DISTRIBUTION... OP. CIT., P. 235.

FIGURA 123: ESBOÇO ESQUEMÁTICO MOSTRANDO A DIFERENÇA ENTRE AS COLUNAS

VERTEBRAIS COM FORMATO DE "S" (I) E EM "J" (II). EXTRAIDO DE TRAITE D'ANATOMIE

HUMAINE, DISPONÍVEL EM (DOUCLEFF, M. 2015).

Figura 124: GURAN, MILTON, Escola KaYAPÓ, ALDEIA DJETUKTIRE, 1991 - FOTOGRAFIA

EM GELATINA/PRATA TONALIZADA, 23,8 X 30,3 CM (ACERVO MASP)........................ 249

FIGURA 125: "CASA DAS ÍNDIAS EM MONE ALEGRE", PARÁ.............................................. 250

FIGURA 126: URNA FUNERÁRIA ANTROPOMORFA DE CERÂMICA DO POVO MARACÁ, SUL DO

AMAPÁ. C. 1000 D.C.. NOTE-SE QUE O BANCO ONDE A FIGURA ANTROPOMORFA ESTÁ 
SENTADA É ZOOMORFA E SUA POSIÇÃO É RITUAL, COM AS MÃOS NO JOELHO E OS COTOVELOS PROJETADOS PARA FORA.

Figura 127: Banco de Chefe. Cultura Chokwe de Angola, SÉc. XIX-XX. Acervo:

Metropolitan Museum of ART, NOVA YoRK. 256

Figura 128: Cadeira de Braços, Museu do Oriente. MombaÇa, sÉculo XVII. Ébano,

OSSO, PALHINHA. NÚMERO DE INVENTÁRIO: FO/1350. FOTO DO AUTOR.....................257

FIGURA 129: RUGENDAS, JOHANN MORITZ. "CASA DE NEGROS”, 1835........................257

FIGURA 130: GUILLOBEL, JOAQUIM CÂNDIDO - "INTERIOR DE UMA CASA DO BAIXO POVO", C. 1820 . 258

Figura 131: DEBRET, JeAN-BAPTISTE. MERCADO DA RUA DO VALONGO. 1835.............259

FIGURA 132: DEBRET, JEAN-BAPTISTE. LOJA DE BARBEIRO. 1835 .....................................260

FIGURA 133: ENDER, THOMAS. “UMA SALA DE ESTAR EM SÃo PAULO”, 1817................262

Figura 134: Sala no Palácio Azurara, Museu de Artes Decorativas de Lisboa.

FOTOGRAFIA DO AUTOR. .

FIGURA 135: FLORENCE, HERCULES “A INOCÊNCIA SOBRE O TÚMULO DE UM ILUSTRE LIBERAL", 1830.

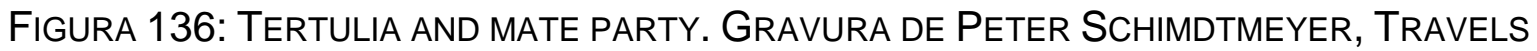

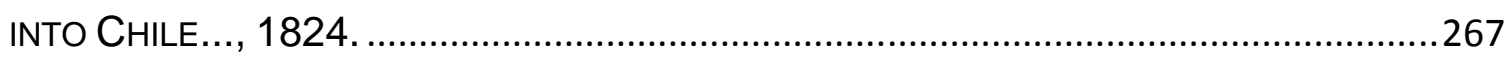

FIGURA 137: DEBRET, JEAN BAPTISTE, "FAMÍLIA POBRE EM SUA CASA", C. 1830...........268 FIGURA 138: DEBRET, JEAN-BAPTISTE. VOYAGE PITTORESQUE ET HISTORIQUE AU BRESIL. UNE DAME BRÉSILIENNE DANS SON INTÉRIEUR. C. 1830. 270

FIGURA 139: DELERIVE, NICOLAS. O MARCENEIRO DE RODAS DE CARROÇA. C. 1801. Foto do Autor. Acervo do Museu de ARtes Decorativas de LISBOA.

FIGURA 140: FOTOGRAFIA DO ESPALDAR DA CADEIRA DE SOLA PERTENCENTE À FAMÍLIA AMARAL GURGEL, ONDE SE PODE VER O BRASÃO. EXIBIDO NO MASP POR OCASIÃO DA

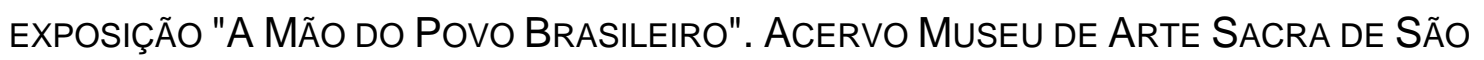
PAULO. FOTOGRAFIA DO AUTOR.

\section{ÍNDICE DE TABELAS}

TABELA 1: TRANSCRIÇÃO DO MAPPA DAS MADEYRAS DE LEY COM QUE COM MAIOR ABUNDÂNCIA SE ACHÃO NOS RIOS RESERVADOS PARA OS CORTES REAES.

TABELA 2: NOMENCLATURA E ESPECIFICAÇÃO DOS PONTOS MEDIDOS POR EDXRF — CADEIRA RG55

TABELA 3: CONCENTRAÇÕES DOS METAIS IDENTIFICADOS PELAS MEDIDAS DE EDXRF — CADEIRA RG55

TABELA 4: NOMENCLATURA E ESPECIFICAÇÃO DOS PONTOS MEDIDOS POR EDXRF NA ARCA RG3242

TABELA 5: CONCENTRAÇÕES DOS METAIS IDENTIFICADOS PELAS MEDIDAS D EDXRF — "ARCA 3242".

TABELA 6: VALORES DOS PIGMENTOS IMPORTADOS ATRAVÉS DOS PORTOS PORTUGUESES EM 1777. 
TABELA 7: LISTA DE MADEIRAS CLASSIFICADAS USADAS NO MOBILIÁRIO E SUAS QUANTIDADES, 1741-1840.

TABELA 8: QUANTIDADE E VALOR DOS MÓVEIS COM MADEIRAS DISCRIMINADAS NO INVENTÁRIO DO BRIGADEIRO JORDÃO (1838).

\section{ABREVIATURAS}

ACMSP - Arquivo da Cúria Metropolitana de São Paulo.

AHMSP - Arquivo Histórico Municipal de São Paulo.

AJESP - Arquivo do Judiciário do Estado de São Paulo.

ANTT - Arquivo Nacional da Torre do Tombo.

APESP - Arquivo Público do Estado de São Paulo.

Atas - Atas da Câmara Municipal de São Paulo.

DI - Documentos Interessantes para a História e Costumes de São Paulo.

FRESS - Fundação Ricardo do Espírito Santo Silva.

I e T - Inventários e Testamentos Publicados do APESP.

RG - Registro Geral da Câmara Municipal de São Paulo. 


\section{INTRODUÇÃO - Peças em um museu}

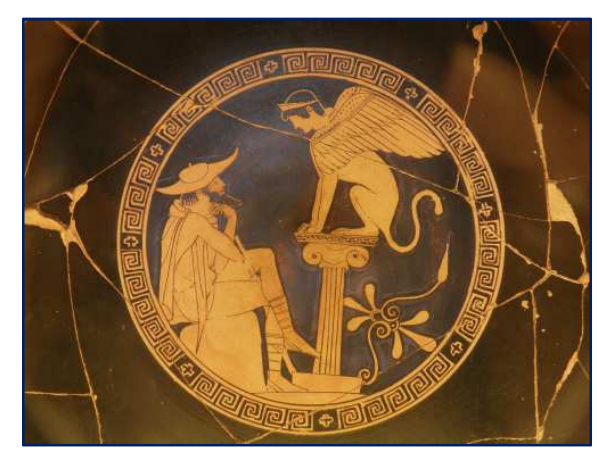

Figura 1: Édipo e a Esfinge. Kylix, c. 470 a.C. Museu do Vaticano

Ao visitarmos um museu e caminharmos por suas galerias, sem a correria típica do dia a dia, mas em um vagar, um percurso mais calmo e com um olhar mais atento - fora dos trajetos da rotina - nos deparamos com os objetos expostos em seus tipos mais variados e nos comicha a curiosidade e a dúvida.

Um turbilhão de perguntas nos vem à mente e assim desperta o historiador que existe em todas as pessoas, na sua acepção mais larga, a de inquiridor sobre o passado. "Quem teria feito aquele objeto?", "de onde vieram as matérias-primas?", "quais os significados que eles possuíam para seus usuários?", "como tal artefato foi conservado até chegar aqui?", são exemplos de indagações e pontos iniciais para o trabalho de achar as respostas, a que chamamos historiar².

Mesmo lendo as legendas, a impossibilidade de obter respostas para muitas das perguntas que temos nos faz querer chegar mais perto para ver os detalhes dos artefatos, saber o que há por trás, por baixo, por dentro... E nos ser chamada a atenção para não ultrapassarmos a linha de segurança...

Muitas vezes ficamos frustrados, pois a única informação que temos sobre as peças, e decerto valiosa, é quem foram seus donos, como se a peça lá estase somente pela importância de seu usuário, sem se tratar de outras várias informações que carregam os objetos. Desta maneira o museu se torna um Teatro

\footnotetext{
${ }^{1}$ Disponível em: https://commons.wikimedia.org/wiki/File:Oedipus_and_the_Sphinx_of_Thebes,_Red_Figure_Kylix,_C._470_BC ,_from_Vulci,_attributed_to_the_Oedipus_Painter,_Vatican_Museums_(9665213064).jpg. Acessado em: 20/05/2018.

${ }^{2}$ POINTON, Marcia. History of Art: A Student's Handbook. 4 ed. London: Routledge, 1994. P. 62
} 
da Memória, na expressão de Ulpiano de Meneses $^{3}$. A instituição de guarda acaba servindo mais como espetáculo para a exibição das grandes figuras que fizeram a história ${ }^{4}$ utilizando-se seus bens pessoais duráveis e deixando à margem grandes potenciais expositivos e informativos.

Não devemos, porém, ver os objetos como fetiches de seus possuidores ${ }^{5}$, ou só como exemplares da História da Arte, que valem pela sua superfície formal, desassociada de complexa profundidade social e mental. Se isto ocorre mesmo para quadros e esculturas e outros objetos artísticos ${ }^{6}$, é especialmente recorrente em relação a objetos decorativos e domésticos, como o mobiliário; em especial o paulista, relembrado pelos expositivamente pelos seus doadores ${ }^{7}$ e geralmente tratado em inferioridade em comparação com o de outros espaços produtores, considerado "rústico" 8 .

Temos como norteadora a perspectiva da cultura material como predicada por Ulpiano Bezerra de Meneses. Segundo sua definição cultura material é todo "segmento do meio físico socialmente apropriado pelo homem" ${ }^{9}$. Desta maneira as peças de mobiliário, por mais cotidiano que possa ser o seu uso, revelam características marcantes das sociedades que as produziram e utilizaram, dotandoas de diferentes significados ao longo do tempo, pois "os objetos materiais só

\footnotetext{
${ }^{3}$ MENESES, Ulpiano Bezerra de. Do teatro da memória ao laboratório da História: a exposição museológica e o conhecimento histórico. Anais do Museu Paulista, n.1 vo. 2. 1994, p. 17.

${ }^{4}$ Como igualmente indaga e problematiza RAMOS, Francisco Régis Lopes. A insustentável leveza do tempo: os objetos da sociedade de consumo em aulas de história. Educ. rev., Belo Horizonte, n. 47, p. 179196, Junho 2008.

${ }^{5}$ MENESES, Ulpiano Bezerra de. Do teatro da memória ao laboratório da História: a exposição museológica e o conhecimento histórico. Anais do Museu Paulista, n.1 vo. 2. 1994, p. 17.

${ }^{6}$ POINTON, Marcia. History of art... op. cit. p. 2.

${ }^{7}$ Vide por exemplo a lógica colecionista da coleção Major Sertório, núcleo fundador do Museu Paulista e da qual diversas das cadeiras que analisamos fazem parte. Cf. CARVALHO, Paula Carolina de Andrade. O Museu Sertório: uma coleção particular em São Paulo no final do século XIX (primeiro acervo do Museu Paulista). An. mus. paul., São Paulo, v. 22, n. 2, p. 105-152, Dec. 2014; bem como BREFE, A. C.. O Museu Paulista. Affonso de Taunay e a memória nacional. São Paulo: UNESP, Ed. 2003. E o guia de exposição feito por Taunay. TAUNAY, Afonso. Guia da Secção Histórica do Museu Paulista: catálogo. São Paulo: Imprensa oficial do estado. 1937. O qual já fora problematizado por BORREGO, Maria Aparecida De Menezes. Artefatos da casa em exposição: o espaço doméstico colonial paulista em acervos do Museu Paulista/USP. 2012. In: ASENSIO, MOREIRA, ASENJO \& CASTRO (Eds.). SIAM. Séries Iberoamericanas de Museología. Vol. 7. 2012.

${ }^{8}$ Cf. RODRIGUES, José Wasth. Descrições de mobiliário. São Paulo: Museu Paulista, 1948. Datilografado e rubricado; bem como LEMOS, C. A. C. . Notas sobre a cultura material e o cotidiano em São Paulo dos tempos coloniais. In: Paula Porta. (Org.). Historia da Cidade de São Paulo. 1ed. São Paulo: Paz e Terra, 2004, v. 1, p. 179-189.

${ }^{9}$ MENESES, Ulpiano Bezerra de. Do teatro da memória ao laboratório da História: a exposição museológica e o conhecimento histórico. Anais do Museu Paulista, n.1 vo. 2. 1994, p. 17.
} 
dispõem de propriedades imanentes de natureza físico-química (...). Todos os demais atributos são aplicados às coisas" ${ }^{10}$.

Afinal, se os seculares artefatos os quais contemplamos nos museus como que de forma esfíngica nos instigam a curiosidade e fazem pensar sobre suas origens e trajetórias, retomamos a passagem mitológica de Édipo invocada na epígrafe para lembrarmos da solução do ancestral enigma e nos inspirar na pesquisa: a história que fazemos não é dos objetos por si, mas sim do ser humano, através dos artefatos que cria, usa e conserva.

Sendo assim, não basta nos determos em apenas um tipo de objeto ou fazer um estudo apenas taxonômico. Devemos, sim, estudar os objetos em séries e em sistemas, para assim podermos compreender seus usos e significados, bem como as continuidades e descontinuidades das quais foram dotadas, além de percebermos a via de mão dupla que existe no uso dos objetos, já que estes não são apenas produto das relações sociais, mas também vetores das mesmas ${ }^{11}$.

Seguindo estas argutas definições, buscaremos nos valer igualmente das discussões teóricas de fundo norteando a chamada "hermenêutica do cotidiano" ${ }^{12}$, a qual, seguindo os novos caminhos metodológicos da desconstrução filosófica, busca enfatizar a crítica do cotidiano sob o viés do processo de politização do mesmo. Deixamos assim de "fetichizar" os objetos musealizados ${ }^{13}$ ou de naturalizar o universo material que nos rodeia de maneira a entender a sua própria historicidade e a vida social dos artefatos ${ }^{14}$.

Partindo da importância de realizar o trabalho de pesquisa da História através dos artefatos musealizados e procurando explorar suas potencialidades, nossa dissertação visa compreender as dinâmicas sociais da cidade de São Paulo entre o século XVIII e as primeiras décadas do século XIX através da análise dos remanescentes de mobiliário doméstico aqui confeccionado e que se conservam

\footnotetext{
${ }^{10}$ Continua o autor dizendo que "Em outras palavras: sentidos e valores (cognitivos, afetivos, estéticos e pragmáticos) não são sentidos e valores das coisas, mas da sociedade que os produz, armazena, faz circular e consumir, recicla e descarta, mobilizando tal ou qual atributo físico (naturalmente, segundo padrões históricos, sujeitos a permanente transformação)". MENESES, Ulpiano Bezerra de. Do teatro da memória ao laboratório da História: a exposição museológica e o conhecimento histórico. Anais do Museu Paulista, n.1 vo. 2. 1994 , p. 17.

${ }^{11}$ MENESES, Ulpiano Bezerra de. Do teatro da memória ao laboratório da História: a exposição museológica e o conhecimento histórico. Anais do Museu Paulista, n.1 vo. 2. 1994, p. 17.

12 DIAS, Maria Odila Leite da Silva. Hermenêutica do Quotidiano na Historiografia Contemporânea. Projeto História: Trabalhos da Memória. São Paulo: Edusp, n. 17, nov. 1998.

${ }^{13}$ MENESES, U. Do teatro.... op. Cit. 1994, p.26.

${ }^{14}$ APPADURAI, Arjun (org.). A vida social das coisas: as mercadorias sob uma perspectiva cultural. Niterói: Editora da Universidade Federal Fluminense, 2008.
} 
hoje em instituições de guarda ${ }^{15}$, sendo o núcleo principal de artefatos que nos utilizaremos pertencente ao acervo do Museu Paulista da Universidade de São Paulo ${ }^{16}$

É pela aplicação da problematização histórica, nas mais variadas articulações possíveis, que se pode explorar a vasta gama de informações passíveis de extração das características físicas dos objetos e pelos dados de suas trajetórias ou de congêneres que foram preservados em arquivos e catálogos, sendo que para tanto nos valemos do "paradigma indiciário" proposto por Carlo Ginzburg ${ }^{17}$, tendo a sensibilidade de notar que os mais banais ou óbvios elementos podem ser excepcionalmente reveladores.

Lançando mão deste prisma da cultura material, buscamos explorar ao máximo as informações que pudemos extrair das peças, com metodologias e problemáticas advindas de variados ramos do saber, tratados com a verticalidade e discussão necessária à dissertação, e concomitantemente buscando, de forma dialética, o esforço transdisciplinar horizontalizado. Tornam-se assim as instituições de guarda "laboratórios da História" e não apenas galerias do passado.

Ajustando as escalas de nossa observação minuciosa até os indícios microscópicos e mesmo àqueles não visíveis ao olho nu, lançaremos mão das técnicas e metodologias das Ciências da Natureza aplicadas ao estudo e conservação do patrimônio, dentro do grande cabedal da Arqueometria ${ }^{18}$, para compreender que mesmo as "propriedades físico-químicas" das matérias-primas dos objetos, as únicas que lhes são imanentes ${ }^{19}$, revelam-se plenas de historicidade quando procuramos compreender com profundidade as cadeias de sua produção e

\footnotetext{
${ }^{15}$ Várias inquirições norteadoras de nosso projeto de mestrado partiram da participação no programa Jovem Pesquisador Fapesp "Espaço doméstico e cultura material em São Paulo colonial a partir do estudo dos acervos do Museu Paulista/USP", orientado pela Prof. a Dr.a Maria Aparecida de Menezes Borrego entre 2011 e 2013, que tivemos a oportunidade de integrar como bolsista de iniciação científica, juntamente com outros graduandos.

${ }^{16}$ Expandindo-se os exames para o de outras instituições como o Museu de Artes Decorativas da Fundação Ricardo Espírito Santo Silva de Lisboa, além de comparações com os acervos exibidos em exposições do Museu de Arte de São Paulo, o Museu de Arte Sacra de São Paulo, o Museu Afro-Brasil e coleções particulares.

${ }^{17}$ GINZBURG, Carlo. Mitos, emblemas, sinais: morfologia e história. 2ạ ed., São Paulo: Companhia das Letras, 2012, p. 178.

${ }^{18}$ Contamos em nosso mestrado com a parceria de análises arqueométricas realizadas em seis móveis do Museu Paulista pelo Laboratório de Análises de Materiais por Feixes lônicos (LAMFI - IFUSP), sob auspícios da Prof. a Dr.a Márcia de Almeida Rizzutto. Igualmente realizamos análises de caracterização fito-botânica dos mesmos móveis com o auxílio do Serviço de Conservação do Museu Paulista, com o auxílio da conservadora Me. Fabiola Zambrano.

${ }^{19}$ Cf. MENESES, Ulpiano Bezerra de. Do teatro da memória ao laboratório da História: a exposição museológica e o conhecimento histórico. Anais do Museu Paulista, n.1 vo. 2. 1994, p. 17.
} 
circulação, no fundamental jogo de escalas entre os micro e macro fenômenos sociais.

Os artefatos analisados são principalmente as cadeiras pela riqueza de dados que nos fornecem sobre as suas mudanças formais e as interfaces corporificadas de seu uso social ${ }^{20}$. Não obstante, nossa pesquisa e reflexão expandem-se ainda por várias categorias de móveis domésticos, como os de assento ou descanso (cadeiras e também bancos, canapés e sofás), de guarda e exposição (arcas, baús, cofres, cômodas, escrivaninhas), de repouso (catres, estrados, leitos) e de suporte (bufetes e mesas), além de tratarmos das ferramentas e componentes utilizados na construção desses móveis.

Este estudo específico visa contribuir para uma melhor compreensão das especificidades socioeconômicas do passado paulista, pois, ao partirmos da análise material dos objetos não nos restringiremos a um estudo meramente formal das peças, mas sim utilizaremos as fontes tridimensionais para fazer uma História Social, tal como podemos extrair das propostas cautelares de Ulpiano de Meneses ${ }^{21}$.

O primeiro intuito geral diz respeito ao campo metodológico, o de realizar uma História a partir dos objetos, de maneira a valorizar as informações contidas em suas estruturas, como marcas de ferramentas, materiais, inscrições, colorações, entre outros. Buscaremos, através da perspectiva da cultura material, analisar pormenorizadamente tais artefatos de forma a colher dados sobre a sua materialidade, fornecendo-nos pistas para compreender os processos de feitura e consumo. Devemos salientar que não possuímos o mesmo repertório e erudição dos historiadores da Arte e connoisseurs sobre os estilos de mobiliário ${ }^{22}$, importando-nos principalmente a compressão social de tais artefatos para a compreensão da sociedade, evidenciada através desses aspectos estilísticos.

De acordo com as considerações de Carlo Ginzburg ${ }^{23}$, o estilo, nas artes visuais, foi usado para delimitar e cercear, sendo poderoso mecanismo que

\footnotetext{
${ }^{20}$ Cf. PINTO, Augusto Cardoso. NASCIMENTO, J. F. da Silva (org). Cadeiras portuguesas. Lisboa, [Edição dos Autores], 1952. P. 9;

${ }^{21}$ MENESES, Ulpiano Bezerra de. Do teatro da memória ao laboratório da História: a exposição museológica e o conhecimento histórico. Anais do Museu Paulista: História e Cultura Material, n.1, vol.2, 1994.

${ }^{22}$ Tanto por isso não nos lançamos nesta dissertação a uma análise visual, por exemplo, dos brasões presentes em cadeiras de sola e arcas-cofre. Apesar de estarmos cientes de sua riqueza imagética e simbólica, necessitaríamos elencar ainda outras metodologias e discussões próprias desses estudos, os quais - não obstante - buscaremos futuramente explorar.

${ }^{23}$ GINZBURG, Carlo. Olhos de madeira: nove reflexões sobre a distância. São Paulo: Companhia das Letras, 2001.
} 
desempenhou função de aceitação ou negação das diversidades culturais. Assim, é preciso considerar ${ }^{24}$ que em nenhuma parte do mundo existem estilos puros nas manifestações artísticas e que os modelos não existiram isolados como etapas independentes, como seria o estilo João V (1700-1750), José I (1750-1777) ou Maria I (1777-1816) do mobiliário português, recobrindo o século XVIII ${ }^{25}$, mas foram resultados e vetores de interações humanas e culturais, especialmente na circularidade de formas com países como a França e a Inglaterra. Devemos assim conceber que ocorrera a gestação e circulação de gostos artísticos, muitas vezes em disputas simbólicas ${ }^{26}$, a recepção, adaptação e longo preparo de mão-de-obra especializada, bem como a formação de um público consumidor que, aos poucos, adota e familiariza-se com suas representações visuais.

Partindo assim do produto final, nosso esforço será o de "dar a vida de volta às coisas", como propõe Tim Ingold ${ }^{27}$, buscando compreender as dinâmicas sociais inter-relacionadas à cadeia produtiva como um todo, desde a extração das matériasprimas que os constituem, passando pelas cadeias de fornecimento de material, pelos espaços e tecnologias de produção, pela sua distribuição, pelas formas de transporte e venda, até o seu consumo e uso doméstico.

Tal análise material tem sempre como horizonte compreender a população paulista dentro dos movimentos de formação e de interiorização das sociabilidades e da domesticidade que se operou entre os séculos XVIII e XIX ${ }^{28}$.

De fato, buscamos através de tais peças lançar outra mirada sobre a história paulista colonial. Durante muitas décadas a historiografia sobre São Paulo reiterou a narrativa da pobreza paulista nos séculos XVII e XVIII, tradicionalmente considerada esvaziada pelo ciclo econômico das Minas, e pela posição periférica entre as capitanias litorâneas. Tal narrativa, composta por autores como Afonso Taunay ${ }^{29}$,

\footnotetext{
${ }^{24}$ Como apontaram perspicazmente ARAÚJO, Jeaneth. DIAS, Renato da Silva. Núcleos urbanos na capitania de Minas Gerais: artistas, oficiais mecânicos e vida cotidiana no termo de vila rica. Revista Mnemosine. Vol.6, n.1, jan/jun. 2015.

${ }^{25}$ RODRIGUES, José Wasth. Mobiliário. As Artes plásticas no Brasil. Coleção brasileira de ouro. Rio de Janeiro: Ed. de Ouro, 1968. P.92.

${ }^{26}$ Como nota Bourdieu em sua sociologia hodierna BOURDIEU, Pierre. A distinção: crítica social do julgamento. São. Paulo: Edusp; Porto Alegre, RS: Zouk, 2007.

${ }^{27}$ INGOLD, Tim. Trazendo as coisas de volta à vida: emaranhados criativos num mundo de materiais. Horiz. antropol., Porto Alegre, v. 18, n. 37, p. 25-44, June 2012.

${ }^{28}$ ALGRANTI, Leila M. "Famílias e vida doméstica". In: SOUZA, Laura de Mello (org.) História da vida privada no Brasil: cotidiano e vida privada na América portuguesa. São Paulo: Companhia das Letras, 1997, pp. 54-90.

${ }^{29}$ TAUNAY, Affonso de E. São Paulo nos primeiros anos (1554-1601): Ensaio de reconstituição social. Tours: Imprenta de Arrault et cia. 1920.
} 
Alfredo Ellis ${ }^{30}$, Alcântara Machado ${ }^{31}$ e Ernani da Silva Bruno ${ }^{32}$ foi realizada principalmente pelos autores se basearem e reproduzirem as narrativas das fontes administrativas, fazendo comparações por vezes tautológicas e com outros espaços coloniais sem a devida consideração pelas especificidades paulistas. Assim, a consideraram isolada politicamente e escassa economicamente, sendo geralmente avaliada "rústica" do ponto de vista da materialidade, depreciando a presença e hibridização ${ }^{33}$ indígena da população e se baseando principalmente em parcelas dos inventários e testamentos mais remotos da vila, quando as dinâmicas da população e mesmo as lógicas de composição das fortunas e das distinções sociais eram diferentes ${ }^{34}$.

Porém, tais concepções passaram por revista ${ }^{35}$ com diversos autores apurando variados aspectos da vida paulista, como - para citar apenas alguns exemplos - as dinâmicas da população e as fronteiras de expansão da colônia, como abordada semanalmente por Sérgio Buarque de Holanda ${ }^{36}$; a integração comercial da capitania e as dinâmicas sociais de seus agentes comerciais, como abordado por Ilana Blaj ${ }^{37}$ e Maria Aparecida de Menezes Borrego ${ }^{38}$; a lógica da vida urbana e da

${ }^{30}$ ELLIS Jr., Alfredo; ELLIS, Myriam. A economia paulista no século XVIII. São Paulo: Boletim da Civilização Brasileira, n.11, 1950.

${ }^{31}$ MACHADO, Alcântara. Vida e morte do bandeirante. Belo Horizonte: Itatiaia; São Paulo: Edusp, 1980.

32 BRUNO, Ernani da Silva. História e tradições da cidade de São Paulo. São Paulo: Hucitec, 1991 (volume 1: Arraial de sertanistas, 1554-1828).

${ }^{33}$ Tal como conceituado por Nestor Canclini: "processos socioculturais nos quais estruturas ou práticas discretas, que existem de forma separada, se combinam para gerar novas estruturas, objetos e práticas" CANCLINI, Néstor Garcia. Culturas híbridas: estratégias para entrar e sair da modernidade. Trad. de Ana Regina Lessa, Heloísa Pezza Cintrão. 4. ed. São Paulo: Edusp, 2003., p. 19. grifos do autor.

${ }^{34}$ MARANHO, Milena Fernandes. A opulência relativizada: significados econômicos e sociais dos níveis de vida dos habitantes da região do Planalto de Piratininga, 1648-1682. Campinas: Dissertação de mestrado UNICAMP. 1999.

${ }^{35}$ Deve-se compreender este movimento de reavaliação historiográfica dentro do contexto historiográfico internacional, sendo que Fernand Braudel já considerara "distinguir entre luxo e miséria é apenas uma primeira classificação, monótona, por si só pouco precisa". BRAUDEL, Fernand. Civilização material, economia e capitalismo - séculos XV-XVIII. São Paulo: Martins Fontes, 1995 (vol.2: As estruturas do cotidiano), p. 300.

É necessário compreender as capacidades produtivas de cada civilização material de acordo com os contextos específicos. Por exemplo, antes da Revolução Industrial a Europa era uma "economia da escassez", sendo que os interiores domésticos em sua grande maioria eram muito mais enxutos dos que os atuais, excedendo-se os locais de morada das ínfimas camadas mais ricas, ainda assim incomparáveis com o volume produtivo alcançado após a mecanização da produção. cf. Fernand Braudel, Civilização Material, Economia e Capitalismo - séculos XV-XVIII: Os Jogos das trocas, São Paulo, Martins Fontes, 1998. Bem como as considerações de ROCHE, Daniel. História das coisas banais: nascimento do consumo nas sociedades tradicionais (XVII-XIX). Rio de janeiro: Rocco, 2000. P. 17ss.

${ }^{36}$ HOLANDA, Sérgio Buarque de. Monções e Capítulos da expansão paulista. Organização de Laura de Mello e Souza e André Sekkel de Cerqueira. Notas de André Sekkel de Cerqueira. São Paulo: Companhia das Letras, 2014.

${ }^{27}$ BLAJ, Ilana. A trama das tensões: o processo de mercantilização de São Paulo colonial (1681-1721). São Paulo: Humanitas/FFLCH/USP : Fapesp, 2002; 
reprodução das formas de distinção e exercício do poder simbólico na estruturação social, compreendida por Mônica Muniz Carvalho ${ }^{39}$; a escravidão indígena e a formação da economia interna, abordada por John Monteiro ${ }^{40}$; a composição das fortunas e a própria problematização historiográfica feitas por Milena Maranho ${ }^{41} \mathrm{e}$ Amílcar Torrão Filho ${ }^{42}$; a vida nas casas rurais feitas através do prisma da Arqueologia, realizada por Paulo Zanettini ${ }^{43}$ e também no âmbito das encomendas de artes sacras o estudo da atuação de pintores por Danielle Manoel dos Santos Oliveira $^{44}$.

A escolha de nossa cronologia deve-se à compreensão do tempo histórico de maneira complexa, como um relevo emaranhado das durações díspares de diversos fenômenos sociais em concomitância. Assim escolhemos analisar um longo século XVIII paulista, escolhendo o último ano do século que the antecede como ponte necessária à compreensão dos fenômenos ainda em curso e as três primeiras décadas do século XIX, onde ainda se desdobram os elementos analisados.

No que tange ao desenvolvimento dos móveis domésticos, o século XVIII foi um momento histórico de especial dinamismo e criatividade, onde as artes decorativas encontraram grande apanágio para alterar as configurações das casas e sendo produto das novas ideias de lar e família e vetor das práticas sociais que levaram a esta conformação.

À produção dos móveis, temos a continuidade da divisão corporativa da sociedade colonial, sistema que é implantado desde os princípios da colonização,

\footnotetext{
${ }^{38}$ BORREGO, Maria Aparecida de Menezes. A teia mercantil: negócios e poderes em São Paulo colonial (17111765). São Paulo: Alameda/ Fapesp, 2010.

${ }^{39}$ CARVAlHO, Mônica Muniz Pinto de. A cidade de São Paulo no século XVIII. Uma sociabilidade constituída em torno de símbolos do poder. São Paulo, dissertação de mestrado - FFLCH-USP, 1994.

${ }^{40}$ MONTEIRO, John Manuel. Negros da terra. Bandeirantes e índios nas origens de São Paulo. São Paulo: Companhia das Letras, 1994.

${ }^{41}$ MARANHO, Milena Fernandes. A opulência relativizada: significados econômicos e sociais dos níveis de vida dos habitantes da região do Planalto de Piratininga, 1648-1682. Campinas: Dissertação de mestrado UNICAMP. 1999.

42 TORRÃO FILHO, Amílcar. Paradigma do caos ou cidade da conversão? São Paulo na administração do Morgado de Mateus. São Paulo: Annablume, 2010.

43 ZANETTINI, P. E. Maloqueiros e seus palácios de barro: o cotidiano doméstico na Casa Bandeirista. Tese de Doutorado em Arqueologia - Museu de Arqueologia e Etnologia, Universidade de São Paulo, São Paulo, 2006.

${ }^{44}$ PEREIRA, Danielle Manoel dos Santos. Autoria da Pinturas Ilusionistas do Estado de São Paulo: São Paulo, Itu e Mogi das Cruzes (Brasil). 2017. Tese de Doutorado em ARTES - UNESP. 2017.
} 
com ajustes e flexibilidades, até a sua extinção com a legislação liberal em 1824 e lento desmantelamento, levando várias décadas a ocorrer ${ }^{45}$.

Igualmente é momento dos primeiros sintomas de desmantelamento da economia assentada no trabalho escravo, onde as pressões externas começam a levar aos esforços institucionais e mudar as formas desse sistema e de sua retroalimentação, iniciando-se também no momento a grande chegada de imigrantes de outras partes da Europa, que muito influíram nas alterações das formas produtivas coloniais ${ }^{46}$.

Em segundo lugar, este século diz respeito a um momento de adensamento e transformação da sociedade colonial $^{47}$ e passagem das formas domésticas de economia para uma sociedade que se encontra com novas maneiras de consumo urbano, em rotatividade com outros ritmos desdobrados na Europa ${ }^{48}$. Tais preocupações foram tema de trabalhos historiográficos sobre o espaço doméstico brasileiro e paulista sob o enfoque da cultura material, como são as pesquisas de Leila Mezan Algranti ${ }^{49}$, Paulo César Garcez Marins ${ }^{50}$ e Maria Aparecida Borrego ${ }^{51}$, bem como, para o avançar dos século XIX, Vânia Carneiro de Carvalho ${ }^{52}$, e Maria Lucília de Viveiros Araújo ${ }^{53}$.

\footnotetext{
${ }^{45}$ FLEXOR, Maria Helena Ochi. O Trabalho Livre em São Paulo - Século XVIII. Tese de Doutorado - São Paulo: FFLCH/USP, 1984. Bem como o excelente artigo FLEXOR, Maria Helena Ochi. Ofícios, Manufaturas e Comércio. In SZMRECSÁNYI, Tamás. História Econômica do Período Colonial. 1993. pp. 175.

${ }^{46}$ FERNANDES, Antônia Terra de Calazans. Memórias de ofício. São Paulo: Tese de Doutorado FFLCH/USP, 1997;

${ }^{47}$ MARCílIO, Maria Luiza. A cidade de São Paulo. Povoamento e população. 1750-1850. São Paulo: Pioneira/Edusp, 1974. E MARCÍLIO, Maria Luiza. Crescimento demográfico e evolução agrária paulista - 17001836. São Paulo: Hucitec/Edusp, 2000..

${ }^{48}$ MCKENDRICK, Neil. "The Consumer Revolution of Eighteenth-Century England." In MCKENDRICK Neil, BREWER John e PLUMB J. H. (eds.), The Birth of a Consumer Society: The Commercialization of Eighteenth Century England. Bloomington: Indiana University Press, 1982. P. 9-33. E KUZNESOF, Elizabeth Anne. Household economy and urban development: São Paulo: 1765 to 1836. Berkeley, University of California, 1976..

${ }^{49}$ ALGRANTI, Leila M. "Famílias e vida doméstica". In: SOUZA, Laura de Mello (org.) História da vida privada no Brasil: cotidiano e vida privada na América portuguesa. São Paulo: Companhia das Letras, 1997, pp. 54-90.

${ }^{50}$ MARINS, Paulo Cesar Garcez. Através da rótula: sociedade e arquitetura urbana no Brasil, sécs. XVII-XX. Tese de Doutorado. São Paulo, Dpto. De História da FFLCH-USP, 1999.

${ }^{51}$ BORREGO, Maria Aparecida de Menezes. Projeto de Pesquisa Jovem Pesquisador FAPESP - Espaço Doméstico e Cultura Material em São Paulo Colonial a partir do estudo de acervos do Museu Paulista/USP. Não Publicado. 2010. Bem como no artigo BORREGO, Maria Aparecida de Menezes; FELIX, Rogério Ricciluca Matiello. Ambientes domésticos e dinâmicas sociais em São Paulo colonial. Rev. Hist. (São Paulo), São Paulo, n. 175, p. 91-132, dez. 2016

${ }^{52}$ CARVALHO, Vânia Carneiro. Gênero e artefato: o sistema doméstico na perspectiva da cultura material: São Paulo, 1870-1920. EdUSP, 2008.

${ }^{53}$ ARAÚJO, M. L. V. Os interiores domésticos após a expansão da economia exportadora paulista. Anais do Museu Paulista: História e Cultura Material, 12, 129-160. 2004;
} 
A temática da materialidade no espaço doméstico foi explorada também sob diversos enfoques, por historiadores de outros países, entre os quais Nuno Luís Madureira ${ }^{54}$, Luís Frederico Dias Antunes ${ }^{55}$, Carlos Franco ${ }^{56}$ para o caso português, Daniel Roche ${ }^{57}$, Leora Auslander ${ }^{58}$ e Mimi Hellman ${ }^{59}$ para o contexto francês e, na Inglaterra, por Amanda Vickery e John Styles ${ }^{60}$.

Ao lidarem com a cultura material, essas pesquisas transcendem, aliás, os limites do espaço doméstico enquanto foco de análise e se inter-relacionam com investigações sobre o papel do consumo de bens domésticos em seus circuitos de produção, comercialização e consumo, como é o caso teorizado por Mary Douglas e Baron Isherwood ${ }^{61}$ e analisado por Neil McKendrick ${ }^{62}$ e Lorna Weatherill ${ }^{63}$.

Isto posto, nossos intuitos historiográficos específicos dizem respeito às problemáticas desdobradas a partir do estudo do objeto, como o do estatuto social do trabalho dos agentes responsáveis pela sua produção na cidade de São Paulo e arredores, e o das configurações específicas que o mercado de artefatos domésticos possuía neste período pré-industrial.

Para tanto, buscaremos identificar os indivíduos responsáveis pela sua fabricação. Na época, sendo vigentes as corporações de ofícios, o trabalho era executado por oficiais mecânicos, como carpinteiros, marceneiros, entalhadores, coureiros, serradores, entre outros. Para além de entender os indivíduos meramente enquanto produtores de móveis, intentaremos compreender o papel mediador que

\footnotetext{
${ }^{54}$ MADUREIRA, N. L. Cidade: Espaço e Quotidiano. Lisboa 1740-1830. Lisboa: Ed L. Horizonte. 1992

${ }^{55}$ ANTUNES, L. F. D. Alguns interiores domésticos nos inventários de mercadores lisboetas: uma avaliação do valor simbólico de objetos asiáticos. In: MENESES, A. de F de; OLIVERIRA E COSTA, J. P. (orgs.) O Reino, As Ilhas e o Mar Oceano: Estudos em Homenagem a Artur Teodoro de matos. Lisboa: Ponta Delgada, Vol.2, 2007.

56 FRANCO, Carlos. O mobiliário das elites de Lisboa na segunda metade do século XVIII. Lisboa: Livros Horizonte, 2007, p. 77.

${ }^{57}$ ROCHE, Daniel. História das coisas banais: nascimento do consumo nas sociedades tradicionais (XVII-XIX). Rio de Janeiro: Rocco, 2000.

58 AUSLANDER, Leora. Taste and Power: furnishing modern France. Berkley: University of California Press, 1996.

${ }^{59}$ HELLMAN, Mimi. "Furniture, sociability, and the work of leisure in eighteenth-century France." EighteenthCentury Studies 32.4. 1999. HELLMAN, Mimi. Introduction In: KODA, Harold; BOLTON, Andrew (eds.).Dangerous Liaisons: Fashion and Furniture in the Eighteenth Century. New Haven: Yale Univ. Press, 2005. ${ }^{60}$; STYLES, J., \& VICKERY, A. Gender, taste, and material culture in Britain and North America, 1700-1830. New Haven. Yale Univ. Press. 2006.

${ }^{61}$ DOUGLAS, Mary, ISHERWOOD, Baron. 0 mundo dos bens: para uma antropologia do consumo. Rio de Janeiro: Editora UFRJ, 2004.

62 MCKENDRICK, Neil. "The Consumer Revolution of Eighteenth-Century England." In MCKENDRICK Neil, BREWER John e PLUMB J. H. (eds.), The Birth of a Consumer Society: The Commercialization of Eighteenth Century England. Bloomington: Indiana University Press, 1982. P. 9-33.

${ }^{63}$ WEATHERILL, Lorna. Consumer behavior and material culture in Britain, 1660-1760. S.I. Psichology Press, 1988.
} 
eles desempenhavam na sociedade. O papel social que tais profissionais possuíam é estratégico para a compreensão da disposição administrativa da cidade bem como da sua vida econômica e de seu arranjo social.

Justifica-se igualmente o estudo deste grupo social, pois, por muito tempo, eles foram excluídos dos campos de interesse dos trabalhos historiográficos, preocupados com as elites, ou apenas com a escravidão nas lavouras. As camadas médias urbanas, de homens livres pobres, ficavam assim num limbo, no qual se incluíam os oficiais mecânicos e os artífices em geral ${ }^{64}$.

Maria Helena Flexor foi uma das pioneiras nos estudos sobre a organização dos ofícios mecânicos, tratando tanto dos casos da Bahia como de São Paulo65. Também foram realizadas análises para esta temática para Minas Gerais, para citar breves exemplos, com os trabalhos de Ângela Brandão ${ }^{66}$ e José Newton de Coelho Meneses $^{67}$. Mônica Martins ${ }^{68}$ e Roberto Guedes ${ }^{69}$ fizeram estudos sobre o Rio de Janeiro. Para o caso específico de São Paulo, ao lado do trabalho de Flexor, Antônia Terra Calazans Fernandes ${ }^{70}$, Daisy Ribeiro de Moraes Barros ${ }^{71}$, Elizabeth Darwiche Rabello $^{72}$, Amália Santos ${ }^{73}$, Maria Aparecida Borrego e Daniel Poletti ${ }^{74}$ fizeram suas

\footnotetext{
${ }^{64}$ Cf. MENESES, José Newton Coelho. Artes fabris \& ofícios banais: o controle dos ofícios mecânicos pelas Câmaras de Lisboa e das Vilas de Minas Gerais (1750-1808). Belo Horizonte: Fino Traço, 2013.

${ }^{65}$ FLEXOR, Maria Helena Ochi. Oficias mecânicos na cidade do Salvador. Salvador: Prefeitura Municipal do Salvador, 1974; FLEXOR, Maria Helena Ochi. O Trabalho Livre em São Paulo - Século XVIII. Tese de Doutorado - São Paulo: FFLCH/USP, 1984.

${ }^{66}$ BRANDÃO, Angela. Das pontes aos castiçais: a produção de mobiliário artístico em Minas Gerais do século XVIII e os ofícios mecânicos. Revista Científica/FAP, v. 4, n. 2. Curitiba: jul./dez. 2009, pp. 50-66.

67 MENESES, José Newton Coelho. Artes fabris \& ofícios banais: o controle dos ofícios mecânicos pelas Câmaras de Lisboa e das Vilas de Minas Gerais (1750-1808). Belo Horizonte: Fino Traço, 2013.

68 MARTINS, Mônica de Souza N. Entre a cruz e o capital: as corporações de ofício no Rio de Janeiro depois da chegada da Família Real (1808-1824). Rio de Janeiro: Garamond Universitária, 2008.

${ }^{69}$ GUEDES, Roberto. Ofícios mecânicos e mobilidade social: Rio de Janeiro e São Paulo (sécs. XVII-XIX). Topoi, v. 7, n. 13, jul.-dez. 2006, pp. 379-423.

70 FERNANDES, Antônia Terra de Calazans. Memórias de ofício. São Paulo: Tese de Doutorado FFLCH/USP, 1997.

${ }^{71}$ BARROS, Daisy Ribeiro de Moraes. Um século dos ofícios mecânicos na Vila de São Paulo. Dissertação de Mestado: FFLCH-USP, 1982, p.97.

72 RABELLO, Elizabeth Darwiche. Os ofícios mecânicos e artesanais em São Paulo na segunda metade do século XVIII. Revista de História, n. 112, 1977, p. 575-588.

${ }^{73}$ SANTOS, Amália Cristóvão dos. Em obras: os trabalhadores da cidade de São Paulo entre 1775 e 1809. 2013. Dissertação (Mestrado em História e Fundamentos da Arquitetura e do Urbanismo) - Faculdade de Arquitetura e Urbanismo, Universidade de São Paulo, São Paulo, 2013.

${ }^{74}$ POLLETI, Daniel Nogueira. Relatório de Iniciação - Fapesp, 2011. Trabalho realizado no âmbito da pesquisa de Pós-Doutorado de BORREGO, Maria Aparecida de Menezes. Projeto de Pesquisa Jovem Pesquisador FAPESP - Espaço Doméstico e Cultura Material em São Paulo Colonial a partir do estudo de acervos do Museu Paulista/USP. Não Publicado. 2010.
} 
pesquisas sobre os ofícios mecânicos e artesanais ${ }^{75}$. Estas pesquisas são referências para nosso trabalho e com eles dialogaremos no sentido de compreender as semelhanças e diferenças entre os casos estudados.

Uma vez que tomamos a cultura material como foco central da análise histórica, isto implica na utilização um vasto manancial de fontes históricas ${ }^{76}$, num "arranjo calibrado de fontes", conforme predicado por Marcelo Rede ${ }^{77}$, de modo a equilibrar o uso conjunto dos documentos textuais e materiais de maneira a ressaltar a qualidade informativa de cada um, bem como compreender os seus limites.

Os artefatos musealizados são os principais documentos sobre os quais nos debruçaremos, porém, as fontes que trazem a materialidade doméstica descrita textualmente servirão para compreendermos estes tão raros objetos remanescentes quantitativamente através, por exemplo, dos arrolamentos de bens presentes nos inventários post-mortem dos habitantes de São Paulo e arredores ${ }^{78}$, dos maços de população que relacionaram os oficiais mecânicos de São Paulo e de várias outras modalidades fontes escritas oficiais, como documentos relativos à administração pública - processos jurídicos - e, na esfera religiosa, os processos de casamento.

Os relatos de viajantes são igualmente fontes importantes, pois guardam descrições dos costumes e do cotidiano paulista, bem como dos interiores domésticos e até mesmo das atividades profissionais urbanas. Essenciais também para o estudo das dinâmicas sociais da terra paulista são as fontes iconográficas, muitas vezes produzidas pelos próprios viajantes. Sobre estas, valemo-nos das propostas cautelares de Ulpiano Bezerra de Meneses a respeito da realização de uma História Visual feita com astúcia, que não reifique as representações visuais, mas as compreenda também como discursos visuais. Elas carregam, tal como os textos e a materialidade dos outros artefatos, grande carga de preciosas

\footnotetext{
75 BARROS, Daisy Ribeiro de Moraes. Um século dos ofícios mecânicos na Vila de São Paulo. Dissertação de Mestrado - FFLCH-USP, 1982; FERNANDES, Antônia Terra de Calazans. Memórias de ofício. São Paulo: Tese de Doutorado - FFLCH/USP, 1997; RABELLO, Elizabeth Darwiche. Os ofícios mecânicos e artesanais em São Paulo na segunda metade do século XVIII. Revista de História. São Paulo: USP, vol. LVI, n. 112, OutubroDezembro 1977, pp.575-588.

${ }^{76}$ MENESES, Ulpiano Toledo Bezerra de. "A cultura material no estudo das sociedades antigas." São Paulo: Revista de História, n. 115, 1983.

${ }^{77}$ REDE, M. História a partir das coisas: tendências recentes nos estudos de cultura material. Anais do Museu Paulista. Nova série, São Paulo, v. 4, p. 165-82, jan./dez. 1996.

${ }^{78}$ Para tanto, usaremos as transcrições de 87 inventários não publicados pertencentes a indivíduos de diversas faixas de riqueza e ramos profissionais entre 1740 a 1840 encontrados no Arquivo Público do Estado de São Paulo, bem como outros 17 inventários já publicados pela mesma instituição que correspondem à primeiras quatro décadas dos Setecentos. Agradecemos nossa orientadora por nos ceder estas transcrições.
} 
informações, caso as saibamos traduzir com as metodologias e parcimônia necessárias $^{79}$.

As pesquisas sobre cultura material - cabe dizer - já possuem longa tradição historiográfica, em grande parte por mérito da escola dos Annales, tendo entre os seus pioneiros Marc Bloch ${ }^{80}$, Fernand Braudel ${ }^{81}$, bem como os continuadores JeanMarie Pesez e Jacques Le Goff ${ }^{82}$. O uso de fontes materiais para os estudos históricos foi preconizado por tal linha de pesquisadores de maneira a enriquecer as análises sobre as realidades sociais diacrônicas e expandir a concepção que se tinha tradicionalmente da História e de suas fontes ${ }^{83}$. Diversas são as abordagens existentes sobre a cultura material, dada a sua amplitude de aplicação e o seu caráter transdisciplinar ${ }^{84}$. Por exemplo, as relações entre cultura material com 0 consumo e também com a memória foram trabalhadas por estudiosos das mais diversas áreas como Jean Baudrillard ${ }^{85}$, Arjun Appadurai ${ }^{86}$, Grant McKraken ${ }^{87}$ e Krzysztof Pomian 88

Um viés de análise bastante proeminente nos estudos de cultura material é o que busca ressaltar as cadeias de interação entre os corpos e os meios materiais

\footnotetext{
${ }^{79}$ MENESES, Ulpiano Bezerra de. Fontes Visuais, Cultura Visual, História Visual. Balanço provisório, propostas cautelares. Revista Brasileira de História. V. 23. N. 45, p. 11-36. 2003, p. 29. Bem como KOSMINSKY, Doris Clara. O olhar inocente é cego: a construção da cultura visual moderna. 2008. Tese (Doutorado)-Pontifícia Universidade Católica do Rio de Janeiro, Departamento de artes \& design, 2008. Em especial para as gravuras de viajantes europeus no Brasil, que utilizaremos largamente, vide as considerações de TRINDADE, Jaelson Bitran. O fantasma de Debret. Revista de História. Rio de Janeiro: Biblioteca Nacional, 7 jan. 2008 e sobre as dimensões indentitárias dos viajantes também em seus escritos CRUZ, Ana L. R. B. . As viagens são os viajantes: dimensões identitárias dos viajantes naturalistas brasileiros do século XVIII. História. Questões e Debates , Curitiba, v. 19, n.36, p. 61-98, 2003.

${ }^{80} \mathrm{BLOCH}$, Marc. Apologia da História ou O ofício do Historiador, Rio de Janeiro, Jorge Zahar, 2002

${ }^{81}$ BRAUDEL, Fernand. Civilização material, economia e capitalismo, séculos XV-XVIII: I. As estruturas do cotidiano. São Paulo: Martins Fontes, 1995.

82 PESEZ, Jean-Marie. Histoire de la culture matérielle. In: LE GOFF, J.; CHARTIER, R.; REVEL, J. (Ed.). La nouvelle histoire. Paris: Retz, 1978;

${ }^{83}$ Vide os trabalhos de Ulpiano Bezerra de Meneses instigadores aos estudos nesse sentido, bem como as definições de cultura material e seus desafios de emprego. MENESES, Ulpiano Bezerra de. O Objeto Material Como Documento - reprodução de aula ministrada no curso Patrimônio cultural: políticas e perspectivas. IAB/CONDEPHAAT, 1980; MENESES, Ulpiano Bezerra de. Fontes Visuais, Cultura Visual, História Visual. Balanço provisório, propostas cautelares. Revista Brasileira de História. V. 23. N. 45, p. 11-36, 2003.

${ }^{84}$ GONÇALVES, José Reginaldo Santos. "Teorias antropológicas e objetos materiais". Antropologia dos Objetos: coleções, museus e patrimônios. Rio de Janeiro: IPHAN / DEMU, Col. Museu, Memória e Cidadania. 2007, P. 20.

${ }^{85}$ BAUDRILLARD, Jean. 0 sistema dos objetos. São Paulo: Perspectiva, 2004.

${ }^{86}$ APPADURAI, Arjun (org.). A vida social das coisas: as mercadorias sob uma perspectiva cultural. Niterói, RJ: Editora da Universidade Federal Fluminense, 2008.

${ }^{87}$ MCCRACKEN, Grant. Cultura e consumo. Rio de Janeiro: Mauad, 2003.

88 POMIAN, Krzysztof. "Coleções" In: Enciclopédia Einaudi, vol.1. Memória/História. Porto: Imprensa Nacional/Casa da Moeda: 51-86, 1984.
} 
por eles produzidos, de maneira a aplicar teorias sobre a influência recíproca das técnicas do corpo e sua extensão em objetos (mise en objects). Este empenho foi especialmente realizado por estudiosos como Richard Sennett ${ }^{89}$, Jean Pierre Warnier $^{90}$ e Tim Ingold ${ }^{91}$, que se dedicaram, cada um em sua vertente específica, a explorar as fronteiras do conhecimento corporificado, bem como a importância do "saber-fazer", rumando em searas lançadas desde o começo do século XX por antropólogos como Marcel Mauss ${ }^{92}$. Procuraremos utilizar estas abordagens em nosso estudo de caso paulista, tendo a atenção como já ressaltar Marcelo Rede, que tal esforço advindo da antropologia hodierna é especialmente difícil de ser realizado para estudos diacrônicos, dada muitas vezes a escassez de fontes e a intangibilidade da cultura imaterial remota. Não obstante, é justamente realizando o esforço de dar atenção aos mínimos indícios sobre as interações entre os corpos e artefatos, presentes tanto nos próprios móveis como registrados em fontes iconográficas e textuais, que podemos apreender a corporificação dos objetos e a objetificação dos corpos, conferindo inteligibilidade ao capital simbólico subjacente a tais práticas, que informa a lógica, ou a economia, nos termos de Bourdieu, das distinções sociais ${ }^{93}$.

No primeiro capítulo realizaremos as análises mais centradas na materialidade do núcleo documental central de nossa pesquisa: o mobiliário doméstico presente no acervo do Museu Paulista. Buscando seguir a orientação teórica acima abordada sobre como abordar as fontes de cultura material, iremos extrair o máximo de informações a partir da materialidade dos objetos para então lançar mão de outros gêneros de fontes, como as textuais e iconográficas, de forma compreender a sua existência e conseguir, através de uma visão comparativa, lançar luz sobre a vida paulista.

Procuraremos observar as características intrínsecas dos móveis e com isso tentar compreender como foram produzidos e com quais ferramentas. A partir

\footnotetext{
${ }^{89}$ SENNETT, Richard. 0 artífice. Rio de Janeiro: Record, 2012

90 WARNIER, Jean-Pierre.Construire la culture matérielle. L'homme qui pensait avec ses doigts. Paris: Presses Universitaires de France, 1999, p. 21-35.

91 INGOLD, Tim. Trazendo as coisas de volta à vida: emaranhados criativos num mundo de materiais. Horiz. antropol., Porto Alegre, v. 18, n. 37, p. 25-44, June 2012.

92 MAUSS, Marcel. Sociologia e antropologia. São Paulo: Cosac Naify, 2003. Para uma visão geral sobre a temática, vide REDE, Marcelo. Estudos de cultura material: uma vertente francesa. Anais do Museu Paulista. São Paulo: Universidade de São Paulo, Museu Paulista, v. 8-9, 2000-2001. p. 281-292.

${ }_{93}$ BOURDIEU, Pierre. A distinção: crítica social do julgamento. São. Paulo: Edusp; Porto Alegre, RS: Zouk, 2007.
} 
desses primeiros indícios, faremos um esforço de contextualização tecnológica da sociedade que produziu esses objetos, atentando sobre suas mudanças pelas variações dos sistemas de objetos de que dispunham.

Tentaremos descobrir a proveniência dos materiais utilizados na produção do mobiliário que estudamos contando com o auxílio das técnicas de análise não destrutivas da Arqueometria, seja na Física Aplicada, seja nos exames dendrológicos da Biologia. Para realizar tais exames, contamos com o apoio de pesquisadores e especialistas nas áreas das Ciências da Natureza. Os dados obtidos foram cruzados com um vasto manancial de outras fontes como as próprias fichas descritivas das peças, mapas, inventários post-mortem, relatos de viajantes e documentação administrativa, além da bibliografia que tratou do extrativismo vegetal, da mineração, da pecuária e do período colonial. Assim, podemos compreender a materialidade das peças dentro do contexto da História Ambiental da colonização paulista, além da sintonia comercial da região com outros espaços produtores de matérias-primas ou mesmo do mobiliário que aqui era vendido e consumido.

Após esse primeiro capítulo, de caráter analítico, seguiremos a nossa tese estruturando-a através de capítulos orientados sempre pelas informações extraídas da perspectiva da cultura material, possamos alargar a compreensão sobre as ações humanas que foram vetorizadas por tais objetos. Ou seja, procuraremos fazer uma historiação através das cadeias de produção e consumo do mobiliário, desde a extração das matérias-primas que Ihes constituem até o seu consumo e legado ao longo dos séculos.

Havendo partido das análises mais densas sobre a materialidade das peças, no segundo capítulo procuraremos utilizar principalmente fontes escritas para tratar da produção do mobiliário.

Partindo das trajetórias individuais de possíveis produtores de móveis, para em um segundo momento abordar a temática de uma forma mais global, procurando articular os momentos produtivos com as dinâmicas político-econômicas do Império Português, além de lançarmos mão de comparativos com os contextos de outras localidades tanto do mundo lusitano quanto de outros países que contam com densa bibliografia sobre o tema no período, como a França e a Inglaterra. Articulando-se a essa visão global, procuraremos, em um jogo de escalas, descobrir quem eram os indivíduos responsáveis pela produção do mobiliário em São Paulo e o seu contexto 
social e econômico ao longo do tempo. Assim, podemos melhor compreender as facetas humanas na longa duração das práticas artesanais de produção do mobiliário, composto das curtas durações intercaladas de dezenas de artífices da madeira, utilizando, dentro dos limites da escassa documentação legada, aplicar o recurso metodológico da prosopografia e da história em rede, que nos permite, mesmo com fontes ralas, compreender as interconexões de indivíduos dentro da tessitura social.

Ainda que estejam necessariamente imbricados, dividiremos os momentos de produção e de consumo dos nossos objetos de maneira metodológica, dado o tipo de metodologia e discussão necessitar de atenções específicas. Sobre o consumo, procuraremos compreender a venda e compra do mobiliário ao longo da longa centúria em questão, buscando notar formas e locais de aquisição e as mudanças existentes nos padrões de consumo no período, bem como realizar a comparação adequada a outras localidades. Utilizando como fonte principal a análise comparada de inventários post-mortem, procuraremos compreender grupos de consumidores e tratar de casos específicos, buscando integrar dados quantitativos e qualitativos.

No capítulo final procuramos sintetizar as informações anteriores ao compreender a dinâmica de uso dos móveis primeiramente examinados em sua relação com o corpo e o seu uso social como elemento de distinção e como índice de mudanças sociais no período, das quais também foram vetores. Somente separamos o uso dos objetos do capítulo sobre o consumo, pois as problemáticas e metodologias para cada caso possuem diferenças. Se no capítulo anterior procuraremos mirar no fenômeno do consumo numa escala maior, para tratarmos do seu uso buscaremos exemplos de uso pessoal dos objetos consumidos, interconectando as configurações da materialidade dos objetos com as formas de ativação pelos seus usuários. Na interconexão do objeto/corpo/prática ao longo do tempo, poderemos compreender antropologicamente o fenômeno econômico do uso e as práticas de distinção social das quais os objetos são vetores e produtos, simultaneamente. 


\section{CAPÍTULO 1. Exames Formais e Técnicos}

Quantas coisas nos mostra a superfície que poderíamos usar, se as conhecêssemos?

José Antonio de Sáa4

\subsection{Exames Formais}

Neste capítulo, buscaremos tratar da tecnologia e materiais envolvidos na produção dos objetos musealizados, atentando para as ferramentas utilizadas ${ }^{95} \mathrm{e}$ as maneiras como foram confeccionadas as peças, para então lançar mão de outras fontes e metodologias que agreguem informações, conferindo, no conjunto, densidade para nosso estudo. Dividiremos este capitulo em duas grandes partes: primeiro os exames formais e técnicos visuais que realizamos tendo como base manuais de connoisseurs, artesãos e historiadores da cultura material e, segundo, nos exames arqueométricas que realizamos em parceria com especialistas das Ciências da Natureza, utilizando instrumentos e metodologias próprias, fornecendo informações materiais não observáveis a olho nu e cujos resultados buscamos problematizar historicamente.

Havendo realizado a análise formal e técnica das peças paulistas, buscamos a confirmação com a perícia de mestres artesãos portugueses que utilizam ainda hoje técnicas tradicionais. Tivemos a oportunidade de observá-los nas oficinas da

\footnotetext{
${ }^{94}$ SÁ, José António de, Compêndio de Observações que foram o plano da Viagem Politica, e Filosófica, que se deve fazer dentro da Pátria, Lisboa, Officina de Francisco Borges de Sousa, 1783, p. 47 Apud RAMINELLI, Ronald. Ciência e colonização: viagem filosófica de Alexandre Rodrigues Ferreira. Revista Tempo, v. 6, p. 157$182,1998$.

${ }^{95}$ Cecília Salles de Oliveira já chamara a atenção para a importância do estudo das ferramentas para a análise da cultura material e das próprias ferramentas compreendidas enquanto elementos materiais da cultura. OLIVEIRA, C. H. L. S. . Ferramentas: dimensões históricas e sociais. In: ABREU, Adilson Avansi de. (Org.). Quantos anos faz o Brasil?. 1a.ed.São Paulo: Editora do Universidade de São Paulo, 2000, v. , p. 18-19. Um dos raros trabalhos que encontramos sobre as ferramentas de marcenaria no Brasil é o de Rubens Matuck MATUCK, Rubens. Instrumentos Manuais de Carpintaria e Marcenaria (catálogo de exposição). São Paulo: Prefeitura do Município de São Paulo: Secretaria Municipal de Cultura. 1982. No mundo de expressão inglesa encontramos trabalhos com essa perspectiva em maior número, como HODGKINSON, Ralph, Tools of the woodworker. American Association for State and Local history. Technical Leaflet, no 119. 1979 e WELSH, Peter. Woodworking Tools, 1600-1900. Washington: Library of Congress. 2008.
} 
Fundação Ricardo Espírito Santo Silva (FRESS), em Lisboa ${ }^{96}$. Realizamos breves visitas à instituição no mês de Novembro de 2017, podendo adentrar as oficinas de marcenaria, entalhe, cinzelaria, fundição e lavragem de couro. Acompanhando as formas sincrônicas de produção e restauro de móveis na instituição lisboeta, pudemos traçar comparativos com as formas diacrônicas que se operaram no passado colonial brasileiro através também de fontes iconográficas como as gravuras feitas por Jean-Baptiste Debret (Paris, 1768 - Paris, 1848).

A possibilidade de termos presenciado e conversado com mestres artesãos que trabalham e ensinam na FRESS usando das técnicas e tradições de produção do mobiliário histórico foi uma oportunidade sem igual para termos melhor compreensão sobre os objetos históricos remanescentes presentes em coleções brasileiras, podendo resgatar parcialmente conhecimentos sobre formas de produção que se realizaram no passado colonial e foram em grande parte arrebatados por sucessivos processos de modernização e obliteração dos saberes artesanais $^{97}$. Igualmente aproveitamos essa oportunidade de perícia técnica para trocar os dados de análise que obtivemos do mobiliário paulista com os mestres portugueses, assim intercambiando conhecimentos sobre a materialidade do mundo Lusitano.

Das dezenas de objetos atribuídos aos séculos XVII ao XIX presentes no acervo do Museu Paulista ${ }^{98}$ e possivelmente confeccionadas na região de São Paulo selecionamos um conjunto de cadeiras para realizarmos as nossas primeiras observações, procurando testar os métodos de análise que delas extraíssem o máximo de informações. Os motivos que nos levaram a selecionar tais objetos relacionam-se primeiramente a uma questão de extensão temporal, dado o fato de que não só houve continuação no uso dos móveis dos seiscentos, bem se continuou

\footnotetext{
${ }^{96}$ A FRESS é um Museu-Escola de utilidade pública, voltada à salvaguarda do patrimônio histórico das artes decorativas e à preservação da memória artesanal portuguesa, promovendo cursos de formação e outras atividades educativas, oferecendo 18 oficinas de artes e ofícios tradicionais portugueses. Este empenho educacional visa perenizar transmissão do saber tradicional, património imaterial de saber-fazer, através dos mestres de ofício que atuam na instituição. Disponível em: http://www.fress.pt/Default.aspx?Pageld=83. Acesso em: 20/05/2018.

97 FERNANDES, Antônia Terra de Calazans. Memórias de ofício. Tese de doutorado em História Social, Faculdade de Filosofia, Letras e Ciências Humanas, Universidade de São Paulo, São Paulo, 1997.

${ }^{98}$ Seriam demasiadas peças para o exame pormenorizado que estabelecemos aqui, mas mereceriam, como indicado pela Profa. Dra. Vânia de Carvalho, análises em arranjos e séries com paralelismos não só de época, mas também de materiais, formas, usos etc. Cf. REDE, Marcelo. História a partir das coisas... op. cit.1996. P. 178. Utilizaremos a abreviação do número de Registro Geral no Acervo do Museu Paulista para nos referirmos ás peças. Os Números de RG completos encontram-se na listagem das fontes aos final.
} 
confeccionando móveis com a mesma forma das décadas anteriores no avançar dos novos estilos ${ }^{99}$. Em segundo lugar, devido ao fato dessas peças serem as mais próprias à análise pela sua própria materialidade, já que suas superfícies trazem as marcas de ferramentas mais salientes que nos móveis ulteriores. Igualmente elas nos permitem abranger os diversos materiais com que são confeccionadas: a madeira e couro, possuindo também partes metálicas. Por fim, elegemos estes móveis mais antigos para depois mobilizar outros artefatos, articulando-lhes problemáticas que transcendem aos objetos como sugere Ulpiano de Meneses ${ }^{100}$.

Após a observação dessas sete cadeiras do Museu Paulista, percorremos diversas outras coleções no Estado de São Paulo e também em Lisboa, observando outras categorias de móveis datados da mesma época. Usaremos fotografias de algumas delas para usar de comparativo sobre as técnicas empregadas na confecção de móveis no mundo português, buscando evidenciar como existem durações diferentes entre as técnicas de confecção e os estilos, bem como proximidades e distancias de tecnologias e técnicas entre os espaços lusos.

Para conduzirmos essas observações pontuamos algumas questões norteadoras de maneira a sempre repetir o procedimento em todas as peças. Distanciando-nos de uma abordagem classificatória rígida, buscando antes, de maneira experimental e tendo atenção ao percurso de aprendizado, ficar antes atentos às idiossincrasias das peças e a elementos novos que nos chamaram a atenção durante o percurso observativo sem que os houvéssemos antes cogitado, de maneira que nosso olhar não ficasse subsumido a concepções anteriores ${ }^{101}$. É justamente na observação indiciária que colhemos elementos inesperados sobre as peças que nos fazem levantar novos questionamentos e enriquecer a nossa análise.

\footnotetext{
${ }^{99}$ RODRIGUES, José Wasth. Mobiliário. As Artes plásticas no Brasil. Coleção brasileira de ouro. Rio de Janeiro: Ed. de Ouro, 1968. P.92.

${ }^{100}$ MENESES, Ulpiano Bezerra de. Do teatro da memória ao laboratório da História: a exposição museológica e o conhecimento histórico. Anais do Museu Paulista, n.1 vo. 2. 1994, p. 32.

101 Alguns trabalhos com semelhante atenção aos aspectos físicos das peças e às marcas das ferramentas impressas nas superfícies e estruturas dos objetos são: FLEMING, E. McClung. Artifact Study: A proposed Model. Chicago: University of Chicago Press Winterthur Portfolio, Vol. 9, 1974.; LYONS, Richard. Restoring Antique Furniture. A Complete Guide. Mineola, New York: Dover Publications, Inc. 1990; e WILLIAMS, Don. "Reading Tool Marks;" The Chronicle (Journal of the Early American Industries Association), September 2008.
} 


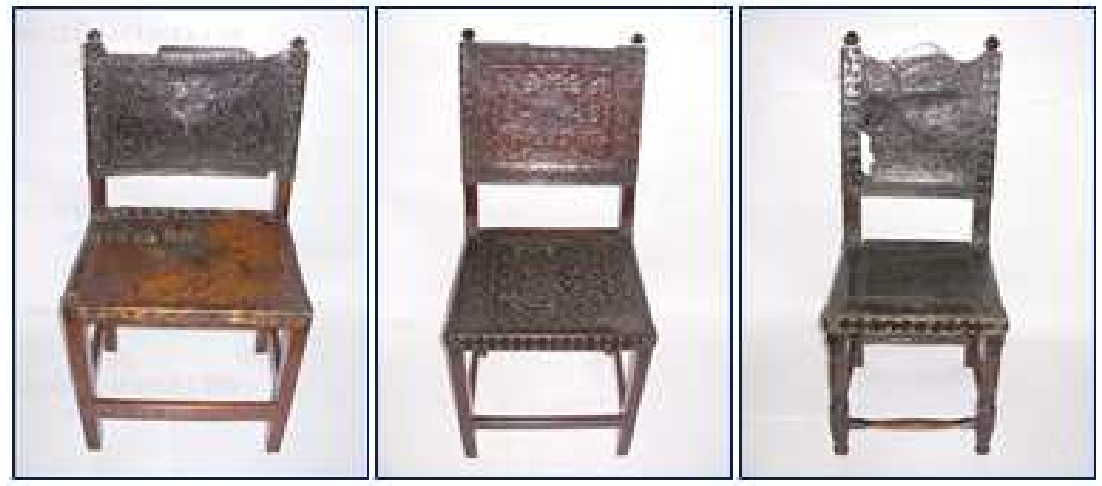

Figura 2: Visão frontal da cadeira RG 55 Figura 3: Visão frontal da Cadeira RG 60 Figura 4: Vista frontal da cadeira RG 61

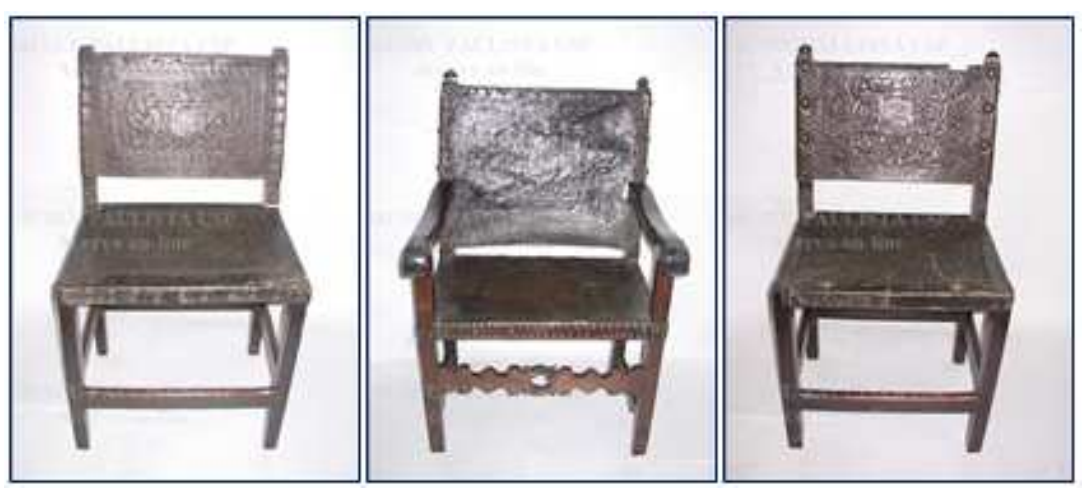

Figura 5:Visão frontal da cadeira RG 57 Figura 6:Visão Frontal da cadeira RG 559 Figura 7:Visão frontal da Cadeira RG 117

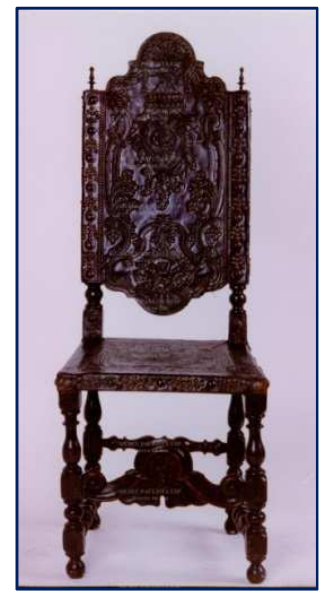

Figura 8: visão frontal da cadeira RG 553.

Os questionamentos foram:

1. Há partes metálicas nas peças?

2. Há pregos ou parafusos? 
3. De que tipo é a ensambladura?

4. Há marcas de ferramentas nas peças?

5. As marcas de corte apresentam regularidade?

6. Há polimento?

7. Há marcas de restauro?

8. Há mais de um tipo de madeira?

Sintetizando os resultados para posteriormente falarmos das especificidades, constatamos que:

1. Todas as cadeiras contam com partes metálicas, seja pelos adornos de pregaria, pelas tarraxas de fixação ou de pregos modernos.

2. Há pregos antigos para a fixação do couro e pregos modernos, sem cabeça saliente, que são evidentes sinais de restauro.

3. Constatamos vários tipos de ensambladura: o de furo e respiga com pino de madeira, varando as pernas, tanto únicos, como em pares. Estas aparecem em "T" (em inglês sub-tenon) (vide Figura 10), ou cega, a qual é arredondada nas peças com pernas torneadas (vide exemplo no mobiliário na Figura 51); e também em "L" (em inglês: barefaced) (vide Figura 9). Todas elas atestam a antiguidade dos móveis, já que modelos mais novos ou réplicas possuíam formas mais complexas e trabalhosas de ensambladura, como as que contam com ganchos de metal, encaixes em parafuso ou em pinos feitos com máquina.

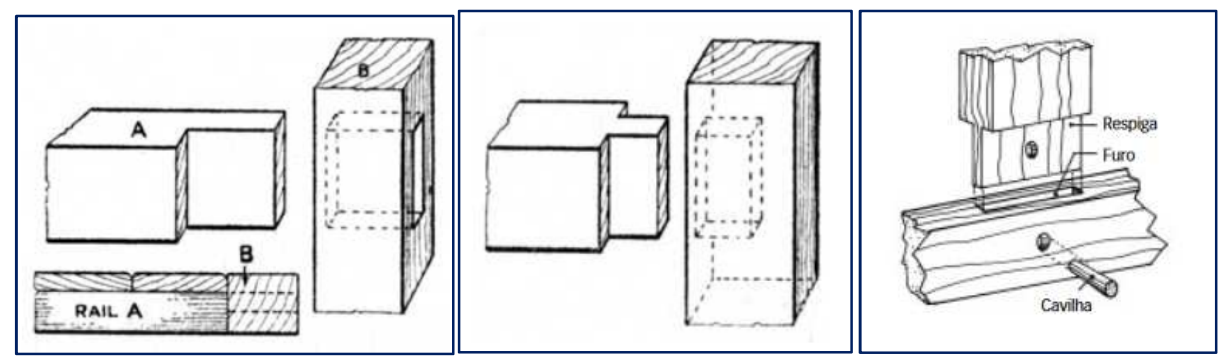

Figura 9: Junta em "L", ou barefaced ${ }^{102}$.

Figura 10: Junta em "T", ou sub-tenon ${ }^{103}$.

Figura 11: Ensamblagem em furo e respiga ${ }^{104}$.

\footnotetext{
102 Extraído de FARSHAM, William. Woodwork joints; how they are set out, how made and where used; with four hundred and thirty illustrations and a complete index of eleven hundred references. Philadelphia and London: J. B. Lippincott company, 1921. Disponível em https://archive.org/details/woodworkjointsho00fair. Acessado em 03 out. 2016.

${ }^{103}$ FARSHAM, William. Woodwork joints. Op.cit.1921.

104 Extraído de BASTOS, Celina; SOUSA, Maria da Conceição Borges - Mobiliário: artes plásticas e artes decorativas. Lisboa: IPM, 2004, p. 40. Pinto Maria Helena Mendes. Os Móveis e o seu Tempo: Mobiliário Português do Museu Nacional de Arte Antiga, Séculos XV-XIX. Lisboa: Instituto Português do Patrimônio Cultural, 1987. Este tipo de samblagem é observável já nos móveis de feição gótica com século XV e XVI em
} 
4. Há marcas de ferramentas em todas as peças, que nos servem como indícios dos equipamentos utilizados pelos marceneiros na sua feitura. Algumas marcas na madeira decerto são resultado de desgaste, batidas e choques ao longo dos anos de uso e manuseio dos objetos, por isso buscamos sempre privilegiar a análise das partes mais escondidas das peças, como as ilhargas na parte inferior do assento.

5. Podemos ver que há semelhança em muitas das marcas das cadeiras, indicando o mesmo tipo de ferramenta utilizada para a confecção de peças diferentes. Algumas peças apresentam marcas de ferramenta bastante simétricas, que são indícios de corte já mecanizado, por exemplo, com serras circulares, possivelmente fruto de restauração.

6. O polimento varia bastante entre as peças, sendo que algumas apresentam as superfícies das madeiras mais lisas e regulares, outras mais ásperas e com fragmentações. Todas as peças contam com algum acabamento nas partes externas, ainda que não seja em toda a superfície e haja variações de aspereza.

7. Todas as cadeiras apresentam uma ou mais marcas de restauro bastante marcantes e outras menos visíveis. Por exemplo, há sinais de cola, de substituições de pregaria, de substituição de fragmentos de couro, fixação de pregos modernos sem cabeça, entre outros.

8. No geral, as peças possuem uniformidade na madeira empregada, pois não há variação de cor entre as partes, ou marchetaria. Porém, em partes menos visíveis, como as junteiras debaixo do assento de alguns exemplares, notamos certa variação na tonalidade das madeiras em relação às pernas e travas, o que seria indicativo do uso de outras espécies de lenho.

Pela análise que fizemos das peças, colhemos alguns indícios sobre o seu processo de confecção pela própria posição da montagem dos componentes. Por exemplo, na cadeira de RG 61, é interessante o fato das madeiras que formam o assento parecem não estar em ângulo reto em relação ao chão como que se vergando em relação ao tamanho do couro.

Portugal, estendendo-se a sua utilização ao longo dos séculos, que a tornaram mais complexa e, principalmente, escondida. 


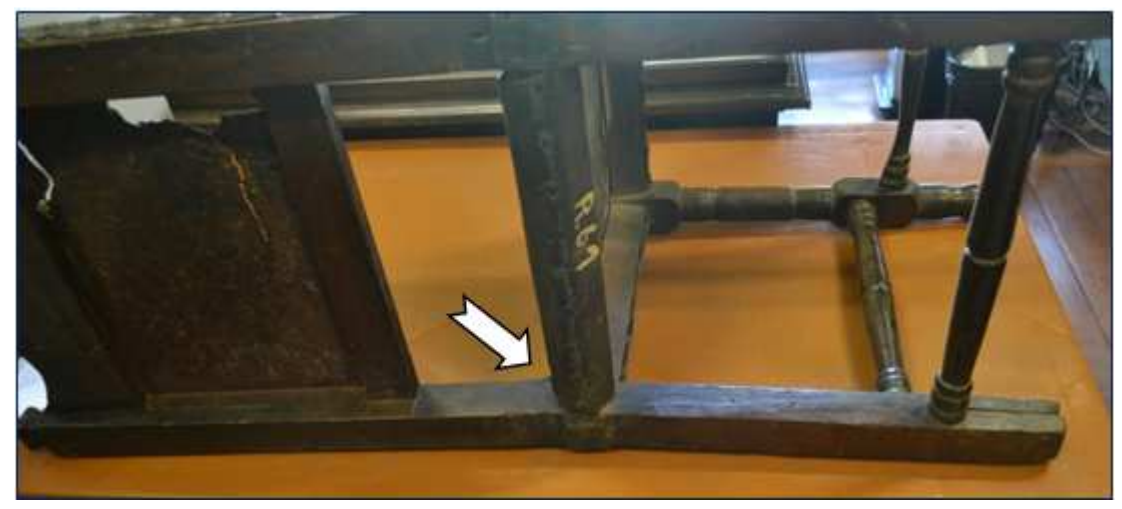

Figura 12: Cadeira de sola. RG 61. Acervo Museu Paulista. Foto do autor.

Extraímos disso não só o primeiro indício sobre a montagem da peça, mas também sobre a divisão social do trabalho envolvida nas etapas da produção. Ora, se a estrutura de madeira é inclinada para pregar o assento, isso nos faz conjeturar que o couro não era produzido no mesmo lugar que a madeira, e o projeto da cadeira e a pregação do couro se dariam em momentos diferentes. Para esclarecer tal questão, buscaremos investigar nos capítulos seguintes se o marceneiro comprava couro de um coureiro, ou se eles trabalhavam em parceria.

Certo, porém, é que estes artesãos tinham grandes diferenças de técnicas e ferramentas, com um "saber-fazer" específico e formado pela prática, como mostrara Franklin Pereira, percorrendo oficinas de couros contemporâneas portuguesas ${ }^{105}$. 0 especialista português divide em quatro etapas a preparação do couro e o processo de lavragem do desenho:
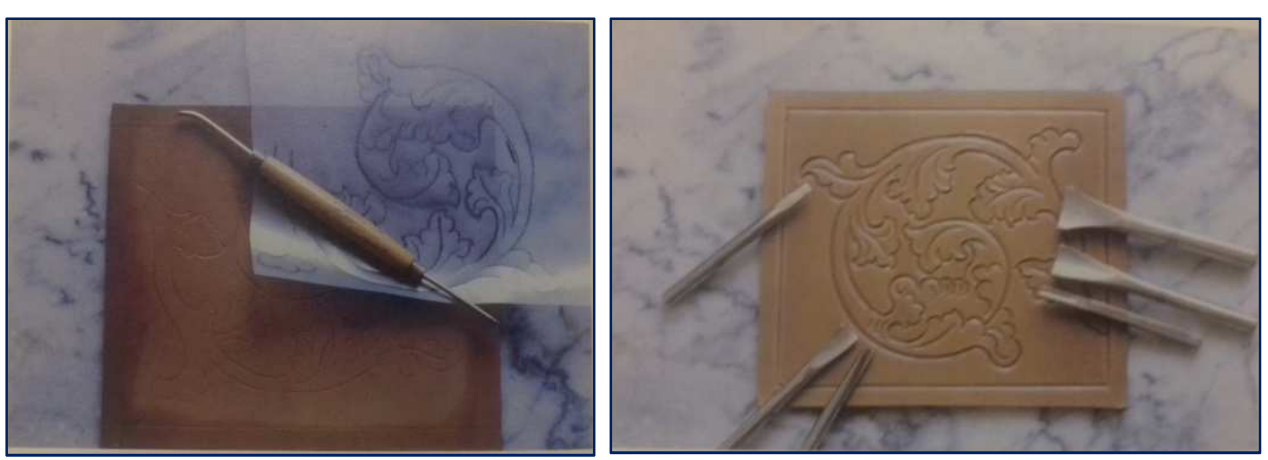

Figura 13: A) com o couro ainda úmido o desenho, elaborado em papel fino, é vincado usando um estilete.

Figura 14: B) os cinzeis abrem as linhas do desenho.

\footnotetext{
105 Imagens extraídas de PEREIRA, Franklin. O couro lavrado no mobiliário artístico de Portugal. Lisboa: Lello Editores. 2000, P. 164ss.
} 

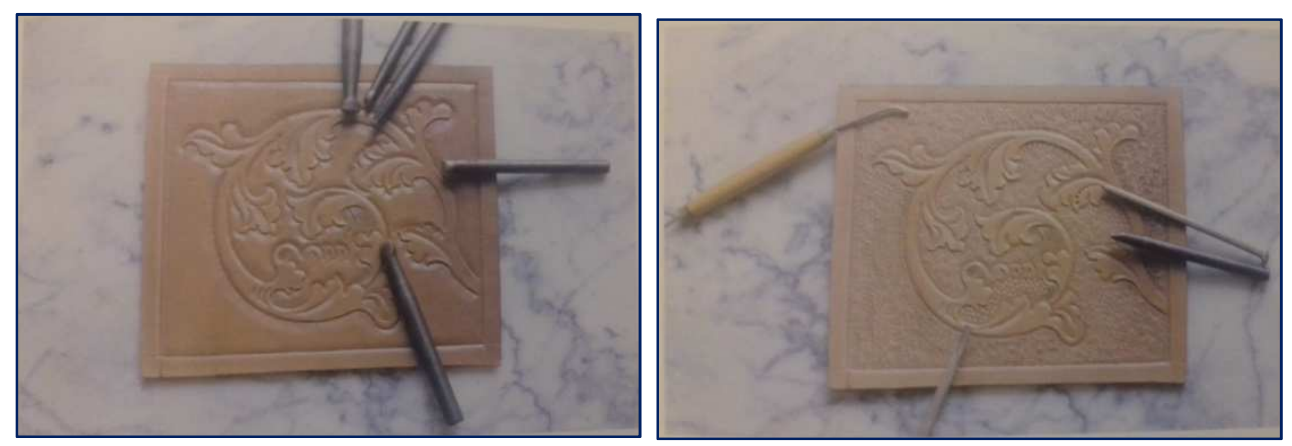

Figura 15: C) O rebaixador inclinado e os calcadores dão ênfase ao motivo.

Figura 16: D) Um ferro "fosco" dá textura ao fundo através de punções que granulam o couro, junto com arremate por cinzéis e modeladores.

Em nossa visita à FRESS pudemos presenciar como existem maiores semelhanças no trabalho dos lavradores de couro com o cinzeleiro no que tange ao universo de práticas corporais executadas pelas partes superiores dos braços e na postura do restante do corpo. Já no plano das mãos, as diferenças são enormes, a ponto de Richard Sennett chegar a classifica-las como "condições humanas especializadas", dada a interação das consciências materiais e dos gestos repetidos que são corporificados, e executados com tamanho grau de habilidade que permitem ao cérebro, durante o labor, fabricar, passando-se de Animal laborens, que executa mecanicamente o trabalho, para o Homos faber, criativo no desempenho ${ }^{106}$.
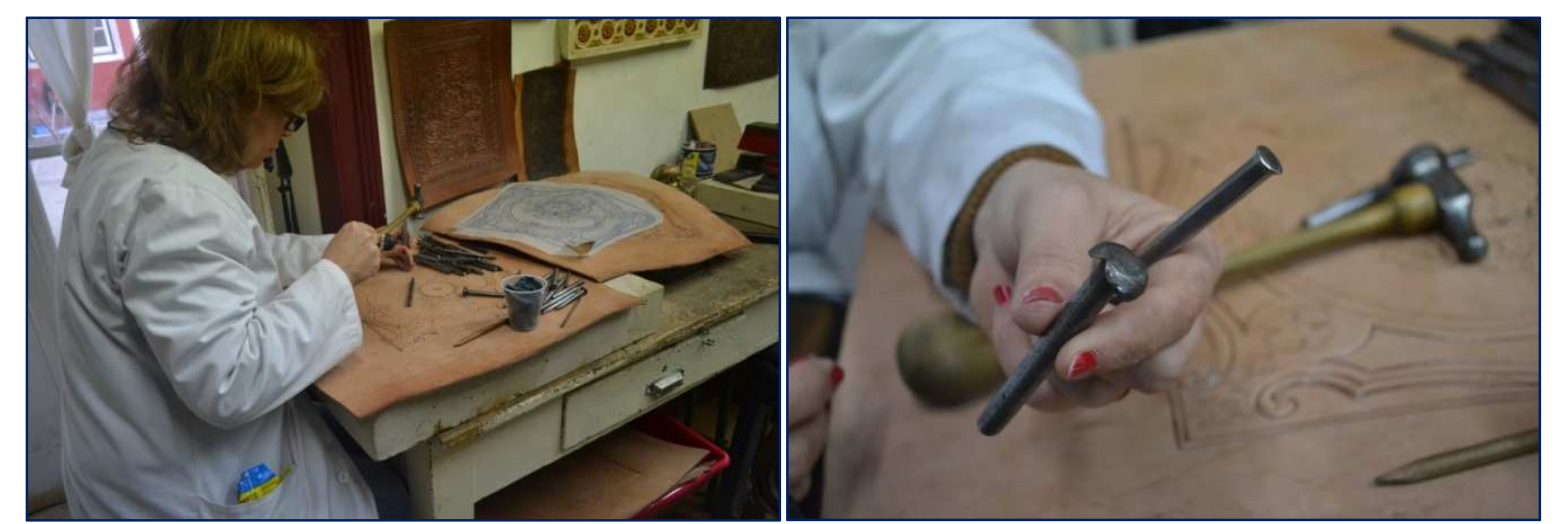

Figura 17: Lavração do couro.

Figura 18: A Mestra Beatriz Leitão Canha mostra alguns dos ferros de lavrar couro que utiliza.

Note-se como a cabeça vai ao longo do tempo se expandindo devido às marteladas. Como o couro é muito mais mole do que o latão trabalhado pelos cinzeladores, esses ferros não precisam passar por ser muito duros, por isso se expandem com maior facilidade do que os utilizados no trabalho com madeira e metal, os quais precisam passar por processo de eletrólise para ganharem mais

\footnotetext{
${ }^{106}$ SENNETT, Richard. O artífice. Rio de Janeiro: Record, 2012. P. 16
} 
resistência. Antes do advento da eletrólise, como explicou o Mestre Arthur de Sousa, os antigos ferreiros, bem como os cinzeladores e entalhadores precisavam ser peritos na forja para conseguir um metal mais resistente - o aço - mas que não passasse por uma temperatura demasiado elevada, a qual o torna rijo demais, correndo o risco de trincar e lascar com as batidas.

Assim, um artesão perito também precisava fazer ou demandar ao ferreiro uma ferramenta de boa qualidade. Note-se também nesta imagem o cabo do martelo utilizado pela mestra correeira Beatriz Leitão Canha ele possui na ponta uma forma oval que se adapta à mão do artesão, estreitando-se até a outra extremidade onde está a cabeça de metal. Com este formato adaptado torna-se muito mais ergonômico o trabalho de martelar com cuidado e repetição toda a superfície dos couros a servir de revestimento para os móveis, seja como espaldares e assentos de cadeiras, seja como tampos de mesas, e cobertura de canastras e arcas, entre outros.

É necessário fazer verdadeira Arqueologia do Saber a respeito dessas técnicas, e por extensão daquelas praticadas no Brasil colonial, para compreender a sua historicidade ao invés de atribuir gratuitamente a qualidade de "técnicas tradicionais portuguesas". Por exemplo, encontramos no Livro $1^{\circ}$ dos termos de mestres fabricantes de nova invenção o requerimento do seguinte artífice ${ }^{107}$ :

Debaixo das mesmas condições (...) sujeita Felipe Mallone, de Nação Inglesa, assistente nesta Cidade, Mestre Surrador de Couros por vários modos com mais perfeição com que se costumam preparar neste Reino; sabendo raspa-los e dar tintura às peles, conveniente para todas as espécies de Obras na forma que se pratica em Inglaterra, e particularmente em Londres, onde teve Estabelecimento da dita loja: como também ensinar um aprendiz, o qual por ele dito, será apresentado na Junta em cada um ano (...) 6 de novembro de 1766.

Podemos ver o Mestre cinzeleiro Arthur Sousa realizando seu trabalho nestas figuras. Afixando a peça de latão dourado em um semicírculo de gesso, este por sua vez apoiado uma plataforma de madeira côncava sobre a mesa com um composto de cera e cola que é aquecido para afixar a peça enquanto recebe a moldagem com as pontas do cinzel.

\footnotetext{
${ }^{107}$ ANTT. Junta do Comércio, Termos de licença para o estabelecimento de fábricas. "Livro 1o dos termos de mestres fabricantes de nova invenção e outros". 1761 a 1796. PT/TT/JC/A-C/2/1.
} 

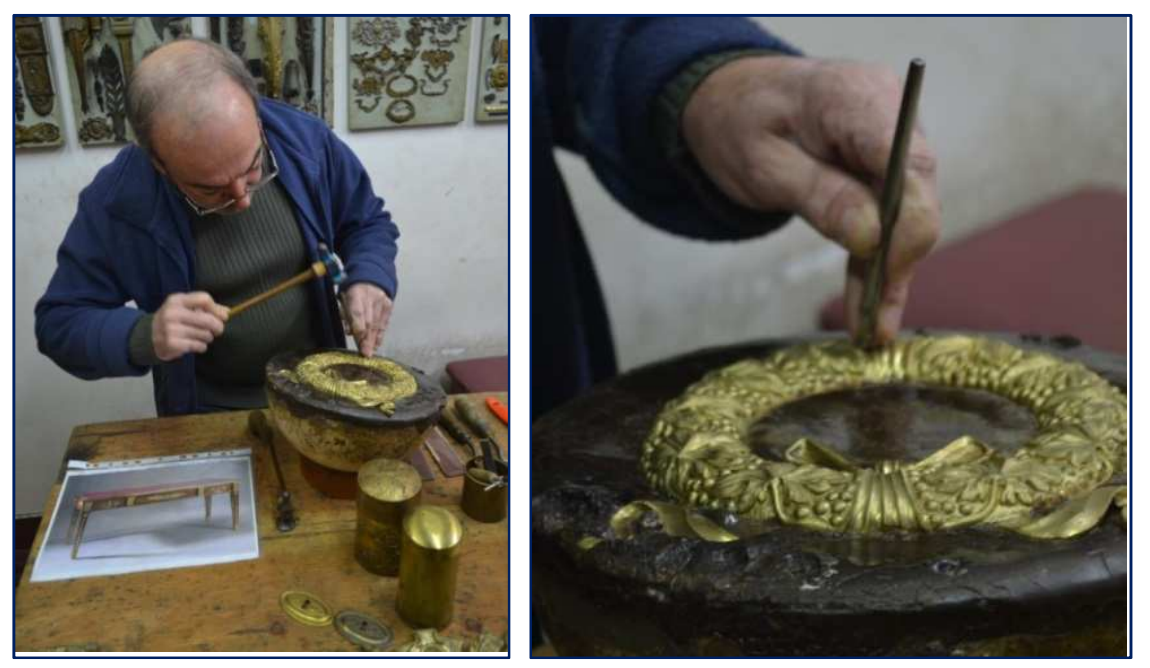

Figura 19: Mestre Arthur de Souza realizando a cinzelagem. fotografia do autor. Figura 20: Detalhe do trabbalho. fotografia do autor.

Reparemos a maneira como ele segura o martelo com a ponta dos dedos de maneira a aplicar golpes suaves, mas certeiros, de maneira a não perfurar a fina espessura da peça e não gerar saliências demasiadamente profundas ou díspares. A outra mão segura o cinzel igualmente de maneira idiossincrática, resultado da adaptação de anos de prática. O dedo indicador e o polegar seguram o cinzel, enquanto o dedo médio apoia-se na superfície da peça, servindo de guia para o cinzel não escapar para os lados. Notemos ainda como a postura de seus ombros é ereta e o pescoço levemente inclinado para frente, postura que a prática ensina como maneira de evitar excessivo esforço repetitivo durante longas horas de trabalho. São essas posturas cotidianas que, para a percepção apurada dos velhos iniciados na profissão revelam-se marcas distintivas da experiência e discriminantes do estatuto profissional dos indivíduos, tal como observara Bourdieu ${ }^{108}$.

Desta maneira, adiantando a discussão que no próximo capítulo teremos sobre as condições sociais de produção nas quais os artífices paulistas viviam, devemos ponderar a apreciação um tanto generalista de Maria Helena Flexor, quando afirma que ${ }^{109}$ :

Os trabalhos mecânicos estavam ligados estritamente à habilidade manual, embora fosse totalmente imbuído de processos empíricos herdados, reforçada pela observação e práticas contínuas, sem preocupação científica de nenhuma ordem ou racionalização das atividades. Assim, os processos de trabalho mecânico baseavam-se quase que

\footnotetext{
${ }^{108}$ BOURDIEU, Pierre. A distinção: crítica social do julgamento. São. Paulo: Edusp; Porto Alegre, RS: Zouk, 2007.

${ }^{109}$ FLEXOR, Maria Helena Ochi. Ofícios, Manufaturas e Comércio. In SZMRECSÁNYI, Tamás. História Econômica do Período Colonial. 1993. p. 190.
} 
exclusivamente na tradição, portanto sem regras escritas, do costume corporativo europeu, com raríssima inovações. Estas, quando apareciam, eram provocadas pelas condições locais que, na maioria dos casos, provocavam retrocesso em vez de avanços. E isso não ocorreu só em São Paulo, como também na Bahia. Faltava, igualmente, incentivo da Metrópole.

Tendo em conta esses primeiros indícios de produção dos móveis, recorremos a manuais de marcenaria que traziam explicações sobre a ordem de construção e fotos comparativas sobre os sinais deixados na madeira pelas várias ferramentas de uso contínuo entre este período e a atualidade ${ }^{110}$.

Esquematicamente começa-se pelas mais longas peças do conjunto, que são as barras verticais posteriores, as quais formam tanto as pernas traseiras quanto as laterais do espaldar. Unem-se a elas o cachaço, ou cimalha do recosto, bem como a barra inferior do respaldar. Juntam-se ainda as travessas traseiras e as ilhargas laterais e posterior do assento. Finaliza-se com a montagem das pernas, aba e travessas frontais. Preparada a armação da cadeira, ocorre a aplicação do couro tanto no assento quanto espaldar, fixados com pregos tanto nas laterais do espaldar, quanto nas partes laterais ou inferiores, escondidas, das ilhargas.

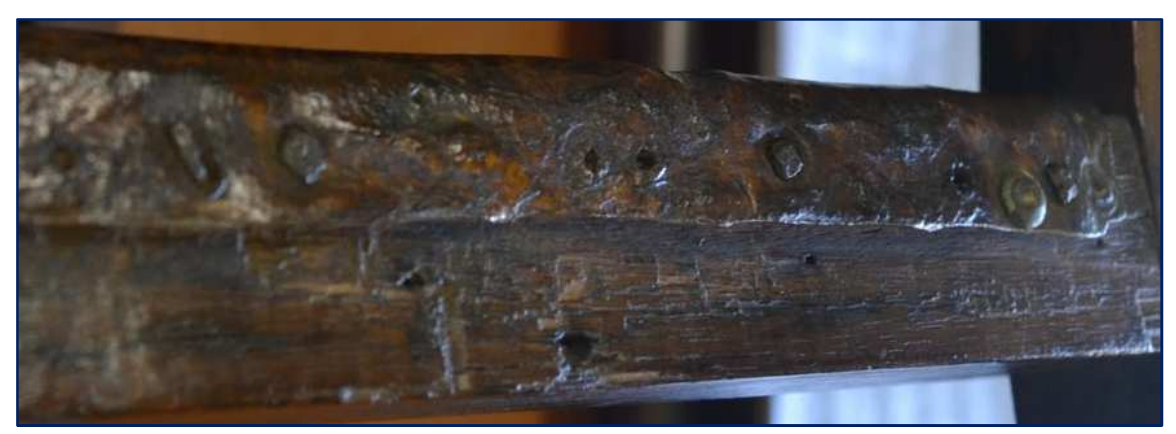

Figura 21: lateral da cadeira de sola RG 55, onde se pode ver os pregos de afixação.

\footnotetext{
${ }^{110}$ Utilizamos para estas análises a terminologia encontrada em MATUCK, Rubens. Instrumentos manuais... Op. cit. 1982. Baseamo-nos para estas observações das peças em LYONS, Richard. Restoring Antique Furniture. A Complete Guide. Mineola, New York: Dover Publications, Inc., 1990, em MOUTINHO, Stella Rodrigo Octavio; PRADO, Rúbia Braz Bueno do.; LONDRES, Ruth Rodrigo Octavio. Dicionário de artes decorativas e decoração de interiores. Rio de Janeiro: Lexikon. 2011.
} 


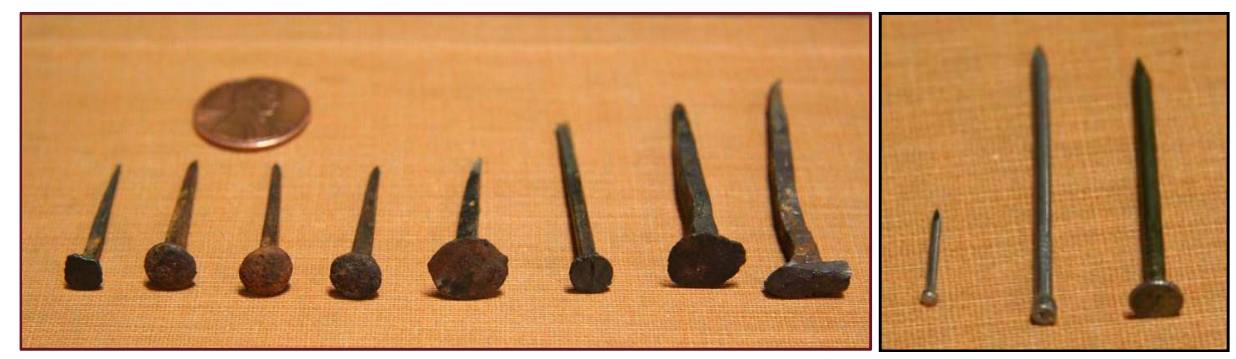

Figura 22: pregos antigos e irregulares. Figura 23: pregos modernos ${ }^{111}$.

Exemplos de pregos utilizados para a fixação dos couros e detalhe da lateral do couro do assento da cadeira RG 55. Vemos semelhantes pregos pré-industriais à esquerda, e à direita temos pregos modernos, uniformes e de aço, assim prescindindo de cabeça alargada para suportar o choque dos martelos.

Como vemos pelas fotos a seguir, algumas cadeiras contam com juntas unindo as ilhargas laterais à traseira e às pernas. Elas servem para reforçar $o$ conjunto evitando que as pernas fiquem bambas, pois, do ponto de vista ergonométrico, essa é a parte da cadeira que recebe o maior peso do corpo do indivíduo. Apesar de escondidas, revelam esmero na feitura, já que possuem curvatura como de moldura, além de contar cada uma com quatro pinos de madeira para a fixação. Parece-nos que ambas as juntas são casos de restauro, dadas as finas marcas de corte ao longo da curvatura são bastante regulares, sinal do uso de maquinário mecânico, discrepante dos dois exemplos com pequenas irregularidades das peças RG 58 e RG 559.

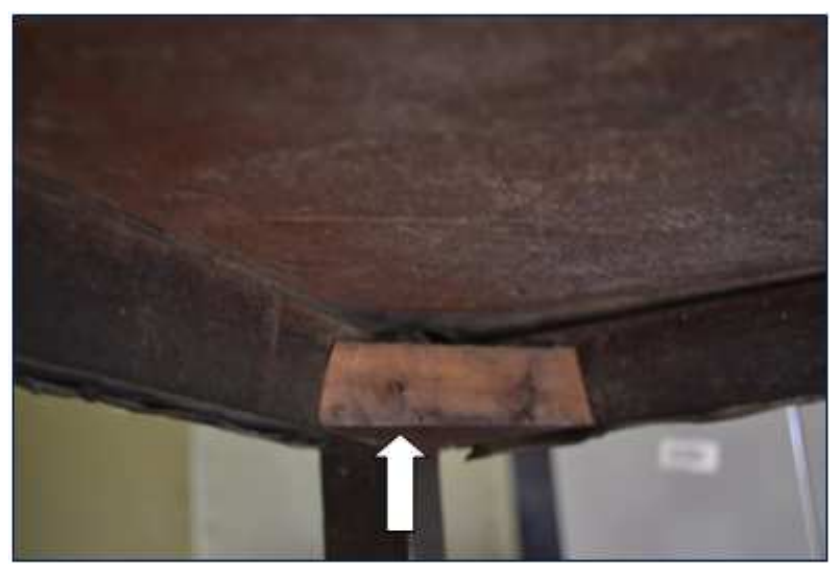

Figura 24: Cadeira de sola. RG 60.Foto do autor.

111 Extraído de: MELCHERT, Ken. The Humble Nail - A Key to Unlock the Past. Disponível em: https://www.harpgallery.com/library/nails.htm. Acesso em 28/04/2018. 


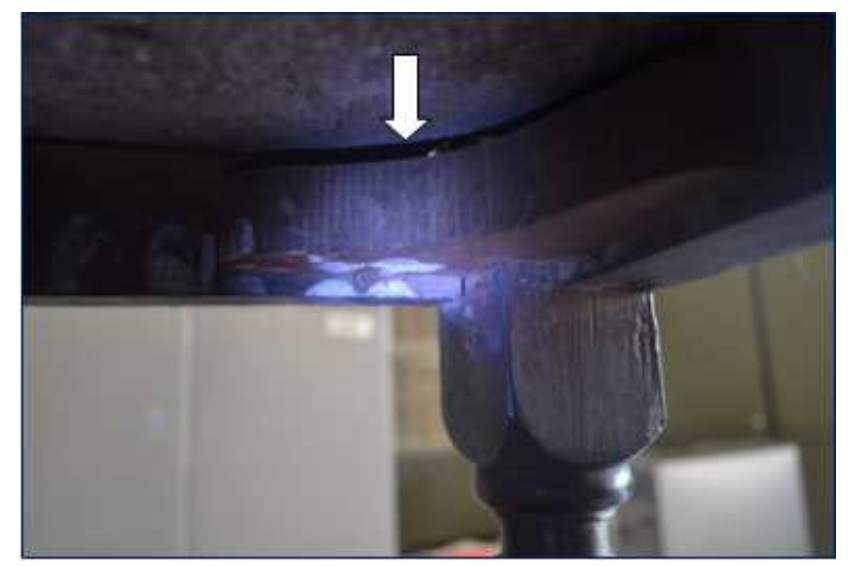

Figura 25: Cadeira de sola. RG 553. Foto do autor

As marcas na madeira funcionam como impressões digitais das ferramentas utilizadas. Vemos marcas de serras de mão nos topos das pernas frontais da cadeira RG 55. Este é um indício por meio do qual podemos diferenciar esses móveis daqueles feitos no período industrial, pois as marcas deixadas pelo corte de serra de fio reto manual são disformes, seguindo o ângulo variável de corte proveniente da mão do artesão.

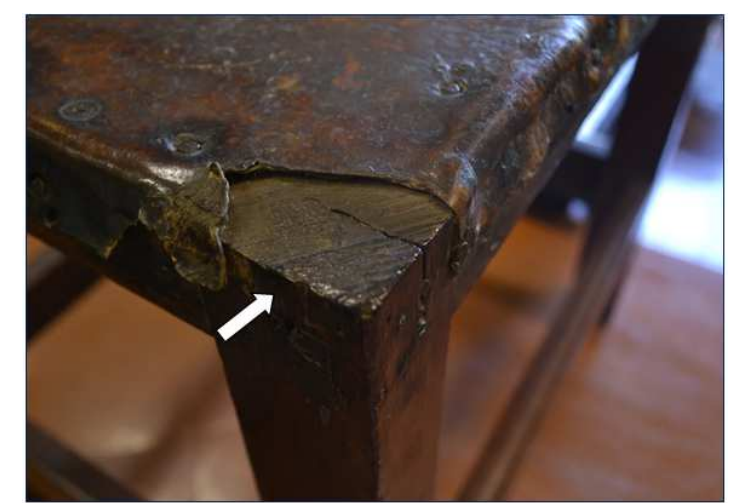

Figura 26: Cadeira de sola. RG 55. Foto do autor.

Apesar de haver vários tipos de serras, é possível que as marcas sejam de serra de costa, utilizada no trabalho mais delicado. Esta ferramenta ficava fixa na banca do marceneiro, conferindo maior precisão, sendo que o seu cabo é inclinado em relação à lâmina como solução ergonômica para melhor eficiência do corte.

As marcas rugosas da madeira nas partes internas das travas e ilhargas seriam indício de que o preparo das cadeiras era mais esmerado nas partes mais visíveis, ao passo que os pontos obscuros não mereciam o mesmo cuidado de acabamento e envernizamento. Parece que não houve o trabalho de aplainar as 
marcas do desbastamento da madeira, processo que deixa visíveis as ásperas fibras repartidas do tronco.

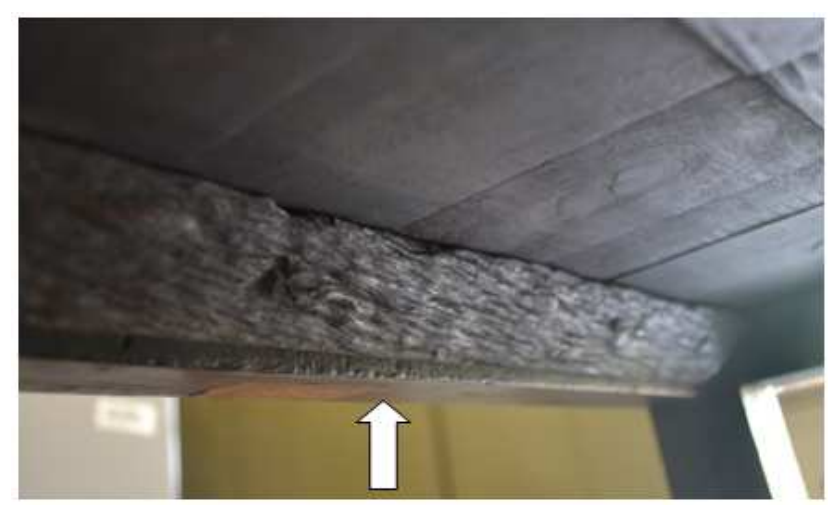

Figura 27: Cadeira de sola. RG 57. Foto do autor.

$\mathrm{Na}$ feitura das mechas de ensambladura sejam as cegas ou as vazadas, utilizava-se a serra de bico, que possuía a extremidade mais fina para o corte do orifício, ou as próprias goivas. Também se lançava mão de um tipo de formão chamado bedame para cavocar as madeiras. Não conseguimos ver as marcas internas na ensambladura para precisar o tipo de ferramenta utilizada para o corte, mas a se julgar pela trava frontal, ou bilharda, da cadeira RG 662, acreditamos que 0 corte tenha sido realizado com serra e depois limado, deixando a madeira com pequenas rebarbas para fora.

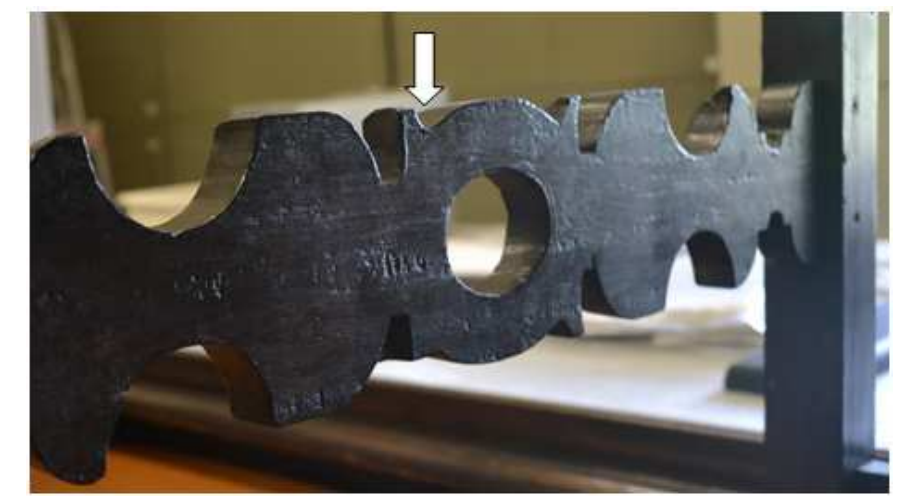

Figura 28: Cadeira de sola. RG 559. Foto do autor.

Vemos também nesta cadeira de sola as marcas de enxó ou mesmo de plaina deixadas nos ângulos das prumadas traseiras, que são compostas das pernas traseiras e dos espaldares. O ângulo de até $10^{\circ}$ no espaldar permite mais conforto para o usuário da cadeira, evitando que a posição de suas costas fique totalmente ereta. Ainda assim, de uma maneira geral, essas cadeiras deviam ser bastante desconfortáveis pelo assento e espaldar duros e a configuração retilínea, não configurada para o conforto do corpo, como viriam ser as cadeiras, poltronas e marquesas de pernas baixas em galbarda (cabriolet) ao gosto do Rococó. 


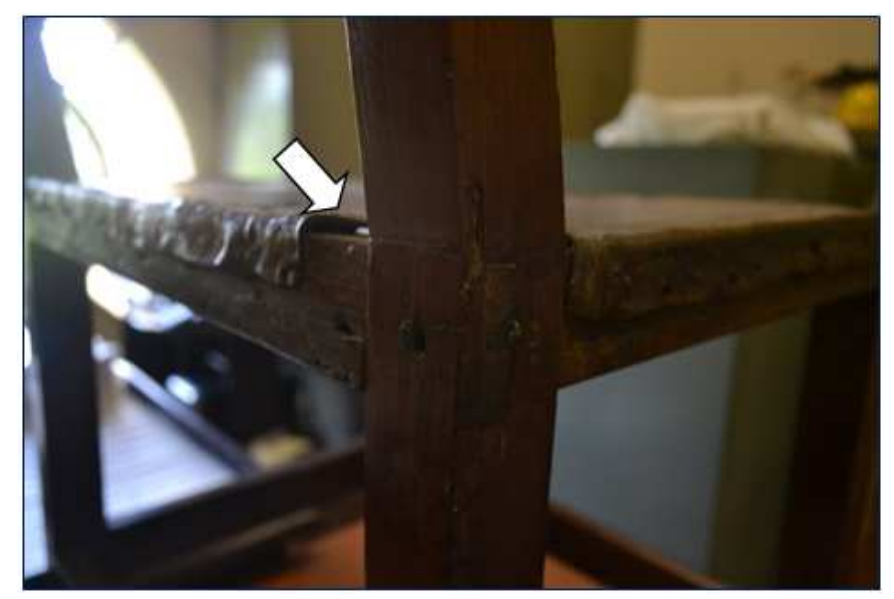

Figura 29: Cadeira de sola. RG 55. Foto do autor.

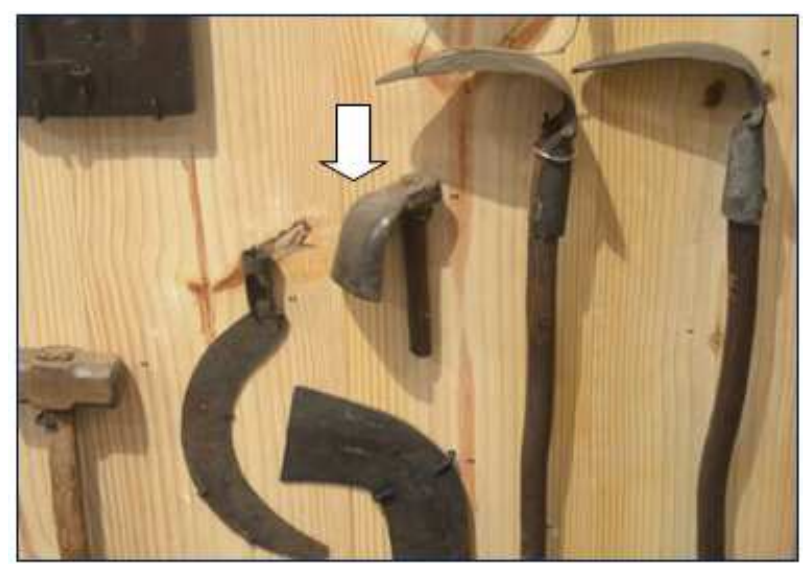

Figura 30: Enxó. S.d. Museu da Cidade de São Paulo. Exibida durante a exposição "A Mão do Povo Brasileiro" (2016-2017) no MASP. Fotografia do autor.

Thomas Ewbank (1792, Durham, Inglaterra - 1856, Nova York, EUA), atento observador da materialidade e das práticas no interior do Brasil, notou em sua viagem de 1846 que $^{112}$ :

A enxó é utilizada com muita habilidade, como substituta do machado para desbastar vigas e também em lugar da plaina, para alisá-las. Os fabricantes de rodas preparam plainas e raios com ela e os fabricantes de cadeiras e carros não podem também passar sem tal instrumento. Tratase de uma ferramenta universal e que por sua utilidade equipara-se ao martelo.

Quanto à pregaria graúda, presente na cadeira RG 117 (8 no encosto e 6 no assento), a posição dessas pregas no assento, bem na região onde as pernas repousam, e a sua dimensão $(0,8 \mathrm{~cm}$ de altura por $2,3 \mathrm{~cm}$ de circunferência)

\footnotetext{
${ }^{112}$ EWBANK. Thomas. Vida no Brasil. Belo Horizonte: Itatiaia; Edusp, 1976.
} 
reforçam a suposição de que este era um móvel bastante desconfortável para 0 usuário.

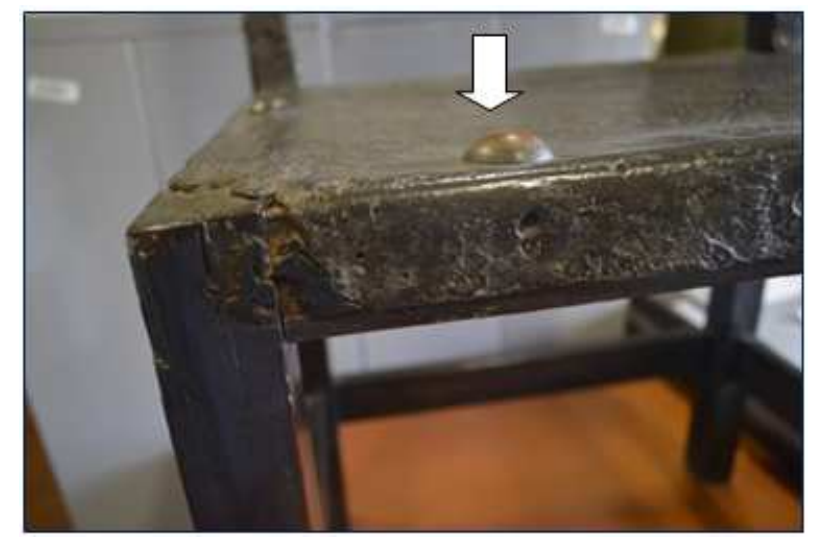

Figura 31: Cadeira de sola. RG 117. Foto do autor.

Infelizmente não dispõe o acervo de nenhum exemplar solto de pregaria para que pudéssemos analisar detalhe de como eram feitas. Notamos visualmente que existem diferenças de coloração e tamanho entre as pregarias das cadeiras, bem como entre os pregos de fixação. Buscamos então aproximar um pequeno e fraco imã - de forma a não causar dano nas peças - para conferir se o metal de que eram feitas imantava. Notamos que algumas imantavam e outras não, demonstrando que eram de latão (CuZn). A aproximação com o imã na pregaria graúda de algumas cadeiras, como a RG117 evidenciou algo ainda mais interessante: no topo da semicircunferência que constitui a pregaria ocorria leve imantação e no restante da superfície ela não ocorria. Isso indica que tais pregarias possuíam a haste e ponta de ferro e a "casquinha" era aplicação de latão dourado. De fato, faz sentido que se utilizassem diferentes metais para a confecção desses elementos, pois o latão é mais mole do que o ferro para que fosse pregado no grosso couro e na dura madeira baiana.
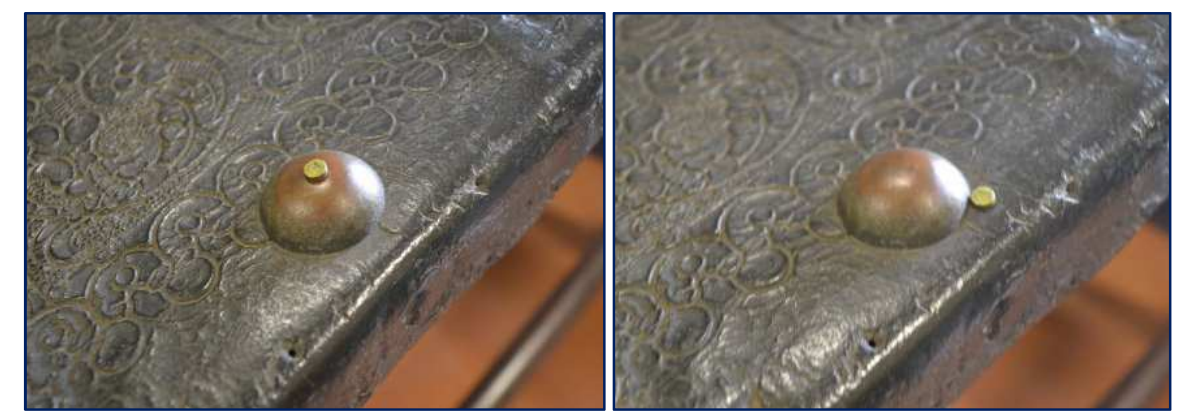

Figura 32 Cadeira de sola. RG 117. Detalhe do ímã sobre a pregaria. Foto do autor 
Figura 33: Cadeira de sola. RG 117. Detalhe do ímã na lateral da pregaria, sem ser atraído. Foto do autor

Note-se como no centro da pregaria o imã se mantem, enquanto o colocamos nas laterais não ocorre atração.

A confecção de tal pregaria, que combina características funcionais de pregadora com as estéticas de adorno, é menos banal do que parece a um primeiro olhar e, a julgar pela irregularidade dos pregos de ferro fundido de fixação, feitos sem a necessidade de simetria, revelariam ser um desafio de habilidade aos artesãos da época ${ }^{113}$.
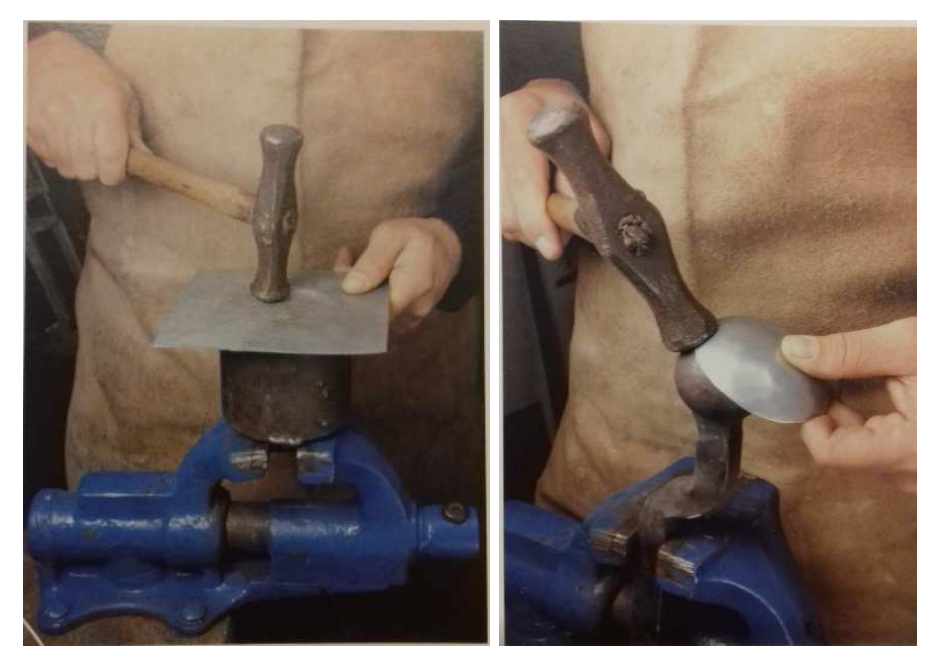

Figura 34: chapa de metal sendo moldada pelas marteladas Figura 35: acabamentos das bordas ${ }^{114}$

No detalhe vemos como poderia ser o processo de confecção dessas peças, no exemplo moderno com técnica tradicional de um casquete esférico de latão, Embora tenha dimensões maiores do que o da pregaria, mas com permitindo o comparativo. Note-se que eram necessárias ferramentas especiais, como o martelo de embutido encima de uma superfície circular oca, onde o metal era batido até adelgar e alargar, tomando o contorno desejado e ser destacada da chapa quando ficasse suficientemente fino. Depois, era martelado até sua superfície ficar igualada sobre um tás em formato de bola apoiado à bancada com uma morsa ou torno, ou

\footnotetext{
113 Devemos ressaltar que o latão é uma liga metálica que também tem qualidades dúcteis, e poderia ser também fundido através de molde. ARES, José Antonio. O Metal: Técnicas de conformação, forja e soldadura. Editorial Estampa, p. 71.

${ }^{114}$ Extraído de ARES, José Antonio. O Metal: Técnicas de conformação, forja e soldadura. Editorial Estampa, p. 71.
} 
ainda a outros tipos de apoio para peças de bancada, como os barriletes, sargentos e cancros ${ }^{115}$.

Para a medição das ensambladuras, notamos incisões com lâminas finas feitas com instrumentos de medição a régua, esquadro, prumo ou o graminho. $O$ fato de 0 artesão ter deixado as marcas de medição nas partes externas da madeira indica a forma de visualização e utilização dessas peças ${ }^{116}$. 0 madeiramento não devia ser destaque dessas cadeiras pela sua fineza de acabamento, posto que o centro das atenções dos observadores decerto era o espaldar e assento lavrados.

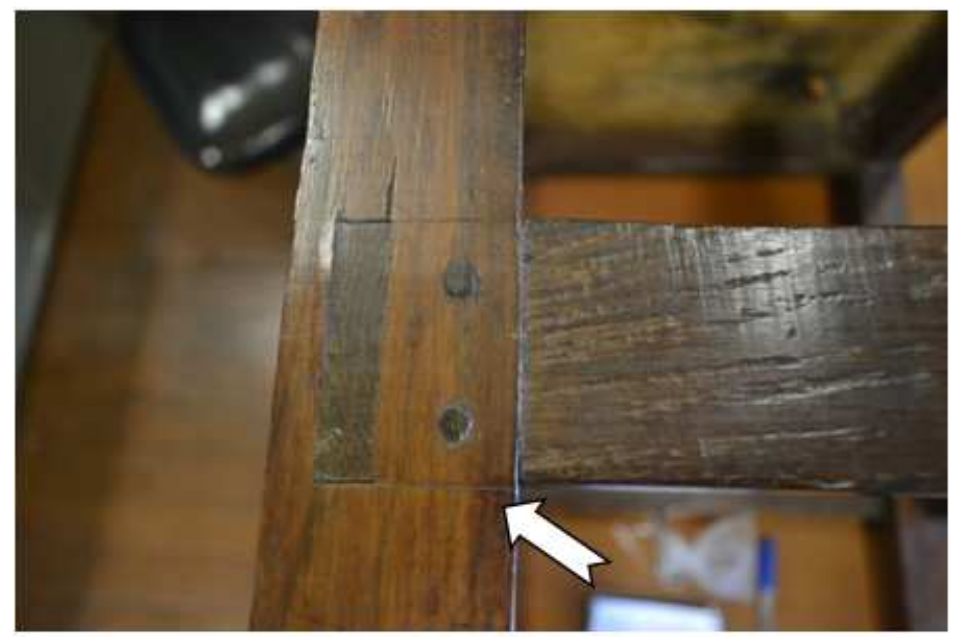

Figura 36: Cadeira de sola. RG 55. Foto do autor.

Note-se como as cavilhas aparecem salientes na superfície da madeira da perna. Este é um sinal da antiguidade do móvel, como observou o Mestre marceneiro David Cruz da FRESS, posto que com o tempo a madeira das peças sofre ressecamento e leve encolhimento, fazendo a cavilha se sobressair.

\footnotetext{
${ }^{115}$ BLUTEAU, Raphael. Vocabulario portuguez \& latino: aulico, anatomico, architectonico... Coimbra: Collegio das Artes da Companhia de Jesus, 1712-1728, 10 vol..

${ }^{116}$ Retiram-se destes pequenos detalhes elementos para a compreensão das representações atribuídas aos objetos e às suas formas de uso, que iremos tratar em capítulo próprio. Por exemplo, na Europa do século XVIII os móveis passaram cada vez mais a serem os centros das atenções de maia amplas camadas de consumidores e alvos privilegiados da observação e discussão nas cortes e círculos abastados. Concomitantemente, os artesãos responsáveis pela sua produção cada vez mais se esmeravam no acabamento e ousadia das formas. Isto é sintomático nas próprias formas em rocaille, e podemos considerar a sua epítome nas espetaculares cômodas e escrivaninhas mecânicas, que realizavam movimentos automáticos através de sistemas de engrenagens. Estas foram feitas, por exemplo, pelo artesão germânico Roentgen e também pelo engenheiro Guéri de Montepellier, sob encomenda do próprio rei Luís XV. Cf. MEUVRET, Jean. FRÉGNAC, Claude. Les Ébénistes due XVIIlâ siecle francais. Paris, Hachette, Collection Connaissance des arts. "Grands artisans d'autrefois". 1963; DEJEAN, Joan. O século do conforto. Rio de Janeiro: Civilização Brasileira, 2012; e GOODMAN, Dena; NORBERG, Kathryn. Furnishing the Eighteenth Century: What Furniture Can Tell Us about the European and American Past. New York and London: Routledge Taylor \& Francis Group, 2007 pp. $155-65$.
} 
Para o trabalho de lixamento e acabamento das peças, os graus de refinamento são decerto muito variados. Antes da invenção das lixas de papel na era industrial, que muito facilitaram os acabamentos, permitindo superfícies extremamente lisas, eram utilizadas lâminas de metal para raspar as marcas grossas deixadas pelas outras ferramentas, como as serras e plainas.

Este processo de raspagem era feito com uma lâmina de metal flexível. Também poderiam ser utilizadas as próprias plainas com o ajuste dos ângulos das lâminas. Ou seja, a mesma ferramenta que atribuímos para uma função poderia ser utilizada de mais de uma maneira, pela criatividade empírica dos artesãos.

Autores como Maurice Halbwachs, Marcel Mauss, Jean-Pierre Warnier e Richard Sennett ${ }^{117}$ atentos tanto às posturas corporais e às práticas envolvidas na inter-relação com os objetos materiais e os processos cognitivos conferem ao trabalho manual também o estatuto criativo do labor intelectual, falando-se mesmo em "pensar com as mãos", posto que a experimentação se efetua na coligação entre mente e corpo e não como "entes separados" como tradicionalmente a filosofia admitiu.

Sendo assim, podemos considerar presente 0 empirismo entre os trabalhadores da América lusitana tanto em face ao universo limitado de ferramentas no espaço colonial, quanto em face das formas idiossincráticas ao longo do tempo assumidas para a execução de atividades repetidas, as quais se configuram técnicas do próprio corpo ${ }^{118}$.

Ainda durante a observação notamos os sinais das lâminas de cantil e buril nas peças torneadas que apresentam a superfície bastante lisa em comparação com as irregularidades nas superfícies planas.

\footnotetext{
117 Vide WARNIER, Jean-Pierre.Construire la culture matérielle.L'homme qui pensait avec ses doigts. Paris: Presses Universitaires de France, 1999, p. 21-35; citando as linhas de Marel Mauss, Maurice Halbwachs e Hannah Arendt a respeito da oposição clássica entre labor e trabalho SENNETT, Richard. $\mathbf{O}$ artífice. Rio de Janeiro: Record, 2011, especialmente cap. 4 "Consciência Material”.

118 Infelizmente, não contamos com séries extensas de objetos cuja proveniência comum seja conhecida, sendo assim difícil encontrar padrões de feitura que revelem os traços dos artesãos.
} 


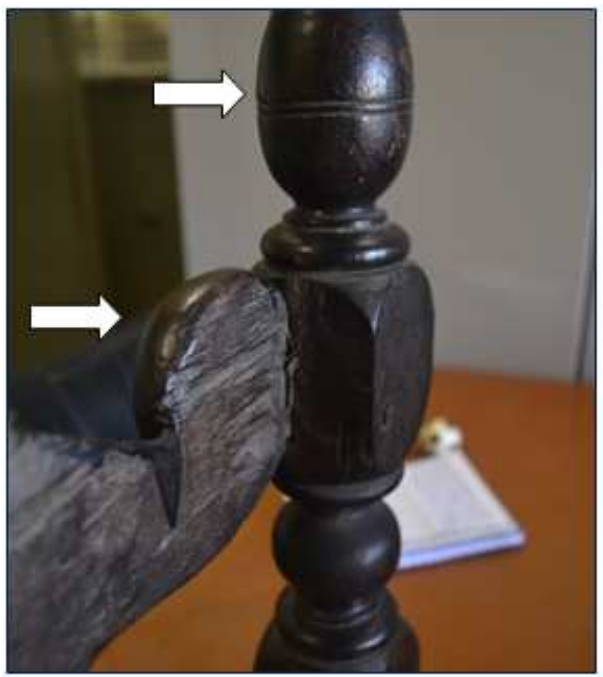

Figura 37: Cadeira de sola. RG 553. Foto do autor.

Para a realização dos furos para o encaixe dos pinos ou mesmo das travas torneadas, poderia ser utilizada a furadeira de prumo, girada por manivela e também as brocas curvas manuais.

Encontramos para o século XVIII ferramentas que teriam pertencido ao mestre entalhador Francisco Viera Servas (1720-1811), pois foram encontradas intactas durante restauro no entablamento detrás do arco do cruzeiro no Altar Mor da Igreja de Nossa Senhora da Conceição em Congonha, Minas Gerais, feito por ele em $1764^{119}$. Note-se nesses exemplares setecentistas a característica manufatureira de sua execução, madeiras improvisadas, adaptadas ao uso.
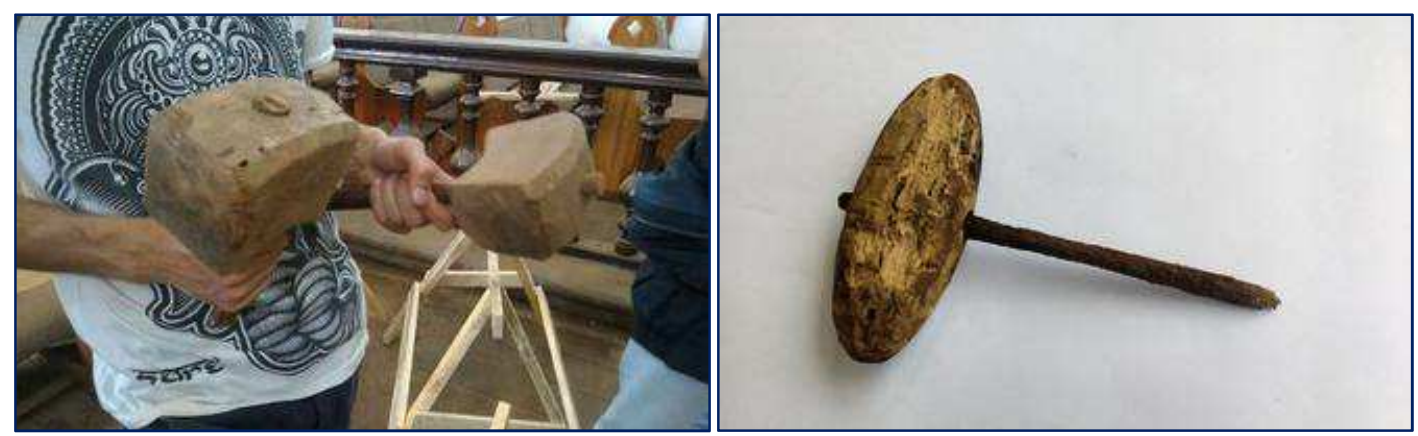

Figura 38: Macetes de madeira.

Figura 39: Verruma usada para fazer furos.

119 ESTADO DE MINAS. Restauradores descobrem ferramentas do século 18 em igreja de Congonhas. 27/12/2016. Disponível em:

https://www.em.com.br/app/noticia/gerais/2016/12/27/interna gerais,835414/restauradores-descobremferramentas-do-seculo-18-em-igreja-de-congonha.shtml. Acesso em: 20/5/2018. 
Em todas as peças notamos o processo de alisamento das pernas e hastes através de plainas, com exceção das já referidas ilhargas ásperas com os sinais de desbastamento ainda presentes.

A plaina chamada "Guilherme", ou desbastador é formada basicamente por uma estrutura de madeira com uma abertura na parte inferior, onde se fixa diagonalmente uma lâmina metálica para dar o primeiro alisamento nas superfícies das madeiras após a serragem. Outros tipos de plaina seguem este modelo, variando seus formatos, curvaturas, apoios para mãos e os ferros usados para conferir o arremate desejado à peça.

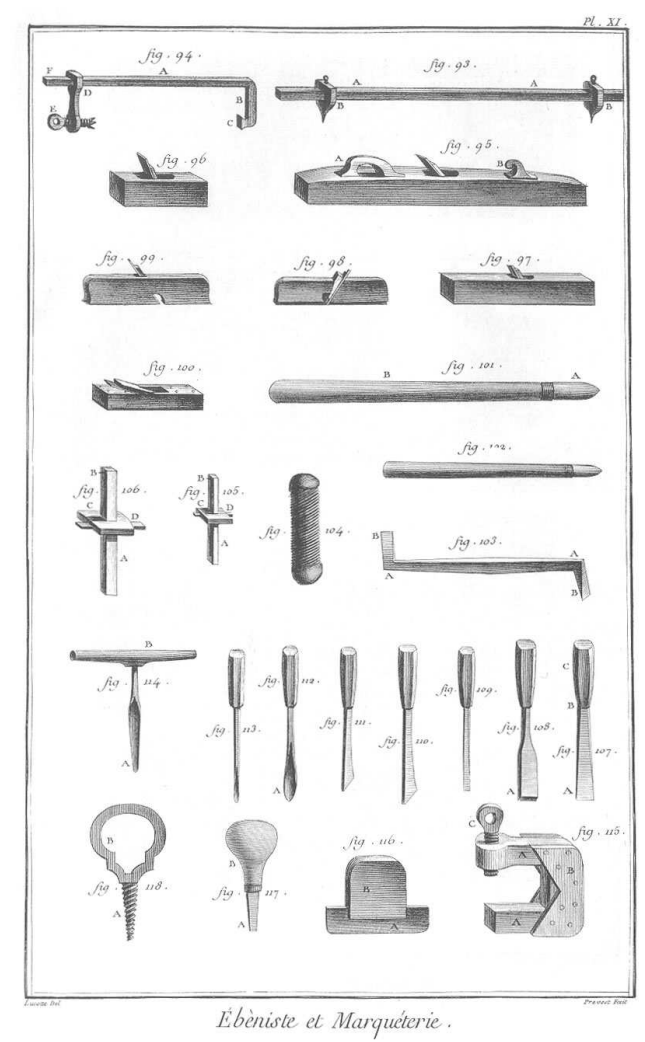

Figura 40: Ferramentas de ebanista e marceneiro esquematizadas na Encyclopédie de Diderot e D'Alambert ${ }^{120}$.

Contando as plainas com uma haste na parte superior, chamada martelo, para dar o ângulo na lâmina metálica, podem ter a superfície inferior lisa ou curva, dependendo do tipo de desenho que se queira conferir à superfície da peça.

120 D'ALEMBERT, Jean le Rond; DIDEROT, Denis.; “Ebenisterie-marqueterie”. P. 24: 1:4. Prancha VIII In: Encyclopédie ou Dictionnaire raisonné des sciences, des arts et des métiers. vol. 4 (plates). Paris, 1769. Disponível em: https:/quod.lib.umich.edu/d/did/did2222.0001.442/--cabinet-making-andmarquetry?rgn=main;view=fulltext;q1=frames. Acessado em 20/05/2018. 


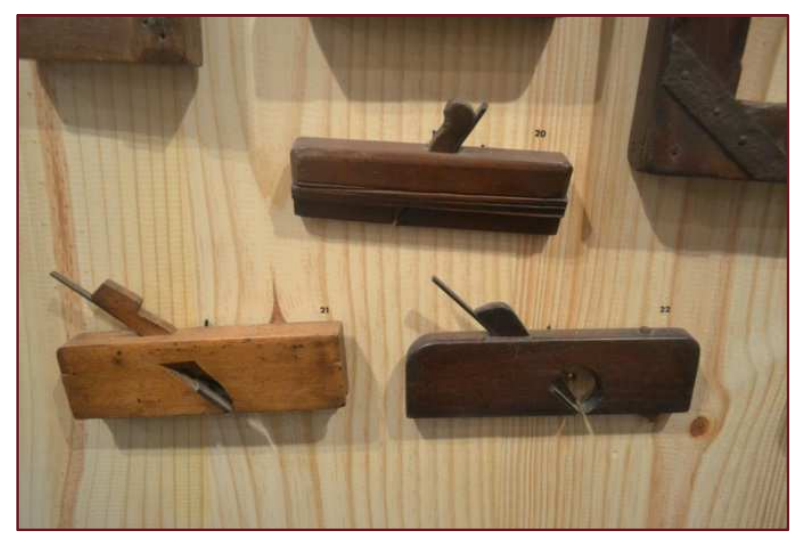

Figura 41: Plainas Séc. XIX Coleção Emanoel Araújo. Fotografada durante a exposição "A Mão do Povo Brasileiro" (2016-2017) no MASP.

Apesar de não sabermos com certeza a idade dessas plainas, vale notar nas suas formas uma série de elementos que dizem muito sobre os artífices a produção. Como nota Sennett, podemos notar nas ferramentas dos artífices, no cuidado com que ele as produziu e modificou, e mesmo na forma como ele as armazena e organiza, o "sinal do amor do artífice por seus instrumentos"121. As formas que apresentam não estão somente relacionadas às adaptações funcionais, no horizonte de "desafios estimulantes" à criatividade, levando a "saltos intuitivos" 122 , mas também a profundas circunstâncias psicológicas e interacionais do artífice com seu meio e suas coisas.

Após o uso da plaina, utiliza-se a raspadeira, que é uma chapa de metal de pouca espessura. Há muitos tipos de cabos e formas, disto variando o grau de precisão e rispidez deixada na madeira. Para o período pré-industrial a qualidade do metal utilizado influenciava diretamente na qualidade do acabamento das peças, já que as lâminas com melhor flexibilidade permitem melhor raspagem.

O coteché ou boxequim (em francês Wabstringue ou Wastringue e em inglês Spokeshave) é um tipo de instrumento de corte, semelhante à plaina, que permite ao artesão fazer sulcos curvados na madeira. Este é um dos instrumentos que permitem fazer as pernas e juntas em cabriolet, típicas do século XVIII, a chamada

\footnotetext{
${ }^{121}$ SENNETT, Richard. 0 artífice. Rio de Janeiro: Record, 2012,, p. 217.

${ }^{122}$ Sennett aponta que existem quatro etapas em que ocorrem os "saltos intuitivos". Estes levam a inovações e adaptações de materiais, maquinas técnicas e ferramentas: primeiro, há a quebra da finalidade específica de uma ferramenta, depois o estabelecimento da proximidade entre ações e domínios de atuação; ocorre também a surpresa, o ato fora do horizonte de cálculo que se poderia esperar, e é quando nos assombramos com elementos que podem ser ou mais simples ou mais complexos do que se imaginava previamente, levando a adaptações nos procedimentos anteriormente adotados. Por fim, compreendem-se os próprios limites do salto inovativo, que sempre encontra barreiras a serem novamente confrontadas. SENNETT, Richard. $\mathbf{O}$ artífice. Rio de Janeiro: Record, 2012, P. 235.
} 
"Era de Ouro" da ebanesteria francesa ${ }^{123}$. Apesar desta ferramenta não constar dos inventários post-mortem de oficiais mecânicos paulistas - analisados mais à frente encontramos algumas descrições genéricas de peças como "ferros de molduras" ou até uma "plaina reversa" ${ }^{124}$, que podemos atribuir ao boxequim.

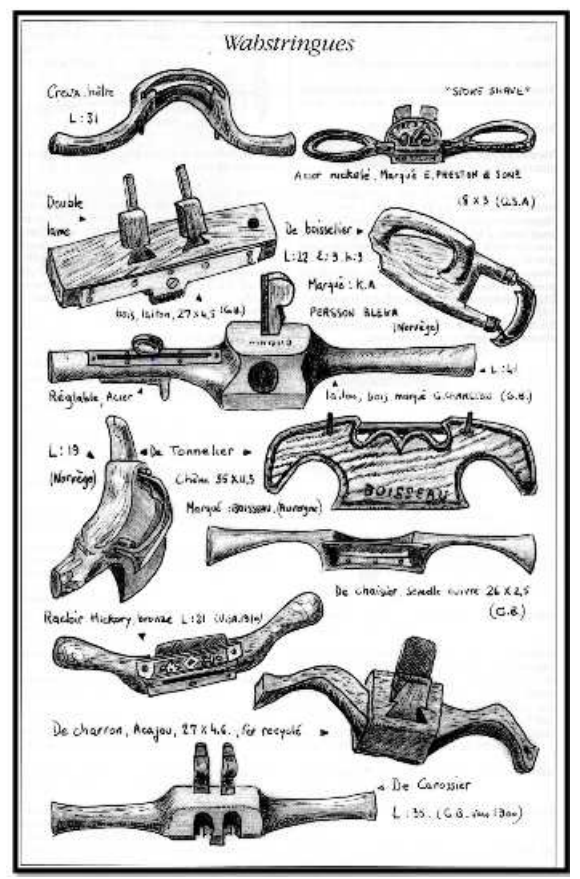

Figura 42: Exemplos de boxequim ou spokeshaves, onde podemos notar a variedade de formas de apoios para as mãos variando conforme o seu emprego ${ }^{125}$.

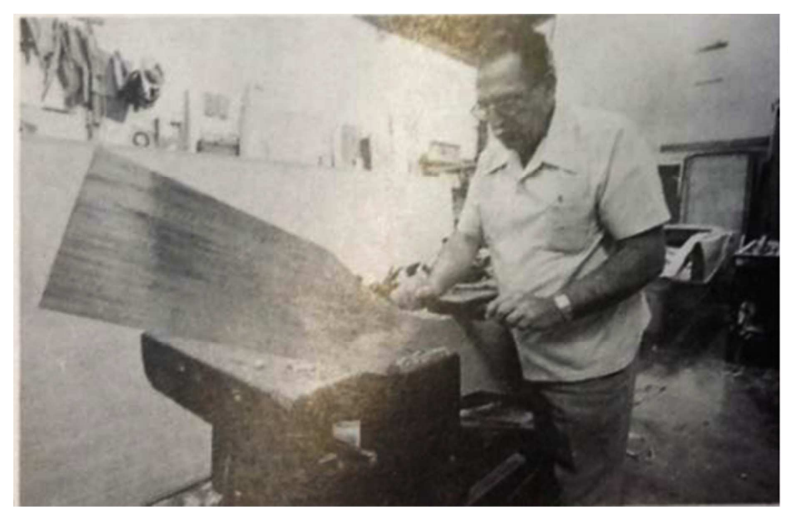

Figura 43: Exemplo do uso contemporâneo do boxequim ${ }^{126}$.

Dentre as peças selecionadas, encontramos formas curvilíneas nos braços da cadeira RG 559, ainda que a voluta da maçaneta seja entalhada. Um exemplo do

\footnotetext{
123 MEUVRET, Jean. FRÉGNAC, Claude. Les Ébénistes due XVIIIâ siecle francais. Paris, Hachette, Collection Connaissance des arts "Grands artisans d'autrefois". 1963.

${ }^{124}$ Cf. o inventário de João da Motta Liver, 1771 que analisaremos mais à frente.

${ }^{125}$ Extraído de BOUCARD, Daniel. Dictionnaire des outils et instruments pour la plupart des métiers. Paris: Éd. JC Godefroy, 2006.

${ }^{126}$ Extraído de MATUCK, Rubens. Instrumentos Manuais de Carpintaria e Marcenaria (catálogo de exposição). Prefeitura do Município de São Paulo: Secretaria Municipal de Cultura. 1982. P.50.
} 
trabalho de entalhe pode ser vista na figura abaixo, reproduzida da Encyclopèdie, na qual o artesão - sinalizado por nós com uma seta - segura no alto um cinzel de madeira, enquanto entalha a peça lateral de uma mesa. Note-se pelas pernas de móveis em preparação apoiadas na bancada de trabalho a coexistência produtiva de pernas em rocalha junto com formas torneadas e também retilíneas.

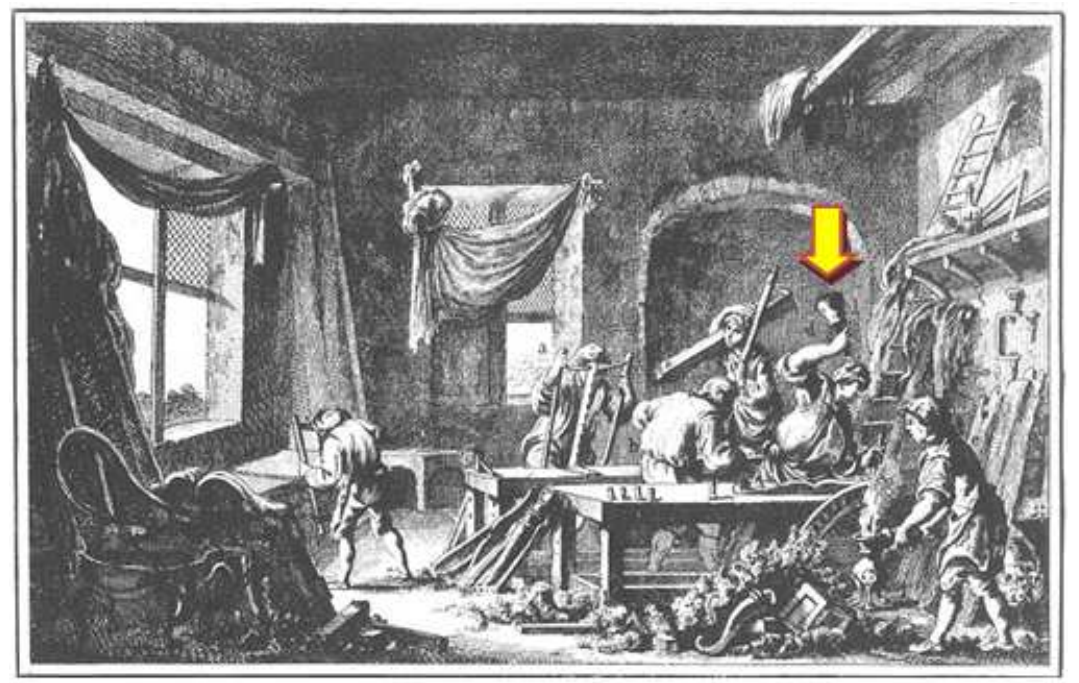

Figura 44: llustração da Encyclopèdie de Diderot e d'Alembert representando o processo de produção de cadeiras ${ }^{127 .}$

$\mathrm{Na}$ figura a seguir temos exemplos de ensambladura em "T", ou sub-tenon extraídos da Encyclopèdie de Diderot e d'Alambert, mostrando o seu emprego em cadeiras roccaile.

\footnotetext{
127 D'ALEMBERT, Jean le Rond; DIDEROT, Denis.; "Menuisier en meubles". In: Encyclopédie ou Dictionnaire raisonné des sciences, des arts et des métiers. vol. 7 (plates). Paris, 1769 . Disponível em: https://quod.lib.umich.edu/d/did/did2222.0001.572/--art-of-the-cabinetmaker?rgn=main;view=fulltext; $q 1=$ cabinet-maker. Acessado em 20/05/2018.
} 


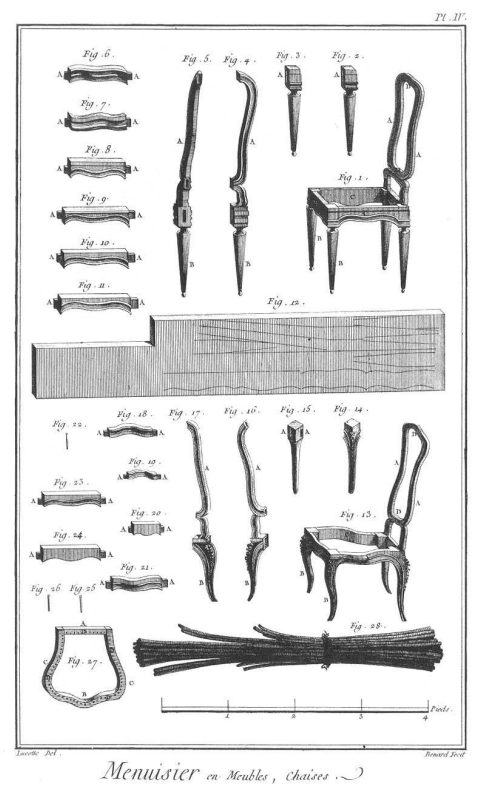

Figura 45: Esquema da produção de uma cadeira em rocalha na ${ }^{128}$

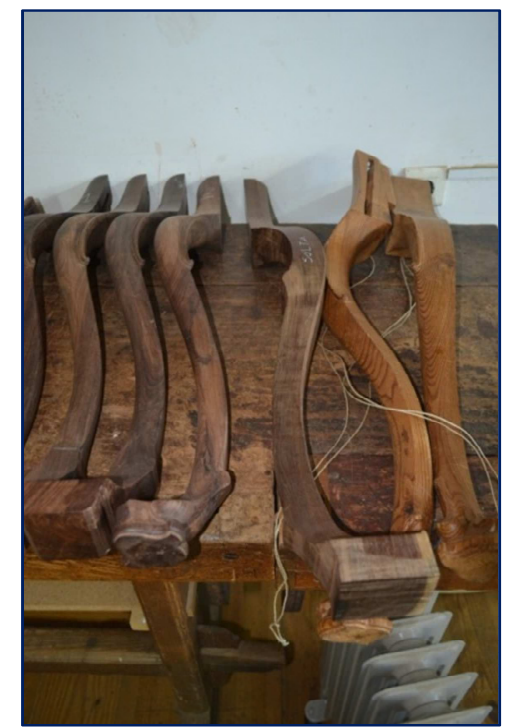

Figura 46: exemplo de pernas de mesa estilo D. José sendo reproduzida na oficina da FRESS.

Vimos nas oficinas da FRESS pernas de mesas sendo produzidas. Na figura anterior conferimos, à esquerda, pernas feitas com pau-santo e, à direita, com castanho. Segundo o Mestre entalhador Miguel Alonso Duarte, o pau-santo é uma madeira muito dura de trabalhar, levando só na oficina de entalhe três semanas só para fazer a talha das pernas da mesa e três meses para fazer toda a peça.

\footnotetext{
${ }^{128}$ D'ALEMBERT, Jean le Rond; DIDEROT, Denis.; “Menuisier en meubles". In: Encyclopédie ou Dictionnaire raisonné des sciences, des arts et des métiers. vol. 7 (plates). Paris, 1769. Disponível em: https://quod.lib.umich.edu/d/did/did2222.0001.572/--art-of-the-cabinetmaker?rgn=main;view=fulltext;q1=cabinet-maker. Acessado em 20/05/2018.
} 
François Biard (Lyon, 1798 - Fontainebleau, 1882) também o observara em sua viagem entre 1858 e $1859^{129}$ :

Consegui outro dia o auxílio de um homem que, munido de martelo e verrumas, me ajudou a construir pequena câmara escura para meus trabalhos fotográficos. Se falei verrumas foi porque as madeiras brasileiras são de tal modo duras que não se podem pregar apenas com pregos.

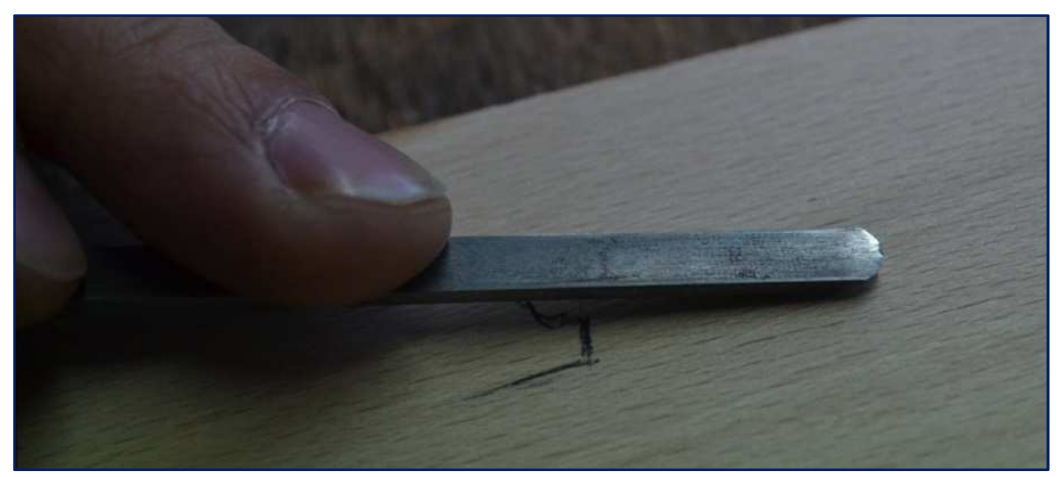

Figura 47: ponta de goiva na oficina da FRESS. Fotografia do autor.

Inclusive pela granulação do pau-santo as ferramentas utilizadas precisam ser constantemente afiadas, como podemos ver pela rebarba feita na ponta desta goiva.
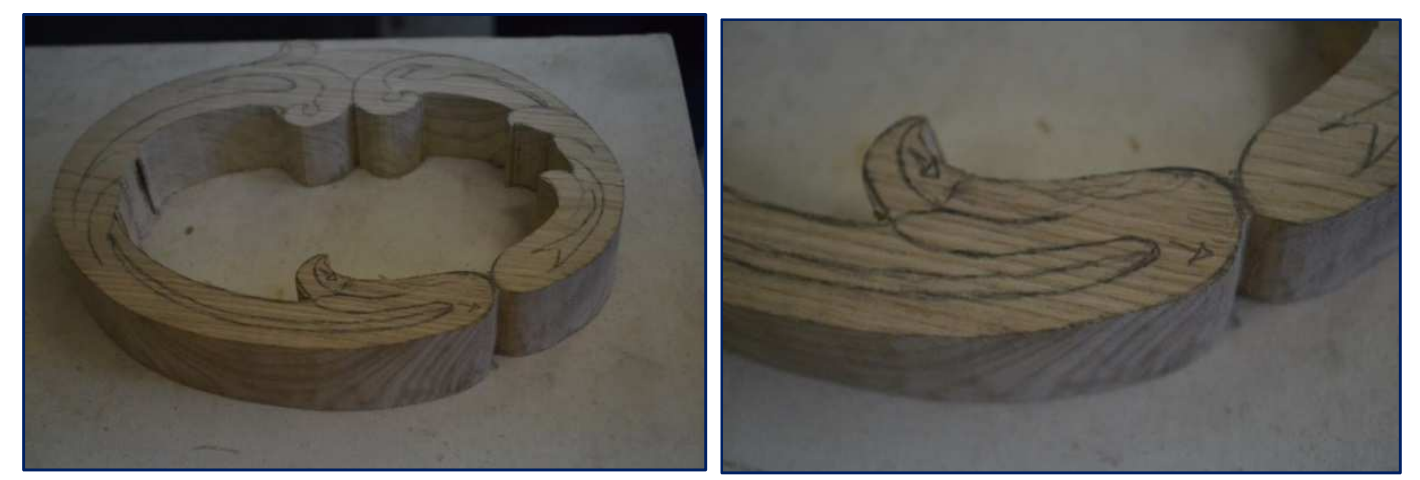

Figura 48 exemplar de ornato estilo D. José I servindo de rascunho para os aprendizes da FRESS fazerem o entalhe

Figura 49: observa-se no detalhe como o Mestre Miguel Alonso Duarte sinalizou com setas a direção do veio das madeiras

O Mestre Miguel Alonso Duarte desenhou as pequenas flechas com lápis mostrando a direção em que os aprendizes deveriam "atacar" a madeira de maneira a seguir os veios e obter bom resultado. As características particulares de cada pedaço de madeira fazem com que cada peça mereça atenção especial, com verdadeira leitura e discussão antes de realizar o trabalho, de maneira a encontrar a

\footnotetext{
${ }^{129}$ BIARD, François. Dois anos no Brasil. São Paulo: Cia. Ed. Nacional. 1945.
} 
melhor forma de fazer o entalhe com menos esforço e facilitar os processos posteriores de limagem e acabamento.

Também vemos formas curvilíneas na trava frontal da cadeira RG 58, um trabalho em forma de canga, possivelmente feita com boxequim. Talvez por essa razão apareça em destaque em relação às outras travas, dada a habilidade necessária ao marceneiro para fazer com perfeição a raspagem curvilínea da madeira.

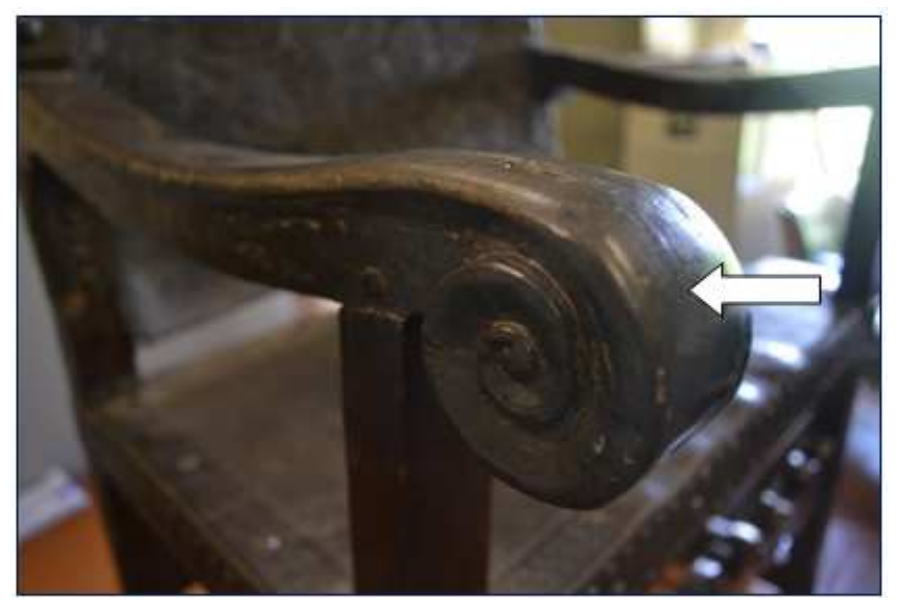

Figura 50: Cadeira de sola. RG 559. Foto do autor.

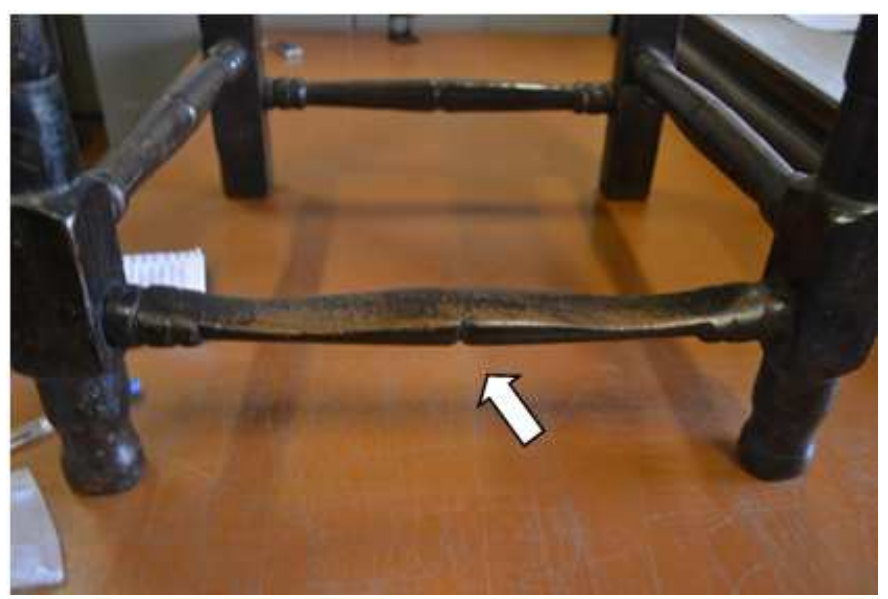

Figura 51: Cadeira de sola. RG 61. Foto do autor.

Por fim, dentre as ferramentas de apoio, que não deixam marcas, há os grampos feitos de madeira ${ }^{130}$, que se prendem à banca do marceneiro, bem como os sargentos. Outras marcas que não são visíveis, mas obviamente foram feitas no lenho dentro da cadeia de produção dos objetos, são as de machado, utilizado para o corte das árvores, e as do traçador ou serra de braço e as serras de armação

\footnotetext{
${ }^{130}$ MATUCK, Rubens. Instrumentos Manuais de Carpintaria e Marcenaria (catálogo de exposição). Prefeitura do Município de São Paulo: Secretaria Municipal de Cultura. 1982, p. 32.
} 
grandes usadas para realizar o corte dos troncos em toras, que dependiam de duas pessoas para o trabalho, como retratado na seguinte gravura de Debret.

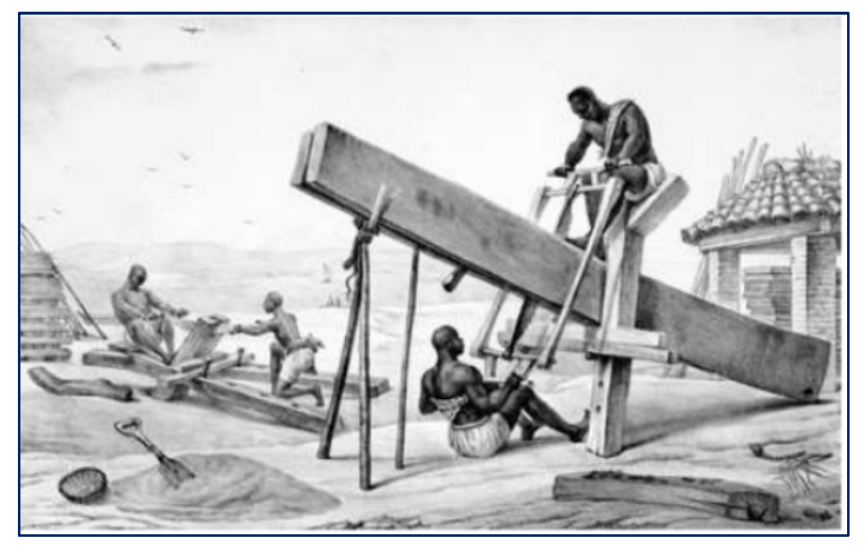

Figura 52: DEBRET, Jean-Baptiste. Negros serradores de tábuas. ${ }^{131}$

Cumpre salientar que esta imagem de Debret, reproduzida em um sem número de publicações, deve ser vista com reservas por se tratar de uma composição em que o autor inclui em um mesmo espaço momentos e técnicas diferentes de manufatura da madeira. Ao que muitos consideram como retrato de "atraso" e "primitivismo" ${ }^{132}$, vale comparação de tais técnicas e ações corporais com fotografias realizadas em Portugal no século XX:

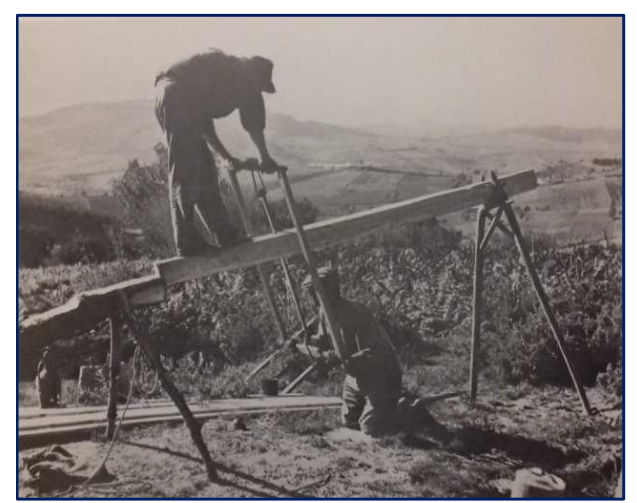

Figura 53 Serração braçal na região de Mafra, Agueira c. $1930^{133}$.

\footnotetext{
${ }^{131}$ DEBRET, Jean-Baptiste. “Negros serradores de tábuas”, em Viagem pitoresca e histórica ao Brasil, 1834-39. Disponível em brasiliana.usp.br.

132 Por exemplo, a descrição de Nestor Goulart Reis Filho em Quadro da Arquitetura no Brasil: (...)a todo um sistema de uso da casa [a limpeza] que, como a construção, estava apoiado sobre o trabalho escravo e, por isso mesmo, ligava-se a nível tecnológico bastante primitivo." pg. 23. Apud. E o negro na arquitetura brasileira? ${ }^{133}$ PEREIRA, Benjamim. Tecnologia Tradicional Portuguesa: Sistemas de serração de madeiras. Etnologia - 5. Instituto Nacional de Investigação Cientifica. Centro de estudos de Etnologia. 1990. Fotografia de Manuel Mucharreira.
} 


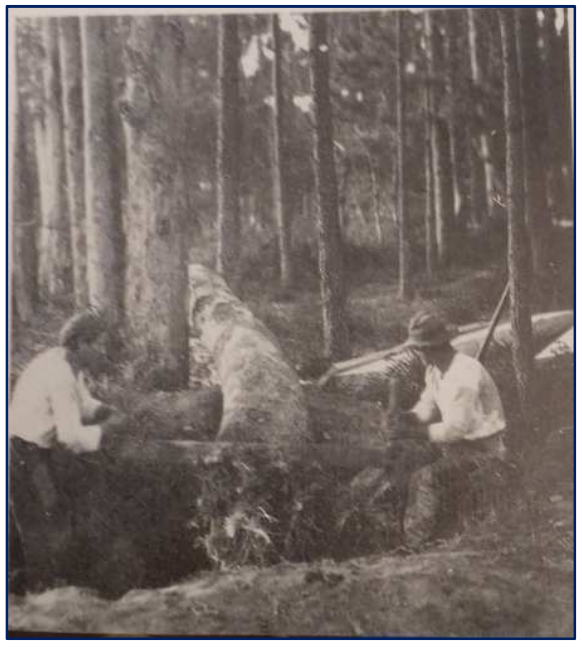

Figura 54 Abate de uma árvore na região do Porto, c. 1930. Processo de corte das raízes por meio de serrão ${ }^{134}$

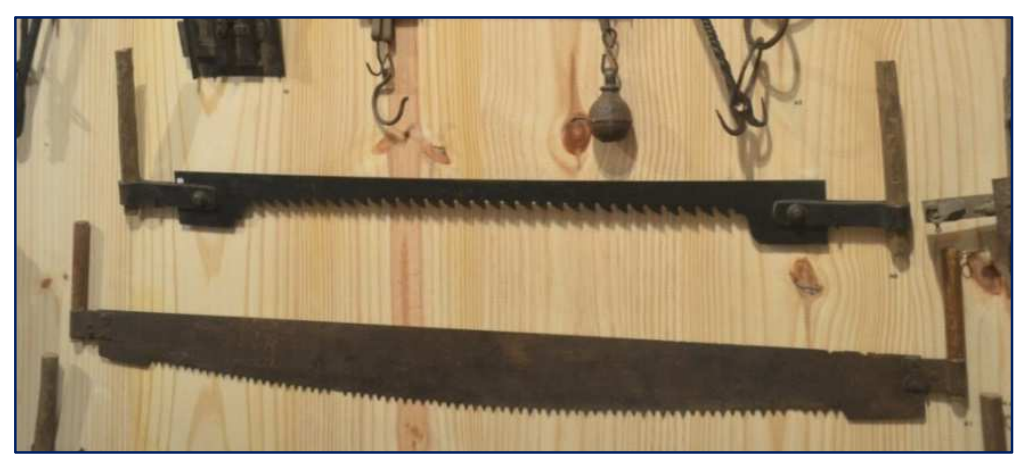

Figura 55 Serrões. s.d. Coleção Emanoel Araújo. Fotografada durante a exposição "A Mão do Povo Brasileiro" (2016-2017) no MASP.

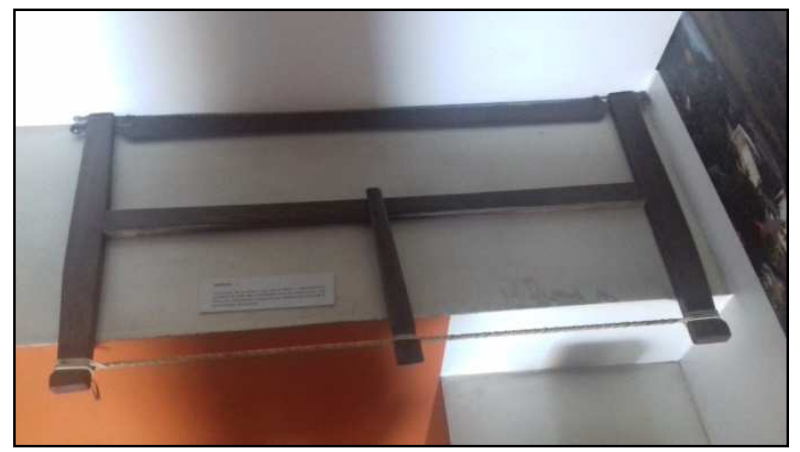

Figura 56 Serrote de Armação ou de São José. S.d. Coleção Museu Casa do Anhanguera em Santana de Parnaíba. Fotografada durante a exposição permanente.

Estendendo as nossas observações para além deste núcleo de cadeiras ricas em informações, notamos as continuidades técnicas de serração das madeiras e tecnológicas no uso de ferramentas em semelhantes móveis em espaços e estilos

\footnotetext{
${ }^{134}$ PEREIRA, Benjamim. Tecnologia Tradicional Portuguesa: Sistemas de serração de madeiras. Etnologia - 5. Instituto Nacional de Investigação Cientifica. Centro de estudos de Etnologia. 1990. S.a.
} 
diferentes, evidenciando-se como salientou Braudel, a longa duração das técnicas $^{135}$.

Apesar de as cadeiras do avançar do século XVIII evidenciarem as grandes mudanças de estilo, uso e tecnologia de encaixes, vemos que no plano das técnicas de serragem e acabamento, ainda havia continuidades com as cadeiras de feição quadrangular típicas dos séculos anteriores. Se no aspecto formal elas estão separadas, no aspecto técnico de sua produção primária elas são agrupáveis.

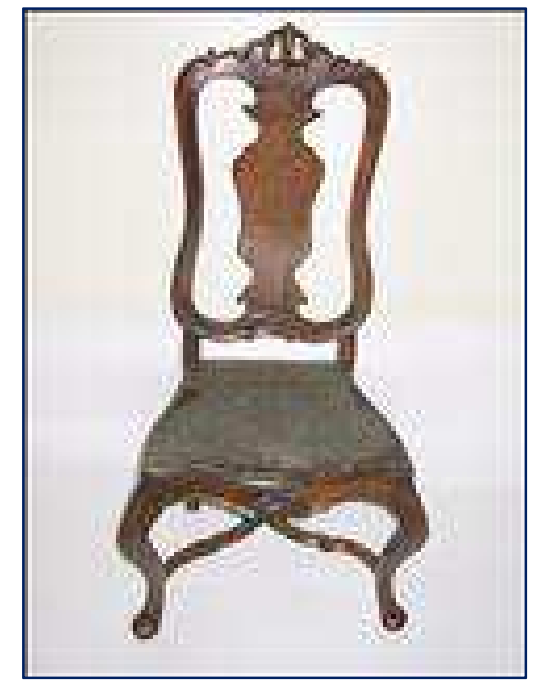

Figura 57: Visão frontal da cadeira em rocalha RG $469^{136}$.

As marcas de ferramentas já são menos visíveis do que nos móveis de estrutura retilínea típicos dos estilos anteriores, ainda que aqueles pudessem ter sido também executados contemporaneamente. Vemos melhor acabamento nas partes anteriores e mesmo nas posteriores, como se pode notar pelo cimalho.

\footnotetext{
${ }^{135}$ Cf. BRAUDEL, Fernand. Civilização material, economia e capitalismo, séculos XV-XVIII: I. As estruturas do cotidiano. São Paulo: Martins Fontes, 1995.

${ }^{136}$ Extraído de: http://acervo.mp.usp.br/ObjetosV2.aspx\#. Acessado em: Acessado em 20/05/2018
} 


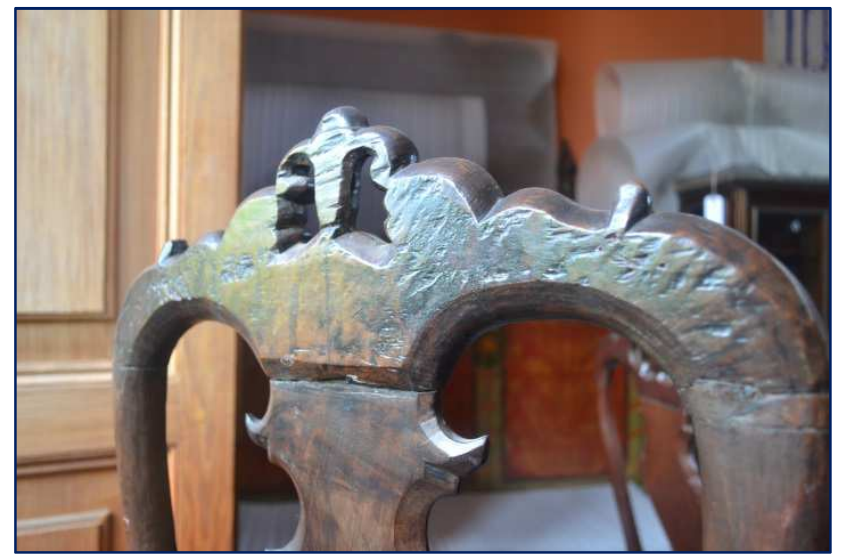

Figura 58: cadeira em rocalha $R G$ 469. Foto do autor

Porém, ainda não há o esmero em esconder essas marcas de trabalho ou as rugosidades do lenho, como por exemplo, o cimalho na parte traseira. Igualmente ao encontrado nas cadeiras de sola de forma quadrangular, vemos as madeiras da face interna dos aros que compõem o assento com as marcas de ferramentas e das rugosidades do lenho bastante salientes e pouco acabadas.

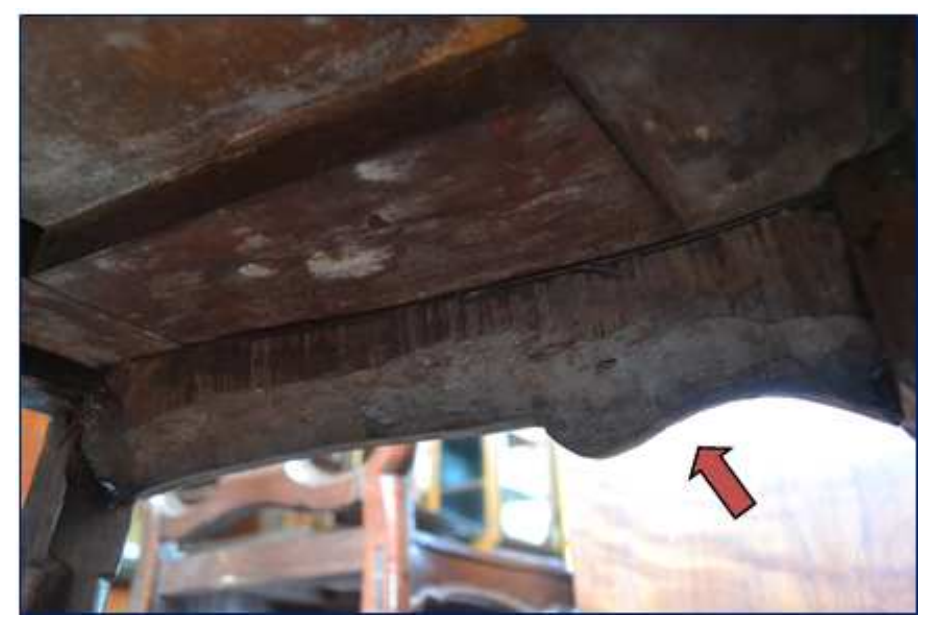

Figura 59: cadeira em rocalha RG 469. Foto do autor

Encontramos também em peças portuguesas deste período os mesmos sinais na estrutura da madeira das cadeiras paulistas e semelhanças no processo produtivo, como o maior empenho em dar excelente acabamento às frentes das peças, ao passo que a parte posterior fica sem o mesmo esmero de finalização, revelando as mãos dos artesãos, os sinais de ferramentas e as rugosidades na madeira. Comprovando nossa arguição temos a mesa de jogo da FRESS, a seguir. Segundo Mestre Marceneiro David Cruz revela a sua origem portuguesa devido a alguns elementos revelam sua origem portuguesa, como não ter um acabamento 
nas faces internas e posteriores feita com o mesmo refinamento, o qual se observa em peças francesas do mesmo período.

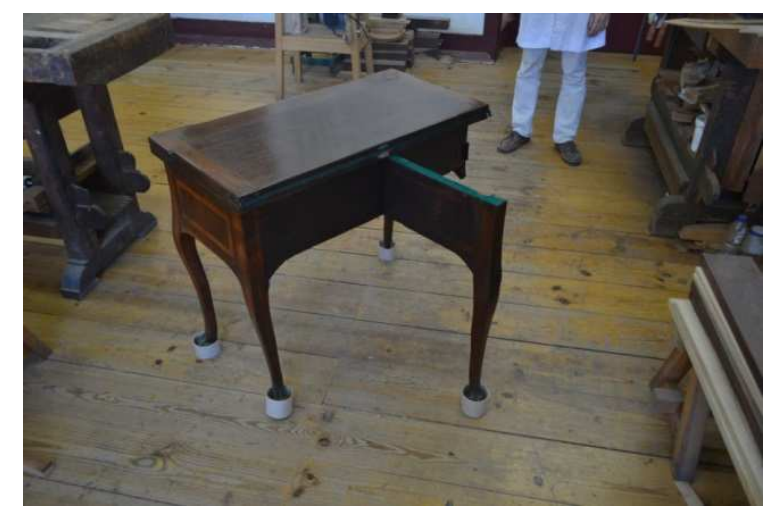

Figura 60: mesa de jogo da FRESS Foto do autor.

Um elemento que não aparecia era o chamado entre-pano, madeira que se fixa no fundo do interior da mesa abaixo da gaveta, de maneira a evitar que as pernas do usuário possam encostar no tampo da gaveta.

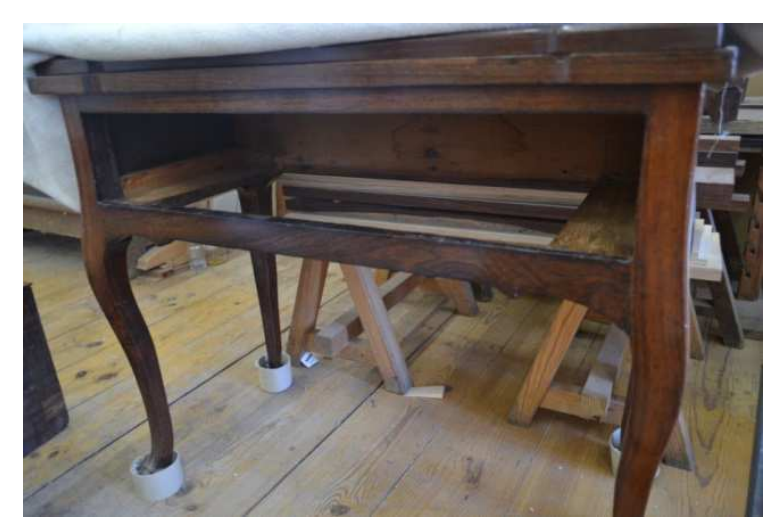

Figura 61: mesa de jogo da FRESS. Foto do autor.

Nas reproduções que a oficina da FRESS iria produzir baseada nessa mesa de jogo, o entre-pano e a as guias da gaveta seriam adicionadas, como mostrou o Mestre David: 


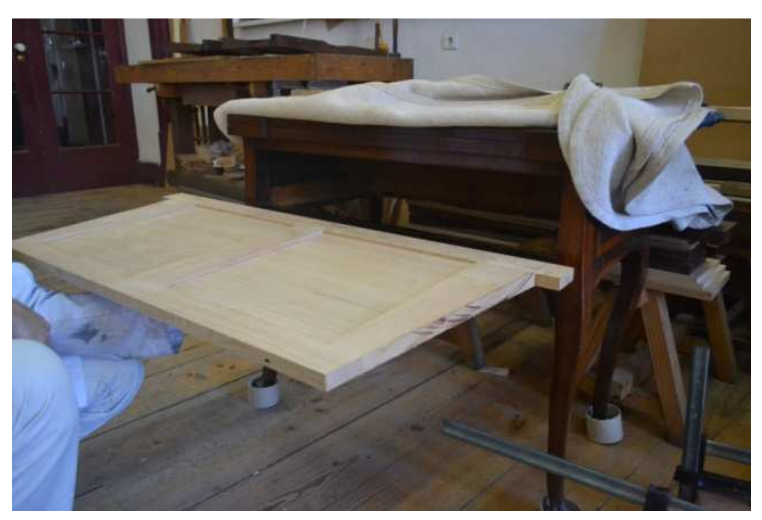

Figura 62: mesa de jogo da FRESS e entrepano a ser usado na reproduçãp. Foto do autor.

Igualmente optaram os artesãos da FRESS em utilizar nas reproduções técnicas diferentes daquelas das peças portuguesas originais. Por exemplo, o encaixe do tampo da mesa não seria feito com pregos ou cavilhas à portuguesa, mas sim com o encaixe em ganzepe, tipicamente francês, com formato de rabo de andorinha, encaixado de frente para trás, se tornando invisível, bem como uma falha da madeira ao lado. Podemos observar o ganzepe na figura seguinte a parte lateral da peça sendo fabricada:

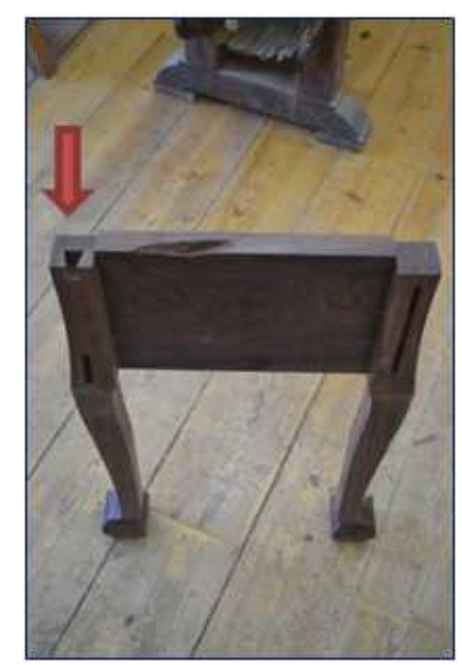

Figura 63: parte lateral de reprodução de mesa de jogo do século XVIII sendo produzida nas oficinas da FRESS. Foto do autor. 


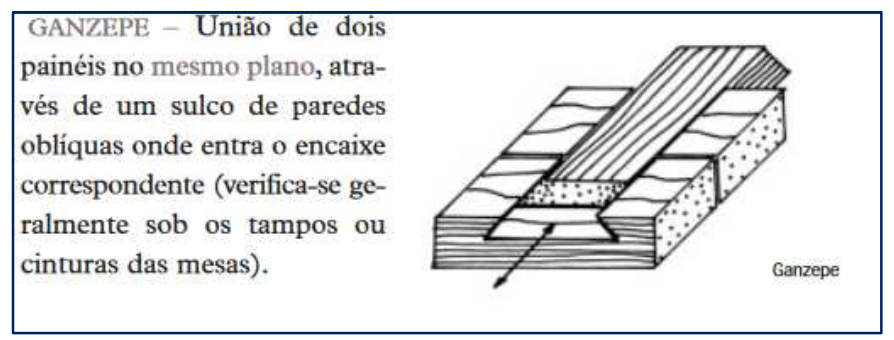

Figura 64: desenho esquemático do ganzepe ${ }^{137}$.

Vemos o fundo da gaveta com encaixes em rabo de andorinha aparentes e a madeira com sinais de serragem ainda visíveis.

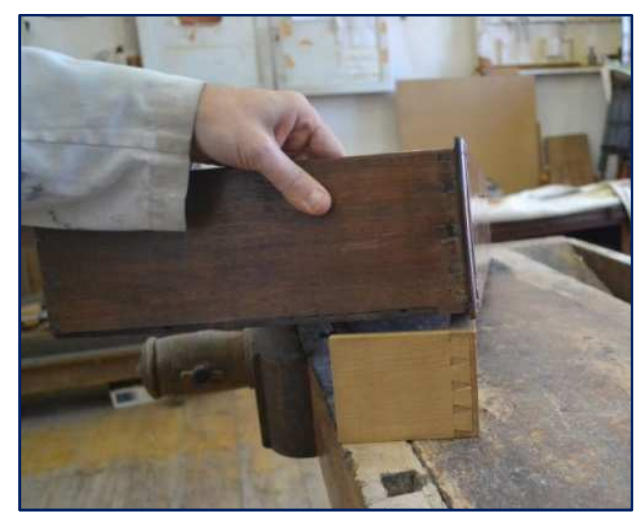

Figura 65: lateral da gaveta da peça original com uma reprodução de encaixes em rabo de andorinha

Neste exemplar, inclusive, não havia guias nas laterais do interior da peça para que as gavetas deslizassem pelas corrediças mais facilmente, sem solavancos. Nessa peça vemos ambas feitas em madeira diferente do restante, pois são restauro e adição posterior.

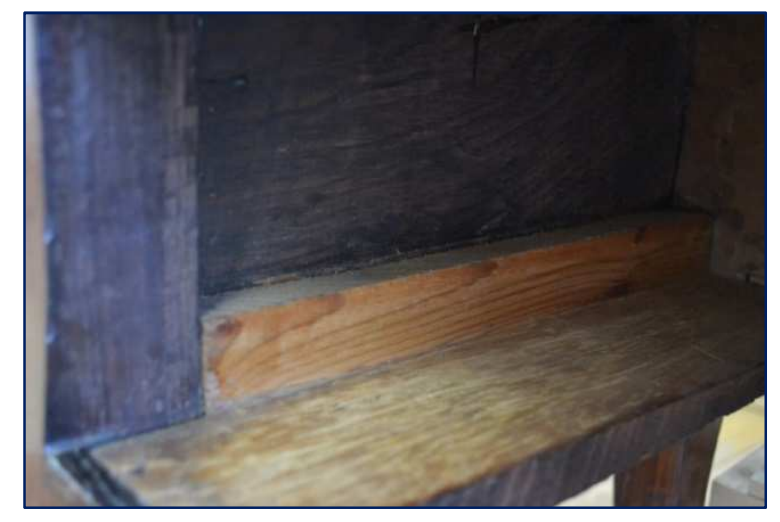

Figura 66: Vista interna da mesa de jogo, onde se observa a guia para a gaveta inserida a posteriori. foto do autor.

\footnotetext{
137 Extraído de: BASTOS, Celina; SOUSA, Maria da Conceição Borges - Mobiliário: artes plásticas e artes decorativas. Lisboa: IPM, 2004. P. 39.
} 
Já no avançar do século XIX vemos que a mecanização dos cortes de madeira trouxe a uniformização da serração, aviltando as madeiras das expressivas marcas deixadas pelos dentes das serras.

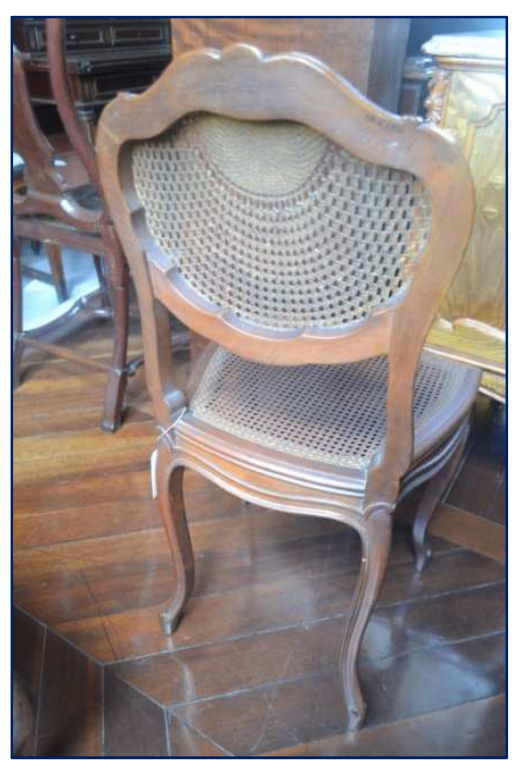

Figura 67: Cadeira de palhinha RG 5883. Foto do autor.

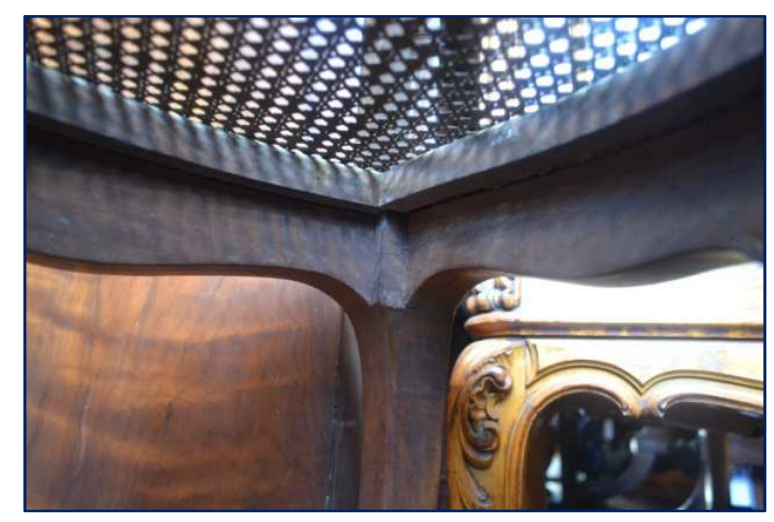

Figura 68: Cadeira de palhinha RG 5883. Foto do autor

Trouxe assim também maior esmero do acabamento, agora ubíquo até nas partes internas menos visíveis, como podemos ver por esta cadeira de palhinha.

\subsection{0 objeto no seu contexto tecnológico}

Apesar de parecer banal e mesmo soar estranho falar sobre a tecnologia produtiva de objetos tão corriqueiros em nossa sociedade industrial como 0 mobiliário, devemos ter em consideração, que ações tão simples e divulgadas 
atualmente eram muito mais complexas e herméticas no período em questão. Afinal, como alertava Marc Bloch "O historiador de uma época em que a máquina é rainha aceitará que se ignore como são constituídas e modificadas as máquinas?" 138.

Um dos poucos autores que fizeram considerações sobre a tecnologia no período colonial especificamente sobre os ofícios da carpintaria, o arquiteto Júlio Katinsky afirma: "apesar dos estudos sobre mobiliário terem sido feitos, os aspectos técnicos parecem ter sido negligenciados" ${ }^{139}$.

Entendendo esses objetos em conjunto na comparação de longa duração entre os séculos XVI e XIX, compreendemos que a própria reprodução das formas europeias do mobiliário no contexto colonial paulista mostrou-se por si só uma adaptação inovadora. Ou seja, a própria existência dessas peças em São Paulo entre estes séculos é sinal de seu dinamismo, da diversidade de sua economia, da sua vida social conectada ao restante do território e do mundo atlântico português e também do intercâmbio com tecnologias provenientes de outras etnias ${ }^{140}$.

Primeiramente devemos fazer uma consideração terminológica, como indicou Florestan Fernandes para evitar as dificuldades que essas terminologias geram. "Tecnologia" refere-se antes à teoria das técnicas, isto é, o pensar com metodologias científicas sobre o fazer técnico ${ }^{141}$ :

Uma forma de integração dos conhecimentos técnicos e dos processos operativos à cultura de um povo, seja qual for o grau de complexidade social, e do tipo de consciência social desenvolvida pelas pessoas em interação a respeito dos mesmos.

Alguns autores inclusive empregam o termo técnica por outros equivalentes como "meio técnico", como o fez Leroi-Gourhan para designar a "totalidade dos meios de ação material" ${ }^{142}$. Este conceito torna muito mais sutil a compreensão de tecnologia e técnica para nos referirmos aos grupos humanos, sejam quais forem, pois evitam de um lado, o reducionismo de "técnica", que conota primitivismo de

\footnotetext{
${ }^{138}$ BLOCH, Marc. Apologia da História ou O ofício do Historiador, Rio de Janeiro, Jorge Zahar, 2002.p. 81.

139 Katinsky, Julio Roberto. "O ofício da carpintaria no Brasil: justificação para uma investigação sistemática." Revista de História 34.70 (1967): p. 534.

${ }^{140}$ LEITE, José Roberto Teixeira. As raízes na África Negra da siderurgia brasileira. In: Arte, adorno, design e tecnologia no tempo da escravidão. (catálogo de exposição) curador Emanoel Araújo. São Paulo: Museu Afro Brasil, 2013.

${ }^{141}$ FERNANDES, Florestan. A função social da guerra na sociedade tupinambá. Globo Livros, 2013. nota 17.

142 LEROI-GOUHAN, André. Evolução e técnicas. Trabalho e técnicas, pp. 363 e 472. Apud, FERNANDES, Florestan. A Função.... op. cit. 2013
} 
ação produtiva, e, de outro, evita a atribuição de logos, raciocínio de matriz ocidental à maneira de produzir, reproduzir e criar das variadas sociedades.

Para citarmos apenas um exemplo que tangencia a nossa temática da cadeia de produção do mobiliário, notamos como os indígenas brasileiros possuíam formas idiossincráticas para abater as árvores, que foram alvo de interesse dos pesquisadores naturalistas no começo do século $X X$, como Emilio Goeldi ${ }^{143} \mathrm{e}$ Herman von Ihering ${ }^{144}$.

Surpreso com os relatos etnográficos sobre a baixa produtividade do trabalho dos indígenas da Amazônia Goeldi buscava alguma razão que explicasse o fenômeno, que não teria sentido de um ponto de vista econômico e prático. Atento à condição técnica da atividade, notou o autor que os machados não teriam tanto a função de cortar quanto a de martelar a árvore, em um ritmo e lógica de corte próprios, mas com resultados surpreendentes. Sintetiza o processo dizendo que se iniciava com a escolha da árvore no período de abundância da seiva e realizava-se primeiramente o corte na camada exterior buscando uma ligadura que interrompesse a circulação da seiva para secar e matar a árvore. Procedia-se com o esmagamento do anel aberto inicialmente com o machado e ateava-se fogo ao redor da árvore um fogo baixo alimentado com certa semente de palmeira. Ocorrendo a carbonização desejada retiravam-se as cinzas e sobras e continuava-se com estas etapas até o corte final das árvores.

Observa o autor que "a operação, embora durando alguns dias, é executada de forma tão habilidosa, que o tronco e a área de corte da árvore não ficam muito diferentes dos daquelas que fossem derrubadas com um moderno machado de aço" 145

Discordando de Goeldi e não acreditando que ocorresse o uso do fogo, Ihering chegou a praticar de "reconstituição arqueológica" para calcular o tempo e produtividade dos indígenas brasileiros e paraguaios, do povo Guaiaqui, fazendo réplicas de machados constantes no Museu Paulista na época em que era o diretor da instituição.

\footnotetext{
143 GOELDI, Emílio A.. Sobre o uso dos machados de pedra de índios sul-americanos, especialmente amazônicos, atualmente existentes. Boletim do Museu Paraense Emílio Goeldi. Ciênc. Humanas., Belém , v. 4, n. 1, p. 131-133, Apr. 2009. (original: 1906)

${ }^{144}$ IHERING, Herman von. Os machados de pedra dos índios do Brasil e o seu emprego nas derrubadas de mato. Revista do Instituto Histórico e Geográfico de São Paulo, São Paulo, v.12, 1907.

${ }^{145}$ GOELDI, Emílio A.. Sobre o uso... op. cit. 2009.
} 


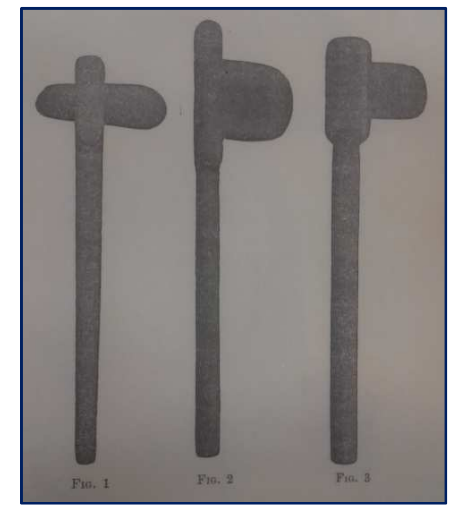

Figura 69: Fotografia dos machados fabricados para o experimento, possuindo o menor (nํ) $8 \times 5 \mathrm{~cm}$ e peso de 240 gramas, o intermediário $10 \times 7 \mathrm{~cm}$, com grossura de $3,5 \mathrm{~cm}$ e peso de 500 gramas, e o maior cerca de $30 \mathrm{~cm}$ de comprimento.

Ihering acreditava que eram "rudes" os machados, e "só em casos relativamente diminutos o machado de pedra prestaria bons serviços e sempre seria muito penoso" o seu uso. Não obstante faz o experimento de tentar abrir uma clareira no mato com o uso das réplicas por ele encomendadas. Notou que com pequenos golpes podia-se talhar, "obtida a necessária pratica" a madeira abrindo brechas cada vez maiores. Nota ainda o naturalista que o corte não podia ser de talho liso e o ângulo mais fechado como o obtido por machado de aço.

Ao tentar cortar madeiras secas com as mesmas ferramentas não conseguiu, evidenciando que eram instrumentos com uso especifico para a derrubada, sendo necessário aos indígenas outra gama de apetrechos para o trabalho com as madeiras secas. Nestas sim poderiam utilizar o fogo para carcomer o lenho de maneira controlada com a água e o vento. Nota-se que o autor critica a ausência de produtividade segundo as suas concepções europeias e modernas de trabalho, sendo que o próprio ritmo era condicionado pelas configurações materiais dos objetos, sendo o pequeno impraticável para tal serviço e o grande muito pesado. Também a força a ser empregada deveria ser ponderada, pois com muita ênfase se poderia quebrar o cabo ou a própria pedra. Exemplifica o autor mostrando fotografias dos cortes nas árvores abatidas: 


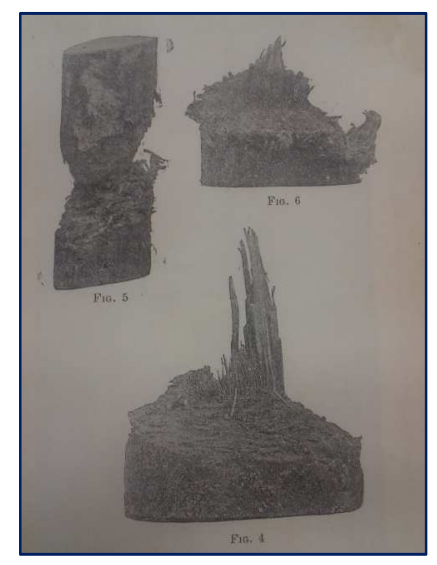

Figura 70: detalhes das árvores derrubadas por Ihering. A foto inferior é uma Tiuna ${ }^{146}$, madeira de lei, com $30 \mathrm{~cm}$ de diâmetro, cortada em 4 horas, contra meia hora com machado de aço e 9 minutos com serra braçal de dupla. A figura superior é uma canela de 12 centímetros de diâmetro.

Ihering termina seu experimento fazendo um roçado de 15x7 metros em três dias com mais dois auxiliares, concluindo que "o trabalho não é tão árduo que se deva dizer que o índio não o executasse" ${ }^{147}$.

Vemos, portanto, como entre os indígenas, e por extensão, entre grande parte da população mestiça que deles descendem, havia processos intrincados para o corte de madeiras não seguindo a lógica produtivista dos comentaristas europeus ${ }^{148}$. Eram por isso taxados de indolentes, atribuindo-se determinismos raciais e climáticos para a sua "morosidade". Por exemplo, o barão Georg von Langsdorff (1774, Wöllstein, Alemanha - 1852, Friburgo, Alemanha) enfureceu-se com os trabalhadores envolvidos na confecção de embarcações próximo a Cuiabá, os quais seguiam processos produtivos, conhecimentos e jornadas de trabalho com temporalidade próprias, afirmando desta forma que era ${ }^{149}$ :

(...) triste ter que depender de um operário daqui (...) 0 carpinteiro, por exemplo, já faz meses que está trabalhando nas canoas e até agora não terminou o serviço. Deve-se atribuir a negligência dos brasileiros não só ao clima, mas também à abundância de alimentos e ao prazer que têm pela bebida.

\footnotetext{
${ }^{146}$ Infelzmente não encontramos o nome cientifico correspondente a esta vulgata usada por Ihering.

147 IHERING, Herman von. Os machados de pedra... op. cit. 1907.

${ }^{148}$ A pesquisa de Francismar Carvalho revelou com grande profundidade as lógicas e tempos próprios do trabalho entre os remeiros mestiços em choque com as visões e narrativas dos viajantes naturalistas e monçoeiros. Cf. CARVALHO, Francismar Alex Lopes de. Viajantes, mareantes e fronteiriços: relações interculturais no movimento das monções - séculos XVIII. Mestrado em História - Universidade Estadual de Maringá, Paraná, 2006.

${ }^{149}$ LANGSDORFF, Georg H. Von. Os diários de Langsdorff. v. 2. Campinas: Associação Internacional de Estudos Langsdorff; Rio de Janeiro: Fiocruz, 1997. p. 88. Apud CARVALHO, Francismar Alex Lopes de. Viajantes, mareantes e fronteiriços: relações interculturais no movimento das monções - séculos XVIII. Mestrado em História - Universidade Estadual de Maringá, Paraná, 2006.
} 
Infelizmente não podemos precisar se havia fornecimento de madeiras aos marceneiros paulistas pelos indígenas ${ }^{150}$ utilizando-se dessas técnicas, mas delas algumas etnias poderiam se dispor na feitura de estruturas centrais de suas habitações e também para os banquinhos rituais providos de densa simbologia, cujo uso abordaremos no último capítulo.

Cabe dessa forma compreender que para esses habitantes ancestrais da terra passar do corte ritual esquematizado para o processo célere introduzido pelo europeu com suas ferramentas de metal decerto significava grande inovação em seu modo de vida, com suas vantagens e contradições.

Também no período que nos compete vemos paralelamente no mundo europeu alterações nas formas de cortar e trabalhar as madeiras, especialmente para a produção dos móveis. Na década de 1730, por exemplo, despontaram na Inglaterra e também na França diversos manuais de carpintaria e marcenaria, como os de Roubo, Sheraton e Chippendale, essenciais no avançar da pioneira industrialização da produção moveleira ${ }^{151}$. Entendemos como esses primeiros guias, já ricamente ilustrados com pranchas explicativas foram decisivos elementos de difusão do saber manual para um público cada vez mais vasto de leitores e de novos artífices. Tais manuais acompanhavam a grande mudança social instaurada pelas melhorias tecnológicas e difusão da imprensa, fruto e também agente do avanço do letramento nas nações europeias, fenômeno mais forte na Grã-Bretanha.

Em Portugal e no Brasil utilizou-se durante todo o período colonial no âmbito arquitetônico o compêndio "O vinhola dos proprietários" criado na época renascentista por lacomo Barrozzi da Vignola (Vignola, Itália, 1507 - 1573) ${ }^{152}$, que trazia processos, desenhos e medidas de como armar estruturas e coordenar 0 trabalho da carpintaria, bem como comentários sobre a marcenaria necessária para fazer portões e telhados. De enorme importância, este compêndio foi responsável, em grande parte, pela monumentalização do mobiliário durante o século XVII e $\mathrm{XVIII}$, e foi a principal obra de referência para os profissionais até o surgimento dos

\footnotetext{
${ }^{150}$ Sabemos que havia o largo emprego de mão de obra indígena em São Paulo, por exemplo, para o transporte de materiais do litoral santista para serra acima, como observado por SANTOS, Amália Cristóvão dos. Em obras: os trabalhadores da cidade de São Paulo entre 1775 e 1809. 2013. Dissertação (Mestrado em História e Fundamentos da Arquitetura e do Urbanismo) - Faculdade de Arquitetura e Urbanismo, Universidade de São Paulo, São Paulo, 2013. P. 105.

${ }^{151}$ FORTY, Adrian. Objetos de desejo. Design e sociedade desde 1750. São Paulo: Cosac \& Naif, 2007..

152 FICHER, Sylvia ; MACEDO, D. M. . Três vinholas no Brasil do século 19. In: 40 Projetar, 2009, São Paulo. Projeto como investigação: antologia. São Paulo: Alter Market, 2009. v. 1. p. 1-20.
} 
manuais setecentistas. Para além de manuais e livros a entrada de gravuras na América foi gerando modelos que passaram a ser reproduzidos. Por exemplo, nas missões jesuíticas no Sul há registros de cartas entre os padres e superiores em Roma em que são solicitadas tais imagens em papel. Marchiori e Schulze-Hofer ${ }^{153}$ encontraram exemplos dessas gravuras usadas pelos jesuítas na igreja de São Luis, em Sete Povos das Missões:

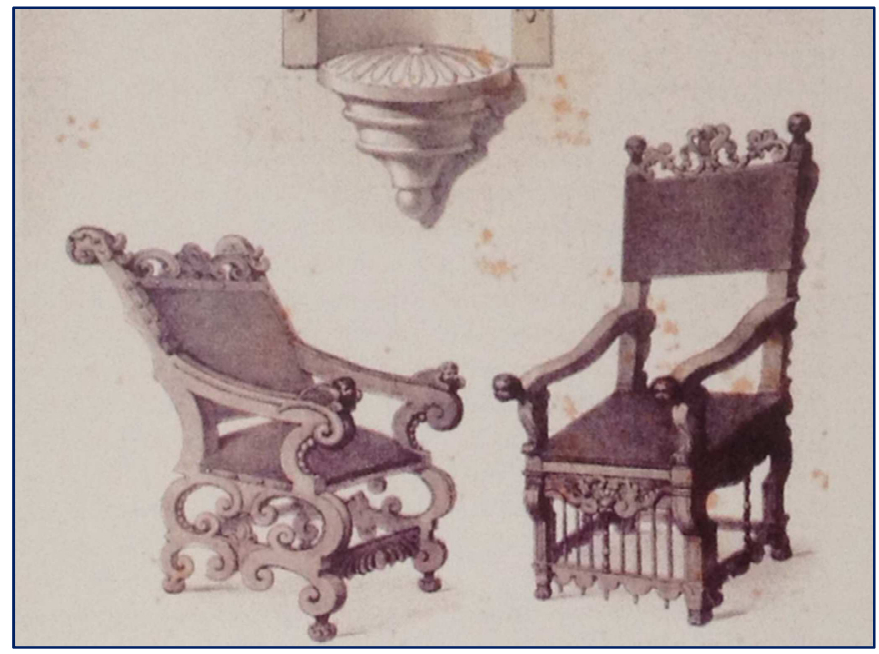

Figura 71: Desenho esquemático de cadeiras (detalhe). A. Dmersay e F. Sorrieu. Arquivo Histórico do Itamaraty ${ }^{154}$.

A partir delas, poderiam ser feitos pequenos modelos tridimensionais, tal qual os móveis em miniatura que os oficiais mecânicos produziam, fosse como prova de habilidade para a licença, fosse para o comercio itinerante, como abordaremos nos capítulos mais à frente.

Avançando em complexidade, o manual de Ignácio da Piedade Vasconcelos Artefactos symmetriacos, e geometricos de $1733^{155}$ chegava a trazer pranchas de como fazer um engenho mecânico para a serração de madeiras:

\footnotetext{
${ }^{153}$ MARCHIORI, J. N. C.; SCHULZE-HOFER, M. C. O uso da madeira nas reduções jesuítico-guarani do Rio Grande. IPHAN, 2008., p. 25

${ }^{154}$ Extraído de MARCHIORI, J. N. C.; SCHULZE-HOFER, M. C. O uso da madeira nas reduções jesuítico-guarani do Rio Grande. IPHAN, 2008. p. 25

155 VASCONCELLOS, Ignacio da Piedade. Artefactos symmetriacos, e geometricos : advertidos, e descobertos pela industriosa perfeição das artes, esculturaria, architectonica, e da pintura. Lisboa: 1733. Apud PEREIRA, Benjamim. Tecnologia Tradicional Portuguesa: Sistemas de serração de madeiras. Etnologia - 5 . Instituto Nacional de Investigação Cientifica. Centro de estudos de Etnologia. 1990.. Não sabemos se tal manual chegou a ser usado na colônia, mas Benjamim Pereira faz menção a um inventor na capitania de Pernambuco que enviou petição a D. João VI em 1804 solicitando privilégio exclusivo sobre seu invento de serrar madeiras.
} 


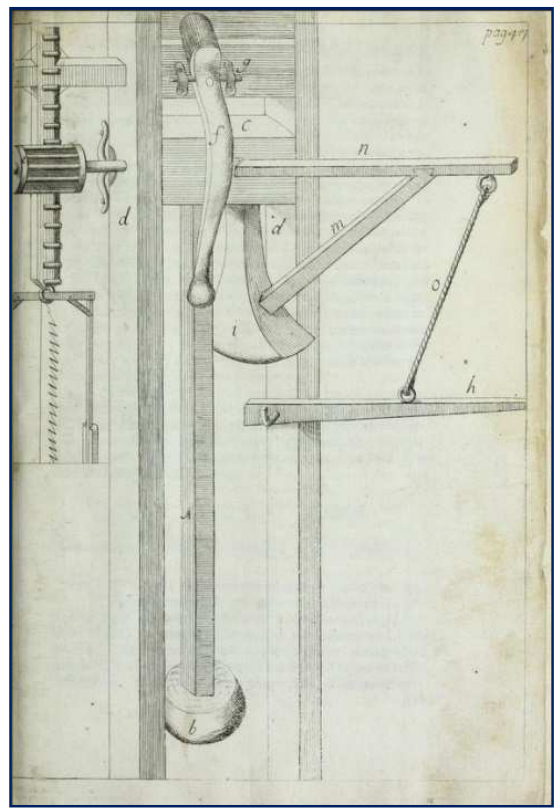

Figura 72: projeto de engenho de corte de madeira de Ignácio de Vasconcelos ${ }^{156}$

Nota Benjamim Pereira, fazendo a história da serração tradicional portuguesa, que a montagem da serração mecânica acionada pelo vento, na Marinha Grande em Portugal no meados do século XVIII, introduziu uma série de restrições à liberdade de atuação dos serradores tradicionais:

O regimento do Superintendente da fábrica, de 1751, extingue "inteiramente todas e quaisquer serrarias a mão que haja no Pinhal, ou na Vieira". E manda que $^{157}$ :

Toda a madeira que for necessária serrar-se por serras de mão, por não abranger o serviço do Moinho, seja serrada dentro dos muros do engenho, recomendando muito ao Superintendente não consinta serras de mão em alguma outra parte, exceto em caso fortuito de tempestade, em que costumam cair muitos paus, ou de alguns cortes grandes em que as bicadas fazem com a sua condução para o Moinho considerável despesa, por se fazerem em partes remotas.

Este processo de mecanização só fez avançar no decorrer dos séculos seguintes, fazendo muitos serralheiros perderem os empregos e serem obrigados a migrar de suas regiões, vindo muitos, inclusive, para o Brasil $^{158}$.

\footnotetext{
${ }^{156}$ Extraído de VASCONCELLOS, Ignacio da Piedade. Artefactos symmetriacos, e geometricos : advertidos, e descobertos pela industriosa perfeicão das artes, esculturaria, architectonica, e da pintura. Lisboa: 1733. Apud PEREIRA, Benjamim. Tecnologia Tradicional Portuguesa: Sistemas de serração de madeiras. Etnologia - 5. Instituto Nacional de Investigação Cientifica. Centro de estudos de Etnologia. 1990.

${ }^{157}$ PEREIRA, Benjamim. Tecnologia Tradicional Portuguesa: op. cit.. 1990. P. 29. Grifos nossos.

${ }^{158}$ PEREIRA, Benjamim. Tecnologia Tradicional Portuguesa: op. cit.. 1990. P. 30
} 
No que tange às inovações tecnológicas ocorridas em São Paulo e mais conectadas com a produção do mobiliário, devemos notar o processo de melhorias na produção dos metais. O governo de Luiz Antônio de Souza Botelho Mourão, o Morgado de Mateus (1722, Vila Real, Portugal - 1798, idem), entre 1765 e 1775, foi um grande momento de estímulo ao desenvolvimento tecnológico interno na colônia americana, catalisando no interior paulista as dinâmicas socioeconômicas das décadas anteriores trazidas pela riqueza do comércio interno.

Grande sinal das inovações trazidas pelo governo restaurador da capitania foi o moderno forno construído na fábrica de ferro sorocabana que atendia à região de São Paulo. Essa inovação está conectada ao caso específico que estudamos da produção moveleira, pois neles poderiam ser fabricadas variadas sortes de ferramentas ou mesmo de metais semimanufaturados, a serem posteriormente trabalhados para a confecção dos instrumentos necessários. De fato, o improviso e a empiria de soluções para o exercício das atividades econômicas mais variadas foram muito presentes durante o secular processo de sedimentação colonial e expansão das fronteiras e extrativismo dos recursos naturais. Por exemplo, o governador Rodrigo Cézar de Menezes, em correspondência para o rei em 1722, ao oferecer um panorama sobre a exploração das minas do Oeste e a conveniência de abrir um caminho para elas, revela que dois sertanistas - os irmãos Lemes - os quais haviam descoberto as minas de Cuiabá disseram-Ihe "que como não tinham ferramentas se valiam dos canos das espingardas, que Ihes serviam em lugar de alavancas e com eles tiravam bastante ouro " 159.

O forno construído na fábrica sorocabana era do tipo Stuckofen, altos fornos que podiam produzir ferro coado (gusa), ou ferro maleável. Pela temperatura que esses atingiam através do bombeamento de ar com o mecanismo impulsionado por água, podia-se obter ferro de baixo teor de carbono, o qual é dúctil, chamado ferro fundido, à diferença do ferro forjado, que precisa ser martelado para livrar-se das impurezas. Até o século XIX, era chamado de aço o ferro forjado com médio teor de carbono, passível de endurecimento por têmpera.

${ }^{159}$ APESP. DI, vol. 32, p. 14. 
Antes, utilizavam-se principalmente os fornos do tipo catalão ${ }^{160}$, usando a insuflação de ar por meio de foles de couro, acionados por rodas ou trompa d'água ${ }^{161}$, à semelhança do que pudemos ver em visita às oficinas da FRESS:

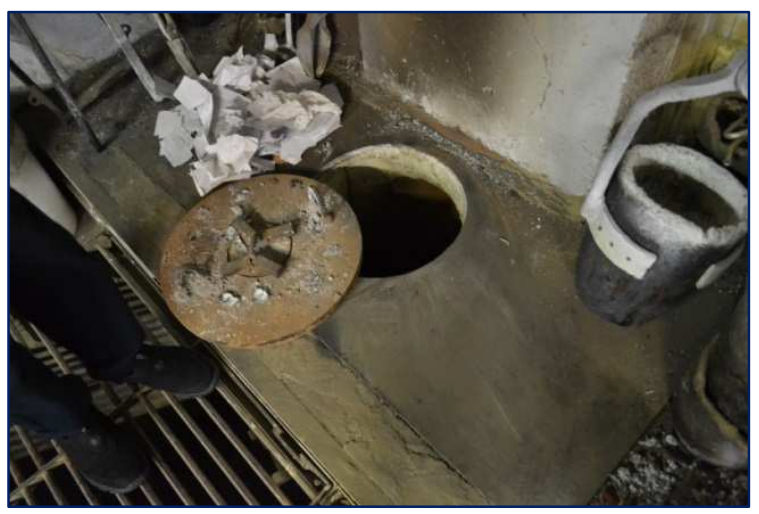

Figura 73: forno de tipo catalão nas Oficinas da FRESS. Foto do autor.

Neste forno, os cadinhos são colocados no interior do forno de abertura circular, e este é então tampado. As chamas são alimentadas pelo ar que entra pela abertura no piso onde há a grade.

Assim, a diferença material entre peças de ferro forjado e de ferro fundido trazia grandes variações de qualidade entre os tipos de ferramentas e utensílios que se poderiam fabricar nos fornos de cadinho. Estes, deve-se ressaltar, eram bastante numerosos na colônia inteira, especialmente devido à agência dos escravos africanos $^{162}$.

Cumpre dizer que o emprego do trabalho indígena e negro, por si só, já foram verdadeiros alteradores das formas de produção e engendraram inovações no trabalho, por mais retrógradas que tivessem parecido à historiografia ${ }^{163}$.

Um fascinante exemplo nos é dado pelas palavras do próprio governador, que, em 1772 relatou ao rei D. José I, "que um hábil escravo africano ali engajado, principiando a trabalhar com o mestre, tira melhores fundições quando a governa"164.

\footnotetext{
${ }^{160}$ ZEQUINI, Anicleide. Arqueologia de uma fábrica de ferro: morro de Araçoiaba séculos XVI-XVIII. 2006. Tese (Doutorado em Arqueologia) - Museu de Arqueologia e Etnologia, Universidade de São Paulo, São Paulo, 2007.

161 LANDGRAF, Fernando et al. Notas sobre a história da metalurgia no Brasil (1500-1850). In: MOTOYAMA, Shozo; (org.). Preludio para uma historia: ciência e tecnologia no Brasil. São Paulo: Edusp, 2004.

162 LANDGRAF, Fernando et al. Notas sobre a história da metalurgia no Brasil (1500-1850). In: MOTOYAMA, Shozo; (org.). Preludio para uma historia: ciência e tecnologia no Brasil. São Paulo: Edusp, 2004. P. 110.

${ }^{163}$ Vide por exemplo o trabalho de TRONCOSO, Lucas. Um estudo arqueometalúrgico dos artefatos do arraial de São Francisco Xavier da Chapada. 2013; bem como CUNHA JUNIOR, Henrique Antunes. Arte e tecnologia africana no tempo do escravismo criminoso. Revista Espaço Acadêmico - Uem. v. 14, n. 166, 2015. e LEITE, José Roberto Teixeira. As raízes na África Negra da siderurgia brasileira. In: Arte, adorno, design e tecnologia no tempo da escravidão. (catálogo de exposição) curador Emanoel Araújo. São Paulo: Museu Afro Brasil, 2013.
} 
Retornando aos dados coletados pela análise das marcas dos móveis, podemos dimensionar a diferença que a qualidade dos metais das ferramentas trazia para a confecção das peças, lembrando que os artífices dependiam de raspadeiras de metal maleável para dar o acabamento. A maleabilidade das lâminas, por seu turno, depende de vários fatores, como a qualidade do minério e o grau de refinamento obtido nas forjas. Possivelmente a instalação da fábrica de ferro em Sorocaba com o forno Stuckofen permitiu a produção de metais mais refinados $^{165}$ na região de São Paulo, inclusive no âmbito das ferramentas empregadas pelos oficiais mecânicos moveleiros.

Não obstante, o protecionismo metropolitano sobre o estabelecimento de indústrias na América foi um forte fator limitador dos empreendimentos tecnológicos no âmbito colonial, interferindo em todas as suas ramificações e setores econômicos tributários, como a produção moveleira. O mais famoso exemplo foi o Decreto da proibição das manufaturas no Brasil, lançado por D. Maria I em 1785, surgindo principalmente como reação à nascente indústria têxtil no Brasil. Deve-se observar, não obstante, que tal lei não conseguiu ter força o suficiente, tanto que logo em 1795 já se excluiu a metalurgia do ferro da proibição real sob as áreas coloniais.

Tal configuração das condições infraestruturais da produção colonial influenciavam, por seu turno, a microeconomia da produção moveleira. Ainda que esses aprimoramentos tecnológicos tenham ocorrido ao longo do século XVIII, eles foram muito tímidos, sendo o metal caro na colônia em geral e o acesso às ferramentas bastante escasso até o século XIX. Especificamente em São Paulo, diz Warren Dean, que foi somente na década de 1820 quando os equipamentos de serraria se tornaram comuns, apesar de já em 1838, haver 53 serrarias a cidade ${ }^{166}$. Isto revela como em pouco tempo houve uma grande mudança no padrão

\footnotetext{
164 FELICÍSSIMO JÚNIOR. José. História da Siderurgia de São Paulo. São Paulo: ABM, 1969. apud LANDGRAF, Fernando et al. Notas sobre a história da metalurgia no Brasil (1500-1850). In: MOTOYAMA, Shozo; (org.). Preludio para uma historia: ciência e tecnologia no Brasil. São Paulo: Edusp, 2004.p. 114.

165 Observa Anicleide Zequini que a composição da magnetita do morro de Araçoiaba é impregnada de óxido de Titânio $\left(\mathrm{Ti}_{2}\right)$ o qual concorre para torná-la inaproveitável para a redução mesmo nos altos fornos a coque, a menos que sofra prévio e demorado tratamento ou que seja misturada a minérios menos densos. Assim, a causa do grande fracasso dos três séculos de tentativas de se produzir ferro de boa qualidade naquele local e das inúmeras críticas que eram feitas aos fundidores e administradores devia-se à composição química da matéria prima, conhecimento que só foi alcançado nos finais do século XIX. Cf. ZEQUINI, Anicleide. Arqueologia de uma fábrica de ferro: morro de Araçoiaba séculos XVI-XVIII. 2006. Tese (Doutorado em Arqueologia) Museu de Arqueologia e Etnologia, Universidade de São Paulo, São Paulo, 2007.

${ }^{166}$ DEAN, Warren. A ferro e fogo: a História e a devastação da Mata Atlântica brasileira. São Paulo: Cia das Letras, 1997, p. 180.
} 
tecnológico existente na cidade - tal como na metade do século XVIII, porém mais intenso - o que alterou e muito a vida material de sua população.

No âmbito que nos compete, o acesso mais amplo às ferramentas estrangeiras gerou alterações nas formas de trabalho e também impulsionou a sua eficiência. Isso não escapou ao olhar dos viajantes estrangeiros, que no começo de século XIX igualmente tornaram-se mais numerosos na América lusa, dada a abertura dos portos com a transferência da corte de Portugal. Por exemplo, os produtos da indústria inglesa passaram a povoar as lojas e armazéns das cidades e vilas. Segundo John Luccock, aportavam no Rio de Janeiro os machados e serras inglesas, muito superiores aos já existentes, tornando menos árduo o trabalho, particularmente nas derrubadas de árvores e, por extensão, nos trabalhos de carpintaria e marcenaria. ${ }^{167}$

Não à toa, a partir deste momento, do ponto de vista da História Ambiental, a devastação das florestas brasileiras, em especial a Mata Atlântica, avançou a passos cada vez mais largos, vindo a se intensificar no século posterior ${ }^{168}$.

Finalizando o recorte temporal deste nosso estudo, novas transições sobre esse tipo de materialidade artesanal do mobiliário se deram ao longo do século XIX, quando o processo de fabricação do mobiliário se alterou para o modelo de maquinofatura e indústria ${ }^{169}$.

Como se vê, a partir da análise pormenorizada das peças, é possível inferir as etapas de produção e as ferramentas utilizadas durante a sua confecção, notando nos detalhes mais banais indícios sintomáticos da condição produtiva do momento e depois, lançando mão de outros conjuntos de fontes, dar uma amostra das alterações técnicas e estilísticas dos móveis, ainda a ser completada com outros conjuntos documentais, como os vários relatos de viajantes, o epistolário administrativo e também os manuais técnico-científicos que circulavam na Europa no período.

\footnotetext{
${ }^{167}$ LUCCOCK, John. Notes on Rio de Janeiro and the southern parts of Brazil. London: Legih, 1820. P. 350.

${ }^{168}$ DEAN, W. A ferro e fogo... op. Cit., 1997, p.193.

169 SANTI, Maria Angélica. Mobiliário no Brasil: origens da produção e da industrialização. São Paulo: SENAC, 2013. P. 99.
} 


\subsection{Arqueometria}

Prosseguindo com nosso esforço de análise histórica das técnicas e materiais utilizados na confecção dos móveis paulistas, agora trataremos das madeiras, dos couros, das tintas, dos vernizes e demais espécies de acabamentos presentes nas superfícies das peças com outras metodologias interconectadas com a perspectiva da cultura material. Examinamos duas peças, a cadeira de sola RG55 e a Arca-cofre RG $3242^{170}$.

Diferente das análises visuais que realizamos anteriormente para determinar as ferramentas usadas na confecção, iremos agora lançar mão de técnicas arqueométricas, mais especificamente da Física Aplicada e Biologia, para precisar quais pigmentos foram utilizados na pintura e quais elementos químicos constituem as madeiras, os couros e mesmo qual a composição das partes metálicas. Lembrando-nos da afirmação de Ulpiano Bezerra de Meneses "os objetos só possuem de intrínsecos as suas características físico-químicas, e todo o resto lhes é atribuído" ${ }^{\prime 17}$, procuraremos mostrar que também os elementos físico-químicos constituintes das peças possuem historicidade, isto é, a escolha de determinadas e específicas parcelas do meio físico para a confecção não é natural, nem automática ou restrita àquilo que determinada comunidade dispõe de seu meio-ambiente mais imediato.

A Arqueometria, segundo define Artioli ${ }^{172}$ de maneira bastante generalista, é a aplicação de princípios e métodos científicos de caracterização de materiais relacionados ao patrimônio cultural. O mesmo autor observa que é um campo de atuação tão vasto e multíplice que não há acordo geral sobre a sua extensão e

\footnotetext{
${ }^{170}$ Conforme apresentado em proposta de análise submetida à nossa orientadora e à direção do Museu Paulista, procuramos realizar com a parceria da Prof.a Dr.a Márcia Rizzutto e a conservadora Me. Fabiola Zambrano a análise comparativa de seis móveis: as cadeiras RG 55, RG 60 e RG 553, as Arcas RG 3241 e RG 3242, além do Leito RG 4996. Usamos a nomenclatura do catálogo do museu. Entretanto, devido ao volume de informações a serem contempladas nesta presente tese, bem como a novos achados ocorridos especialmente em torno do Leito - que evidenciou materiais com datação e origens diferentes daquelas presentes na ficha catalográfica do Museu - , decidimos, com anuência de nossa orientadora e compreensão da Prof.a Márcia e da conservadora Me. Fabiola, contemplar apenas os resultados da cadeira RG 55 e da Arca RG 3242 de maneira a contemplar os outros móveis em futuros trabalhos e publicações.

${ }^{171}$ MENESES, Ulpiano Bezerra de. Do teatro da memória ao laboratório da História: a exposição museológica e o conhecimento histórico. Anais do Museu Paulista, n.1 vo. 2. 1994, p. 17.

172 ANGELINI, Ivana; ARTIOLI, Gilberto. Scientific Methods and Cultural Heritage: An Introduction to the Application of Materials Science to Archaeometry and Conservation Science. Oxford: Oxford University Press. 2010. p, 1.
} 
mesmo sua definição enquanto uma disciplina própria ${ }^{173}$. Para muitos dos pesquisadores envolvidos, sejam os advindos das Ciências da Natureza, seja os das Ciências Humanas, a fluidez deste campo de pesquisa é essencial e seria, aliás, empobrecedor o seu fechamento enquanto uma disciplina própria, que limite escopos e técnicas. O próprio surgimento do termo se dá em 1958 com o jornal Archaeometry, de Oxford $^{174}$, relacionado principalmente à caracterização quantitativa de objetos e processos arqueológicos. Entretanto, desde os anos 1930 já se utilizavam técnicas como os raios $X$ para radiografar pinturas e peças de coleções artísticas $^{175}$, desta maneira evidenciando o paralelismo de intenções de pesquisa que acabavam por convergir dois campos de pesquisa, cada um com suas metodologias, e usando cada vez mais novas técnicas de exame das peças.

O que une a vasta gama de profissionais sejam físicos, engenheiros, biólogos, químicos, ou historiadores, arqueólogos, conservadores, museólogos é a busca por capturar com o maior número de técnicas e metodologias disponíveis o maior número de informações possíveis sobre os mais variados vestígios de cultura material. Pode-se desta maneira compreender historicamente quais foram os materiais e técnicas empregadas, a idade dos materiais e produção, bem como, mirando o futuro, saber como conservá-las pelo maior tempo possível e quais técnicas e instrumentos criar ou melhorar para dar mais precisão às análises e capturar novos dados ${ }^{176}$.

Assim, dada a escassez de informações que possuímos sobre a trajetória das peças que buscamos analisar nesta dissertação, buscamos lançar mão dessas metodologias multidisciplinares para caracterizar seus componentes materiais. Ultrapassando o caráter meramente comprobatório, o uso de metodologias desses outros campos do saber nos permite descobrir informações que não seriam obtiveis apenas com fontes escritas ou com a observação a olho nu e luz visível. Tais procedimentos ajudarão a repensar nossa abordagem histórica sobre as peças, de maneira a fornecer novas informações sobre a sociedade portuguesa e brasileira nos séculos XVIII e XIX. Também ajudará a complementar o conhecimento sobre o

\footnotetext{
${ }^{173}$ CASTELLANO, Alfredo; MARTINI, Marco; SIBILIA, Emanuela. Elementi di archeometria. Metodi fisici per i beni culturali. Milão: EGEA. 2007, p. 4; p. 9.

${ }^{174}$ CASTELLANO, A. Et al. Elementi di archeometria... Op. cit., 2007, p. 11.

${ }^{175}$ Idem, ibidem, p. 13.

${ }^{176}$ ANGELINI, Ivana; ARTIOLI, Gilberto. Scientific Methods... op. cit. 2010, p. 15.
} 
acervo do Museu Paulista, resgatando sua história institucional, a trajetória de suas peças e ajudando na conservação de seu patrimônio.

Apesar de não dispormos de conhecimento técnico nas áreas de Física aplicada e Dendrologia, procuramos em nosso trabalho contar com o valoroso apoio de conservadores e pesquisadores destas áreas específicas. Como já recomendava Marc Bloch, dada a multiplicidade de saberes com os quais os historiadores tem que lidar $^{177:}$

Nenhum remédio senão substituir a multiplicidade de competências em um mesmo homem por uma aliança de técnicas praticadas por eruditos diferentes, mas todas voltadas para a elucidação de um tema único. Esse método supõe o conhecimento no trabalho por equipes. Exige também a definição prévia, por comum acordo, de alguns grandes problemas predominantes. São êxitos de que nos encontramos ainda bastante distantes. Eles determinam, porém, numa larga medida - não dividamos -, o futuro de nossa ciência.

No tocante à caracterização físico-química dos componentes das peças como vernizes, tintas e metais buscamos o auxílio da pesquisadora Pr. ${ }^{\text {a }}$ Dr. ${ }^{\text {a }}$ Márcia de Almeida Rizzutto, coordenadora de diversos projetos de caracterização física de objetos do patrimônio cultural, atuando junto ao Núcleo de Pesquisa de Física Aplicada ao Estudo do Patrimônio Artísitico e Histórico (NAP-FAEPAH ${ }^{178}$ ). Para a análise Dendrológica tivemos o apoio da supervisora do Serviço de Conservação e setor madeiras do Museu Paulista, Me. Fabiola Zambrano.

Devemos salientar que não nos propomos, no entanto, a tratar de tal temática à exaustão: o mundo dos móveis pintados e a História Global dos materiais e técnicas utilizadas para a sua confecção merecem dissertações próprias, havendo bastante material para exames específicos. Buscaremos oferecer nessas breves considerações um vislumbre sobre a temática, aplicando as análises em dois móveis apenas $^{179}$, apontando caminhos e, dentre o punhado de dados que pudemos encontrar sobre as práticas e fontes de pintura moveleira e sobre a atuação dos

\footnotetext{
${ }^{177}$ BLOCH, Marc. Apologia da História ou O ofício do Historiador, Rio de Janeiro, Jorge Zahar, 2002, p. 81.

${ }^{178}$ Página do Núcleo disponível em: <http://www.usp.br/faepah> Acessado em 03 out. 2016.

${ }^{179}$ Realizamos exames em seis móveis do Museu Paulista, conforme requisitado em nossa proposta de análise dos móveis. Porém, devido a uma série de problemáticas que surgiram com a análise das peças decidimos restringir as análises a apenas duas peças. Nossa decisão deveu-se especialmente o leito RG 3241, atribuído ao século XVIII e de pressuposta origem veneziana, que mostrou evidencias contrárias ao constante no catálogo. Como a problemática que envolve esse leito e sua análise estavam se afastando demasiadamente do nosso foco de estudo paulista, decidimos não integrá-la nesta dissertação, não obstante guardando o material para futuras comparações e integrações. Também reduzimos as análises pois elas estavam demasiadamente extensas para este sub-capítulo, tendo-se em conta ainda a variedade de temáticas que abarcaremos nos seguintes capítulos.
} 
pintores, buscar compreendê-los dentro de nossa abordagem e propósitos maiores da História Social paulista.

\subsubsection{Análises de Dendrologia}

A caracterização biológica das madeiras que compõem as peças nos permite inferir quais processos eram empregados nos séculos passados para sua confecção. Tais informações, cruzadas com as pesquisas realizadas com diversas fontes históricas e análises arqueométricas concorrem para a compreensão dos locais de proveniência e distribuição das madeiras e o seu consumo, lançando luz sobre as dinâmicas comerciais e culturais do Império Português nos setecentos. Tal esforço de caracterização das espécies não se resume auxiliar nossa pesquisa de caráter histórico, mas também ser útil aos Serviços de Objetos e de Conservação e Restauro do Museu Paulista. O conhecimento dos vários tipos de madeiras e materiais presentes nas peças do acervo permitirá a essas equipes melhor proteger as peças, podendo estimar quais delas necessitam de tratamentos especiais ou alocação específica, escalonando-as em graus de durabilidade e resistência a agentes danificadores, como cupins e fungos.

O exame de caracterização botânica macroscópica foi realizado junto ao Instituto Florestal do Governo do Estado de São Paulo, através da bióloga Dr. a Sandra Monteiro Borges Florsheim, no dia 15 de setembro de 2016.

As observações macroscópicas são feitas à luz visível com o auxílio de uma lupa "conta fio" com aumento de 10x em áreas com cortes transversais das madeiras que compõem dos móveis. Elas visam identificar os lenhos pelos suas características organolépticas, no caso seus espectros físicos particulares. 


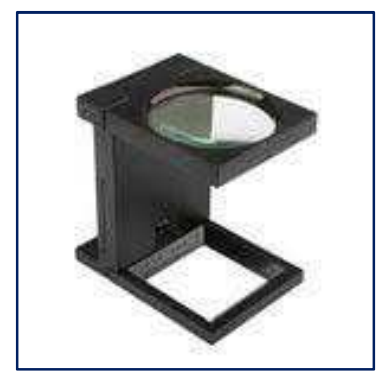

Figura 74: exemplo de lupa "conta fio" com aumento de $10 \mathrm{X}^{180}$

Dado o fato de que as diferentes espécies de madeiras assumem configurações exclusivas nos filamentos lenhosos, tal como as digitais humanas, pode-se assim precisar o gênero da árvore utilizada na confecção da peça, ainda que a espécie necessite de averiguações mais profundas.

Os biólogos primeiramente procuraram arestas dos móveis que apresentassem cortes transversais no lenho da árvore e fossem suficientemente escondidas para não afetar o aspecto nem a estrutura dos móveis. Procedeu-se então com diminutas incisões manuais com uma fina lâmina de navalha para remover as camadas superficiais da madeira danificadas pelo tempo de uso, onde os micro-filamentos dos vasos ficam amassados, não sendo possível distinguir-lhes. Isto feito pode-se observar através de um microscópio portátil o espectro da sessão transversal da madeira e precisar o gênero arbóreo.

Posteriormente realizaram-se fotografias macroscópicas das áreas de caracterização das madeiras para divulgar os resultados. Elas foram feitas através de equipamento possuído pelo próprio Museu Paulista, o microscópio digital DinoLite® acoplável em computador, com capacidade de até 100x de aumento.

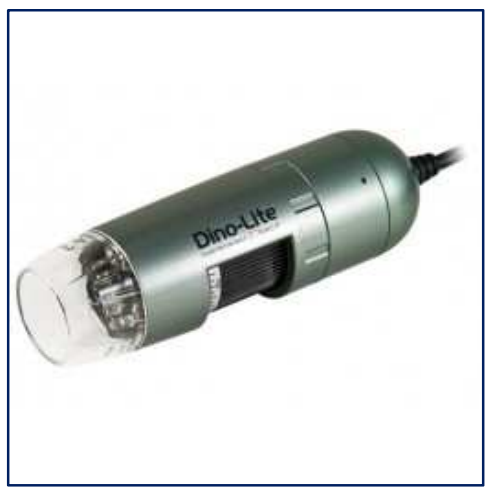

Figura 75: Microscópio Digital Dino-Liteß AM3113T ${ }^{181}$.

Apresentamos abaixo as fotografias das peças, indicando com setas os pontos onde foram realizadas as incisões para as análises macroscópicas. A seguir

\footnotetext{
${ }^{180}$ Extraido de: www.casadocontafios.com. Acessado em 03 out. 2016

${ }^{181}$ Extraído de: http://www.dinolite.com.br/dino-lite-am3113t. Acessado em 03 out. 2016
} 
constam as fotografias dos pontos onde ocorreram os exames, com aumento de $10 \mathrm{x}$ e 100x, e as explicações das nossas hipóteses de análise.

\subsubsection{Cadeira RG55}

Consultando a ficha catalográfica da cadeira RG 55, conforme consultada no Banco de Dados e Imagens do Museu Paulista, encontramos a seguinte descrição, que reproduzimos em parte, com informações as quais buscamos conferir e problematizar $^{182}$ :

Época: Século 17 (COLÔNIA)
Mat./Técnica: couro - madeira - metal
Origem: Brasil (Provável)
Descrição: Ornamento: águia. Ornamento: coroa.
Ornamento: iniciais. Ornamento: coração.
Cadeira de jacarandá do século XVII, em linhas
retas, de construção rústica, com assento de
couro cru em mau estado, e espaldar guarnecido
de sola lavrada com ramagens e ornatos, tendo
no centro águia bicefálica coroada, com cartela
na qual se vê um coração em chamas
atravessado por duas setas e a cifra ídmr. Nos
cantos do espaldar remates de madeira em
ectaedro. Pernas retas, de seção retangular, com
travessas simples. (J. WASTH RODRIGUES
1948: 24).

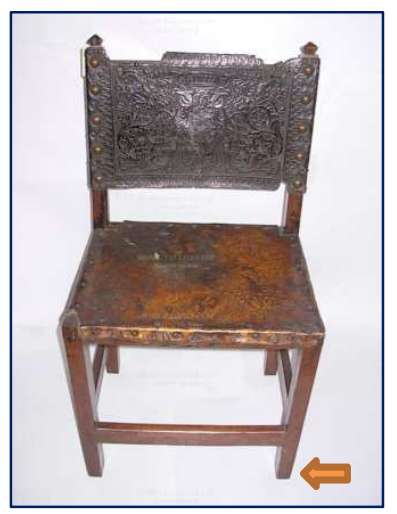

Figura 76: Cadeira RG 55. A seta indica o ponto de análise, no caso na face inferior, apoiada no chão $0^{183}$

\footnotetext{
182 RODRIGUES, José Wasth. Descrições de mobiliário. São Paulo: Museu Paulista, 1948. Datilografado e rubricado. Disponível em: http://www.acervo.mp.usp.br/ObjetosV2.aspx\#. Grifo nosso.

${ }^{183}$ Acervo Museu Paulista. Fotografia: http://www.acervo.mp.usp.br/Acervo.aspx. Acessado em 03 out. 2016.
} 
Interessou-nos assim identificar a madeira usada no corpo da peça, já que presumimos ser constituída de Jacarandá-Paulista (Machaerium villosum) por apresentar coloração mais clara em relação as outras cadeiras da mesma época (RG 60 e RG 553, como se pode comparar pelas peças já analisadas), ainda que também seja ela descrita na ficha catalográfica como feita de Jacarandá da Bahia (Dalbergia nigra). Compare-se a coloração do travamento frontal da figura acima com a foto de corte tangencial da ficha do Jacarandá Paulista abaixo.

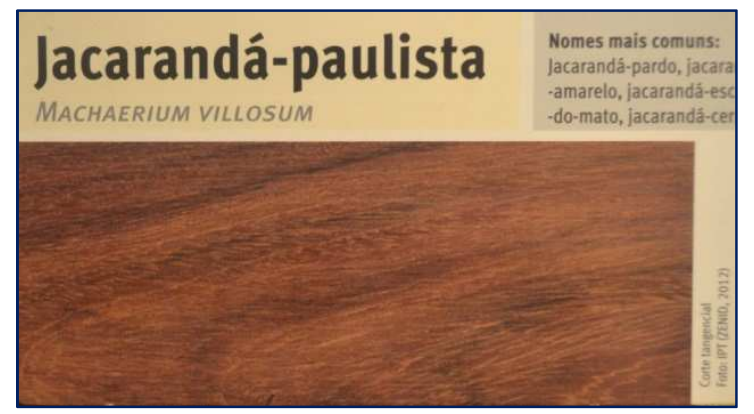

Figura 77: reprodução da ficha do Jacarandá paulista (Machaerium villosum) ${ }^{184}$.

Ainda que a coloração do Machaerium villosum seja parecida com espécimes mais claros de Dalbergia nigra, a análise macroscópica permitiu sanar a dúvida, pois seus arranjos celulares são bastante distintos, como se pode comparar pelas imagens macroscópicas de suas seções transversais (compara-se a Figura 78 abaixo com a Figura 79)

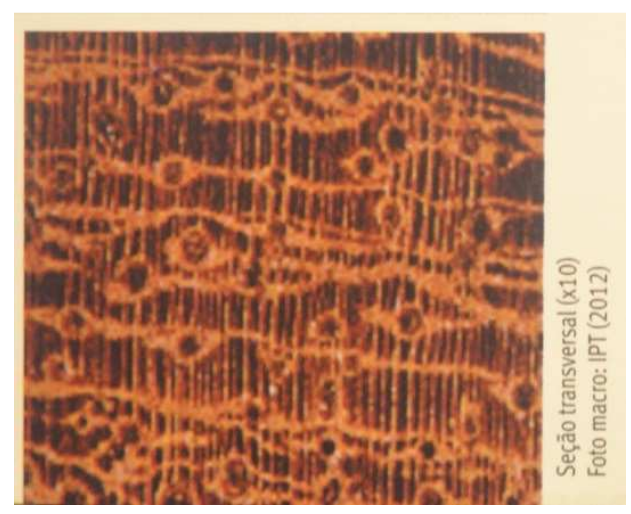

Figura 78: reprodução da ficha do Jacarandá paulista (Machaerium villosum).

\footnotetext{
${ }^{184}$ PEREIRA, Andréa Franco. Madeiras brasileiras. Guia de combinação e substituição. São Paulo: Blucher, 2013. ficha 71.
} 


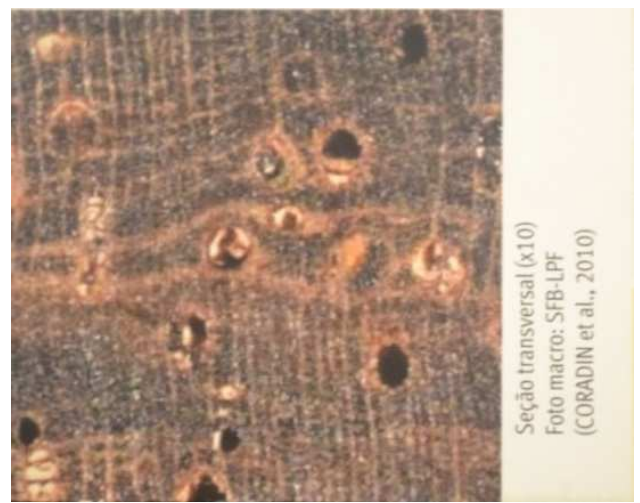

Figura 79: Reprodução da ficha do Jacarandá da Bahia (Dalbergia nigra) ${ }^{185}$.

Uma amostra da parte inferior dos pés das cadeira fora suficiente para revelar que este móvel de assento é constituído realmente do gênero Dalbergia.

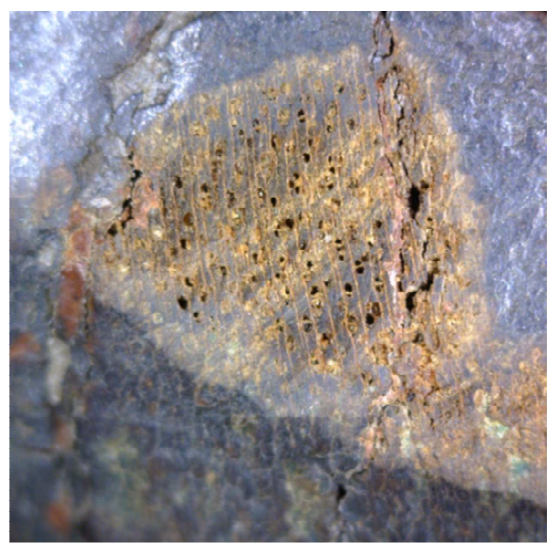

Figura 80: Ampliação de 10x da madeira de Jacarandá (Dalbergia sp.) da Cadeira RG 55. Fotografia: Fabiola Zambrano.

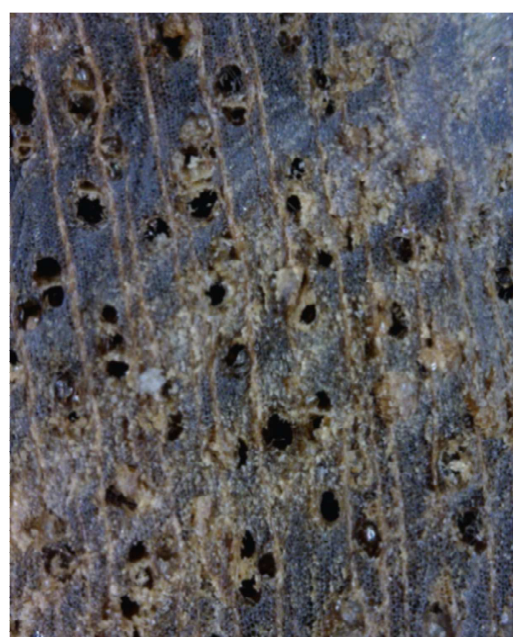

Figura 81: Ampliação de 100x da madeira de Jacarandá (Dalbergia sp.) da Cadeira RG 55. Fotografia: Fabiola Zambrano.

${ }^{185}$ PEREIRA, Andréa Franco. Madeiras brasileiras. Guia de combinação e substituição. São Paulo: Blucher, 2013. Ficha 88. 


\subsubsection{Arca-Cofre 3242.}

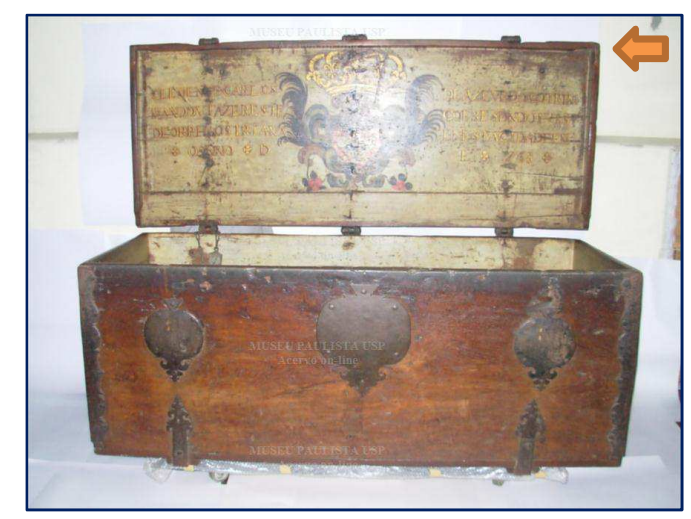

Figura 82: Arca RG 3242. A seta indica o ponto de análise. Acervo Museu Paulista. Fotografia: http://www.acervo.mp.usp.br/Acervo.aspx

Apesar de ter sido um móvel de uso público, pertencente ao juizado de órfãos da câmara municipal de São Paulo, esta peça nos interessou por permitir comparativos com os móveis domésticos e por indicar a sua proveniência paulistana através de registro escrito presente no próprio tampo, bem como datação: 1738. Ao contrário do que consta na ficha catalográfica presente do Museu Paulista, onde consta a madeira como "Cedro Rosa", a análise revelou o uso da imbuia (Ocotea $\mathrm{sp.).} \mathrm{Sendo} \mathrm{esta} \mathrm{provadamente} \mathrm{uma} \mathrm{madeira} \mathrm{rígida,} \mathrm{resistente} \mathrm{a} \mathrm{infestações} \mathrm{e}$ também com boa trabalhabilidade e repleto de ferragens, servindo de cofre, compreende-se o seu uso nesse caso. Abaixo reproduzimos a ficha catalográfica da peça, conforme consultada no banco de dados do Museu Paulista:

Época: 1738
Mat./Técnica: Madeira (Cedro Rosa) - Metal
(Ferro)
Origem: Brasil/São Paulo/São Paulo
Histórico: Pertenceu à antiga câmara municipal
de São Paulo, usado como cofre e arquivo.
Mandado fazer pelo juiz de órfãos em São Paulo,
Clemente Carlos Cotrim, em 1738, conforme
inscrito na parte interna da tampa. - as armas de
Portugal, período D. João V, que foram pintadas
na parte interna da tampa, eram utilizadas na
bandeira da câmara municipal de São Paulo (J.
WASTH RODRIGUES 1948: 2). ${ }^{186}$

${ }^{186}$ RODRIGUES, José Wasth. Descrições de mobiliário. São Paulo: Museu Paulista, 1948. Datilografado e rubricado. Disponível em: http://www.acervo.mp.usp.br/ObjetosV2.aspx. Grifo nosso. 


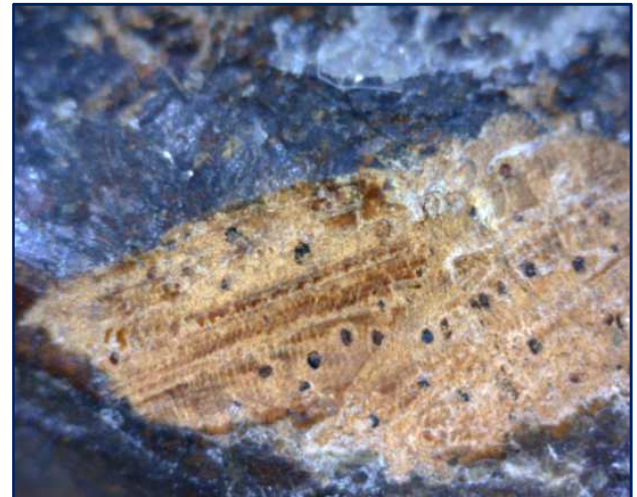

Figura 83: ampliação de 10x da madeira de Imbuia (Ocotea sp.) do tampo da Arca RG 3242. Fotografia: Fabiola Zambrano.

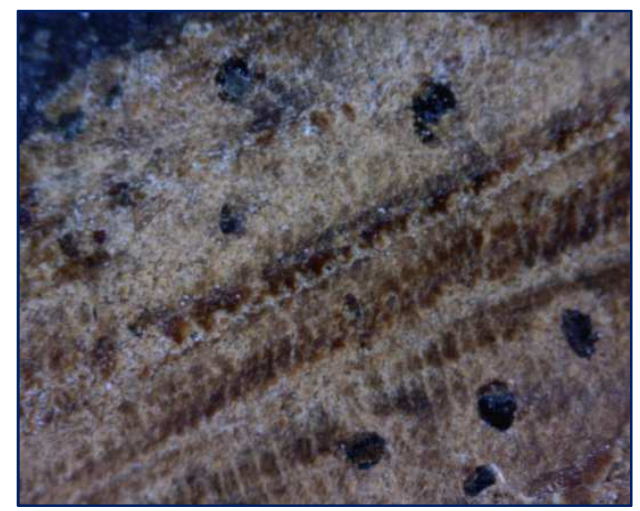

Figura 84: ampliação de 100x da Imbuia da Arca 3242. Fotografia: Fabiola Zambrano.

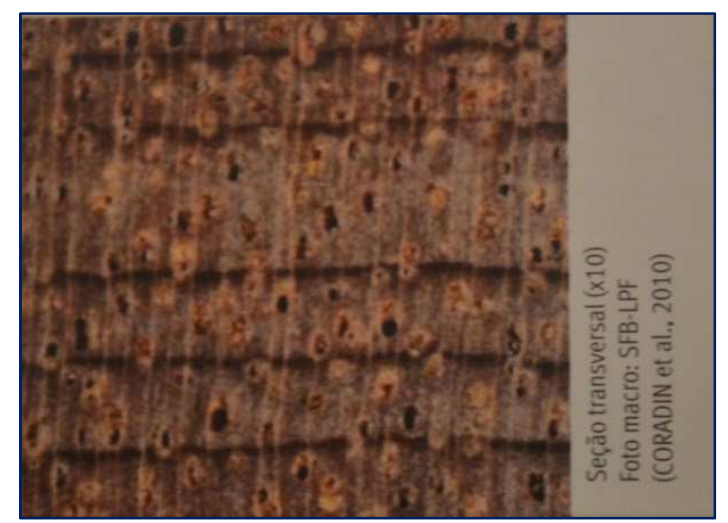

Figura 85:Reprodução da ficha da Imbúia (Ocotea porosa) ${ }^{187}$.

O interesse em precisar os tipos de madeira dos móveis através da identificação dendrológica aplicada ao patrimônio histórico ${ }^{188}$ segue na direção de

\footnotetext{
${ }^{187}$ PEREIRA, Andréa Franco. Madeiras brasileiras. Guia de combinação e substituição. São Paulo: Blucher, 2013. Ficha 75.

${ }^{188}$ Outros exemplo de trabalhos que realizaram tais análises são MIRANDA, Maria José de Andrade Casimiro; PIGOZZO, Raphael Jaquier Bossler. Most common timbers in Brazilian wood historical artefacts. Pro Ligno, v. 9, n. 4, p. 312-318, dez., 2013.; e BERNAL, Rocio Astrid; VALENT, Adelina; PISSARRA, José. Wood identification of
} 
investigar o próprio processo de fornecimento da madeira para marcenaria em São Paulo. Sendo a primeira etapa da cadeia de produção dos móveis, também ela está permeada de historicidade. Tal como predicado por Tim Ingold ao trazermos "as coisas de volta à vida", vendo como os objetos estão integrados aos ciclos e às dinâmicas da vida e do meio ambiente, podemos compreender muitos dados sobre a sociedade passada em suas articulações de grupos e classes através destes objetos que foram produtos, vetores e conformadores dessas relações ${ }^{189}$.

Apesar de estudos de História Ambiental de feição interdisciplinar ainda estarem começando a ganhar volume ${ }^{190}$, já existem notáveis estudos, valendo citar o do fornecimento de madeiras para o mobiliário produzindo em Londres, onde se identificou a malha hídrica que servia a tais conexões econômicas e mostrando como na capital havia predomínio do uso de matérias-primas estrangeiras, enquanto nas províncias eram usadas madeiras das matas locais. Foi notável também nas províncias um progressivo aumento no uso de madeiras de fora, relacionadas a fatores econômicos e estéticos e de ampliação do consumo ${ }^{191}$. Para além dos aspectos econômicos do abastecimento da cidade com madeiras, procuraremos evidenciar outros aspectos sociais que Ihes são imbricados.

Como frisamos na hipótese de análise, a cadeira RG 55 chama a atenção, pois possui uma madeira de coloração mais clara do que as outras peças analisadas em seus aspectos formais e técnicos. Em nossa primeira análise visual, achamos que poderia se tratar de um exemplar feito com o Jacarandá Paulista (Machaerium Villosum), cuja coloração, na secção tangencial se assemelha ao homônimo baiano, apesar de serem gêneros diferentes. Ficamos interessados em pesquisar com mais profundidade a identidade desta madeira, pois ela fugiria à regra dos outros objetos analisados anteriormente, onde predominam madeiras escuras, conforme o gosto da época (XVII e XVIII) por móveis de ébano e também os laqueados ao estilo oriental chinês e japonês ${ }^{192}$. A análise dendrológica confirmou, porém, ser tratar-se de

18 th century furniture: interpreting wood naming inventoires. International Journal of Conservation Science, v. 2, n. 3, 2011.

189 INGOLD, Tim. Trazendo as coisas de volta à vida: emaranhados criativos num mundo de materiais. Horiz. antropol., Porto Alegre, v. 18, n. 37, p. 25-44, Junho 2012.

${ }^{190}$ MARTINEZ, Paulo Henrique (org.). História ambiental paulista: temas, fontes e métodos, vol. 1. São Paulo: Senac, 2007.

191 BOWETT, Andam. Furniture woods in London and Provincial Furniture, 1700-1800. Londres: Regional Furniture, Vol. XXII, 2008.

192 Tendo em conta a História dos vocábulos, vemos a influência do gosto por madeiras escuras e o impacto delas nos móveis de luxo pelo fato de o escuro e africano Ébano (Diospyros $s p$ ) ter dado origem ao substantivo 
Dalbergia sp., explicando-nos a bióloga que existem variações de cores entre os indivíduos de uma mesma espécie de árvores.

Apesar de não ser tão escuro quanto a madeira nordestina, o Jacarandá Paulista poderia ter sido utilizado nas épocas coloniais de São Paulo dadas as suas qualidades de trabalhabilidade e a próprias semelhança visual com o jacarandá baiano, sendo também conhecido como jacarandá-pardo ${ }^{193}$. Talvez tenha sido uma das árvores utilizadas pelos artífices paulistas e classificadas genericamente como "madeiras da terra", principalmente nos inventários post-mortem que serão contemplados nos próximos capítulos ${ }^{194}$.

Dado o silêncio das fontes escritas em fornecer pistas dobre a identidade das "madeiras da terra", a Arqueometria pode fornecer informações que nos auxiliem a vislumbrar quais espécies poderiam ser usadas. Um estudo que recompila o trabalho de identificação dendrológica pelo Instituto de Pesquisas Tecnológicas de São Paulo sobre 97 artefatos históricos coloniais ao longo de 12 anos levantou as madeiras que mais frequentemente apareciam, servindo como um parâmetro, decerto a ser adensado, sobre o repertório de madeiras utilizadas no Brasil Colonial ${ }^{195}$ :

- American cedar (Cedrela fissilis and C. odorata, Meliaceae);

- Vinhatico (Plathymenia reticulata, Leguminosae)

- Laurel (Nectandra spp. and Ocotea spp., Lauraceae);

- Parana pine (Araucaria angustifolia, Araucariaceae)

- Jequitiba (Cariniana estrellensis and C. legalis, Lecythidaceae)

- Canjerana (Cabralea canjerana, Leguminosae)

- Carvoeiro (Miconia sp., Melastomataceae)

- Rosewood (Dalbergia spp., Leguminosae)

- American cordia (Cordia spp., Boraginaceae)

- Caviuna (Machaerium scleroxylon, Leguminosae)

- Balsamo (Myroxylon balsamum, Leguminosae)

- Brauna (Melanoxylon brauna, Leguminosae)

- American guarea (Guarea sp., Meliaceae)

- Cambara (Gochnatia sp., Compositae)

- Guapere (Lamaninia sp., Cunnoniaceae)

Este indício nos levou não só a procurar a comprovação dendrológica da madeira, dado que realmente pode existir variação na coloração dos indivíduos de

\footnotetext{
"ebanista", utilizado praticamente como um título pela habilidade, tanto no espanhol, francês (ébéniste), quanto no inglês (ebanist).

${ }^{193}$ PEREIRA, Andréa Franco. Madeiras brasileiras. Guia de combinação e substituição. São Paulo: Blucher, 2013.

${ }^{194}$ BRANDÃO, Angela. Anotações para uma história do mobiliário brasileiro do século XVIII. Revista CPC (USP), vol. 9, 2009-2010, p. 42-64.

195 MIRANDA, Maria José de Andrade Casimiro; PIGOZZO, Raphael Jaquier Bossler. Most common timbers in Brazilian wood historical artefacts. Pro Ligno, v. 9, n. 4, p. 312-318, dez., 2013.,
} 
uma mesma espécie arbórea, como a conjecturar sobre a distribuição geográfica dessas duas árvores, fornecendo-nos valorosas reflexões sobre a distribuição diacrônica da flora brasileira e as interações econômicas entre as regiões brasileiras no período colonial.

Infelizmente, não encontramos um mapa dos biomas das espécies de jacarandá para o período coevo ao que estudamos. Desta forma, buscamos tentar inferir como era a distribuição dessas espécies de árvores em épocas remotas. Vemos pelo mapa de atual distribuição do Jacarandá da Bahia um dado curioso e que nos parece contraditório: a distribuição atual de tal espécie é maior nos limites do atual estado do Rio de Janeiro do que na própria Bahia. Não podemos inferir com certeza que a condição que vemos no mapa é o retrato fiel da distribuição natural de tal espécie, pois é possível que tal área tenha uma plantação extensiva de tal madeira realizada em tempos modernos. De qualquer forma, é fato que tal espécie foi bastante dizimada e sofre risco de extinção e aparece muito raramente na região do estado de São Paulo, sendo limitada no interior do território a alguns rincões do interior mineiro, baiano e cearense.
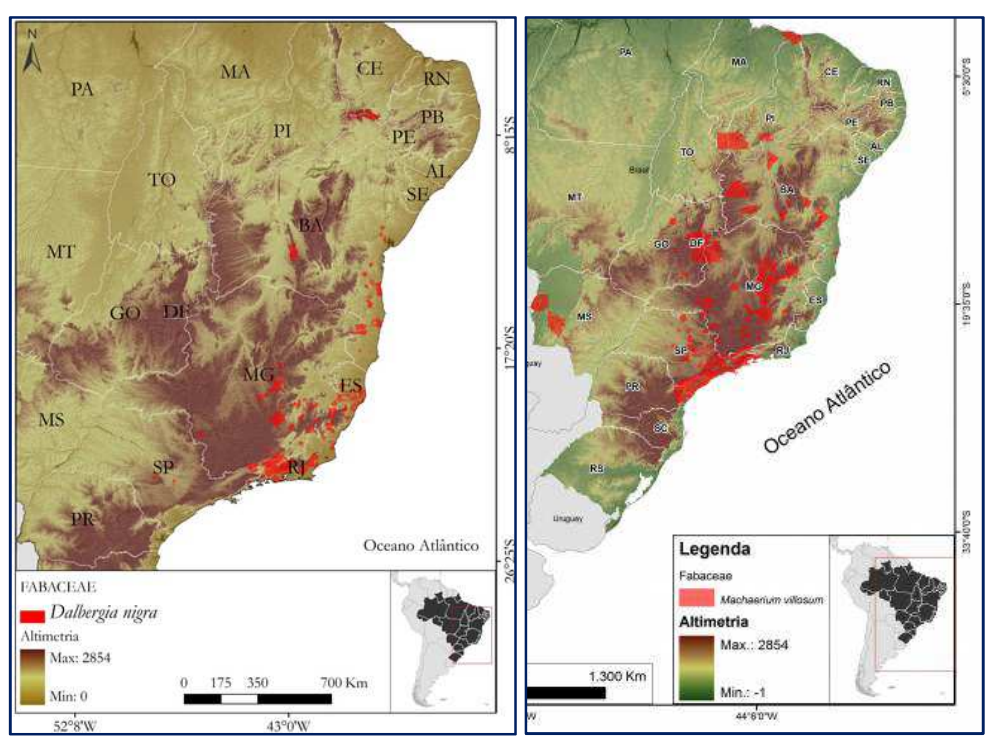

Figura 86: Distribuição do Jacarandá da Bahia. Corre risco de extinção. Estima-se que $30 \%$ da população foi destruída ${ }^{196}$.

Figura 87: Distribuição atual do Jacarandá Paulista. Não corre risco de extinção ${ }^{197}$.

\footnotetext{
${ }^{196}$ Extraído de: http://cncflora.jbri.gov.br/portal/pt-br/profile/Dalbergia\%20nigra.

${ }^{197}$ Extraído de: http://cncflora.jbri.gov.br/portal/pt-br/profile/Machaerium\%20villosum
} 
Notamos que essas duas espécies vegetais ocorrem por toda a extensão da Mata Atlântica, mas cada uma predomina em sua região específica. Desta forma, se nos inventários mais antigos o mobiliário, bastante escasso, era feito de madeira nobre e longínqua, Esse dado indica que o móvel era raro e luxuoso nestas terras. $\mathrm{O}$ indivíduo que iria dispor de uma determinada soma de dinheiro para mobiliar sua casa o faria desta forma com um material exógeno e de qualidade: uma madeira de lei.

Assim reforçamos a importância da economia interna no período colonial nas trocas entre as capitanias e formação dos polos locais de concentração de poder político, econômico e tecnológico, materializados nos móveis de jacarandá baiano penetrando as várias regiões coloniais. Conforme havíamos frisado na introdução, a história dos móveis da terra paulista também é a história do mobiliário baiano para além dos limites nordestinos.

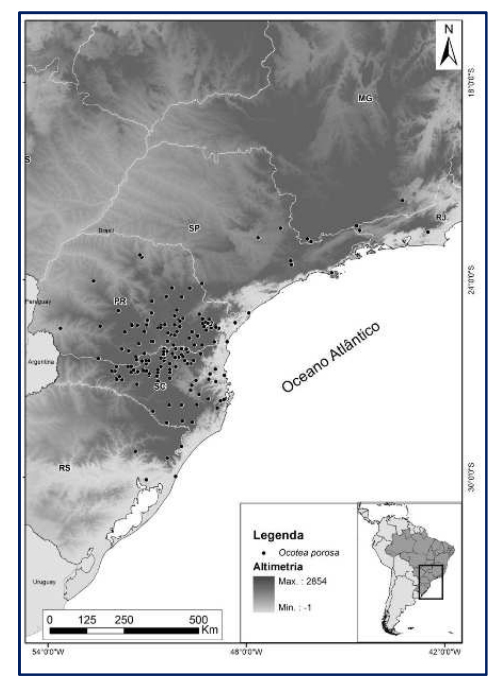

Figura 88: Distribuição da Imbuía (Ocotea porosa) $)^{198}$.

A respeito da Imbuia (Ocoetea porosa), a qual teria sido usada na Arca-cofre, notamos pelo mapa de distribuição atual que ela está presente apenas no sul e sudeste brasileiro, especialmente no Paraná e Santa Catarina ${ }^{199}$. Novamente frisamos a necessidade de compreender que o abatimento intensivo e o replantio com vistas ao extrativismo impõe barreiras à dimensão original da distribuição da

\footnotetext{
${ }^{198}$ Extraído de: Martins, Eline Matos. Conservação de Ocotea catharinensis, O. odorifera e O. porosa: espécies de Lauraceae ameaçadas de extinção. Tese de mestrado. Rio de Janeiro, RJ: Escola Nacional de Botânica Tropical, 2013. , p. 88.

199 Idem, ibidem, p. 90.
} 
espécie, mas serve para tomarmos como parâmetro da distribuição intercapitanias no século XVIII.

Como salientamos, apesar de não conhecermos mapas setecentistas da distribuição de jacarandá ou imbuia pelo litoral da Mata Atlântica, a produção de mapas botânicos no período coevo não deixava de existir. Especialmente na segunda metade do século XVIII, seguindo a lógica da potencialização do extrativismo natural e agrícola na Colônia americana, a precisão dos espaços levou à confecção de cartas $^{200}$ com apuração sobre os locais de cortes de madeiras exclusivos ao beneficio real. Uma delas é a Carta corographica e hydrographica de toda costa do mar da capitania de S. Paulo, datada de 1789, feita pelo Coronel João da Costa Ferreira, do Real Corpo de Engenheiros, em colaboração com o Ajudante Antônio Rodrigues Montesinhos e do desenhista Segundo Tenente Rufino José Felizardo e Costa ${ }^{201}$.

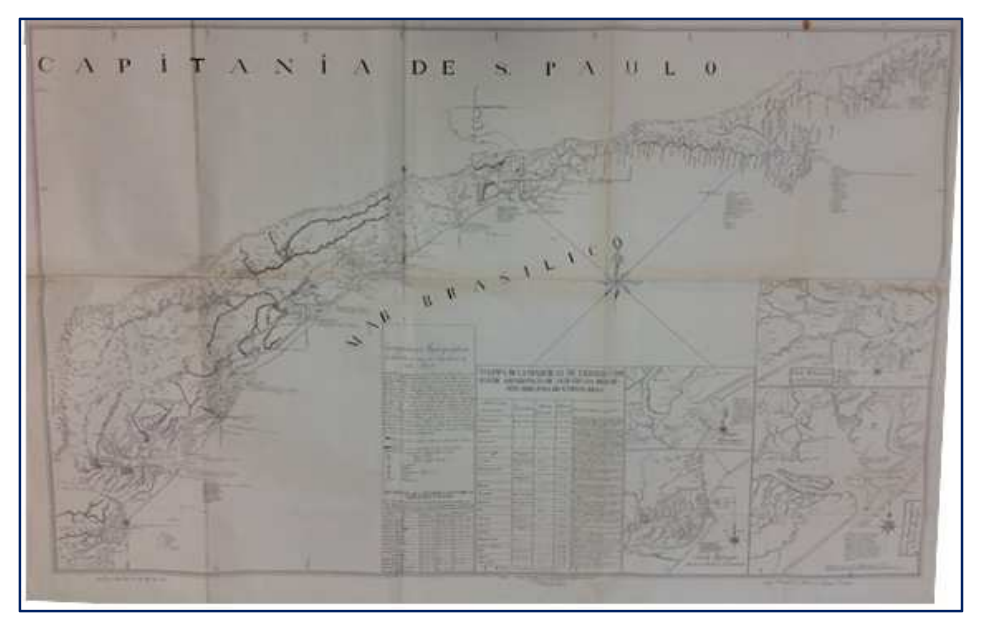

Figura 89: Imagem: Carta corographica e hydrographica de toda costa do mar da capitania de $S$. Paulo. (1789). Dimensões 0,980m X 1,42m.

Abaixo vemos o detalhe do mapa onde se vê a coordenada longitudinal e latitudinal da cidade de São $\mathrm{Paulo}^{202}$ e a baixada de São Vicente até a região de

\footnotetext{
${ }^{200}$ CAVENAGHI, Airton José. O território paulista na iconografia oitocentista: mapas, desenhos e fotografias. análise de uma herança cotidiana. An. mus. paul., São Paulo, v. 14, n. 1, p. 195-241, Junho 2006; bem como BUENO, Beatriz Piccolotto Siqueira. Do borrão às aguadas: os engenheiros militares e a representação da Capitania de São Paulo. An. mus. paul., São Paulo, v. 17, n. 2, p. 111-153, Dec. 2009

201 Reproduzida em MUSEU PAULISTA. Collectanea de Mappas da Cartographia Paulista Antiga. (Cartas de 1612 a 1837, acompanhadas de breves comentários por Affonso D'Escragnolle Taunay). São Paulo: Cia Melhoramentos de São Paulo, 1922. Agradecemos ao Ms. Rogério Beier pela indicação deste valoroso documento.

${ }^{202}$ Este mapa ainda contém cartas hidrográficas dos portos de Santos, Cananéia, Paranaguá e Guaratuba, bem como uma lista de observações feitas de 1791 a 1793 pelo astrônomo Francisco de Oliveira Barbosa, relativas às coordenadas de treze pontos do litoral, de Guaratuba à barra do Juqueriquerê e na cidade de S. Paulo. Ela
} 
Bertioga, com aproximação para o rio Cubatão, um dos reservados ao corte real e marcados com hachura segundo a legenda do próprio mapa.

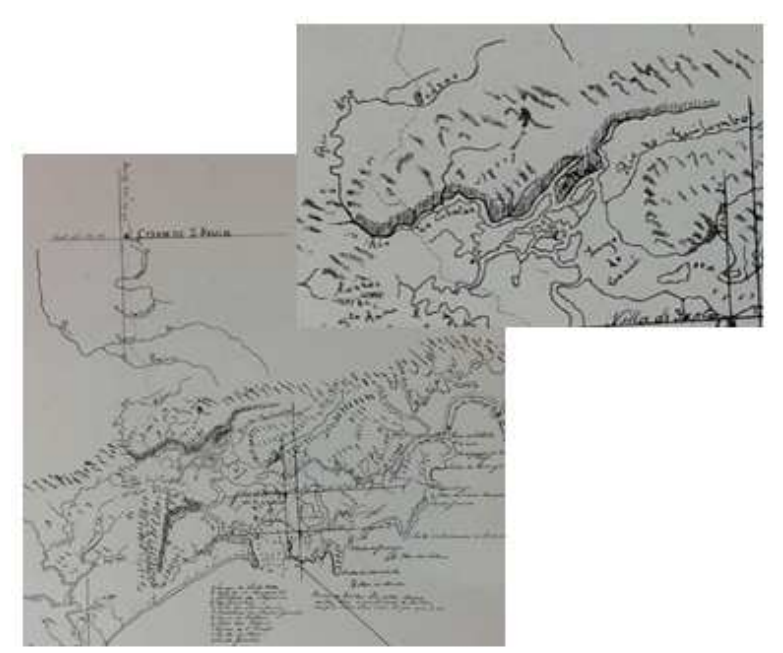

Figura 90: Detalhe da Carta corographica e hydrographica, onde se vê o Rio Cubatão e destaque.

Documento muito valioso pela densidade de informações, notamos que 0 autor não só fez acurado traçado do litoral paulista com seus portos, reentrâncias e ilhas, mas também indicou os rios navegáveis e mesmo os barcos que podiam entrar nas enseadas sem encalhar. Incluiu ainda uma lista das madeiras reservadas ao corte real e o tipo de proveito que se poderia extrair delas, que reproduzimos abaixo.

Tabela 1: transcrição do Mappa das Madeyras de Ley com que com maior abundância se Achão nos rios reservados para os cortes reaes.

\begin{tabular}{|c|c|c|c|c|}
\hline $\begin{array}{l}\text { Nome das } \\
\text { Madeiras }\end{array}$ & Quantidades & $\begin{array}{l}\text { Maiores } \\
\text { Grossuras } \\
\text { [palmos } \\
\text { de } \\
\text { diâmetro] }\end{array}$ & $\begin{array}{l}\text { Maiores } \\
\text { Cumprimentos } \\
\text { [palmos] }\end{array}$ & $\begin{array}{l}\text { Suas qualidades e } \\
\text { préstimo }\end{array}$ \\
\hline Canela Preta & $\begin{array}{l}\text { Há com } \\
\text { abundância }\end{array}$ & 5 & De 90 a 100 & $\begin{array}{l}\text { É madeira muito rija, } \\
\text { resistente no tempo. } \\
\text { O seu tronco serve } \\
\text { para quilhas de } \\
\text { navios e dá bom } \\
\text { Taboado } \\
\text { costado e convés. } \\
\text { De sua galhada se } \\
\text { tiram braços } \\
\text { cavernas. } \\
\text { excelente } \\
\text { curtume. }\end{array}$ \\
\hline
\end{tabular}

possuía a longitude do Oeste de Paris, para a ponta ocidental da llha do Ferro, como sendo de vinte e meio graus exatos. 


\begin{tabular}{|c|c|c|c|c|}
\hline Canela Preta & $\begin{array}{c}\text { Há com } \\
\text { abundância }\end{array}$ & 5 & De 90 a 100 & $\begin{array}{l}\text { É madeira muito rija, } \\
\text { resistente no tempo. } \\
\text { O seu tronco serve } \\
\text { para quilhas de } \\
\text { navios e dá bom } \\
\text { Taboado para } \\
\text { costado e convés. } \\
\text { De sua galhada se } \\
\text { tiram braços e } \\
\text { cavernas. } \\
\text { excelente } \\
\text { curtume }\end{array}$ \\
\hline Operoba & $\begin{array}{c}\text { Há com } \\
\text { abundância }\end{array}$ & De 4 a 5 & 30 a 40 & $\begin{array}{l}\text { É madeira rija, dá } \\
\text { bom Taboado para } \\
\text { forro e convés de } \\
\text { navio e é boa para } \\
\text { curtume. De sua } \\
\text { galhada tiram-se } \\
\text { braços e cavernas. } \\
\text { Resiste alguma } \\
\text { coisa ao tempo e } \\
\text { sendo da legítima } \\
\text { resiste muito. }\end{array}$ \\
\hline Urucurana & $\begin{array}{c}\text { Há com } \\
\text { abundância }\end{array}$ & 2 a 5 & 25 a 30p. & $\begin{array}{l}\text { Esta madeira é rija, } \\
\text { porém custa muito a } \\
\text { secar para que } \\
\text { conserva anos a sua } \\
\text { humidade. Para cuja } \\
\text { causa apodrece com } \\
\text { facilidade. Sendo } \\
\text { seca é boa para } \\
\text { corretame e de sua } \\
\text { galhada tiram-se } \\
\text { braços e cavernas }\end{array}$ \\
\hline Upiubá ou Ypê & $\begin{array}{c}\text { Não há com } \\
\text { grande } \\
\text { abundância }\end{array}$ & 2 & 25 a 30 & $\begin{array}{l}\text { É madeira muito rija } \\
\text { e resistente ao } \\
\text { tempo tão rija que os } \\
\text { artífices usam pouco } \\
\text { dela por que lhes } \\
\text { quebram muitos as } \\
\text { ferramentas e os } \\
\text { braços. É boa para } \\
\text { pés direitos, para } \\
\text { varais e seges e } \\
\text { para eixos de } \\
\text { carretas. }\end{array}$ \\
\hline Araribá & $\begin{array}{c}\text { Há com } \\
\text { abundância } \\
\text { em alguns } \\
\text { ditos rios }\end{array}$ & 2 a $21 / 2$ & 30 a 35 & $\begin{array}{l}\text { É madeira de } \\
\text { bastante duração e } \\
\text { bonita. Dá excelente } \\
\text { Taboado. Tem muito } \\
\text { uso na marcenagem. } \\
\text { Serve para } \\
\text { carretame }\end{array}$ \\
\hline Guarapeapunha & É rara & 2 a $21 / 2$ & 30 a 35 & $\begin{array}{l}\text { É excelente madeira } \\
\text { para carretame e }\end{array}$ \\
\hline
\end{tabular}




\begin{tabular}{|c|c|c|c|c|}
\hline & & & & $\begin{array}{l}\text { para várias obras } \\
\text { das embarcações. E } \\
\text { sendo rija é boa de } \\
\text { lavrar. Dá excelente } \\
\text { taboado. }\end{array}$ \\
\hline $\begin{array}{lr}\text { [deixada } & \text { em } \\
\text { branco } & \text { no } \\
\text { documento] } & \end{array}$ & $\begin{array}{l}\text { Não há com } \\
\text { abundância }\end{array}$ & 4 & 60 a 70 & $\begin{array}{l}\text { É madeira muito } \\
\text { direita. Dá para } \\
\text { mastros e vergas } \\
\text { dos navios. Dá bom } \\
\text { Taboado e boas } \\
\text { canoas. }\end{array}$ \\
\hline Vapuam & $\begin{array}{l}\text { Não há com } \\
\text { abundância }\end{array}$ & 5 a $51 / 2$ & 90 a 100 & $\begin{array}{l}\text { Dá bom Taboado e } \\
\text { pranchas para } \\
\text { carretame é muito } \\
\text { direita tem muito uso } \\
\text { na marcenagem, } \\
\text { porém empena } \\
\text { muito. }\end{array}$ \\
\hline Óleo Pardo & $\begin{array}{c}\text { Há com } \\
\text { abundância }\end{array}$ & 5 & 90 a 100 & $\begin{array}{l}\text { É madeira muito } \\
\text { direita de que se } \\
\text { fazem mastros e } \\
\text { vergas; porém é } \\
\text { muito pesada e não } \\
\text { resiste ao tempo. }\end{array}$ \\
\hline Guarandi & $\begin{array}{l}\text { Não há com } \\
\text { abundância }\end{array}$ & 4 a 5 & 90 a 100 & $\begin{array}{l}\text { É madeira muito } \\
\text { direita de que se } \\
\text { fazem mastros e } \\
\text { vergas, porém é } \\
\text { preciso ter grande } \\
\text { grossura para que } \\
\text { não terça ou } \\
\text { empene. }\end{array}$ \\
\hline Louro & É raro & 4 a $41 / 2$ & 60 a 70 & $\begin{array}{l}\text { É madeira muito } \\
\text { direita, leve e boa } \\
\text { para mastros e } \\
\text { vergas, porém não } \\
\text { resiste ao tempo. Dá } \\
\text { excelente Taboado } \\
\text { para forros das } \\
\text { casas. }\end{array}$ \\
\hline Bracuhe & $\begin{array}{l}\text { Não há lá } \\
\text { com } \\
\text { abundância }\end{array}$ & 4 a 4 1/2 & 70 a 80 & $\begin{array}{l}\text { É madeira muito } \\
\text { direita por suja razão } \\
\text { fazem-se mastros, } \\
\text { vergas e canoas. Dá } \\
\text { excelente Taboado. }\end{array}$ \\
\hline Pequihá & $\begin{array}{l}\text { Não há com } \\
\text { abundância }\end{array}$ & $11 / 2$ a 2 & 25 a 30 & $\begin{array}{l}\text { É madeira rija e } \\
\text { bonita, boa para } \\
\text { marcenagem. }\end{array}$ \\
\hline Carvalho & $\begin{array}{l}\text { Não há com } \\
\text { abundância }\end{array}$ & 4 & 25 a 30 & $\begin{array}{l}\text { É madeira } \\
\text { bastantemente rija, }\end{array}$ \\
\hline
\end{tabular}




\begin{tabular}{|c|c|c|c|c|}
\hline & & & & $\begin{array}{l}\text { boa para corretame, } \\
\text { porém racha muito. }\end{array}$ \\
\hline & & & & $\begin{array}{l}\text { É uma madeira } \\
\text { muito arevizada. De } \\
\text { sua galhada se } \\
\text { tirambraços e da sua }\end{array}$ \\
\hline Maçaranduba & É rara & 4 & 30 a 40 & $\begin{array}{l}\text { raiz se tiram } \\
\text { cavernas, assim } \\
\text { como também da } \\
\text { Urucurana. }\end{array}$ \\
\hline $\begin{array}{l}\text { Canela } \\
\text { salsafraz }\end{array}$ & É rara & 4 & 30 a 40 & $\begin{array}{l}\text { É boa para Taboado } \\
\text { e não resiste muito } \\
\text { ao tempo. }\end{array}$ \\
\hline Cedro & $\begin{array}{l}\text { Não há com } \\
\text { abundância }\end{array}$ & 4 & 30 a 40 & $\begin{array}{l}\text { É madeira de lavrar, } \\
\text { boa para os entalhes } \\
\text { e para as obras } \\
\text { mortas dos navios. }\end{array}$ \\
\hline Angelim & $\begin{array}{l}\text { Há com } \\
\text { abundância }\end{array}$ & 4 a 5 & 40 a 50 & $\begin{array}{l}\text { Dá excelente } \\
\text { Taboado, é muito } \\
\text { boa para se lavrar, } \\
\text { tem muito uso na } \\
\text { marcenagem. }\end{array}$ \\
\hline Folha larga & $\begin{array}{l}\text { Há com } \\
\text { abundância }\end{array}$ & 4 a 5 & 40 a 50 & $\begin{array}{l}\text { É madeira de que se } \\
\text { fazem aduelas para } \\
\text { obras de tanoaria, } \\
\text { também dá bom } \\
\text { taboado e canoas. }\end{array}$ \\
\hline
\end{tabular}

Fonte: MUSEU PAULISTA. Collectanea de Mappas da Cartographia Paulista Antiga. (Cartas de 1612 a 1837, acompanhadas de breves comentários por Affonso D'EscragnolleTaunay). São Paulo: Cia Melhoramentos de São Paulo, 1922.

Para além do que poderíamos esperar dessa listagem, onde se indica o uso das árvores segundo suas maleabilidades, trabalhabilidades e resistências para o uso na carpintaria de casas e embarcações, sem falar no uso para o curtume, também o autor foi atento a indicar o seu uso na marcenaria, indicando o Araribá, o Vapuam, o Pequinhá e o Angelim.

Assim, devemos notar como a produção moveleira, ainda que não isolada, era de interesse dos agentes coloniais, tal como a produção naval e arquitetônica, como a defesa do litoral, a navegabilidade dos rios e as coordenadas astronômicas. 
Vemos como a atenção aos menores detalhes nos apresenta a relevância desta indústria, contemplada à época pelas principais potências europeias ${ }^{203}$.

Compreendendo este mapa como produção discursiva e parcelar da realidade espacial que procura condensar ${ }^{204}$, notamos como os rios reservados aos cortes das madeiras reais são sempre os voltados para o litoral e são próximos a zonas portuárias, ou com reentrâncias permissíveis de entrada com embarcações, facilitando o corte, carregamento e exportação das madeiras. Não são trazidos dados de rotas para ou rios interioranos, sendo assim um indício de que este era um extrativismo voltado principalmente para a saída do território.

Para além da localização dos rios com árvores de lei no mapa e a listagem de seus nomes, medidas e funções, o esforço de identificação dos gêneros naturais que poderiam ser de proveito econômico marca toda a história colonial americana ${ }^{205}$, sendo que os exames pormenorizados sobre a flora e fauna das terras lusoamericanas se adensaram no século XIX. Conforme Diogo de Carvalho Cabral "os inventários florestais da sociedade colonial eram quase sempre inventários de utilidades." ${ }^{206}$ Note-se que mesmo com as concepções idílicas sobre a vegetação da América, já havia embutida na doutrina cristã a interpretação na qual toda a natureza fora criada pela Divindade para servir aos humanos, não se dimensionando seu esgotamento 207 .

Vários religiosos, em especial os jesuítas, tiveram nos mais variados pontos do mundo onde se estabeleceram o esforço de conhecer os bens naturais locais, registrá-los pormenorizadamente e coletar o conhecimento dos habitantes locais sobre o mundo natural. Um pioneiro estudo histórico que se utilizou como nós da Arqueometria pelas técnicas da Fito-botânica foi realizada em Sete Povos das

\footnotetext{
${ }^{203}$ Vide o estudo de Leora Auslander a respeito da importância do mobiliário como base material e simbólica do poder político na corte francesa e a formação do "gosto" como elemento de disputa entre classes sociais, bem como entre com as outras potencias europeias ao longo dos séculos XVIII e XIX. AUSLANDER, Leora. Taste and Power: furnishing modern France. Berkeley: University of Berkeley press. 1996. P. 31ss. Agradecemos a Profa. Vânia Carneiro de Carvalho por esta indicação.

204 HARLEY, Brian. Mapas, saber e poder. Confins [Online]. vol. 5.2009 ,. Disponível em: http://confins.revues.org/index5724.html. Acessado em 03/10/2016.

${ }^{205}$ CABRAL, Diogo de Carvalho. Na Presença da Floresta:, Mata Atlântica e História Colonial. Rio de Janeiro: Garamond/FAPERJ, 2014.

${ }^{206}$ CABRAL, Diogo de Carvalho. Na Presença da Floresta: Mata Atlântica e História Colonial. Rio de Janeiro: Garamond/FAPERJ, 2014. P. 83.

${ }^{207}$ Fora somente nos meados do século XIX, como mostrado por Keith Thomas que o nível de poluição em Londres e o esgotamento dos recursos naturais da região metropolitana tornaram-se tão insuportável ao ponto de levar a medidas de saneamento público e a uma revalorização da natureza. THOMAS, Keith. O Homem e o Mundo Natural: mudanças de atitude em relação às plantas e aos animais (1500-1800). São Paulo: Companhia das Letras, 1988.
} 
Missões por Marchiori e Schulze-Hofer ${ }^{208}$. Os pesquisadores realizaram o exame de 10 amostras em quatro imagens de santos e seis estruturas arquitetônicas, evidenciando o emprego de diferentes espécies de árvores: ipê-roxo (Tabebuia heptaphylla), ipê-amarelo (Tabebuia pulcherrima), cedro (Cedrela fissilis) e pinheirobrasileiro (Araucaria angustifolia).

Os autores sublinharam como houve pelos agentes coloniais a escolha adequada dos ipês para as vergas, pilares e demais usos que pressupõem resistência e durabilidade. O cedro aparece sempre nas esculturas e talha, pela durabilidade natural e bom acabamento, inclusive aceitando pigmentos com facilidade. Apesar de o cedro ser a melhor árvore da região para o uso em esculturas, a araucária também foi usada em alguns casos possivelmente devido à tradição europeia de trabalhar com madeiras de coníferas. Nos relatos de época os jesuítas elogiavam a araucária notadamente pelo verniz natural fornecido pela sua resina ${ }^{209}$.

Grande exemplo para o século XVIII é o livro Cultura e Opulência do Brasil por suas Drogas e Minas, de 1711 do jesuíta italiano João Giovanni Antônio Andreoni (1649, Luca, Itália - 1716, Salvador, Brasil), conhecido por Antonil, Em suas considerações sobre o estado da indústria açucareira e da exploração mineradora ele faz apreciação sobre as madeiras utilizadas pelos carpinteiros não só para fazer as moendas dos engenhos, mas também outros objetos encadeados nesta indústria, como as canoas e barcos, além de listar os paus de lei, exclusividade da majestade ${ }^{210}$. A Memória sobre madeiras para construção de casas e para marcenaria de Alexandre Rodrigues Ferreira (Salvador, 1756 - Lisboa, 1815) ${ }^{211}$, já para os finais da mesma centúria é um exemplo bastante significativo desse período, pois revela o interesse desse naturalista e demarcador não apenas por espécies ligadas às plantações para o proveito econômico do sistema de plantation, mas também para o uso doméstico dos habitantes da Capitania do Rio Negro, que aos

\footnotetext{
${ }^{208}$ MARCHIORI, J. N. C.; SCHULZE-HOFER, M. C. O uso da madeira nas reduções jesuítico-guarani do Rio Grande. IPHAN, 2008. p. 25.

${ }^{209}$ MARCHIORI et al. 0 uso da madeira... op. cit., 2008, p. 33.

210 ANTONIL, André João. Cultura e Opulência do Brasil por suas drogas e minas etc [1711]. Introdução e comentário crítico de Andrée Mansuy Diniz Silva. Lisboa: Comissão Nacional para as Comemorações dos Descobrimentos Portugueses, 2001.

${ }^{211}$ Agradecemos a Dra. Maria de Fátima Gomes Costa pela indicação dessas informações.
} 
olhos dos administradores, deveriam ser assentados para defender as fronteiras com as terras espanholas ${ }^{212}$.

Encontramos raros documentos em São Paulo que registram o fornecimento de madeira para obras, geralmente públicas, de onde podemos atribuir por extensão o fornecimento para a confecção moveleira. A câmara municipal e os religiosos, bem como os particulares necessitavam encomendar madeiras e todos os materiais necessários à confecção de móveis, construção de pontes, chafarizes e outras obras e reformas, variando bastante os fornecedores na cidade e fora dela ${ }^{213}$. Por exemplo, vemos que em 1789 para a construção da nova cadeia, o senado chegava a pagar até mesmo o aluguel de cavalos para o transporte das madeiras, que vieram de Santo Amaro ${ }^{214}$.

Em alguns episódios de encomenda de madeiras encontrados na documentação camararia, notamos sinais de que esse processo de aquisição não deixava de ser permeado por atritos entre as etapas de produção, revelando clivagens entre quem podia usufruir desses recursos, e as divisões sociais do trabalho, desde o carapina ou serralheiro nas matas, passando pelo marceneiro ou carpinteiro que fazia as peças até o supervisor e o encomendante da obra.

Por exemplo, vemos como os moradores da cidade reclamavam da necessidade de ter madeiras para o seu uso doméstico, sendo impossibilitados de usufruir das árvores mais vizinhas ao núcleo urbano por serem já todas elas terras de particulares, restando apenas matos no Bairro do Pari ${ }^{215}$ :

Representação a VM.ces Snr. Juiz Presidente e mais Snr.es do Nobilíssimo Senado, os moradores desta Cidade, que todos os matos do Subúrbio da mesma tem senhorio, que impedem dele a extração das lenhas, de necessidade m.to precisa para o viver, e conservação do Povo. O único mato desimpedido são as várzeas alagadiças nas margens daquém do Bairro do Pary, de onde a maior parte do Povo tira lenha para o mister de suas casas no tempo seco. Este mato brevemente fica extinto, por estarem neles vários moradores das circunvizinhanças, fazendo grande derrubadas de paus para secarem, e tirarem em carradas de lenhas para negócio, sem atenderem que cortando-se os paus do mato, extinguem-se, não

\footnotetext{
${ }^{212}$ FERREIRA, Alexandre Rodrigues. Viagem filosófica pelas capitanias do Grão-Pará, Rio Negro, Mato Grosso e Cuiabá [1789]. Memórias antropológicas. Brasília, Conselho Federal de Cultura. 1974. P. 322.

${ }^{213}$ SANTOS, Amália Cristóvão dos. Em obras: os trabalhadores da cidade de São Paulo entre 1775 e 1809. 2013. Dissertação (Mestrado em História e Fundamentos da Arquitetura e do Urbanismo) - Faculdade de Arquitetura e Urbanismo, Universidade de São Paulo, São Paulo, 2013.

${ }^{214}$ AHMSP, Fundo Câmara Municipal Série Documentos Avulsos, caixa 41.

${ }^{215}$ AHMSP, Fundo Câmara Municipal, Documentos Avulsos, caixa 28. Não encontramos datação neste documento, mas julgamos ser de 1750 para frente pelas datas limites dos outros documentos da mesma caixa no arquivo.
} 
beneficiando a terra para produzir; pois pastando por eles criações, ficam em campo e os que quiserem fazer esta negociação façam em matos próprios, ou conduzam de partes mais distantes, donde não podem ir os lenhadores da cidade. Prevendo o grande prejuízo que há de resultar os habitadores na extinção deste mato, a extrema necessidade em que se [...] reduzir os povos em breve tempo com falta de lenhas. Requerem a V.Mces que sejam servidos providenciar esta desordem, inibindo, que pessoa alguma faça derrubadas daquém do Rio do Bairro do Pary, para lenha, nem os mesmos paus verdes possam conduzir em Carros, nem em Cavalos ou na cabeça. E. R.M.

Este problema fundiário já se apresentava no começo do século XVIII, chegando até a instância Real, em carta de nove de dezembro de 1706, a notícia de que $^{216}$ :

O Cap.tam Pedro Taques de Almeida dizia ter "direito e domínio" sobre uma restinga de matos ao redor da vila, cerca de meia légua, que o senado nunca quisera aforar antes, pois a conservava por ser de utilidade pública. Ela provia de comum a todas as pessoas do povoado para tirarem madeiras, lenha, canas e cipós "sem contradição de pessoa alguma". Porém, dada a indefinição do senado este capitão já havia principiado três sítios, e começado a serrar os matos.

Em outro documento vemos mais sinais de atrito em relação ao abastecimento da cidade com recursos florestais. Documento bastante sintomático do sistema social e jurídico da época, podemos notar, para além do interesse da História Ambiental e da cultura material, como a visão escravista estava presente nos discursos dos administradores e da população em geral: o motivo pelo qual os madeireiros não teriam entregado a encomenda era atribuído ao seu fenótipo e etnia $^{217}$ :

\section{Sr.s Juiz Ordinário José da Cunha de Abreu,}

Mandei chamar a Antônio Mi.z [Muniz] para me dar conta das madeiras, que se the encomendou, veio e foi a essa cidade dizendo que ia trazer recibo, e dar-me conta da madeira que dizia ter mandado, e de lá me mandou somente recibo por um meio irmão pequeno, um recibo de dez dúzias de caibros, e nada mais e ocultou-se; e na mesma forma um Jeronimo Rib.o [Ribeiro] mandei chamar para me dar conta da madeira que se the encomendou, não obedece, nem vem, e como os tais madeireiros são uns mulatos e caboclos, gente sem vergonha (...) VM.ce já me mandou dizer pelo Cap.m do mato Geraldo Vr.a que quando houvesse

\footnotetext{
${ }^{216}$ AHMSP, Fundo Câmara Municipal, Série Assuntos Diversos (encadernados) Livro 149: Editais, Alvarás e Provisões Reais. Fl. 6.

${ }^{217}$ AHMSP, Fundo Câmara Municipal, Série Documentos Avulsos. Caixa 36. Doc. 2. “Expedição de mandato de prisão, 1785" Grifo nosso.
} 
madeira lhe desse aviso para Vm. de lá mandar alguns carros (...) enfim, Sr. Juiz Ordinário não é descuido, nem faltas minha não irem há tempo e a hora as madeiras, pois bem cuido em que elas vão a tempo. Deus guarde a VM.ce Santo Amaro a 27 de setembro de 1785.

De VM.ce humilde súdito Joaquim Francisco.

Expede-se mandado de prisão contra os dois rebeldes a 28 de setembro, assinado pelo Sr. Juiz presidente.

Note-se que as madeiras vinham da Vila de Santo Amaro, região ao sul de São Paulo, onde a Mata Atlântica era mais densa em relação às áreas centrais, que continham vegetação mais baixa, semelhantes ao cerrado e ao Pantanal alagadiço $^{218}$. As áreas citadinas de São Paulo além de serem carentes de grandes árvores ${ }^{219}$, lidavam com grande desmatamento antrópico, que já ocorria por parte dos ameríndios e se adensou enormemente com os europeus ${ }^{220}$.

Procuramos, desta maneira, oferecer apenas um vislumbre do manancial de informações que poderíamos contemplar para a compreensão do fornecimento das madeiras para o uso da marcenaria e carpintaria em São Paulo colonial, evidenciando locais específicos de corte na cidade, os atritos envolvidos no abastecimento e aproveitamento de tais recursos, bem como oferecendo uma visão geral sobre o extrativismo florestal durante a empresa colonial portuguesa, permeado de mudanças e lógicas econômicas próprias.

\subsubsection{Análises de materiais por Física Aplicada}

Apresentaremos de modo geral quais são e como são feitas as análises físicas nos objetos e quais são os componentes utilizados ${ }^{221}$. Os experimentos realizados pela Prof. ${ }^{\text {a }}$ Dr. Márcia Rizzutto ocorreram no próprio Museu com

\footnotetext{
${ }^{218}$ Baseados no estudo do biólogo Fernando Cardim, com livro no prelo sobre o paleoambiente da cidade de São Paulo. Cf. FELLET, J. Antes dos portugueses, SP teve floresta tropical, Cerrado e mini-Pantanal. BBC Brasil, Brasília, 24 de fevereiro de 2018. Disponível em: http://www.bbc.com/portuguese/geral-43148025. Acessado em: 24 de fevereiro de 2018.

${ }^{219}$ Com exceção às Araucárias (Araucaria angustifólia). CABRAL, Diogo de Carvalho. Na Presença da Floresta: Mata Atlântica e História Colonial. Rio de Janeiro: Garamond/FAPERJ, 2014.

${ }^{220}$ DEAN, Warren. A ferro e fogo: a História e a devastação da Mata Atlântica brasileira. São Paulo: Cia das Letras, 1997, p. 180. ; CABRAL, Diogo de Carvalho. Na Presença da Floresta: Mata Atlântica e História Colonial. Rio de Janeiro: Garamond/FAPERJ, 2014.

${ }^{221}$ Baseando-nos no curso "Física aplicada ao estudo de objetos do patrimônio cultural: métodos e técnicas" ministrado pela Prof. a Dr. a Márcia Rizzutto no Programa de Pós-Graduação em Museologia da USP.
} 
equipamentos portáteis. Lançando mão de variadas técnicas de radiação, foram todos não invasivos, isto é, não necessitaram da remoção de fragmentos das peças e não Ihes causaram danos estruturais. Por exemplo, a Fluorescência de Raios X, a o imagiamento com raios ultravioletas (UV), o imagiamento com reflectografia de Infravermelho (IF) e a Espectrografia Raman ${ }^{222}$.

$\mathrm{Na}$ análise do mobiliário para a nossa dissertação foram utilizadas especificamente a Fluorescência de Raios X e o imagiamento com raios ultravioletas (UV).

A Fluorescência de Raios X por dispersão de energia (EDXRF - Energy Dispersive X-Ray Fluorescence), utilizada para investigar a composição elementar dos materiais presentes em objetos de arte, arqueológicos e do patrimônio histórico cultural.

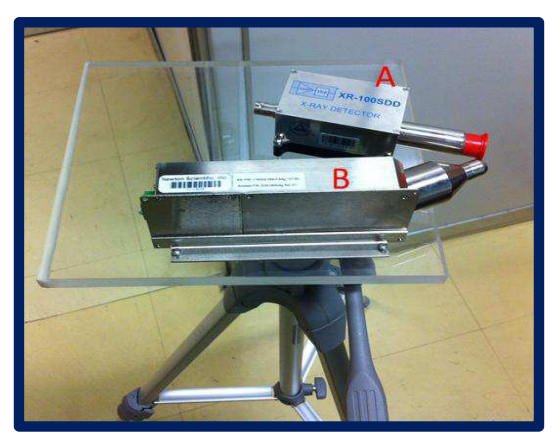

Figura 91: Fotografia do sistema portátil de XRF: A) Detector; B) Tubo de raios $\mathrm{X}$ com anodo de prata (Amptek®)

Para as análises utilizou-se um sistema portátil, constituído por um tubo de raios $X$ da Amptek $\AA$, com anodo de Prata, e um detector Si-Drift também da Amptek®. Durante as medidas o sistema de XRF é posicionado próximo à amostra sem tocá-la, nem causar nenhum tipo de dano. Como cada elemento químico emite um determinado espectro de raios $X$ característico, é possível detectar qual a composição dos artefatos sem a necessidade de exames em laboratórios e de

\footnotetext{
${ }^{222}$ Cabe dizer que inicialmente havíamos proposto realizar a análise com estas quatro metodologias em seis móveis do museu, porém, devido às limitações de tempo em nossa tese e mesmo o avolumar de informações que tais técnicas nos revelaram, especialmente no leito RG 4996, que evidenciou, surpreendentemente pelo EDXRF pigmentos mais recentes do que a datação constante na ficha catalográfica, baseada nos seus aspectos estilísticos e também pela reflectografia de IF pinturas sob as camadas de tinta visíveis, além de restauros sucessivos. Cruzando os dados dendrológicos, notamos ainda que apesar de na ficha catalográfica a origem provável da peça ser a Itália, foram usadas madeiras brasileiras para a sua confecção como o Pau-Marfim (Balfourodendron sp.) Procuramos assim nos limitar nesta dissertação a apresentar apenas os dados de EDXRF e do imagiamento UV, e futuramente complementar e publicar os dados das análises dos outros móveis e das outras técnicas.
} 
fragmentação de amostras. Desta forma é possível descobrir quais pigmentos foram utilizados nas tintas ou quais elementos estão presentes nos metais dos objetos.

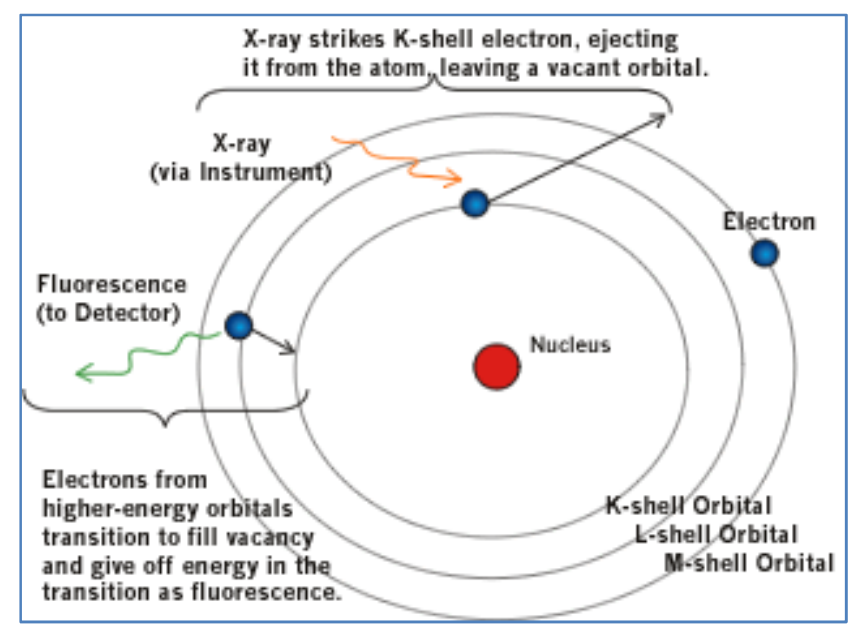

Figura 92: representação esquemática da excitação por raios-x dos elétrons e a sua alteração de camada energética, fluorescendo raios $x$ característicos ${ }^{223}$.

Os pigmentos possuem componentes que nos podem servir como datadores históricos, por exemplo, como o branco de chumbo, tinta muito utilizada até o século $\mathrm{XX}$ e depois proscrita ${ }^{224}$, dado o surgimento do branco de zinco, popularizado por volta de 1834, e depois do branco de titânio, por volta de $1918^{225}$. Nesta análise ainda podemos identificar substâncias utilizadas em momentos históricos precisos, como o couro wet blue, resultado da hidratação das peles com sais de cromo, que passou a ser fabricado somente após $1890^{226}$.

Igualmente utiliza-se a técnica de imageamento com raios ultravioletas (UV) para identificar possíveis sinais de intervenção nas peças, como restauros e existência de vernizes e pinturas em momentos diferentes. A importância do entrecruzamento das informações de cada uma dessas técnicas é essencial, pois isoladas permitem apenas frações de entendimento, muitas vezes conduzindo a erros. Por exemplo, o imagiamento com ultravioleta nos permite ver sinais de

\footnotetext{
${ }^{223}$ Disponível em: http://www.easternapplied.com/XRF-Technology-Overview, acessado em 20/05/2018.

${ }^{224}$ MAYER, Ralph. NAZARETH, Christine (trad). Manual do artista: de técnicas e materiais. São Paulo: Martins Fontes, 2 ed., 1999. P. 42.

${ }^{225}$ APPOLONI, Carlos Roberto e SILVA, Wislley Dueli da. Pigmentos: propriedades físicas, químicas e o período histórico de utilização. Londrina: Publicação Técnica do Laboratório de Física Nuclear Aplicada, Volume 13, Número 1, 1a Edição, Outubro de 2009. S.p.

${ }^{226}$ POULIOT, Bruno P., MASS, Jennifer, KAPLAN, Lara. Using XRF for the identification of Chrome tanning in leather. American Institute for Conservation $43^{\text {rd }}$ Annual Meeting. 2015. Disponível em: <http://www.conservation-us.org/docs/default-source/annualmeeting/2015am poster 92.pdf?sfvrsn=2> Acessado em: 03 Out. 2016
} 
restauro com as variadas colorações que assumem as diferentes camadas de tintas e pigmentos díspares.

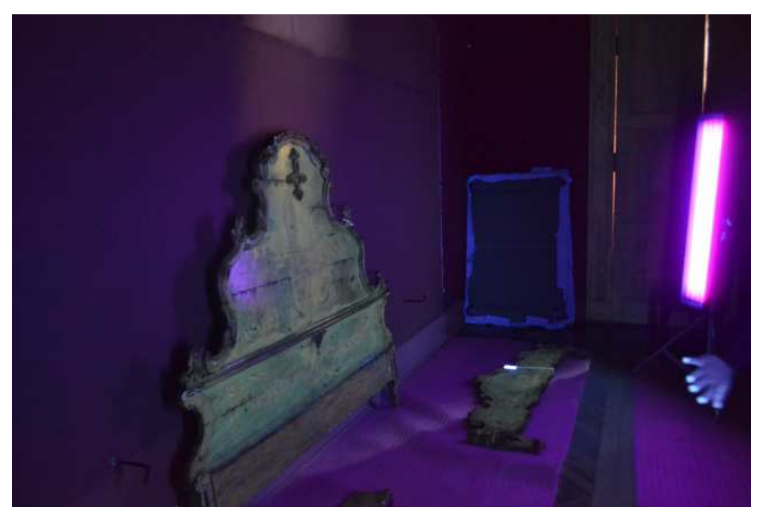

Figura 93: Sessão de fotografias com fluorescência de Raios UV sobre os móveis (no caso o leito RG 4996) feita por José Rosael. Fotografia do autor.

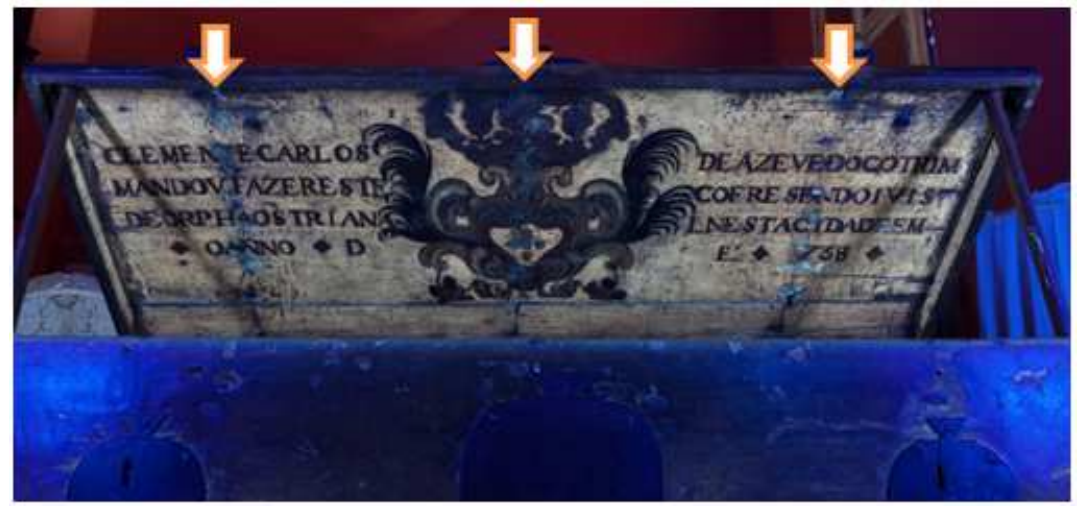

Figura 94: Exemplo de fotografia com fluorescência de luz UV na Arca RG 3242 mostrando sinais de restauro, como três linhas verticais na parte interna do tampo que revelam outros tipos de tintas. Fotografia de José Rosael.

Iremos agora apresentar os passos tomados durante o exame de duas peças e a análise dos dados obtidos para posteriormente realizarmos a problematização histórica dessas informações.

\subsubsection{Cadeira RG 55}

A cadeira RG55, pertencente ao acervo do Museu Paulista, foi inicialmente analisada por imagem de fluorescência visível com luz ultravioleta. Através do uso de lâmpadas de ultravioleta é possível evidenciar a fluorescência dos materiais na região do visível. As imagens obtidas evidenciam os pontos de danos e intervenções, através dos tons violetas mais claros ou mais escuros. Nas figuras a seguir podem ser observados os pontos de perda de material e a intervenção de 
restauro realizada através da imagem do possível rasgo estruturado novamente, em tom mais claro.
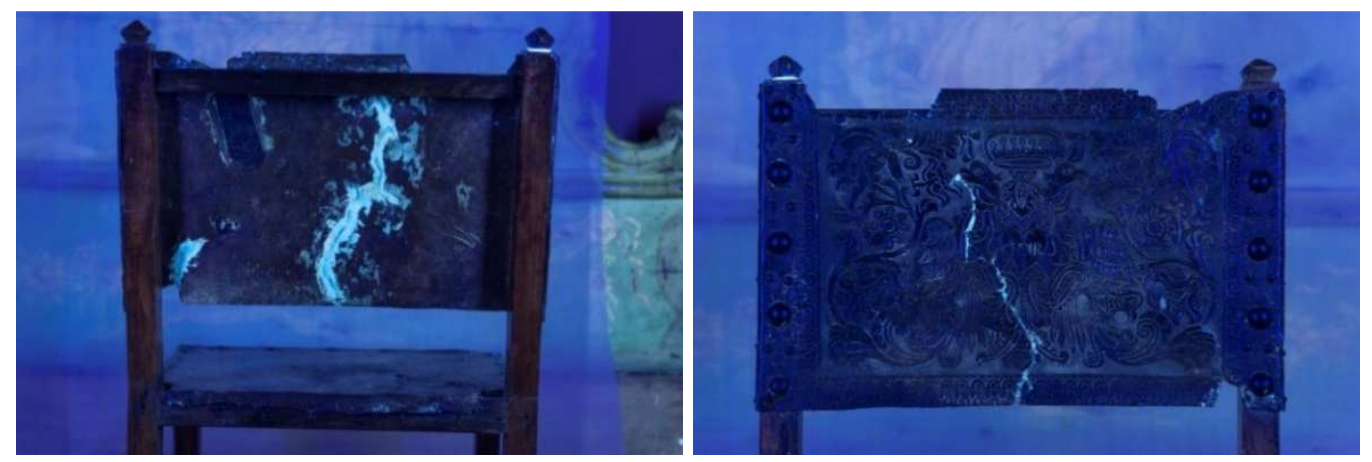

Figura 95 e Figura 96: Imagem de fluorescência de UV da cadeira RG55 do acervo do Museu Paulista. Encosto visto da parte frontal e do verso, evidenciando a marca de restauro no couro. Fotografia de José Rosael.

A análise com o sistema de fluorescência de raios $X$ (XRF) ocorreu no dia 26/08/2016. Ela pôde ser realizada em diferentes pontos na obra, pois 0 equipamento pode ser posicionado bem próximo ao ponto de estudo sem danos ao objeto. A figura 98 mostra o equipamento sendo utilizado para medidas de um ponto sobre o objeto em estudo. Vários pontos foram medidos em diferentes posições no objeto para melhor caracterizar os diversos materiais existentes.

Os raios $X$ característicos de cada elemento são registrados por detectores específicos que geram espectros, o quais são gráficos apresentando a quantidade de raios $X$ medidos em função da sua energia nos pontos analisados. Com os resultados obtidos pudemos obter importantes dados que nos dão aval para a compreensão dos materiais presentes nos objetos e também o processo produtivo dos móveis. 


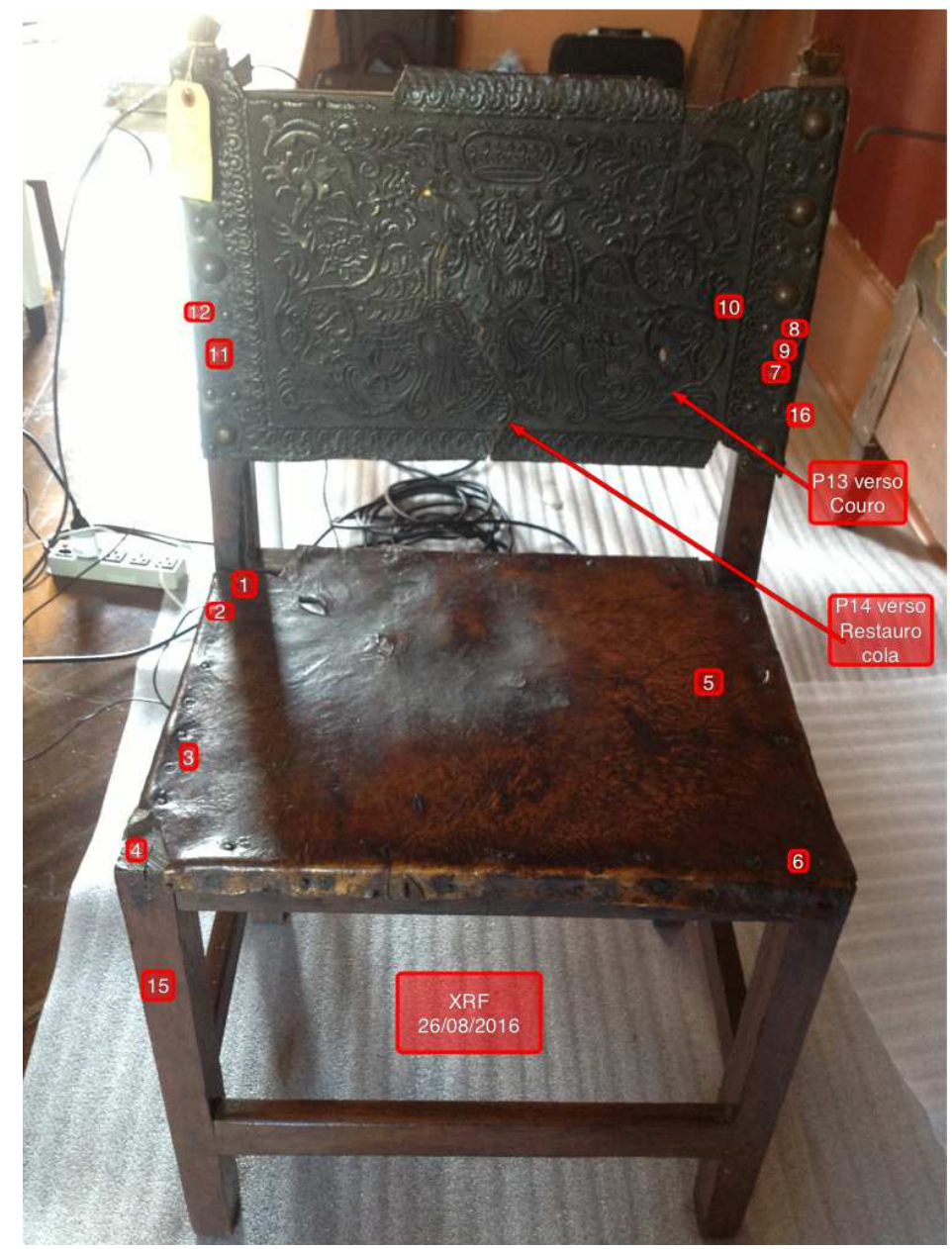

Figura 97: Imagem a luz visível da cadeira RG55 do acervo do Museu Paulista com a identificação dos diferentes pontos medidos pela técnica de fluorescência de raios $\mathrm{X}$.

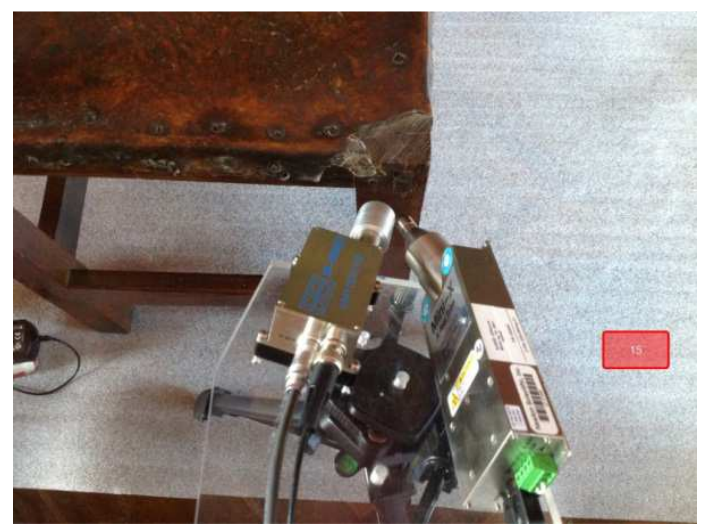

Figura 98: Fotografia da cadeira RG55 onde se vê o emissor de raios $X$ e o detector acoplados incidindo no ponto P15, tomando-se o cuidado para não realizar contato com o móvel. 
Tabela 2: Nomenclatura e especificação dos pontos medidos por EDXRF - Cadeira RG55

\begin{tabular}{ccc}
\hline REFERÊNCIA & Nome & $\begin{array}{c}\text { ESPECIFICAÇÃO } \\
\text { V=30KV, i =20uA, t=100seg }\end{array}$ \\
\hline 160824ac & P1 & Couro do assento, lado superior. \\
160824ad & $\mathbf{P 2}$ & Prego no assento, lado superior. \\
160824ae & P3 & Couro assento, liso, claro. \\
160824af & $\mathbf{P 4}$ & Madeira do topo da perna dianteira \\
160824ag & $\mathbf{P 5}$ & Couro do assento, lado superior. \\
160824ah & $\mathbf{P 6}$ & Couro assento, superior, escuro. \\
160824aj & $\mathbf{P 7}$ & Pregaria graúda do espaldar, parte frontal. \\
160824ak & $\mathbf{P 8}$ & Pregaria miúda do espaldar, parte frontal. \\
160824al & $\mathbf{P 9}$ & Couro do espaldar, parte frontal, liso. \\
160824am & $\mathbf{P 1 0}$ & Couro do espaldar, parte frontal. Lavrado \\
160824an & $\mathbf{P 1 1}$ & Pregaria grande superior no espaldar, parte frontal. \\
160824ao & $\mathbf{P 1 2}$ & Prego no espaldar, parte frontal. \\
160824ap & $\mathbf{P 1 3}$ & Couro do espaldar, parte posterior. \\
160824aq & $\mathbf{P 1 4}$ & Corte com cola couro do espaldar, parte posterior central. \\
160824ap & $\mathbf{P 1 5}$ & Madeira pé frontal direito (lateral) \\
160824aq & $\mathbf{P 1 6}$ & Prego lateral esquerdo \\
\hline
\end{tabular}

Em conjunto com a Prof. ㅁ. Dr. Márcia Rizzutto, realizamos várias etapas de análise e discussão dos dados obtidos pelos exames de EDXRF. Primeiramente os dados coletados pelo detector foram registrados por programa específico da Amptek $\AA$ e a análise de dados é feita pelo programa WinQxas ${ }^{227}$. Um exemplo do gráfico obtido pela técnica de EDXRF para o ponto P1 (couro do assento, lado superior) medido na cadeira e exibido pelo programa de análise, pode ser visto no Gráfico 1 a seguir:

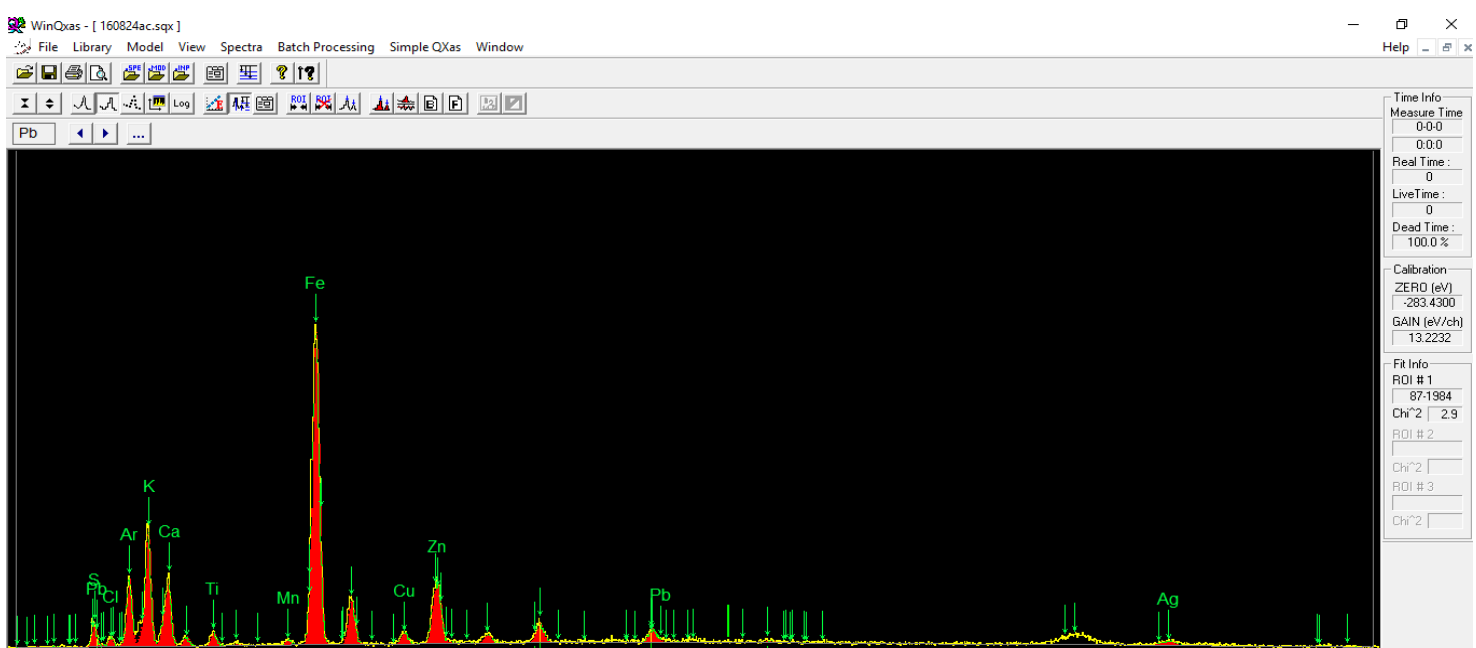

Gráfico 1: representação gráfica da incidência de elementos no ponto P1(160824ac - P1 - couro do assento, lado superior) usando o programa WinQxas.

\footnotetext{
${ }^{227}$ CAPOTE, R.; LOPEZ, E.; MAINEGRA, E. WinQXAS Manual (Quantitative X'Ray Analysis System for Windows) Version 1.2. Austria: IAEA, 2000.
} 
Nota-se pela altura dos picos do gráfico como há presença marcante de $\mathrm{Fe}$, K, Ca, Zn. Outros elementos como Ti, Mn, Cu e Pb são minoritários. Ar (argônio) e $\mathrm{Ag}$ (prata) são elementos que não pertencem ao objeto e são devido ao argônio do ar e ao tubo de prata utilizado.

A análise dos diferentes espectros obtidos permite realizar comparações entre pontos específicos, como podemos ver pela comparação de duas partes metálicas na figura a seguir, a pregaria graúda do espaldar - P7 - e pregaria pequena do espaldar - P8. Pode-se observar que a pregaria graúda do ponto P7 apresenta maior quantidade de $\mathrm{Cu}$ e $\mathrm{Zn}$ (materiais presentes no latão), enquanto o ponto P8 pregaria miúda apresenta maior quantidade de Fe (ferro).

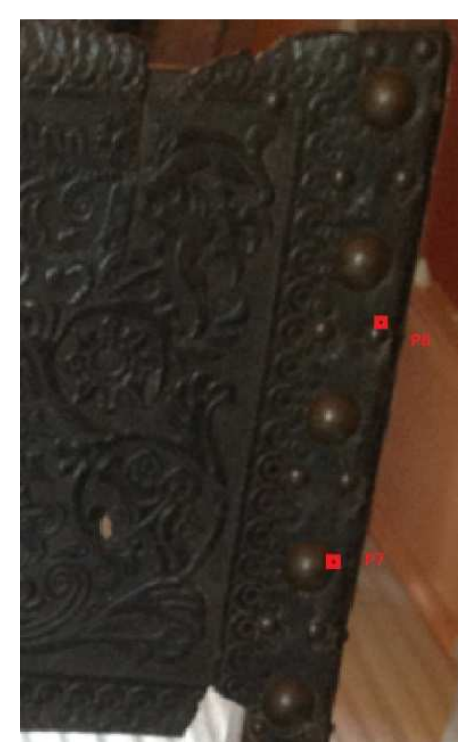

Figura 99: Detalhe da incidência das medições nos pontos P7 e P8 pregaria graúda e miúda, respectivamente. Fotografia do autor.

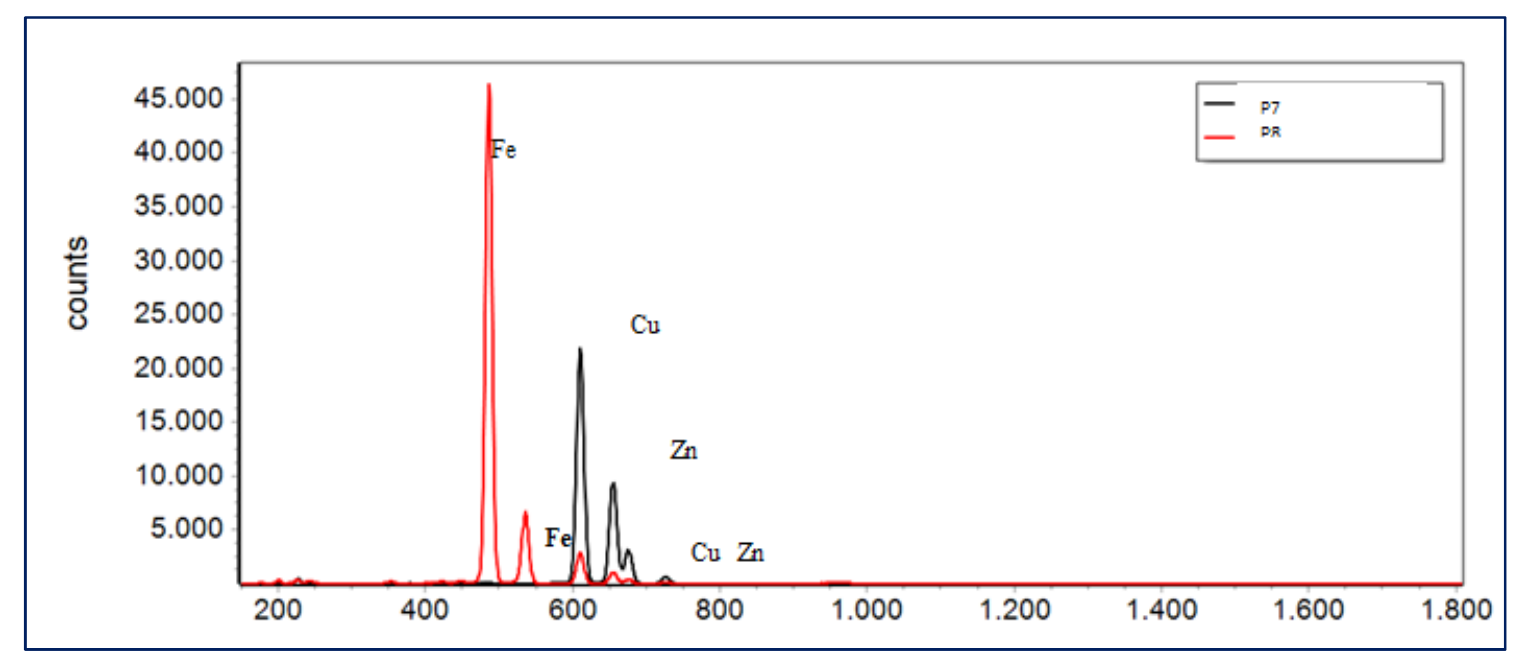

Gráfico 2: comparativo dos pontos P7 pregaria graúda e P8, pregaria miúda. 
$\mathrm{Na}$ linha preta do gráfico nota-se a presença de $\mathrm{Cu}$ e $\mathrm{Zn}$, que compõem o latão. No ponto P8 predomina o ferro, correspondente à pregaria miúda e representado pela linha vermelha.

Com os processamentos dos dados coletados, ou seja, a determinação das áreas dos picos obtidos em cada espectro pelo WinQxas, pudemos fazer gráficos com barras para as quantidades de cada elemento químico presente em cada um dos pontos medidos, e assim verificar a correlação entre as quantidades presentes em para cada ponto do móvel medido. 


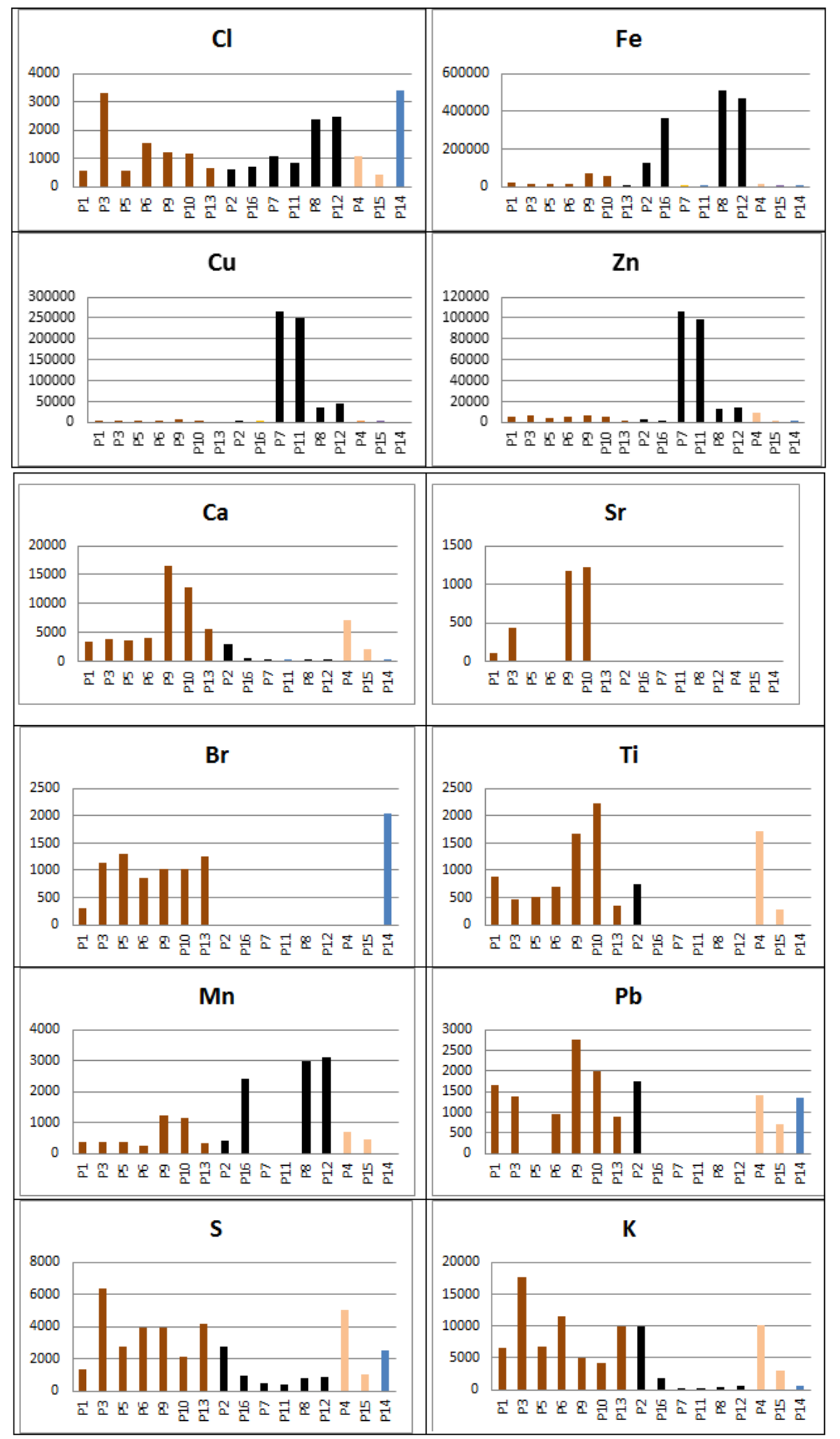

Gráfico 3 a-l: Gráficos de barras das áreas obtidas nos picos dos diferentes espectros e a sistematização e correlação entre estes pontos. Pelo esquema de cores correlacionamos ao ponto de medição: os marrons referem-se aos couros, os pretos aos metais, o bege à madeira e o azul à cola usada no restauro do espaldar. 
Com a análise conjunta dos dados obtidos com o exame das peças, chegamos a algumas conclusões, pontuadas a seguir:

1) Notamos que os pontos relativos aos couros possuem bastante cálcio (picos marrons - P1, P3, P5, P6, P9, P10 e P13). Também o cálcio esta presente na madeira do ponto no topo da perna dianteira (picos beges - P4 e P15) do pé frontal. Dado o fato de ser um ponto no topo da perna dianteira, onde está ausente o couro que o recobria originalmente, é possível que tenha ocorrido passagem do cálcio do couro para a madeira ao longo do tempo.

2) o Estrôncio está presente principalmente nos couros do espaldar (P9 e P10) e em menor quantidade no assento. Estes pontos P9 e P10 apresentam também maior quantidade de $\mathrm{Ca}, \mathrm{Pb}, \mathrm{Mn}$ e $\mathrm{Ti}$, o que pode revelar processos de feitura diferentes ou desgastes, bem como restauros e aplicações de produtos de limpeza ${ }^{228}$. Estes poderiam ser elementos presentes no couro, mas devido ao uso teriam suas quantidades diminuídas no assento e teriam sido mais preservados no espaldar. Os pontos de couro também apresentam grandes quantidades de bromo, sugerindo um elemento adicionado a tal pele. Outros elementos presentes no couro em quantidades variadas e pouco esclarecedoras são: $\mathrm{S}, \mathrm{K}, \mathrm{Ti}, \mathrm{Pb}, \mathrm{Mn}$ e $\mathrm{Cl}$.

3) A presença de ferro nos pontos 9 e 10, couros do espaldar, podem revelar que esta sola foi curtida através de sais desse metal, ou ter recebido uma camada de verniz ou outro tipo de substância com tal elemento. A quantidade menor de couro do assento (ponto 3 menor), que é couro em pelo, demonstra que os processos de curtição foram diferentes. Neste estudo preliminar não podemos precisar como foi o processo de curtição do couro, mas pela baixa concentração de Fe ou outros metais no couro cru em pelo, pode-se aventar que sua curtição não foi realizada com a imersão em sais metálicos. Essa seria uma evidência do processo de curtição usando o tanino de espécies vegetais.

4) Nos pontos de madeira P4 e P15 temos a presença de $\mathrm{Ca}, \mathrm{Ti}, \mathrm{Mn}, \mathrm{Pb}, \mathrm{S}, \mathrm{K}$ e Cl. O ponto P4 apresenta geralmente maior quantidade destes elementos em relação ao ponto P15 sugerindo que este teve muito contato com o couro e durante

\footnotetext{
228 Decerto todas as camadas de produtos e intemperismos pelos quais passaram tais cadeiras devem ser consideradas ao analisarmos os elementos químicos de suas superfícies. Por exemplo, encontramos em uma ficha do Laboratório de Conservação e Restauração do Museu Paulista, gentilmente fornecida pela Me. Fabiola Zambrano, o registro de limpeza e tratamento da cadeira RG553 em 21/11/1994 com a aplicação de cera e óleo de mocotó contra o ressecamento do couro. Assim, componentes químicos não utilizados no século XVIII poderiam aparecer nesses objetos devido aos produtos de limpeza e conservação industrializados aplicados ao longo da trajetória de uso familiar e museal desses objetos.
} 
os anos pode ter sido contaminado com estes elementos do couro. Não foi possível detectar ou correlacionar algum elemento de tratamento de superfície que poderia ter ocorrido no ponto P15.

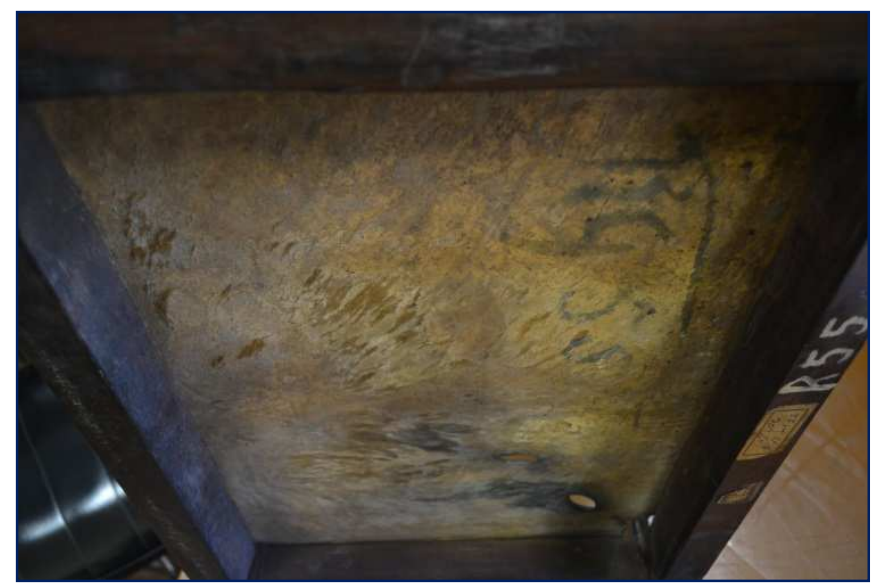

Figura 100: parte inferior do assento da cadeira RG55 onde ainda há pelos do animal. Fotografia do autor.

5) Nos pregos (pontos pretos - P2 e P16), nas pregarias grandes (P7 e P11) e nas pregarias pequenas (P8 e P12) observamos diferentes constituições deste metais.

6) O ferro está presente no ponto P2 e P16 e em maior quantidade nos pontos P8 e P12 (pregaria pequena) pois são pregos ou pregaria sem o revestimento de latão. Somente o ponto P2 possui chumbo e titânio indicando que este é diferente do ponto P16. Nas pregarias temos potássio em menor quantidade, mas está mais intenso no ponto P2 e P16. O cloro e enxofre também estão presentes nos metais. $\mathrm{O} C \mathrm{Cl}$ mais presente na pregaria pequena (P8 e P12) e 0 enxofre mais intenso no prego P2.

7) Os pontos P7 e P11 apresentam grande quantidade de cobre e zinco, comprovando que são "pregaria graúda" ou "grossa" feita da liga desses dois metais componentes do latão. Os pontos P8 e P12 também possuem pequenas quantidades de $\mathrm{Cu}$ e Zn sugerindo uma liga diferente para a "pregaria pequena" em comparação à pregaria de latão (pregaria grande). Isso significa que a "pregaria pequena" possivelmente não é constituída exclusivamente de latão, pois apresenta quantidade de ferro muito maior. Nota-se que eram originalmente encapados de latão, sobrando, porém, traços de sua presença.

8) As medidas no ponto de cola utilizado para restauro revelam a presença de bromo, chumbo, enxofre e cloro. Através da fotografia ultravioleta realizada pelo 
fotógrafo do Museu Paulista José Rosael, pudemos observar com maior detalhe e precisão a incidência da cola usada no restauro da peça.

9) As intensidades das áreas dos picos dos espectros de EDXRF dos metais estão correlacionadas as concentrações de acordo com a tabela abaixo:

Tabela 3: Concentrações dos metais identificados pelas medidas de EDXRF - Cadeira RG55

\begin{tabular}{ccccccc}
\hline \multirow{2}{*}{ Elemento } & $\begin{array}{c}\text { Prego } \\
\mathrm{P} 2\end{array}$ & $\begin{array}{c}\text { Prego } \\
\mathrm{P} 16\end{array}$ & $\begin{array}{c}\text { Pregaria G } \\
\mathrm{P} 7\end{array}$ & $\begin{array}{c}\text { Pregaria G } \\
\mathrm{P} 11\end{array}$ & $\begin{array}{c}\text { Pregaria P } \\
\mathrm{P} 8\end{array}$ & $\begin{array}{c}\text { Pregaria } \mathrm{P} \\
\mathrm{P} 12\end{array}$ \\
& $\%$ & $\%$ & $\%$ & $\%$ & $\%$ & $\%$ \\
\hline $\mathrm{Ti}$ & 0,56 & & & & & \\
$\mathrm{Mn}$ & 0,30 & 0,66 & & & 0,53 & 0,58 \\
$\mathrm{Fe}$ & 95,28 & 98,14 & 0,14 & 0,11 & 90,92 & 88,11 \\
$\mathrm{Cu}$ & 0,30 & 0,71 & 71,47 & 71,44 & 6,22 & 8,64 \\
$\mathrm{Zn}$ & 2,23 & 0,49 & 28,39 & 28,44 & 2,32 & 2,66 \\
$\mathrm{~Pb}$ & 1,32 & & & & & \\
\hline
\end{tabular}

\subsubsection{Arca-cofre RG3242}

A Arca-Cofre também foi submetida à análise por fluorescência com raios UV para identificarmos sinais de restauros. Na Fotografia com a luz UV da figura abaixo percebe-se a existência de pontos de restauro na Arca, especialmente em uma faixa vertical ao centro do brasão, aparentando borrados azulados mais intensos. Nesta imagem há também pequenos pontos espalhados pela superfície.

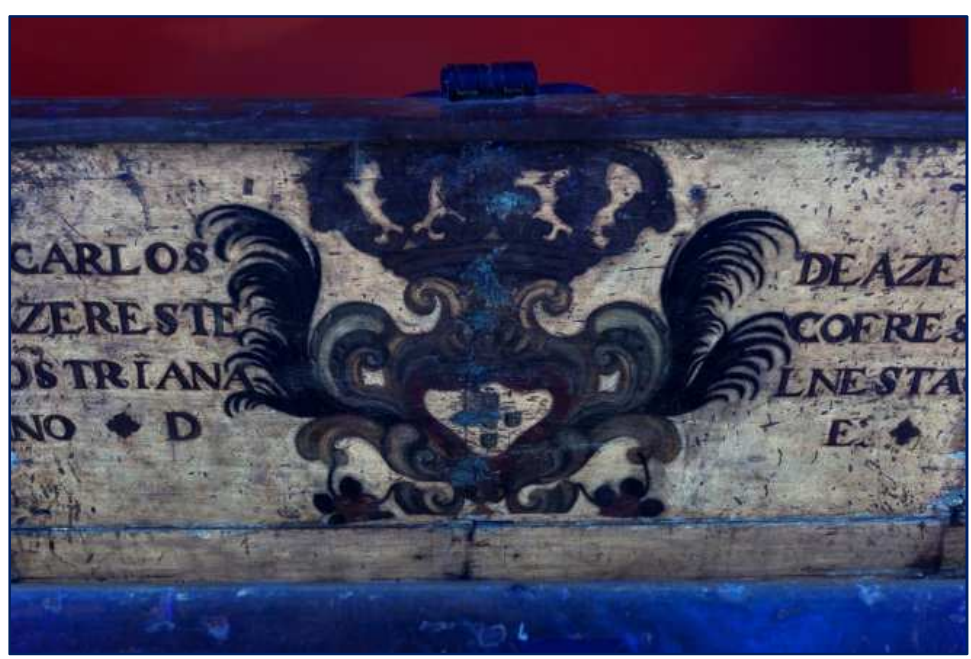

Figura 101: Fotografia com a luz UV onde se percebe a incidência de pontos de restauro na arca, especialmente em uma faixa vertical ao centro do brasão, no tom azulados. Há também pequenos pontos espalhados pela superfície. Fotografia de José Rosael. 
$\mathrm{Na}$ arca RG3242 analisada utilizou-se novamente a técnica de EDXRF nos dias 24 e 26 de agosto de 2016 no próprio Museu Paulista e os diferentes pontos medidos estão identificados na figura abaixo. Os detalhes da descrição de cada ponto medido em cada obra podem ser vistos nas tabelas abaixo em cada sessão.

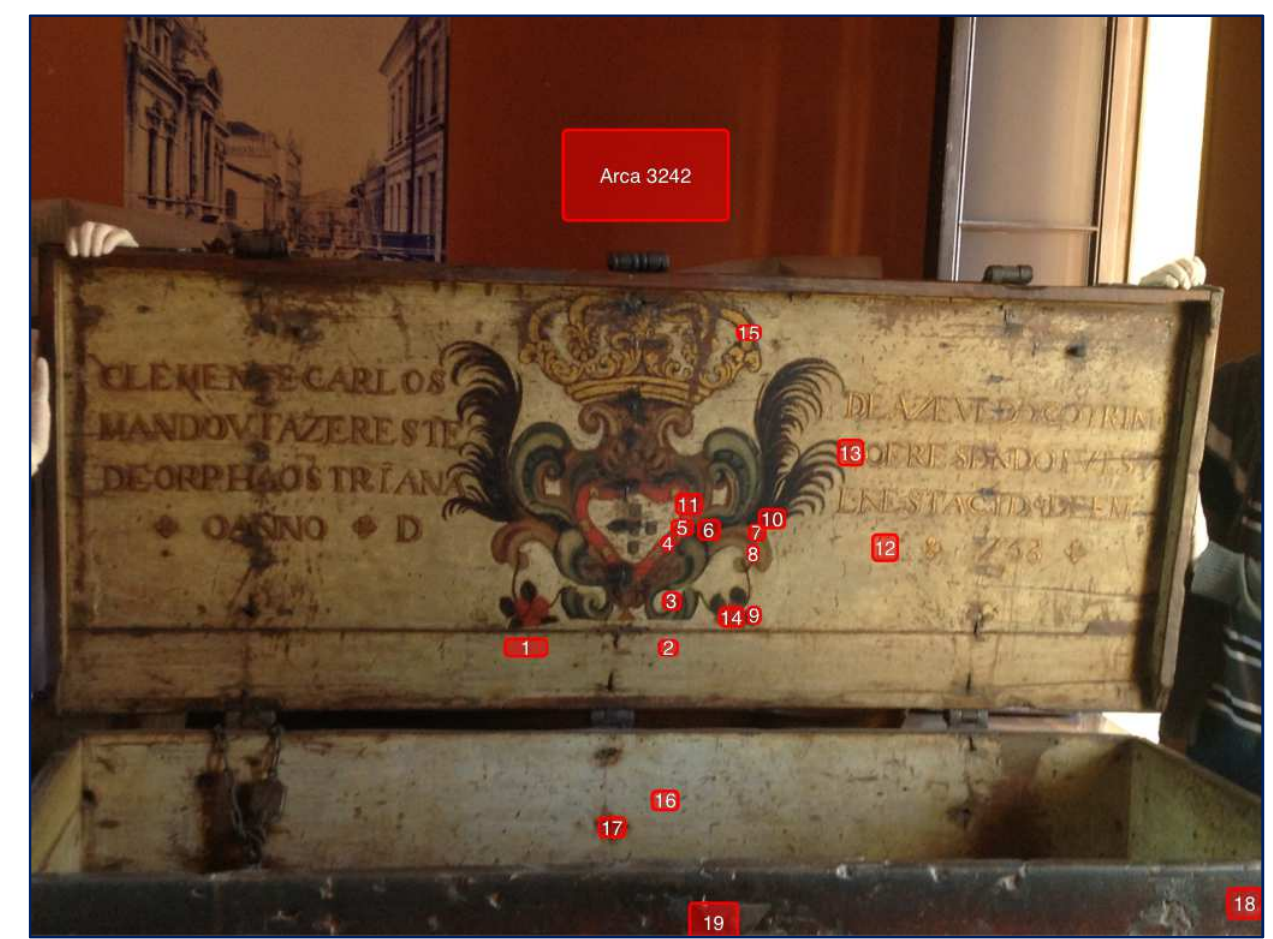

Figura 102: Fotografia da Arca-Cofre RG3242 com os pontos das medidas de EDXRF identificados: Foto da Prof. ${ }^{\stackrel{a}{ }}$ Dr. ${ }^{-}$Márcia Rizzuto.

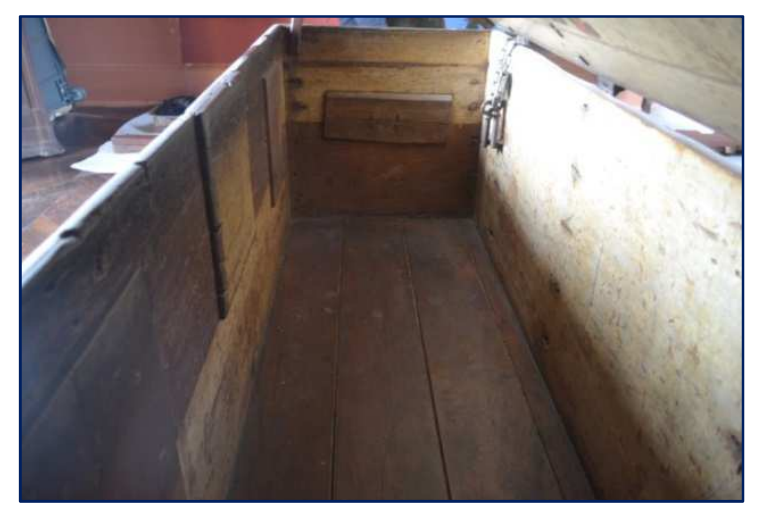

Figura 103: Interior da Arca RG3242. Fotografia do autor 


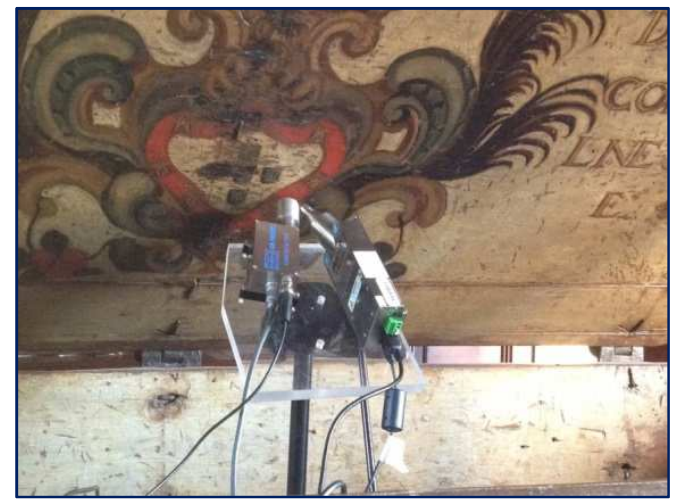

Figura 104: Fotografia no momento de medição do ponto P4, incidindo na tinta vermelha do brasão da Arca-Cofre RG3242.

Tabela 4: Nomenclatura e especificação dos pontos medidos por EDXRF na arca RG3242

\begin{tabular}{|c|c|c|}
\hline REFERÊNCIA & Nome & $\begin{array}{c}\text { ESPECIFICAÇÃO } \\
\mathbf{V}=\mathbf{3 0 K V}, \mathbf{i}=\mathbf{2 0 u} \mathbf{A}, \mathbf{t}=\mathbf{1 0 0} \text { seg }\end{array}$ \\
\hline $160824 \mathrm{ca}$ & P1 & Ponto pigmentação branca \\
\hline $160824 \mathrm{cb}$ & $\mathbf{P 2}$ & Ponto pigmentação branca \\
\hline $160824 c c$ & P3 & Ponto pigmentação verde claro \\
\hline $160824 \mathrm{~cd}$ & $\mathbf{P 4}$ & Ponto pigmentação vermelho \\
\hline 160824ce & P5 & Ponto dourado castelo \\
\hline $160824 \mathrm{cf}$ & P6 & Ponto pigmentação preto \\
\hline $160824 \mathrm{cg}$ & P7 & Ponto pigmentação bege \\
\hline $160824 \mathrm{ch}$ & P8 & Ponto pigmentação vermelha (marrom claro) \\
\hline $160824 \mathrm{ci}$ & P9 & Ponto pigmentação verde escuro \\
\hline $160824 c j$ & P10 & Ponto pigmentação preto \\
\hline $160824 \mathrm{ck}$ & P11 & Ponto pigmentação vermelha \\
\hline $160824 \mathrm{cl}$ & P12 & Ponto letra E (na linha inferior direita) \\
\hline $160824 \mathrm{~cm}$ & P13 & Ponto pigmentação vermelha letra C de "Cofre" \\
\hline $160824 \mathrm{cn}$ & P14 & Ponto pigmentação rosa inferior \\
\hline $160824 \mathrm{co}$ & P15 & Ponto dourado coroa \\
\hline $160824 \mathrm{cp}$ & P16 & Ponto pigmentação branco interno \\
\hline $160824 \mathrm{cq}$ & P17 & Ponto ferragem - prego interno \\
\hline $160824 \mathrm{cr}$ & P18 & Ponto ferragem - espelho da fechadura \\
\hline $160824 \mathrm{cs}$ & P19 & Ponto ferragem - ornamento central \\
\hline
\end{tabular}




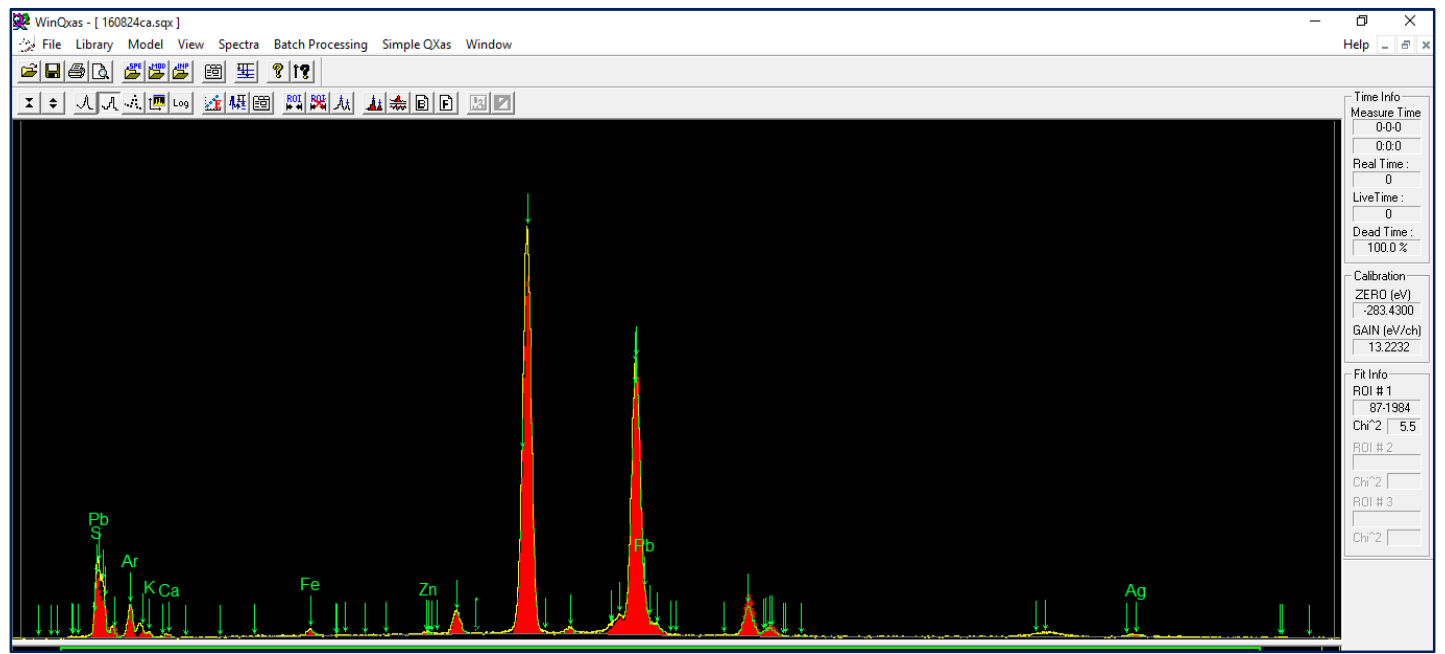

Gráfico 4: Exemplo do espectro de raios $X$ gerado pelo software de análise WinQxas a partir dos dados recolhidos com o detector acoplado ao tubo de raios X para o ponto P1 (160824ca) de pigmentação branca.

Os picos dos gráficos indicam o maior número de contagens dos elementos que estão presentes em cada ponto específico, permitindo assim a comparação de diferentes elementos químicos encontrados na superfície do objeto estudado. Por exemplo, neste espectro evidenciamos os elementos químicos: $\mathrm{K}, \mathrm{Ca}, \mathrm{Fe}, \mathrm{Zn}$ e Pb, este em concentração muito alta. 

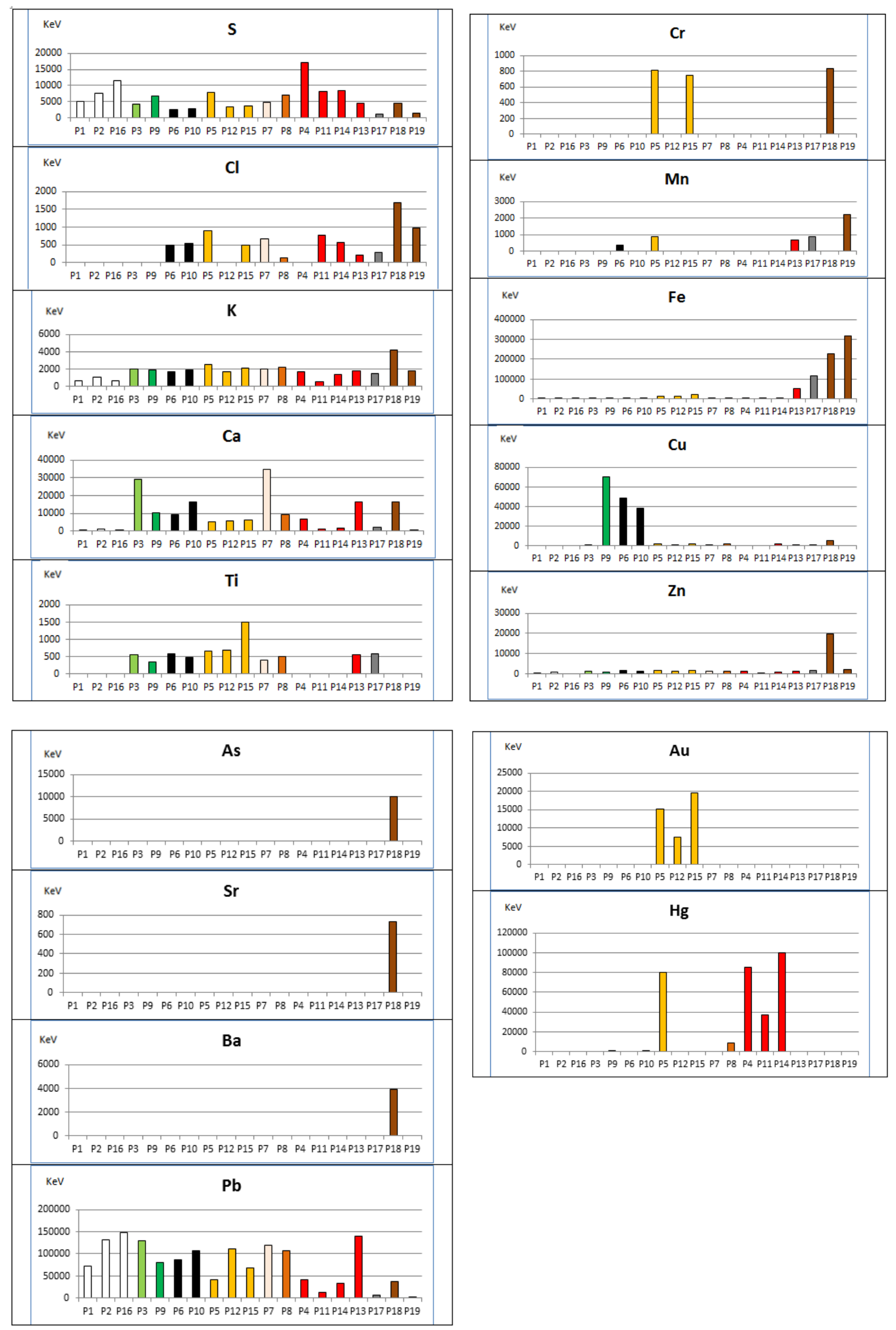

Gráfico 5 a-p: resultados das diferentes quantidades de cada elemento químico determinado nas medidas da Arca RG3242. 
$\mathrm{Na}$ figura acima vemos os gráficos de barras das áreas obtidas nos picos dos diferentes espectros e a sistematização e correlação entre estes pontos. Pelo esquema de cores correlacionado ao ponto de medição, podemos ver a quantidade de cada elemento compondo os respectivos pigmentos usados na pintura: brancos, verdes, pretos, ouro (em amarelo), bege (que se revelou ser da mesma composição dos brancos), vermelhos e os componentes metálicos (em marrom).

Como pudemos observar pelos gráficos de elementos, diversos pontos, como o P13 e P15 incidiram em zonas de restauro, dada a presença anacrônica de Titânio, componenete que só aparece em tintas do século $X X^{229}$. As conclusões, sintetizadas, são as seguintes:

1) Notamos que os pontos dourados (P5, P12 e P15) possuem bastante ouro, sendo o P5 a figura do castelo, P12 a letra "E" e P15 parte da coroa. Deste modo confirma-se o uso de Au para fazer o adorno das letras na parte interna do tampo, bem como a iconografia que compõem o brasão imperial de Portugal, seja nos castelos, seja na coroa. Estes mesmos pontos (5, 12 e 15) apresentam picos espúrios de Cromo e Titânio devido a refletâncias no receptor.

2) Os pigmentos vermelhos são a base de mercúrio que foram identificados nos pontos P8, P4, P11, P14. Neste caso o pigmento utilizado é o Vermilhon, dada a presença marcante de $\mathrm{Hg}$ e S. Somente no ponto P13 (vermelho da letra "C" de "Cofre") não temos o $\mathrm{Hg}$, e temos altos $\mathrm{Pb}, \mathrm{Fe}, \mathrm{Ca}$ e $\mathrm{Ti}$, o que talvez nos indique que neste ponto utilizou-se o vermelho de chumbo ou de óxido de ferro e talvez também seja um restauro dado o uso do Ti.

3) Os pontos brancos possuem alta quantidade de chumbo (P1, P2 e P16) sugerindo o pigmento Branco de Chumbo. Este se coaduna com a datação que os próprios móveis carregam, do século XVIII, posto que este era o único pigmento branco que se utilizava na pintura antes do século XIX.

4) Os pontos verde escuro (P9) e pretos (P9 e P10) possuem alta quantidade de $\mathrm{Cu}$, não sendo, porém, possível determinar com precisão qual é o pigmento presente. A hipótese é que tenha sido utilizada a tenorita, o óxido de $\mathrm{Cu}$.

${ }^{229}$ Cf. APPOLONI, Carlos Roberto e SILVA, Wislley Dueli da. Pigmentos: propriedades físicas, químicas e o período histórico de utilização. Londrina: Publicação Técnica do Laboratório de Física Nuclear Aplicada, Volume 13, Número 1, 1a Edição, Outubro de 2009. s.p. disponível em: www.uel.br/grupos/gfna/pigmentos2009.pdf. Acesso em: 20/05/2018. 
Pode ter havido o uso de mistura com pigmento azul de azurita. Ou pigmentos pretos a base de chumbo: Galena ( $\mathrm{PbS}$ ) ou Plattnerite ( $\mathrm{PbO} 2)$.

5) $\mathrm{O}$ ponto com pigmento verde claro possui bastante $\mathrm{Ca}$ e $\mathrm{Pb}$, possivelmente provenientes de tintas brancas atenuantes do tom.

6) Os pontos dos metais medidos (P17, P18 e P19) apresentam diferentes elementos químicos. O ponto P18 que é o metal do espelho da fechadura apresenta uma composição metálica composta de chumbo, zinco, cobre, cromo, ferro. Mas possui também cálcio, arsênio, bário e estrôncio, que podem estar vinculados à contaminação de solo ou ambiental. O ponto P17 (prego interno) é basicamente de $\mathrm{Fe}$ e um pouco de chumbo. Possivelmente o $\mathrm{Pb}$ usado nas ligas com o Fe foram utilizadas pelo artesão para dar mais maleabilidade ao metal, espacialmente no espelho utilizado para o orifício da fechadura. O ponto P19 referente ao ornamento central é composto de ferro com traços de manganês, zinco e chumbo.

7) As intensidades das áreas dos picos dos espectros de EDXRF dos metais revelam uma concentração dada de acordo com a tabela abaixo:

Tabela 5: Concentrações dos metais identificados pelas medidas d EDXRF - "Arca 3242"

\begin{tabular}{|c|c|c|c|}
\hline \multirow[t]{3}{*}{ Elemento } & $\begin{array}{l}\text { Prego } \\
\text { P17 }\end{array}$ & $\begin{array}{l}\text { Fechadura } \\
\text { P18 }\end{array}$ & $\begin{array}{l}\text { Metal do ornamento } \\
\text { P19 }\end{array}$ \\
\hline & $160824 \mathrm{cq}$ & $160824 \mathrm{cr}$ & $160824 \mathrm{cs}$ \\
\hline & $\%$ & $\%$ & $\%$ \\
\hline $\mathrm{Cr}$ & & 0,29 & \\
\hline $\mathrm{Mn}$ & 0,71 & 0,00 & 0,69 \\
\hline $\mathrm{Fe}$ & 92,69 & 78,03 & 98,40 \\
\hline $\mathrm{Cu}$ & 0,38 & 1,80 & 0,00 \\
\hline $\mathrm{Zn}$ & 1,34 & 6,81 & 0,62 \\
\hline $\mathrm{Pb}$ & 4,88 & 13,08 & 0,28 \\
\hline
\end{tabular}

Debruçando-nos sobre as análises sobre os dados coletados nos exames das peças, procuramos agora lançar mão de outras fontes para compreender estes dados e dar-Ihes densidade histórica.

Os resultados das amostras deixam ainda várias incógnitas para serem melhor apuradas por meio do cruzamento de informações obtiveis com o uso de várias técnicas conjuntamente, mas pudemos precisar uma série de elementos que nos ofereceu pistas valiosas para a compreensão da vida social desses objetos. Como pudemos ver, a luz UV deu-nos visão dos pontos restaurados de maneira a 
tornar os pontos de EDXRF mais compreensíveis, ou teríamos grandes dúvidas sobre a datação e o tipo de pigmento em cada ponto feito "às cegas", como nas partes do couro com grande incisão de restauros e cola.

Primeiramente, obtivemos dados interessantes sobre os dois diferentes tipos de couro não só visualmente, sendo um trabalhado com ferros e outro a pelo, mas também pela presença de elementos químicos diferentes, indicando processos de curtição diferentes. Utilizavam-se sais metálicos no couro do espaldar lavrado como indicado pelo volume de ferro encontrado. Entretanto, no couro piloso do assento notamos que ele possuía outra curtição, onde estariam ausentes os sais.

Sabemos que na própria Europa eram utilizados os taninos de árvores para a curtição dos couros, para além só dos metais ${ }^{230}$. Pesquisando em fontes textuais, notamos que havia uma forte fabricação brasileira de couros curtidos, dado o enorme volume de gado que existia nas capitanias do nordeste e do sul.

Vemos pelas correspondências dos capitães-generais a importância da fábrica de atanados pela preocupação com o extrativismo nas florestas ${ }^{231}$ de mangues, especialmente do litoral paulista ${ }^{232}$ :

Os homens que fazem neste país a extração da casca das árvores chamadas Mangues, que serve para o curtume da fábrica dos atanados dessa cidade, a tiram com tal desordem que expoleando o tronco de toda a que o circula com a ambição de juntarem com menos trabalho maior quantidade, que interessando nisto os mesmos contratadores pelo interesse de lhe comprarem por este modo mais barato, deixam as árvores despidas de toda a sustância que as anima, e vem totalmente a secarem-se e a perecer, e tem chegado a tal excesso neste particular, que sendo inumerável a quantidade de Árvores Mangues que havia neste Distrito se acham hoje totalmente extinguidas, e para as haverem são obrigados de as ir buscar para as partes do Cubatão pelas não poderem já encontrar nestas vizinhanças, ocasionando este abuso a infalível certeza de vir a faltar todo este gênero e com a sua falta acabar-se em breve tempo (...) a fábrica de atanados.

A produção desta fábrica de couros devia decerto ser suficientemente lucrativa ao ponto de que sobre ela incidiu um dos impostos reais para a

\footnotetext{
${ }^{230}$ RIBA, M. T. L.; MIRÓ, E. P. O couro: as técnicas para criar objectos de couro explicadas com rigor e clareza. Lisboa: Editorial Estampa, 2007.. P. 23; bem como PEREIRA, Franklin. 0 couro lavrado no mobiliário artístico de Portugal. Lisboa: Lello Editores. 2000, P. 162.

${ }^{231}$ Cabral em seu estudo mostrou a formação de uma das primeiras legislações ambientais no Brasil dado extrativismo excessivo e desordenado. CABRAL, Diogo de Carvalho. Na Presença da Floresta:, Mata Atlântica e História Colonial. Rio de Janeiro: Garamond/FAPERJ, 2014.
}

${ }^{232}$ APESP. DI, volume 72, Ofício do Morgado de Mateus, p. 25. 
reconstrução de Lisboa após o terremoto de 1755, como recorda Pereira Cleto no Dicionário da Capitania de São Paulo ${ }^{233}$ :

Na sua Dissertação sobre a Capitania de São Paulo, de 1782, o mesmo autor ainda fornece informações mais precisas, dando a relação dos gêneros que pagavam o Novo Imposto ${ }^{234}$ :

\footnotetext{
Cada arroba de Casca de Mangue que sair para fora [sic] da Vila, cem réis;

Cada cem paus de Mangue, cem réis;

Cada dúzia de caibros de Mangue, oitenta réis;
}

Note-se que era um valor alto para este gênero de madeira específico, quando comparado com outros ${ }^{235}$ :

\footnotetext{
Cada vigote [de madeira] grande, oitenta réis;

Dito pequeno, quarenta réis;

Cada dúzia de Taboado, cento e vinte réis.
}

Não sabemos quais espécies vegetais poderiam ser utilizadas na cidade de São Paulo para a curtição de couros, mas notamos que também havia quem os trabalhasse. Em 1825 encontramos registrado no Bairro de Boaçava, Francisco Pereira da Silva, o qual além de "viver de seus couros" era oficial de ordenança. Já Joaquim Aranha e Mariano Gomes de Andrade, ambos negros e este último miliciano, viviam do mesmo ofício neste mesmo ano no Bairro de Pinheiros ${ }^{236}$. Notese que esses dois bairros são próximos ao Rio Pinheiros, possivelmente onde eles poderiam se servir das águas para o curtume.

As peças de mobiliário com couro lavrado nos levam a conjeturar sobre a criação de gado para produção de mobiliário, sobre o fornecimento do couro por fazendas de gado mais próximas ou distantes da cidade - sobretudo do Rio Grande ${ }^{237}$.

Nos termos de fiança da documentação camarária setecentista - até 1765 -, foi constante a passagem de gado pela capital paulista, sobretudo, em direção às Minas Gerais, ao Rio de Janeiro e a Goiás, secundadas por outras áreas da própria

\footnotetext{
${ }^{233}$ ANTT. Coleção Papéis do Brasil. Cleto, Marcelino Pereira. "Dicionário da capitania de São Paulo", vol. I. [microfilmado]. PT/TT/PBR/11. .

${ }^{234}$ CLETO, Marcelino Pereira. Dissertação a Respeito da Capitania de São Paulo, sua decadência e modo de restabelece-la. 1782. Em: CLETO, Marcelino Pereira et al. Roteiros e notícias de São Paulo colonial: 17511804. São Paulo: Governo do Estado de São Paulo, 1977.

${ }^{235}$ Idem, ibidem.

236 APESP. Maços de população $1825 . \quad$ Disponível em: http://www.arquivodoestado.sp.gov.br/viver/recenseando.php. Acesso em: 10/12/2016.

${ }^{237}$ Observações que já foram pontuadas por nós em BORREGO, Maria Aparecida de Menezes; FELIX, Rogério Ricciluca Matiello. Ambientes domésticos e dinâmicas sociais em São Paulo colonial. Rev. Hist. (São Paulo), São Paulo, n. 175, p. 91-132, dez. 2016.
} 
capitania, que poderiam consumi-las ou servir como entreposto dada a localização estratégica - Guaratinguetá, Santos, Piedade, Parnaíba, Mogi Guaçu ${ }^{238}$.

Com a abertura do caminho do Viamão, na década de 1730, as tropas de muares, vindas do Prata, de Curitiba e dos próprios campos de Viamão passaram a se dirigir em maior quantidade e frequência para a feira de animais de Sorocaba. De lá, o gado comprado pelos negociantes era levado para diversas regiões, tendo a cidade de São Paulo como destino ou área de apoio ${ }^{239}$. A implantação do registro de Sorocaba, ainda em 1750, comprova que o volume de cabeças trazidas para essa vila era atraente do ponto de vista fiscal ${ }^{240}$.

Acerca do intenso comércio entre a região sul e sudeste da América Portuguesa no século XVIII, Renato Leite Marcondes comenta que paralelamente à condução de tropas via terrestre para atender à demanda por transporte, vestuário e alimentação, realizava-se o envio de couro, sebo, carne seca e charque por via marítima $^{241}$. Entretanto, os estudos dos especialistas não são conclusivos sobre a extração do couro para o mobiliário, nem no próprio Rio Grande do Sul, ou em São Paulo, nem sobre o trajeto de cabotagem percorrido pelo material ${ }^{242}$.

Outro produto de grande importância na economia colonial, a Arca RG 3242, o ouro nas representações da coroa real e dos castelos do brasão imperial português. Poderia parecer evidente a um primeiro olhar e mesmo algo desnecessário realizar a averiguação arqueométrica de tais pontos, entretanto devemos ser cautelosos: sabemos que a fabricação de pigmentos que imitavam o ouro era recorrente no mundo europeu e colonial americano, como atesta - para citar um exemplo contemporâneo à arca - o manual de Bernardo Montòn, "Secretos

\footnotetext{
${ }^{238}$ Nesse lapso temporal, houve a taxação sobre as cabeças de gado para contribuição ao donativo voluntário para reconstrução de Lisboa, em virtude do terremoto ocorrido em 1755. O fato de a pecuária figurar no topo da lista das mercadorias tributadas revela sua importância no conjunto de artigos comercializados na cidade de São Paulo. BORREGO, Maria Aparecida de Menezes. A teia mercantil..., 2010.

${ }^{239}$ REIS Filho, Nestor Goulart. O caminho do Anhanguera. São Paulo: Via das Artes, 2014, pp. 30-1.

${ }^{240}$ Segundo Carlos Bacellar, "infelizmente, não sobreviveram quaisquer documentos contábeis desse Registro relativos ao século XVIII. Funcionando, desde o momento de sua criação até 1825 , sob o sistema de arrendamento para particulares, os eventuais livros de controle de passagem de animais também ficaram sob a posse desses indivíduos". BACELLAR, Carlos de Almeida Prado. Viver e sobreviver em uma vila colonial Sorocaba, séculos XVIII e XIX. São Paulo: Annablume/Fapesp, 2001. p. 101.

${ }^{241}$ MARCONDES, Renato Leite. Formação da rede regional de abastecimento do Rio de Janeiro: a presença dos negociantes de gado (1801-1811). Topoi, Rio de Janeiro, mar. 2001, pp. 41-71.

${ }^{242}$ Sobre a criação de gado no sul da América Portuguesa ver OSORIO, Helen. O Império Português no Sul da América: estancieiros, lavradores e comerciantes. Porto Alegre: Editora da UFRGS, 2007; HAMEISTER, Martha Daisson. O Continente do Rio Grande de São Pedro: os homens, suas redes de relações e suas mercadorias semoventes (c.1727-c.1763). Dissertação (Mestrado em História) - Universidade Federal do Rio de Janeiro, Rio de Janeiro, 2002.
} 
de Artes Liberales y Mecanicas", de 1734. Nele ensinava o "Secreto para hacer oro de la China para dorar", que consistia em amálgama de mercúrio e enxofre, passado por água de cal filtrada. Depois de ser queimado e reduzido a pó e destemperado com bolo-arménio e cola de peixe, poderia ser utilizado para a pintura ou mesmo brunimento. Também o chamado Ouro-da-Alemanha, consistia num amálgama de prata com açafrão, preparado em infusão de agua e gema, a partir da qual se obtinha a aparência de ouro fino, como o folheado, e ainda de mais fácil aplicação, com pincel ${ }^{243}$.

Para além da mensagem escrita na arca, informando quem a encomendou onde fora feita e a data, o que Ihe confere legitimidade jurídica, a presença do branco de chumbo como principal pigmento compondo a base branca da pintura, que funciona como um importante datador. Este é um dos pigmentos mais detalhadamente registrado pelas fontes históricas a respeito da extensão de seu uso e substituição, pois foi o principal pigmento branco utilizado na pintura até os inícios do século XIX, quando em 1834 se popularizou o branco de zinco $(Z n O){ }^{244}$. O próprio perigo do uso do branco de chumbo, que envenenava muitos pintores e artistas, levou à busca de um pigmento branco que o substituísse. No século XX também o branco de zinco caiu em desuso com o advento em 1918 do branco de titânio, elemento este utilizado em vários pigmentos sintéticos ${ }^{245}$.

Podemos ainda apreender simplesmente pela presença deste raro elemento na arca a sua época de fabricação e mesmo a conjuntura econômica vivenciada na colônia em relação às políticas da Metrópole. Therezinha de Moraes Sarmento fazendo um estudo sobre um preguiceiro integrante do acervo do Museu Histórico Nacional contextualiza as suas condições de produção e de seu estilo artístico, à época de D. José I. Este monarca, que enfrentou o terrível momento do Terremoto de Lisboa (1755) estabeleceu como uma regra aos seus súditos a modéstia nos costumes e no mobiliário para que assim se voltasse à antiga simplicidade da

\footnotetext{
${ }^{243}$ Apud. SANDÃO, Arthur de. O móvel Pintado Português. Barcelos: Companhia Editora do Minho, 1966. Pg. 40

${ }^{244}$ APPOLONI, Carlos Roberto e SILVA, Wislley Dueli da. Pigmentos: propriedades físicas, químicas e o período histórico de utilização. Londrina: Publicação Técnica do Laboratório de Física Nuclear Aplicada, Volume 13, Número 1, 1a Edição, Outubro de 2009.s.p.

${ }^{245}$ APPOLONI, C; SILVA, W. Pigmentos... op. cit. 2009. S.p.
} 
nação ${ }^{246}$. Seu pai, D. João $V$, por sua vez, já havia anteriormente ordenado, em pragmática de 24 de maio de 1749:

"Cap. V - Proíbo deste dia em diante fazer de novo móveis alguns de casa, em prata, nem ouro fino ou falso ou bordadura de qualquer sorte ou matéria seja (...)"

"Cap. VII - pelo prejuízo que causam a muitos artífices dos meus domínios as carruagens, mesas, bufetes, cômodas, papeleiras, cadeiras, tamboretes, tremós e outras alfaias que se trazem de fora, ordeno (...) fique proibida nas alfandegas dele a entrada das ditas coisas (...,247

Conclui Sarmento que tais medidas modificaram grandemente a feição dos móveis portugueses, já que os oficiais mecânicos proibidos de usar metais ricos em seus produtos foram obrigados a empregar outros métodos para incrementá-los. Esta seria a razão pela qual o trabalho de talha assumiu destaque na cultura material portuguesa setecentista. No caso citado, vemos que tais medidas políticas restringiam os recursos a serem empregados na microeconomia moveleira, afetando assim as tecnologias da estrutura produtiva. Reforça-se: a dimensão políticoeconômica também se apresenta sobre a própria cultura material produzida pela população.

Quanto aos pigmentos utilizados nas cores verdes e no preto, notamos que o recurso ao EDXRF, se nos permitiu precisar os elementos químicos presentes, não foi, porém suficiente para dar exatidão sobre qual composto de tais elementos teria sido usado. Ambas as cores apresentam semelhanças de componentes e dada a presença marcante de cobre, abre-se a possibilidade ao seu óxido ( $\mathrm{CuO}$ ) chamada de tenorita ${ }^{248}$, donde se faz o Verdete, também chamado verde de cobre, que é o seu acetato $^{249}$. Também existe a probabilidade de tal espectro verde, decerto esmaecido pelo tempo e por sucessivas camadas de vernizes passados na peça ao longo dos anos ser advindo da mistura do verde de cobre com pigmentos azuis, como a azurita $\left(\mathrm{Cu}_{3}\left(\mathrm{CO}_{3}\right)_{2}(\mathrm{OH})_{2}\right)^{250}$. Notando-se a forte presença de chumbo nos

\footnotetext{
${ }^{246}$ SARMENTO, Therezinha de Moraes. Um preguiceiro no Museu Histórico Nacional. Anais do Museu Histórico Nacional, vol. XXI. Rio de Janeiro, MEC, pp.43-52. 1969, p. 47.

247 SARMENTO, ibidem, p. 49.

${ }^{248}$ APPOLONI, Carlos Roberto e SILVA, Wislley Dueli da. Pigmentos: propriedades físicas, químicas e o período histórico de utilização. Londrina: Publicação Técnica do Laboratório de Física Nuclear Aplicada, Volume 13, Número 1, 1a Edição, Outubro de 2009. s.p. disponível em: www.uel.br/grupos/gfna/pigmentos2009.pdf. Acesso em: 20/05/2018.

${ }^{249}$ APPOLONI, C; SILVA, W. Pigmentos... op. cit. 2009. S.p.

${ }^{250}$ APPOLONI, C; SILVA, W. Pigmentos... op. cit. 2009. S.p.
} 
pretos, elemento que aparece em praticamente todos os pontos dada a impregnação da base de branco, adventa-se que essa tinta seja derivada do chumbo, talvez seu óxido $\left(\mathrm{PbO}_{2}\right)$ ou seu sulfeto (PbS), também chamado Galena.

Os pigmentos vermelhos indicam dois tipos de tintas: o Vermelho de chumbo, ou Azarcão $\left(\mathrm{Pb}_{3} \mathrm{O}_{4}\right)$ e o Vermilhon ( $\mathrm{HgS}$ ), bastante utilizados desde a Antiguidade até o século XVIII ${ }^{251}$. O Vermilhon, ou Vermilhão foi decerto o pigmento mais importante para a nossa investigação, pois nos ofereceu uma importante pista sobre a origem e cadeia produtiva dos pigmentos utilizados em São Paulo.

Isso, pois, Alberto Jacqueri de Sales, escrevendo no Diccionario do Commercio, de 1760, informa-nos sobre o Vermelhão que "a mayor parte vem de Hollanda", o que António Cruz ${ }^{252}$ confirma com dados estatísticos de importação entre 1777 e 1797, notando que este era o único país fornecedor para Portugal. De fato, era este o grande produtor mundial e não à toa o topônimo emprestava o nome ao modo de obtenção tradicional, alcunhado de "processo holandês" ${ }^{253}$. Necessitaríamos de um estudo mais largo sobre a produção de pigmentos ou sua importação no Brasil, mas a julgar pelo fato de que mesmo em Portugal se importava da Holanda tal componente, é verossímil pensar que também viesse de fora o usado no Brasil, seguindo as lucrativas rotas comerciais dos materiais artísticos europeus, bem como a lógica mercantilista de fornecimento de bens manufaturados para a colônia. Mesmo a terra americana contando em abundância os minérios usados no Vermelhão, dados os empecilhos do saber-fazer, tornava mais praticável a sua compra do que a tentativa de produção local. Também em Portugal, nota António Cruz, mesmo havendo menções à extração do cinábrio, equivalente natural do pigmento Vermelhão, tendo em conta a dimensão técnica da produção do pigmento não é provável que depois da Idade Média tal variante natural fosse utilizada na pintura ${ }^{254}$.

Em nossas pesquisas infelizmente encontramos apenas uma única relação de compra de tintas, entre outros apetrechos, encomendadas pela Câmara Municipal

\footnotetext{
${ }^{251}$ APPOLONI, C; SILVA, W. Pigmentos... op. cit. 2009. S.p.

${ }^{252}$ CRUZ, João António. A proveniência dos pigmentos utilizados em pintura em Portugal antes da invenção dos tubos de tintas: problemas e perspectivas. SERRÃO, Vítor et al., As Preparações na Pintura Portuguesa. Séculos XV e XVI. Lisboa: Faculdade de Letras da Universidade de Lisboa, 2013. p. 303.

${ }^{253}$ CRUZ, idem. Ibid. 2013. P. 303.

${ }^{254}$ CRUZ, João António. A proveniência dos pigmentos utilizados em pintura em Portugal antes da invenção dos tubos de tintas: problemas e perspectivas. SERRÃO, Vítor et al., As Preparações na Pintura Portuguesa. Séculos XV e XVI. Lisboa: Faculdade de Letras da Universidade de Lisboa, 2013.
} 
de São Paulo ao Rio de janeiro, evidenciando ainda que tais produtos passavam pelo porto de Santos para serem remetidos serra acima ${ }^{255}$ :

Rio de Janeiro 22 de abril de 1789

O Snr. Capitão Antônio da Cunha Lobo

Fazendas que pediu para o Senado da Câmara de São Paulo, e remeto para a Vila de Santos a entregar ao Alf.es João Xavier da Costa Aguiar, marca a Mg.e.

A granel 80 quintas de ferro, a $5.000,400.000$

(...)

76 libras de Olio de linhaça, 160, 12.160

Custo das ancoretas $800,1.600$

(...)

soma 13900

1 cunhete

$4 \backslash \backslash$ pregos caibrares $-5.600-22.400$

$4 \backslash \backslash$ ditos pau a pique $3.800-15.200$

Custo do cunhete -240

Soma 3.784..

1 cunhete

2 @ e 8 lbs. Alvaiade ... 2.800, 6.550

Custo do Supra vae 160

(...)

1 lba. de fezes 180

$16 \mathrm{lbs}$. de Verdete a $800-. .800$

$1 \mathrm{lb}$. a de Sinopla fina 1.600

$1 \backslash 2 \mathrm{lb}$. a de Vermilhão f.o 1000. 22.830

soma 474.570

carreta do ferro $.480(\ldots)$

Se compararmos os dados arqueométricos da arca do começo do século XVIII com esta conta já dos finais do século, notamos como se continuava a importar, ao menos de outras capitanias se não da própria Europa, pigmentos que encontramos na arca: o Alvaiade, que é o branco de chumbo; o Verdete, outro nome para o verde de cobre; o Vermelhão, cujo alto valor (22\$830 réis) pela pequena quantidade (meia libra) seria um indício de sua vinda do exterior e as "fezes de ouro", outro nome do litargírio, o óxido de chumbo $(\mathrm{PbO})$ extraído da jazidas de Galena, utilizado também para a separação de ouro e prata na mineração. Também constam a Sinopla, pigmento vermelho-terra também chamado Terra de Sienna ${ }^{256}$

\footnotetext{
255 AHMSP. Fundo Câmara. Série Documentos Avulsos. Caixa 41. Pela ilegibilidade dos documentos não pudemos transcrever algumas das linhas, possivelmente contendo mais nomes de pigmentos.

${ }^{256}$ APPOLONI, Carlos Roberto e SILVA, Wislley Dueli da. Pigmentos: propriedades físicas, químicas e o período histórico de utilização. Londrina: Publicação Técnica do Laboratório de Física Nuclear Aplicada, Volume 13, Número 1, 1a Edição, Outubro de 2009. s.p. disponível em: www.uel.br/grupos/gfna/pigmentos2009.pdf. Acesso em: 20/05/2018.
} 
(óxido de ferro argiloso), e, por fim, fornece-nos ainda esta rica listagem dados de que se utilizava como base para pinturas o óleo de linhaça.

António Cruz elabora ainda uma tabela com os valores dos pigmentos importados através dos portos portugueses em 1777, que chama a atenção pelos altos valores mesmo na metrópole, comprovando a importância desses elementos para os artistas e mecenas da época ${ }^{257}$ :

Tabela 6: valores dos pigmentos importados através dos portos portugueses em 1777

\begin{tabular}{lll}
\hline Pigmentos & Arrobas & Réis \\
\hline Alvaiade & 2366 & $2012 \$ 265$ \\
Fezes de ouro & 354 & $290 \$ 280$ \\
Sinopla & 4 & $29 \$ 120$ \\
Verdete & 249 & $1248 \$ 645$ \\
Vermelhão & 43 & $1027 \$ 820$ \\
\hline
\end{tabular}

Vemos inclusive o alto valor das tintas se comparadas com as outras matérias-primas usadas na confecção dos móveis em São Paulo. Os gastos registrados pela Câmara Municipal com o fabriqueiro da Igreja de Santa Ifigênia no ano de 1815 , revela-nos ${ }^{258}$ :

(...) haver importado a madeira que se comprou para a feitura do caixão da Sacristia a quantia de $3 \$ 600$ réis;

Achou mais (..). importarem 4 fechaduras e 4 argolas para o mesmo (...) $5 \$ 120$ réis;

Achou mais ele dito ministro haver dispendido com o jornal de 10 dias a dois carpinteiros para fazer o dito caixão, em um a $\$ 400$ réis e outro a $\$ 320$ réis a quantia de $7 \$ 200$ réis;

Achou mais ele haver dispendido com o pintor por pintar a sacristia e a caixa da mesma e pondo ele todas as tintas a quantia de $6 \$ 000$ réis.

Assim, vemos como as tintas usadas em São Paulo possivelmente cumpriam uma grande rota comercial, ao menos do que podemos inferir do Vermelhão: dos Países Baixos para Lisboa, e desta para o Rio de Janeiro, depois para Santos até finalmente subir a serra, possivelmente nas costas de indígenas, alcançando São Paulo, isto se no meio do caminho os navios não tivessem cabotado em outros portos, agregando valores.

Danielle dos Santos também encontrou semelhante lista de encomenda de tintas feita pelo pintor José Soares de Araújo para pintura da capela-mor de São

${ }^{257}$ CRUZ,J. A proveniência... op. ct. 2013, p. 299.

${ }^{258}$ AHMSP. Fundo Câmara. Série Assunto Diversos. Livro 286. FI. 10v. 
Francisco Assis em Diamantina, Minas Gerais, ocorrida por volta de 1782. Reproduzimo-la a seguir para notar que também nas Minas se utilizavam pigmentos importados:

"Rol das tintas q. se carecem p. a a pintura da

Capela de N P. e S. Fran co .

10 ' ' Milheiros d'Ouro

5 ' ' C a d'geço groso

$4^{\prime \prime}$ ' $\mathrm{d}$ as d'geço Mate

$5^{\prime \prime}$ ' $L$ as de bolo (?)

$1 / 4$ ' ' de pinta unha (?)

$3 . '$ ' $L$ as de maquim (?)

$1 / 2$ ' ' $d$ a de rom (?)

$1^{\prime}$ ' $\mathrm{d}$ a . de flor d'Anil

1 ' ' d a de Vermilhão

2 ' ' $d$ as de Sinõpla (?)

$1 / 4$ ' ' d'Verde Eszilado (estilado)

$1 / 2$ ' ' (cx ou lata?) de jalde lino (Amarelo)

$1 / 4$ ' ' d'Flor d'jalde (lalde)

$1 / 2$ ' 'I a de lacara

2' ' $\mathrm{C}$ a de Alvayade

12 ' 'I aS do d a fino

$1 / 4$ ' ' d'preto de roma

$1 / 4$ ' ' de gomas graxas

$1 / 4$ ' ' $d$ a detromentina fina

1 ' ' pele d'lixa fina de pintor grande ou duas

piquenas

4 ' ' broxas grandes

2 ' ' duzias d'broxas piquenas surzidas co

algumas de ponta

4 ' ' $d$ as d'pinceis d'cabra surzidas

3 ' ' $\mathrm{C}$ a de retalho de luva

1 ' ' barril de olio d'linhaça

2 ' 'I aS d'Sombra d'Colonia.

Pedece venha tudo bem acondicionado e no milhor comedo que puder ser 1 "' I a de fezes de ouro

(no verso desse rol está escrito:)

"Rol das tintas pa Dourar e pintar a capela mor da ordem 3. a de S. Franc.0 s/ data. 259

A mesma autora informa-nos ainda que para a pintura do jazigo da igreja da Ordem Terceira do Carmo de São Paulo em 1801 encomendaram-se tintas da

\footnotetext{
259 PEREIRA, Danielle Manoel dos Santos. A pintura ilusionista no Meio Norte de Minas Gerais -Diamantina e Serro - e em São Paulo - Mogi das Cruzes (Brasil); 2012; Dissertação (Mestrado em Mestrado em Artes Visuais) - Instituto de Artes da UNESP. 2012. Pg. 121
} 
Bahia $^{260}$, reforçando desta maneira os nossos dados sobre a importância dos pigmentos usados na pintura, que desta forma se revelariam importantes não só pelas execuções artísticas, mas pela própria qualidade de seus materiais importados.

Não obstante esses dados que apontam a importação das tintas e a continuidade do standard europeu de pintura sabemos que houve no espaço colonial adaptações as mais variadas e mesmo a perspectiva dos coevos em realizar tais amoldamentos.

Disso o sabemos através de outros exemplos de estudos arqueométricos, como descrito por Adriana Cianciarulo ${ }^{261}$. Claudina Moresi ${ }^{262}$, realizando exames em arte sacra mineira, revelou que uma substância denominada Ouro-pigmento (sulfeto de arsênio) era utilizada para representar as chagas e gotas de sangue de imagens de Cristo, chamadas "rubis", não ocorrendo o uso desta substância nas esculturas sacras europeias. Nota Adriana Cianciarullo ${ }^{263}$ que a composição deste pigmento também assumiu contornos locais, pois sendo já tradicional na Europa ${ }^{264}$, era aqui misturado a resinas, as quais secando, conferem um aspecto vermelho brilhante às gotas de sangue. Ademais, o próprio preparo era o segredo que conferia essa qualidade única: o tubo fechado de ouro-pigmento, o qual era amarelo, quando aquecido ao ponto de sublimar e depois resfriado, adquiria a coloração vermelha e brilhante ${ }^{265}$.

Esse preparo evidencia que os pintores coloniais decerto desenvolviam empiricamente a qualidade de seus materiais, pois, apesar de o ouro-pigmento já constar em manuais portugueses como os de Cenino Cennini (1398), Felipe Nunes (1615) e nos Segredos necessários para os officios, artes e manufacturas, e para muitos objetos sobre a economia doméstica (1794), não se encontra o mesmo com

\footnotetext{
${ }^{260}$ PEREIRA, Danielle Manoel dos Santos. Autoria da Pinturas Ilusionistas do Estado de São Paulo: São Paulo, Itu e Mogi das Cruzes (Brasil). 2017. Tese (Doutorado em ARTES) - UNESP. 2017, p. 119.

${ }^{261}$ CIANCIARULO, Adriana Quilici Barreto. Materiais usados como pigmento no período colonial brasileiro. Tese de Mestrado em História da Ciência - PUC-SP. 2014.

${ }^{262}$ MORESI, Claudina M. D. "Materiais usados na decoração de esculturas em madeira policromada no período colonial em Minas Gerais." Revista Imagem Brasileira, 1 de 2007: 79-82.

${ }^{263}$ CIANCIARULO, Adriana Quilici Barreto. Materiais usados como pigmento no período colonial brasileiro. Tese de Mestrado em História da Ciência - PUC-SP. 2014, P. 81.

${ }^{264}$ APPOLONI, Carlos Roberto e SILVA, Wislley Dueli da. Pigmentos: propriedades físicas, químicas e o período histórico de utilização. Londrina: Publicação Técnica do Laboratório de Física Nuclear Aplicada, Volume 13, Número 1, 1a Edição, Outubro de 2009.

${ }^{265}$ SINKANKAS, J. Gemstone and mineral data book. New York: Collier Macmillan, 1974. p.204., Apud MORESI, Claudina M. D. "Materiais usados na decoração de esculturas em madeira policromada no período colonial em Minas Gerais." Revista Imagem Brasileira, 1 de 2007: 79-82.
} 
esse preparo e coloração nas esculturas europeias e mesmo hispano-americanas ${ }^{266}$. Outra adaptação local foi o uso do caulim, argila branca presente em Minas Gerais como base de preparação das superfícies a receber a policromia e utilizada em substituição ao gesso, que precisava ser importado da Europa ${ }^{267}$.

Vemos como o interesse em substituir componentes produtivos europeus por nacionais estava em voga no período colonial quando, em 1803, na Viagem pela Capitania de São Paulo, Martim Francisco Ribeiro Andrada notava a qualidade dos solos da região de Cananéia ${ }^{268}$ :

Continuando de sul a norte, vem desaguar no barco de mar por detrás da vila dos rios Upiranga á esquerda e Arariaiuçu à direita, fazendo uma só barra; a formação das margens é a mesma, e nela se acham bancos de uma argila branca muito sofrível, de barros ocráceos amarelos, cor de rosa, vermelhos e cor de chumbo, muito bons para tintas.

A respeito da produção de tintas na cidade de São Paulo, Nuto Santana chamou a atenção para a indústria da cor azul, presente na louça e azulejaria, no fardamento dos militares, nas calças dos escravos, nas rótulas e batentes dos prédios e nas sobrecasacas dos homens, que eram descritos tendo a "cor de pedra lipes", o sulfato de cobre. Também azul, o anil ${ }^{269}$ foi em São Paulo bastante produzido e exportado, sendo usado principalmente nos tecidos. Registrou o Governador Martim Lopes de Lobo Saldanha ser abundante na terra a "erva a que chamam caurú, de que facilmente se faz anil" ${ }^{270}$. Em 1776, por exemplo, ele remetera para Portugal diversas amostras dos mais variados produtos naturais produzidos na terra, dentre eles um caixão de sementes desta planta, indo para o Rio de Janeiro a pedido do Marques do Lavradio, dado que o anil paulista seria melhor que o produzido na sede do governo e até o momento principal centro produtor $^{271}$. Chama a atenção o aumento dessa produção dentro da conjuntura maior da chamada diversificação agrícola, notando-se que ele compunha a pauta de

\footnotetext{
${ }^{266}$ CIANCIARULO, Adriana. Materiais usados... op. cit. 2014, p. 18.

${ }^{267}$ Idem, ibidem, p. 19.

268 ANDRADA, Martim Francisco Ribeiro. Jornais de Viagem pela Capitania de São Paulo, 1803. CLETO, Marcelino Pereira et al. Roteiros e notícias de São Paulo colonial: 1751-1804. São Paulo: Governo do Estado de São Paulo, 1977, p. 191.

${ }^{269}$ SANT'ANNA, Nuto. Metrópole (Histórias da cidade de São Paulo de Piratininga e São Bernardo do campo em tempos de El-Rei, o Cardeal Dom Henrique, da Dinastia de Avis). São Paulo: Departamento de Cultura, v.1,1953. ${ }^{270}$ SANT'ANNA, Nuto. São Paulo Histórico. Vol. VI. São Paulo: Dpto. De Cultura de S. Paulo. 1944. P. 26.

271 PESAVENTO, Fábio. Novas perspectivas sobre o comércio de anil no Rio de Janeiro colonial: 17491820. Revista de História Econômica e de Economia Regional Aplicada, v. 1, n. 1, p. 1-19, 2006.
} 
gêneros exportados de 1777 computando $106 \$ 000$ réis. Ainda que não fosse avultada soma perto dos $665: 156 \$ 040$ réis do primeiro colocado, o açúcar branco, ele não deixava de ser do interesse econômico da metrópole ${ }^{272}$.

No campo das tintas feitas com materiais orgânicos, vegetais ou animais, há um grande universo de pigmentos a serem analisados, mas que necessitam de outras técnicas arqueométricas de Física Aplicada como a Espectrografia Raman, que permite analisar não só os elementos químicos como o EDXRF, mas também os compostos formados por estes ${ }^{273}$.

Tais materiais naturais e locais, porém, não parecem ter sido usados na Arca, o que indicaria que os produtores utilizavam antes pigmentos importados do que tintas da terra. Isso reforça o caráter distintivo dos materiais usados na pintura, evidenciando a função social do adorno e da encomenda aos pintores nos quadros e móveis.

Feitas estas análises, ainda que muito breves pela densidade da temática, pudemos notar como os próprios materiais dos móveis nos fornecem indícios de sua importância para a sociedade da época, bem como carregam consigo pistas de suas trajetórias passadas. São mais indícios materiais que permitem relativizar a narrativa do isolamento e pobreza paulista e a atribuída rusticidade de suas condições de produção. Notamos como a câmara municipal, apesar da recorrente retórica de ausência de cabedais que permeia suas correspondências com o governo metropolitano, possuía recursos para encomendar os necessários aparatos à sua governança, como esta monumental arca para a época, ao propósito de conferir segurança aos seus documentos oficiais.

Para além da função mais prática da guarda, os materiais dos ornatos são reveladores do peso simbólico dessa peça ${ }^{274}$. Sendo objeto de uso restrito, não é, porém, difícil imaginar retroativamente cenas cotidianas de sua utilização. Por exemplo, quando os escravos de ganho, os jornaleiros ou os oficiais mecânicos mais

\footnotetext{
${ }^{272}$ SANT'ANNA, Nuto. São Paulo Histórico. Vol. VI. São Paulo: Dpto. De Cultura de S. Paulo. 1944. P. 30.

${ }^{273}$ Cf. ANGELINI, Ivana; ARTIOLI, Gilberto. Scientific Methods and Cultural Heritage: An Introduction to the Application of Materials Science to Archaeometry and Conservation Science. Oxford: Oxford University Press. 2010. Como mencionado anteriormente, chegamos a realizar as análises com a Espectrografia Raman nos móveis, porém nos limitamos a apresentar os dados obtidos com as outras técnicas.

274 LISBOA, M. G. P. ; GONÇALVES, C. A. O. . O adorno como objeto simbólico de um habitus de classe. In: INTERCOM, 2011, Recife-PE. INTERCOM NACIONAL 2011, 2011.
} 
desprovidos ao irem tirar as licenças e registros ${ }^{275}$ se admirariam com este grande cofre exibindo o resplendor dourado da Coroa Real e multicolorido de seu brasão, assim reforçando no espaço interno o poder do conjunto de objetos da sede do governo, exteriorizados pelo edifício da câmara, o pelouro e também a organização dos desfiles em festas públicas ${ }^{276}$.

Veremos nos capítulos seguintes mais profundamente os significados da posse e do uso de móveis com esses pigmentos e compostos que acabamos por identificar. Trazendo essa multiplicidade de fontes que utilizamos, como mapas, processos jurídicos, registros de pagamentos, manuais de época e relatos de memorialistas tentaremos aplicar a reflexão de Tim Ingold ${ }^{277}$ de não nos limitarmos à forma final e "morta" das coisas, objetificadas, mas procurar compreender cada um de seus elementos - literalmente desde o nível atômico - no seu vir-a-ser no passado, pelas várias mãos pelas quais passou em suas "vidas sociais" 278.

\footnotetext{
${ }^{275}$ Acreditamos que os funcionários da Câmara os recebiam na própria sala de reunião do Senado, já que esta foi ganhar divisão com secretaria só em 1830. “Ano de 1830 (...) Agosto (...) dia 30 (...)pela dita de 20 de julho próximo passado pago ao Pedreiro Nicolau de rebocar a parede nova da Secretaria, e (...) o vão da porta que vai para (...) a Sala da Sessões, obras estas avaliadas em $10 \$ 560$, e que foram feitas a jornal por não haver quem arrematasse 7360." AHMSP. Fundo Câmara Municipal. Série Receita e Despesa. Livro 1656, fl. 127.

${ }^{276}$ Cf. CARVAlHO, Mônica Muniz Pinto de. A cidade de São Paulo no século XVIII. Uma sociabilidade constituída em torno de símbolos do poder. São Paulo, dissertação de mestrado - FFLCH-USP, 1994.

277 INGOLD, Tim. Trazendo as coisas de volta à vida: emaranhados criativos num mundo de materiais. Horiz. antropol., Porto Alegre, v. 18, n. 37, p. 25-44, June 2012.

${ }^{278}$ APPADURAI, Arjun (org.). A vida social das coisas: as mercadorias sob uma perspectiva cultural. Niterói: Editora da Universidade Federal Fluminense, 2008.
} 


\section{CAPÍTULO 2. Produção}

Lector, si monumentum requiris, circumspice ${ }^{279}$.

Tendo examinado com variadas técnicas os aspectos materiais dos móveis paulistas e portugueses, surgem na sequência outras perguntas nesta HistóriaProblema: Quem as produziu? Como e onde viviam? Como era a sua vida em sociedade? De que maneira essas relações influenciavam na sua produção?

Uma vez que, como vimos, os próprios objetos possuem limitações de informações sobre quem as produziu, buscaremos agora compreender os dados obtidos lançando mão principalmente de documentos de outras qualidades, como as fontes textuais e iconográficas.

Primeiramente, devemos apreender a produção moveleira de maneira ampla, compreendendo que não somente os especialistas oficiais mecânicos produziam essas peças. A produção empírica e também a realizada por escravos e mesmo os membros de ordens religiosas eram efetivas e merecem ser contempladas, apesar de serem raras as memórias sobre esses indivíduos. Articularemos esta produção com a dos artífices oficiais, dos quais temos mais informações.

Tal como nossa atenção aos diminutos detalhes dos móveis que revelaram grandes informações contextuais, buscaremos neste capítulo focar nas trajetórias individuais de artífices. Compreendendo de maneira mais aproximada as facetas humanas na longa duração das práticas artesanais de produção do mobiliário, composto das curtas durações intercaladas dos artífices, utilizamos dos recursos metodológicos da Prosopografia e da História em Rede ${ }^{280}$, que nos permitem

\footnotetext{
279 "Leitor, se lhe procura o monumento, olhe ao teu redor". Citamos o epitáfio do arquiteto inglês Sir Christopher Wren (1632-1723), enterrado na catedral de São Paulo em Londres, que construiu durante 35 anos. Da mesma forma, para vermos os monumentos dos artífices paulistas, podemos olhar ao redor da cidade e reparar nas rugosidades espaço-temporais da paisagem, dos arruamentos, dos prédios, das estátuas, fontes e também dos poucos móveis e ferramentas que restaram o seu trabalho, anonimo pelo tempo e pela condição inferiorizada a que eram relegados, à obscurecescia dos registros históricos.

${ }^{280}$ Apesar de semelhantes, existem diferenças básicas entre esses dois métodos, sendo que a Prosopografia busca escrever biografias através da comparação de trajetórias entre indivíduos da mesma época, mas não necessariamente relacionados por conexões sociais. Por seu turno, são justamente estas conexões, por mais tênues e distantes que possam entre as pessoas ser que a História em Rede busca, e que procuraremos praticar. A primeira já era praticada por historiadores das grandes figuras políticas desde o século XVI, sendo renovadores dessa metodologia Lawrence Stone nos anos 1970, junto com E. P. Thompson e outras figuras da New Social History. A segunda por sua vez é tributária da Social Network Analysis desenvolvida pela Sociologia
} 
compreender as interconexões de indivíduos na tessitura social. Observar dessa maneira ao longo do tempo o "pequeno x" da história ${ }^{281}$ nos permite ver com melhor resolução os processos históricos que constituem, na longa duração, a dinâmica social do Império Português.

Diversos historiadores já utilizaram essas metodologias buscando compreender as trajetórias individuais de diversas pessoas comparativamente a seus pares no grupo social, bem como de outras classes e grupos ${ }^{282}$. Mesmo que não tenha sido possível encontrar grandes redes familiares e de contatos entre os artesãos estudados, demos atenção às relações tênues, como as marcadas por dívidas e fianças. Como explica Beunza "la fuerza de los lazos débiles" ${ }^{283}$, muitas vezes são mais importantes para os indivíduos dentro do jogo social, especialmente quando inter-classes, do que as relações fortes intra-classes e familiares ${ }^{284}$.

A micro-análise social também é de grande importância para nossa mirada sobre a cultura material, pois podemos ver com ela os nós onde se interligam atores, o meio físico e os objetos. Pelos artefatos e seus trânsitos arrolados nos inventários e testamentos podemos dar relevo à noção de "vida social", ou melhor, trajetória social dos objetos como proposto por Appadurai. A posse, mesmo que elementar e transitória de qualquer espécie de objeto por uma determinada pessoa em um dado período é eivado de história e possui significado cultural e mesmo político, no

e Antropologia nos anos 1950 e 1960. BEUNZA, José María Imízcoz. Introducción. CASADO, I.; RODRÍGUEZ, J.; VEGA, D. Redes Sociales y económicas en el mundo bajomedieval. Valladolid: Castilla Ed. 2011, p. 24 e BEUNZA, José María Imízcoz. Redes, grupos, classes. Uma perspectiva desde el análisis relacional. MOLINA PUCHE, S. ; IRIGOYEN LÓPEZ, A. (Eds.). Territorios distantes, comportamientos similares. Familias, redes y reproducción social en la Monarquía Hispánica (siglos XIV-XIX). Murcia: Editium. 2008, p. 52. ALBERNAZ, Cássio. Da História política dos "grandes homens" a prosopografia das elites políticas: considerações historiográficas e metodológicas. São Paulo: ANPUH. Anais do XXVI Simpósio Nacional de História, 2011.

${ }^{281}$ LORIGA, Sabina. O pequeno “x” da História: da biografia à História. Belo Horizonte: Autêntica, 2011. p. 19. Expressão de Johan Droysden de 1863, que buscou compreender o gênio individual, expresso por $A$ na fórmula $A=a+x$, onde $a$ são todos os fatores das circunstancias externas que influenciam o individuo e o pequeno $x$ representa a sua contribuição pessoal. Se decerto este tipo de formulação revela o momento cientificista da História em que o autor escreveu, sua linha de raciocínio não deixa de ser relevante. Foram nos anos 1970 com as contribuições da Micro-História que se buscou dar nova compreensão à dimensão individual da História, dado fundamental para compreende-la mais humanizada e heterogênea. Esta renovação de abordagem na historiografia deveu-se principalmente aos italianos Carlo Ginzburg, Giovanni Levi e Edoardo Grendi, com paralelismos em autores de outros países, como Frederik Barth e Emmanuel Le Roy Ladurie. cf. DORTIER, J. Dicionário de Ciências Humanas. São Paulo: Martins Fontes. 2011, p. 407. Verbete: Micro-História.

282 A presente dissertação, pelas várias frentes que assumimos em nosso esforço transdisciplinar não realizamos pesquisa prosopográfica na mesma extensão e sistematização que autores como Maria Aparecida Borrego e Milena Maranho, ou com dados demográficos e regulatórios, como fizeram Darwiche Rabello e José Newton de Carvalho. Nossa contribuição foca-se mais em aspectos qualitativos sobre os produtores e na sua materialidade.

${ }^{283}$ BEUNZA, J. Introduccion... op. cit. 2011, p. 30

${ }^{284}$ BEUNZA, J. Redes, grupos, classes... op. cit. 2009, p. 87. 
sentido da vetorização das sociabilidades permitido e propulsado pelos objetos. ${ }^{285}$ Esta é a preocupação fulcral que o historiador deve ter e à qual o historiador da cultura material deve estar duplamente atento, dado o risco de se fazer uma História apenas do objeto, e não do homem em sua relação intrinsecamente encadeada com o artefato, como nos adverte Ulpiano de Meneses ${ }^{286}$.

\subsection{A produção de móveis, de mãos em mãos.}

Os artesãos portugueses que chegavam no Brasil ao longo dos vários séculos de colonização traziam consigo a sabedoria de como produzir o mobiliário europeu e os aqui nascidos aprendiam com estes. Vimos no capítulo anterior pela materialidade das peças as mudanças nas configurações dos móveis, em seus materiais e formas, advindas de modelos de centros europeus. Buscamos fazer uma imersão verticalizada sobre a vida de alguns artífices da madeira para observarmos as dimensões de produção atreladas à condição de vida de cada um, como suas conexões sociais, suas localizações e pertences, além das ferramentas. Assim coligaremos informações à historiografia que já se debruçou sobre o tema, criando quadros gerais de compreensão.

Nosso esforço voltou-se principalmente em encontrar inventários post mortem desses indivíduos, localizados pelas indicações profissionais nas Atas e Registro Geral da Câmara Municipal e os Maços de População da Capitania feitos entre 1765 e 1830, posto ser a fonte que pode nos informar sobre as ferramentas e peças, trabalhos e dívidas, riqueza e endereços desses indivíduos, permitindo compreender quais trabalhos eles realizavam. Apesar de termos encontrado muitos nomes de indivíduos relacionados às obras publicas na documentação camarária, poucos deles tinham testamentos e inventários post-mortem. Tanto por isso usamos registros de indivíduos não só de São Paulo como de outras cidades com Itu e Santana de Parnaíba, que se mostraram muito relevantes pelas conexões e fluxos de pessoas e bens com a capital. De qualquer forma, os oito inventários de artífices

\footnotetext{
${ }^{285}$ APPADURAI, Arjun (org.). A vida social das coisas: as mercadorias sob uma perspectiva cultural. Niterói: Editora da Universidade Federal Fluminense, 2008.

${ }^{286}$ MENESES, Ulpiano Bezerra de. Fontes Visuais, Cultura Visual, História Visual. Balanço provisório, propostas cautelares. Revista Brasileira de História. V. 23. N. 45, p. 11-36. 2003, p. 29.
} 
ligados de alguma maneira à produção de móveis ${ }^{287}$ que encontramos são de grande valia informacional, como a seguir veremos. Alguns desses documentos possuem muitas informações e grande minúcia de descrição de objetos e dívidas e outros, ao contrário, têm parcos dados, mas são válidos em teor comparativo. Conseguimos inventários que cobrem quase toda a duração de nosso recorte temporal, o que permite identificar elementos de mudanças e continuidades entre eles. Por exemplo, encontramos as assinaturas grafadas pelas próprias mãos de apenas alguns deles - que reproduzimos em figuras mais adiante -, revelando a sua heterogeneidade, pois tal condição poderia representar para os letrados um sinal distintivo na sociedade colonial.

Transcrevemos resumidamente 0 arrolamento de seus bens e os valores para podermos comparar as condições de cada um, notando que apesar de estarem no mesmo ramo de atividade, particularmente havia grande multiplicidade de status. Posteriormente utilizaremos as informações desses exemplos individuais para compara-los com dados mais amplos extraídos da historiografia e das outras fontes, tecendo nossas considerações sobre a historiografia que já tratou da temática.

O primeiro inventário post-mortem de um artífice da madeira que encontramos para o século XVIII foi o de João Fernandes, de 1717, feito na Vila de Parnaíba ${ }^{288}$. O inventário, que não possui testamento, se apresenta fragmentado, constando poucos bens, os mais caros duas espingardas uma por $2 \$ 560$, e outra $7 \$ 000$ réis. Não obstante, aparecem as ferramentas que possuía - semelhantes às encontradas nos Inventários e Testamentos publicados dos primeiros séculos de São Paulo ${ }^{289}$, totalizando $6 \$ 760$ réis.

Um enxó-goiva com seu cabo, $\$ 400$ réis; uma enxó grande com rabicho, sem cabo, \$320; Uma foice de mão pequena, $\$ 800$; uma serra, $\$ 400$; uma faca de ponta, 800 ; uma lima grande, $\$ 480$; quatro limas pequenas, $\$ 320$; um buril, $\$ 160$; pregos, $\$ 160$; um martelo quebrado, $\$ 160$; um puam, $\$ 400$; seis escopros grandes, $\$ 480$; seis cepilhos pequenos, $\$ 700$; garlopa grande, $\$ 640$; duas junteiras, $\$ 320$; um graminho, $\$ 040$; uma rosca, $\$ 080$; um rebote, $\$ 100$.

\footnotetext{
${ }^{287}$ A primeira menção que encontramos nas Atas da Câmara sobre marceneiro foi a de Luis Preto Sena, em 1722, realizando junto com o carpinteiro José de Goes e Morais avaliação sobre a obra da cadeia cf. APESP. Atas, vol. 9, p. 154.

${ }^{288}$ APESP, Inventários e testamentos não publicados. Caixa 504. João Fernandes, 1717.

${ }^{289}$ Cf. BRUNO, Ernani da Silva. O equipamento da casa bandeirista segundo os antigos inventários e testamentos. São Paulo: Departamento do Patrimônio Histórico, 1977.
} 
A presença de um "martelo quebrado" inventariado revela alguma valia $-\$ 160$ réis - talvez pelo metal, ou que pudesse ser utilizado pelo artífice de maneira improvisada, driblando a difícil situação da escassez de ferramentas e metal, mais expressiva no interior do território colonial. Aliás, note-se que nos outros inventários do século XVIII não aparecem ferramentas quebradas. Pode ser mais uma evidência das melhorias nas condições tecnológicas de produção metalúrgica em São Paulo no decorrer do século XVIII, como buscamos apontar no capítulo anterior.

Nota-se que não houve partilha no final, pois não havia dinheiro a repartir ${ }^{290}$.

Apesar de ser nascido na vila de Itu, utilizamos também o inventário de Estevão Ribeiro Garcia, aberto em 1736, por uma série de motivos. Inicialmente, deve-se às fortes conexões dessa vila com São Paulo, que se iniciam já no século XVII, sendo passagem da rota de interiorização para o extremo oeste e o Paraguai, além de ter permanecido como caminho para as minas do Cuiabá no século XVIII, circuito percorrido por muitos artífices partindo de São Paulo, como revelou José Carlos Vilardaga ${ }^{291}$. Soma-se também a importância da comparação dos artífices da madeira desta vila com os seus pares que atuaram em São Paulo. Este inventário 292 se revela especialmente interessante pela trajetória que este indivíduo realizou e foi contada com precisão através de várias testemunhas depoentes no processo, revelando uma história em rede com múltiplas conexões espaciais marcadas por bens materiais, alguns dos quais muito significativos na sua descrição, que buscamos reproduzir na ordem com que aparece no processo.

Inicia-se o inventário com o Sargento-mor Antônio Moraes de Navarro, morador do Rio Cuiabá indo até à Câmara de Vila Real do Senhor Bom Jesus, nas Minas do Cuiabá, no dia 14 de novembro de 1736. Disse o Sargento-mor que Estevão Ribeiro Garcia, seu vizinho, havia feito viagem destas minas para o novo descobrimento do Mato Groso pelo mês de junho daquele mesmo ano, falecendo, porém, na roça de Jorge Soares, localizada no Paraguai Grande antes de adentrar o dito descobrimento. Como havia deixado com o depoente algumas criações de cabras, 14 cabeças no total, este procurava declará-las para dar o inventário dos

\footnotetext{
290 João Fernandes tinha oito filhos, entre os quais: Micaela Fernandes, casada com Antônio, mineiro; Marica Fernandes, casada com Albano Freire; Felipa; Catherina; Francisca, de doze anos; Manoel de seis anos, que falecera naquele ano.

${ }^{291}$ VILARDAGA, Jose Carlos. São Paulo na órbita do Império dos Felipes: conexões castelhanas de uma vila da América Portuguesa durante a União Ibérica (1580-1640). FFLCH/USP - Tese de Doutorado. 2010.

${ }^{292}$ APESP. I e T, vol. 26. p.375 ss.
} 
bens. Declarou ainda ter o defunto deixado com ele diversos bens, entre os quais duas armas de fogo, dois machados e três enxadas.

Vale destacar a notória descrição de "uma arma de fogo comprida com cinco anéis de latão, fechos portugueses coronha à paulista, avaliada em 12 oitavas de ouro", mais tarde repetida como "Uma patrona com seu polvarinho usado à paulista". Infelizmente não temos conhecimento do que seria uma "coronha à paulista", mas decerto é significativo existir, já neste principio do século XVIII a adjetivação "paulista" a um elemento da cultura material, que seria tipicamente de São Paulo, inclusive mostrando como já se identificava nos interiores das minas cuiabanas uma especificidade paulista, diferente dos fechos das armas que eram "portugueses".

Dizia saber mais o Sargento-mor que o defunto havia mandado alguns índios Carijós para o novo descoberto do Mato Grosso com três ou quatro foices para botarem roça e tinha notícia de que haviam derrubado mato para meio alqueire de plantação. No entanto, não tinha conhecimento com certeza se a dita roça se plantou ou não. Termina por dizer que João Barreto Garcia, morador no dito "descoberto" poderia dar melhor noticia do referido por ser ao pé de sua roça.

Somente no ano seguinte, aos 23 de setembro de 1737 foi que chegou à Vila de Bom Jesus Jorge Soares, o dono da roça por onde falecera Estevão Ribeiro Garcia. Declarou que com ele ficaram os seguintes bens do falecido, igualmente avaliados em oitavas de ouro, para compor o inventário ${ }^{293}$.

Três ceroulas de algodão em bom uso, 2 oitavas e um quarto de ouro. Duas toalhas, uma de algodão e outra de linho, meia oitavas de ouro. Quatro pares de meia de linha de Itália, dois pares velhos e dois novos, 1 oitavas de ouro.

Um par dito [de meias] de laia cor canela muito velhas, sem valor.

Duas navalhas de fazer barba com sua pedra, muito usadas, três quartos de oitava.

Uma vestia de seda vermelha com ramos brancos muito usada, oitava e meia.

Uma dita de pano de algodão usada, oitava e meia.

Uns borzeguins de couro de veado já usados, meia pataca.

Um prato grande, dois pequenos e um covilhete, tudo de estanho, e usados, oitava e meia.

Uma colher de prata com oito oitavas de prata de peso, 80 réis cada uma oitava, que faz soma de uma oitava.

Dois frascos de vidro rachados, cheios de sal, 5 oitavas.

Um capote de barregana azul forrado de baeta encarnada com alguns buracos do bicho grilo, 6 oitavas.

Dez colares de ferro de pescoço muito delgados, 2 oitavas e meia.

${ }^{293}$ APESP. I e T. vol. 26, p. 380ss. 
Dois enxós, goivas e uma foice velha, 2 oitavas e meia.

Um compasso de ferro, 3 oitavas.

Uma arma de fogo comprida com 4 anéis e guarda-mão tudo de ferro, sem ponto nem mira, com seu polvarinho e patrona à paulista, 15 oitavas.

Uma arma de fogo curta com 4 anéis de prata, mira, ponto e guarda-mão de ferro, 12 oitavas.

Um tacho de cobre muito usado, 6 libras, 8 oitavas.

Um almocafre novo, 2 oitavas.

Um feitio de uma Imagem de Nossa Senhora do Carmo com um palmo de altura e um lenço de seda usado com que se cobre, uma oitava.

Quatro côvados de baeta azul usada , 3 oitavas.

Dois pares de sapatos de couro de veado um par usado e outro novo, 3 oitavas.

Umas Horas portuguesas velhas e desencadernadas, sem avaliação. Uma caixa de carga de caminho com sua fechadura e chave, 5 oitavas. Um cepilho, 1 oitava.

Dois libras de chumbo e uma quarta de pólvora,1 oitava.

É muito significativo ver quais objetos portava um individuo em locomoção para uma área ainda não colonizada. Chama a atenção o alto valor dos vidros de sal, que valiam o mesmo que a caixa de carga, bem como o valor do tacho de cobre e das armas de fogo, as peças mais caras que tinha. São bens que dão conta da materialidade essencial a ser levada na circulação das pessoas para o sertão para cumprir as necessidades mais básicas de transporte dos apetrechos e roupas, além dos papeis das dívidas e das Horas de devoção; da defesa contra os indígenas; do preparo da alimentação; além da manutenção da saúde pelo iodo do sal, bem tão escasso no sertão e que causava graves moléstias na população.

Destaca-se também os quatro pares de meia de linha da Itália, mostrando a penetração de bens estrangeiros nas fronteiras da colonização até mesmo pelos seus agentes mais pioneiros, que ainda estavam por abrir roça e se fixar. Ainda que ele não possuísse nenhum móvel de distinção a não ser a polivalente caixa de carga - que além de transportar poderia servir para o assentar e até para deitar-se - as meias italianas, o sapato de couro de veado, as camisas e o capote azul forrado de baeta encarnada e a colher de prata já eram suficientes para se distinguir dos indígenas que mandou para fazer roça, que não usavam sapatos e comiam com as mãos e cujos únicos apetrechos talvez fossem os terríveis 10 colares de ferro que forçosamente se lhes vestiam.

As ferramentas que possuía eram poucas, como se vê, mas de fato é muito significativo este arrolamento se levarmos em conta o deslocamento espacial de Estevão Riberio e a necessidade de levar somente o essencial. Por meio delas 
podemos compreender qual seria o mínimo de apetrechos necessários para um artífice ter consigo e realizar as suas obras, ao menos para serrar a madeira, desbastá-la com a enxó, aplainar com o cepilho e entalhar com as goivas ${ }^{294}$.

Aliás, quando do leilão dos bens em praça pública ocorrido a 25 de setembro de 1737, o compasso de ferro, avaliado inicialmente por três oitavas de ouro, foi, porém arrematado por Ambrósio Pedroso à custa de cinco oitavas de ouro, o que demonstra como este era um equipamento decerto raro e inflacionado na região.

Outros artefatos bastante significativos, mas que trazem questionamento insolúvel são as "duas navalhas de fazer barba com sua pedra, muito usadas", mas que ainda assim valiam "três quartos de oitava". Para além da utilização deste acessório pelo próprio Estevão, a presença não só de uma, mas duas navalhas pode ser de indício de que ele também exercia o serviço de barbeiro e cortador. Aliás, as navalhas são de rara menção entre todos os inventários compulsados por nós, só aparecendo outra vez no arrolamento de Juliana Maciel em 1754, também em duas unidades, com sua pedra, valendo \$320 réis; e no de Rosa Maria, em 1777 , com seu estojo no valor de $1 \$ 280$ réis.

Guardava ainda o depoente, papéis e créditos que pertenciam a Estevão Ribeiro Garcia ${ }^{295}$ :

Um crédito de José Vieira de Barros em que é devedor ao defunto da quantia de quarenta e oito oitavas de ouro, fiador Antônio do Prado Tenório.

Um crédito de José Francisco de Oliveira passado ao defunto da quantia de sessenta oitavas de ouro com dois recibos nas costas e resta vinte e uma oitavas de ouro.

Um crédito de João Pedroso Ribeiro da quantia de 34 oitavas de ouro com um recibo de 9 oitavas e resta somente 25 oitavas de ouro.

Dois anos depois, em 25 de janeiro de 1739, Antônio Leme, que assistia no Arraial da Chapada de São Francisco Xavier, distrito da Vila Real de Bom Senhor Jesus, trouxe novas informações, relacionando mais agentes conectados à circulação de Estevão Ribeiro para explorar e se fixar no Oeste.

\footnotetext{
${ }^{294}$ Resta dúvida, porém, se podemos depreender da descrição de "feitio" da imagem de Nossa Senhora que era obra não terminada se estava sendo feita por Estevão, o qual poderia ter ofício de santeiro.

${ }^{295}$ Fator de credibilidade importante, por exemplo, para empreender viagens, como revela GUEDES, Roberto. Ofício mecânicos e mobilidade social: Rio de Janeiro e São Paulo (sécs. XVII-XIX). Topoi, v. 7, n. 13, jul.-dez. 2006, pp. 379-423.
} 
Declarou este depoente que um primo do falecido, Francisco Ribeiro Baião, fora na verdade, o responsável por ir com os Carijós para plantar e fazer roça, em arraial chamado de Ouro Fino, chegando a plantar sete ou oito prato de milho, mas sem ter conhecimento se eles frutificaram. Este primo, que também estava adoecido, por sua vez deixara com o depoente "cinco foices velhas, um machado quebrado, uma enxó velha e uma verga de aço com 3 quartas de peso, tudo avaliado em 5 oitavas de ouro".

O inventário só termina quatro anos depois, quando em 13 de março de 1740 veio à Vila Real do Bom Jesus, João Poderoso Ribeiro, irmão de Estevão. Declarou este parente que o defunto era natural da Vila de Itu, único filho legitimo de Estevão Ribeiro de Alvarenga e de sua mulher Maria Garcia, já defuntos, sendo que do dito matrimônio não tiveram mais filhos. O depoente, João Poderoso, era filho bastardo do mesmo pai e assistia junto com o irmão naquelas frentes de colonização.

Seu pai, porém, havia casado uma segunda vez, por ocasião do falecimento de sua primeira esposa, com Isabel da Costa. Este casal seguiu viagem de Itu para as Minas Gerais, onde tiveram vários filhos. Dentre estes eram vivos até pouco tempo atrás, pelo que sabia, Francisco Sutil e outro chamado Lourenço.

Disse mais que Estevão Ribeiro Garcia, apesar de ter falecido na condição de solteiro, havia deixado quatro filhas bastardas, uma delas chamada Catarina, sendo que esta e mais duas viviam nas minas de Cuiabá, e uma quarta assistia na Vila de Itu.

Este inventário é grande exemplo da circulação dos paulistas pelas minas do oeste e do norte, e de como as redes de familiares, tanto legítimas como bastardas, se entrelaçavam pelas vilas e cidades de várias capitanias diferentes.

Manuel de Oliveira, mestre carpinteiro, natural do Alentejo e casado em Lisboa com Luísa dos Santos, não deixara nem herdeiros, nem testamento, tendo sido seus bens arrematados em praça pública quando falecera em $1747^{296}$. Seu monte-menor era de $651 \$ 040$ réis, sendo devedor apenas ao cônego Lourenço Leite Penteado a soma de $1150 \$ 140$ réis.

Não há descrição pormenorizada de suas ferramentas, apenas o conjunto que fora avaliado em $3 \$ 000$ réis, além de duas bancas de taboa "lisas e velhas", que perfizeram $\$ 960$ réis.

${ }^{296}$ APESP. Inventários e Testamentos não publicados, Caixa 652. Miguel de Oliveira, 1747. 
Seus móveis eram: uma rede branca em bom uso, $3 \$ 200$; uma caixa de madeira da terra pequena $1 \$ 200$; duas caixas de madeira da terra menores $1 \$ 300$; um baú velho com forro 1\$000; uma frasqueira com 6 frascos $2 \$ 000$; dois tamboretes de couro velhos e um de pau, $1 \$ 600$; um oratório com seis imagens metidas em uma caixa de pau da terra $20 \$ 000$; uma caixa de tabaco de prata.

Tinha seis escravos, entre eles duas mulheres das nações Mina, Benguela e Angola. O mais caro, Francisco, fora avaliado em $100 \$ 000$ réis, pouco menos do que o valor de seu sitio, $150 \$ 000$, situado no bairro de "Santa Ana", com terras e casas velhas. Possivelmente plantava feijão para o seu sustento e o de seus escravos, pois possuía três alqueires de feijão no valor de $1 \$ 220$ réis.

Ele constara como juiz do ofício de carpinteiro em 1736, junto com Manuel da Silva Cruz como escrivão ${ }^{297}$. Neste mesmo ano, fizera obras na cadeia, por que the pagaram $2 \$ 400$ réis.

Em 1743 os camaristas the pagaram $20 \$ 000$ por uma obra ${ }^{298}$ e no ano seguinte, fizera também obras do caminho e da ponte da Cruz das Almas ${ }^{299}$. Em 1746 aparecia no Senado da Câmara com uma petição, na qual os senadores consignaram dar-Ihe o rendimento da casa do açougue por três anos até pagar-Ihe 0 que o senado devia a ele ${ }^{300}$, que havia feito retificação na obra em $1744^{301}$.

O entalhador Nicolau Francisco Rosal era nascido em Lisboa, na freguesia de Santa Catarina do Monte Sinai, filho de Manuel Francisco e Maria da Encarnação. Tinha por irmãos Aureliano Batista, Vicente Ferreira de Jesus e Ana Maria, a qual "assistia em Lisboa" ${ }^{302}$.

O fato de ter deixado como única herdeira esta sua irmã indica que suas conexões com o Reino continuavam mesmo migrando para o Brasil. No seu testamento, feito em 1746, dizia ser solteiro, mas no seu inventário feito em 1751, aparecia Úrsula Maria Vieira como viúva. Teria tido com ela dois filhos, Vicente, à época de sua morte, com três anos e Maria de dois anos.

\footnotetext{
${ }^{297}$ APESP. RG., vol. 5 pg. 22.

${ }^{298}$ AHMSP. Série Assuntos Diversos, Livro 292, fl.41.

${ }^{299}$ APESP. Atas. vol. 12 p. 47

${ }^{300}$ APESP. Atas. vol. 12, p. 250.

${ }^{301}$ APESP. Atas. vol. 12, p. 47.

302 APESP, Inventários e Testamentos não publicados, Caixa 641. Nicolau Francisco Rosal, 1751.
} 
Possuía oito escravos, mas não se indica se eram também oficiais na sua mesma profissão. Suas origens eram bastante diversas, sendo Pedro, de 18 anos, Angola; Catto, Mina; e Ana, Carambola ${ }^{303}$.

Era irmão de Nossa Senhora da Salvação no convento da Trindade, da de Nossa Senhora das Mercês, na freguesia de São Nicolau na cidade de Lisboa. Em São Paulo era ligado à irmandade de São Francisco, da qual possuía o hábito, com "capa, cordão e volta", avaliados em $4 \$ 000$ réis.

Tinha uma casa na Rua do Rosário de dois lanços e com "chãos místicos a elas que avizinham por uma parte com chãos de Thomé João (...) outra parte com Catherina Cardosa", avaliada em $300 \$ 000$.

Seus móveis eram poucos, menos até que os do viajante Estevão Ribeiro Garcia: uma mesinha redonda e velha, $\$ 320$; um mocho, $\$ 320$; uma caixa feita na terra com sua fechadura, $1 \$ 600$; um catre de tabuletas, $1 \$ 600^{304}$.

Através das dívidas podemos compreender a sua atividade, pois Francisco Alvares da Cunha devia-lhe "pelas custas de um Santinho". Entretanto, seu ramo de trabalho não girava apenas em torno da produção de imagens, ou somente no campo religioso, mas também da carpintaria de componentes das estruturas prediais. Isto pois vemos que dentre as peças descritas no inventário de Rosal havia a "ferramenta do ofício de entalhador de junteiras, martelo, enxó, barrilete e mais ferros" tudo pelo valor de $4 \$ 000$ réis, além de já haver prontos dois batentes de janela, que somavam $\$ 320$ réis. E decerto esses vários ramos the geraram bom cabedal, constando seu monte-menor de 1:180\$998.

Vemos Rosal em conexão com outros carpinteiros atuantes em São Paulo, pois Luís Rodrigues Lisboa fora testemunha em seu processo de casamento de $1748^{305}$. A inter-relação desses dois artífices não se resume ao momento do matrimônio, pois, no final da vida, encontramos Rosal entre seus credores, com uma dívida de $4 \$ 420$ réis.

Pelas dívidas também notamos que sua atuação possivelmente não se restringia somente a São Paulo, dado que ao morrer devia a João Domingues de

\footnotetext{
303 Da raíz Calhambola, ou quilombola, significa negros fugidos que eram re-escravizados. MOURA, Clóvis. Dicionário da escravidão negra no Brasil, São Paulo, SP, Brasil: Edusp, 2004. p. 79.

${ }^{304}$ Não obstante serem poucos, é significativo ver uma mesinha cuja forma redonda é mencionada, algo raro entre os vários inventários compulsados - e que veremos mais detalhadamente no capítulo seguinte constando apenas outras 34 dentre as mais de 250 computadas.

${ }^{305}$ ACMSP - Dispensas e processos matrimoniais, livro 260, Nocolau Francisco Rosal, 1748.
} 
Carvalho, o moço, que vivia em Mogi. Aliás, nota-se que Rosal tinha firma reconhecida e bom nome na praça, ao ponto de passar crédito a Francisco Alvares da Cunha.

O fiador de Rosal fora Felipe Fernandes, que se obrigara "a todas as condenações que lhe fossem feitas pelos oficiais da Câmara como também a todos os desconcertos de seu ofício" em 18 de janeiro de $1736^{306}$.

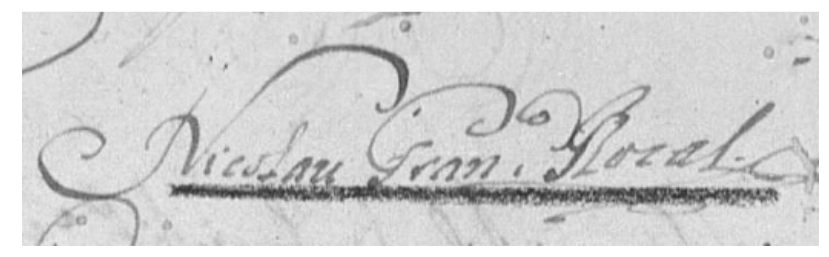

Figura 105: Assinatura de Nicolau Francisco Rosal ${ }^{307}$.

O entalhador Luis Rodrigues Lisboa era nascido em Portugal, na Freguesia de Santa Catarina do Monte Sinai, na Cidade de Lisboa ${ }^{308}$, filho de Manuel Rodrigues Lisboa e Josefa Maria do Espírito Santo. Foi casado com Paula Marques da Silva, a qual tinha por irmão João Ferreira. Teve quatro filhos: Cipriana, de 10 anos, Maria, Francisco e Thomas. Viviam no fim da Rua da Quitanda Velha, avaliada em $300 \$ 000$ réis, possuindo também um sitio próximo à Serra, no Bairro de Nossa Senhora do Ó, com moenda e alambique, valendo $102 \$ 000$ réis $^{309}$.

Foi, aliás, um dos poucos entalhadores que encontramos assim discriminado nos registros camarários ao tempo em que chegou a São Paulo, em 17 de janeiro de $1738^{310}$ :

Luiz Rodrigues Lisboa, perito no referido ofício de entalhador e, por, não haver juiz dele se the passasse licença geral para que nesta cidade e seu termo, possa usar do dito ofício de entalhador publicamente e como mestre examinado, sem impedimento algum.

Um dos grandes exemplos de como os oficiais mecânicos em São Paulo podiam exercer funções publicas que lhe davam possibilidade de ascender no meio social, é vê-lo como secretário da penitenciaria em 1755 e $1756^{311}$.

\footnotetext{
${ }^{306}$ APESP. RG. vol. 5, p. 12

${ }^{307}$ ACMSP, Dispensas e processos matrimoniais, 4-42-260 Nicolau Francisco Rosal, 1748. fl. 17

${ }^{308}$ Encontramos esta informação no processo de casamento de Nicolau Francisco Rosal. Cf. ACMSP, Dispensas e processos matrimoniais, 4-42-260 Nicolau Franciso Rosal, 1748.

${ }^{309}$ APESP, Inventários e Testamentos não publicados, Caixa 538. Luís Rodrigues Lisboa, 1761.

${ }^{310}$ APESP. RG, vol. 5, p. 77.

${ }^{311}$ Cf. ORTMANN, Adalberto. História da antiga capela da Orde Terceira da Penitenciária de São Francisco em São Paulo. Rio de Janeiro: Ministério da Educção e Saúde/DPHAN, 1951.
} 
Era irmão da Ordem de São Francisco, a quem devia $10 \$ 940$ réis. Também no campo religioso tinha dívidas de penhora com o Frei Miguel de Santa Rita do Mosteiro de São Bento.

Suas dívidas revelam novamente a interação dos artífices atuantes em solo paulista com os agentes colonizadores das minas do Oeste, como fica patente pelas quantias que Ihe deviam José da Silva Barros, "que assiste nos Goyases", bem como César, que também a Goiás havia viajado, e eram consideradas perdidas, não obstante computarem $80 \$ 080$ e $40 \$ 080$ réis, respectivamente.

Bastante reveladora da sua diversificação de atividades é o termo de fiança para abrir uma loja, em 5 de novembro de 1746, sendo seu fiador Manuel de Sousa ${ }^{312}$. Igualmente aparece em termo de fiança que fez para sua escrava Graça em $1747^{313}$, e o registro de uma avença de seis meses com a Câmara de $2 \$ 900$ réis. Esta fora paga pela sua escrava de ganho, em 1752, como consta do Livro da Receita Classificada da Câmara, na qual se registrava a licença semestral dos escravos para comerciar ${ }^{314}$. Esta escrava não consta na época de seu inventário, aberto em 1761, onde só aparecem outros dois, Manoel, Angola e Eva.

Decerto essas várias atividades eram bastante lucrativas, sendo que o montemor de seu inventário chegou a 1:020\$275 e seu monte-menor 317\$865 réis.

No seu arrolamento post-mortem ${ }^{315}$ encontramos ferramentas relacionadas ao ofício por ele exercido: "Dezenove escopros de ferro pequenos e maiores goivas exatas do ofício de entalhador", comportando o valor de $\$ 960$ réis, bem como "um machado em bom uso", por $\$ 320$ e "um ferro de pé de cabra de banco de entalhador" pelo preço de $\$ 800$ réis. Tal como nos inventários do século anterior ${ }^{316}$, vemos entre seus bens "um registo grande de papel de tinta preta", demonstrando haver continuidade no âmbito das impressões na cidade.

Ao olharmos as suas dívidas pendentes, pudemos descobrir que seu ofício de entalhador relacionava-se com o campo sacro. Estando este artífice lisboeta doente, havia deixado com o Reverendo Doutor da Sé Paulo de Souza Rocha uma dívida sobre uma obra de talha para o altar de São José, que comportava no total $60 \$ 000$

\footnotetext{
${ }^{312}$ APESP. RG, vol. 8 p. 285.

${ }^{313}$ APESP. RG, vol. 8, p. 480.

${ }^{314}$ AHMSP. Série Receita e Despesa, livro 263, fl. 41.

${ }^{315}$ APESP, Inventários e testamentos não publicados. Caixa 538.

${ }^{316}$ Vide a listagem de ferramentas e equipamentos feitos por Ernani da Silva Bruno e compilados em GUERRA, José Wilton e SIMÕES, Renata (orgs.). Equipamentos - Equipamentos, Usos e Costumes da Casa Brasileira, Marlene Milan Acayaba (organizadora da coleção). Vol. 5, São Paulo, MCB, EDUSP, 2001.
} 
réis. Luis Rodrigues Lisboa havia recebido $38 \$ 000$ réis, porém não a concluiu. Ele teria, portanto, de pagar o resto se outro artesão não terminasse dentro do orçamento.

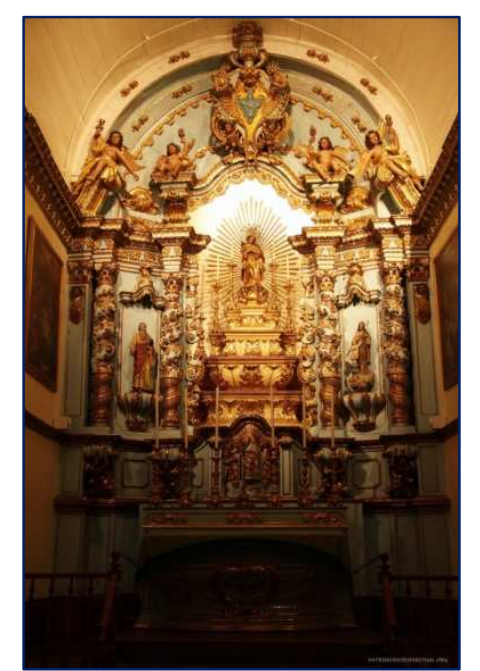

Figura 106: Retábulo dedicado a N. S. da Conceição, feito por Luís Rodrigues Lisboa entre 1736 e $1740^{317}$.

Danielle dos Santos Pereira encontra este entalhador construindo o retábulo mor da Igreja da Venerável Ordem Terceira de São Francisco da Penitência da cidade de São Paulo ${ }^{318}$ :

Em 1735 a Ordem aspirava a um novo e vistoso retábulo mor, o qual fora elaborado pelo mestre entalhador Luís Rodrigues Lisboa, entre 1736 a 1740. O retábulo-mor perdeu a função de altar principal na construção do novo presbitério, mas o belíssimo altar joanino fora preservado no antigo espaço para o qual fora concebido, hoje capela lateral de Nossa Senhora da Imaculada Conceição no transepto.

Entre seus móveis encontramos três caixas, dois baús, um deles de moscóvia, dois catres, uma mesa e dois tamboretes, avaliados todos em $11 \$ 680$ réis.

Não obstante o seu trabalho no campo religioso, encontramos no arrolamento dos bens presentes em sua casa "uma armação de catre sem tissume". Isso revela que tal artífice atuava na produção de mobiliário tanto sacro quanto doméstico.

Ainda, entre as peças de mobiliário, encontramos outro início de produção moveleira própria na descrição de uma caixa grande de "tampa inteiriça", de sete por dois palmos, com fechadura avaliada em $3 \$ 200$ réis. Nos vários inventários que

\footnotetext{
${ }^{317}$ Disponivel em: https://patrimonioespiritual.org/2015/07/07/igreja-da-ordem-terceira-de-sao-francisco-dapenitencia-sao-paulo-sp/. Acessado em: 9/3/2018.

318 PEREIRA, Danielle Manoel dos Santos. Autoria da Pinturas Ilusionistas do Estado de São Paulo: São Paulo, Itu e Mogi das Cruzes (Brasil). 2017. Tese (Doutorado em ARTES) - UNESP. 2017, p. 123.
} 
arrolamos, raramente aparece descrição desta característica da peça, pelo que acreditamos seja uma exceção ${ }^{319}$. Decerto seria um fator discriminatório para a avaliação da caixa, pois deveria ser bastante raro conseguir construir uma tampa inteiriça para uma caixa grande, demonstrando assim a habilidade do artesão.

Vemos assim uma evidência dos múltiplos usos de ferramentas para a confecção dos móveis, que no outro capítulo pudemos colher analisando a materialidade dos objetos, mostrando a versatilidade dos entalhadores e o seu conhecimento técnico para produzir tanto ornatos no espaço eclesiástico, quanto móveis de uso doméstico, como o catre ${ }^{320}$.

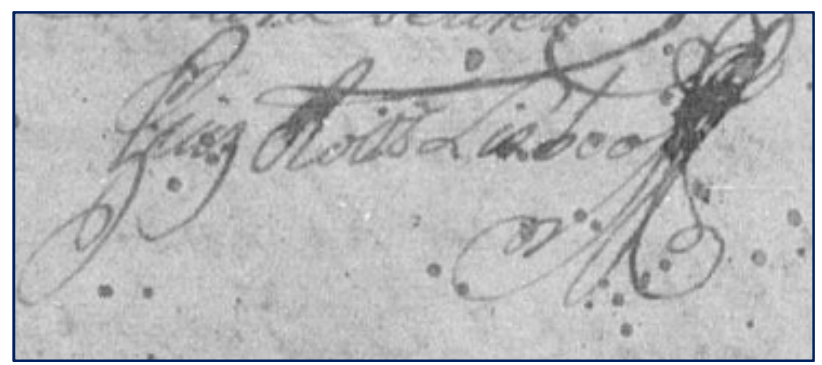

Figura 107: Assinatura de Luiz Rodrigues Lisboa

O processo mais rico em aparatos que localizamos dentre os oficiais falecidos em São Paulo e que deixaram inventários decerto é o do marceneiro João da Mota Liver (ou Livel ${ }^{321}$ ), de $1767^{322}$. João era nascido na Freguesia de Santo André de Liver, comarca do Bispado do Porto. Era filho legítimo de Manuel da Mota e Ana da Mota $^{323}$. Saiu de sua pátria na idade de doze anos, embarcando no Porto e indo para o Rio de Janeiro, onde assistiu por cerca de dez anos.

\footnotetext{
${ }^{319}$ Há outros oito casos dentre as mais de 250 caixas que computamos.

${ }^{320}$ Esses fatos servem como evidência dos variados trabalhos exercidos pelos carpinteiros no espaço colonial, tal como encontrado no contexto mineiro por Angela Brandão Cf. BRANDÃO, Angela. Das pontes aos castiçais: a produção de mobiliário artístico em Minas Gerais do século XVIII e os ofícios mecânicos. Revista Científica/FAP , v. 4, n. 2. Curitiba: jul./dez. 2009, pp. 50-66. Trataremos com profundidade dessa problemática também em capítulo específico, fazendo as comparações para os vários contextos coloniais e a metrópole. Vale ainda fazer breve menção no contexto metropolitano de uma reclamação apresentada no Senado da Câmara de Lisboa, em 1793, pelos juízes de ofício de carpinteiro de móveis contra o palheiro francês Francisco Gastor que havia aberto loja por conta própria e iniciado aprendizes no seu ofício, além de fazer cadeiras e vender cadeiras, o que the era vedado em seu requerimento feito à Rainha em 1780. Apud. PINTO, Augusto Cardoso. NASCIMENTO, J. F. da Silva (org). Cadeiras portuguesas. Lisboa, [Edição dos Autores], 1952. P. 106.

${ }^{321}$ No se processo de casamento, de 1761 aparece a grafia "João da Motta Livel". Talvez a transformação para "Liver" seja mais um exemplo da aclimatação do Português à língua geral praticada em São Paulo, onde ocorre o rotacionismo do $L$ pelo $R$.

${ }^{322}$ APESP. Inventários e Testamentos não publicados, cx. 654. João da Mota Liver, 1771.

${ }^{323}$ ACMSP. Processos de Casamento, ordem 4-75-543, João da Mota Liver, 1761, p. 20.
} 
Pela transcrição do registro de sua carta de exame em São Paulo, ${ }^{324}$ notamos como ele aprendeu o ofício na capital do vice-reinado ${ }^{325}$ :

Jacinto de Lemos Magalhães juiz que sou do ofício de marceneiro este presente ano em esta cidade de São Sebastião do Rio de janeiro e seu termo - fazemos saber a vs. mercês em como nós examinamos a João da Motta Livre filho de Manuel da Motta e sua mulher Anna da Motta natural de Livre comarca da Feira bispado do Porto o qual examinamos em o ofício (...) também será obrigado examinado a registrá-la em mesa do espiritual Senhor São José para constar que é nosso irmão na forma do nosso compromisso e regimento Rio de Janeiro 24 de setembro de 1756 anos eu Pedro José Rocha escrivão do mesmo ofício o subscrevi e assinei Jacintho de Lemos Magalhães - Pedro José da Rocha.

Aliás, o avaliador de Liver, Jacinto de Lemos Magalhães, ao que tudo indica, fora acusado de não respeitar a divisão de trabalhos no famoso processo de litigio entre marceneiros e entalhadores tratado por Noronha Santos ${ }^{326}$.

Seu fogo consta no Maço de 1767, na "Rua de João Esteves até o Campo da Forca", onde aparecia com 37 anos, casado com Maria Garcia, 22 e a filha Ana de colo. Declarava possui cabedal de $500 \$ 000$ réis $^{327}$. No seu inventário a sua moradia aparece no Largo da Igreja de São Gonçalo, "em um dos cantos principais", tendo um lanço "com suas tacanissas, corredores, repartimentos, sala". Tinha na casa um oratório pequeno de telha, pintado, e dourado, embutido na parede, avaliado em $150 \$ 000$ réis.

Possuía ainda outros bens de raiz, como uma casa contigua à sua "para a parte de baixo na rua por que se vai para a Capela do Santíssimo Sacramento". Dado o fato de ser unida ao outro lanço, nota-se na descrição uma solução arquitetônica voltada para a privacidade do locatário, pois estas casinhas tinham "um corredor pequeno da parte de fora debaixo da banda do autor com porta somente para a rua", valendo $60 \$ 000$ réis.

\footnotetext{
${ }^{324}$ Os artífices portugueses ou originários de regiões diversas do Brasil não precisavam prestar novo exame, mas portar a Carta de Exame, documento comprobatório e registrado do juramento de ofícios, a qual deveria ser registrada na Câmara da vila ou cidade em que fossem exercer suas funções FLEXOR, Maria Helena Ochi. Ofícios, Manufaturas e Comércio. In SZMRECSÁNYI, Tamás. História Econômica do Período Colonial. 1993. P. 184.

${ }^{325}$ APESP. RG, "Registro de uma carta de exame e licença geral passada a João da Motta Livre (sic) official do ofício de marceneiro" Vol. 10. p. 513/4.

${ }^{326}$ SANTOS, Noronha. Um litígio entre marceneiros e entalhadores no Rio de Janeiro. Revista do Sphan, no 06, 1942, p. 295-317.

${ }^{327}$ APESP Maços de População. 1767, p. 292.
} 
Perto das casas de São Bento "por onde se vai para Santos", tinha ainda outras moradas com lanços unidos, avaliadas em 50\$000, e um quintal murado no valor de $16 \$ 000$ que ficavam entre estas casas e as casas do "Jogo da Bolla", decerto bem localizado próximo a este espaço de sociabilidade lúdica.

Pudemos encontrar no Livro de Receita e Despesa da Sé que este marceneiro havia feito em 1768 o altar para receber a imagem de São Paulo trazida do Rio de Janeiro: "Despendi com o marceneiro João da Motta para um andar que fez de talha para a dita imagem pondo ele todas as madeiras e pregos $32 \$ 000$ " 328 .

Esta imagem por sua vez, custou $42 \$ 700$ réis, gasto ao qual se soma $25 \$ 600$ ao pintor que dourou o andar e fez o resplendor do santo, bem como com "18 covados de ruão" para a cobertura do andar de São Paulo, no valor de $4 \$ 475$, mais seu feitio por $\$ 710$ réis.

Sua obra decerto seria a de maior visibilidade pública dentre todas as da cidade, servindo como chamariz para consumidores na busca de possuir em seus espaços domésticos móveis de requinte, à semelhança de sua obra para o prelado.

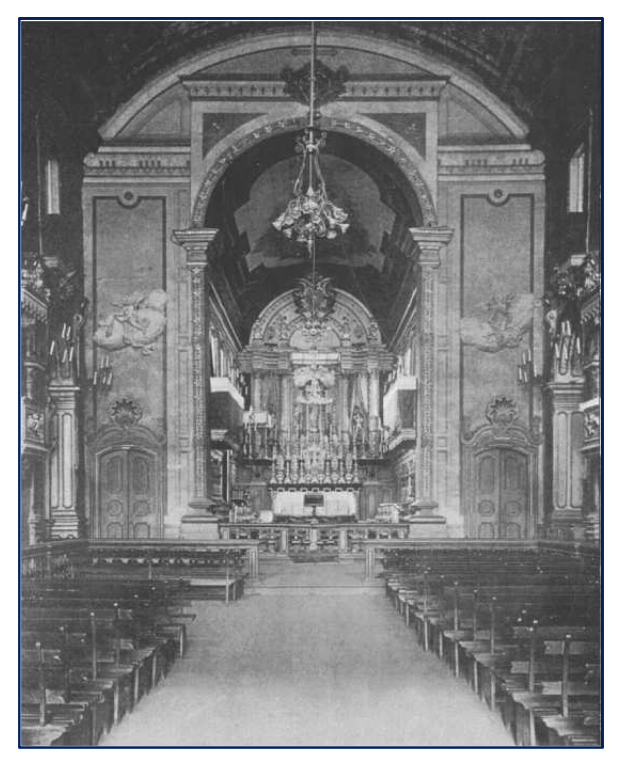

Figura 108: fotografia feita em 1911 da nave e capela mor da antiga Igreja da Sé, com a imagem de São José ao centro ${ }^{329}$.

\footnotetext{
${ }^{328}$ ACMSP. Livro da receita e despesa da Fábrica da Sé de 1 o de janeiro de 1748 a 18 de janeiro de 1817. Ordem: 02-03-042. 1768. Fl. 86 e 89.

${ }^{329}$ Reprodução de: A CATHEDRAL de São Paulo. São Paulo: [s.n], [1911]. Apud. RAMIREZ, Karen Niccoli; NETO, Henrique Lindenberg. De igreja de taipa a catedral: aspectos históricos e arquitetônicos da igreja matriz da cidade de São Paulo. Pós. Revista do Programa de Pós-Graduação em Arquitetura e Urbanismo da FAUUSP, v. 21, n. 35, p. 186-199, 2014.
} 
Nota-se que após esta obra ele ainda mantinha relações com a Sé, talvez por meio de outros trabalhos, posto que o fabriqueiro da igreja registra um ano depois do falecimento de Liver, em 1772 a "receita de resto da execução feita nos bens de João da Motta Liver pelo que devia a fábrica 57\$680".

Ele era inclusive irmão do Santíssimo Sacramento e membro da irmandade de São Francisco, possuindo um hábito de terceiro de Sam Francisco de Barbarisco(?) já usado com suas trajaduras(?) (...) avaliado em 1\$920, bem como outros objetos que revelam sua participação em festas religiosas em posição de destaque: "um balandrão da Misericórdia já todo arrasado de crepe abandado de tafetá preto e o capuz forrado do mesmo, \$800" e "um dito balandrão da Irmandade do Senhor dos Passos de tafetá roxo já usado... \$960".

Possuía uma boa quantidade de móveis, ainda que seja difícil precisar se eram exclusivamente de uso de sua família, ou se poderiam ser vendidos. De qualquer forma, no inventário aberto em 1771, as 27 peças computavam $18 \$ 080$ réis, contando-se entre elas um bofete de gavetas e com pés de cabras por $4 \$ 000$ réis - decerto um aparato de destaque sendo o único marceneiro a possuí-lo - bem como um espelho de parede, $\$ 640$; uma caixa de cedro, com gavetas, $4 \$ 800$; três bancos velhos, $\$ 120$; e nove tamboretes de encosto de madeiras da terra, $3 \$ 600$. Encontramos, inclusive, objetos bastante simbólicos para uso em ocasiões de distinção no espaço público, como uma cana da Índia, com argola de prata e ponteira de ferro, no valor de $\$ 480$ réis, e uma espada de vestir com punhos de fieira, ponteira e botão de prata, com sua bainha de sola, por $1 \$ 000$ réis.

Não obstante a obra no plano da arte sacra, por seu inventário constatamos que Liver também fazia móveis de uso comum. Isto porque, no momento de sua morte, constavam no inventário "duas poltronas de madeira vapuã, por acabar as armações e sem assentos" em $9 \$ 600$ réis. Ainda constavam por fazer "duas canastras de cedro por encourar sem engonços nem fechaduras", as quais foram avaliadas em $1 \$ 280$.

Muito possivelmente estas peças de mobiliário eram feitas pelos seus três escravos que constavam ser "oficiais de marceneiro", tal como ele: João, Rebolo, de 50 anos; Mateus, Benguela, de 36 anos, casado com Maria, Angola, de 40 anos; e Paulo, Benguela, de 26 anos, casado com Gertrudes, crioula, de 20 e mãe de Thomas e Rosa, de 3 anos e 4 meses, respectivamente. Haviaainda o escravo 
Máximo, de 17 anos que não aparecia como oficial de marceneiro, podendo ser aprendiz.

Era enorme era o volume de ferramentas que Liver possuía: eram mais de 70 peças, distribuídas em 25 tipos, dentre as quais enxó, serra, serra de mão, serrote, serra braçal, garlopa, rebotes, plaina revessa, plana direita, junteira, guilhermes, ferro de molduras de painéis com cepo, ferros machos de molduras com cepos, ferros de molduras fêmeas, ferro de caibrar, goivas grandes, goivas pequenas, limas pequenas, formões pequenos, formões largos, raspador, travadeira de serra, repuxo, paus de bastões.

João da Motta Liver foi um dos poucos "marceneiros" que encontramos assim mencionado na documentação camarária. Não o encontramos denominado de torneiro, ainda que possuísse um torno com banco, o qual fora avaliado em $\$ 320$ réis, bem como um banco novo de imprensa, de oito palmos de comprido, avaliado em $1 \$ 280$ réis. Apesar de serem descritos em separado, utilizava-se no torno "sete ferros de tornear, como buris, cantis, dois pequenos e os mais grandes", os quais somavam $\$ 640$ réis.

Outro maquinário possuído por Liver, "um banco novo de imprensa com esta imprensa de oito palmos de comprido", por $1 \$ 280$ réis, demonstra que sua oficina era bastante diversificada em termos de instrumentação e de tipos de trabalho que poderiam ser realizados.

Para além das ferramentas de seu inventário, outros itens nos dão informações sobre os procedimentos produtivos dos móveis. Liver também possuía estocadas as matérias-primas usadas para o trabalho: "Nove tábuas grossas de cedro de largura de palmo e meio e de cumprido onze palmos e de grossura meio palmo", que saíam por $2 \$ 880$ réis.

O fato de se discriminar a espécie de madeira dessas tábuas como sendo de cedro demonstra-se um sinal do prestígio deste tipo de lenho, dado que outras madeiras eram chamadas apenas de "da terra", confirmado pelo valor alto, se compararmos com os valores de "oito taboas de assoalho, entrando duas costaneiras, algumas rachadas, e algumas mais curtas" também possuídas por João da Mota Liver, cuja espécie de árvore não é discriminada e que foram avaliadas no valor de $1 \$ 280$.

Liver também possuía "um dito tabuleiro mais pequeno de molduras com dois palmos e um meio de largo de madeira de cedro... \$240 réis"; "duas canastras de 
cedro por encourar sem engonços nem fechaduras... $1 \$ 280$ réis" e "uma caixa de madeira da terra com suas molduras e gavetas por baixo com sua fechadura e chave e quatro palmos e meio de comprido e dois e meio de largo de madeira de cedro... $4 \$ 800$ réis".

Significativo notar na descrição da última caixa ela aparecer como feita tanto de "madeira da terra", designação genérica, quanto de "madeira de cedro", mostrando o emprego variado de materiais-primas em uma mesma peça. Não temos mais informações sobre a espécie do cedro, que poderia ser, por exemplo, o Cedrela lilloi, o qual ocorre somente no Sul do território brasileiro, justificando-se o valor mais elevado, tal como era discriminado nos inventários o Dalbergia nigra, o jacarandá da Bahia ou do Pará ${ }^{330}$.

De qualquer forma, pelo fato de termos encontrado estas menções de trabalho com cedro no inventário de João da Mota Liver, as consideramos evidências de que este marceneiro produzia móveis requintados em São Paulo. Este diferencial de matéria-prima permite compará-lo, guardadas as devidas proporções, com os ebènistes franceses ${ }^{331}$. Estes eram artesãos que recebiam essa designação especial por trabalharem com madeiras importadas e raras, como o ébano africano Diospyros ssp., reservados - devido ao seu valor - aos artífices mais habilidosos ${ }^{332}$. Acreditamos que a presença de móveis constituídos de madeiras diferenciadas, como o cedro, produzidas em São Paulo, indica a produção de mobiliário refinado sendo feito localmente durante o século XVIII, não sendo as peças de requinte apenas provenientes da Bahia ou Rio de Janeiro, à época já grandes centros produtores de mobiliário na colônia, ou importadas da Europa ${ }^{333}$.

O inventário de João da Mota Liver e dos outros carpinteiros do século XVIII são muito significativos quando fazemos a análise comparada com a descrição geral do que havia no primeiro século e meio de povoamento português em São Paulo. Apesar de, no geral, muitas das ferramentas se repetirem, bem como as técnicas e

\footnotetext{
${ }^{330}$ PEREIRA, Andréa Franco. Madeiras brasileiras. Guia de combinação e substituição. São Paulo: Blucher, 2013. P. 103

${ }^{331}$ Decerto é merecido maior aprofundamento e outros comparativos para compreender o repertório de madeiras usadas pelos artesãos em São Paulo e as suas implicações e adaptações no trabalho. Por exemplo as considerações de BRANDÃO,Angela. Antônio Francisco Lisboa e um ebanismo de jacarandá. Belo Horizonte: IX colóquio luso-brasileiro de História da Arte. 2014. Disponível em: http://www.forumpatrimonio.com.br/aleijadinho/artigos/pdf/9.pdf. Acesso em: 20/05/2018.

332 MEUVRET, Jean. FRÉGNAC, Claude. Les Ébénistes due XVIIIâ siecle francais. Paris, Hachette, Collection Connaissance des arts "Grands artisans d'autrefois". 1963;

${ }^{333}$ FLEXOR, Maria Helena Occhi. Mobiliário baiano. Brasília: IPHAN/ Projeto Monumenta. 2009.
} 
os fazeres também permanecerem na longa duração da tradição manual, algumas ferramentas são sintomáticas de um novo momento técnico da cidade que estava surgindo e da possibilidade de executar novos estilos de peças ou de acabamentos em edifícios e esculturas.

Primeiramente, o já mencionado ${ }^{334}$ caso do boxequim ou cortechê, espécie de goiva utilizada para a confecção de sinuosidades nas peças de madeira, que possibilitariam a produção das cadeiras com pernas em cabriolle, ou galbarda ao gosto rococó da segunda metade do século XVIII ${ }^{335}$. Ainda que tal ferramenta não tenha sido encontrada nos inventários analisados, podemos considerar a presença coletiva de vários tipos de plainas diferentes - garlopa, plana revessa, plana direita no inventário de João da Motta Liver, um sinal de que ele produzia peças intrincadas e a presença individual da "plaina revessa", a qual seria uma descrição literal do boxequim.

Em segundo lugar, ao associarmos o torno de João da Motta Liver com um número bem maior de ferros que podemos supor que seriam utilizados para criar móveis e adornos de variados tipos, como as pernas de cadeiras e mesas com torneados complexos.

Ademais vemos também a presença de limas pequenas, detalhe que não aparece na listagem mais remota, bem como a presença de um raspador e várias sortes de plainas. Estas ferramentas são indícios claros de uma qualidade de acabamento mais fina, inclusive permitindo a produção de novos tipos de peças, de acabamento mais arrojado, como as sinuosas cadeiras de estilo $D$. João $\vee$ e $D$. José s36. $^{336}$.

Igualmente notamos o fato de José da Mota confeccionar duas ferramentas próprias, como constatado no trecho: "Duas ditas serras novas de palmo e meio inda por abrir os cortes, ou dentes (...) $\$ 320 "$. Este é mais um sinal do amplo universo de expertise prática que os oficiais mecânicos em São Paulo possuíam para lidar tanto com as carências de material, quanto o que poderiam ser embriões do desenvolvimento tecnológico interno da colônia.

\footnotetext{
${ }^{334}$ Remetemos ao primeiro capítulo, onde inferimos através das marcas nos moveis os tipos de ferramentas usadas, compreendendo sua historicidade.

${ }^{335}$ Conforme JOYCE, Ernest; PETERS, Alan. Encyclopedia of Furniture Making. Ed.1. Nova York: Sterling Publishing Company, Inc., 2000. P. 208.

${ }^{336}$ RODRIGUES, José Wasth. Mobiliário. As Artes plásticas no Brasil. Coleção brasileira de ouro. Rio de Janeiro: Ed. de Ouro, 1968. P.92.
} 
João da Motta Liver era figura recorrente nas tramitações camarárias concernentes aos trabalhos públicos. Apesar de ser marceneiro ele chegou a ser eleito escrivão do ofício de carpintaria em 1762, revelando como a divisão de atividades entre os ofícios mecânicos mesmo no plano oficial, tal como predicado pelas Ordenações não era cumprida.

Ao falecer, Liver deixara um portentoso monte-mor de 1:019\$048 réis, dos quais ficaram líquidos aos herdeiros 301\$298 réis. Entre as suas dívidas, que eram as maiores dentre todos os artífices que encontramos, notamos como possuía bom crédito com figuras graúdas da cidade, como o Arcipreste Paulo de Souza Rocha, ao qual devia $101 \$ 880$ réis (e este devia-lhe por aluguéis de casas), ao Arcediago Mateos Lourenço de Carvalho, $60 \$ 810$ réis; ao Convento de São Bento, $50 \$ 000$ réis. Chegam mesmo a fazer empréstimo de $90 \$ 000$, dos quais o Dr. Luís de Campos era mostrador, ao Alferes Caetano Barbosa.

Também notamos suas relações espalhadas geograficamente. Jozepe da Mota, seu irmão assistia nas partes da Vila de Sorocaba. Este Ihe devia $67 \$ 480$, do resto de um crédito. Também teria deixado conexões com artífices no Rio de Janeiro, a julgar pelo fato do marceneiro Antônio da Cruz, conterrâneo de Liver do Bispado do Porto, freguesia de Santo Antônio de Lemba e estabelecido no Rio, ter sido sua testemunha de casamento, ainda que Liver já tivesse subido a serra havia mais de um ano.

Liver fazia ainda outros negócios, com aluguéis de casas e com escravos, dado que o Licenciado Francisco Antônio devia-lhe tanto por aluguéis, quanto pelas custas da penhora de uma escrava sua, a crioula Quitéria. Liver também comprara o escravo Máximo de Francisca Xavier da Cruz, à qual ainda precisava pagar 17\$705 de resto.

Indícios de que Liver empreitava a construção de casas para aluguel são dadas tanto por estes devedores, quanto pelo fato de Liver dever a Jeronimo de Castro Guimarães "duas doblas de quatro milheiros de telhas e meia dobla e dois cruzados de 60 tijolos, que somavam $26 \$ 400$ réis".

Pela sua trajetória, passando pelo Rio de Janeiro e seguindo para a Piratininga é o grande exemplo de como esta, apesar da aura de pobreza a ela relegada, produzia suficientes excedentes que bancava obras artísticas e recheava, cada vez mais, os lares de móveis, sendo assim uma localidade também atrativa aos 
artesãos que nela se instalavam, não obstante as disparidades em relação a outros centros coloniais.

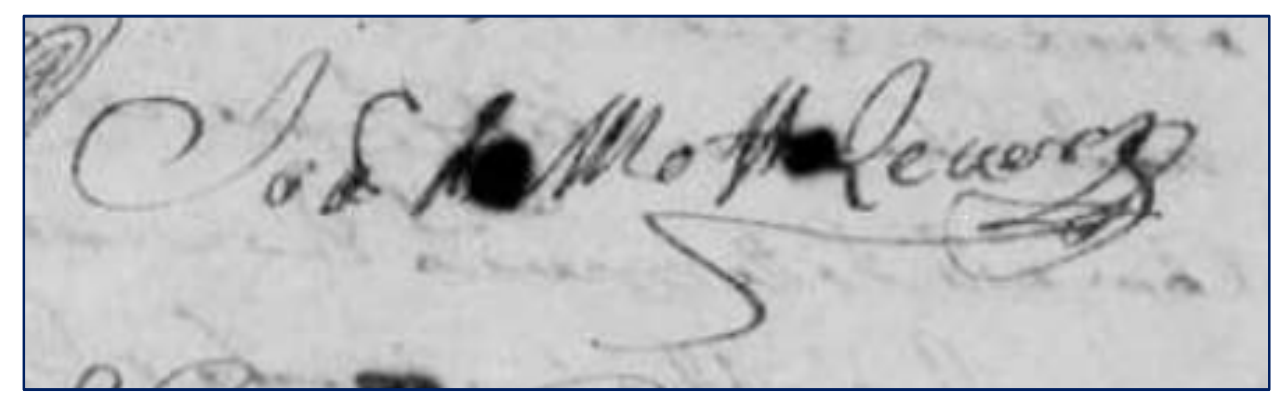

Figura 109: Assinatura de João da Mota Liver ${ }^{337}$.

Manuel Antônio da Cruz, mestre carpinteiro, constava, em seu inventário de $1775^{338}$, ser "filho de Portugal", sem precisar-se de qual localidade, bem como o nome de sua esposa, pois só dizia ser casado na metrópole. Ele falece em 19 de março de 1775 a Vila de Itu sem deixar herdeiros, nem testamento.

Por sua vez, em seu inventário, também encontramos objetos ainda não terminados: "duas caixas novas sem dobradiças e fechaduras". Outras ferramentas indicam o seu tipo de trabalho, como os "dois cepos com seus forros de correr molduras", além de mais "quinze cepinhos de correr molduras" e "duas dobradiças e uma fechadura nova", que possivelmente seriam utilizadas nas caixas inconclusas.

A somatória de suas ferramentas computava $11 \$ 740$ réis, constando além dos cepos de molduras, três junteiras, quinze cepos de moldar, sete formões entre pequenos e grandes. Para medição, um prumo de bronze e dois graminhos, estes sem valor, revelando como este era um objeto de medição bastante pessoal e quiçá intransferível, daí sua ausência de valor, para além de sua fácil produção.

Possuía somente um escravo, Antônio, de nação Congo, com quarenta anos. Fora enviado para São Paulo para que lá se fizesse sua avaliação para ser vendido novamente. Como já the havia dado por três vezes gota e estava "coxado", mas possuía "algum exercício de ajudar a trabalhar em ofício de carpinteiro" fora avaliado em $80 \$ 000$ réis.

Manuel Antônio da Cruz não possuía residência própria e entre suas dívidas, vemos o gasto com o Padre Francisco Manuel Mendes de oliveira religioso carmelitano, $2 \$ 800$ réis de aluguéis de casas. Batente itinerante, seus móveis se resumiam a dois mochos de pau, uma bufeta (sic) de Taboado de latão amarelo e

\footnotetext{
${ }^{337}$ ACMSP. Processo de Casamento. João da Mota Liver, 1761. Livro 4-75-543. FI. 22

${ }^{338}$ APESP, Inventários e testamentos não publicados. Caixa 705. Manuel Antônio da Cruz, de 1775.
} 
duas caixas. Ele aparece com 52 anos nos Maços de População de São Paulo de 1765 morando no 338 fogo computado, na "Rua do canto do cirurgião Fonseca até - beco de Santa Teresa e travessas", onde vivia com o agregado Luís Mendes, também carpinteiro, de 70 anos $^{339}$. Já no censo de 1767 , declarava ter $200 \$ 000$ réis, sendo membro da $3^{\underline{a}}$ companhia de pé de Jacinto José ${ }^{340}$.

Ao falecer, deixara bens em vários endereços, tanto na mesma vila de Itu onde falecera, em São Paulo e em Santos, as quais estavam tanto em poder de Manoel José da Encarnação, quanto em poder de Ana do Rosário, "mulher e solteira, moradora na Rua das Flores". Esta declarara que: "tinha alguns trastes em sua casa que lhe entregou João da Silveira da vila de Santos pertencente ao defunto (...) um baú velho coberto de couro cru pela quantia de 6 patacas e um bofete de pau da terra que deu em pagamento por oito patacas e que tinha feito ele dito mesmo defunto." Novamente temos um exemplo da importância da "vida social dos objetos" de que fala Arjun Appadurai, materializando relações sociais de amizade e compadrio entre espaços distantes ${ }^{341}$. Notamos, assim, através da delegação de bens narrado neste inventário compreendemos a importância das relações sociais não-parentais numa sociedade de constante fluxo de artífices e bens.

Para marcar a atuação de Manuel da Cruz em São Paulo, vemos pelas Atas da Câmara que ele prestara serviços nesta cidade antes de ir para Itu, pois aparece registrado em 1764 como averiguador das obras na cadeia ${ }^{342}$.

A única peça de metal precioso que possuía era um par de fivelas de prata, no valor de $1 \$ 520$ réis. Possuía inclusive uma cabeleira com sua caixa, e uma boceta de tabaco e seda, indicando objetos simbólicos de uso público.

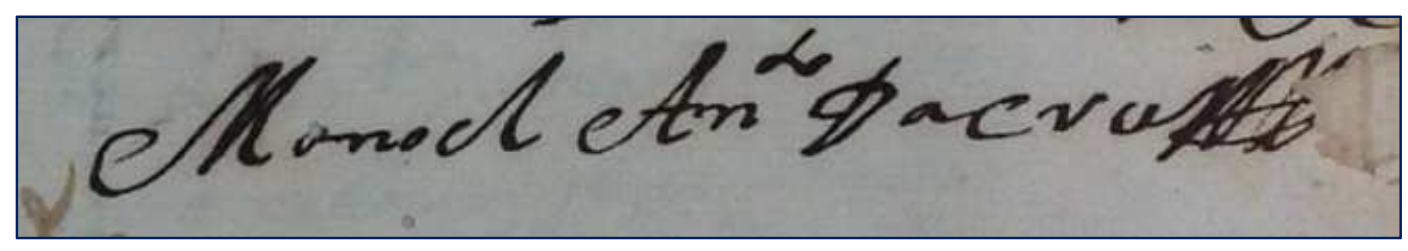

Figura 110: assinatura de Manoel Antonio da $\mathrm{Cruz}^{343}$.

Sobre o pintor Francisco Duarte do Rego não há dados de sua naturalidade, só se declara ser casado com Maria Rodrigues de Oliveira, que fora sua

\footnotetext{
${ }^{339}$ APESP. Maços de população, 1765, pg. 94.

${ }^{340}$ APESP. Maços de população, 1767, pg. 306

${ }^{341}$ APPADURAI, Arjun (org.). A vida social das coisas: as mercadorias sob uma perspectiva cultural. Niterói, RJ: Editora da Universidade Federal Fluminense, 2008. P. 78.

${ }^{342}$ APESP. Atas. vol. 15, p. 449.

${ }^{343}$ APESP, Inventários e Testamentos não publicados, Manuel Antonio da Cruz, 1775. Caixa 705.
} 
inventariante ${ }^{344}$. Consta-lhe um filho, Manoel Duarte, de oito anos, no Maço de População de 1776. No maço de 1767, quando tinha 26 anos, tinha como agregados os irmãos José, de 20 anos, também pintor ${ }^{345}$; Inácio, 16; e Joaquim, $14^{346}$.

Era um artífice que vivia bem localizado no centro da cidade, na Rua de São Bento, onde tinha uma morada de casas de taipa, com dois lanços, cobertas de telha assoalhadas e forradas. Aliás, em sua casa havia "um oratório embutido na parede, dourado, com várias imagens, a saber, do Senhor crucificado, do senhor dos passos, e outras várias e uma da Senhora de Conceição". Todos os atributos e localização da casa decerto influíram para o alto valor de sua avaliação, em $840 \$ 000$ réis.

A presença desse oratório em sua casa é bastante significativo, pois poderia ser um chamariz e propaganda do exercício de sua atividade no campo da arte sacra. Ele possivelmente também era presepeiro, dado que consta entre seus bens dois presépios:

\footnotetext{
"Um presépio pequeno, com o Senhor Menino de cera, sua vidraça (...) $3 \$ 200 "$

"Outro dito presépio com molduras douradas, velho, figuras de barro encarnadas (...) 6\$400"
}

Além de ser ligado às arte sacras era também membro de mais de uma irmandade religiosa, sendo tanto franciscano quanto irmão do Santíssimo Sacramento e das Almas e também da Santa Casa de Misericórdia.

O inventário, aberto em 1782, não possuía testamento e segundo declaração, já haviam feito pagamentos de dívidas antes do inventário. As dívidas que se deviam ao casal são bastante significativas: o Capitão Jacinto José de Abreu, da Vila de Sorocaba, devia-Ihe $11 \$ 000$, possivelmente indicando que este artesão realizava trabalhos para além da cidade de São Paulo. Também the devia José Duarte do Rego, $28 \$ 160$ réis, que pelo sobrenome era possivelmente seu parente.

Possuía sete escravos, entre eles Reginaldo, "Criolo, de vinte anos sem moléstia, com principio de pintor", avaliado em $102 \$ 400$ réis.

\footnotetext{
${ }^{344}$ APESP, Inventários e Testamentos não publicados, Caixa 726. Francisco Duarte do Rego, 1782.

345 PEREIRA, Danielle Manoel dos Santos. Autoria das Pinturas Ilusionistas do Estado de São Paulo: São Paulo, Itu e Mogi das Cruzes (Brasil). 2017. Tese (Doutorado em ARTES) - UNESP. 2017.. P. 276

${ }^{346}$ APESP. Maços de população, 1767, p. 44 e 1776, p. 15 apud PEREIRA, Danielle Manoel dos Santos. Autoria das Pinturas... op. cit. 2017.p. 265.
} 
Apesar de ser pintor, encontramos no inventário de Francisco Duarte do Rego poltronas ainda sendo fabricadas: "Outra dita poltrona, que ainda lhe falta o coxim, de madeira da terra", pela a quantia de $2 \$ 000$. Igualmente constam ferramentas deste ofício: "Declarou a inventariante vários ferros do ofício de carpinteiro, novos, que vieram do Rio de Janeiro (...) que aprende o ofício de carpinteiro, (...) $3 \$ 140$ réis."

É difícil precisar se os móveis que foram descritos em sua casa eram de seu uso, ou se teriam sido feitos para serem vendidos; mas constavam dois bofetes com gavetas de jacarandá da Bahia torneados, as poltronas mencionadas e duas caixas de madeira da terra. Possuía também um armário de portas, artigo raro nos inventários ${ }^{347}$. Igualmente, era o único dentre esses artífices cujos inventários compulsamos que possuía esporas de prata, no valor de $5 \$ 160$ réis. Seu inventário chegou ao computo de $1: 759 \$ 180$ réis de monte-mor e líquidos, $780 \$ 947$ réis.

\subsection{Remendões e Oficiais: a produção de mobiliário compreendida de maneira ampla.}

As trajetórias que vimos forneceram importantes elementos para compreender o contexto de sua atuação no espaço colonial e a produção do mobiliário, que era resultado de condições paralelas e conflitantes: o empirismo da produção e a regulamentação dos produtores oficiais. Pelo que já pudemos observar, as fronteiras de seus trabalhos eram bastante tênues, exercendo variadas atividades simultaneamente. Assim tentaremos contemplar todos aqueles agentes que poderiam ter produzido peças por si só ${ }^{348}$, bem como entender o estatuto social

\footnotetext{
${ }^{347}$ Encontramos apenas 40 entre os 104 inventários analisados.

348 Tentar entender a maneira como esses grandes agrupamentos étnicos, compostos de centenas de grupos culturais específicos que foram ao longo dos séculos amalgamando-se complexamente no nas várias regiões brasileiras, compreendiam a produção e o uso de artefatos utilizados nas moradias confere maior riqueza ao estudo histórico, o que até o momento se recente de estudo específico sobre o mobiliário doméstico, ainda que Tilde Canti tenha feito considerações intercaladas a respeito dos bancos indígenas. CANTI, Tilde. $\mathbf{O}$ móvel no Brasil: origens, evolução e características. Rio de Janeiro: Ed. Candido Guinle de Paula Machado, 1980, p. 74 e 75. Bem como nos estudos do mobiliário sacro surjam recentemente dados sobre as idiossincrasias étnicas na produção. Cf. MARTINS, Renata Maria de Almeida. Tintas da terra tintas do reino: arquitetura e arte nas Missões Jesuíticas do Grão-Pará (1653-1759). Tese (Doutorado em História e Fundamentos da Arquitetura e do Urbanismo) - Faculdade de Arquitetura e Urbanismo, Universidade de São Paulo, São Paulo, 2009.
} 
dos oficiais mecânicos em suas particularidades regimentais, espaciais e de interação social.

Incluímos trajetórias no estudo, como a de Estevão Ribeiro Garcia e Francisco Duarte do Rego, que, apesar de não serem oficiais especialistas na produção moveleira tinham o ferramental competente para fazê-lo, e portavam objetos em construção ou reparo. Essa compreensão é essencial na perspectiva da cultura material, pois, tal como as ferramentas são propiciadores de atividades que não respeitam necessariamente a sua função inicialmente proposta, os indivíduos, de posse delas, poderiam justamente extrapolar os seus afazeres primordiais e produzir por si móveis e outro artefatos com as madeiras disponíveis ${ }^{349}$.

Dá-nos um exemplo dessa produção empírica, não seleta aos oficiais mecânicos e seus escravos, entre a população em geral, o relato do deputado provincial Francisco de Assis Vieira Bueno na segunda metade do Século XIX, provando que o empirismo existiu por todo período colonial. Ao tratar da fiação, prática comum entre as mulheres em São Paulo, diz que os utensílios domésticos para a sua execução reduzia-se a um pequeno descaroçador de mão, feito de madeira, o qual "Qualquer carpinteiro remendão podia construir. Era tão pequeno e maneiro, que de ordinário eram meninos que o faziam trabalhar" ${ }^{350}$.

A fricção entre o empirismo dos artífices da madeira e mesmo dos outros vários tipos de atividades artesanais e o esforço governamental em regimentar os ofícios mecânicos é mais uma dimensão a ser estudada no projeto colonizador de Portugal na América. É necessário compreender este projeto principalmente como um esforço adaptativo, decerto impositivo, mas também eivado de maleabilidades entre as populações ameríndias pré-existentes e as europeias e africanas que se

\footnotetext{
${ }^{349}$ A produção empírica do mobiliário e mesmo das casas foi particularmente presente nos primórdios da colonização, e não só no Brasil, mas também em outros locais das Américas, como nas Treze Colônias inglesas e nas áreas coloniais espanholas. Em uma civilização material pré-industrial que dependia absolutamente da madeira enquanto substrato plástico basilar e como matriz energética principal, é impossível considerar que somente serralheiros, carpinteiros e outros artífices da madeira especializados fossem responsáveis por fazer todos os artefatos utilizados nas casas. CABRAL, Diogo de Carvalho. Na Presença da Floresta:, Mata Atlântica e História Colonial. Rio de Janeiro: Garamond/FAPERJ, 2014,

${ }^{350}$ Faz ainda uma minuciosa descrição desse aparato: "consistia num pequeno banco, no centro do qual de encravavam dois suportes, para sustentarem dois cilindros transversais, de uma polegada de dímetro, que eram postos em movimento por duas manivelas fixas, em sentido oposto, nas extremidades." em MOURA, Carlos Eugênio Marcondes. (Org.). Vida cotidiana em São Paulo no século XIX: memórias, depoimentos, evocações. São Paulo: Ateliê Editorial, 1998. p. 156.
} 
assentaram no território e formaram novas comunidades e vilas ${ }^{351}$. O artífice também deve ser entendido como agente colonizador ${ }^{352}$, com suas cooperações e contradições com o próprio poder administrativo, suas trajetórias individuais e coletivas, que ditavam o ritmo e as formas que assumiam as fronteiras de fixação.

O clássico e pioneiro estudo de Gilberto Freyre sobre as condições cotidianas de vida colonial demostrou a grande autonomia dos engenhos de cana-de-açúcar no nordeste brasileiro, onde os senhorios contavam com quase tudo que pudessem necessitar ${ }^{353}$. Esses organismos produtivos completos quase se bastavam por si mesmos, contando com ofícios próprios como pedreiros, ferreiros e carpinteiros, algo também observado nas fazendas no Rio de Janeiro Imperial e no Maranhão no começo do século XVIII, onde as casas particulares eram como verdadeiras "republicas" ${ }^{354}$. Ainda que se deva relativizar essa autonomia, principalmente no que dela se considerou "isolacionismo", como considerou Sergio Buarque de Holanda, Carlos Vilardaga observa que a produção dentro dos engenhos também seria uma realidade em São Paulo, fator de grande peso para a dificuldade de artesãos especializados se fixarem e produzirem móveis em suas tendas ${ }^{355}$.

Aliás, seguindo a lógica elaborada por Rubens Matuck ${ }^{356}$, se os escravos e servos eram responsáveis por boa parte da produção de carpintaria e marcenaria, isso significa que os oficiais mecânicos que vinham e se fixavam em São Paulo deviam ser especialistas e fazer obras de qualidade, o suficiente para um individuo deixar de se valer da produção doméstica, e encomendá-la ao artesão, ou comprá-la no varejo. Decerto pela dificuldade de obtenção de ferramentas no espaço colonial, mesmo que muitos indivíduos pudessem, com maior ou menor habilidade confeccionar móveis de uso simples e doméstico, os artesãos com ferramentas,

\footnotetext{
351 Por exemplo, num ofício de 1765 do governador-geral do Mato Grosso Câmara Coutinho, fala-se da ida de um pároco e um carpinteiro para a aldeia dos índios Pama. Por este documento contemplam-se dois braços da colonização atuando junto: a Igreja e o artífice, portador do saber-fazer da cultura material europeia, a ser comunicada e difundida entre os indígenas. CT-AHU-ACL-CU-010,CX 13, DOC 768. Projeto Resgate Documentos manuscritos avulsos da Capitania de São Paulo - Mendes Gouvêa.

${ }^{352}$ Tal como llana Blaj compreendeu, baseada em Florestan Fernandes o colono como colonizador, inclusive os itinerantes mercadores. BLAJ, Ilana. A trama das tensões: o processo de mercantilização de São Paulo colonial (1681-1721). São Paulo : Humanitas/FFLCH/USP : Fapesp, 2002;

${ }^{353}$ FREYRE, Gilberto. Casa-Grande \& Senzala. São Paulo: Global, 2006..

354 HOLANDA, S. B. de. Raízes do Brasil. São Paulo: Cia das Letras, 2009. p. 81,

${ }^{355}$ VILARDAGA, Jose Carlos. São Paulo na órbita do Império dos Felipes: conexões castelhanas de uma vila da América Portuguesa durante a União Ibérica (1580-1640). FFLCH/USP - Tese de Doutorado. 2010. P. 106.

${ }^{356}$ MATUCK, Rubens. Instrumentos Manuais de Carpintaria e Marcenaria (catálogo de exposição). Prefeitura do Município de São Paulo: Secretaria Municipal de Cultura. 1982.
} 
ainda que poucas, teriam condições muito melhores de fazê-lo. De fato, John Monteiro mostra como no século XVII quase toda a produção artesanal era executada por oficiais e aprendizes índios, sendo que muitos senhores, em especial os que viviam nas vilas, viviam apenas da renda dos serviços de seus índios ${ }^{357}$.

Já pudemos notar mais acima, nas entrelinhas dos inventários dos artífices os seus escravos atuando enquanto produtores de móveis, como os oficiais de marceneiro João, Mateus e Paulo, cativos de João da Mota Liver, e Reginaldo, de Francisco Duarte do Rego, pintor principiante ${ }^{358}$. Outros exemplos apresentam-se em inventários para todo o período colonial, como podemos ver em inventários de agentes comerciais, terratenentes e mesmo nos redutos de religiosos pelos maços de população ${ }^{359}$.

Os escravos africanos eram responsáveis por exercer todo tipo de ofício braçal entre a população civil. Geralmente ficavam com os serviços degradantes do cotidiano, seja rural ou urbano, doméstico ou público. Grandes "motores da máquina colonialista", como definiu Lúcio Costa ${ }^{360}$, temos notícia de escravos por empirismo servindo de construtores e mesmo exercendo obras de arte e entretenimento nos espaços residenciais. Compreender a produção como não somente limitadas aos oficiais mecânicos é fazer jus ao trabalho de seus escravos, muitas das vezes os verdadeiros produtores, ocupando-se de grande parte, se não da totalidade, das etapas produtivas ${ }^{361}$.

\footnotetext{
357 MONTEIRO, John Manuel. Negros da terra. Bandeirantes e índios nas origens de São Paulo. São Paulo: Companhia das Letras, 1994.p. 172.

${ }^{358}$ APESP. Inventários e Testamentos não publicados, cx. 654, João da Mota Liver, 1771. Para além do contexto paulista, vale também citar Mahommah Baquaqua, único escravo que passara pelo Brasil - dos milhões aqui padecidos - a ter o registro de suas memórias publicado. Escravizado em Pernambuco e depois passando aos Estados Unidos e à Inglaterra, ele relata que havia aprendido na infância o ofício de ferreiro com o seu tio, de alto status na sua sociedade original, pois ferreiro do rei. Inclusive Baquaqua havia frequentado a escola de letramento, para se tornar um orador, revelando que os africanos muitas vezes chegavam com conhecimento prévio de ofícios. Cf. BAQUAQUA, Mahommah Gardo; MOORE, Samuel. Biography of Mahommah G. Baquaqua, a Native of Zoogoo... Detroit: Tribune Office.1854. Disponível em: http://docsouth.unc.edu/neh/baquaqua/baquaqua.html. Acesso: 20/05/2018. Recordemos ainda Juan manzano, exemplo cubano, o único relato de escravo escrito pelo próprio - ainda que revisto por letrados brancos - para toda a América Latina. Manzano conseguiu aprender, pelas suas capacidades de observação e por suas habilidades pessoais, a ler, compor poemas de memória e mesmo a pintar móveis empíricamente. MANZANO, Juan Francisco. A autobiografia do poeta-escravo.Organização e tradução de Alex Castro. São Paulo: Hedra. 2015.

${ }^{359}$ Vide no próximo capítulo o inventário de José Pinto Tavares, 1815. APESP. Inventário e Testamentos não publicados. José Pinto Tavares, 1815. Processo 201007000466 - 1169. pg. 524.

${ }^{360}$ COSTA, Lúcio. Notas sobre a evolução do mobiliário luso-brasileiro. Revista do SPHAN.no.3 1939.

${ }^{361}$ Certamente a pesquisa com mais fontes e a integração de dados, não só brasileiras, mas também africanas e ameríndias, poderá no futuro render trabalhos que dissertem com mais profundidade sobre a atuação dos escravos no processo produtivo, particularizando suas atuações e trajetórias e permitindo melhor
} 


\section{Em alguns avisos de jornal, nos inicio do século XIX, vemos o emprego dos escravos nos mais variados ofícios e serviços domésticos, registrando-se até em quais não possuíam boas habilidades ${ }^{362}$ :}

Há seis meses fugiu da Vila da Constituição um pardo, de nome Anastazio (sic), cujos sinais são os seguintes: cor de garapa, cheio de corpo, rosto redondo, bem barbado, cara bexigosa, usa de trazer os cabelos aparados altos, e são grenhos, um dedo mínimo do pé de menos, altura sete palmos e meio, bom oficial de carpinteiro, bom lavrador, bom serrador, cozinha sofrível, tem o vicio de se embebedar.

Em outro anuncio, no caso de venda e não de procura de fugitivo, aparece outro exemplo, em que o escravo não só é oficial de carpinteiro, como lhe é atribuído maestria em processos alimentícios ${ }^{363}$ :

Avisos - quem quiser comprar um Pardo de nome Antônio, idade 17 a 18 anos, Oficial de Carpinteiro, e Mestre de fazer chá, procure falar com seu dono na Chácara do Marechal Arouche.

Igualmente fontes iconográficas nos revelam o trabalho de negros livres e escravos na carpintaria de casas, como a famosa gravura de Debret no Rio de Janeiro ${ }^{364}$ :

compreensão integrada entre eles, seus senhores e as configurações produtivas no Império Português. Apenas para citar um exemplo paulista de escravos que exerciam ofícios mecânicos, lembremo-nos o do pedreiro Thebas, um dos raríssimos indivíduos escravos cujos nomes e feitos ficaram registrados pelos memorialistas, dado o fato se que ele realizara a proeza de construir a torre do sino da igreja da Sé e realizado vários outros trabalhos, inclusive alçando a liberdade, tornando-se senhor de outros cativos e arrematando obras públicas. Cf. BUENO, Beatriz Piccolotto Siqueira. Sistema de produção da arquitetura na cidade colonial brasileira: mestres de ofício," riscos" e" traças". Anais do Museu Paulista: História e Cultura Material, v. 20, n. 1, p. 338, 2012. Decerto mais um exemplo que comprova o conhecimento técnico e tecnológico africano no Brasil, aliado à criatividade empírica dos escravos e seus descendentes.

362 Aviso no jornal Farol Paulistano, no 273. 19 de novembro de 1829,. Disponível em: bndigital.bn.gov.br/hemeroteca-digital. Acesso em: 20/08/2018.

363 Aviso no Jornal Farol Paulistano, n. 214. 16 de maio de 1829. Disponível em: bndigital.bn.gov.br/hemeroteca-digital. Acesso em: 20/08/2018.

364 Decerto não devemos tomar as fontes iconográficas como retrato fiel da verdade ou mesmo uma cena tal qual vista pelo desenhista e pintor da época, porém a somatória de detalhes nos permite extrair informações de grande importância, a serem comparadas, por exemplo, com relatos escritos e inventários. Um indicativo de licença poética do pintor seria o fato de que as Ordenações Filipina proibiam a os oficiais mecânicos portarem nas ruas as suas ferramentas abertamente, sendo necessário que as transportassem em " uma bolsa ou saquinho com a boca tapada", ou sofreriam com proibição e multa de seis mil réis. Cf. Ordenações Filipinas, Tomo Primeiro, 1749. P. 478. 


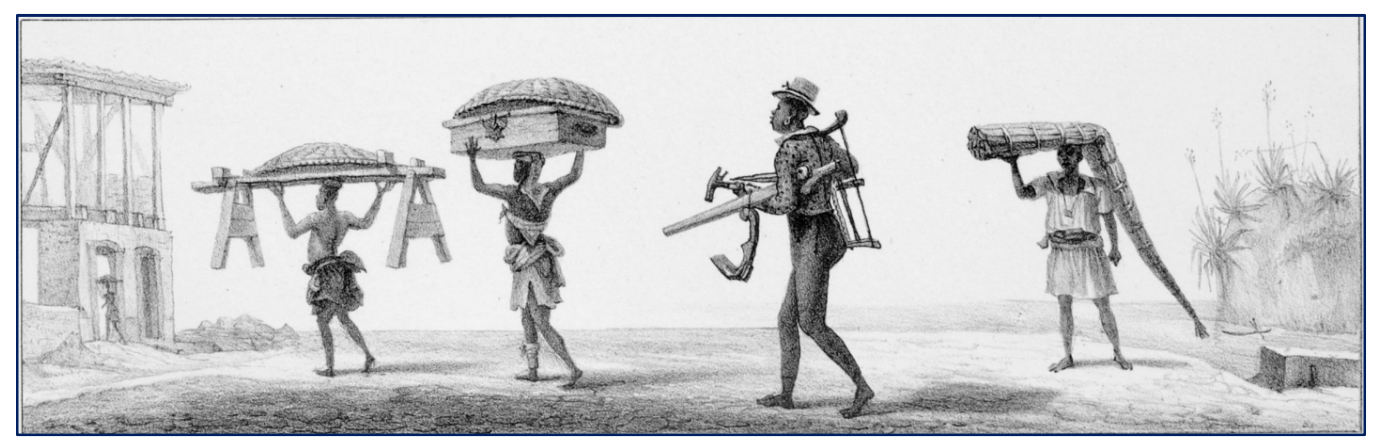

Figura 111: DEBRET, Jean-Baptiste. "Carpinteiro indo para a obra" (detalhe), em Viagem pitoresca e histórica ao Brasil, 1834-39365

Tomando atenção aos detalhes da obra, vemos o carpinteiro negro trajado de maneira pomposa, com veste estampada, calça e chapéu de fita; o fato de ter tais roupas poderia ser um indicativo de sua liberdade, ou talvez sua ausência de sapato o revele ainda cativo. O fato de possuir um brinco na orelha esquerda é um indicativo étnico de que ele era de proveniência angolana ${ }^{366}$. Em comparação, os outros escravos possuem apenas panos e cordas para se cobrirem, e o carregador de caibros de Azebre (Aloés, segundo Debret) parece portar amarrado no pescoço uma bolsa de mandinga. As ferramentas que o carpinteiro carrega são um martelo na mão, e uma enxó pendurado por cordão. Régua e faca vão apoiadas no braço esquerdo, e uma serra com armação no braço direito.

Sabemos também que outros artífices moveleiros não oficiais eram os membros de ordens religiosas $^{367}$, especialmente os irmãos da Companhia de Jesus. Serafim Leite e Paulo Assunção, traçando a trajetória dos irmãos jesuítas no Brasil notaram que eles exerciam as artes mecânicas não só para a própria manutenção de seus colégios, donde há casos exemplares de empirismo observados pelos comentadores

\footnotetext{
365 DEBRET, Jean-Baptiste. Voyage pittoresque et historique au Brésil . Paris, Firmin Didot Freres, 1834-39. Disponível em: https://digital.bbm.usp.br/handle/bbm/3163. Acesso em: 20/05/2018.

366 "Os velhos cronistas falam, insistentemente, do brinco dourado colocado na orelha esquerda como marca dos chamados Angolas. Elementos externos outros eram também marcas que podem ser vistos como sinais diacríticos na identificação dos africanos da África Sub-equatorial. Não interpreto como mera coincidência o fato de no Rio de Janeiro do século XIX, Carlos Eugênio Soares chamar a atenção para um tipo de chapéu, o barrete, que junto com as fitas de cores transformou-se em mais um elemento de identificação dos capoeiras."(grifos nossos). Cf. A Idade d' Ouro, 16/04/1813; Alexandre Melo Morais Filho, Festas e tradições populares do Brasil, Rio de Janeiro, Secretaria Municipal de Cultura, DGDI, 1994, p. 296. Apud TRINDADE, Pedro Moraes. Do lado de cá da Kalunga: Os africanos Angolas em Salvador - 1800-1864. Salvador: Dissertação de Mestrado - UFBA, 2008, p. 58.

367 Decerto outras ordens religiosas deveriam ter entre seus membros e escravos artífices, como os Beneditinos, responsáveis pela construção e aluguéis de muitas casas em São Paulo, sendo os maiores senhorios da cidade à época da Décima Urbana de 1809. cf. BUENO, Beatriz Piccolotto Siqueira. Tecido urbano e mercado imobiliário em São Paulo: metodologia de estudo com base na Décima Urbana de 1809. An. mus. paul., São Paulo, v. 13, n. 1, p. 59-97, June 2005.
} 
contemporâneos como Anchieta ${ }^{368}$, mas também produziam para vender e ensinavam os ofícios, além de intercambiarem bens entre seus estabelecimentos, que eram verdadeiros entrepostos comerciais ${ }^{369}$.

Decerto o trabalho dos jesuítas era tão volumoso nesta produção moveleira, que para termos uma ideia, quando do confisco dos bens do colégio de Pernambuco e venda em praça, só o lucro sobre os móveis em madeira foi de $160 \$ 600$ entre 1759$63^{370}$. A memória do Conde de Assumar sobre a jornada do Rio de Janeiro a Vila Rica em 1717 para tomar posse como governador, também revela a produção de móveis de arruar pelos jesuítas em São Paulo, junto com uma reclamação sobre o preço $^{371}$ :

\begin{abstract}
Neste dia se acabou de fazer uma cadeirinha (...) sendo preciso um couro de boi para fazer-se umas correias para a cadeirinhas, não se achando outra parte senão no colégio dos mesmos (padres jesuítas) o venderam este por duas patacas, constando-Ihe que era para serviço da sua Ex. ${ }^{\underline{a}}$ pois no mesmo colégio se fazia a Cadeirinha(...).
\end{abstract}

Vemos ainda que os membros da fraternidade também faziam obras publicas, como a obra de ajuste da ponte de "Nossa Senhora Goarê" sobre o Rio Tietê, a qual ficou ao encargo do Padre João Moura Gavião, em $1733^{372}$. Ficou acordado que ele providenciaria todo o material de madeiras de lei ao valor de $300 \$ 000$ réis. Após a feitura, os avaliadores, Capitão José de Gois Morais e o Capitão Pedro Taques Pires consideraram que a ponte "estava mais bem beneficiada do que prometeu" o Reverendo, havendo utilizado como prometido travessas e tachões de Ubá-mirim e Canela Preta, com pregaria forte provida pelo mesmo. Aliás, julgaram que a feitura valia mais que o valor acordado, por "não se pagar o jornais aos índios com que se fabricou" 373 .

Os padres jesuítas, aliás, não eram somente artífices, mas também instrutores dos ofícios em meio aos indígenas que catequizavam. Vemos nas capelas remanescentes dos aldeamentos jesuíticos exemplos materiais da convivência

\footnotetext{
${ }^{368}$ Como o Pe. Afonso Brás (1524-/550-1610). Cf. LEITE, Serafim. Artes e ofícios dos Jesuítas no Brasil, 15491760. Lisboa: Edições Brotéria, 1953. P. 138

369 ASSUNÇÃO, P. Negócios Jesuíticos: O cotidiano da administração dos bens divinos. São. Paulo: Editora da Universidade de São Paulo, 2004. 341.

${ }^{370}$ ASSUNÇÃO, P. Negócios Jesuíticos... op. cit. 2004. p. 350.

${ }^{371}$ Conde de Assumar. Do Rio de Janeiro a Vila Rica.. Op. cit. 1717. Revista SPHAN, n.3. 1939.. p. 305.

${ }^{372}$ APESP. Atas. vol. 10., p. 361.

${ }^{373}$ APESP. Atas. vol. 10. p. 386.
} 
indígena com os padres artífices da madeira e da pintura, como na capela de São Miguel Paulista ${ }^{374}$. Deve-se observar que o interesse no ensino de ofícios mecânicos entre os indígenas pelos jesuítas os levou a influir nas políticas da empresa colonizadora portuguesa. Isso nos revela uma ordenança de D. João $V$, de 1727 , onde se determinava que "nas aldeias de índios houvesse sempre alguns que fossem oficiais ferreiros, tecelões, carpinteiro e oleiros, e que não pudessem ser tirados delas por nenhuma pessoa, de qualquer qualidade que fosse, sem ordem dos Padres" 375376 .

Todos estes exemplos comprovam como a vida na colônia não era possível sem artífices da madeira sejam os oficiais, sejam "remendões", que merecem decerto mais estudo. Como vimos, a historiografia apenas recentemente começou a lidar com os oficiais mecânicos e há muito a ser pesquisado.

Discordamos em parte com a visão desta historiografia mais recente sobre os ofícios mecânicos em São Paulo no que tange a alguns pontos em específico, posto endossarem em grande parte a visão da pobreza paulista. Maria Helena Flexor, ao comparar Salvador com São Paulo pontua que a exiguidade de oficiais mecânicos deveu-se à pobreza da vila e cidade, bem como ao "espírito paulista de não se fixar na terra" ${ }^{377}$, o que não teria permitido a organização da infraestrutura da vila tão rapidamente como no centro político.

Segundo a autora ${ }^{378}$ :

Além de poucos em número, os oficiais mecânicos paulistas eram ineficientes, como pode constatar Morgado de Mateus, que pedia oficiais mecânicos mais eficientes no Rio de Janeiro e como foi registrado pelos

\footnotetext{
${ }^{374}$ KOK, Glória. A presença indígena nas capelas da capitania de São Vicente (século XVII). Espaço Ameríndio, v. 5 , n. 2, p. 45, 2011. Deve-se ponderar que ornatos com motivos da flora brasileira não são indicativo de autonomia criativa dos ameríndios, mas sim exotismos dos preceptores europeus. Até onde iria o fator de influência simbólica sobre os índios catecúmenos é difícil precisar, mas não é de se ignorar. Vide a discussão em BATISTA, Eduardo Luis Araújo de Oliveira. Iconografia tropical: motivos locais na arte colonial brasileira. An. mus. paul., São Paulo, v. 25, n. 1, p. 359-401, Apr. 2017.

375 Apud BARDI, Pietro Maria. Mestres, artífices, oficiais e aprendizes no Brasil. São Paulo: Banco Sudameris Brasil, 1981 p. 52 . Vemos que a utilização do ameríndio como artífice não cumpria apenas a função econômica de se apropriar do dinheiro de seu trabalho, mas estava complexamente inserida na mentalidade catequizadora dos agentes coloniais, especialmente dos religiosos. Este dado figura em diversos trabalhos sobre o ensino nos redutos jesuíticos, como o de ARAUJO, Renata. Tintas da Terra.

${ }^{376}$ FLEXOR, Maria Helena Ochi. O Trabalho Livre em São Paulo - Século XVIII. Tese de Doutorado - São Paulo: FFLCH/USP, 1984.p. 249. De acordo com a autora, proibia-se aos ferreiros levar forjas ao sertão para não ensinar o ofício aos índios e não armá-los.

${ }^{377}$ FLEXOR, Maria Helena Ochi. Ofícios, Manufaturas e Comércio. In SZMRECSÁNYI, Tamás. História Econômica do Período Colonial. 1993. pp. 175

${ }^{378}$ FLEXOR, Maria Helena Ochi. Ofícios, Manufaturas ... op. cit. 1993. pp. 176.
} 
viajantes que estiveram na região ${ }^{379}$. Provavelmente devido à pobreza da capitania paulista, ou mesmo por terem-se tornado comuns as construções de taipas-de-mão ou de pilão até o inicio do século XIX, não havia mestre pedreiro e mestre carpinteiro hábeis como os havia no Rio de Janeiro e Bahia.

Esta visão de escassez e ineficiência deve ser ponderada ${ }^{380}$. Ainda que consideremos as reais dificuldades do exercício da profissão serra acima, há um discurso bastante arraigado e lastreado nas falas dos agentes administrativos e viajantes do século XIX, e largamente reproduzida pela historiografia do começo do século $X X$, que acabou por desvalorizar o trabalho dos artífices paulistas sem compreender contextualmente as suas condições.

Por exemplo, no primeiro inventário de artífice que encontramos, João Fernandes em 1717, vemos que não houve partilha por terem ficado dívidas. Se esse dado pode parecer um sinônimo de que os oficiais mecânicos em São Paulo eram "desprovidos" e "vadios", e a cidade "muito pobre", devemos levar em conta o inventário do carpinteiro lisboeta Feliciano da Cruz, de 1799. Apesar de distante espacialmente e temporalmente de João Fernandes, o artífice reinol também faleceu em condição de endividamento, restando $9 \$ 778$ réis a serem pagos, apesar de possuir um monte-mor de $209 \$ 478$ réis e sua mulher ter vendido seis dúzias de cadeiras pré-fabricadas ${ }^{381}$. A visão de que os artífices coloniais eram "vadios", que aparece nos discursos muitos viajantes estrangeiros foi refutada por Maria Helena Flexor, devendo-se ao fato de que muitos oficiais trabalhavam por encomenda, e só entravam em atividade quando a demanda surgia ${ }^{382}$.

Acreditamos também que uma das raízes historiográficas dessa concepção negativa sobre os artífices paulistas deva-se a um dado ainda anterior ao século XVIII: o famoso caso do procurador João Fernandes (homônimo do carpinteiro setecentista), em 1575, reclamando da ausência de uma caixa para usar de arquivo

\footnotetext{
${ }^{379}$ APESP. DI. v. 73, nota 8, p. 49 e Revista do Instituto Histórico Geográfico Brasileiro. v. 6. Rio de Janeiro: IHGB e Imprensa Nacional. 1844. p. 236. Apud. FLEXOR, Idem, Ibidem.

${ }^{380}$ Como o fez para o contexto camponês dos países europeus SARTI, Rafaella. Casa e Família. Habitar, Comer e Vestir na Europa Moderna. Lisboa: Estampa, 2001 e ROCHE, Daniel. História das coisas banais: nascimento do consumo nas sociedades tradicionais (XVII-XIX). Rio de janeiro: Rocco, 2000, P. 251. E especificamente para a França, comparando Paris e a Alsácia.

${ }^{381}$ ANTT. Inventários post mortem dos Feitos Findos (1500-1800). Feliciano da Cruz (mestre do ofício de carpinteiro de móveis), 1799. PT/TT/IFF/006/0175/00006.

${ }^{382}$ FLEXOR, Maria Helena Ochi. Ofícios, Manufaturas e Comércio. In SZMRECSÁNYI, Tamás. História Econômica do Período Colonial. 1993, p. 191.
} 
dos papéis da Câmara, dizendo que "não havia carpinteiro que a pudesse fazer nem se acharia alguma a comprar" ${ }^{383}$. Esta passagem foi coletada e divulgada por Afonso Taunay em História da Cidade de São Paulo, em 1953 como argumento do pretenso isolamento da vila. Essa visão, porém não encontra fundamento ${ }^{384}$. O próprio Afonso Taunay, relatando a mesma passagem em São Paulo nos Primeiros Tempos, de 1920, relata o resultado do caso, ao contrário do livro posterior onde omite que "Felizmente possuía o antigo escrivão municipal Fructuoso da Costa uma arca que podia servir "boa e nova" para nela se conservarem "os papéis e pesos e medidas e outras cousas do concelho, tendo sido adquirida a novecentos réis, preço elevado" ${ }^{385}$.

Influenciando largamente a visão historiográfica sobre são Paulo, vemos o mesmo trecho reproduzido, para citar apenas um exemplo, em Formação Histórica do Brasil de Nelson Werneck Sodré, em 1962, adicionando ao caso que "A comunidade permaneceu pobre, esquecida e isolada, pois, por longos decênios." ${ }^{\text {"A6 }}$, imputando-se a cidade essa condição paupérrima até praticamente o século XIX, com o advento do "ciclo do café".

Para os séculos XVII e XVIII continua a tônica na historiografia paulista sobre a pobreza, isolamento e decadência, inclusive pela perda de autonomia da capitania, considerada uma época tenebrosa para a historiografia paulista ${ }^{387}$. O século XIX é o momento em que encontramos os episódios mais recorrentemente utilizados pela historiografia para reforçar a ineficiência dos artífices brasileiros, reproduzindo a visão depreciativa dos viajantes europeus. Outro exemplo clássico, já mencionado por Antônia Terra e Amália Santos, é a peripécia das caixas do viajante Auguste de Saint-Hilaire (1779, Orleães, França - 1853, idem) em 1819. Procurando alguém que

\footnotetext{
${ }^{383}$ TAUNAY, Affonso de E. História da cidade de São Paulo no século XVIII (1711-1720). São Paulo: Imprensa Oficial do Estado, 1931, t.1. P. 15.

${ }^{384}$ Não se fundamenta a "pobreza de carpinteiros" de São Paulo sequer nos primeiros séculos. Como já mostrara Daisy Barros, os carpinteiros estão sempre presentes na vila a se considerar as ferramentas dos inventários. Justamente em 1575 encontra-se a primeira menção a carpinteiro propriamente dito em São Paulo, no caso Gonçalo Fernandes, que avaliara para a Câmara as portas dos muros da cidade, que haviam sido apropriadas e vendidas indevidamente pelos mordomos da Câmara. APESP. Atas, vol 1. p. 64, apud BARROS, Daisy. Um século....op. cit., 1982, p. 115.

${ }^{385}$ TAUNAY, Affonso de E. São Paulo nos primeiros anos (1554-1601): Ensaio de reconstituição social. Tours: Imprenta de Arrault et cia. 1920., p. 66.;

${ }^{386}$ SODRE, Nelson Werneck. Formação Histórica do Brasil. São Paulo: Brasiliense. 1962. p. 119

${ }^{387}$ Um exemplo bastante enfático desta historiografia tradicional sobre São Paulo é o livro de SYLOS, Honório de. São Paulo e seus caminhos. Editora McGraw-Hill do Brasil, 1976. O autor começa seu primeiro capítulo, chamado "Tempo de Vacas Magras" da seguinte maneira: "São Paulo foi, até a segunda metade do século passado [i.e. 1850!] (quem o ignora?) uma província pobre. Explica esse atraso o isolamento a que se viu condenada pela sua situação geográfica...". p 9 ss.
} 
fizesse duas caixas para ele transportar seus apetrechos, teve dificuldade de conseguir que um dos três marceneiros com quem entrou em contato fizesse tal obra. O viajante só teve sucesso quando recorreu ao governador da província, contando o seu caso ${ }^{388}$.

Este episódio demonstra como as condições de produção dos artífices em São Paulo cumpriam lógicas de interações sociais locais, de compadrio e clientelismo tanto para o fornecimento das matérias-primas pelos consumidores, quanto pela influência do poder politico - muitas vezes abusivo -, e menos as lógicas de mercado. Igualmente deve-se considerar o tempo social do trabalho pré-industrial, do qual o próprio naturalista havia sido notificado: "apesar de existirem bons artesãos em São Paulo, eles não tinham o costume de trabalhar com rapidez e nem de cumprir seus compromissos em prazos certos" ${ }^{389}$. Se isto impressionou negativamente o francês, que recriminou a indolência desses paulistas como fruto da "imprevidência da raça indígena", devemos inclusive notar que ela não seria muito diferente do que se praticava na própria Europa antes do regime das fábricas, como revela a clássica obra de E. P. Thompson ${ }^{390}$.

Ponderadas essas camadas de historiografia fortemente consolidadas, precisamos primeiramente reforçar para o recorte que nos compete que a cidade, mesmo nos começos do século XVIII não deixou de ter oficiais mecânicos e de atrair novos migrantes portugueses. Ainda que muitas famílias tenham, de fato, partido de São Paulo para outras regiões atrás das oportunidades e dos sonhos de enriquecimento, aos poucos, adensava-se a população de São Paulo e principalmente de seus entornos ao longo dos caminhos para as Minas e nas fluidas fronteiras das terras indígenas ${ }^{391}$.

\footnotetext{
${ }^{388}$ SAINT-HILAIRE. Auguste de. Viagem à Província de São Paulo e resumos das viagens ao Brasil, província Cisplatina e Missões do Paraguay. Tradução e notas de Rubens Borba de Morais. São Paulo: Martins Editora/EDUSP, 1972. p. 180ss.

389 Idem, ibidem.

390 Segundo Thompson, no século XVIII "o processo do capitalismo e a conduta não econômica baseada nos costumes estão em conflito, um conflito consciente e ativo (...). por isso, podemos entender boa parte da história social do século XVIII como uma série de confrontos entre uma economia de mercado inovadora e a economia moral da plebe, baseada no costume" in THOMPSON, E. P. Costumes em comum. São Paulo: Companhia das Letras, 1998, pg 21. Igualmente citamos a pesquisa de Francismar Carvalho a respeito dos tempos próprios do trabalho dos mestiços para o contexto das viagens monçoeiras. CARVALHO, Francismar Alex Lopes de. Viajantes, mareantes e fronteiriços: relações interculturais no movimento das monções séculos XVIII. Mestrado em História - Universidade Estadual de Maringá, Paraná, 2006.

${ }^{391}$ Notado por NAZZARI, Muriel. Oliveira, Lólio Lourenço de (trad). O desaparecimento do dote: mulheres, famílias e mudança social em São Paulo, Brasil, 1600-1900. São Paulo: Companhia das Letras, 2001, p. 85 e SCARATO, Luciane Cristina. Caminhos e descaminhos do ouro nas Minas Gerais: administração, territorialidade
} 
Os contra fluxos de retornados das Minas também existiam, trabalhando com o crescente comércio entre as regiões, atividade que igualmente permitia a formação de fortunas, muitas vezes mais perenes do que a de muitos faiscadores ${ }^{392}$. Deste modo, precisamos sempre ter em conta que nas fronteiras de colonização decerto havia mais indivíduos capacitados a produzir móveis e todo o aparato da vida material do que qualquer censo demográfico poderia indicar. Aliás, a pretensa escassez de oficiais mecânicos na cidade de São Paulo, se por um lado revela esse efeito de dispersão espacial causada pelo ouro, por outro indica que os artífices que se fixavam na cidade, bem como os quais eram "mineiros que não mineram"393, poderiam lucrar com sua permanência no ofício, dada a elevada demanda por esses serviços $^{394}$.

Um exemplo que nos indica a necessidade e presença perene de artífices em São Paulo, e a sua atuação na primeira metade do século XVIII, mesmo quando a Capitania havia sido extinta, foi justamente a elevação de São Paulo a bispado em 1746. Inclusive ocorreu a demolição em 1744 da velha igreja e ereção de um novo templo na Sé, cuja descrição revela esplendor e mesmo modernização, decerto a D. João $\mathrm{V}^{395}$ :

Esta igreja, que tem de comprido da porta principal até o seu arco do altar mor 157 palmos e de largo 506 cujas paredes são de taipa de pilão, tem 7 capelas ou altares. O maior também de taipa de pilão, pra a parte do sul onde esta o coro (....) cujo retábulo do altar mor de madeira é moderna com 4 colunas que tem os capitéis de talha dourada e os frisos a madeira

\footnotetext{
e cotidiano (1733 - 1783). Dissertação de mestrado. Universidade Estadual de Campinas. Campinas/ SP. 2009, p. 147 ss. ; HOLANDA, Sérgio Buarque de. Monções e Capítulos da expansão paulista. Organização de Laura de Mello e Souza e André Sekkel de Cerqueira. Notas de André Sekkel de Cerqueira. São Paulo: Companhia das Letras, 2014.

${ }^{392}$ Cf. MENZ, Maximiliano. Crédito e a economia colonial e SANTOS, Raphael. O ouro e a palavra. In: CARRARA, Angelo. À Vista ou à prazo: comércio e credito nas Minas Setecentistas.

${ }^{393} \mathrm{Na}$ feliz expressão de José Newton Meneses. MENESES, José Newton Coelho. Artes fabris \& ofícios banais: o controle dos ofícios mecânicos pelas câmaras de Lisboa e das vilas de Minas Gerais (1750-1808). Belo Horizonte: Fino Traço, 2013.

394 Poderíamos acrescentar a essa mirada geral de BARROS, Daisy. Um século....op. cit., 1982, p. 106 sobre a vida na cidade de São Paulo o fato de que nem todos os seus habitantes orbitavam em torno do ouro e a vida de desbravamento para a aquisição de riqueza. Lembremos que, se o grosso dos imigrados de Portugal para a colônia americana decerto buscavam o enriquecimento e o ideal de fidalguia, muitos outros foram para a colônia por coerção, fossem expulsos, fossem por falta de trabalho em Portugal. Assim, não obstante a forte atração que as promessas de enriquecimento com a mineração de ouro exercia sobre todo gênero de trabalhador que migrava para a América, parte dos oficiais mecânicos que já possuía estes conhecimentos prévios na metrópole teria a tendência a exercer a sua profissão na área colonial, da qual poderiam não só obter sustento, mas mesmo obter um bom cabedal dada a demanda geral pelos seus trabalhos.

395 ACMSP. Livro no. 20, Inventário 1747-1876, Paroquia de Na Sạ de Assunção de São Paulo, Catedral da Sé P.. 8ss. Grifos nossos.
} 
de mesmo retábulo, tudo dourado e o mais tudo é liso e pintado e fingindo pedra e encima tem uma tarja de talha dourada, pela parte posterior do Altar de $\mathrm{S}$. Miguel esta uma escada que segue para ir para a casa do claustro (?) a qual casa tem duas janelas de sacada para o pátio e tem no meio duas mesas de madeira lisa com suas gavetas e cobertas com um pano verde; tem mais a mesma casa uma bancada de 14 cadeiras em 4 peças e cobertas de tripé azulejos verdes um pano o dois panos de linha que cobre as mesmas cadeiras para livrar do pó. Tem mais mesma casa 3 retratos de meio corpo, a saber um do papa Benedito XIV, outro de EI Rei D. João V e outro de D. Bernardo, primeiro Bispo desta Igreja e Bispado

Decerto o trabalho que emanava com esse novo posto de poder e centralidade cultural da cidade deve ter atraído artífices não só pelos trabalhos de madeira, mas também para a produção e manutenção de todo o aparato litúrgico renovado, doado por D. João V ao bispo Bernardo Rodrigues Nogueira. Constavam no inventário, para citar apenas alguns exemplos ${ }^{396}$ :

Três mitras em uma caixa de jacarandá; quatro estantes pequenas para os missais, também de jacarandá; três escabelos pintados para os assistentes do prelado; uma escada de 3 degraus para se tirar a vela do candeeiro triangular, de jacarandá; uma cadeira episcopal em dois degraus pintada, de Nogueira e uma credencia do mesmo; dois confessionários novos; onze estrados espalhados pela igreja, Uma banqueta que foi de altar e está a apoio da porta principal; Um esquisse de pau torneado pintado de preto com seus frisos dourados e sua coberta de ruão preto; sacra do altar mor com sua taboa de trás e chapas de latão pesa tudo 8 libras e 110 oitavas tem coberta de ruão vermelho; um retábulo lavrado com suas candeias; naveta também lavrada que pesa uma libra e 120 oitavas e meia; Coroa imperial que pesa 41 oitavas; Resplendor de S. José antigo feito a moderna que pesa 37 oitavas; Um relógio de parede com sua competente caixa.

Mesmo que grande parte desses objetos tenha sido importada ${ }^{397}$, decerto eles influenciaram na produção local, mesmo no mobiliário doméstico. Sendo a

\footnotetext{
${ }^{396}$ Podemos ver no Livro de Receita e Despesa da Fábrica da Sé como a cada festa religiosa ou grande evento político ocorriam demandas por novas obras e reformas na igreja, muitas vezes com recursos enviados pelos imperadores de maneira a propagandear sua imagem e seu poder e conquistar o apoio e fidelidade de seus súditos por esta dádiva, numa "troca de dons". ACMSP. Livro da receita e despesa da Fabrica da Sé de 10 de janeiro de 1748 a 18 de janeiro de 1817 (manuscrito). Ordem: 02-03-042. 1768. Fl. 86 e 89. Grifos nossos.

${ }^{397}$ Veremos nos próximos capítulos a passagem da chegada do bispo em São Paulo e a importância simbólica e politica conferida a ela pela câmara, que manda arrumar os caminhos de Cubatão para a "condução dos trastes" do Reverendo. APESP. RG. vol. 8 pg. 289.
} 
igreja o principal polo de sociabilidade e distinção no século XVIII ${ }^{398}$, este era o espaço modelo para os habitantes captarem e reproduzirem as sub-reptícias posturas, atitudes, símbolos e adornos exteriorizadas pelos indivíduos das mais variadas classes e grupos sociais. A chegada em peso de novos objetos sacros de distinção a São Paulo com o feitio "moderno", não teria escapado à admiração e desejo dos civis. ${ }^{399}$

Na segunda metade do século XVIII observamos ainda mais mudanças nos ofícios mecânicos em São Paulo, através das alterações da politica administrativa encarnadas por D. Luiz Antônio de Souza Botelho Mourão, o Morgado de Mateus. Podemos apontar vários macro-fatores que concorreram para a potencialização da economia paulista ${ }^{400}$. No tocante ao nosso estudo específico, vemos como o trabalho dos oficiais mecânicos foi estimulado pelo Morgado de Mateus dentro de suas medidas para alavancar o desenvolvimento urbano e mesmo para povoar o Oeste no contexto das guerras com a Espanha. Maria Helena Flexor mostra que o Morgado recorrentemente falava na necessidade de mais oficiais mecânicos na cidade - e mais fixos - e também de regulamentar os seus trabalhos para a reestruturação da capitania paulista e nos esforços de guerra no Oeste ${ }^{401}$.

A posição discursiva do próprio Morgado de Mateus deve ser aquilatada, pois suas cartas descrevendo a capitania em duras penas possuem uma forte retórica de captação de recursos a partir do governo metropolitano, e serviram acriticamente de base para grande parte da historiografia ressaltar a pobreza paulista ${ }^{402}$. Ao considerar a dispersão populacional enquanto "índice de anarquia governamental e pobreza", D. Luiz observa, em 1766, que: "Conta esta cidade atualmente, segundo

\footnotetext{
398 Cf. CARVAlHO, Mônica Muniz Pinto de. A cidade de São Paulo no século XVIII. Uma sociabilidade constituída em torno de símbolos do poder. São Paulo, dissertação de mestrado - FFLCH-USP, 1994. e ALGRANTI, Leila. Famílias e vida doméstica... op. cit. 1997.

${ }^{399}$ Como diz PEREIRA, Danielle Manoel dos Santos. Autoria da Pinturas llusionistas... op. cit. 2017, é difícil de corroborar a visão de pobreza da capitania inclusive em igrejas como a da matriz de Itú, sendo que "Adentrar o espaço da igreja matriz é comprovar que não havia nada de pobre, ingênuo ou popular na arte colonial paulista. Sim os paulistas seguiam o conceito do horror vacui de perto." P. 318.

400 Entre elas estão as reformas que o novo Capitão General ilustrado implantou devido à necessidade de enfrentar os inimigos espanhóis durante a Guerra dos Sete Anos (1756 - 1763) que repercutia nas terras da colônia do Rio Grande, no sul, bem como as ligações com o Centro-Oeste. Também fez parte das alterações trazidas pelo Morgado a implantação da lavoura de cana açucareira na região paulista com maior fôlego, de maneira a incrementar a infra-estrutura na sua ligação com as áreas de exportação e das Gerais e a contribuir com a riqueza de seus comerciantes, os quais já eram prósperos desde antes da chegada do Governador, como mostraram BLAJ, Ilana. A trama das tensões... op. cit. 2002 e BORREGO, Maria Aparecida de Menezes. A teia mercantil... op. cit. 2010.

${ }^{401}$ FLEXOR, Maria Helena Occhi. Mobiliário baiano. Brasília: IPHAN/ Projeto Monumenta. 2009, p. 615

${ }^{402}$ Cf. BORREGO, Maria. A teia mercantil... op. cit. 2010. P. 15.
} 
lista que mandei tirar, de 392 fogos, 649 homens e 867 mulheres", número que decerto era reduzido comparando-se, especialmente com os arraiais e cidades mineiras do período. Não obstante, continua o Capitão-general contabilizando que "a sua freguesia que se estende a doze léguas em 899 fogos, em que se compreendem 1748 homens e 2900 mulheres" 403 404. Aos governadores e à administração metropolita isto não era nada bom, denominando-se nas Cartas Régias de 1765 estas populações de "vadios dispersos ou que vivem em sítios volantes”. Assim, podemos elucidar uma configuração típica da vida material colonial que os historiadores consideraram como pobre e desabitada, reproduzindo muito da visão dos administradores críticos às condições locais e prosélitos da fixação da população de modo a melhor controlá-la e fazê-la seguir as estruturas legais, decerto podendo arrecadar mais impostos e manter seu status quo ${ }^{405}$.

Acreditamos que a visão de ineficiência e ausência de artífices da madeira em São Paulo merece também ser relativizada tendo-se em conta a configuração espacial da cidade paulista, tal como mapeado com acuidade no trabalho de Amália dos Santos ${ }^{406}$, bem como sua posição conjunto das capitanias do Sul ${ }^{407}$.

Note-se que nem todas as regiões da cidade, divididas em Companhias de Ordenanças, contavam com carpinteiros, carapinas, torneiros ou serralheiros. Segundo os Maços de População de $1798^{408}$, no Bairro da Nossa Senhora do Ó,

\footnotetext{
${ }^{403}$ APESP. DI, v. 73, pp. 62 e ss.

404 FLEXOR, Os núcleos urbanos planejados do século XVIII: Porto Seguro e São Paulo. Bahia: Salvador Universidade Federal da Bahia, Centro de Estudos Baianos, 1989. A autora fornece exemplo expressivo da itinerancia urbana paulista. Mostra a autora como em 1797 na freguesia de Jaguari só havia 25 fogos no centro, contando toda a freguesia 1.106 fogos, ou seja, apenas 2,2\% da povoação estava na "capital", dirigindo-se a ela, certamente nas ocasiões festivas, para comercializar seus excedentes de produção ou para outras necessidades, como a aquisição de mantimentos e apetrechos que não pudessem fabricar por si, ou que pudessem obter através de seus vizinhos, onde decerto existiam produtores empíricos de casas, móveis e equipamentos

405 BACELLAR, Carlos de Almeida Prado. As famílias de povoadores em áreas de fronteira da Capitania de São Paulo na segunda metade do século XVIII. Revista Brasileira de Estudos de População, v. 34, n. 3, p. 549-566, 2017.

${ }^{406}$ SANTOS, Amália Cristóvão dos. Em obras: os trabalhadores da cidade de São Paulo entre 1775 e 1809. 2013. Dissertação (Mestrado em História e Fundamentos da Arquitetura e do Urbanismo) - Faculdade de Arquitetura e Urbanismo, Universidade de São Paulo, São Paulo, 2013. p. 123 ss.

${ }^{407}$ Este interim foi estudado por Maria José Goulão, mas ainda merece estudos mais exaustivos, apontando a importância de tratar em conjunto as capitanias do sul em suas interconexões em um jogo de escalas com as historias locais das cidades e vilas em suas especificidades locais. GOULÃO, Maria José. "La Puerta Falsa de América". A influência artística Portuguesa na região na Região do Rio da Prata no período colonial. 1 vol. Tese de Doutoramento na Faculdade de Letras da Universidade de Coimbra, 2005.
}

${ }^{408}$ APESP, Maços de População. 1798. 
local onde havia 152 fogos, não havia artífice algum da madeira. No centro da cidade, no mesmo ano, viviam $17^{409}$.

Por sua vez, em 1807 só foram contados três carpinteiros para os enormes bairros de N. S. do Ó e Penha de França, locais que contavam com 153 e 227 fogos respectivamente. Igualmente, só aparecia um carpinteiro para toda a Santana de 114 fogos. Não obstante, concentravam-se 25 artífices na $2^{\underline{a}}$ e $3^{\text {a }}$ Capitanias de Ordenanças, na região do centro da Cidade e mais 10 só na Rua de São Bento e imediações.

Dentre os artífices da madeira que pudemos encontrar nos maços de população, notamos inclusive transições entre os artesãos listados nesses anos em cada bairro. É o caso de Salvador, filho de Francisco Lopes de Barros, um dos poucos carpinteiros residentes na Penha de França. Salvador "se mudou para a cidade trabalhar pelo ofício" de seu pai ${ }^{410}$. Francisco Lopes de Barros, por sua vez, era bastante estável no bairro de Santana, ao que consta aparecer nos censos de 1807, 1815 e $1818^{411}$. Dada a indispensabilidade do trabalho dos artífices da madeira para a vida material da sociedade paulistana, esses dados evidenciam que os habitantes desses bairros precisavam requisitar artífices de outras regiões para trabalhar em suas casas, ou deles se compravam móveis e outros produtos em suas tendas ${ }^{412}$.

Encontramos justamente referências sobre a atuação dos artífices trabalhando fora de suas tendas e realizando trabalhos mesmo em outras vilas. Num requerimento, o Padre Joaquim José de Siqueira pedia que fosse aliviado da multa imposta pelo Fiscal do Norte por ocasião do concerto de uma sua propriedade cita na Rua da Feira. A multa teria se dado pelo motivo de ignorar a Postura o carpinteiro responsável pela obra, "que não reside nesta Capital, mas sim em Juqueri". Dado o evidente transito e desconhecimento da norma pelo artífice, eles foram aliviados da multa ${ }^{413}$.

\footnotetext{
${ }^{409}$ APESP, Maços de População. 1798. Contando a 2ª e $3^{a}$ capitanias de Ordenanças.

${ }^{410}$ APESP, Maços de População. 1818.

${ }^{411}$ APESP, Maços de População. 1807, 1815, 1818.

${ }^{412}$ Notamos com esse exemplo singular da mudança de Salvador para cidade servir de carpinteiro que a lógica de concentração dos serviços e bens no centro da cidade operava em São Paulo, sendo decerto um componente de desigualdade entre as regiões, como pode observar John Monteiro no que tange às fortunas e impostos. MONTEIRO, John Manuel. Distribuição da Riqueza e as Origens da pobreza rural em São Paulo (século XVIII). Revista Estudos Econômicos, São Paulo, v.19, 1989, p. 121.

${ }^{413}$ APESP. Atas. Vol. 40 p. 111.
} 
Outra prova de que os carpinteiros paulistas estavam em forte transito no período é o fato de que eles estavam em considerável demanda para a construção de engenhos de açúcar ${ }^{414}$. Os altos preços do açúcar no cenário internacional durante as guerras europeias, sem contar os crescentes públicos consumidores na nova sede da Corte, foram de grande estímulo à produção açucareira e de todos os aparatos necessários à essa indústria, bem como dos bens domésticos dos enriquecidos fazendeiros. Extrapolando apenas a cidade de São Paulo, o número de oficiais mecânicos aumentara consideravelmente entre os finais do século XVIII e inícios do XIX em outras cidades da capitania, como Itu, Campinas e mesmo no Vale do Paraíba, com o incremento da produção cafeeira, em cidades como Areias ${ }^{415}$.

Também devemos considerar a itinerância além de São Paulo como um fator que os camaristas não apreciavam quando criticavam a falta de artífices na cidade, desde os mais iniciais anos da vila. Já pudemos conferir os exemplos de Manuel Antônio da Cruz e de Estevão Ribeiro Garcia transitando por várias cidades enquanto exerciam seus trabalhos, mantendo pelo caminho redes contatos e de objetos. Assim, é necessário ponderarmos quando Flexor diz que "os oficiais mecânicos eram sedentários, deviam ficar, sem exceções, presos à sua cidade ou vila e pequena região de produção". Aliás, a própria autora ${ }^{416}$ notara como "especialmente no caso de São Paulo iam mecânicos os mais preciosos como: sangradores, carpinteiros, ferreiros, pedreiros e calafates, nas expedições, oficiais ou particulares", inerência que notamos continuar pelas vilas da capitania na procura de trabalhos ao longo do século XVIII. O trânsito dos artífices para além da cidade de São Paulo e seu termo também é revelado por outros autores para o século

\footnotetext{
${ }^{414}$ Segundo RABELLO, Elizabeth Darwiche. Os ofícios mecânicos... 1977, P. 585 e KUZNESOF, Elizabeth Anne. Household economy... 1976. P. 119. Aliás, nota esta que reclamações contra carpinteiros durante a construção dos engenhos eram bastante comuns no primeiro quartel do século XIX. Pois, se os moinhos não estivessem completos em tempo, os plantadores de cana sofriam perdas terríveis, já que sua perecível matéria-prima não poderia ser processada. Em 1818 Antônio da Silva Prado sofreu desta dificuldade e no outro ano ele ameaçou processar o carpinteiro que se ele não terminasse o moinho a tempo para a próxima colheita. Em alguns casos, aliás, nota-se como as relações de carpinteiros com senhores de engenho levavam a vantagens: em 1821 o capitão-major do Porto Feliz, requisitando que um carpinteiro fosse dispensado do serviço militar por que ele necessitava de seu serviço para edificar moinhos. PETRONE, Maria Schorer, A lavoura canavieira em São Paulo. 1968, p. 100 apud. KUZNESOF, Elizabeth Anne. Household economy... 1976. P. 120

${ }^{415}$ LUNA, Francisco Vidal, e KLEIN, Herbert. Evolução da sociedade e economia escravista de São Paulo, de 1750 a 1850. São Paulo: Edusp, 2006, p. 231.

${ }^{416}$ FLEXOR, Maria Helena Ochi. Ofícios, Manufaturas e Comércio. In SZMRECSÁNYI, Tamás. História Econômica do Período Colonial. 1993., P. 190.
} 
anterior, como José Carlos Vilardaga, Maria José Goulão e Aracy Amaral ${ }^{417}$. Evidenciam-se na cultura material essas conexões através de vasta gama de artefatos, práticas e costumes, por exemplo, tradições confeccionais escultóricas das imagens de santos chamadas paulistinhas ${ }^{418}$, levada por viajantes seguindo o rio Tietê até a bacia do rio da Prata e a região de Buenos Aires, que tem como símbolo desse intercambio a própria padroeira nacional, a escultura da Virgem de Luján ${ }^{419}$. Os exemplos mais elucidativos do transito de artesãos entre os impérios espanhol e português - tendo São Paulo como um dos eixos - foram mostrados por Maria José Goulão. Nota a autora que na própria Buenos Aires adotou-se móveis e hábitos domésticos adquiridos com os portugueses, os quais constituíam parte considerável da população portenha ${ }^{420}$.

A chegada da Família Real ao Brasil e a abertura dos portos a outras nacionalidades decerto foram fatores que estimularam a economia em São Paulo. Eudes Campos comenta que a mudança da corte foi muito estudada no plano macro das mudanças econômicas e politicas, mas ainda devem-se explorar os efeitos verificados na vida do povo comum em comunidades além do Rio de Janeiro, como em São Paulo ${ }^{421}$. Este autor evidencia aspectos dessas alterações nos aspectos materiais da cultura, como as mudanças de nomes de ruas e a impostação predial, as festas e lamentações públicas pelos nascimentos e falecimentos dos membros da família Real, a proibição das mantilhas e os móveis franceses da Marquesa de

\footnotetext{
${ }^{417}$ VILARDAGA, Jose Carlos. São Paulo na órbita do Império dos Felipes: conexões castelhanas de uma vila da América Portuguesa durante a União Ibérica (1580-1640). FFLCH/USP - Tese de Doutorado. 2010. GOULÃO, Maria José. "La Puerta Falsa de América". A influência artística Portuguesa na região na Região do Rio da Prata no período colonial. 1 vol. Tese de Doutoramento na Faculdade de Letras da Universidade de Coimbra, 2005. AMARAL, Aracy. A hispanidade em São Paulo: da casa rural à capela de Santo Antônio. São Paulo: Livraria Nobel, 1981.

418 Outras dimensões materiais do Planalto Paulista perpassaram no surgimento das manifestações culturais híbirdas no Centro-Oeste brasileiro, como as casas com rótulas e muxárabis em Pilar dos Goiases, as igrejas com torre de sino, separada do corpo da nave, inspirada nas capelas alpendradas paulistas. SCHUNK, R. Arte Colonial e Imperial da cidade de Santana de Parnaíba. 1. ed. Osasco: MB Gráfica, 2015.

${ }^{419}$ VILARDAGA, José Carlos. Imagens em trânsito: as virgens de Luján e Sumampa e os circuitos coloniais na América Meridional na primeira metade do século XVII. Anais do Museu Paulista: História e Cultura Material, v. 23, n. 2, p. 43-67, 2015. Ver também as mercadorias contrabandeadas de São Paulo rumo ao Paraguai em VILARDAGA, José Carlos. Na bagagem dos peruleros: mercadoria de contrabando e o caminho proibido de São Paulo ao Paraguai na primeira metade do século XVII. An. mus. paul., São Paulo, v. 25, n. 1, p. 127147, Abr. 2017.

${ }^{420}$ GOULÃO, Maria José. "La Puerta Falsa de América". Op. cit. 2005. AMARAL, Aracy. A hispanidade em São Paulo: op. cit. 1981.

${ }^{421}$ CAMPOS, Eudes. Ecos paulistanos da vinda da Família Real para o Brasil. In: Informativo do Arquivo Histórico Municipal. São Paulo: PMSP/SMC/DPH, março/abril de 2008. Disponível em: http://www.arquiamigos.org.br/info/info17/i-inter.htm. Acesso em: 20/05/2018.
} 
Santos $^{422}$. De fato não só chegaram móveis estrangeiros com essas mudanças, mas também não tardaram a chegar artífices de outras nações europeias em São Paulo, como vemos pelo registro do censo de 1815, já apareciam dois marceneiros ingleses em São Paulo. Na Rua de São Bento, (fogo 85) Guilherme Quirtins (sic), inglês, de 53 anos, solteiro. Note-se que vivia em um sobrado, sendo que habitavam "nos baixos" Manoel da Silva Carmo, de Coimbra, vendeiro; sua mulher e filha e um agregado $^{423}$. E na Rua do Rosário (fogo 33) Roberto Ovatim (sic), marceneiro natural da Inglaterra, de 24 anos, casado com Francisca Rosa, natural de São Paulo. Tinham uma filha, uma agregada e dois escravos: Miguel e Joaquina, ambos de 15 anos $^{424}$.

Buscando compreender nos emaranhados entre história e historiografia a posição social e atuação na idiossincrasia urbana paulista dos artífices da madeira, cabe entender a posição que tinham dentro de seu grupo especifico, levando em conta a sua regulamentação, suas interações sociais e aspectos étnicos da mobilidade social. Inicialmente, devemos considerar que, especificamente para São Paulo mesmo entre os mestres e oficiais nunca houve precisamente a organização em corporações de ofícios. Em realidade a divisão do exercício dos ofícios nunca foi muito respeitada nem na capital baiana, nem na fluminense, como nota Maria Helena Flexor ${ }^{425}$.

Sequer em Portugal havia uma divisão plena dos trabalhos. Como mostrara Lisye Reis em similar estudo para o contexto de Lisboa, também havia diversos casos de sobreposições de trabalhos e litígios entre corporações, a tal ponto de ocorrer em 1771 uma grande reforma na divisão representativa da Casa dos 24 com a separação de diversos corpos de ofícios em bandeiras de santos diferentes. Por exemplo, os carpinteiros de móveis e entalhadores foram tirados da bandeira de São

\footnotetext{
422 CAMPOS, Eudes. Os móveis franceses da Marquesa de Santos. In: Informativo do Arquivo Histórico Municipal. São Paulo: PMSP/SMC/DPH, março/abril de 2008. Disponível em: http://www.arquiamigos.org.br/info/info17/i-inter.htm. Acesso em: 20/05/2018.

Ano 3 N.17

${ }^{423}$ APESP. Maços de População, 1815. P. 8.

${ }^{424}$ APESP. Maços de População, 1815. P. 15.

${ }^{425}$ MARTINS, Mônica de Souza. Entre a cruz e o capital: as corporações de ofícios no Rio de Janeiro após a chegada da família real (1808-1824). Rio de Janeiro: Garamond, Prefeitura do Rio de Janeiro, 2009.
} 
José, onde disputavam representatividade com os carpinteiros de casas e colocados na bandeira de Nossa Senhora da Encarnação ${ }^{426}$.

José Newton de Meneses e Roberto Guedes também observaram semelhante fluidez na colônia, não só no prosseguimento das maleabilidades portuguesas, mas mais ainda nos contextos locais adaptativos das normas legais ${ }^{427}$. Vale neste caso lembrar a metáfora utilizada por José Newton de Meneses de que o modelo administrativo e legislador de Lisboa teria funcionado na "passividade de espelho", um "exemplo modular, adaptável a situações e contingencias dispares, ou como um exemplo remoto de justificativa ordenadora". A necessidade de adequação às realidades locais, especialmente nos contextos tão dispares da América nesta fronteira da colonização, fazia com que houvesse muitas manipulações do predicado pela metrópole ${ }^{428}$.

Para além da já comentada friç̧ão com os produtores não-oficiais, havia também clivagens entre os próprios mecânicos, como vemos no Regimento de 1780. Taxava-se não só pelo posto, como aprendiz, oficial e mestre, mas também pelo grau de habilidade, medida em "boas notas", que gerava subdivisões dentro de cada camada, mesmo no nível superior dos mestres $^{429}$ :

(...) [os senadores] ordenaram taxa do que devem levar de hoje em diante os mestres de carpinteiros e aprendizes de seus jornais por dia e assentaram todos uniformemente o seguinte:

Que os mestres examinados de boa nota levassem por dia de jornal $\$ 480$ réis;

Que os mestres examinados de menos nota ou merecimento levem de seu jornal por dia quatrocentos;

Que os oficiais do dito ofício de carpinteiro de boas notas levem de seu jornal por dia $\$ 320$ rs;

Que os oficiais do dito ofício de carpinteiro de menos nota pudessem levar de seus jornais por dia a $\$ 240$ rs;

\footnotetext{
${ }^{426}$ FLEXOR, Maria Helena Ochi. Ofícios, Manufaturas e Comércio. In SZMRECSÁNYI, Tamás. História Econômica do Período Colonial. 1993., p. 173. REIS, Lysie. "Os Homens Rudes e muito Honrados Mesteres", Revista da Faculdade de Letras: Ciências e Técnicas do Património, vol IV, Porto, (2005). 235-259.

${ }^{427}$ HOLANDA, Sérgio Buarque de (org.). História Geral da Civilização Brasileira: 0 Brasil monárquico - 0 Processo de Emancipação. 1.ed. São Paulo: Difel, 1962. t.II, v1. P. 26. Resume também Sergio Buarque de Holanda: "Como esperar a proliferação de grêmios, ao modo da Europa, em terras onde um senhor de escravo podia empregar seus negros e mulatos nas obras que bem entendesse, para negociar depois o produto de seu trabalho?".

${ }^{428}$ MENESES, José Newton Coelho. Artes fabris \& ofícios banais: o controle dos ofícios mecânicos pelas câmaras de Lisboa e das vilas de Minas Gerais (1750-1808). Belo Horizonte: Fino Traço, 2013. p. 173.
}

${ }^{429}$ APESP. Atas. vol. 17, p. 247. 
que os oficiais do dito ofício de carpinteiro mais somenos pudessem levar de seu jornal por dia 160rs e nada mais....

Eram assim obrigados "os mestres examinados a tirarem este regimento por traslado para observarem" e "não poderão de hoje em diante levar mais do conteudo nele debaixo das penas de serem presos e da cadeia pagarem 6000rs de condenação a metade para o concelho e a outra para quem vier denunciar ${ }^{430}$.

Encontramos para o caso lisboeta ainda uma outra categoria que gozava de mais prestígio: o de mestre marceneiro da Casa Real, como o fora Domingos Antônio da Silva elevado em 27 de setembro de $1824^{431}$. Este oficial teria não só como cliente a Casa Real, como não teria "vencimento algum da minha Real Fazenda, gozando somente de todos os privilégios, e isenções que como tal the pertencerem, e poderá ter as Armas Reais à sua porta", decerto um fator de grande importância na obtenção de clientes, dada a qualidade de seu trabalho estampado com as Armas Reais.

Porém, ao mesmo tempo em que havia este controle principalmente tributário em São Paulo, a organização regimental oferecia força representativa aos oficiais, já que Ihes era permitido ter representação na Câmara através de um Juiz de Ofício, eleito anualmente entre os pares, bem como um escrivão ${ }^{432}$, cargo exercido, por exemplo, por João da Mota Liver.

Como já apontara Maria Helena Flexor, o posicionamento dos oficiais mecânicos na sociedade paulista deve ser revisto, pois não necessariamente eram

\footnotetext{
${ }^{430}$ As penas por infração dos estatutos dos regimentos eram bastante altas, como comprova a condenação do alferes José Ferreira Leite, que por não ter comparecido ao Senado por ocasião da eleição de juiz e escrivão do ofício de carpinteiros foi multado em $\$ 300$ réis por desobediência, dado ter sido notificado pelo juiz do respectivo ofício. APESP. Atas. vol. 22, p. 575.

${ }^{431}$ ANTT. Domingos António da Silva Mestre. Marceneiro da Casa Real registro da mercê, 1824. PT/TT/RGM/F/0019/143583

${ }^{432}$ Decerto tal válvula de representação administrativa de indivíduos considerados de inferior status na sociedade de Antigo Regime, não deixava de gerar atritos. Prova-nos, por exemplo, requerimentos enviados em 1755 pelos juízes de mesa ou bandeira dos oficiais de carpinteiro do Rio de Janeiro ao Rei Dom José solicitando a confirmação do compromisso e regimento pertencente a sua corporação, de maneira que assim Ihes garantisse os meios de subsistência legal aos seus ofícios._ Projeto Resgate - Documentos manuscritos avulsos da Capitania do Rio de Janeiro. Arquivo Ultramarino. Rio de Janeiro 1755, Setembro, 6 documento no 4914.. Não obstante, três anos depois, em 1758, ainda estava em discussão esta questão do que se depreende da consulta do Conselho Ultramarino ao rei a respeito da confirmação daquele requerimento "para o bom governo dos ditos ofícios". Projeto Resgate - Documentos manuscritos avulsos da Capitania do Rio de Janeiro. Arquivo Ultramarino. Rio de Janeiro 1758, Março, 13, no 5300. E a palavra final dos Conselheiros indicava ao rei antes de se acatar ao pedido que se consultasse os pareceres dos oficiais da Câmara do Rio de Janeiro e do chanceler da Relação, de maneira a averiguar a conveniência do compromisso daqueles juízes de ofícios subalternos e se era conveniente para a Fazenda Real. Assim ficavam os ofícios mecânicos dos municípios subservientes aos poderes locais, corroborado pela estrutura de poder monárquica que emanava de Lisboa.
} 
gente da "raia miúda" como na terminologia reinol. Tal como analisado para os casos lusitanos e ainda notados para Salvador pela mesma autora, nota-se que eles eram um setor bastante multiforme, com alguns membros bastante modestos, mas outros portadores de bens de ouro e prata, importados, escravos aos quais delegavam trabalhos assim afastando-se do "vício mecânico", além de importantes relações sociais e crédito em praça. Assim, é um contrassenso equipará-los aos escravos como bem pondera Flexor ${ }^{433}$. Buscamos evidenciar essas variações mais de perto com a trajetória, bens e atividades dos artífices que pudemos rastrear: desde o endividado João Fernandes aos senhores de escravos João da Mota Liver e Nicolau Francisco Rosal.

A ausência de organização nos moldes corporativos e a condição social de classe inferiorizada pelo ofício e regulamentada de cima para baixo, foram fatores considerados pela historiografia como barreiras instransponíveis no seio da sociedade colonial ${ }^{434}$. Porém, elas não significavam que os artífices não tivessem a possibilidade de acessar a vida política, ainda ela fosse quase inexpressiva ${ }^{435}$. Pelo contrário, a participação dos oficiais mecânicos paulistas no governo da Câmara deu-se não tanto sob a forma de representação, quanto ativamente na condição de oficiais do próprio Senado ou como funcionários, gozando de prestígio e privilégios $^{436}$.

Exemplo de artífices da madeira exercendo cargos funcionais na Câmara vemos em 1717 quando José Correa da Silva, oficial de Carpinteiro foi eleito aferidor da cidade, recebendo "as varas e côvados, medidas, e meios-alqueires; a quem se entregarão os padrões que ha neste concelho" ${ }^{437}$.

A respeito da representatividade social dos oficias mecânicos também devemos considerar a importância das festividades religiosas. Como revelou Mônica

\footnotetext{
${ }^{433}$ FLEXOR, Maria Helena Ochi. Ofícios, Manufaturas e Comércio. In SZMRECSÁNYI, Tamás. História Econômica do Período Colonial. 1993. P. 178.

434 GUEDES, Roberto. Ofício mecânicos e mobilidade social: Rio de Janeiro e São Paulo (sécs. XVII-XIX). Topoi, v. 7, n. 13, jul.-dez. 2006, pp. 379-423.

${ }^{435}$ Como pondera Rabello, mas sem considerar o que significava na trajetória social do indivíduo e de seus pares. RABELLO, Elizabeth Darwiche. Os ofícios op. cit. 1977.

${ }^{436}$ Essa maleabilidade das estruturas regimentais no mundo colonial, aliás, foram notadas por Maria Helena Flexor com bastante minúcia na terminologia utilizada pelo Morgado de Mateus para descrevê-los: o invés de tais ocupações serem "desprezíveis" eram "desprezadas", isto é, abria-se margem para que estes indivíduos pudessem atuar nos espaços de poder, não obstante este mesmo governador ter sempre tintas carregadas sobre os exercício das profissões mecânicas em São Paulo. Cf. FLEXOR, Maria Helena. Ofícios, manufaturas... op. cit. 1993, p. 176.
}

${ }^{437}$ APESP. Atas. v. 8, p. 420. 
Muniz, elas cumpriam um papel agregador na urbanidade do século XVIII, e embora estes indivíduos não tivessem confraria, se uniam algumas vezes ao ano por ocasião dos desfiles aos quais eram obrigados a participar ${ }^{438}$. Esses atos públicos guardavam enorme importância na sociedade portuguesa em especial e na paulista em particular, dado que as formas de sociabilidade urbana, controle politico e distinção de status efetuavam-se à partir dos símbolos de poder desfilados durante as procissões nestas datas especificas, que propagavam as estruturas desta sociedade e reproduziam os seus laços e ordenamento ${ }^{439}$. Como pudemos ver pelo caso de João da Mota Liver, este marceneiro de largo cabedal tinha o destaque de ser porta-bandeira das Irmandades da Misericórdia e do Senhor dos Passos ${ }^{440}$.

Ainda se deve pontuar que a participação nos serviços camarários também poderia ser atribuída à melhoria das condições econômicas por parte desses artesãos, abrindo-lhes as portas para círculos de prestígio em suas localidades, fenômeno que se assemelha ao setor mercantil, como estudado por llana Blaj e Maria Aparecida Borrego para São Paulo, ainda que no caso dos oficiais mecânicos não se tenha observado a obtenção nem de semelhantes cabedais, nem a ascensão a cargos de prestigio muito elevados ou ligações com famílias tradicionais ${ }^{441}$.

Havendo visto que alguns dos artífices compulsados demonstravam pertencer ao rol de fiadores da cidade, esse dado já serve de comprovante do status desses indivíduos. Como observa Roberto Guedes, apenas as pessoas bem quistas na praça poderiam servir de fiadoras ${ }^{442}$. Encontramos exemplos onde os fiadores dos novos oficiais de carpintaria também eram oficiais, mostrando como se davam as

\footnotetext{
${ }^{438}$ Em São Paulo elas eram quatro: São Sebastião, Anjo Custódio, Santa Isabel, e o Corpus Christi, havendo sido regulamentadas desde a primeira correição que se fez a respeito dos ofícios mecânicos, datada de 1628.

${ }^{439}$ CARVALHO, Mônica Muniz Pinto de. A cidade de São Paulo no século XVIII. Uma sociabilidade constituída em torno de símbolos do poder. São Paulo, dissertação de mestrado - FFLCH-USP, 1994.

${ }^{440}$ Algumas notas sobre como eram essas procissões aparecem também nas Atas da Câmara: no terceiro e quarto dias de desfile em homenagem "pelo feliz nascimento do augusto filho da sereníssima Princesa do Brasil a Senhora Maria Thereza”, em 1811. APESP. Atas vol. 21 p. 258. Era o momento da brincadeira das cavalhadas, transcorridas no largo de São Gonçalo, onde iriam alguns carros levados pelas corporações de ofícios. O dos carpinteiros, por exemplo, era "um navio com suas danças à maruja" APESP. Atas. vol. 21, p. 261. Nota-se a influência dos carpinteiros de naus mesmo na interiorana Piratininga nessas práticas de tradição. Por sua vez, percebe-se também singularidades nas danças de outras corporações, como dos sapateiros, "que aparecerão com seus brincos, contradansas e cavallinhos de cestos".

${ }^{441}$ ABUD, Kátia Maria. Autoridade e riqueza. Contribuição para o estudo da sociedade paulistana na segunda metade do século XVIII. São Paulo: dissertação de mestrado FFLCH-USP, 1978. P. 52.

${ }^{442}$ GUEDES, Roberto. Ofício mecânicos e mobilidade social: Rio de Janeiro e São Paulo (sécs. XVII-XIX). Topoi, v. 7, n. 13, jul.-dez. 2006, pp. 379-423.
} 
inter-relações tênues de que fala Imizcoz Beunza ${ }^{443}$ entre os colegas de profissão. Em 1736 temos o registro do mestre João Fernandes pelo mestre examinado Romão Rodrigues ${ }^{444}$. Encontramos também fiadores recorrentes nos registros da Câmara e entre ramos diferentes de atuação. Por exemplo, Felipe Fernandes da Silva, escrivão da casa de fundição entre 1751 a $1756^{445}$ aparece como fiador tanto do mestre carpinteiro José Nunes Pinto em $1737^{446}$ quanto de Nicolau Francisco Rosal, oficial de entalhador, em $1736^{447}$, revelando mais ligações entre esses artífices que atuaram em São Paulo.

Apesar de não terem grande cabedal ou status social elevado, vemos como alguns carpinteiros tinham relações com pessoas de alta patente na sociedade paulista, evidente nas dívidas cruzadas como vimos nos vários inventários e também nos registros de fiança, como João Fernandes, oficial de carapina e o Capitão Manuel Luiz Ferráz, seu fiador em $1734^{448}$.

Além da melhoria de condições dentro das profissões e no meio administrativo, vemos vários casos dos oficiais mecânicos exercendo paralelamente outras atividades econômicas ${ }^{449}$. Para além dos casos de João da Mota Liver com o aluguel de casas e escravos artífices, Manuel de Oliveira, com plantação de feijão e Luís Rodrigues Lisboa com loja e escrava de ganho, temos também Antônio de Sousa, oficial de carpinteiro, que se achava ${ }^{450}$ :

Roçando no rocio desta cidade para cá da ponte grande para formar sitio e pasto aonde costumam as pessoas que vêm para esta cidade a vender seus mantimentos arranchando-se por não terem dinheiro para pagarem pastos e sem licença deste Senado.

Os Senadores mandaram que ele fosse notificado para não continuar com a roça em terra pública, e que tampouco fizesse valos e casas naquelas terras.

\footnotetext{
443 BEUNZA, José María Imízcoz. Introducción. CASADO, I.; RODRíGUEZ, J.; VEGA, D. Redes Sociales y económicas en el mundo bajomedieval. Valladolid: Castilla Ed. 2011.

${ }^{444}$ APESP. RG. vol. 5. $1735-1742$ p. 24

${ }^{445}$ APESP. Atas. vol 13. e vol. 14.

${ }^{446}$ APESP. RG. vol. 5, p. 33.

447 APESP. RG. vol. 5, p. 12

${ }^{448}$ APESP. RG.V.4. p. 573

${ }^{449}$ Aliás, não deixamos de encontrar também especializações, especialmente ao da segunda metade do século XVIII em diante e principalmente no começo do século XIX, como era o caso de Marciano Gomes, descrito nas Atas da Câmara como "mestre de fazer pontes" APESP. Atas. vol. 24, 1826-29, p. 284. Este chegava a cobrar $500 \$ 000$ réis para a feitura de uma ponte, sem a sua mão de obra e de seu escravo, valor bastante expressivo APESP. Atas. Vol. 24, p. 275.

${ }^{450}$ APESP. Atas. Vol. 15, p. 529.
} 
Igualmente encontramos Nicolau da Silva, mestre torneiro, que fora cumplice no corte de carne de uma reze do mestre Manuel, oficial de ferreiro, ocultamente em casa de Angela de Siqueira ${ }^{451}$.

Tal como mostrado por Kátia Abud, vemos que alguns oficiais mecânicos conseguiam mesmo alcançar elevado cabedal com o exercício de suas profissões em São Paulo. Ademais, devemos ainda considerar que outras formas de enriquecimento, distinção e melhoria de status estavam em jogo nessa sociedade, não necessariamente indicadas pelo cabedal: a possibilidade de delegar a escravos ou índios serviçais o trabalho miúdo e ainda poder lucrar com o seu serviço, o que não ocorria no sistema corporativo no Reino com os aprendizes de ofício, sobre os quais não se podia lucro com o serviço durante o estágio de aprendizado ${ }^{452}$.

De fato, pontua Flexor que por muito tempo a historiografia gerou distorções no entendimento sobre os oficiais mecânicos no seio da sociedade colonial, dada as generalizações sobre a seu status. Fazia-se a ideia de que eles não tinham nem remotas possibilidades de ascensão social.

Nota Roberto Guedes que "na colônia brasileira, a hierarquia derivada da escravidão se acopla à estamental" e desta maneira nesta sociedade em formação adaptativa nos trópicos, o que exclui ou inclui não era tanto a atividade exercida, mas principalmente a cor e/ou a condição social ${ }^{453}$. E de fato vimos como vários dos artífices inventariados possuíam escravos, constituindo estes uma classe ainda mais inferior que a dos "pobres do reino" ${ }^{\text {"54 }}$, na qual estes artífices se apoiariam para se projetar socialmente. A julgar pelos inventários que analisamos, vemos como a maioria dos que tiveram boa condição social - ao ponto de terem os bens arrolados em seus inventários - eram brancos e reinóis, ficando os artífices negros e mulatos pobres obscurecidos nos registros ${ }^{455}$.

\footnotetext{
${ }^{451}$ APESP. Atas vol. 12, p. $232 .$.

452 MENESES, José Newton Coelho. Artes fabris \& ofícios banais: o controle dos ofícios mecânicos pelas câmaras de Lisboa e das vilas de Minas Gerais (1750-1808). Belo Horizonte: Fino Traço, 2013.

${ }^{453}$ GUEDES, Roberto. Ofício mecânicos e mobilidade social: Rio de Janeiro e São Paulo (sécs. XVII-XIX). Topoi, v. 7, n. 13, jul.-dez. 2006. P. 398.

${ }^{454}$ MENESES, José Newton Coelho. Artes fabris \& ofícios banais: op. cit. 2013., p.85.

455 Elizabeth Rabello nota inclusive que algumas profissões tinham composições marcantemente raciais, algumas dominadas por negros outras por brancos. Em São Paulo os brancos predominavam como ferreiros e oleiros e os mulatos nos ofícios de carpinteiros, alfaiates e sapateiros e os negros nos ofícios de pedreiros. RABELLO, Elizabeth Darwiche. Os ofícios mecânicos e artesanais em São Paulo na segunda metade do século XVIII. Revista de História, n. 112, 1977, p 586. Sérgio Buarque de Holanda também atentou para a composição étnica dos oficiais mecânicos em São Paulo, notando grandes mudanças ao longo do tempo. Em 1765, 75\% eram brancos, $18 \%$ negros e mulatos, e apenas $7 \%$ eram "bastardos", i.e. mestiços de índios e brancos. Já os
} 
Por fim, já não podemos ver muitas das obras desses artífices dada a destruição de grande parte dos templos paulistas e de remanescentes do mobiliário, certamente tão desprezados quanto as casas e igrejas de taipa no advento da cidade moderna. Mas decerto vale contemplar remanescentes como o altar feito por Luís Rodrigues Lisboa e seus escravos, bem como as poucas e esquecidas "Casas Bandeiristas" e os raros móveis que nos restaram do período, espalhados por diversos museus para decidir se eram assim tão parcos e ineficientes esses construtores da serra acima.

\subsection{Fim dos códigos e continuidade das práticas.}

Segundo Mônica Martins, a mudança da Corte para o Brasil trouxe mais dinamismo ao mercado interno, decerto estimulando o trabalho dos artífices principalmente no Rio de Janeiro ${ }^{456}$ e como vimos, também com o aumento do número desses profissionais em São Paulo. Porém, esse dinamismo trouxe consigo ambiguidades para os artífices, pois as vantagens foram crescentes aos grandes comerciantes e as mudanças de pensamento econômico foram progressivamente retirando os privilégios monopolistas das irmandades e se cristalizaram na constituição liberal.

Por fim, a mudança na legislação após o advento da Independência trouxe alterações na posição social dos artífices, dada a constituição liberal ter abolido o

\footnotetext{
dados para o começo do século XIX mostrava proporções muito diferentes, com $60 \%$ dos recenseados sendo negros ou pardos e os bastardos já inexistentes. Pesquisas mais aprofundadas sobre esta questão específica são necessárias, mas aventamos as hipóteses de que o aumento de negros e pardos na estatística poderia ser reflexo do aprendizado de ofícios se difundindo entre livres e libertos, bem como seria retrato do aumento do uso de escravos para a produção moveleira, que se avolumava a respeito do aumento da demanda já não mais regulados pelos poderes da Câmara . HOLANDA, Sérgio Buarque de. (pref.). In: QUEIRÓZ, Suely Robles Reis de. Escravidão negra em São Paulo, um estudo de Tensões provocadas pelo Escravismo no Século XIX. Rio de Janeiro: Instituto Nacional do Livro. José Olympio. 1977, p. xiii. Documentos Brasileiros, 176. Há que se relevar neste momento também a alteração na composição demográfica geral com o adensamento da produção canavieira e posteriormente cafeeira, levando ao aumento do número dos componentes africanos no território paulista, em movimento já evidenciado desde o século XVII por MONTEIRO, John. Os negros da terra... op. cit. 1994.. Igualmente nota Maria Flexor clivagem nitidamente racial entre os próprios oficiais tanto em São Paulo (baseada nos dados de Sérgio Buarque de Holanda) quanto em Salvador, onde os marceneiros brancos ascendiam aos cargos de juiz e escrivão de ofício, além de normalmente fazerem parte das tropas de auxiliares.

${ }^{456}$ MARTINS, Mônica de Souza N. Entre a cruz e o capital: as corporações de ofício no Rio de Janeiro depois da chegada da Família Real (1808-1824). Rio de Janeiro: Garamond Universitária, 2008.. e também FLEXOR, Maria Helena Ochi. Ofícios, Manufaturas e Comércio. In SZMRECSÁNYI, Tamás. História Econômica do Período Colonial. 1993.p. 188.
} 
modelo corporativista de trabalho. "Quando a Constituição do Império, em seu artigo 179, parágrafo XXV, determinou que ficavam abolidas [as corporações] e assim os seus "juízes, escrivães e mestres", com o que se julgava melhor resguardar a liberdade individual, as corporações de ofícios não encontram meios de prosperar“ 457 .

O recurso à História em Rede mostrou-nos de perto a fluidez desse sistema em São Paulo bem antes do advento liberal, com os artífices delegando aos seus escravos seus trabalhos e exercendo variadas atividades econômicas ${ }^{458}$. A alteração legal dos ofícios, talvez à maneira das lentas e progressivas leis abolicionistas, marca mais um prenúncio da alteração da posição social dos artífices e das mudanças globais que seriam mais intensas na segunda metade do século $X X^{459}$.

Todavia, esta conjuntura política deu-se de maneira parcial, sendo que os artífices em grande parte seguiram com suas práticas produtivas e mesmo com muitos procedimentos antigos em relação à Câmara, mesmo tendo saído da alçada administrativa desta em 1828. Foi o fim do código, mas não o fim das práticas, lembrando-se sempre da necessidade de destacar as diferenças entre prescrições normativas e as realidades locais diversas, circunstanciadas por predominâncias étnicas, econômicas, geográficas e políticas, como notado por Roberto Guedes ${ }^{460}$.

Ainda assim, anos mais tarde pode-se notar a continuação dos procedimentos antigos de exercício dos trabalhos dos artesãos e condutas administrativas, como obras publicas e solicitações. Um exemplo é fornecido por uma pitoresca noticia de jornal $^{461}$ :

Aconteceu depois, que uma ponte feita por um carpinteiro particular, o qual para se indenizar do seu trabalho impusera fortes e arbitrárias taxas aos passageiros, veio a danificar-se, a tempo que já a Câmara (...) tinha tomado a si o mantê-la; e sendo talvez mui fácil o concerta-la com pequena

\footnotetext{
${ }^{457}$ HOLANDA História Geral da Civilização Brasileira, Tomo 2: O Brasil Monárquico. Volume 1: O Processo de Emancipação. P. 26.

${ }^{458}$ FLEXOR, Maria Helena Ochi. Ofícios, Manufaturas e Comércio. In SZMRECSÁNYI, Tamás. História Econômica do Período Colonial. 1993, P. 175. Por exemplo, em Salvador onde os Juízes do Povo e Mestres haviam sido criados em 1641, eles já haviam sido extintos em 1713 através de Carta Régia solicitada pela própria Câmara municipal, pois tais oficiais estavam interferindo nos negocio da Câmara e opinando acerca os preços dos mais variados gêneros, dos impostos e mesmo levantando bandeiras nativistas pioneiras em prol dos direitos brasileiros.

${ }^{459}$ HOLANDA, Sérgio Buarque de (org.). História Geral da Civilização Brasileira: O Brasil monárquico - 0 Processo de Emancipação. 1.ed. São Paulo: Difel, 1962. t.Il, v1., p. 30.

${ }^{460}$ E evidenciado para outros contextos por BORREGO.

${ }^{461}$ Jornal O Farol Paulistano, n. 166, 22 de novembro de 1828, p. 697. bndigital.bn.gov.br/hemeroteca-digital. Acesso em: 20/08/2018.
} 
despesa, a câmara em vez de assim faze-lo, incumbiu o concerto ao mesmo Carpinteiro dando-Ihe o privilégio de impor de novo as mesmas taxas arbitrárias por espaço de quatro anos.

Aliás, na Bahia os próprios oficiais mecânicos foram os responsáveis pela fundação, mais para o fim do século, de Liceus de Artes e Ofícios após a extinção as Corporações de Ofícios em 1824 pela Constituição Liberal. Notamos como este grupo social manteve fortes relações de cooperação, ultrapassando os limites institucionais da sociedade do Antigo Regime a ponto de fundar instituições de ensino de acordo com os novos moldes liberais de ensino e em processo de conformação com as formas capitalistas de produção, ainda que com a especificidade local ${ }^{462}$.

O segundo quartel do século XIX assinala o momento em que a economia cafeeira no sudeste brasileiro já revelava sua importância, mas ainda não sua predominância, que viria a ter na segunda metade dos oitocentos ${ }^{463}$. Estruturais mudanças viriam com chegada em massa cada vez maior de imigrantes europeus variados e com o empenho administrativo de inserir os trabalhadores nacionais desclassificados nas lógicas modernizantes de produção, principalmente com a expansão da cidade e periferização das populações, especialmente as mestiças, de seus arrabaldes.

Os efeitos da economia cafeeira trouxeram transformações sociais, econômicas e políticas de forma global. A produção moveleira não ficou de fora desse contexto de transformações, impulsionada não só pelos conhecimentos produtivos inovadores que os imigrantes traziam consigo e as máquinas e ferramentas que eram importadas, mas também pelos modismos europeus, os quais cada vez mais chegavam aos olhos da população e passavam a ser adotados nos lares.

Cabe também contemplar a chegada a São Paulo e ao restante do país de mais móveis feitos nos centros produtores tradicionais, como o Rio de Janeiro que expandiu as mais variadas empresas com as medidas de favorecimento da indústria brasileira por D. João VI. De fato, o jogo das distinções sociais pelas várias capitais

\footnotetext{
462 REIS. Lysie. A liberdade que veio do ofício: práticas sociais e cultura dos artífices na Bahia do século XIX. Salvador: EDUFBA. 2012, p. 172.; FLEXOR, Maria Helena Ochi. Os Oficiais Mecânicos na cidade notável do Salvador. Actas VII Colóquio Luso-Brasileiro de História da Arte, 2005., p. 383.

463 LUNA, Francisco Vidal, e KLEIN, Herbert. Evolução da sociedade e economia escravista de São Paulo, de 1750 a 1850. São Paulo: Edusp, 2006.
} 
do Brasil sofreram impactos com a mudança de eixo do Império, o que decerto abriu espaço para mais artesãos atuarem na produção de apetrechos cotidianos cada vez mais necessários nas novas sociabilidades urbanas.

O mundo em que viveram esses oito artífices cujas trajetórias acompanhamos desintegrava-se através de mudanças nos mais variados planos: a regulação governamental, a disponibilidade de ferramentas, a circulação entre as cidades e capitanias, e mesmo as formas simbólicas de pertença àquela sociedade. Por exemplo, quando, por exemplo, em 1824 "foi determinado ao atual procurador mande fazer quatro fardamentos completos de cor nacional para o estado de São Jorge visto haver sido abolida a contribuição dos oficiais mecânicos pelo projeto de Constituição" 464 .

Encontramos raros casos em que os descendentes dos oficiais mecânicos atuando em São Paulo continuaram na profissão de seu pai ${ }^{465}$, como o caso de Francisco Lopes de Barros e seu filho Salvador no censo de 1818, o que seria mais uma indicação da ascensão social dos mesmos, de maneira intergeracional, como a forma mais típica de mudança em sociedades com traços estamentais ${ }^{466}$.

Mas fica a dúvida sobre em quais casos as futuras gerações dos oficiais produtores de móveis ou mesmo dos artífices "remendões" continuaram a trabalhar com suas pequenas lojas. Ou será que a concorrência com as grandes fábricas e com os móveis importados os teria feito abdicar dessa profissão? Teriam os marceneiros paulistas partido para outros trabalhos, ou mesmo vendido sua força de trabalho e conhecimento por um emprego assalariado? Quais seriam suas relações com os trabalhadores europeus que chegavam cada vez em maior volume ao longo do século XIX? E principalmente: de que maneira a materialidade dos móveis produzidos em São Paulo teriam sido alterados por essas enormes mudanças? Essas são histórias que merecem outras pesquisas.

\footnotetext{
${ }^{464}$ APESP. Atas. vol. 23, p. 199.

465 Maria Flexor já o notara, vendo padrão atípico de São Paulo em relação a outras capitanias que formavam gerações com a mesma profissão. FLEXOR, Maria Helena Ochi. Ofícios, Manufaturas e Comércio. In SZMRECSÁNYI, Tamás. História Econômica do Período Colonial. 1993, p. 186.

${ }^{466}$ Apontado por GUEDES, Roberto. Ofício mecânicos e mobilidade social: Rio de Janeiro e São Paulo (sécs. XVIIXIX). Topoi, v. 7, n. 13, jul.-dez. 2006, pp. 422. Ao contrário das sociedades burguesas, onde valoriza-se principalmente o self-made man, que enriquece por seu próprio trabalho.
} 


\section{CAPÍTULO 3. Consumo}

\begin{abstract}
E para todos os mercadores mais ricos, como era inevitável, a vida tornou-se um tanto tediosa e insatisfatória, levando-os a pensar que isto era devido as limitações dos mundos em que eles haviam se estabelecido - nenhum deles era inteiramente satisfatório. Ou o clima não era muito bom no final da tarde, ou o dia era meia hora mais comprido do que devia ser, ou o oceano era precisamente da tonalidade errada de rosa. Assim, surgiram circunstâncias favoráveis ao nascimento de uma espetacular indústria: a construção de planetas de luxo sob medida. (...) planetas de sonho - planetas de ouro, planetas de platina, planetas de borracha macia cheios de terremoto, todos eles encantadoramente feitos segundo as mais detalhadas especificações determinadas pelos homens mais ricos da Galáxia.
\end{abstract}

ADAMS, Douglas. Guia do Mochileiro das Galáxias. São Paulo: Sextante. 2004.p. 56.

\subsection{Formas de aquisição e circulação do mobiliário.}

Continuando a nossa análise multifacetada sobre o mobiliário utilizado pela sociedade paulista setecentista, cabe-nos falar do consumo desses móveis, fontes disparadoras de nossa pesquisa. Uma vez que tratamos de seus materiais, produção e agentes, devemos compreender a circulação dos bens entre quem fazia e quem comprava, e os vários estágios e receptores existentes nesse percurso.

Apesar de separarmos em capítulos diferentes, entendemos a produção e 0 consumo em um continuum dadas as suas interpenetrações. A divisão em momentos deve-se ao método analítico que propomos, visto a necessidade de compreender suas nuances com metodologias próprias. Durante muito tempo foi preponderante a compreensão de que a produção dita o consumo, mas cada vez mais se dá importância às idiossincrasias e decisões do consumidor informando e configurando a produção e o comércio onde pesam os fatores culturais de maneira fulcral, agindo inclusive na cadeia de produção muito antes de o produto chegar às mãos do consumidor ${ }^{467}$.

\footnotetext{
${ }^{467}$ Como enfatiza Mary Douglas e Baron Isherwood: "a ideia mesma do consumo tem de ser trazida de volta para o processo social, deixando de ser vista apenas como um resultado ou um objetivo de trabalho. 0
} 
A atenção ao momento de consumo deve ser ainda especial ao tratarmos de momento pré-industrial. $\mathrm{O}$ que entendemos por consumismo em nossa sociedade atual é bastante diferente das formas e propósitos pelos quais se adquiria um determinado bem antes das Revoluções Industriais e dos processos de modernização iniciados dentro do período abordado, desde a metade do século $\mathrm{XVIII}{ }^{468}$.

Com relação à cidade de São Paulo, sobre a qual larga historiografia tão enfaticamente cristalizou a visão de uma cidade vazia e isolada, onde quase não havia comércio pelo que se podia depreender do vazio das ruas e precariedade de

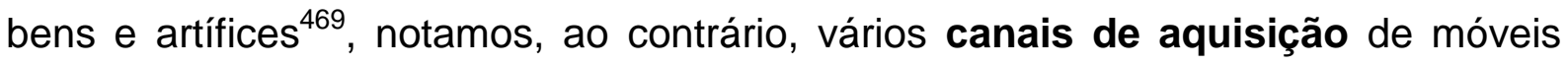
que configuraram o mercado do mobiliário doméstico em São Paulo.

Sendo a produção dos móveis bastante heterogênea, como já evidenciamos, pois não restrita somente aos oficiais mecânicos consequentemente o consumo dos móveis e as formas de venda também eram plurais. Em nossa pesquisa constatamos diversas maneiras de se obter móveis em São Paulo no período, formas que coexistiam e poderiam até mesmo se sobrepor umas às outras.

Para o contexto de Lisboa na segunda metade do século XVIII Carlos Franco também encontrou os diversos canais de aquisições de móveis naquela capital. Concentrando-se nas ruas do Ouro e da Prata as principais lojas de joias e artefatos domésticos dos mais variados tipos, lá estavam além dos ourives e mestres entalhadores. Por várias regiões da cidade onde habitavam os artífices, suas casas misturavam nas suas oficinas, onde ocorria a encomenda ou venda a varejo de móveis $^{470}$.

consumo tem de ser reconhecido como parte integrante do mesmo sistema social que explica a disposição para o trabalho, ele próprio parte integrante da necessidade social de relacionar-se com outras pessoas, e de ter materiais mediadores para essas relações." DOUGLAS, Mary, ISHERWOOD, Baron. O mundo dos bens: para uma antropologia do consumo. Rio de Janeiro: Editora UFRJ, 2004.

${ }^{468}$ De acordo com Baudrillard o consumo pré-industrial não se relaciona ao "consumismo" regido pelo volume e avidez em descartar. A dinâmica do adquirir era mais relacionada ao "consumar", ou seja, obter, adquirir um bem que fosse o mais durável o possível. BAUDRILLARD, Jean. $\mathbf{O}$ sistema dos objetos. São Paulo: Perspectiva, 2004. P. 26.

${ }^{469}$ Como observara Mônica Muniz, autores como Ernâni da Silva Bruno, Affonso Taunay e Alcântara Machado entendiam a cidade como "rural" e em decadência por que, até 1870, a vida ocorria entre as quatro paredes das casas e das chácaras e fazendas, e a vida pública, como eles a comparavam com o começo do século XX em que estavam situados historicamente, inexistia. Consideravam assim São Paulo a "cidade da falta", definindo as ruas como espaço ausente, esvaziado de conteúdo, sem sentido, inexistente. Cf. CARVALHO, Mônica Muniz Pinto de. A cidade de São Paulo no século XVIII. Uma sociabilidade constituída em torno de símbolos do poder. São Paulo, dissertação de mestrado - FFLCH-USP, 1994.pg.17.

${ }^{470}$ Em nossas pesquisas no Arquivo Nacional da Torre do Tombo encontramos alguns exemplos nos inventários orfanológicos desses artífices ou de suas esposas vivendo em épocas e espaços bastante diferentes entre si: 
Havia ainda lojas e armazéns especializados em produtos importados, vindos do Oriente ou do Brasil, a compra com contratantes de produtos específicos, os armazéns de fábricas locais, os mercados de rua, como a Feira da Ladra na Praça da Alegria, bem como outras formas de venda ocorridas com a divulgação indireta, como os anúncios nos jornais e também as "sortes de bilhetes", onde os prêmios podiam ser "pinturas de vários Mestres", bem como "rifas de trastes". Uma das formas mais importantes de venda, especialmente entre os mais ricos era através dos leilões, que ocorriam principalmente na Praça dos Leilões, bem como nos próprios Palácios onde os falecidos haviam residido.

A forma mais usual de se adquirir móveis em Piratininga certamente era através da encomenda com os oficiais mecânicos, vendedores registrados na câmara e praticantes de preços tabelados. Fruto da configuração normativa sobre a economia, os preços dos trabalhos e itens eram pautados por um "Regimento", isto é uma lista fixa dos valores que deveriam ser cobrados dos produtos ou serviços prestados pelos oficiais mecânicos. Como mostrou Flexor para São Paulo, os oficiais mecânicos deveriam retirar seus Regimentos na Câmara Municipal, pagando \$600 réis de taxa inicial ${ }^{471}$. Estas tabelas de preços serviam até o estabelecimento de novas posturas, apesar de que as licenças para exercer a profissão deveriam ser renovadas anualmente ${ }^{472}$.

Os Regimentos deveriam ser pendurados nas portas das tendas ou lojas para que todos tivessem conhecimento dos preços cobrados, e os infratores que não cumpriam com os valores estipulados estavam sujeitos a pesadas multas chegando a $6 \$ 000$ réis e mesmo reclusão na cadeia ${ }^{473}$. Em desobediência à regulamentação, muitos abusavam dos preços e jornais, inclusive incorrendo em pitorescas formas de subversão, como pendurar a tabela dos preços no alto das portas de maneira a impossibilitar que o consumidor tivesse conhecimento dos valores estipulados ${ }^{474}$.

entalhador Estevão da Silva morava nas calçadas de Santa Anna em 1704; Antonio Duarte, carpinteiro de seges, na rua Direita de São Bento da Saúde, freguesia de Santa Isabel, em 1752; Feliciano da Cruz, na Rua da Vinha, Freguesia das Merces, em 1799 e Francisco José da Paiva na Rua do Laureto, na N. S. da Encarnação, ao número 25, em 1823, época em que a cidade já contava com a numeração das casas. ANTT. Inventários postmortem dos Feitos Findos (1500-1800). As cotas são, respectivamente: PT/TT/IFF/020/0015/00010; PT/TT/IFF/005/0010/00003; PT/TT/IFF/006/0175/00006; PT/TT/IFF/006/0049/00003.

${ }^{471}$ FLEXOR, Maria Helena Ochi. Ofícios, Manufaturas e Comércio. In SZMRECSÁNYI, Tamás. História Econômica do Período Colonial. 1993. P. 182.

472 APESP. Atas. v. 5 p. 185.

${ }^{473}$ FLEXOR, Maria Helena Ochi. Ofícios, Manufaturas e Comércio. In SZMRECSÁNYI, Tamás. História Econômica do Período Colonial. 1993. p. 189.

${ }^{474}$ APESP. DI. v. 23 nota 8 p. 292. 
A maior parte destas posturas era fruto de alterações daquelas vigentes anteriormente, com novas adições feitas periodicamente. E não era um processo emanado simplesmente de cima para baixo, pois os próprios oficiais mecânicos pediam aos senadores da Câmara alterações, através de sua instância representativa, os juízes de ofício. Aos juízes também cabia em determinadas ocupações comprar os materiais para serem vendidos a preços menores aos componentes do corpo sob seu controle ${ }^{475}$.

Segundo os Regimentos, algumas atividades recebiam pagamento por peças elaboradas como alfaiates, sapateiros, ferreiros, marceneiros. Outras eram pagas por jornais diários, como os carpinteiros e pedreiros ${ }^{476}$.

Os preços não previstos nas taxas previamente estipuladas eram então discutidos pela Câmara que pedia uma avaliação do Juiz de Ofício ou de uma pessoa perita. Para além do tabelamento, nota Flexor que o preço de obras mais luxuosas era acertado entre o encomendante e o produtor diretamente ${ }^{477}$. Nesse aspecto vimos já pelos inventários dos oficiais mecânicos como haviam dívidas por trabalhos variados, seja encomenda de peças ou de estruturas sacras. Este aspecto de negociação deveria ser tanto mais presente até o inicio do sec. XVII, quando o pagamento dos produtos dos ofícios mecânicos era feito em espécie, dada a crônica falta de numerário na colônia. Mesmo com a abertura das casas de fundição e maior circulação de moeda, continuava-se a comercializar nos séculos seguintes das duas formas $^{478}$.

Este é um aspecto sobre o qual podemos traçar comparativo com estudos para a Inglaterra do século XVIII. País onde a imprensa teve grande circulação muito antes do Brasil, a noção de Politeness dos agentes da época guiava e estruturava os anúncios de venda dos mais variados produtos em folhetos, numa economia onde já se prenunciava o Liberalismo. As convenções, normas e linguagens "polidas" estavam presentes nos anúncios e no trato do vendedor diretamente com seus clientes, sendo a boa apresentação e temperança na maneira de se portar fatores essenciais durante o processo de propaganda e venda. Se atualmente 0 consumo de massa, despersonificado e cada vez mais feito à distância, alterou as formas e concepções sobre o que consumimos, no período pré-industrial a boa

\footnotetext{
${ }^{475}$ FLEXOR, Maria Helena Ochi. Ofícios, op. cit. 1993. p. 183

${ }^{476}$ FLEXOR, Maria Helena Ochi. Ofícios, op. Cit.. 1993. p. 188

${ }^{477}$ FLEXOR, Maria Helena Ochi. Ofícios, op. cit. 1993. p. 187.

${ }^{478}$ APESP. DI. V. 45, p 133.
} 
compostura nos mais variados aspectos, desde a linguagem empregada nos anúncios, os gestos e qualidade dos serviços corteses na loja do vendedor ${ }^{479}$, até os próprios produtos que transmitiam o valor de polidez pesavam às vezes mais do que a pretensa "opção racional" de quem buscava adquirir pelos melhores preços. Inclusive o rol de clientes anteriores de importância, como reis, nobres, clérigos e os burgueses em ascensão, aos quais o mercador ou o produtor havia vendido, servia para lustrar o seu "currículo", chamando mais clientes na busca por distinção e produtos de qualidade, certificada pela gravidade do consumidor famoso ${ }^{480}$.

Acreditamos que os casos já citados de João da Mota Liver e Nicolau Francisco Lisboa, os quais executaram obras em importantes igrejas da cidade de São Paulo contavam através destas obras com importante fator atrativo de novos clientes, dada a exibição pública de seus trabalhos e a distinção social agregada às obras do espaço sacro, além de possuírem crédito na praça, dadas as suas dívidas ativas e passivas com diversas pessoas, inclusive de alto status como clérigos.

Para além do teor econômico e regulatório vemos que a ocasião de compra também era coberta de tabu social, como depreendemos das memórias de Maria Paes de Barros, publicadas em 1946 quando a autora já alçava 94 anos de idade e cujas preciosas e detalhistas memórias chegam a remontar à década de 1850 e a práticas ainda mais antigas.

Ao narrar a vida das mulheres em São Paulo na condição de agente dos fatos, diz que ${ }^{481}$ :

A parte feminina da família, sobretudo, levava vida quase unicamente restrita ao lar. A senhora só saía à rua pelo braço do marido, as meninas unicamente com os pais ou parentes idosos. O pretexto único eram as visitas, pois as compras eram feitas pelos pajens, visto que uma senhora nunca entrava numa loja.

Igualmente notou semelhante tabu Neil McKendrick, ao estudar as mudanças no consumo na Inglaterra do século XVIII, onde o grupo das mulheres de elite vivia em transições causadas pelos novos hábitos de consumo. Se antes da "Revolução

\footnotetext{
${ }^{479}$ FORTY, Adrian. Objetos de desejo. Design e sociedade desde 1750. São Paulo: Cosac \& Naif, 2007.

480 STOBART, Jon. Selling (through) politeness: advertising provincial shops in eighteenth-century England. Cultural and Social History, v. 5, n. 3, p. 309-328, 2008..

${ }^{481}$ BARROS, Maria Paes de. No Tempo de Dantes. 1946. in MOURA, Carlos Eugênio Marcondes de. (org). Vida Cotidiana em São Paulo no XIX. São Paulo: Ateliê. 1999. p. 91. Grifos nossos.
} 
do Consumo" 482 elas raramente frequentavam as lojas de rua, passavam, na metade do século em diante, a frequentar mais as lojas de retalho dada a necessidade de trocar presentes entre os novos círculos de amizades que cresciam à proporção das formas de sociabilidade domésticas e citadinas. As lojas também se tornavam espaços mais abertos ao lazer e à permanência dos clientes, com reformas que as dotaram de vitrinas e confortáveis móveis, além da proliferação de cafeterias e lojas de chá, tão importantes para a circulação de ideias e expansão da esfera pública de debates naquele século.

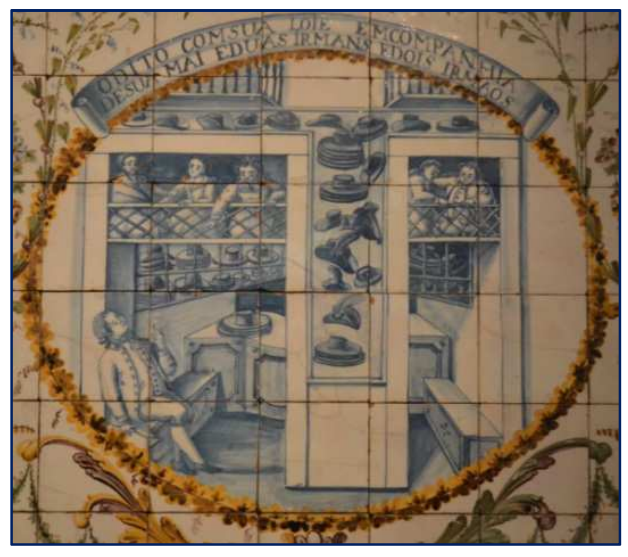

Figura 112: História do Chapeleiro António Joaquim Carneiro. C. 1790. Museu do Azulejo de Lisboa. Foto do autor.

Exemplo de loja de chapeleiro enriquecido em Lisboa ${ }^{483}$. Note-se a configuração espacial da loje onde a área de recepção dos clientes se dá no espaço mais exterior do recinto, dividido por um grande balcão. Para a acomodação do cliente a escolher e experimentar os chapéus havia dois bancos, encostados à parede, num dos quais se assenta o oficial mecânico, com meio corpo para fora da loja a esperar clientes e conversar com as mulheres de sua família, reservadas a um espaço superior da loja, como que um falso sobrado entre o térreo e o segundo andar, recurso construtivo que melhor aproveitava o espaço das residências.

\footnotetext{
482 MCKENDRICK, Neil. "The Consumer Revolution of Eighteenth-Century England." In MCKENDRICK Neil, BREWER John e PLUMB J. H. (eds.), The Birth of a Consumer Society: The Commercialization of Eighteenth Century England. Bloomington: Indiana University Press, 1982. P. 9-33.

${ }^{483}$ Cf. MENESES, José Newton Coelho. Artes fabris \& ofícios banais: o controle dos ofícios mecânicos pelas câmaras de Lisboa e das vilas de Minas Gerais (1750-1808). Belo Horizonte: Fino Traço, 2013.
} 


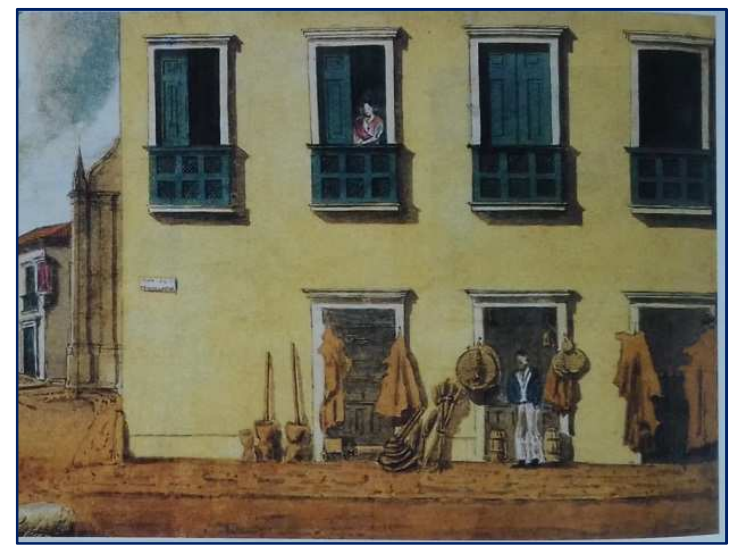

Figura 113: PINK, Edmund. Vista da cidade - palácio da sola. (detalhe). c. $1820^{484}$.

Nesta gravura de uma loja de couros localizada no largo da Misericórdia, em São Paulo, apesar de mão conseguimos visualizar a parte interna da loja, podemos notar como as peles, derivados de couro e outros apetrechos como vassouras e pilões ficavam pendurados para fora à vista dos viandantes. Os dois pequenos barris na porta central são indicativos dos multiusos de artefatos não mobiliares que assumiam as mesmas funções, diversas ao propósito prioritário, mas ressignificados e reutilizados conforme a necessidade pratica. Sua posição ao pé da rua fornece indicativo das formas de sociabilidade que poderia vetorizar: tal como no azulejo reinol, o comerciante paulista poderia ficar sentado com meio corpo para fora da loja, de olho no movimento da rua, monitorando seus escravos de ganho a fazer entregas ou vendendo comidas em tamboladeiras e conversando com viandantes, clientes e vizinhos que poderiam esporadicamente tomar assento no outro barril para prosear. A figura feminina ficava restrita ao piso superior do sobrado, de olho na rua através do balcão de treliça da janela, em continuidade com uso das rótulas que passavam a ser proibidas naquele século ${ }^{485}$.

Por fim, evidenciamos o continuum entre o consumo e a produção através dos registros de receitas e despesas da Câmara, onde encontramos uma raríssima passagem, da qual transcrevemos a folha inteira ${ }^{486}$, que contempla grande parte da cadeia de produção de doze cadeiras encomendadas pelo senado em 1731.

Recebeu Ignácio de Siqueira Fernandes de uma porta e uns batentes $2 \$ 240$ réis;

\footnotetext{
${ }^{484}$ Extraído de: LAGO, P.C. do. Iconografia paulistana do século XIX. 2a ed. São Paulo: Capivara. 2003.p.62.

485 cf. MARINS, Paulo Cesar Garcez. Através da rótula: sociedade e arquitetura urbana no Brasil, sécs. XVII-XX. Tese de Doutorado. São Paulo, Dpto. De História da FFLCH-USP, 1999. .

${ }^{486}$ Infelizmente a folha se encontra rasgada na parte inferior e não foi possível ler toda a conta da encomenda. AHMSP. Fundo Câmara Municipal. Série Receita e Despesa. Livro 314 fl. 74 [aparece como folha 90 no escrito do canto da folha]
} 
Recebeu Gregório Gl.z [Gonçalves] carpinteiro do seu trabalho por uma fechadura e de pregos que tudo importou $2 \$ 880$

Md.o .. para se comprar uma dúzia de cadeiras para este Senado

Recebeu Antônio da Costa Nunes cento e vinte mil réis de uma dúzia de cadeiras com suas pregaduras douradas $120 \$ 000$ réis

Recebeu Manoel da Silva Vidigal onze mil setecentos e cinquenta procedidos do trabalho de armar as ditas cadeiras e um milheiro de pregos com que assistiu para pregar os couros e mais preparos das ditas cadeiras $11 \$ 750$ réis.

Recebeu Antônio Lopes sapateiro quatro mil réis procedidos do trabalho de [lavrar?] as ditas cadeiras $4 \$ 000$ réis.

Recebeu Manuel Pr.a [Pereira] e Sylva oitocentos réis de suas peles de carneiro vermelhas para as d.... rens? das ditas cadeiras $\$ 800$ réis

Recebeu Manuel Alz Fer.a [Alvares Ferreira?] mil e quatrocentos e quarenta réis procedidos de três couros crus para... [papel corroído] [velhos?] tamboretes $1 \$ 440$ réis.

Reforçamos assim por outras fontes a compreensão que tivemos sobre os diferentes estágios da cadeia de produção dos móveis analisados pelos sinais presentes na sua própria materialidade através do exame formal e técnico.

Vemos que na feitura das cadeiras de sola estavam envolvidos fornecedores de couro, de pregaria, da armação de madeira e os responsáveis por lavrar o couro e pregá-las. Mais uma evidência da multiplicidade de trabalhos exercidos pelos artífices da cidade, notamos que ao sapateiro foi encomendado o trabalho de lavrar o couro da cadeira, função não incluída em seu Regimento, mas que a encomenda da proporia Câmara subvertia. Encontramos para um ano antes, em 1730, nas Atas da Câmara o pedido de compra de cadeiras pelo Senado.

Esta passagem foi alvo das atentas anotações de Afonso Taunay sobre a vida camarária em sua Historia da Cidade de São Paulo no Século XVIII, a qual transcrevemos em parte para acompanhar sua narrativa de interpretação do episódio de "Renovamento do mobiliário":

A 20 de maio de $1730^{487}$, Antônio Pinto Duarte procurador do Concelho, chamou atenção dos colegas para um fato que não era condigno à respeitabilidade do nobre Senado paulistano.

Que horrível mobiliário o da sua sala de reuniões!

\footnotetext{
${ }^{487}$ Apesar de Afonso Taunay não citar de onde extraíra a informação, como era típico da historiografia do momento, a encontramos na publicação das Atas da Câmara. APESP. Atas, vol. 10, P. 46.
} 
Venerável, não havia dúvida, mas reduzido à quase imprestabilidade. Já não havia mais "tamboretes de assento capazes", tão velhos estavam! "Eram do tempo em que se principiou esta república", como deles se mostrava clamava escandalizado este inovador, inimigo dos móveis seculares.

Esquecia-se que as veneráveis mobílias haviam tido a honra de servirem a um João Ramalho! a um Afonso Sardinha!... a um Dom Francisco de Souza, a um Amador Bueno da Ribeira! A um Antônio Raposo Tavares! A um Fernão Dias Paes!

Assim, reclamava o anti-tradicionalista procurador, adquirisse a Câmara "uma dúzia de cadeiras que se achavam de venda na cidade, em peso $\left(\mathrm{sic}^{488}\right)$ conveniente, pela bondade elas".

Obtemperaram os senhores vereadores a este desejo de seu colega pelo que nos conta o escrivão Antônio Correia Ribeiro: "que ouvido pelos vereadores e achando ser preciso o seu requerimento a respeito não haver assentos capazes pera qualquer ato de junta de Ministros ou outras pessoas titulares mandaram se lhes passasse mandado para a compra das ditas cadeiras".

Não vemos no decorrer da década de 1730 nenhuma outra manifestação estética da municipalidade paulistana ${ }^{489}$.

É importante notar nesta passagem a importância que o procurador dá ao fato dos tamboretes serem antigos "como deles se mostra" ${ }^{490}$, pois possivelmente essas peças teriam inscrições de quando foram feitas nos espaldares, como os exemplares de cadeiras de sola maciços e pesados do Museu Paulista que analisamos. Atentando à terminologia, como o fez Maria Borrego ${ }^{491}$, note-se que as peças antigas são denominadas tamboretes e as peças novas a serem compradas são cadeiras. É uma possível indicação de que neste momento já se observavam alterações formais entre estas peças, sendo que Ernani da Silva Bruno ${ }^{492}$ computara cadeiras nos inventários post-mortem seiscentistas, depois aparecendo o termo "tamboretes de encosto" como possível designação genérica dada à cadeira de sola

\footnotetext{
${ }^{488}$ Na transcrição publicada nas Atas, encontramos o termo "preso", isto é, preço. APESP. Atas. vol. 10, P. 47.

${ }^{489}$ TAUNAY, Affonso d'Escragnolle. Historia da Cidade de São Paulo no Século XVIII. SP: Imprensa Oficial, tomo 3, capítulo XI, 1931. pg 74.

490 Partícula alterada do original por Taunay, que usa "mostrava".

491 BORREGO, Maria Aparecida de Menezes; FELIX, Rogério Ricciluca Matiello. Ambientes domésticos e dinâmicas sociais em São Paulo colonial. Rev. Hist. (São Paulo), São Paulo, n. 175, p. 91-132, dez. 2016.

492 BRUNO, Ernani da Silva. O equipamento da casa bandeirista segundo os antigos inventários e testamentos. São Paulo: Departamento do Patrimônio Histórico, 1977.
} 
no século XVIII ${ }^{493}$, e o termo cadeira voltaria a público mais enfaticamente a partir dos anos 1770, para preponderar nas primeiras décadas dos Oitocentos nas casas da elite.

A reclamação do procurador é ainda muito relevante do ponto de vista das noções de consumo dos objetos neste período pré-industrial: de fato os antigos tamboretes foram usados até a exaustão, revelando que a lógica da compra era dada pela "bondade delas", ou qualidade dos móveis, que deveriam ser bem executados durar o máximo possível.

Do ponto de vista historiográfico, a maneira como Afonso Taunay relata a passagem também é muito reveladora, pois vemos a importância, e mesmo o tom de pesar e represália sobre o remoto procurador, de que os antigos tamboretes tinham especial relevo, enquanto fetiche das "heroicas" personagens históricas e que as teriam usado, faceta que também se revela em suas decisões museológicas durante o comando do Museu Paulista, onde eram expostos os móveis, inclusive as cadeiras por nós previamente analisadas, mais pelo valor de relíquia, ou fetiche, de uso pelos "grandes homens" da história paulista, do que pelos seus aspectos materiais e tecnológicos.

Para finalizar, Afonso Taunay faz questão de pontuar que a Câmara não teve mais "preocupações estéticas" ao longo daquela década, fator que reforça o teor de desleixo sobre a instituição pública e serve como mais um fator para atestar a pobreza paulista.

Entretanto, devemos dicotomizar esta visão através da própria despesa camarária que encontramos no Arquivo Histórico Municipal, onde vimos o pagamento destas cadeiras um ano depois do pedido de compra do procurador Antônio Pinto Duarte. Notamos que possivelmente ocorreu a reforma dos antigos tamboretes, indicada pelo pedido de compra de couros a Manuel Alvares Ferreira ${ }^{494}$. Compreendemos assim que a concepção de consumo da época, em que as despesas com móveis e outras "manifestações estéticas" não precisavam ser corriqueiras, mas duradoras.

\footnotetext{
${ }^{493}$ Tal hipótese foi confirmada por Maria Helena Flexor no trabalho seminal sobre o mobiliário baiano FLEXOR, Maria Helena Ochi. Mobiliário baiano. Brasília, DF: Iphan / Programa Monumenta, 2009; bem como por João Filipe da Silva Nascimento, estudioso das cadeiras portuguesas. PINTO, Augusto Cardoso \& NASCIMENTO, João Felipe da Silva. Cadeiras portuguesas. Lisboa: Ed. dos autores, 1952.

${ }^{494}$ AHMSP. Fundo Câmara Municipal. Série Receita e Despesa. Livro 314, fl. 74.
} 
Aliás, acreditamos que Afonso Taunay deixa de considerar o gasto rotineiro e anual da câmara com a pintura das varas dos juízes e dos brandões utilizados nas festas religiosas como gastos de teor "estéticos" feitos pela câmara dentro da lógica de exibição dos símbolos de poder municipais. Se decerto ocorridos fora do espaço camarário, eram, porém reforçadores de seu domínio nos momentos de sociabilidade externa congregadora da população citadina e rural.

Como revela Rodrigo Almeida Bastos ${ }^{495}$ e Maria Cristina Neves Azevedo para Minas Gerais, a conexão do poder administrativo com o braço religioso estava repleto de interpenetrações, observáveis desde a própria fundação das vilas, onde a ereção de capelas e igrejas não tinha como objetivo apenas a expansão demográfica, mas também sob a lógica da distinção social o serviço ao "acrescentamento" de dignidade às localidades e seu moradores ${ }^{496}$.

Para além da encomenda de peças aos oficiais mecânicos também encontramos sinais da convivência com a venda a varejo ou retalho de móveis em São Paulo através dos inventários de comerciantes, inclusive contando com escravos artífices. Devemos, porém, tomar cuidado com esses inventários, pois sabemos que em muitos casos não havia divisões rígidas entre a loja do comerciante e a casa de sua família ${ }^{497}$.

Um desses comerciantes era José Pinto Tavares, natural da Freguesia de São Cosme de Gondomar, bispado do Porto. Inventariados os seus bens em 1815, consta-lhes as fazendas que possuía em sua loja, localizadas na Rua do Comércio no número 9. Ao lado das mais variadas drogas, onde se uniam de erva mate, salsaparrilha e "Rheubarba da Índia" até os mais variados componentes para pintura como água forte, gesso e bolo armênio, encontramos os seguintes móveis e componentes ainda por terminar ${ }^{498}$ :

12 cadeiras de madeira de óleo novas sem assento, $6 \$ 720$ réis;

12 ditas [cadeiras] da mesma madeira com as peças competentes por armar por $3 \$ 840$.

\footnotetext{
495 BASTOS, Rodrigo Almeida. O urbanismo conveniente luso-brasileiro na formação de povoações em Minas Gerais no século XVIII. An. mus. paul. 2012, vol.20, n.1, pp.201-230.

${ }^{496}$ AZEVEDO, Maria Cristina Neves. Arte sacra e distinção social: Joaquim José da natividade no sul de Minas Gerais na primeira metade do século XIX. Dissertação de Mestrado em História Social da Cultura - Pontifícia Universidade Católica do Rio de Janeiro. 2014.p. 32.

497 MARINS, Paulo Cesar Garcez. Vida cotidiana entre os paulistas: moradias, alimentação, indumentária. In: SETUBAL, Maria Alice (org.). Terra paulista: histórias, arte, costumes. São Paulo: C. Imesp, 2004.

498 APESP. Inventário e Testamentos não publicados. José Pinto Tavares Processo 201007000466 - 1169 . pg. 524.
} 
Uma marquesa de óleo com seus pertences por armar, menos [o] assento, $2 \$ 000$.

15 batentes já lavrados e prontos, $2 \$ 400$.

10 batentes curtos sem estarem acabados de emparelhar, $1 \$ 200$.

Três portas de cinco peças novas e um por armar, $3 \$ 360$.

Este trabalho seria feito possivelmente pelos escravos João, de nação Congo, ou Miguel, crioulo, que eram ambos oficiais de carpinteiro, auxiliados por outro chamado Miguel, ainda aprendiz deste ofício.

Também notamos como no seu inventário constavam as matérias-primas a serem usadas por seus escravos na confecção do mobiliário, fornecendo mais indícios sobre o abastecimento desse setor produtivo. Repare-se o fato do jacarandá vir - provavelmente da Bahia - em toras brutas, possivelmente pela sua dureza e impraticabilidade em ser tabuado, podendo também servir a entalhadores para fazer esculturas, sendo assim necessária a tora íntegra:

Três toras de jacarandá bruto, $\$ 720$ réis.

Quatro tábuas finas de óleo, $\$ 640$.

21 vigotas curtas, $2 \$ 100$.

Quatro couçoeira ${ }^{499}$ de canela, $\$ 480$.

Constavam ainda neste inventário partes de móveis ou peças desmanchadas, que não eram incomuns em tais arrolamentos ${ }^{500}$ :

Dois canapés de madeira da terra desmanchadas, $3 \$ 200$ réis.

Uma mesa com armário por baixo desmanchado de madeira da terra, $\$ 960$.

Note-se assim como na época mesmo os móveis já velhos também tinham valor para o consumo, fosse pelo seu restauro, fosse pelo seu material que poderia ser reutilizado. Encontramos inclusive em fontes iconográficas indícios indicando o valor não desprezível do mobiliário, mesmo que desmanchado.

\footnotetext{
${ }^{499}$ Segundo Bluteau, Couçoeira é "Taboa grossa, que vem do Brasil, com que se fazem portas e outras obras". BLUTEAU, Raphael. Vocabulario portuguez \& latino: aulico, anatomico, architectonico... Coimbra: Collegio das Artes da Companhia de Jesus, 1712-1728. Vol. 2, p. 593.

${ }^{500}$ Encontramos 38 menções entre os 104 inventários de 1700 a 1840.
} 


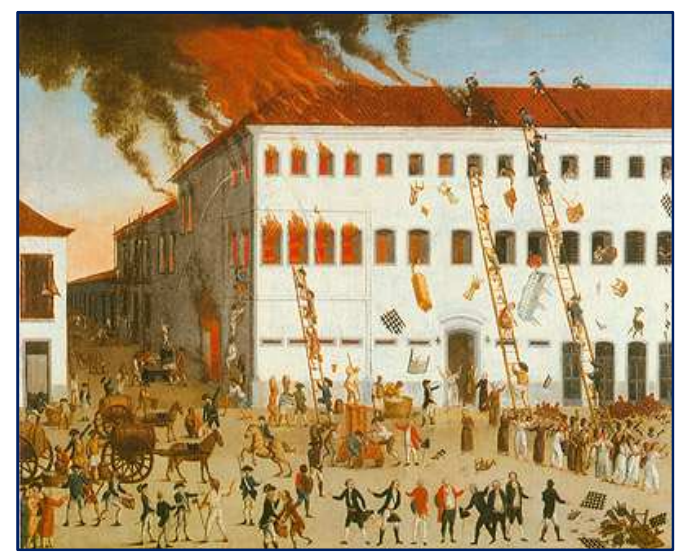

Figura 114: MUZZI, João Francisco. INCÊNDIO do Recolhimento de Nossa Senhora do Parto. Acervo: Museus Castro Maya - IPHAN/MinC.501

No incêndio ocorrido no recolhimento de Nossa Senhora do Parto no Rio de Janeiro e registrado por João Francisco Muzzij ${ }^{502}$ em 1789, vemos o retrato de uma terrível cena, onde o mobiliário é defenestrado à rua para ser salvo das chamas que consumiam o edifício. Mesmo que o impacto da queda quebrasse e desmanchasse as peças, seria ainda menor prejuízo reformá-las ou utilizar os seus componentes, pois poderiam ser de madeiras nobres e importadas a julgar pela preocupação em lançá-las antes de evacuar do prédio ${ }^{503}$.

José Pinto Tavares possuía também em sua loja diversas ferramentas destinadas a variadas profissões, bem como componentes para a fabricação de peças. Isto revela como ele ${ }^{504}$ detinha o controle de grande parte da cadeia de produção dos móveis, unindo em seus ganhos a fabricação com a venda não só de peças prontas, mas de componentes e ferramentas que os oficiais mecânicos, em nítida desvantagem, poderiam comprar dele ou de outros artesãos igualmente restritos na possibilidade de criar e vender.

Compreendemos como a predominância do liberalismo econômico quando da constituição de 1824 que extinguiu as corporações de ofício trouxe legitimação da

\footnotetext{
${ }^{501}$ In: ENCICLOPÉDIA Itaú Cultural de Arte e Cultura Brasileiras. São Paulo: Itaú Cultural, 2018. Disponível em: <http://enciclopedia.itaucultural.org.br/obra14154/incendio-do-recolhimento-de-nossa-senhora-do-parto>. Acesso em: 26 de Abr. 2018. Verbete da Enciclopédia.

${ }^{502}$ Pintor italiano falecido em 1802. Apud. ENCICLOPÉDIA Itaú Cultural de Arte... op. cit.

${ }^{503}$ Agradecemos a M.e Angélica Brito Silva e ao educador Eron Bitencourt por esta atenta observação e interpretação do quadro conforme apresentada no encontro temático "Cotidiano e mobiliário no Aldeamento de Mboy", ocorrida em 13 de maio de 2017 no Museu dos Jesuítas de Embú das Artes.

${ }^{504}$ APESP. Inventários não publicados, José Pinto Tavares, 1815. Processo 201007000466 - 1169.
} 
vantagem que os grandes comerciantes já possuíam e o fim das proteções legais dos oficias mecânicos, como mostrado por Guedes para o Rio de Janeiro. ${ }^{505}$.

Transcrevemos alguns dos itens da "Fazenda da loja" para chamar a atenção à diversidade de bens, o seu grande volume e permitir um comparativo de preços ${ }^{506}$.

10 milheiros de pregos meio-ripares, $10 \$ 000$ réis.

Oito dúzias e meia de limas de mais de palmo, $20 \$ 400$

Seis goivas largas, $1 \$ 200$

Nove badames estreitos, $\$ 900$

Nove formões meia largura, $\$ 900$

13 ferros de plana sortidos, $1 \$ 300$

Cinco junteiras, $\$ 400$

Cinco ferros de rebotes, $\$ 700$

Cinco ferros de Guilherme, $\$ 300$

Quatro compassos grandes, $\$ 960$

Seis dúzias de fechaduras inglesas para gavetas, todas por $14 \$ 400$

Uma enxó-goiva grande, $\$ 800$

Cinco enxós de carpinteiro com cobertos, $3 \$ 600$

10 verrumas de ferro, $2 \$ 000$

10 verrumas caixares, $\$ 600$

Três verrumas de pregos de pau a pique, $\$ 240$

49 fechaduras de porta grandes, $23 \$ 520$

24 milheiros de arestas grandes para rótulas, $12 \$ 000$

Três couros de veado curtidos, $\$ 960$

Três couros de cotia sortidos, $\$ 180$

Sete torqueses pequenas sem martelo, $\$ 560$

Sete canivetes grandes, $\$ 840$

13 espelhos de latão para cômodas, $\$ 480$

Quatro jogos de ferragens douradas para cômodas antigas, $1 \$ 200$

16 rodilhas de latão para pé de mesa, $3 \$ 200$

Sete folhas de serra azuladas[?] ${ }^{507}$ de comprimento de 4 palmas, $3 \$ 820$

8500 taxas douradas baixas, $12 \$ 240$

2850 taxas douradas altas, $8 \$ 208$

10 troninhos de mão, de ourives, $4 \$ 000$

Duas balanças de ourives de marco de uma libra nova, $3 \$ 200$

50 tarraxas de sapateiro, $1 \$ 220$

10 pedras de cantaria, $4 \$ 800$

Ao avançar da década de 1830 vemos alguns inventários trazendo mais precisa a divisão entre os itens da loja e da casa, bem como dos cômodos da casa.

\footnotetext{
${ }^{505}$ GUEDES, Roberto. Ofícios mecânicos e mobilidade social: Rio de Janeiro e São Paulo (sécs. XVII-XIX). Topoi, v. 7, n. 13, jul.-dez. 2006, pp. 379-423.

${ }^{506}$ APESP, Inventários não publicados, José Pinto Tavares, 1815, pgs. 438 a 453. Listamos de acordo com a ordem com que aparece no documento, mas selecionamos os itens mais relevantes para nossa análise.

${ }^{507}$ Merece destaque este detalhe à coloração "azulada" da folha de serra, pois poderia ser um indicativo de que seria metal galvanizado, obtido através da aplicação de camada protetora de zinco fornecendo o espectro azul. Entretanto, sabe-se que o aço galvanizado apesar de ter sido descoberto em 1742 na França só veio a ser mais amplamente utilizado quase um século depois, em 1837, quando houve melhoria no processo de obtenção e na qualidade final. Cf. MCNEIL, lan (Ed.). An encyclopedia of the history of technology. Routledge, 2002, p. 95.
} 
Fornecido pela própria organização do inventário, temos assim mais uma prova do aumento do espaço doméstico, da especialização dos cômodos, como a "sala de chá" e dos móveis que recheavam os recintos. Este incremento é bastante evidente no rico inventário de Genebra de Barros Leite, ituana falecida a Lisboa em $1837^{508}$. Quase ao final das seiscentas páginas descrevendo o enorme número de bens que possuía, há listagem dos "móveis na loja":

\author{
Uma mesa de jacarandá com pés de cabra por 6400; \\ Uma escrivaninha com sua mesa, 12000; \\ Um armário pequeno, 4000; \\ Um mocho tecido de palha, 1200 (...)
}

A este mobiliário à venda acompanhavam ainda pratos de estanho, machados, resmas ou ramas de papel, barras de ferro e caixões com garrafas de vinho.

Conectada ao varejo, a importação também deve ser uma forma de consumir a ser contada. Para além da transposição de objetos do Reino pelos povoadores desde os primórdios da colonização da América, como as caixas e canastras indispensáveis para o transporte dos mais variados apetrechos, ferramentas e alimentos, a importação de mobiliário foi notada por Flexor na Bahia bem como em outras capitanias desde os primeiros séculos ${ }^{509}$.

Como já discutimos no capítulo anterior, em seu trabalho sobre os mobiliários produzido na Bahia e os artesãos que os confeccionavam, Maria Helena Flexor mostrou que a primeira capital da colônia chegou mesmo a exportar móveis para as outras capitanias do Brasil. Segundo a autora, num único carregamento saído de Salvador, em 1797, para todos os portos do continente americano de barra-fora constavam "4 mesas de vinhático, 5 camas de vento, 2 coxos de banho, 110 cadeiras de couro, 5 cadeiras de arruar, uma caixa de vinhático, uma cômoda do dito" 510 .

Extrapolando os limites da colônia portuguesa, até mesmo nos interditos portos da América Espanhola, os móveis baianos teriam penetrado, com destaque para a tão longínqua Buenos Aires, atestado pelo trabalho de Maria Goulão

\footnotetext{
${ }^{508}$ APESP, Inventários e Testamentos não publicados. Genebra Barros Leite, 1838. Processo 201007000804 531.

${ }^{509}$ FLEXOR, Maria Helena Ochi. Ofícios, Manufaturas e Comércio. In SZMRECSÁNYI, Tamás. História Econômica do Período Colonial. 1993. P. 191.

${ }^{510}$ FLEXOR, Maria Helena Ochi. Mobiliário baiano. Brasília, DF: Iphan / Programa Monumenta, 2009, p. 84.
} 
Machado ${ }^{511}$. Se de Piratininga acreditamos ter sido mais difícil o envio de móveis para a vizinhança espanhola, por São Paulo passaram artífices portugueses que trabalharam nas áreas fronteiriças do Prata ${ }^{512}$.

Em São Paulo a penetração do móvel baiano é confirmada pelos inventários post-mortem onde não só constam peças com jacarandá da Bahia, mas propriamente "feito na Bahia" 513.

Em alguns inventários paulistas aparecem os valores das compras de encomendas que vinham do Rio de Janeiro, e, apesar de não especificarem quais bens seriam transportados por tamanha distância, não se pode descartar a possibilidade de serem trazidos bens luxuosos. Por exemplo, no inventário de Mathias Rodrigues da Silva de 1710 aparece entre as dívidas que "na cidade do Rio de Janeiro está o procedido de 1:317\$920 que o defunto mandou vir em fazendas do Reino a qual importância se deve partir o esperar pela venda da dita fazenda para se partir o seu procedido" 514.

E a exportação e envio de móveis para o Brasil e outras localidades decerto era de grande preocupação dos comerciantes reinóis, como vemos no exemplo de um requerimento presente no Arquivo Ultramarino ${ }^{515}$ :

REQUERIMENTO de José Ramos da Fonseca ao rei [D. José], solicitando certidão de que os móveis que embarcou de Lisboa para o Rio de Janeiro no ano de 1746 no navio Nossa Senhora da Bonança e Santa Cruz foram efetivamente desembarcados no Rio de Janeiro.

Um meticuloso estudo feito por Eudes Campos chegou a identificar que um leito estilo Império atualmente pertencente ao acervo do Museu Paulista pertencera à Marquesa de Santos e fora feito pelo famoso marceneiro Alexandre-Louis Bellangé (1799-1863). Dedicado originalmente ao Rei Carlos X de França, não foi comprado

\footnotetext{
${ }^{511}$ GOULÃO, Maria José. "La Puerta Falsa de América". A influência artística Portuguesa na região na Região do Rio da Prata no período colonial. 1 vol. Tese de Doutoramento na Faculdade de Letras da Universidade de Coimbra, 2005.

512 GOULÃO, Maria José. A encomenda a entalhadores portugueses nas missões franciscanas do Paraguai no século XVIII. FERREIRA-ALVES, Natália. (coord.). A Encomenda. O Artista. A Obra. CEPESE: 2010, p. 435.

${ }^{513}$ Como um leito pertencente a João Francisco Lustosa (1746) e um bufete de Manoel Veloso (1752).

${ }^{514}$ APESP. I e T. vol. 25.

515 Projeto Resgate - Documentos manuscritos avulsos da Capitania do Rio de Janeiro. Rio de Janeiro 1774, Julho, 27. Cota: 8374.
} 
pelo guarda-móveis real e assim comercializado na Exposição dos Produtos da Indústria Francesa, de $1827^{516}$.

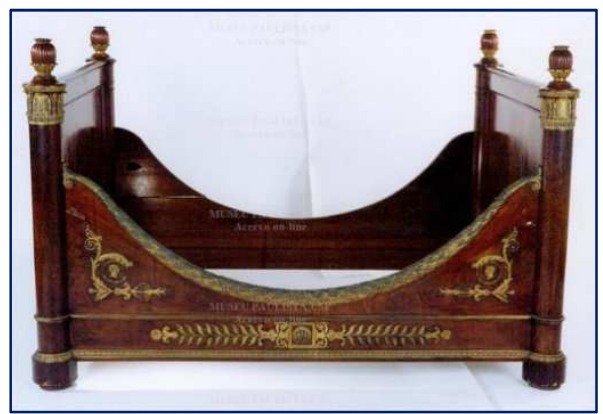

Figura 115: Leito feito por Alexandre-Louis Bellangé e pertencente à Marquesa de Santos. Acervo Museu Paulista ${ }^{517}$.

E o móvel da portentosa Marquesa de Santos não era exceção, como nos revela o "leito francês de vinhático quase novo", mencionado no inventário do mercador João Rodrigues Vaz, aberto em $1746^{518}$, exemplos nítidos da importação moveleira para além da metrópole.

Analisando os inventários de comerciantes paulistas Maria Borrego notou a presença de tecidos estrangeiros, como: marroquim, bretanha, lã de camelo, lã inglesa, linhagem de Hamburgo, linhagem de olanda, riscado de Malta e riscado de Hamburgo ${ }^{519}$. E de fato em vários móveis inventariados aparecem tais tecidos nos estofamentos, especialmente o marroquim, revelando mais uma faceta complexa da produção moveleira local ${ }^{520}$.

Além da venda em lojas, a encomenda com os oficiais mecânicos com seus preços e lojas fixas, e a importação de móveis e matérias-primas, encontramos também menções sobre o consumo urbano e rural através de artesãos ambulantes. Segundo José Carlos Barreiro ${ }^{521}$ estes iam de porta em porta oferecendo os seus serviços, sendo principalmente ferreiros e ferradores, que se ocupavam em calçar as

\footnotetext{
516 CAMPOS, Eudes. Os móveis franceses da Marquesa de Santos. In: Informativo do Arquivo histórico Municipal. São Paulo: PMSP/SMC/DPH, março/abril de 2008. Disponível em: http://www.arquiamigos.org.br/info/info17/i-inter.htm. Acesso em: 20/05/2018. Agradecemos sobremaneira ao Sr. Dr. Eudes Campos que gentilmente, e com muita erudição, corrigiu para nós a informação que havia veiculado neste seu artigo que o ebanista produtor desses móveis não seria Louis-Alexandre (1797-1861), mas Alexandre-Louis Bellangé (1799-1863), seu primo que possuía o nome invertido e por isso causa bastante confusão entre vários estudiosos.

${ }^{517}$ Acervo Museu Paulista. Leito. RG 1-05-04-000-03962-00-00.

${ }^{518}$ APESP. Inventários e Testamentos não publicados. João Rodrigues Vaz, 1746, C00659 + avulso.

519 BORREGO, Maria Aparecida de Menezes. A teia mercantil...op. cit., 2010.

520 BORREGO, Maria Aparecida de Menezes; FELIX, Rogério Ricciluca Matiello. Ambientes domésticos e dinâmicas sociais em São Paulo colonial. Rev. Hist. (São Paulo), São Paulo, n. 175, p. 91-132, dez. 2016.

${ }^{521}$ BARREIRO, José Carlos. Imaginário e viajantes no Brasil do Século XIX: cultura e cotidiano, tradição e resistência. São Paulo: Editora UNESP, 2002. P. 144.
} 
bestas das tropas que circulavam pelo interior, preparar pedras para fuzil ou realizar transportes com suas carroças, além dos afiadores de faca e tesoura, talvez um dos últimos ofícios que ainda encontram resquícios nas grandes metrópoles atuais ${ }^{522}$.

Estes ambulantes constituíam uma camada social numerosa que não estava na dependência de um patrão ou senhor e sujeitava-se a um processo de intensa mobilidade. Eram "servidores de ninguém", para usar a expressão empregada por Christopher Hill ao caracterizar categoria social com traços semelhantes, na Inglaterra do século $\mathrm{XVI}^{523}$.

Em suas viagens, Saint-Hilaire observou como nas estradas que serviam de principais rotas de circulação comercial a existência de artesãos ambulantes, carreiros e ferradores em grande número nos ranchos que as beiravam ${ }^{524}$. Igualmente o notaram Sérgio Buarque de Holanda para os caminhos do Oeste e Luciane Scarato para a estrada velha de São Paulo para as Minas Gerais ${ }^{525}$.

Vários museus ainda guardam exemplos materiais desse tipo de consumo itinerante através das miniaturas de mobiliário, que serviam de modelo para o interessado em ver a qualidade do trabalho do artífice. Se não encontramos exemplos em São Paulo de móveis em miniatura, temos a evidência de várias imagens de Santanas Mestras representadas seguindo o cânone da posição sentada em tronos ou tamboretes rasos e recorrentemente com pés apoiados em banquinhos, enquanto dão lição a sua filha, a Virgem Maria. Segundo Ângela Brandão ${ }^{526}$ a feitura dessas imagens também servia ao artesão sacro para exibir sua capacidade de fazer mobiliário doméstico.

Apesar de ser menos usual, também não podemos desprezar os leilões, ou arrematações de bens em praças publicas e nas casas do senado durante

\footnotetext{
522 FERNANDES, Antônia Terra de Calazans. Memórias de ofício. Tese de doutorado em História Social, Faculdade de Filosofia, Letras e Ciências Humanas, Universidade de São Paulo, São Paulo, 1997.

${ }^{523}$ Apud BARREIRO, José Carlos. Imaginário e viajantes no Brasil do Século XIX: cultura e cotidiano, tradição e resistência. São Paulo: Editora UNESP, 2002. P. 146

524 SAINT-HILAIRE. Auguste de. Viagem à Província de São Paulo e resumos das viagens ao Brasil, província Cisplatina e Missões do Paraguay. Tradução e notas de Rubens Borba de Morais. São Paulo: Martins Editora/EDUSP, 1972. p. 43.

525 SCARATO, Luciane Cristina. Caminhos e descaminhos do ouro nas Minas Gerais: administração, territorialidade e cotidiano (1733 - 1783). Dissertação de mestrado. Universidade Estadual de Campinas. Campinas/ SP. 2009.

${ }^{526}$ BRANDÃO, Angela. Móveis em miniatura: a demonstração de um saber fazer. An. mus. paul., São Paulo, v. 25, n. 1, p. 169-197, Abr. 2017 Disponível em: <http://www.scielo.br/scielo.php?script=sci_arttext\&pid=S0101-47142017000100169\&lng=en\&nrm=iso>. Accessado em 01/02/2018.
} 
liquidação de dívidas, por vacância de herdeiros ou mesmo em vendas gerais por decorrência da morte de algum membro de família.

Para o caso de Lisboa, Carlos Franco evidência a importância dos leilões para um grupo de elite ascendente, que frequentava grandes lojas com pinturas, bustos e móveis dos mais variados tipos, Inclusive a divulgação no leilão de que eram objetos pertencentes a pessoas de nobreza e prestígio era um fator atraente aos interessados, especialmente os colecionadores novos-ricos, os quais ascenderam após as grandes mudanças vividas na sociedade e economia portuguesa dado o grande abalo da cidade em $1755^{527}$.

Encontramos inclusive no inventário do marceneiro e lojista lisboeta Feliciano da Cruz, de 1799, que a sua viúva havia vendido "seis dúzias de cadeira que havia na casa por $60 \$ 000$ ", decerto um valor baixo, se compararmos com os $192 \$ 000$ réis que devia o artífice só da compra de diversas madeiras. Possivelmente a viúva havia feito liquidação dessas cadeiras, a baixo preço, motivada pelo desespero em quitar dívidas ${ }^{528}$.

Para São Paulo, porém, não encontramos semelhantes lojas de leilões e são poucos os exemplos de inventários que descrevem a venda de resquícios para a liquidação de dívidas dos herdeiros, mas, no entanto, eles são bastante significativos.

Vimos no outro capítulo o caso de Estevão Ribeiro Garcia, falecido em 1738 na Vila de Bom Jesus do Goiás, que por não ter deixado testamento, nem herdeiros e seus bens estarem espalhados entre as paragens nas mãos de diversos conhecidos seus, levaram seus bens a leilão público, alguns arrematados em conjunto por valor mais baixo do que foram avaliados ${ }^{529}$. Esta poderia ser inclusive uma forma de indivíduos de classes mais baixas poderem adquirir bens de melhor qualidade que não teriam condições de encomendar e ainda de pagar o feitio.

Desta forma compreendemos a importância nesta época dos indivíduos fazerem testamentos e darem atenção aos bens que ficariam prometidos para cada filho ou parente em particular. Daí a importância de haver nesta época o entesouramento nas famílias de joias e enxoval enquanto bens duradouros, não

\footnotetext{
527 FRANCO, Carlos. O mobiliário das elites de Lisboa na segunda metade do século XVIII. Lisboa: Livros Horizonte, 2007. p. 43.

${ }^{528}$ ANTT. Inventários orfanológicos dos Feitos findos (1500-1800). Feliciano da Cruz, 1799. PT/TT/IFF/006/0175/00006.

${ }^{529}$ APESP. I e T., vol. 26.
} 
desvalorizáveis, armazenáveis, transportáveis, ao ponto de passarem por gerações, que poderiam, ainda que com muito pesar sentimental - como revela Maria Luiza de Oliveira $^{530}$ já para o final do século XIX -, ser leiloados ou mesmo penhorados para quitar dívidas evitando que se perdesse a residência.

Outrossim, notamos em registros de mandados de cumprimento de dívidas como, antes de mais nada, se liquidavam os bens móveis que o individuo possuísse e somente se os valores devidos não fossem cobertos se sequestravam os bens imóveis e, por fim, levava-se à prisão e ao cumprimento de pena ${ }^{531}$.

\subsection{Padrões de consumo}

Tendo viso os canais de aquisição dos móveis, devemos também entender o consumo em São Paulo através do que os paulistas ${ }^{532}$ possuíam em seus espaços domésticos, sendo os testamentos e inventários post-mortem documentos privilegiados para tanto ${ }^{533}$. Entender os padrões de posse de móveis ao longo dos séculos XVIII e XIX, notando as diferenças entre indivíduos de variados níveis de riqueza e ramos de atividade econômica, é uma mirada fundamental para compreender as dinâmicas socioeconômicas pelas quais passava a cidade e a agência de grupos específicos neste interim, especialmente os comerciantes, como evidenciado por Maria Borrego ${ }^{534}$. Faremos uma análise geral sobre a quantidade,

\footnotetext{
${ }^{530}$ OLIVEIRA, Maria Luiza Ferreira de. Entre a casa e o armazém: relações sociais e experiência da urbanização, São Paulo, 1850-1900. São Paulo: Alameda, 2005. P. 90ss.

${ }^{531}$ Exemplo no registro de mandado executivo de 1746 contra Agostinho Nogueira de Andrade da divida de $20 \$ 000$ réis de laudêmio da compra de uma casa de seu pai. No caso quitou-se com o sequestro de uma escrava, Bárbara, de nação Angola. APESP. Atas. Vol. 8. p. 208

532 Tal como Estevão Ribeiro Garcia, que era ituano, utilizamos também os inventários transcritos de Lucrécia Leme e Antônio Antunes Maciel, ambos também de Itu e o testamento de Antônio Castanho da Silva, de Santana de Parnaíba. APESP. I e T.. Vols. 23,24, 25 e 26.

${ }^{533}$ Como revelam Ângela Brandão e Viveiros de Araújo. Cf. BRANDÃO, Angela. Inventários como Fontes para a História da Arte e do Mobiliário Brasileiro. Cultura Visual, n. 13, p. 11-23, 2010. E ARAÚJO, Maria Lucília Viveiros. Reflexões sobre a pesquisa historiográfica dos testamentos. 2005. https://www.tjrs. jus.br/export/poder_judiciario/historia/memorial_do_poder_judiciario/memorial_judiciario_gaucho/revista_ju stica_e_historia/issn_1676-5834/v5n10/doc/9_Maria_Lucilia_Viveiros.pdf. Devemos ser cautelosos com as listagens presentes em tais documentos, pois revelam apenas um fragmento do que foi possuído durante a vida daquele individuo, compactação de muitos outros objetos que decerto teve e descartou, bem como de objetos que herdou e já eram usados por antepassados. De qualquer maneira, são riquíssimas fontes para compreender os interiores domésticos e mesmo o perfil do consumidor em sua circunstância.

534 Utilizamos neste capitulo em grande parte os conteúdos presentes em artigo realizado em conjunto com nossa orientadora Maria Borrego, onde evidenciamos através dos aspectos materiais dos móveis as dinâmicas sociais capitaneadas na cidade pelos setores mercantis paulistas durante o século XVIII.
} 
qualidade e preços dos móveis ${ }^{535}$, privilegiando casos específicos de grupos de riqueza e setores profissionais guiando-nos pelos atributos físicos das peças descritas, já desmaterializadas pelo tempo, em comparação com os exemplares remanescentes da época.

Inicialmente apresentaremos dois gráficos dos extremos temporais de nossa cronologia que servem para comparar o número de bens e a distribuição das diferentes categorias entre as posses dos inventariados. Através deles poderemos compreender quantitativamente os processos de mudança neste interregno, equilibrando tais dados com as informações qualitativas de casos específicos sobre os mesmos bens computados.

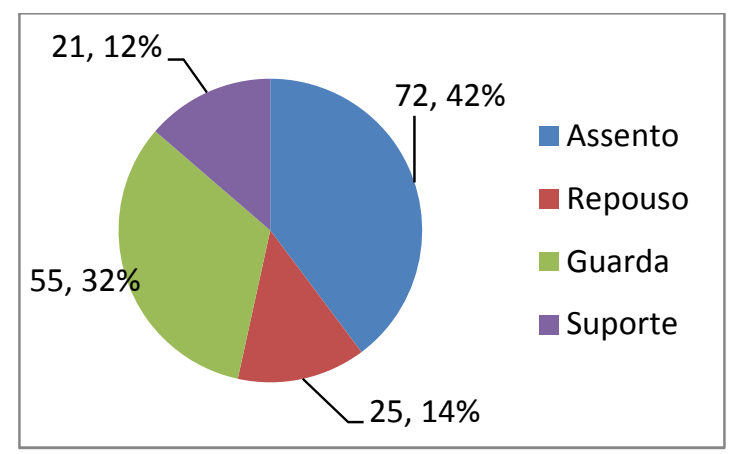

Figura 116: Gráfico de proporção entre categorias de móveis, em 15 inventários do intervalo entre 1700-1740. Números absolutos da quantidade dos móveis e porcentagens divididas por vírgulas.

As tipologias de móveis que encontramos no começo do século, em inventários entre 1700 e 1740, foram os seguintes:

Assento: arquibanco, banco, cadeira, escabelo, estrado, tamborete.

Repouso: cama, catre.

Guarda: baú, caixa, caixão, escrivaninha, peroleira.

Suporte: bufete, mesa de cozinha.

Um século depois, encontramos outros padrões de distribuição nas categorias de móveis e um número de peças imensamente maior.

\footnotetext{
535 Procuramos dentro do esforço geral da dissertação, ter a atenção em obter dados para quase todas as décadas de nosso recorte, focando nas diferenças dos objetos ao longo do tempo. Assim, tentamos realizar uma análise que equilibra os dados quantitativos com os qualitativos, em que buscamos dar atenção às descrições das peças inventariadas, à materialidade presente em fontes textuais paulista, como já praticado por historiadores como Carlos Franco para as elites lisboetas. Cf. FRANCO, Carlos. O mobiliário op. cit, 2007.
} 


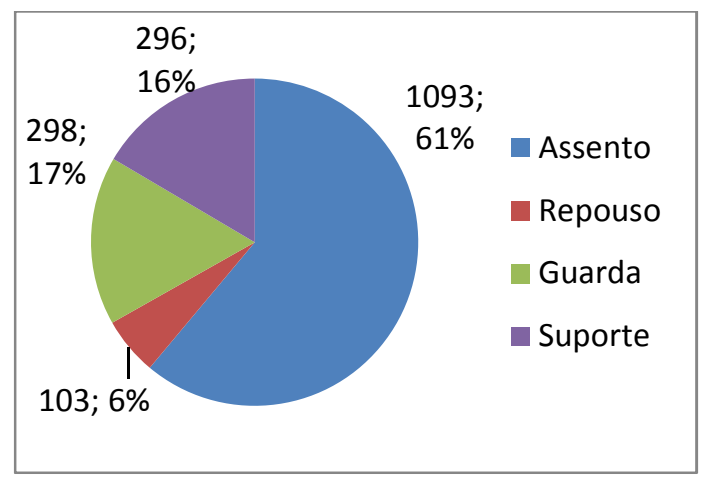

Figura 117: Gráfico de proporção entre categorias de móveis, em 23 inventários do intervalo entre 1801-1840. Números absolutos da quantidade dos móveis e porcentagens divididas por vírgulas.

Evidencia-se a grande escalada dos móveis de assento e de suporte e o recuo dos móveis de descanso e guarda. Pelo maior número de móveis prova-se como o consumo aumentou e as casas se tornaram mais recheadas de peças, as quais eram cada vez mais específicas, como podemos notar pelas suas tipologias:

Assento: banco, cadeira, canapé, escabelo, estrado, marquesa, mocho, poltrona, sofá, tripeça.

Repouso: cama, catre, leito, berço, preguiceiro.

Guarda: ancorote, armário, baú, cômoda, caixa, caixão, canastra, contador, guarda-roupa, papeleira, bruaca, cantoneira, cofre, escrivaninha, gaveta, guardalouça, patuá, urna.

Suporte: aparador, banca, bofete, cabide, carteira, credência, estante, mesa, toucador.

Se decerto o número de móveis possuídos pelos moradores de São Paulo do começo dos Setecentos era quase um décimo do que encontramos um século depois, é, porém, essencial compreender espaço doméstico paulista até o começo do século XVIII de uma maneira alargada, inter-relacionada com as condições de vida dos coevos. Nesta sociedade colonial as principais ocasiões de sociabilidade ocorriam fora das paredes das residências, fosse na rua, fosse nas igrejas ${ }^{536}$. Muitos habitantes, principalmente os donos de grandes fazendas, viviam principalmente nos sítios fora da área da cidade, apesar de terem casas na sua área central, as quais muitas vezes ficavam fechadas durante boa parte do ano, sendo utilizadas principalmente nos momentos em que a população se congregava na cidade em

\footnotetext{
${ }^{536}$ ALGRANTI, Leila Mezan. Famílias e vida doméstica. In SOUZA, Laura de Mello e. História da vida privada no Brasil. São Paulo: Companhia das Letras, v. 1, 1997, p. 113.
} 
razão de festividades religiosas e de festas reais ou por recepção de autoridades ${ }^{537}$. A afirmação do status da família se fazia, então, nestes momentos públicos de congraçamento social, por meio do lugar ocupado nas festividades, dos trajes "de festa", do séquito de escravos. Eram estes os principais sinais exteriores de riqueza e distinção social.

Para além do trânsito entre as áreas rural e urbana, que era bastante fluido, este era um momento de bastante itinerância para boa parte da população ${ }^{538}$, não só passando por São Paulo atraída para as Minas, bem como retornando para a cidade de modo a usufruir das riquezas e prestígios alcançados.

Sergio Buarque de Holanda e Laura de Mello e Souza ${ }^{539}$ já trataram das "formas provisórias de existência" na vida cotidiana nos caminhos e fronteiras do território luso americano. Os autores salientam uma divisão por períodos do desenvolvimento dos hábitos cotidianos, desde o pretenso abandono dos hábitos europeus e adoção de formas indígenas de fixação, passando por hibridismo de formas e depois a readoção de formas europeias de vida cotidiana ${ }^{540}$.

Acreditamos que afora o efetivo amálgama de práticas e soluções entre os europeus, indígenas e africanos, esses processos coexistiram durante boa parte da história colonial e possuíam verdadeira interdependência: os apetrechos citadinos levados pelos colonizadores, ainda que bastante reduzidos, eram justamente expressão material do esforço de "domesticar" os novos espaços dentro de suas noções de conforto, seja levando as redes aprendidas com os índios para dormir e carregar, seja transportando caixas com roupas, ferramentas e outros apetrechos, como Estevão Ribeiro Garcia ${ }^{541}$, que deixavam ainda pelo caminho roças com plantações variadas, como o milho, de maneira a auxiliar no suprimento dos próximos viajantes.

Vemos especialmente nos testamentos deste período menções a objetos que eram de posse dos falecidos, mas estavam fora de suas casas, emprestados ou

\footnotetext{
${ }^{537}$ CARVALHO, Mônica Muniz Pinto de. A cidade de São Paulo no século XVIII. Uma sociabilidade constituída em torno de símbolos do poder. São Paulo, dissertação de mestrado - FFLCH-USP, 1994.

${ }^{538}$ Vide BACELLAR, Carlos de Almeida Prado. As famílias de povoadores em áreas de fronteira da Capitania de São Paulo na segunda metade do século XVIII. Revista Brasileira de Estudos de População, v. 34, n. 3, p. 549566, 2017 bem como o clássico HOLANDA, Sérgio Buarque de. Movimentos da população em São Paulo no século XVIII. Revista do Instituto de Estudos Brasileiros. v. I, 55-111, 1966. .

539 Apud. SOUZA, Laura de Mello; Formas provisórias de existência: a vida cotidiana nos caminhos, nas fronteiras e nas fortificações. In: SOUZA, Laura de Mello (Org.). História da vida privada no Brasil: cotidiano e vida privada na América portuguesa, 1. São Paulo: Companhia das Letras, 1997, p 41ss.

${ }^{540}$ Idem, ibidem, p 46

${ }^{541}$ Tal como abordamos no capitulo anterior. Cf. p. 134-138.
} 
dados para parentes e amigos que tinham ido para as Minas. Por exemplo, no testamento de Maria Egipciana Domingues, de 1703, declarava-se que ela havia "mandado para as Minas por Manuel de Lima filho de Felipe de Lima que de presente assiste nas Minas um tacho que pesou 5 libras e meia." ${ }^{242}$ Igualmente Leonor de Siqueira, nas contas de seu inventário de 1704, registrou-se ter enviado para as Minas um caldeirão através do escravo Antônio Dias ${ }^{543}$. 0 envio desses dois tachos é de grande importância se pensarmos como eles poderiam ser usados para o processamento da alimentação em uma localidade onde a extração de metais se iniciava e os ferreiros e escravos especialistas ainda estavam se fixando, não havendo quem executasse semelhante apetrecho. Poderia ainda ser a garantia de uma renda para esse paulista através da venda de comidas e doces.

Também na dinâmica de fluxo e refluxo do comércio nas minas através, por exemplo, das vendas de tecidos, geralmente feitos nas casas e pelas mulheres, vemos essa inter-relação com as áreas de nova colonização. Antônio Castanho da Silva, cujo testamento foi feito em 1700 em Santana de Parnaíba registrava a sua dívida de $31 \$ 000$ réis a Felipe de Abreu da volta das Minas, onde fora com carregamento de aviamentos ${ }^{544}$.

Entendemos desta maneira que os bens enviados como "encomendas", bem como os equipamentos de defesa como as espingardas e outras armas de fogo geralmente presentes nos inventários revelavam por outras formas o espaço doméstico paulista em expansão, se estendendo no interim colonizador das novas áreas, e dotando-as também de artífices, como evidenciamos anteriormente. Os apetrechos das casas insuflando o raio de influência da dominação portuguesa merecem ser compreendidos como objetos tecnológicos a providenciar tanto a domesticação do território como sustentar o mínimo de conforto com que essas populações estavam acostumadas a viver e praticar as suas atividades econômicas. Acreditamos que estas são uma faceta das expressões materiais da assertiva de llana Blaj de como "é o desenvolvimento da vila de São Paulo e de seus arredores que explica a possibilidade do abastecimento do mercado mineiro, e não o contrário" 545

\footnotetext{
${ }^{542}$ APESP, I e T, vol. 23.

${ }^{543}$ APESP, l e T, vol. 24.

544 APESP. I e T. vol. 25.

${ }^{545}$ BLAJ, llana. A trama das tensões: o processo de mercantilização de São Paulo colonial (1681-1721). São Paulo : Humanitas/FFLCH/USP : Fapesp, 2002; , p. 205.
} 
Em decorrência dessa forma de vida conectada à intermitência dos principais agentes econômicos da cidade nos primeiros anos do século XVIII encontramos padrões de posse bastante contrastantes, que serviram de aval para a historiografia taxar a cidade de decadente e esvaziada. Contamos, decerto, poucas peças de mobiliário declaradas, o que poderia parecer em um primeiro olhar sinônimo de pobreza. Porém, notamos que os mesmos indivíduos eram proprietários de grande volume de escravos indígenas e terras, como é o caso de Antônio Machado do Passo, com testamento de 1704, feito em Itu. Apesar de possuir apenas quatro caixas e um bufete, era dono de duas casas e onze escravos, tanto indígenas quanto africanos ${ }^{546}$ e centenas de braças de terras.

Sobre seus bens imóveis dizia ter "nesta vila umas casas de parede de mão coberta de telhas de dois lanços com seu bufete e uma caixa grande já bastantemente velha". É curioso notar como na descrição das casas elas já vêm associadas com a presença de caixas e também do bufete, indicação da importância dos objetos de guarda no espaço doméstico e sua função associada à manutenção dos pertences na casa durante as viagens dos donos. No caso do bufete, se pudermos compará-lo aos maciços exemplares torneados com pés de bolachas presentes no Museu Paulista, notamos a centralidade desta peça para o recinto doméstico, uma vez ser descrita a peça que continha, dado geralmente ocupar o centro das salas ou ficar recostado nas paredes, servindo de suporte para contadores, oratórios e ornatos religiosos, a depender do número de gavetas ${ }^{547}$.

Também devemos tomar atenção aos valores das fazendas como indicadores da posição social, do volume das posses e consequentemente da capacidade de consumo. Um dos inventários com menor riqueza declarada, procedente do casal Antônio Ribeiro de Moraes e Catharina Ribeiro, foi feito entre 1688 e $1700^{548}$, trazendo o Monte-mor de $10 \$ 300$, e o menor de $7 \$ 260$ réis. Não obstante o valor numérico, eles possuíam grande volume de bens para a época, sendo 41 móveis. Dentre eles se destacam 12 cadeiras de estado e um "Archibanco". Este é bastante interessante, pois revela a ambivalência das peças na época, já que segundo Maria Helena Flexor o arquibanco era um "banco-arca de encosto alto e assento móvel"

\footnotetext{
${ }^{546}$ APESP. I e T., vol. 25.

${ }^{547}$ CANTI, Tilde. 0 móvel no Brasil: origens, evolução e características. Rio de Janeiro: Ed. Candido Guinle de Paula Machado, 1980.

${ }^{548}$ APESP. I e T., vol. 22.
} 
549. Segundo Carlos Franco, a denominação arquibanco para móveis desse tipo provém do francês archebanc, "que são assim denominados porque, na realidade, são formados por arcas ou "caixas" cujos bancos também servem como assento" 550 . Possuía ainda o casal no seu cabedal 22 "peças", isto é, escravos indígenas, a atestar o seu status.

Bem antes do que a historiografia paulística considerara o incremento material do planalto, vemos o inventário de Mathias Rodrigues da Silva, em $1710^{551}$, reinol nascido em Setúbal ${ }^{552}$, possuidor da maior fortuna encontrada para o começo do século, de mais de 12 contos de réis e 18 escravos, quase todos da Guiné. Mathias Rodrigues da Silva possuía nada menos do que 1080 caixetas de marmelada, cada uma contabilizada a $\$ 160$ réis, perfazendo um total de $172 \$ 800$ réis ${ }^{553}$. Apesar de sua função específica no momento ser a de invólucro para a exportação deste gênero alimentício local, forte indústria de São Paulo como notado décadas antes por Fernão Cardim ${ }^{554}$, eram objetos que poderiam servir como móveis de guarda, tal qual ocorria com as caixas que levavam os pães de açúcar saindo das zonas produtoras do Nordeste e eram reutilizadas na Europa e na intermediária Ilha da Madeira para a fabricação de móveis, chamados "móveis caixa de açúcar" 555.

Também possuía Mathias Rodrigues da Silva valiosas peles de cordovão, um couro de cabra ou bode "çurrada" como denomina Bluteau ${ }^{556}$, a $1 \$ 000$ réis cada, e uma centena de "carneiras", totalizando $27 \$ 000$ réis, indicativo que o inventariado exercia diversos tipos de atividades econômicas.

\footnotetext{
${ }^{549}$ Cf. FLEXOR, Maria Helena. Mobiliário Bahiano.Op. Cit., 2009, p. 147.

550 FRANCO, Carlos. O mobiliário das elites de Lisboa na segunda metade do século XVIII. Lisboa: Livros Horizonte, 2007, p. 77.

${ }_{551}^{551}$ APESP. I e T, vol. 25.

552 Disponível em: http://www.projetocompartilhar.org/SAESPp/mathiasrodriguesdasilva1709.htm. Acessado em 20/05/2018.

${ }^{553}$ Deve-se salientar que removemos da listagem no gráfico tais caixetas, para não gerar distorções, mas se a considerarmos integrantes da somatória, teríamos os dois extremos de nossa cronologia equiparados no número de móveis.

${ }^{554}$ CARDIM, Fernão. Tratados da terra e gente do Brasil. Belo Horizonte: Itatiaia; São Paulo: Edusp, 1980. p. 173 apud VILARDAGA, Jose Carlos. São Paulo na órbita do Império dos Felipes: conexões castelhanas de uma vila da América Portuguesa durante a União Ibérica (1580-1640). Tese de Doutorado em História Social Faculdade de Filosofia, Letras e Ciências Humanas, Universidade de São Paulo, São Paulo, 2011.

p. 91.

555 HENRIQUES, João Maria, A "caixa de Açúcar", in Das Artes e da História da Madeira, 1950, vol. I, no..4, pp.28-29.

${ }^{556}$ BLUTEAU, Raphael. Vocabulario portuguez \& latino: aulico, anatomico, architectonico... Coimbra: Collegio das Artes da Companhia de Jesus, 1712-1728, Vol. 2, p. 548.
} 
Decerto para contabilizar o volume de dinheiro adquirido com suas várias atividades Mathias Rodrigues da Silva utilizava uma "escrivaninha com sua gaveta" avaliada por $1 \$ 000$ réis, a mais remota que encontramos inventariada. Também com tal móvel deveria praticar atividades literárias, pois possuía 18 livros, entre eles uma "Arte da Inglaterra", avaliada em $\$ 320$.

Possuía oito tamboretes, sendo sete descritos em conjunto possuindo pregaria miúda e um enorme valor de $11 \$ 200$ réis, ao passo em que suas três cadeiras velhas tinham valor baixo, de $\$ 480$ réis a mais cara. A diferenciação entre estes dois tipos de móveis, como acentua Maria Borrego, é bastante sutil, sendo muitas vezes o seu uso intercambiado ${ }^{557}$. Pelo fato de aparecer nos inventários a descrição "tamboretes de encosto", leva-se a crer que originalmente o tamborete não o possuiria, assemelhando-se a outras formas de móveis de assento como os banquinhos e os mochos. Interessante notar como nos inventários desaparece a denominação cadeira durante certo tempo, predominando os "tamboretes com encosto", revelando que as dinâmicas dos móveis em seus usos, formas e estilos também se espelham na história dos termos usados para classifica-los, como perspicazmente notado pela historiadora ${ }^{558}$. Já na segunda metade do século ocorre inversão de valoração entre os tamboretes e as cadeiras, como mais à frente discorreremos.

Possuía também o mais remoto escabelo arrolado dentro de nosso recorte, avaliado como "grande e em bom uso" por $3 \$ 200$. Há grande imprecisão sobre o que se definia como escabelo na época, pois diferentemente do móvel descrito por Bluteau como "assento pequeno de madeira, sem braços, nem espaldares" ${ }^{559}$, igualmente assim considerado por Flexor, os escabelos registrados podiam chegar a medir 13 palmos, eram providos ou não de encosto e alguns possuíam tampa e fechadura no assento. Segundo Tilde Canti, tal móvel figurava nas cozinhas portuguesas ou nas igrejas ${ }^{560}$. Para o contexto paulista, somente encontramos mais

\footnotetext{
557 BORREGO, Maria Aparecida de Menezes; FELIX, Rogério Ricciluca Matiello. Ambientes domésticos e dinâmicas sociais em São Paulo colonial. Rev. Hist. (São Paulo), São Paulo, n. 175, p. 91-132, dez. 2016.

${ }^{558}$ E como frisamos anteriormente neste capítulo, sobre a encomenda de cadeiras pela câmara municipal.

559 BLUTEAU, Raphael. Vocabulario portuguez \& latino: aulico, anatomico, architectonico... Coimbra: Collegio das Artes da Companhia de Jesus, 1712-1728, v.3, p.200.

${ }^{560}$ CANTI, Tilde. 0 móvel no Brasil: origens, evolução e características. Rio de Janeiro: Ed. Candido Guinle de Paula Machado, 1980, p. 111.
} 
uma menção a tal móvel em 1755, alocado no alpendre do sítio de Alexandre Monteiro de Sampaio, localizado na paragem do Ipiranga ${ }^{561}$.

Nota-se também no caso de Mathias da Silva as conexões internacionais por meio de um curioso coxim de palha "de Angola", objeto que evidenciaria como ainda que raras as influências africanas também se faziam presentes em objetos do espaço doméstico luso-americano ${ }^{562}$. Apesar do baixo valor de $\$ 320$ réis, notamos que era significativo ao ponto de ser listado. Tinha ainda "oito covilhetes da Índia", espécies de jarros de barro de forma côncava, os quais evidenciam os fluxos de objetos estrangeiros em São Paulo e desanuviam a aura de "vila isolada".

Lançando mão destes exemplos do começo dos Setecentos, notamos nas análises dos inventários do avançar do século como foram principalmente os homens de negócios catalisadores de dinâmicas sociais na cidade, com suas múltiplas conexões, atividades e esforços para angariar posições sociais elevadas $^{563}$. Suas casas e bens não eram somente produtos de seu enriquecimento, mas também vetores desse mesmo processo, se compreendermos o agenciamento realizado com os móveis nas ocasiões de sociabilidade para a recepção de convidados e clientes, sendo arena para novas parcerias e projetos.

Um exemplo para a metade dos setecentos, Manoel de Macedo já possuía em $1753^{564}$, quando foi feito seu inventário, quase três centenas de bens móveis, entre os quais 48 peças de mobília, sendo o mais caro um oratório dourado com imagens e resplendor de prata, avaliado em $32 \$ 000$ réis. Compunha seu espaço doméstico 3 mesas, 3 bufetes, 16 tamboretes, 12 caixas de diversos tamanhos e 5 catres de diversas qualidades, onde se juntam tanto o torneado, o de jacarandá e o com "sua grade e cabeceira" com outros dois "toscos", que "tinham servido aos

\footnotetext{
561 BORREGO, Maria Aparecida de Menezes; FELIX, Rogério Ricciluca Matiello. Ambientes domésticos e dinâmicas sociais em São Paulo colonial. Rev. Hist. (São Paulo), São Paulo, n. 175, p. 91-132, dez. 2016.

562 Segundo Bluteau "coxim de estrado" é sinônimo de "Almofada". Não se menciona a acepção mais corrente atualmente de assento usado sobre a cavalgadura, decerto da onde é derivada cf. dicionário Priberam. Aliás, é digno de nota o exemplo de uso literário de tal termo na citação de Bluteau, extraído de Miguel leitão de Andrada (1553-1630): "E he bem, que a tal Raynha/Thronos Ihe dem o Coxim". BLUTEAU, Raphael. Vocabulario portuguez \& latino: aulico, anatomico, architectonico... Coimbra: Collegio das Artes da Companhia de Jesus, 1712-1728, Vol. 2 pg. 598.

563 BORREGO, Maria Aparecida de Menezes. A teia mercantil: negócios e poderes em São Paulo colonial (17111765). São Paulo: Alameda/ Fapesp, 2010.

564 APESP. Inventários e Testamentos não publicados, Caixas 531 e 705. Manoel de Macedo, 1753. Seu Monte-mor computava 33:198\$832.
} 
caixeiros", possivelmente hospedados em um quarto de visitas na sua casa urbana, tal como ocorria no espaço externo do alpendre, típico das casas rurais ${ }^{565}$

Também outros tipos de móveis para o descanso são bastante reveladores sobre as novas fortunas comerciais da cidade: os preguiceiros, que atendiam ao conforto dos habitantes. Retrato da consolidação das fortunas e a sedimentação das populações em solo piratiningano, esse tipo de móvel, talvez um misto de cama e cadeira, atesta como os paulistas tinham mais tempo para ocasiões de repouso durante o dia e condições materiais para encomendar móveis específicos e requintados para tal prática.

Também evidencia o gradual aumento de requinte doméstico o consumo de um maior número de móveis de guarda especializados, como as cômodas, os guarda-roupas, e contadores. Até os princípios dos Setecentos as caixas e canastras predominavam nos inventários como objetos destinados à guarda em miscelânea de alimentos, roupas, dinheiro e comida. Vemos ao longo deste século por seu turno o gradual aparecimento de desdobramentos destes artefatos transportáveis que serviam para acomodar objetos específicos ou divididos categoricamente, como caixas com gavetas embaixo e "com seus pés".

O aumento da incidência desses móveis ao longo do século XVIII é forte evidência da perenização de parcelas da população paulista em suas casas, assentando suas caixas sobre pés fixos e dotando-as ao longo do tempo de escaninhos e gavetas. Esses objetos de transição entre aparato de viagem e móvel fixo são uma dos precursores das cômodas, xifonetes e armários de porta e prateleira, sendo sintomático o termo em inglês para cômoda ser Chest of Drawers, "caixa com gavetas", carregando no nome a sua ancestralidade locomóvel ${ }^{566}$.

Atesta a predominância dos comerciantes como agentes de sociabilidade na cidade o fato de que até os indivíduos pertencentes a esta categoria, mas com somas menos avultadas que os seus pares, também possuíam interiores domésticos atentos às sociabilidades lúdicas é o caso de Diogo José da Silva, que em 1824, possuía 298\$277 de monte-menor, pequena soma se comparada a de comerciantes que tinham dezenas de contos de réis. Ele decerto recebia diversos convidados em seu espaço doméstico, pois possuía 14 cadeiras com assentos de palhinha, bem

\footnotetext{
565 MAYUMI, Lia. Taipa, canela-preta e concreto. São Paulo: Romano Guerra Editora, 2008.

566 BORREGO, Maria Aparecida de Menezes. Laços familiares e aspectos materiais da dinâmica mercantil na cidade de São Paulo (séculos XVIII e XIX). An. mus. paul., São Paulo , v. 18, n. 1, Junho 2010, p. 31,
} 
como marquesa e canapé também de palhinha, onde deviam se acomodar sua família e os convivas enquanto se divertiam com as duas bancas de abrir para jogo e uma mesinha de gamão, esta acompanhada de copo de marfim para jogar os dados.

A multiplicidade de móveis de apoio possuídos pelos comerciantes atesta como o número de atividades exercidas nos interiores domésticos aumentava à mesma proporção à qual os paulistas ficavam mais em suas casas, usufruindo da riqueza alçada por suas famílias, ou pelas famílias de suas esposas ${ }^{567}$, após muitos anos de jornadas comerciais interconectando as capitanias coloniais. Notamos como recai sobre esta espécie de móvel o maior número de especializações funcionais, como as bancas atreladas ao carteado, que figuravam nos inventários paulistas como bancas "para jogar cartas", "de abrir para jogos", "com embutidos para jogos", "de jacarandá de abrir forrada de baeta verde"; bem como as mesas "para Chá", "de Janta”, "de Sofá", "com Armário”, e também as mesas "de Canto", revelando um horror ao espaço vazio por essas camadas da elite econômica, que na abundância de peças demonstrava a sua pujança econômica ${ }^{568}$. O lazer associado aos jogos e a proliferação de móveis destinados a tal fim nos interiores domésticos foi também constatada por Nuno Madureira e Carlos Franco para o contexto lisboeta, ainda na segunda metade do século XVIII ${ }^{569}$, momento em que a cidade assumia novas feições com a reconstrução e novas práticas e espaços de sociabilidades surgiam ${ }^{570}$.

A circulação pelos recintos, a acomodação dos residentes do domicílio, a recepção a pessoas alheias ao fogo - membros da família, vizinhos, parceiros comerciais - levam-nos a avaliar também o papel dos móveis de assento na

\footnotetext{
${ }^{567}$ Como notado por Muriel Nazzari NAZZARI, Muriel. Oliveira, Lólio Lourenço de (trad). 0 desaparecimento do dote: mulheres, famílias e mudança social em São Paulo, Brasil, 1600-1900. São Paulo: Companhia das Letras, 2001, p. 119; e evidenciado também por BORREGO, Maria Aparecida de Menezes. Laços familiares e aspectos materiais da dinâmica mercantil na cidade de São Paulo (séculos XVIII e XIX). An. mus. paul., São Paulo, v. 18, n. 1, p. 11-41, Junho 2010.

${ }^{568}$ Guardadas as devidas proporções cabe comparativo com o fenômeno doméstico ocorrido na Inglaterra séculos antes, onde os setores burgueses enriquecidos passaram a ter lares cada vez mais recheados, em paralelo com os palácios dos nobres, a cujo status não podiam ascender, ainda que suas fortunas se equiparassem. Cf. RICE, Charles, The Emergence of the Interior: Architecture, Modernity, Domesticity. Oxford: Routledge, 2007.

${ }^{569}$ MADUREIRA, Nuno Luis. Cidade: Espaço e Quotidiano. Lisboa 1740-1830. Lisboa: Livros Horizonte, 1992; FRANCO, Carlos. Op. Cit., 2007.

570 Como mostrado por OLIVAL, Fernanda. Os lugares e espaços do privado nos grupos populares e intermédios. In: MONTEIRO, Nuno Gonçalo. História da vida privada em Portugal, vol. 2. Lisboa: Círculo de Leitores, 2011.
} 
intermediação das relações sociais. Esse tipo de mobiliário era o mais numeroso nos ambientes domésticos de agentes mercantis em São Paulo setecentista, fornecendo indícios sobre as sociabilidades desenvolvidas em salas de recepção.

Os traços mouriscos na cultura material paulista estão presentes principalmente em objetos de assento, não necessariamente mobílias de madeira, mas também tecidos. Exemplos são o estrado, a treliça, a almofada, o tapete, e a alcatifa. É importante compreender a distinção destes dois últimos termos feita por Bluteau. A alcatifa é definida como um "pano de lã ou seda de várias cores e lavores que se estende para cobrir o chão ou assoalhado de uma casa, ou um estrado, ou outra coisa" ${ }^{571}$. Por sua vez, o tapete é "uma pequena alcatifa de lã das que vem da Índia, que se põem ao pé da cama, ou com que se cobre um bofete (...) Deriva-se do grego Tapis, que quer dizer cobertor" ${ }^{572}$.

Para além do uso destes dois tecidos, para a cobertura de móveis encontramos especificamente o lambe ${ }^{573}$ ou alambel, presente no inventário de Antônio Ribeiro de Morais, de 1700. Não encontramos no avançar dos séculos XVIII e XIX menções da presença do alambel, da alcatifa ou de almofadas, ainda que continuem aparecendo tapetes e estrados. Acreditamos ser sintomático desaparecerem dos inventários ao longo do tempo as menções a esses objetos relacionados à herança árabe na Península Ibérica, revelando como as práticas domésticas vão se alterando à medida em que novas categorias de móveis ligados aos estilos europeus foram se somando às listagens, ainda que encontremos reminiscências nas práticas do corpo.

Os atributos físicos levados em consideração pelos avaliadores no que tange aos pés e espaldares dos móveis de assento fornecem evidencias da introdução de novos tipos e formas de peças, como os pés de cabra, trazendo consigo práticas sociais que pressupunham mais pessoas acomodadas em cadeiras nas salas de recepção e objetos com formas mais audaciosas e tecnicamente desafiadoras que a retilinidade das cadeiras de sola ${ }^{574}$. Por exemplo, Inácia Maria Rodrigues, esposa do

\footnotetext{
${ }^{571}$ BLUTEAU, Raphael. Vocabulario portuguez \& latino: aulico, anatomico, architectonico... Coimbra: Collegio das Artes da Companhia de Jesus, 1712-1728, vol. 1 p. 222.

572 BLUTEAU, Raphael. Vocabulario portuguez \& latino..., op. cit.,, vol. 8, p. 46.

573 BLUTEAU, Raphael. Vocabulario portuguez \& latino..., op. cit.,, vol. 5 p. 26 "Pano de lã grosso e de ordinário listrado de varias cores e que serve para cobertura de algum banco".

${ }^{574}$ A seguir, as análises aqui apresentadas foram desenvolvidas com mais vagar em nosso artigo: BORREGO, Maria Aparecida de Menezes; FELIX, Rogério Ricciluca Matiello. Ambientes domésticos e dinâmicas sociais em São Paulo colonial. Rev. Hist. (São Paulo), São Paulo, n. 175, p. 91-132, dez. 2016.
} 
mercador Lopo dos Santos Serra, falecida em 1768, dispunha de 51 móveis de assento. Neste inventário reaparece a designação cadeiras ao lado de tamboretes e o que percebemos pelas descrições é que as primeiras se caracterizavam pelo encosto de jacarandá e pés de cabra: "uma dúzia de cadeiras de encosto de jacarandá de pés de cabra grandes com assento de sola lavrada"575; "dez cadeiras de encosto de jacarandá mais pequenas com assento de sola lavrada"; "seis ditas [cadeiras] de encosto de jacarandá e assentos de marroquim de pés de cabra".

A menção a pés de cabra possivelmente indica que as pernas dianteiras das cadeiras e tamboretes eram curvas, chamadas de galbardas ou cabriolet, que terminavam em volutas sobre sapatas (denominadas pés de cachimbo em Portugal $)^{576}$. Tais características afastam as peças das tradicionais cadeiras de sola mencionadas anteriormente, o que é reforçado pelas descrições do espaldar de jacarandá - provavelmente vazado - e do assento de couro ou marroquim.

Além disso, os valores alcançados pelas cadeiras foram superiores aos dos tamboretes com encosto. Para que se tenha uma ideia, as cadeiras com pés de cabra foram avaliadas em cerca de $\$ 500$ a unidade, enquanto os "oito tamboretes de madeira de encosto bem feitos" contabilizados na residência de Antônio Barbosa de Lima, em 1764 , alcançaram a cifra de $3 \$ 200$, ou seja, $\$ 400$ a peça.

Interessante perceber, contudo, que nos inventários setecentistas paulistas não há menção a móveis coletivos como canapés, ainda que em Portugal eles já fossem confeccionados desde a segunda metade do século XVIII, com assento forrado de tecido ou de palhinha ${ }^{577}$. Em São Paulo apareciam de coletivo principalmente os bancos, sendo que seus congêneres mais requintados como os canapés e marquesas estrearam nas salas de visitas somente nos inícios dos Oitocentos, reproduzindo a forma e a decoração das cadeiras que os ladeavam, quando o processo de interiorização das sociabilidades já estava mais vulgarizado, sobretudo entre os membros da elite ${ }^{578}$.

\footnotetext{
${ }^{575}$ Móvel de características semelhantes às descrições dos inventários pode ser encontrado no Museu Nacional de Arte Antiga, em Lisboa. Disponível em:

http://www.matriznet.dgpc.pt/MatrizNet/Objectos/ObjectosConsultar.aspx?ldReg=254193.

${ }^{576}$ Cf. CANTI, Tilde. O móvel no Brasil: origens, evolução e características. Rio de Janeiro: Ed. Candido Guinle de Paula Machado, 1980, p. 249.

${ }^{577}$ FREIRE, Fernanda Castro. Mobiliário, v. 1. Lisboa: Fundação Ricardo do Espírito Santo Silva, 1994; PINTO, Pedro da Costa. O móvel de assento português do século XVIII. Lisboa: Mediatexto, 2005.

578 BORREGO, Maria Aparecida de Menezes. Laços familiares e aspectos materiais da dinâmica mercantil na cidade de São Paulo (séculos XVIII e XIX). Anais do Museu Paulista. História e cultura material, vol. 18, n. 1, São Paulo, 2010, p. 11-41.
} 
Principalmente nas descrições de tamboretes e cadeiras houve menção por parte dos avaliadores dos materiais com que eram produzidos. Preferencialmente o eram a partir do vinhático ou de madeira "da terra", enquanto nas cadeiras se empregava o nobre jacarandá da Bahia, destinado à produção de peças de luxo ou honra ${ }^{579}$.

Também encontramos outros móveis com semelhantes descrições sobre as madeiras utilizadas como critério diferenciador na valoração. Por exemplo, o comerciante José da Silva Ferrão, inventariado em 1762 com 56:358\$408 réis de monte-menor, possuía um leito de madeira de vapuã e "feito na terra" que valia $12 \$ 800$ réis. Julgamos ser mais um sinal de que a São Paulo era um local com produção moveleira ascendente, recordando-se ter sido este homem de comércio um contemporâneo de artífices como João da Mota Liver e Luís Rodrigues Lisboa.

Se de fato a menção a móveis feitos na terra com madeiras nobres revela que o consumo local mostra sinais de requinte e a produção se sofistica, também as menções a madeiras "da terra" são relevante para compreendermos o consumo interligado á produção moveleira paulista.

Um dos mais singelos inventariados contemporâneos ao portentoso comerciante José da Silva Ferrão era o alfaiate João Pinto Rodrigues, contando em $1761,57 \$ 180$ réis de monte-menor. Seus onze bens resumiam-se a um "gavetam [sic] com gavetas e fechaduras feito na terra", duas bancas, uma caixa e dois catres feitos na terra, sendo um deles tecido de cipó e outro de couro.

Para o primeiro período encontramos de fato poucos móveis descritos como "da terra", divididos entre três inventários: Mathias Rodrigues da Silva, em 1710 possuía "três painéis grandes, feitos na terra", $9 \$ 600$ réis; dois catres da terra usados, 2\$560; Manuel Pacheco Gato, em 1715: três catres feitos na terra; $3 \$ 000$ um bufete de seis palmos com sua gaveta com fechadura feitio da terra, $1 \$ 600$. E Diogo Bueno e Isabel Bueno de Oliveira, em 1729: dois catres usados feitos na terra $2 \$ 000$; um bufete da terra sem gaveta $2 \$ 000$; um bufete com duas gavetas da terra $2 \$ 000$.

Nos 87 inventários post-mortem desde 1741 selecionamos os casos em que houve atenção em se falar da madeira, encontramos grande aumento no número de

\footnotetext{
${ }^{579}$ BRANDÃO, Angela. Anotações para uma história do mobiliário brasileiro do século XVIII. Revista CPC (USP), v. 9, 2009-2010, p. 42-64.
} 
peças onde se usou madeiras "da terra". Para melhorar a visualização elaboramos gráficos e dividimo-los comparativamente.

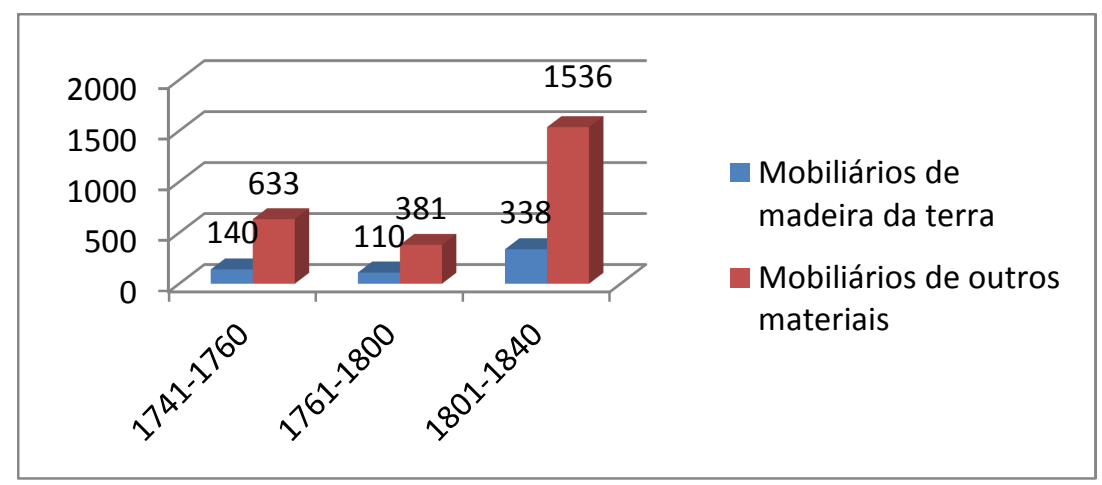

Gráfico 6: Gráfico de distribuição entre os mobiliários de Madeira da Terra e outras madeiras por período.

Vale notar que nos casos em que há definição da árvore, este discriminante serve como critério diferenciador do valor das peças. Especialmente madeiras como o vinhático, o cedro, a madeira "de óleo" e o jacarandá. Por exemplo, o leito de madeira da terra mais barato que encontramos fora avaliado em $3 \$ 200$ réis, mas a mesma categoria de peça poderia chegar a $40 \$ 000$ se feitio de jacarandá baiano.

Tabela 7: Lista de madeiras classificadas usadas no mobiliário e suas quantidades, $1741-1840^{580}$.

\begin{tabular}{lc}
\hline \multicolumn{1}{c}{$\begin{array}{c}\text { Classificação da } \\
\text { Madeira }\end{array}$} & $\begin{array}{c}\text { Quantidade de } \\
\text { móveis }\end{array}$ \\
\hline Canela & 5 \\
Cedro & 21 \\
Jacarandá & 479 \\
Jacarandá e madeira & 1 \\
"de óleo" & 1 \\
Jacarandá e mogno & 2 \\
Madeira "de fora" & 287 \\
Madeira "de óleo" & 14 \\
Madeira "do Rio" & 31 \\
Madeira "amarela" & 1 \\
Nogueira & 1 \\
Pequeá & 5 \\
Pinho & 1 \\
Vapuã & 31 \\
Vinhático & 880 \\
Total & \\
\hline
\end{tabular}

Cabe ainda notar que o uso da madeira da terra revela que a produção de mobiliário local, apesar de ser geralmente de peças mais modestas, como as possuídas pelo alfaiate João Pinto Rodrigues na década de 1760, também era

\footnotetext{
580 Quantidades presentes no total de 3163 móveis constando em 87 inventários. Cf. BORREGO, Maria Aparecida de Menezes. Projeto de Pesquisa Jovem Pesquisador FAPESP - Espaço Doméstico e Cultura Material em São Paulo Colonial a partir do estudo de acervos do Museu Paulista/USP. Não Publicado. 2010.
} 
presente nos inventários dos mais ricos do século seguinte, como o Brigadeiro Jordão, com suas 86 cadeiras feitas "na terra" e tecidas de palhinha, tipo de material que fornecia muito mais leveza às cadeiras, que poderiam ser mais facilmente manuseadas, alterando as relações com os corpos e os espaços de seus usuários nas ocasiões de sociabilidades, como veremos no próximo capítulo.

A maior fortuna de São Paulo ao final do período estudado era pertencente ao Brigadeiro Manuel Rodrigues Jordão (inventário de 1828) ${ }^{581}$, grande homem de comércio. Possuía mais de três centenas de móveis, sendo as cadeiras responsáveis por mais de um terço deste total. Especial destaque merecem as variações nos tipos de cadeiras que possuía, sendo um grande exemplo das alterações sofridas pelo espaço doméstico desde o começo do século XVIII, quando as casas não traziam semelhante abundância de móveis de assento, mesmo a do abastado Mathias Rodrigues da Silva um século antes, com suas 15 peças.

Tabela 8: quantidade e valor dos móveis com madeiras discriminadas no inventário do Brigadeiro Jordão (1838)

\begin{tabular}{lcc}
\hline $\begin{array}{l}\text { Descrição dos tipos de cadeiras e suas } \\
\text { características }\end{array}$ & Quantidade & Valor (réis) \\
\hline $\begin{array}{l}\text { (Cadeiras de) madeira amarela, de encosto } \\
\text { com suas almofadas de seda }\end{array}$ & 12 & $6 \$ 400$ \\
Jacarandá de braços, também de palhinha & 2 & $6 \$ 000$ \\
Jacarandá preto com seus embutidos, com & 18 & $4 \$ 000$ \\
$\begin{array}{l}\text { assento de palhinha } \\
\text { Braços tecida de palhinha }\end{array}$ & 1 & $4 \$ 000$ \\
Madeira amarela, de assento de palhinha & 18 & $3 \$ 000$ \\
Braços de óleo & 10 & $3 \$ 000$ \\
Madeira da terra, tecidas de palhinha & 86 & $2 \$ 000$ \\
$\begin{array}{l}\text { Bidê que serve para banho, com seus tecidos } \\
\text { de palhinha }\end{array}$ & 1 & $2 \$ 000$ \\
Madeira de óleo tecidas de palhinha & 2 & $2 \$ 000$ \\
$\begin{array}{l}\text { Madeira de jacarandá, com seus embutidos, } \\
\text { também tecidas de palhinha. }\end{array}$ & 8 & $2 \$ 000$ \\
$\begin{array}{l}\text { Jacarandá, antigas, com assento de sola } \\
\text { picada e velhas }\end{array}$ & 12 & $2 \$ 000$ \\
Total & 158 & $36 \$ 400$ \\
\hline
\end{tabular}

Também possuía bancos, mesas, mochos e canapés com madeiras locais. Vemos assim pelos dados do consumo e da posse como a produção dos móveis paulistas acrescia em quantidade e qualidade, em paralelo com as dinâmicas econômicas e tecnológicas em que estavam envoltas.

\footnotetext{
581 ATJSP. Inventários e testamentos Manuel Rodrigues Jordão (brigadeiro): Inventários do 10 cartório de família, proc. 229-1828.
} 
Assim compreendemos como em meados do século XVIII os agentes comerciais, residentes na cidade de São Paulo, enriquecidos, sobretudo, em função das transações com as minas de Cuiabá e Goiás já faziam de suas residências espaços incipientes para maior convívio social, evidenciado pelo número elevado de móveis de assento, bem como pelo estilo cabriollé do qual foram pioneiros, pelas variadas bancas de jogos, e pelos ostensivos preguiceiros. Todos estes dados materiais indicam como os setores ligados à lide mercantil, em especial os mais abastados, mas não só, estavam em sintonia com o que se produzia em outras áreas coloniais e estrangeiras. Assim, suas casas de morada são a prova de que a cidade de São Paulo estava articulada ao Império Português, por meio da circulação e consumo de artefatos domésticos.

Complementando nossa compreensão sobre as facetas do consumo de móveis em São Paulo, onde notamos a singular agência dos comerciantes na introdução de tipos de móveis e de sociabilidades, lançamos mão ainda dos documentos de outra categoria social que também tomava parte nesse interim, ainda que de maneira muito rarefeita e nos permite agregar novos prismas à compreensão dos estratos sociais em São Paulo e a dinâmica de enriquecimento e consumo dessa população. São os casos raríssimos, que encontramos em nossas pesquisas, de dois inventários post-mortem de escravas negras alforriadas que revelam atípico volume de riqueza para ex-integrantes do estrato social mais inferior.

Rosa de Souza ${ }^{582}$, falecida em 2 de dezembro de 1777, possuía cabedal de $226 \$ 197$ réis. Não deixando testamento, desconhecemos ao certo quem fora o seu senhor e qual sua relação com o mesmo. Diz-se apenas que fora sempre solteira, não obstante ter duas filhas, Ana Joaquina e Bárbara. Tendo sido escrava, possuía também uma cativa em sua casa: Joana, 25 anos, de nação Benguela, a qual fora avaliada na quantia de $64 \$ 000$ réis.

É difícil precisar que atividade exerceria para o sustento de sua casa, mas talvez o tacho meão de 9 libras fosse usado para fazer comidas a serem vendidas pela escrava que a liberta possuía, ou talvez esta lavasse roupa para fora, com os dois bancos de lavar roupa, orçados em $\$ 160$ réis. Por não possuir muitas dívidas, era pouco possível que exercesse atividade comercial. Basicamente era devedora ao licenciado José Antônio de Lacerda por um remédio no valor de $\$ 160$ réis; a

${ }^{582}$ APESP. Inventários e Testamentos não publicados, Caixa 680. Rosa de Souza, 1777. 
Bernardo Luís do Rego, $\$ 820$ réis, de resto de fazendas que comprara durante a sua vida e a Antônio Rodrigues Picanto, a quem penhorara por $9 \$ 315$ réis uma peça de ouro, a qual completava o caixilho que possuía.

Tal exemplo mostra que os ex-escravos ainda que raramente poderiam ascender socialmente e mesmo valer-se dos artefatos de distinção utilizados pelos colonizadores brancos. Vemos que a liberta possuía grande número de peças de ouro (13 itens, total de $45 \$ 985$ réis) e prata (16 itens, $23 \$ 870$ ), bem como pratos de estanho (6 itens, $1 \$ 400)$ e roupas ( 6 itens, $17 \$ 400)$.

Tinha 13 "trastes de casa", com valores não muito aviltados (10\$980 réis), como uma arca, uma canastra e três caixas, uma delas com escaninho e algumas de madeira de pinho, onde guardava as roupas e joias que possuía. Completavam os móveis um bofete com gaveta e dois mochos.

Habitava em localidade próxima ao coração da cidade, com morada de casas no pátio de São Gonçalo, com os fundos para a banda do quintal de São Francisco, cujas casas tinham dois lanços e corredores. Possuía sala e alcova, além de dois quartos, um deles forrado, cada um com sua porta e fechadura. Havia janela para a rua e em outro quarto, para a banda do quintal. A casa fora avaliada em $75 \$ 000$.

Anos depois do fim do inventário, em 20 de junho de 1780 a sua filha Ana Joaquina solicitou ao juiz de órfãos sua emancipação para casar-se com João Gomes de Andrade, que possuía sitio na Freguesia de Santo Amaro.

O segundo inventário de ex-escravo que encontramos foi o de Anna Maria ${ }^{583}$, falecida ainda antes de Rosa de Souza, em 21 de novembro 1765, que chegou a possuir $1.145 \$ 000$ de monte-mor.

Infelizmente não consta descrição dos bens móveis que possuía, mas sabemos que ela vivia em um sobrado entre a Rua do Carmo e a Rua das Flores, com três lanços, dois quintais, de taipa de pilão pintada, com telhas novas e forradas. Foi avaliada no avultado valor de $800 \$ 000$ réis.

Possuía inclusive um cabedal de seis escravos, sendo o mais valioso Thomaz, 36 anos, de nação Angola, que era oficial de ferreiro, avaliado por $100 \$ 000$ réis. Como vimos anteriormente ela era dona do escravo Domingos, também Angola, o qual teria sido aprendiz de um mestre serralheiro no Rio de Janeiro. Ele foi avaliado por $80 \$ 000$ réis, pois possuía um "achaque das pernas".

\footnotetext{
${ }^{583}$ APESP. Inventários e Testamentos não publicados, Caixa 680. Anna Maria, 1765.
} 
Ana Maria vivia em concubinato de Manuel Soares de Carvalho, negociante de avultado cabedal, nascido em Óbidos e falecido em São Paulo em 1772. Declarava em seu testamento que ${ }^{584}$ :

Morei nas minas de Cuiabá muitos anos, e nas mesmas tive uma preta de nação Mina por nome Ana Maria a qual se forrou, e viveu alguns anos com sua venda tratando de sua vida em casa à parte, e outro tempo em minha companhia, e na mesma veio para esta cidade

Estas trajetórias pessoais são eidências de como os indivíduos estabelecidos em São Paulo enriqueciam nas minas e retornavam a São Paulo, nunca deixando esta cidade de ser um polo de grandes fluxos econômicos.

Em um recibo de compra do hábito de São Francisco por Carvalho para ela, descrevem-na também como "negra forra de sua casa" ${ }^{585}$. Por não ter sido casado nem ter filhos legítimos, instituía por herdeiros os filhos de Ana Maria, como se depreende de seu testamento ${ }^{586}$ :

Declaro que depois de pagar minhas dívidas, legados e obras pias tudo que por qualquer título me ficar se lhe partirá igualmente pelos quatro irmãos, a saber Rita do Espírito Santo casada com o testamenteiro Manoel Domingues Justo e por Tereza de Jesus casada com Domingos Pais e pela moça Francisca [das Chagas] e pelo moço Antônio [Soares] todos quatro filhos da dita preta Ana Maria já defunta os quais, se para isso for necessário, instituo por meus herdeiros por não ter outros, alguns forçados o que se cumprirá infalivelmente.

Deve-se salientar que Domingos Paes, casado com a herdeira Teresa de Jesus era carpinteiro de profissão. Este dado revelou-se muito importante, pois foi a única menção que encontramos do cruzamento familiar entre escravos, oficiais mecânicos e comerciantes, evidenciando brechas de fluidez nesta sociedade escravista com traços estamentais do Antigo Regime ${ }^{587}$.

Não aparecendo seus bens, que haviam sido repartidos entre os herdeiros entes de falecer, consta, porém, nos anexos do inventário uma pormenorizada descrição das dívidas feitas a credito de Manuel Soares de Carvalho, a quem ela devia 403\$665. Nessas contas aparecem vários dispêndios, como a compra de

\footnotetext{
${ }^{584}$ APESP. Inventários e Testamentos não publicados, Caixa 549. Manuel Soares de Carvalho, 1772.

585 APESP. Inventários e Testamentos não publicados, Caixa 680. Anna Maria, 1765. Recibo anexado ao final do Cura Gaspar de Sousa Leal, de 29 de novembro de 1765.

${ }^{586}$ APESP. Inventários e Testamentos não publicados, Caixa 549. Manuel Soares de Carvalho, 1772.

${ }^{587}$ Como enfatizado por GUEDES, Roberto. Ofício mecânicos e mobilidade social: Rio de Janeiro e São Paulo (sécs. XVII-XIX). Topoi, v. 7, n. 13, jul.-dez. 2006, pp. 379-423, p. 398.
} 
escravos para Ana Maria, gastos com remédios para ela e também seus escravos adoentados.

Aparece ainda a impressionante quantia de $80 \$ 000$ réis gastos pelo inventariante Domingos Pais para rezar nada menos do que 250 missas pela alma de sua sogra. Tendo-se em conta a centralidade das missas para esta sociedade compreendemos o grande dispêndio neste consumo litúrgico. As cerimônias religiosas eram as principais ocasiões de sociabilidade, congregadora da população paulista e momento fulcral da exteriorização do status e poder econômico, mesmo depois da morte ${ }^{588}$.

\footnotetext{
588 Maria Luiza Ferreira também nota para o final da centúria de oitocentos a importância dos gastos com funerais, enterros e lápides como critérios de distinção entre os diversos grupos de riqueza da cidade. OLIVEIRA, Maria Luiza Ferreira de. Entre a casa e o armazém: relações sociais e experiência da urbanização, São Paulo, 1850-1900. São Paulo: Alameda, 2005. P. 95.
} 


\section{CAPÍTULO 4. Uso}

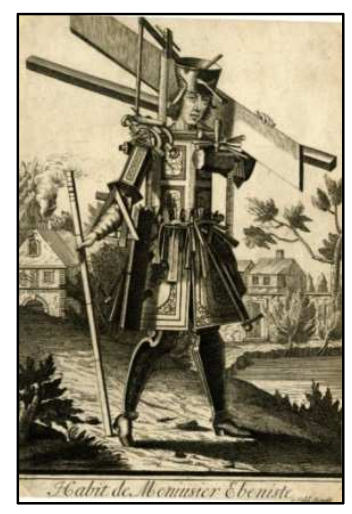

Figura 118: Nicolas II de Larmessin (1632-1694), Habit de Meniusier Ébeniste. Les costumes grotesques et les métiers, ${ }^{589}$

Havendo examinado os artefatos musealizados pelos seus materiais e tecnologias produtivas, sua cadeia de produção e de consumo, iremos agora, agregar esses vários dados ao compreender as peças sob mais um ângulo. Não focaremos somente em sua estática expositiva nos museus, ou na compressão temporal hodierna do exame formal e técnico, mas também na dinâmica do seu uso pelos agentes que as conceberam, produziram, compraram e usaram. Vimos no primeiro capítulo as mudanças formais das cadeiras pelas condições tecnológicas de produção; agora avaliaremos tais móveis do ponto de vista do uso corpóreo, instância concomitante a essas complexas dinâmicas dos estilos.

Somente separamos o uso dos objetos do capítulo sobre o consumo, pois as problemáticas e metodologias para cada caso possuem diferenças. Se no capítulo anterior procuraremos mirar no fenômeno do consumo do ponto de vista dos valores e das mudanças nos padrões dos móveis e de sua aquisição, neste capítulo iremos

\footnotetext{
589 Pelo final do século XVII, o pintor e gravador francês Nicolas II de Larmessin produziu uma série de 97 gravuras representando de maneira estilisada os personagens da época compostos de ferramentas e produções de seus ofícios. Abre-se margem à interpretação de que tais gravuras expressam a visão corporativa da sociedade de Antigo Regime, onde os mecânicos eram desprestigiados e comparados aos móveis e as mais diversas mercadorias, adornos e serviços que produziam e vendiam para a aristocracia, distinta por não executar este trabalho manual, de cuja aquisição se servia. Segundo Roland Barthes, estas gravuras se aproximam das pinturas de Giuseppe Arcimboldo. "Trata-se de um pansimbolismo desbragado. [...] Nessa fantasia, o vestuário acaba por absorver completamente o homem; o trabalhador é anatomicamente assimilado a seus instrumentos", como se fosse um "robô avant la lettre". Cf. KOSMINSKY, Doris Clara. O olhar inocente é cego: a construção da cultura visual moderna. 2008. Tese (Doutorado)-Pontifícia Universidade Católica do Rio de Janeiro, Departamento de artes \& design, 2008. p. 172.
} 
focar na ativação dos objetos adquiridos pelos corpos, nas suas dimensões interacional entre as práticas do corpo, bem como no peso distintivo dos objetos nas paisagens domésticas, privadas ou publicas.

O uso dos móveis nos revela como tais artefatos cumpriam parte essencial nas divisões sociais. Distinguem-se as pessoas por gênero, etnia, riqueza, herança cultural e também pelo saber corporificado na ativação dos bens pelo corpo, que em grande parte reflete todas essas outras condições. $\mathrm{Na}$ interconexão do objeto/corpo/prática ao longo do tempo, podemos compreender historicamente 0 fenômeno do uso dentro de simbolismos sociais próprios e as práticas de distinção social das quais os objetos são vetores e produtos, simultaneamente. Assim, na ativação das peças pelos indivíduos, na interpelação das práticas corporais e culturalmente estabelecidas é que compreendemos em última instância os motivos de sua existência, da sua função e da sua dinâmica na vida social.

Avaliada a materialidade da peça no capítulo inicial, onde pudemos ver muito para além dos dados funcionais e seu valor estético, reforçamos a ideia de que elas são resultado e vetor de elucubrações, tecnologias e trabalho eivado de cultura, bem como são conformadoras de posições corporais.

$\mathrm{Na}$ ativação dos objetos pelo corpo configura-se aquilo que Warnier chama de "extensão em objetos" (mise em objects) ${ }^{590}$, onde pela repetição de determinada forma de se usar os objetos ocorre adaptações também nos corpos indivíduos, à mesma proporção com a qual os próprios indivíduos moldam seus objetos e ferramentas para obter melhores ou novos resultados em sua praticidade, como salientado por Sennett ${ }^{591}$.

É importante notar como Warnier retorna à proposta de Mauss em seu célebre ensaio As técnicas do corpo, de 1936, entendendo-o como o precursor de uma teoria antropológica da cultura material. Entretanto, Mauss acabaria por separar as "técnicas do corpo" das "técnicas instrumentais", que dependem de objetos para serem realizadas, apesar de se revelarem justamente a extensão em objetos das próprias técnicas do corpo, e que procuraremos evidenciar para nosso estudo

\footnotetext{
590 WARNIER, Jean-Pierre. Retorno a Mauss (tradução de Christian Pierre Kasper). In: WARNIER, Jean-Pierre. Construire la culture matérielle. L'homme qui pensait avec ses doigts. Paris: Presses Universitaires de France, 1999, p. 21-35. Disponível em: https://aforcadascoisas.files.wordpress.com/2011/07/warnier-retorno-amauss.pdf. Acesso em: 20/05/2018.

${ }^{591}$ SENNETT, Richard. 0 artífice. Rio de Janeiro: Record, 2012
} 
específico. Justamente esta conciliação que Warnier procura realizar em seus estudos, mostrando a incorporação da dinâmica dos objetos nas condutas motoras. Donde se aquilatam as escalas entre a subjetivação das condutas motoras e o aprendizado normatizado socialmente, e entre 0 aspecto simbólico e representacional da cultura material com a faceta motora de síntese corporal dilatada, sub-reptícia ${ }^{592}$.

A interiorização dos mais diversos e sutis práticas, manuseios e posturas corporais cotidianas revela-se em procedimentos, técnicas e discursos muitas vezes imperceptíveis, constituindo toda uma instrumentalidade de práticas quase inconscientemente repetidas que (re)inventam continuamente o cotidiano ${ }^{593}$.

Assim, mesmo as mais banais posições que os corpos assumem revelam-se substantivas na gramatica social de um determinado grupo cultural e ficam patentes quando este se fricciona com outros grupos em um choque cultural sobre a ativação corporal praticado por outras etnias. Choque este apreensível pelas informações de diversos tipos de fontes, principalmente relatos de viajantes quando estiveram em face ao "outro".

A respeito do uso de móveis domésticos, geralmente tratou-se em separado o mobiliário luso-brasileiro dos artefatos a eles semelhantes feitos pelos povos ameríndios, como os bancos de madeira, as redes e os vários tipos de artefatos de conter, bem como deixando lacunas à compreensão nesta complexa formação social brasileira às posses e concepções dos escravos negros e mestiços, sendo tratados como "usos e costumes".

Em nosso esforço afastamo-nos justamente de apenas elencar "usos e costumes", efemérides curiosas que envolveriam os apetrechos do cotidiano. Esta é uma compreensão eivada, de modo geral, por um folclorismo e teve a sua historicidade posta em crítica, por exemplo, pelo clássico trabalho de Edward Thompson ${ }^{594}$. Se costume foi chamado aquilo que é praticado pelas camadas rurais e pelo povo comum citadino, os hábitos de prestígio foram compreendidos na chave de cultura, e principalmente de civilidade. Tais comportamentos prestigiosos não eram estudados sob o teor etnológico por serem normalizados e reificados como a

\footnotetext{
592 WARNIER, Jean-Pierre. Retorno a Mauss... Op. cit. 1999, p. 3ss.

593 DE CERTEAU, M. A invenção do cotidiano: Vol. 1. As artes de fazer. Petrópolis: Vozes, 2001.

${ }^{594}$ THOMPSON, E. P. Costumes em comum. São Paulo: Companhia das Letras, 1998, pg 21ss.
} 
prática correta a ser seguida ${ }^{595}$. Não dimensionavam os comentadores da época, especialmente os viajantes estrangeiros, que os "usos" não deixam de ser menos histórica e culturalmente pontuais da mesma maneira que as "boas maneiras" civilizadas que os mesmos praticavam e preconizavam.

Portanto, uma de nossas intenções é aventar uma compreensão inclusiva sobre as populações ameríndias e africanas, somada aos esforços de outros historiadores que se propuseram a analisar o uso social dos objetos entre a população colonizadora europeia ${ }^{596}$. Urge fazer uma história que inclua estes componentes essenciais da vida colonial e do processo colonizador, valendo-nos não só de metodologias historiográficas, mas também emprestando a outras ciências sociais, como a antropologia, métodos para a sua compreensão, mesmo levando-nos a breves incursões de histórias comparadas entre outros contextos culturais e históricos, mais globais espacialmente e longas temporalmente, que nos permitam compreender em um jogo de escalas o caso especifico paulista setecentista abordado em especifico.

\subsection{Artefato, corpo e conforto}

Novamente partindo da materialidade dos exemplares de mobiliário já analisados, pudemos notar como as setecentistas cadeiras de sola, pesadas e robustas, eram, em geral, destinadas à posição rígida e definida, sem permitir e impulsionar ao corpo muita flexibilidade para movimentação ${ }^{597}$. Dispostas junto às paredes, se exigiam posturas físicas mais protocolares, dentro de uma grande cenografia barroca e não estimulavam situações de interação social em grande amplitude. Essa explanação, entretanto, não significa que os interiores domésticos setecentistas não se prestassem a abrigar reuniões sociais, haja vista que foram

\footnotetext{
${ }^{595}$ A naturalização das práticas entre os próprios europeus foi um longo Processo Civilizador, na expressão de Norbert Elias, ele mesmo histórico e com tendências uniformizadoras sobre a pluralidade étnica na própria Europa, quanto mais em suas colônias. ELIAS, Norbert, O Processo Civilizador. 2 vol. Rio de Janeiro: Jorge Zahar Editor. 1994.

${ }^{596}$ Como realizamos em artigo com Maria Aparecida Borrego, focando na materialidade dos objetos indicando práticas sociais que revelam a dinamicidade social do grupo mercantil paulista. BORREGO, Maria Aparecida de Menezes; FELIX, Rogério Ricciluca Matiello. Ambientes domésticos e dinâmicas sociais em São Paulo colonial. Rev. Hist. (São Paulo), São Paulo, n. 175, p. 91-132, dez. 2016.

${ }^{597}$ Para que se calcule, as cadeiras de sola do Museu Paulista pesam entre 6,700 kg e 8,100 kg.
} 
localizados cerca de 652 móveis de assento, entre tamboretes e cadeiras nos inventários post-mortem ${ }^{598}$.

Igualmente tivemos a oportunidade, ao quantificar o consumo, de notar através do mais sutil indício material descrito nos inventários que novos tipos de cadeiras passam a adentrar as casas paulistas ao longo dos Setecentos, especialmente aquelas dos comerciantes. A menção a pés de cabra possivelmente indica que as pernas dianteiras das cadeiras e tamboretes eram curvas que terminavam em volutas sobre sapatas (denominadas pés de cachimbo em Portugal) 599. Tais características afastam as peças das tradicionais cadeiras de sola mencionadas anteriormente, o que é reforçado pelas descrições do espaldar de jacarandá - provavelmente vazado - e do assento de couro ou marroquim.

Nesse caso, parece ficar evidente que a casa não é somente um espaço eficaz para a reprodução de condutas sociais, mas também um ambiente onde as transformações são engendradas, não como meros reflexos do mundo exterior, mas como parte ativa na indução dessas alterações ${ }^{600}$.

Sobre a diferença entre esses móveis nos diz Leila Algranti e também Tilde Canti para o contexto brasileiro e Nuno Luís Madureira para Portugal, que o século XIX foi o período de triunfo do móvel ligeiro, mais leve e fácil de ativar com o corpo, seja transportando-os pelos cômodos, seja praticando com eles posturas diversas durante as conversas e demais atividades rotineiras. Neste período as ocasiões de sociabilidade passaram a se dar mais no interior das casas do que em espaços públicos, como as praças e igrejas. Resultava disto diferentes formas de acomodação e usos do espaço doméstico, condicionados pelos objetos.

Das pesadas cadeiras de sola, com as retilíneas travas nas pernas que não poderiam receber os pés dos indivíduos ${ }^{601}$, passou-se ao provimento do conforto trazido com cadeiras em rocalha dos estilos joanino e josefino, onde as travas dos pés já não incomodam o usuário, em assentos mais baixos e recortados em curva,

\footnotetext{
${ }^{598}$ Compare-se também com a marcante presença desses móveis nas casas dos comerciantes, como pudemos observar em outra oportunidade: BORREGO, Maria Aparecida de Menezes; FELIX, Rogério Ricciluca Matiello. Ambientes domésticos e dinâmicas sociais em São Paulo colonial. Rev. Hist. (São Paulo), São Paulo, n. 175, p. 91-132, dez. 2016.

${ }^{599}$ Cf. CANTI, Tilde. 0 móvel no Brasil: origens, evolução e características. Rio de Janeiro: Ed. Candido Guinle de Paula Machado, 1980, p. 249.

${ }^{600}$ CARVALHO, Vânia Carneiro de. Gênero e Artefato... Op. cit., 2008, p. 216.

${ }^{601}$ Vide mais a frente o manual de conduta de D. Alvares da Cunha (1700-1791) ao seu filho D. João Lourenço.
} 
de acordo com a posição das pernas do utilizador, bem como os espaldares acompanhando a coluna vertebral.

A respeito das cadeiras de palhinha, vimos também anteriormente o enorme volume dessas peças que o Brigadeiro Manuel Rodrigues Jordão, possuía em seu inventário de 1828. Sendo a figura mais rica de São Paulo ao seu tempo, notamos a sua conexão comas práticas europeias das festividades em grandes salões repletos de mobiliário, como mesas dos mais variados tipos, marquesas, armários, cômodas, entre outros. Destacam-se nesse rol pela sua grande quantidade 86 cadeiras, que como vimos, foram descritas como sendo feitas de madeira da terra tecidas de palhinha, somando o valor total de 172 mil réis, revelando o incremento da produção de móveis em São Paulo nestes princípios do século XIX.

A respeito da diferença de peso entre essas cadeiras, para podermos materialmente dimensionar o quanto essas mudanças poderiam significar para as formas corporais de ativação desses artefatos, Maria Borrego notou que exemplares como a cadeira de sola RG 55, já previamente examinada, pesa em torno de $7 \mathrm{~kg}$, enquanto as cadeiras de palhinha, como a que pode ser vista na Figura 120, pesa menos de $4,5 \mathrm{Kg}$, uma diminuição de quase $40 \%$. Tal modelo de cadeira com armação simplificada e espaldares e assentos de material entrelaçado e leve, de fato instavam o corpo para práticas de sociabilidade, condicionando a maneira de estabelecer o contato com outras pessoas ${ }^{602}$.

Importante notar como coexistia com essas dezenas de cadeiras de palhinha uma dúzia de cadeiras de jacarandá, descritas em contraposição as primeiras, como "antigas, com assento de sola picada e velhas", sinal de que os novos e ligeiros móveis estavam se impondo frente às peças de tradição.

As cadeiras de palhinha eram móveis leves que se mostraram não só produtos das novas sociabilidades oitocentistas, mas também vetores das mesmas, já que o espaço doméstico dos imponentes sobrados paulistanos poderia ser arranjado de maneira a comportar diversos tipos de eventos sociais, como refeições, bailes, concertos além de visitas de parceiros comerciais e notáveis.

Cumpre notar que não foram somente os móveis de assento que passaram por essa mudança em relação aos corpos dos usuários: também os móveis de apoio e suporte se tornam mais leves e especializados.

\footnotetext{
${ }^{602}$ BORREGO, Maria A de M. Artefatos domésticos e práticas sociais em São Paulo... 2013, Op. cit. p, 10 e Vânia C. de C. Gênero e Artefato... 2008, p. 211.
} 


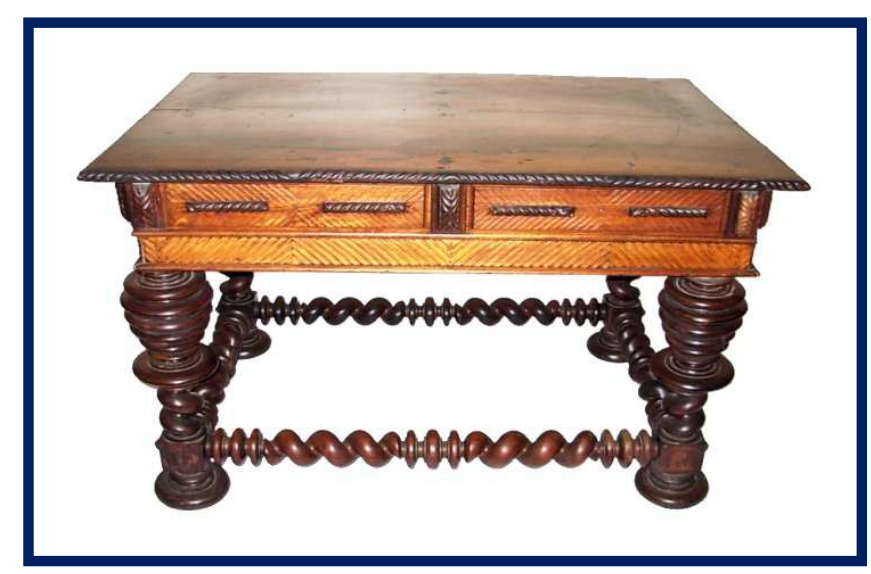

Figura 119: Bufete com pés de bolacha - século XVIII - Acervo do Museu Paulista/ USP. Fotografia de Hélio Nobre ${ }^{603}$.

Bastante diferente dos austeros e pesados bufetes ao redor do qual as pessoas realizavam o uso do espaço, raramente movendo tal peça de lugar, móveis ligeiros como as mesas de jogo retráteis que vimos tanto nas oficinas da FRESS quanto nos inventários dos dinâmicos comerciantes paulistas, bem como as sofatables ou mesas console, que eram leves e facilmente levadas de um lugar para o outro., começavam a ganhar espaço nos interiores domésticos.

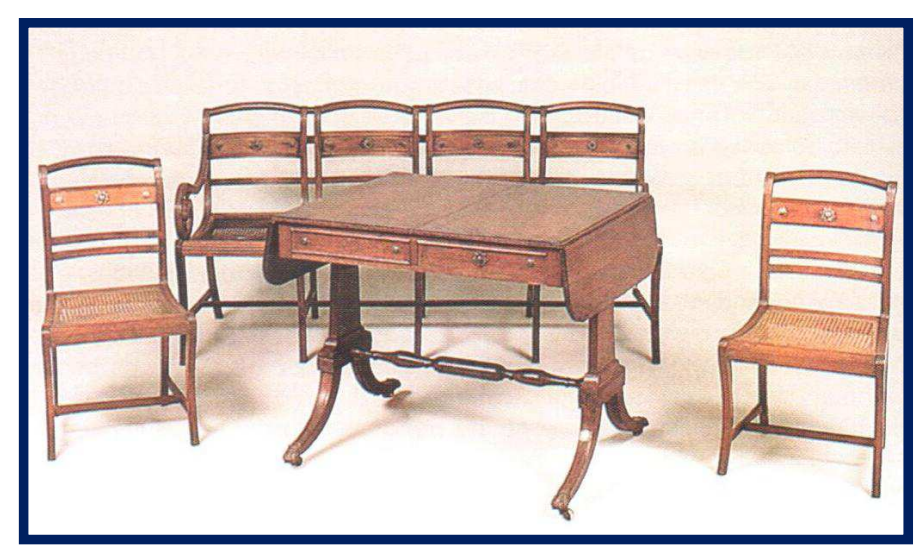

Figura 120: Mesa console, cadeiras e sofá do Brigadeiro Luís Antonio ${ }^{604}$. Século XIX. Acervo do Museu Paulista/ USP. Fotografia de Rômulo Fieldini.

O Museu Paulista possui um conjunto completo desse jogo de sala, que pode ser visto na figura acima, com influência do estilo Sheraton, pertencente a um dos mais ricos comerciantes de São Paulo nos princípios do século XIX, o Brigadeiro Luís Antônio de Souza Queirós. Este leve e prático aparato permitia que o uso do espaço fosse diferente e voltado prioritariamente ao usuário e seu conforto.

\footnotetext{
${ }^{603}$ Acervo Museu Paulista. Mesa Bufete RG 1-05-01-000-00116-00-00.

${ }^{604}$ Acervo Museu Paulista. Mesa Console RG 1-05-01-000-00069-00-00 e cadeiras de palhinha RG 1-05-02-00000072-00-00.
} 
Enquanto sentado no sofá ou nas cadeiras, o usuário poderia alcançar facilmente os objetos sobre a pequena mesa. Com as abas retraídas, o ligeiro suporte podia ser movido aos cantos das salas para abrir espaço a danças e festas ou outras sortes de ocasiões de lúdicas de sociabilidade, cada vez mais rotineiras no período ${ }^{605}$.

Em termos materiais de comparação, Maria Aparecida Borrego notou a diferença nos pesos de um bofete com pernas torneadas em bolachas (figura 119), com $81 \mathrm{~kg}$ e uma mesa de sofá (figura 120), ou sofá-table, de $30 \mathrm{~kg}$, ou seja, quase $75 \%$ mais leve. Assim, nota a autora, aos bufetes ou grandes mesas de jantar, categoria que surge neste século como mais um sinal das especializações dos móveis, permaneceram traços ligados à austeridade e solidez, enquanto as mesas adquiriram maior leveza, servindo como apoio para os vários conjuntos de assentos que povoavam as salas, cada vez mais abertas a um público maior ${ }^{606}$.

Notamos como as mesas vão se tornando diferentes, mais próximas do uso corporal, e não o contrário como obrigava o grande peso dos bufetes geralmente estacionados no mesmo lugar. É também o momento de novas práticas nas mesas, como revela Nobert Elias no contexto europeu ${ }^{607}$, José Newton de Meneses para Minas Gerais ${ }^{608}$ e Maria Aparecida Borrego em São Paulo ${ }^{609}$. A prática de comer com talheres tornando-se mais corrente exigia pratos, baixelas e móveis de suporte apropriados. A boa etiqueta obrigava a novos objetos e usos em um arranjo contínuo.

\subsection{Posturas públicas}

Para além dos espaços privados o estatuto social do uso do móvel, especialmente o de assento, passava também em espaços públicos pela clivagem

\footnotetext{
${ }^{605} \mathrm{O}$ lazer associado aos jogos e a proliferação de móveis destinados a tal fim nos interiores domésticos foi também constatada por Nuno Madureira e Carlos Franco para o contexto lisboeta, ainda na segunda metade do século XVIII. MADUREIRA, Nuno Luís. Cidade: Espaço e Quotidiano. Lisboa 1740-1830. Lisboa: Livros Horizonte, 1992; FRANCO, Carlos. Op. Cit., 2007.

${ }^{606}$ BORREGO, Maria Aparecida de Menezes. Artefatos e práticas sociais em torno das refeições (São Paulo, séculos XVIII e XIX). Varia hist., Belo Horizonte, v. 32, n. 58, p. 101-137, Apr. 2016.

${ }^{607}$ ELIAS, Norbert, O Processo Civilizador. 2 vol. Rio de Janeiro: Jorge Zahar Editor. 1994.

608 MENESES, José Newton Coelho. O Continente Rústico. Abastecimento alimentar nas Minas Gerais setecentistas. Diamantina: Maria Fumaça, 2000.

609 BORREGO, Maria Aparecida de Menezes. Artefatos e práticas sociais em torno das refeições (São Paulo, séculos XVIII e XIX). Varia hist., Belo Horizonte, v. 32, n. 58, p. 101-137, Apr. 2016.
} 
da categoria do homem que possuía a peça e a ocasião, posição e espaço em que o utilizava. Encontramos fulcrais exemplos na legislação e na vida camarária da época, como nesta Provisão Real de 1729610:

Hei por bem, por resolução de trinta do presente mês e ano, tomada na dita consulta, que o Ouvidor de São Paulo tenha nos casos de que se trata da mesma jurisdição que tem o do Rio de Janeiro, com declaração que nas sentenças além do dito Governador assistirão sempre como adjuntos os dois Juízes de fora de Santos e Itu, e Provedor da Fazenda, e um dos ditos Juízes que o Governador nomear assistirá as execuções, cujas causas, na qual presidirá o Governador sentado em Cadeira na Cabeceira e em bancos de espaldas, os Ministros adjuntos ficando a mão direita do dito Governador nas referidas juntas o Ouvidor de São Paulo; e a esquerda o Juiz de fora da Praça de Santos, o qual há de proceder ao Juiz de fora de Itu. Esta Provisão se cumprirá inteiramente, como nela se contém sem dúvida alguma e para que em nenhum tempo se possa alegar ignorância e não passará pela chancelaria, e valerá como carta sem embargo da ordenação do Livro 2. iii.. 40 em contrário e se passou por duas vias. Lx. a ocidental em trinta e um de Março de mil setecentos e trinta e um de março de mil setecentos e vinte e nove. REI [D. João V].

Quase setenta anos depois, notamos que as posições continuavam em disputa na cidade, neste caso com o choque de autoridades de cidades diferentes ${ }^{611}$ :

Para a Câmara desta Cidade Recebi a carta de Vm.ce, de 18 do presente mês, em que me participam a dúvida que tive sobre assentos, 0 Juiz Presidente dessa Câmara com o Sargento mor das Ordenanças, que por moléstia do Capitão Mor tinha ido assistir a eleição de um capitão; e sendo necessário providenciar dúvidas prejudiciais ao Real Serviço. Ordeno a $V m$.ces que deve haver só duas cadeiras iguais no meio da cabeceira da mesa, para o Juiz Presidente, e o Capitão Mor, sendo a direita deste último, como se tem até agora praticado com o atual e com os Ouvidores data Comarca nas Eleições dos Capitães Mores, sendo certo que as Ordens de Sua Magestade determinam que se pratique a mesma formalidade com os Capitães Mores nas eleições de Sargentos Mores d'Ordenanças, que já haviam determinado para os Ouvidores da Comarca nas Eleições de Capitães Mores. É o que Vm.ces devem observar, fazendo registrar esta nos livros dessa Câmara enquanto Sua majestade não

\footnotetext{
${ }^{610}$ APESP. DI. “Provisão Real de 1729”. Vol. 16, p. 95. Grifos nossos.
}

${ }^{611}$ APESP. DI. Vol. 46, p.358. Grifos nossos. 
determinar o contrário, a quem esse Senado pode recorrer quando the pareça ter razoes para o fazer. D.s g.e a Vm.ces S.Paulo a 25 de Fev. ${ }^{\circ}$ de 1797// Bernardo José Lorena// Snr.s Juiz Presidente e Oficiais da Câmara desta Cidade.

A importância do status do mobiliário e de seu uso pessoal como signo de cada esfera social aparece ainda em momentos de congregação da sociedade paulista, como na ocasião de posse do primeiro governador das Minas, o Conde de Assumar $^{612}$ :

4 [de Setembro de 1717] Dia destinado para a posse; depois de jantar vieram os oficiais da Câmara ao Palácio a procurar a sua Ex. ${ }^{-}$, que metendo-se debaixo de um Palio de tafetá de carmezim, que o levavam quatro cidadãos, o conduzirão a igreja de nossa Senhora do Carmo, que por ser capaz pela sua grandeza, foi elegida para esta função, devendo-se fazer na casa da Câmara, mas a sua pequinês o não permitia. Estava posto um eitial (sic) [Cadeiral?] na parte esquerda em cima de hum tablado, e a uma e outra parte estavam cadeiras para os oficiais da Câmara, e algumas mais, em frente do tablado estavam muitos bancos para 0 Povo chegarão a igreja, e sentado que esteve sua Ex. ${ }^{\text {a }}$, tomou cada hum o lugar que Ihe tocava, o secretário do Governador Domingos da Silva, leu a carta Patente [...]

Assim compreendemos como o uso dos objetos também reproduz e faz reproduzir as divisões dos indivíduos na sociedade colonial. A qualidade do lugar necessita ser compreendida pelo uso especializado dos objetos ponderar as atuações de seus usuários. Para o caso reinol, Nuno Luís Madureira lembra um sintomático episodio quando, em meados do século XVIII, o fidalgo José de Brito Castro e Melo sentara-se durante uma grande festividade na Sé de Évora em um assento de distinção, estofado de brocatel, com pavilhão e cortinados, próximo ao altar-mor. Arrogante de sua qualidade nobre, mas evidenciando sua ignorância sobre as condutas apropriadas neste meio social hierarquizado, avisaram-lhe que 0 assento era reservado ao irmão do rei D. José, D. Pedro II. Não querendo levantarse foi expulso à força e encarcerado, não sem antes irromper confronto armado de sua espada para grande escândalo público ${ }^{613}$.

\footnotetext{
612 Diário da jornada, que fez o Exm. o Senhor Dom Pedro (conde de Assumar) desde o Rio de Janeiro até a Cidade de São Paulo, e desta até as Minas Ano de 1717. Publicado em Revista do SPHAN, n. 3, 1939, p. 303. Grifos nossos

${ }^{613}$ MADUREIRA, Nuno Luis. Cidade: Espaço e Quotidiano. Lisboa 1740-1830. Lisboa: Livros Horizonte, 1992; p. 151.
} 
Também as Constituições Primeiras do Arcebispado da Bahia, válidas para toda a colônia, dão-nos interessantes pistas sobre o uso dos móveis não só no meio aristocrático, mas também clerical, espraiando-se para todas as outras categorias sociais, inclusive nos próprios espaços domésticos privados. Estas prerrogativas eram válidas não somente para as pessoas comuns em suas casas, mas também para as autoridades eclesiásticas e civis, que poderiam ser excomungadas acaso, nas ocasiões da missa se assentassem em "cadeiras de espaldas", caso não fossem - nesta ordem - Cardeais, Duques, Marqueses, Governadores, Inquisidores, Visitadores e os membros administrativos, caso estivessem em corpo de câmara ${ }^{614}$.

Durante a passagem da procissão pelas ruas ninguém poderia estar sentado em cadeiras de espaldar nas casas $^{615}$.

Titulo XVI: Da solene procissão de corpo de Deus, e que pessoas a devem acompanhar [...] 501 - E outrossim mandamos, que nem um homem, (não tendo legitima causa) em quanto a Procissão passar pelas ruas, esteja às janelas ou sentados em cadeiras de espaldas com a cabeça coberta, e tanto que avistarem o Senhor se porão de joelhos sob pena de excomunhão maior.

Tão diminuto trecho e extremamente revelador: primeiro, nos dá início de onde se localizavam no espaço doméstico estas cadeiras de destaque, geralmente na sala principal, próximas das portas e janelas com vistas às ruas. Segundo, revela que os possuidores desses móveis faziam questão de estar sentados em cadeiras espaldadas, exteriorizando sua posição de notáveis a partir do espaço doméstico, fosse na rua defronte de suas casas, fosse mais recuado dentro da casa, na sala, mas ainda assim expostos o suficiente para serem vistos pela comunidade reunida por ocasião da festa sacra e receberem as reprimendas dos clérigos, que perpetuaram por escrito essa proibição nas suas constituições.

Outro exemplo que encontramos sobre a ativação das peças e o cuidado dispensado a elas enquanto símbolo de exteriorização de distinção é o transporte público dos próprios móveis das casas em ocasiões de mudança. O viajante François-Auguste Biard com grande minúcia descreve uma mudança sendo feita nas

\footnotetext{
614 "Título XXVIII: Que nas igrejas se não assentem em cadeiras de espaldas, o tamboretes, nem os leigos estejão sentados na capella-mór em quanto se fazem os officios divinos." CONSTITUIÇõES Primeiras do Arcebispado da Bahia. 1707. São Paulo: Tipografia 2 de Dezembro, 1853, p. 265 ss..

${ }^{615}$ CONSTITUIÇÕES Primeiras do Arcebispado da Bahia. 1707. São Paulo: Tipografia 2 de Dezembro, 1853, P. 195.
} 
ruas do Rio de Janeiro e nos faz compreender a importância social do mobiliário doméstico ${ }^{616}$ :

Logo que cheguei aqui tive de interromper, um dia, o que estava fazendo, impelido pela curiosidade; ouvira uns sons estranhos de uma ponta à outra da rua: era apenas uma mudança. Cada negro conduzia um móvel, grande ou pequeno, leve ou pesado, conforme a sorte de cada um; e esses carregadores executavam sua tarefa obedecendo a um certo ritmo, entoando um canto, gutural por vezes, em que uma ou duas sílabas eram repetidas. Havia alguns que transportavam barris vazios, três vezes maiores que as suas pessoas, e, no fim de tudo, vinha um piano de cauda carregado por seis homens, em duas filas. (...) Como de hábito entre os negros, os objetos transportados vão equilibrados às cabeças, sem se tornar necessário o auxílio das mãos para sustentá-los.

Nesta ocasião excepcional em que os móveis caseiros são postos às vistas públicas, mostra-se o seu relevo como marcadores de distinção e chamariz da atenção de todos, especialmente pelo volume de bens e pela quantidade de serventes envolvidos no transporte. Nota-se ainda que a solução prática adotada pelas etnias das quais provinham os escravos africanos e indígenas, de carregar objetos equilibrando-os no topo das cabeças era ainda mais um fator de exotismo ao europeu que assistia a cena - talvez associado à simbologia das cariátides e naginis que estilizam peças neoclássicas e indo-portuguesas ${ }^{617}$-, e não fugiu aos comentários de Biard, que se impressiona com a força e destreza para equilibrar enormes volumes no cume de seus corpos, chegando a registrar a cena em uma prancha.

\footnotetext{
${ }^{616}$ BIARD, François. Dois anos no Brasil. São Paulo: Cia. Ed. Nacional. 1945. P. 118.

${ }^{617}$ CANTI, Tilde, op. Cit. P. 38. Decerto tal episódio valeria maior aprofundamento sobre a carga simbólica da representação de figuras exóticas na condição de cariátides de móveis, reiteração de sua dominação. Eudes Campos chegou a traçar semelhantes conexões em uma erudita História Visual sobre o espelho denominado psyché de origem francesa da Marquesa de Santos, presente no Museu Paulista, e adornada com a figura de indígenas, seguindo tradição figurativa que teria se iniciado desde os primeiros ameríndios levados à França entre os séculos XV e XVI. Cf. CAMPOS, Eudes. Os móveis franceses da Marquesa de Santos. In: Informativo do Arquivo Histórico Municipal. São Paulo: PMSP/SMC/DPH, março/abril de 2008. Disponível em: http://www.arquiamigos.org.br/info/info17/i-inter.htm. Acesso em: 20/05/2018.
} 


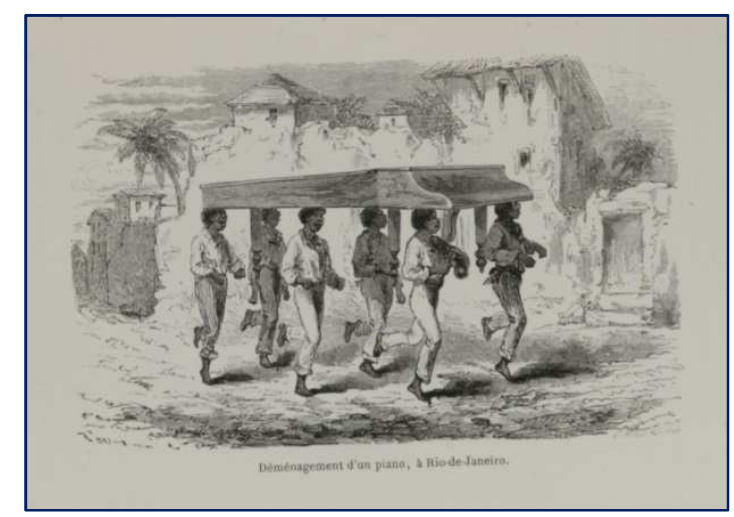

Figura 121: BIARD, François. Carregadores de piano, $1859^{618}$.

A transladação do piano na rua, o uso público dos móveis de assento em igrejas, as imagens de santos em nichos nas ruas, as cadeirinhas de arruar, elementos comuns nas paisagens grafadas pelos viajantes oitocentistas ao Brasil, são todas formas de dar visibilidade à posse conquistada pelo trabalho, ou ganho de posição estamental de nobreza e de legitimação da ancestralidade. São formas de comunicação pública das posses materiais.

Seguindo assim a compreensão da multiplicidade de formas com que os bens podem ser ativados pelo corpo, também devemos considerar que não são somente os consumidores e usuários de status elevado ativavam e mexiam nos móveis, mas também uma vasta gama de pessoas como os serviçais e escravos, ao limparem, reordenarem e transportarem os móveis. Desta forma a importância do individuo também é dada de acordo com a maneira como o seu corpo pode, ou não, interagir com a materialidade doméstica: ao escravo era interdito sentar na cadeira tal como o seu senhor não deveria carregar publicamente o seu assento, sinal ultrajante de esforço braçal.

Em mais uma passagem dos registros da Câmara Paulista temos outro exemplo da gravidade das boas condições para o transporte das pessoas de status e dos seus bens quando se mandou arrumar os caminhos da estrada de Santos para a passagem da comitiva do primeiro bispo que viria para São Paulo, D. Bernardo Rodrigues Nogueira (Santa Marinha, 1695 - São Paulo, 1748), de maneira a carregar com segurança os trastes que o prelado trazia consigo ${ }^{619}$.

\footnotetext{
${ }^{618}$ Extraído de: https://digital.bbm.usp.br/bitstream/bbm/3185/1/002856 IMAGEM 018.jpg. Acessado em: 20/05/2018.

${ }^{619}$ APESP. RG. "Registo de uma carta do ilustríssimo e excelentíssimo senhor general escrita á Câmara como nela se declara". Vol. 8, p. 289.
} 
Faz-se digno de reparo, e estranhável que recomendando a vossas mercês e aos seus ministros fizessem toda a boa passagem ao excelentíssimo e reverendíssimo Bispo e lhe pusessem tudo pronto, esteja ainda o caminho do Cubatão para essa cidade no seu antigo estado totalmente intratável e se poder por ele andar de sorte que faz-se incrível a condução assim dos trastes do dito excelentíssimo reverendíssimo senhor Bispo como da sua pessoa (...) Escrito na Praça de Santos 29 de outubro de 1746. Dom Luiz Mascarenhas.

Tão breve documento é prova de como os reinóis migrados para São Paulo traziam também os seus trastes consigo, os quais quiçá poderiam incluir suas mobílias, como parece ser o caso do bispo, dado que seria mesmo necessário ajeitar a estrada para a sua passagem. A qualidade e importância dos "trastes" que vinham com o bispo faziam jus à reforma do caminho e o imposto sobre 0 rendimento dos molhados na cidade que financiaria o trabalho. Dom João $V$ doou para a nova instituição uma banqueta de prata maciça, um crucifixo e quatro castiçais, que serviriam de adorno para a catedral diocesana a ser edificada. Dado o fato de que a capitania paulista se encontraria submetida à Capitania do Rio de Janeiro de 1748 a 1765, a conquista da elevação de bispado aos paulistas significaria um avanço politico e religioso para a região, e os aparatos materiais que ressaltariam essa nova condição decerto mereciam esta atenção ${ }^{620}$.

A importância dos bens semi-públicos como os apetrechos das igrejas, também aparece entre os particulares nas cadeirinhas de arruar, liteiras, serpentinas e bangués ${ }^{621}$ - meios de transporte usados no espaço público, assemelhando-se a "pequenas casas" portáteis. Nelas as mulheres poderiam transitar pela cidade ao mesmo tempo guardando sua privacidade sem serem vistas, mas exibindo a pujança de suas famílias através desses vistosos objetos, geralmente decorados com entalhes arrojados, como as cabeças zoomorfas nas pontas das alças que os escravos levavam sobre seus ombros.

A importância de estudar esse transporte dentro do espectro do consumo e do uso deve-se ao fato de que era também sinal de distinção na lógica do Antigo Regime, de raízes aristotélicas, ao evitar o esforço físico e o trabalho manual,

\footnotetext{
${ }^{620}$ BERTELLI, Luiz Gonzaga. A construção de São Paulo e seus artífices: notas biográficas. São Paulo: Engenho Editora Técnica. 2016. pg 36.

${ }^{621}$ BOTELHO, Nilza. Serpentinas e cadeirinhas de arruar. Rio de janeiro, Anais do Museu histórico Nacional. IX: 445-72, 1943. As serpentinas eram
} 
denegridores da condição de homem-bom ${ }^{622}$. Isto é, existia uma áurea ao entorno da posse e compra do objeto que de certa forma se ritualiza com o cuidado e com os transportes e a capacidade administrativa do dono dos bens em comandar os carregadores $^{623}$.

\subsection{Saber usar}

No sutil jogo dos sinais corporais das sociabilidades setecentistas, não bastava ter as peças que o dinheiro comprou, cumpria também saber usá-las, e mais ainda cuidar de sua manutenção e supervisionar os serviçais que delas deveriam cuidar e limpar.

Este é um dos tipos de ativação dos objetos que não é executado pelos seus possuidores, mas sim por gente de status inferior. Uma forma de ativação do objeto que não cumpre sua função primeira, mas sim função adjacente.

A distinção pelo ócio ocorria em São Paulo, como na Europa, pelo intrincado jogo de posturas corporais e também pela publicização da ausência de necessidade da mulher trabalhar fora de casa e do homem não exercer atividade manual, apenas administrativa. Não obstante, era de bom tom que a mulher realizasse trabalhos manuais como a costura e fiação dentro das casas, mostrando como eram prestativas. Fonte de renda para as famílias pobres, esta prática não deixava também de ocorrer entre as famílias abastadas, porém os produtos da confecção não eram vendidos, mas sim guardados no entesouramento do dote ou para uso próprio no caso das vestimentas e panos de mesa e cama.

As poucas ocasiões de sociabilidades domésticas eram geralmente a das visitas familiares ou de amigos, bem como os momentos de festividades ou lamentos por falecimentos. Eram nestes períodos onde o jogo das práticas corporais entrava

\footnotetext{
${ }^{622}$ Como assinala Mimi Hellman, o trabalho físico e as preocupações com os ganhos econômicos e conquistas profissionais eram consideradas incompatíveis com uma herança nobre e um status elevado. Assim o meio mais poderoso de demonstrar superioridade pessoal era buscar uma vida de prazer, luxo e refinamento. Ser da elite era tornar a existência cotidiana em uma elaborada rejeição ao esforço físico e às necessidades básicas humanas. HELLMAN, Mimi. Introduction In: KODA, Harold; BOLTON, Andrew (eds.).Dangerous Liaisons: Fashion and Furniture in the Eighteenth Century. New Haven: Yale Univ. Press, 2005.

${ }^{623}$ Alfredo e Myriam Ellis aponta que o transporte realizado sobre os ombros dos escravos ou índios serviçais era bastante dispendioso. Em comparação com o coeficiente tonelagem-quilometro praticado pelo transporte com muares, estes saiam até 8 vezes mais barato. ELLIS JUNIOR, Alfredo, e ELLIS, Myriam. "A economia paulista no século XVIII." São Paulo: Boletim História da Civilização Brasileira. n. 11. 1950.
} 
em cena, com a necessidade das mulheres apresentarem o comportamento e posturas corporais adequadas. De fato, no interim do século XVII vemos que estes processos sofrem mudanças e se tornam mais cobrados, a julgar por comentadores da época como o famoso poeta inconfidente de Minas Gerais, Tomás Antônio Gonzaga (1744, Porto, Portugal - 1810, Moçambique), em suas Cartas Chilenas ${ }^{624}$.

Ninguém antigamente se sentava

Senão direito e grave; nas cadeiras,

Agora as mesmas damas atravessam

As pernas sobre as pernas. (...)

Perspicaz observador dos hábitos de sua época, o poeta mineiro também realiza diagnóstico das dinâmicas sociais de grupos como os comerciantes enriquecidos que praticavam novas formas de se vestir e portar em momentos de sociabilidade por parte dos homens, vistos pelo narrador das cartas de maneira crítica e saudosista dos velhos tempos ${ }^{625}$ :

Em outro tempo, amigo, os homens sérios

Na rua não andavam sem florete;

Traziam cabeleira grande e branca,

Nas mãos os seus chapéus. Agora, amigo,

Os nossos próprios becas têm cabelo.

Os grandes sem florete vão à missa.

Com a chibata na mão, chapéu fincado,

$\mathrm{Na}$ forma em que passeiam os caixeiros

Também diversos manuais de conduta e civilidade europeus fizeram minuciosas observações sobre os mais efêmeros detalhes do comportamento cotidiano, criando a etiqueta moderna, dentro do longo processo que Norbert Elias chamou Processo Civilizador ${ }^{626}$.

Mesmo sobre o uso das cadeiras e a relação do corpo do usuário com a estrutura do objeto, vemos severas normas passadas de pai para filho, membros de uma família nobre, sendo predicadas dentre outros concelhos como quais palavras

\footnotetext{
${ }^{624}$ GONZAGA, Tomás, Antonio. Cartas Chilenas (quinta), 1787-8. Disponível em: http://www.dominiopublico.gov.br/download/texto/ua000293.pdf. Acesso em: 20/05/2018. ${ }^{625}$ GONZAGA, T. Cartas Chilenas. op. cit. Idem.

${ }^{626}$ ELIAS, Norbert, O Processo Civilizador. 2 vol. Rio de Janeiro: Jorge Zahar Editor. 1994.
} 
usar dependendo do interlocutor e o local e o momento de assentar à mesa em relação à gravidade dos outros convivas ${ }^{627}$ :

E se as palavras se hão de medir pelas pessoas com quem falares, muito mais o deveis fazer nas ações e assim diante dos fidalgos velhos não vos senteis sem que eles tenham tomado os melhores lugares e no assento não useis da liberdade que nos trouxe com tanto dano da nossa gravidade a comunicação dos estrangeiros; por nenhum caso lanceis a perna para cima de uma da outra, nem pela travessa da cadeira, nem façais outras ações que desautorizam a vossa inteireza...

Como assinala Mimi Hellman para o contexto francês, a efetividade do uso do mobiliário apresentava certos desafios que, se não executados com graciosidade, poderiam comprometer seriamente a sedução social de uma pessoa ${ }^{628}$.

$\mathrm{E}$ de fato, compreendendo a noção de mise em objects usado por Warnier às práticas com objetos em síntese corporal dilatada, também vemos como na dinâmica temporal as modificações que as formas de usar implicaram e foram implicadas em mudanças nas materialidades dos corpos humanos, tendo-se sempre em conta a via de mão dupla do objeto na vida social.

\subsection{Corpo e cultura}

Por mais naturais e automáticos que possam parecer, as próprias formas de assentar, abaixar o corpo e mesmo de repousar, dormir e ficar em pé pausado são também permeadas e condicionadas cultural e historicamente. Os estudos clássicos de Marcel Mauss lançaram iniciativas para a comparação das técnicas do corpo entre os vários grupos culturais e históricos, e influenciam até hoje grande parte da antropologia ${ }^{629}$. Tal como feito Mauss no começo do século $X X$, as atentas catalogações de registros antropológicos comparados levou Gordon Hewes, na

\footnotetext{
${ }^{627}$ D. António Álvares da Cunha [1700-1791] a seu filho D. João Lourenço passando aos Estados da Índia. S.d. Publicado em CARVALHO, José Adriano de Freitas. Pais e Nobres. Cartas de instrução para educação de jovens nobres (Sécs. XVI-XVIII) Volume I. Porto: FLUP Ed, 2009 p. 170.

${ }^{628}$ HELLMAN, Mimi. Introduction In: KODA, Harold; BOLTON, Andrew (eds.). Dangerous Liaisons: Fashion and Furniture in the Eighteenth Century. New Haven: Yale Univ. Press, 2005. p. 15ss.

${ }^{629}$ MAUSS, Marcel. As técnicas do corpo. Sociologia e Antropologia. São Paulo: Cosac \& Naify. 2003. p.399-422.
} 
metade deste mesmo século, a contemplar a distribuição mundial de hábitos posturais $^{630}$.

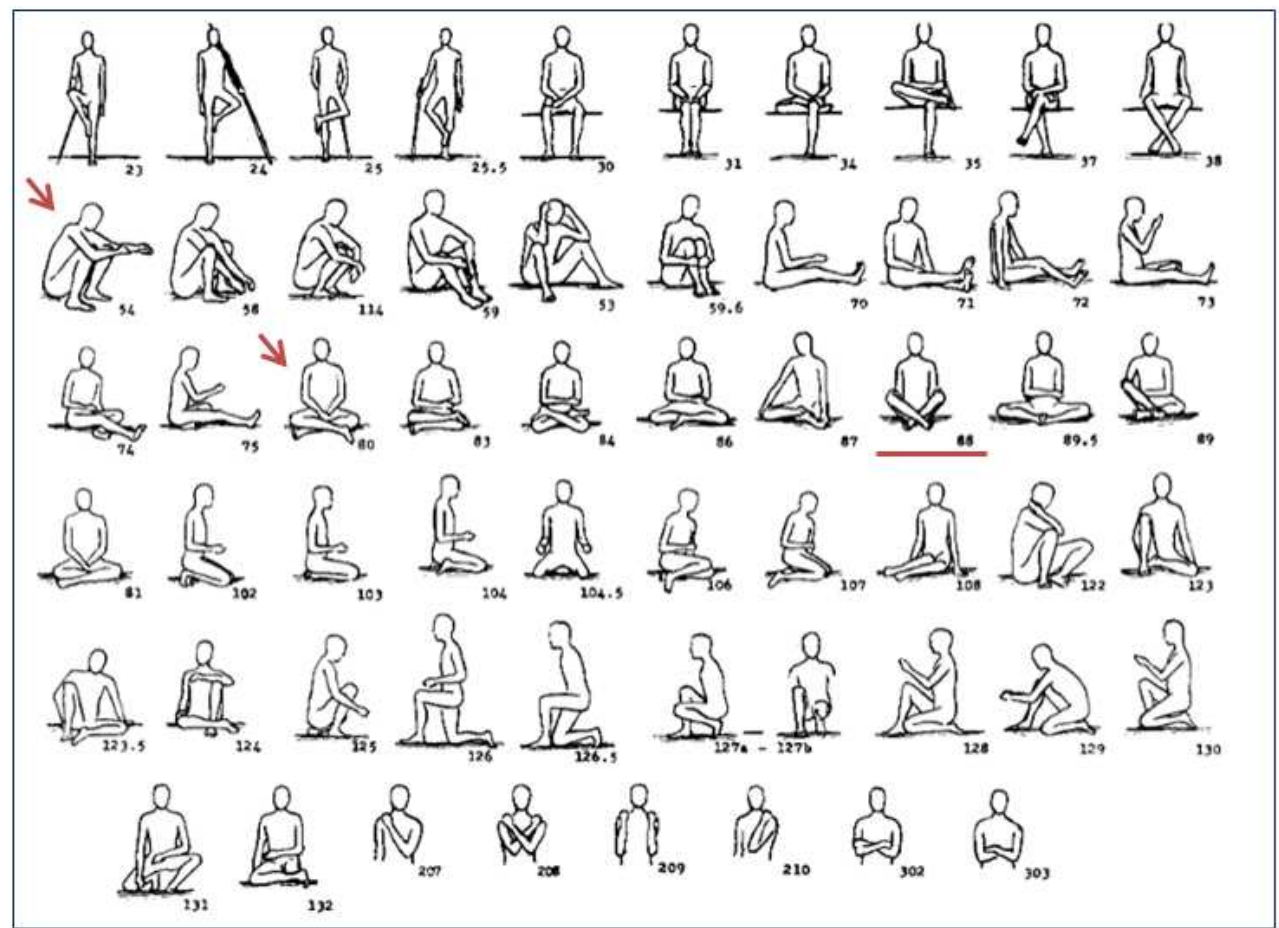

Figura 122: figuras esquemáticas de algumas das posturas catalogadas para o estudo comparativo. Produzidas a partir de fotografias da literatura etnográfica. Extraído de HEWES, Gordon. World distribution... op. cit., p. 235.

Certamente algumas posturas aparecem em todas as sociedades, dada a ligação com as estruturas corporais, como permanecer de pé com as mãos na cintura. Entretanto, a variação de posições que o corpo pode assumir nas maneiras de sentar muitas vezes se afasta do que seria "confortável" à musculatura, estimulada pelas posições praticadas por um e outro povo.

Por exemplo, permanecer de pé equilibrado em só uma perna, ou sentar-se sobre as pernas como os povos japoneses e também acocorar como muitos ameríndios. De fato, autores como Michaeleen Doucleff e Fran Barone, notam que sentar ao chão e acocorar, em inglês squatting (marcados na figura 122 por flechas), são as posturas mais comuns no mundo todo, mais do que sentar recostado a cadeiras ou outros móveis. Aquela prática leva à chamada coluna em "S", responsável por dores nas costas de grandes contingentes da população

\footnotetext{
${ }^{630}$ HEWES, Gordon. World distribution of certain Postural Habits. American Anthropologist. 1955, p. 231 ss.
} 
sedentarizada das grandes cidades e não observada em populações indígenas, que mantem a coluna em "J"631.

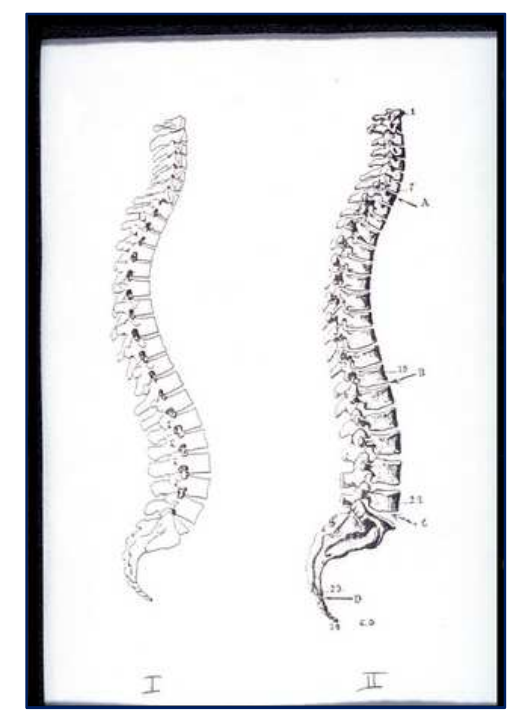

Figura 123: esboço esquemático mostrando a diferença entre as colunas vertebrais com formato de "S" (I) e em "J" (II). Extraido de Traite d'Anatomie Humaine, disponível em (DOUCLEFF, M. 2015).

E estas posições, pelo uso cotidiano ao longo da vida, acabam por fortificar e alongar músculos específicos do corpo, tornando tais posições mais fáceis e por isso parecerem mais "naturais" em serem executadas. Por exemplo, os músculos da panturrilha dos indígenas é mais extensa que a dos europeus acostumados a sentar em cadeiras, permitindo a estes apoiar a planta do pé por completo no chão e se acomodar nesta posição por longas horas. Tal postura é dificultada para os ocidentais, pois ficam somente apoiados nas pontas dos pés ao lhe praticarem, dado não terem ao longo da vida exercitado e alongado tal musculatura devido ao uso de cadeiras e outros móveis de assento, bem como pelo uso de calçados, que limitam e condicionam a forma dos pés ${ }^{632}$. A posição determinada culturalmente acaba, portanto, mudando o próprio corpo dos indivíduos ao longo do tempo, processo que o uso de artefatos potencializa, sempre em via de mão-dupla.

Para além da execução de posturas mais ou menos "confortáveis", diversos antropólogos notaram que em alguns povos várias posturas corporais são praticadas de acordo com a ação sendo desempenhada. São técnicas do corpo que se

\footnotetext{
${ }^{631}$ DOUCLEFF, Michaeleen. Lost Posture: Why some indigenous cultures may not have back pain. 2015. http://wshu.org/post/lost-posture-why-indigenous-cultures-dont-have-back-pain\#stream/0. Acessado em: Acesso em: 20/05/2018.

${ }^{632}$ BARONE, Fran. A cross-cultural look at posture in eHRAF (Human Relations Area Files Cultural) Yale: 13 de junho de 2015. Disponível em: hraf.yale.edu/a-cross-cultural-look-at-posture-in-ehraf/. Acessado em 01/08/2017.
} 
tornaram "tecnologias de si", na dialética entre a subjetivação e a o ensinamento do grupo de origem, interiorizadas e praticadas de maneira automática dentro do comportamento simbólico esperado pela sua sociedade. Alois Musil, em 1928, descreveu algumas dessas posturas entre os beduínos em detalhe ${ }^{633}$ :

When a man is narrating a story, he sits on his crossed legs (...) During a meal he kneels on his left knee and sits on his left heel (...) while inspecting anything or testing a weapon, he kneels on both knees and sits on his heels, (...) when he washes his hands, he squats (...) When it is hot, he lies down on his stomach (...) when he takes a nap (...) he turns over on his back (...).

Aliás, tal variação ritualizada de posturas, por mais que possa ter sido considerada exótica pelos antropólogos europeus, também aparece entre populações europeias. Segundo Toivo Itkonen (et al.) em 1948, os lapões da Finlândia sentavam em suas tendas de maneira similar, seja ao chão com as pernas cruzadas para frente, ou com seus joelhos quase tocando o chão enquanto apoiados no calcanhar esquerdo, posição geralmente praticada pelas mulheres jovens enquanto amamentavam ${ }^{634}$.

À parte toda a discussão teórica antropológica e as problemáticas do relato etnográfico, o que seria demasiadamente longo e afastado de nosso enfoque principal para ser tratado aqui, notamos como os objetos cujo uso corpóreo cotidiano parece ser óbvio para indivíduos de uma determinada cultura apresentam-se estranhos para os membros de outra. Ocorre, portanto, desconexão entre a mensagem ocultada pela obviedade do uso e a interpretação sobre a sequência de ações a serem desenvolvidas para usá-la ${ }^{635}$.

Isto é, se - hipoteticamente - perguntássemos a indivíduos que nasceram e praticam cotidianamente das formas de vida doméstica de matriz europeia moderna como se usa uma cadeira, esta pergunta soaria tão estranha quanto simples é a forma como de fato a usam, sem cogitar nesta ação corporificada e rotineira. Porém,

\footnotetext{
633 MUSIL, Alois. "Manners And Customs Of The Rwala Bedouins." Oriental Explorations And Studies. New York: The American Geographical Society, 1928. Apud BARONE, Fran. A cross-cultural look at posture in eHRAF (Human Relations Area Files Cultural) Yale: 13 de junho de 2015. Disponível em: hraf.yale.edu/a-cross-culturallook-at-posture-in-ehraf/. Acessado em 01/08/2017

${ }^{634}$ ITKONEN, Toivo Immanuel; GUEMATI, Olga; PEREZ-ROMAN, Elisabeth. Lapps In Finland Up To 1945. Vol. 2. Porvoo, Helsinki: Werner Söderström Osakeyhtiö, 1948. Apud BARONE, Fran. A cross cultural... Op. cit. 2015.

635 Vide os minuciosos esquemas feitos por Norman sobre os ciclos de ação entre ao "conhecimento do mundo", pelo individuo utilizador, e o "conhecimento no mundo", arquitetado pelo designer e produtor do artefato a ser utilizado da maneira mais simples, rápida e buscando-se evitar ao máximo o aprendizado ou leitura prévia por parte do utilizador. NORMAN, Don. The design of everyday things: Revised and expanded edition. Nova York: Basic Books, 2013. P. 46.
} 
tal como as cadeiras e outros móveis, roupas e ferramentas, as práticas corporais não são elementos naturais. Seu uso é regido também por normas culturais. Como podemos observar pela perspicaz fotografia de Milton Guran (Jacarepaguá, 1948), no final do século XX, o uso das cadeiras gera "ruído" para os utilizadores que não praticam da mesma matriz cultural.

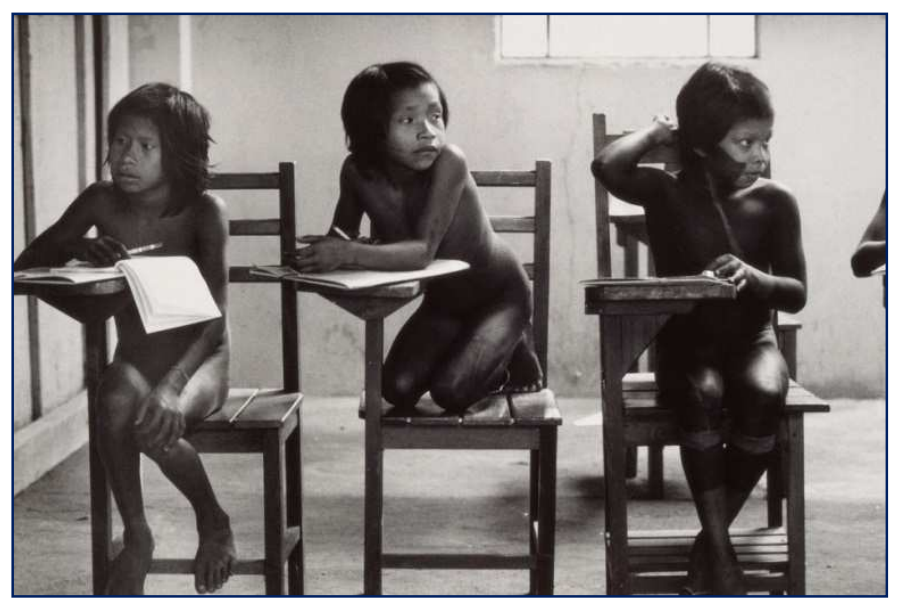

Figura 124: GURAN, Milton, Escola Kayapó, aldeia Djetuktire, 1991 - fotografia em gelatina/prata tonalizada, 23,8 x 30,3 cm (Acervo MASP).

A criança kayapó ao centro evidencia como o uso das cadeiras é menos obvio do que pode parecer aos seus usuários habituais: a criança, na sala de aula, assenta-se sobre as duas pernas como está acostumada e é praticado e ensinado pelos adultos de sua comunidade. Assim, ao se sentar na cadeira de escola, a postura corporal que pratica é diferente daquela à qual a cadeira de tipo ocidental foi concebida primordialmente e mesmo induz ao corpo. A estrutura retilínea do assento, encosto baixo, e braço com apoio para o caderno induz ao aluno uma posição corporal de atenção, voltada para a frente, sem o conforto que levam ao relaxamento como as poltronas, sendo inclusive alta de maneira ao pé não se apoiar no chão, mas na travessa das pernas.

Note-se neste exemplo como este jovem, mesmo sobre a cadeira, devido à adaptação de sua musculatura acostumada a assentar-se sobre os joelhos acaba por reproduzir esta posição, o que se pode considerar no seu corpo o contraste à "extensão em objetos" típica dos usuários das cadeiras.

Sobre as formas de sentar dos indígenas que habitavam a região de são Paulo não encontramos descrições de suas práticas do corpo. Porém, podemos traçar um comparativo com imagens feitas por Alexandre Rodrigues Ferreira em suas viagens pelo norte da colônia. 


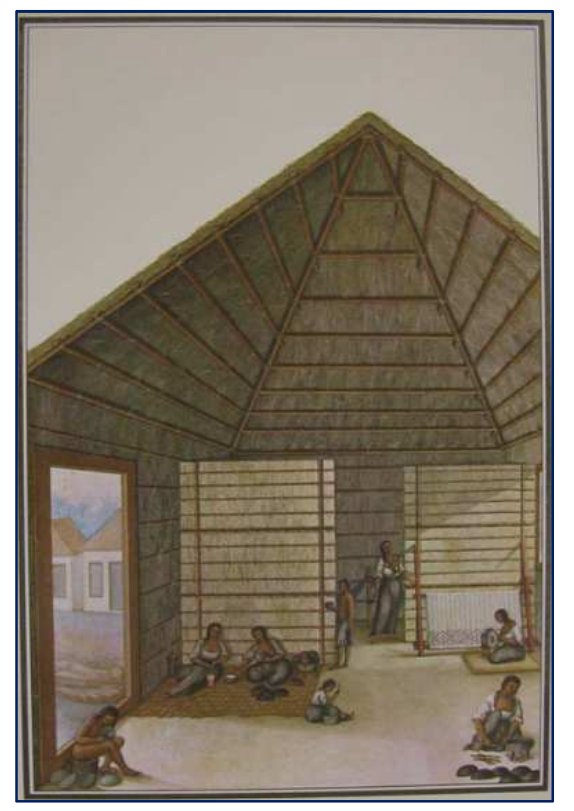

Figura 125: "Casa das Índias em Mone Alegre", Pará ${ }^{636}$.

Vemos pelos detalhes como várias posturas corporais estão presentes de acordo com cada atividade exercida pelas indígenas, e comparáveis com os esquemas de Hewes na figura 122 apontados por flechas.

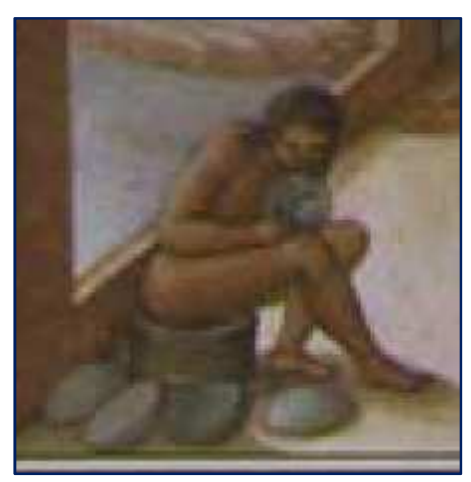

Figura 125 a: "Casa das Índias em Monte Alegre" (detalhe).

No primeiro plano vemos no canto esquerdo da imagem uma figura nua sentada sobre um assento circular, onde parece moldar as bordas das cuias.

636 "Casa das Índias em Monte Alegre”. FERREIRA, Alexandre Rodrigues. Viagem filosófica pelas capitanias do Grão-Pará, Rio Negro, Mato Grosso e Cuiabá [1789]. Memórias antropológicas. Brasília, Conselho Federal de Cultura. 1971, p. 28 apud. MARTINS, Renata Maria de Almeida. Tintas da terra tintas do reino: arquitetura e arte nas Missões Jesuíticas do Grão-Pará (1653-1759). 2009. Tese de Doutorado. FAU-USP. P. 266. 


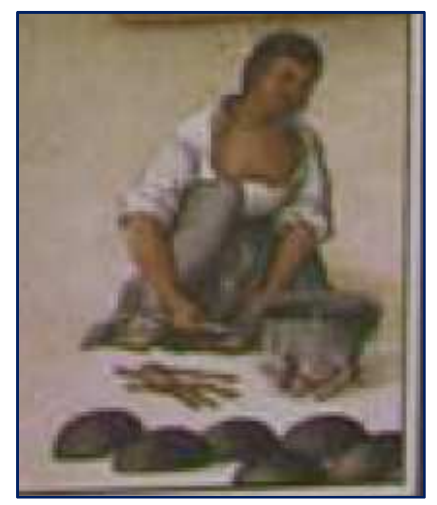

Figura 125 b: "Casa das Índias em Monte Alegre" (detalhe).

Outra senhora no canto direito da imagem parece alimentar o fogo com gravetos para aquecer uma cumbuca ajoelhada sobre a perna esquerda, posição que mostraria atenção ao trabalho com fogo e permite levantar rapidamente.

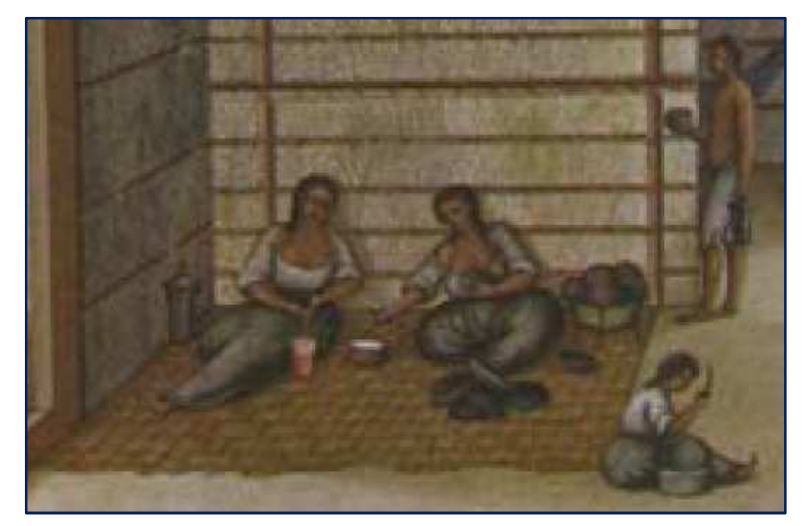

Figura 125 c: "Casa das Índias em Monte Alegre" (detalhe).

No segundo plano, na esquerda, as duas senhoras pintam as cuias sentadas com as pernas cruzadas "à oriental" sobre uma grande esteira, bem como uma menina o faz ao pé da mesma esteira, mas talvez interdita ao seu uso. Também não adentra a esteira uma figura masculina que está de pé, talvez trazendo mais tinta para as senhoras. 


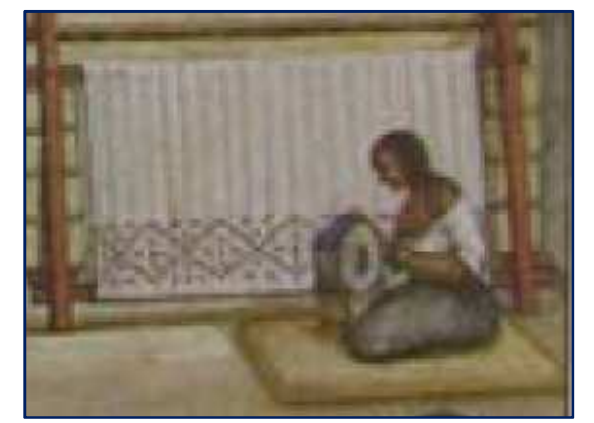

Figura 125 d: "Casa das Índias em Monte Alegre" (detalhe).

Ainda neste segundo plano, na direita, vemos no tear uma senhora assentada sobre as duas pernas em uma pequena plataforma que não se assemelha à grande esteira, sendo talvez almofadada para melhor conforto das pernas sobre as quais se assenta.

Ao fundo da imagem vemos ainda uma figura de pé próxima ao tear, e atrás desta, quase escondido por paredes sem portas, está uma rede amarrada em um pequeno poste de madeira, indicando de alguma forma privacidade entre os cômodos domésticos, talvez por assimilação europeia, tal como as roupas que usam.

Quais seriam os pesos dessas técnicas do corpo no seio dos grupos indígenas no que tange às posições e distinções sociais? Como saber o impacto do mobiliário europeu entre esses grupos indígenas naquilo que dentro de seus grupos foi absorvido ou repulsado, imposto ou proibido? Infelizmente, esses dados cotidianos tiveram pouquíssimo registro pelos comentadores coevos.

Mas em alguns casos esporádicos notamos que nesse interim de forte choque cultural também os indígenas davam especial atenção ao espaço e às posições que assumiam seus membros e essas práticas também entravam em jogo no contato com os europeus.

Benedito Prezia ${ }^{637}$ nos recorda uma importantíssima passagem descrita por Frei Vicente do Salvador ${ }^{638}$ sobre as interações entre indígenas e colonizadores, onde as práticas corporais de cada povo entraram em choque de traduções dentro das inter-relações politicas e econômicas que estavam sendo traçadas:

\footnotetext{
${ }^{637}$ PREZIA, Benedito Antônio Genofre. Os Tupi de Piratininga: acolhida, resistência e colaboração. 2008. 407 f. Tese (Doutorado em Ciências Sociais) - Pontifícia Universidade Católica de São Paulo, São Paulo, 2008.

${ }^{638}$ SALVADOR, Frei Vicente do. História do Brasil, 1500-1627. São Paulo: Ed. Itatiaia. 1982, p. 187. Apud PREZIA. Op. cit. 2008.
} 
Frei Vicente Salvador traz igualmente um episódio, que ilustra a postura deste cacique. Quando tomou posse o governador das capitanias do Sul, Antônio Salema, foi-Ihe oferecida uma recepção no Rio de Janeiro, da qual participara o cacique e outras personalidades portuguesas. Ao sentar-se na cadeira, ao lado do governador, o cacique cruzou as pernas, contrariando a etiqueta oficial. Repreendido, respondeu, através de um intérprete, "não sem cólera e arrogância", como registrou o cronista. DisseIhe: "Se tu souberes quão cansadas eu tenho as pernas das guerras em que servi a El-Rei, não estranharias dar-lhe agora este pequeno descanso; mas já que me achas pouco cortesão, eu me vou para minha aldeia, onde nós não curamos desses pontos e não tornarei mais à tua corte". Infelizmente esta ruptura foi temporária, voltando ele em breve a colaborar com os lusitanos.

Através da cultura material ainda existente entre povos ameríndios, como os bancos antropomorfos de madeira ou cerâmica ${ }^{639}$ que eles produziam e continuam ainda a fazer, podemos também compreender o status veiculado pela posição corporal do assento acocorado. Como revelaram Cristiana Barreto e Lucia Velthem ${ }^{640}$, as práticas do assento em artefatos especialmente feitos para tal uso, que podem soar banais aos europeus, são extremamente ritualizadas e interditas. Por exemplo, esclarece Barreto que "o ato de sentar sobre bancos implica flexionar as pernas e colocar os pés no solo com os joelhos apontando para o alto, numa posição que cria o contato entre a terra e o céu, entre o mundo natural dos humanos e o mundo sobrenatural dos espíritos, posição esta muitas vezes só permitida a alguns homens mais importantes da aldeia" ${ }^{641}$.

\footnotetext{
${ }^{639}$ É importante notar como há variação no tipo de contato e hibridismo entre os povos: se os portugueses ao chegar na Índia se apropriam de formas de mobiliário e o peso de seus motivos e adornos artísticos surte grande peso nos estilos, o mesmo não ocorre em relação aos ameríndios, apenas esporadicamente representados. Cf. KOK, Glória. A presença indígena nas capelas da capitania de São Vicente (século XVII). Espaço Ameríndio, v. 5, n. 2, p. 45, 2011..

${ }^{640}$ VAN VELTHEM, Lucia Hussak. Artes indígenas: notas sobre a lógica dos corpos e dos artefatos. Textos escolhidos de cultura e arte populares, v. 7, n. 1, 2010.

${ }^{641}$ Barreto, Cristina. Bancos indígenas do Brasil. São Paulo: BEl, 2017. p. 21.
} 


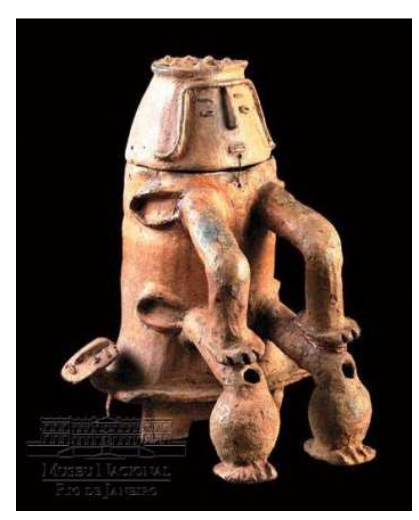

Figura 126: Urna funerária antropomorfa de cerâmica do povo Maracá, Sul do Amapá. c. 1000 d.C.. Note-se que o banco onde a figura antropomorfa está sentada é zoomorfa e sua posição é ritual, com as mãos no joelho e os cotovelos projetados para fora ${ }^{642}$.

Para além da produção e uso dos bancos rituais, há indícios de que o mobiliário europeu também entrou em interlocução com essas populações.

Diz Alfred Métraux baseado nas pesquisas de Nordenskiöld (1920) e Ambrosetti (1895) que entre os Caingua, nas fronteiras do Paraguai com o Brasil, o catre tem completamente a aparência de uma imitação da cama europeia. As cadeiras dos Tupinambás, feitas de caniço ou varinhas, foram descritas por Piso, em 1648, como "sem dúvida de origem europeia" ${ }^{643}$.

Independente da adoção ou não de formas moveleiras europeias pelos indígenas, o que de fato cumpre salientar nesta compreensão sobre o uso social destes artefatos no mundo colonial é o aspecto relacional entre essas diferentes civilizações materiais em choque e hibridismo, onde tais móveis possuem em ambos os grupos valores simbólicos de uso que distinguem seus portadores, cada um segundo o próprio universo cultural.

Tal como o status social do assento entre os ameríndios, também devemos compreender o uso do mobiliário pelos senhores luso-americanos como um instrumento de poder em choque com as formas culturais advindas das etnias de seus escravos africanos, que também possuíam práticas de assento ao chão ${ }^{644} \mathrm{e}$ usando bancos rituais. Alguns exemplos são dados pelos próprios agentes colonizadores portugueses em suas viagens. Interessante episódio onde vemos os

\footnotetext{
${ }^{642}$ Museu Histórico Nacional. Disponível em:

http://www.museunacional.ufrj.br/dir/exposicoes/arqueologia/arqueologia-brasileira/arqbra002.html. Acesso em: 20/05/2018.

643 PISO, Guilherme. Historiae Naturalis Brasiliae. 1648. apud. MÉTRAUX, Alfred. A civilização material tupiguarani. 1928. Campo Grande: Ed. Alvorada. 2012.

${ }^{644}$ HEWES, Gordon. World distribution of certain Postural Habits. American Anthropologist, 1955. p. 231 ss.
} 
portugueses em ocasiões de sociabilidade com populações africanas das mesmas etnias donde provinham grande parte de seus escravos, é contado pelo Pe. Vicente Ferreira Pires, nascido na Bahia e enviado à África em 1796, na Fortaleza de S. João de Ajudá, atual Benin ${ }^{645}$ :

As grandes festividades do rei, pois que todos os anos se fazem duas festas chamadas costumes do jirau; a primeira a 24 do mês de junho e a segunda a 25 do mês de dezembro, das quais se pode ver o plano.(...). Um grande átrio, fronteiro à porta do palácio do rei em Abôme, serve de campo onde se representa a sanguinosa cena. Fora da porta do palácio se forma um pequeno anfiteatro, com a elevação de três ou quatro palmos, para se assentar o rei, e toda a família do paço. Para estas funções são também convidados, além de todos os outros feudatários, príncipes e potentados, os três governadores das fortalezas de gregué, os quais têm assento à direita do rei. Em suas cadeiras os grandes da terra estão sentados ou deitados no chão na forma do costume, em cima dos seus coiros com banquinhos, o que só nestas duas ocasiões lhes é permitido usar diante do rei. O mais povo existe aos bandos, munidos de todas as qualidades de instrumentos negrais, e sempre em contínua e furibunda cantarola, fazendo uma espécie de círculo, para o átrio ficar livre.

Para termos apenas um exemplo da efetiva importância do status da prática de assentar e da sua própria materialidade, podemos notar o emblemático trono de chefe da cultura Chokwe de Angola, cuja forma revela a circularidade das cadeiras de sola portuguesas também entre os povos africanos donde surge neste interim de apropriação e circularidade a exuberante reinterpretação do móvel de forma híbrida, contendo estatuetas figurativas de poder ritual e novas soluções de arremates nos pés e pináculos, ainda que o formato trapezoidal da estrutura, o couro e a pregaria estejam também presentes.

\footnotetext{
${ }^{645}$ PIRES, P.e Vicente Ferreira. Viagem ao Reino do Daomé. 1800. In: LESSA, Clado Ribeiro de. Crônica de uma Embaixada Luso-Brasileira à Costa d'África em fins do século XVIII, incluindo o texto da Viagem de África em o Reino de Dahomé escrita pelo Padre Vicente Ferreira Pires no ano de 1800 e até o presente inédita. São Paulo: Companhia Editora Nacional (Brasiliana), 1957. P. 47
} 


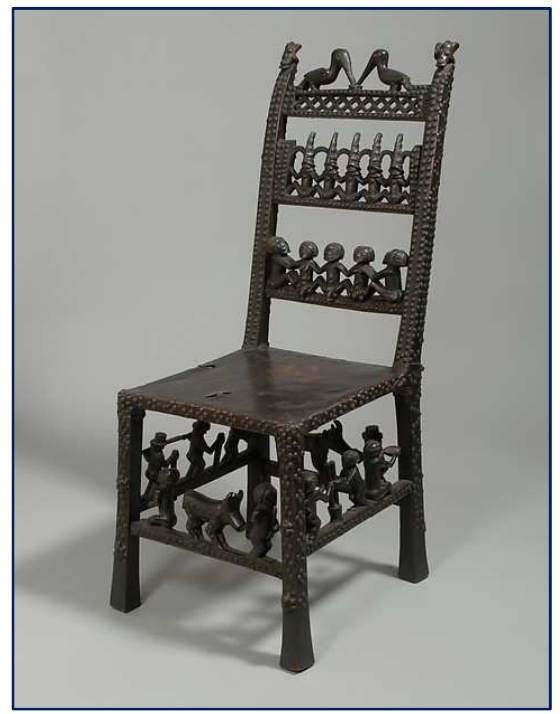

Figura 127: Banco de chefe. Cultura Chokwe de Angola, séc. XIX-XX ${ }^{646}$. Acervo: Metropolitan Museum of Art, Nova York.

Este exemplo de hibridismo demonstra o desejo dos chefes, ou soba, em expressar seu status perante os estrangeiros, demonstrando aos novos parceiros comerciais igualdade de posição e mesmo abrindo espaço a uma corrida simbólica agonísticas com floreio nas formas de maneira a superar os exemplares europeus em complexidade decorativa ${ }^{647 .}$

Encontramos ainda para o contexto luso-africano, mas na margem índica do continente, outro exemplo de móvel que revela em sua materialidade os fluxos e refluxos de influências entre estes povos:

\footnotetext{
${ }^{646}$ Disponível em: http://www.metmuseum.org/collection/the-collection-online/search/311078. Acesso em: 20/05/2018.

${ }^{647}$ Cf. FACTUM, Ana Beatriz Simon. Joalheria escrava baiana: a construção histórica do design de joias brasileiro. 2009. Tese (Doutorado em Design e Arquitetura) - Faculdade de Arquitetura e Urbanismo, Universidade de São Paulo, São Paulo, 2009. P. 87.
} 


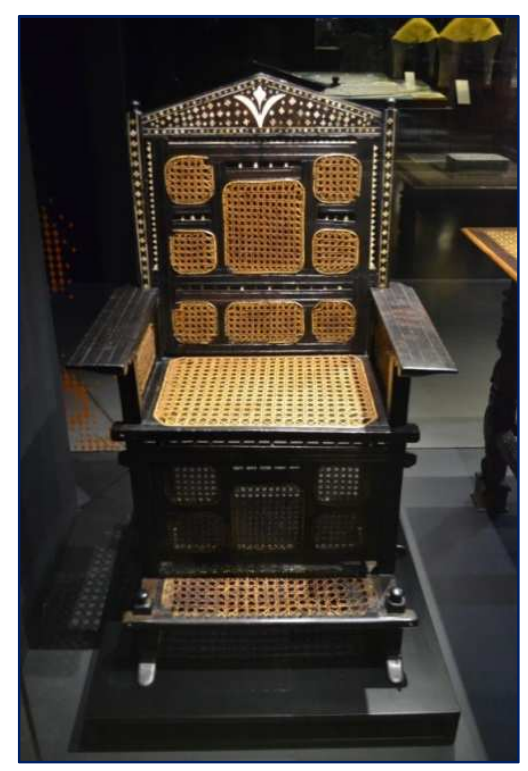

Figura 128: Cadeira de Braços, Museu do Oriente. Mombaça, século XVII. ébano, osso, palhinha. Número de Inventário: FO/1350. Foto do autor.

Segundo a descrição do Museu do Oriente de Lisboa, este móvel de assento assemelha-se às cadeiras peninsulares quinhentistas levadas para a Índia, com as suas prumadas retas e travejamento inferior junto ao chão. Executadas na costa oriental africana refletem assim essa dupla influência em um amálgama de grande riqueza cultural.

Também como no caso das populações ameríndias, mas ainda mais raras, temos o registro por gravuristas europeus sobre as casas e práticas cotidianas dos negros trazidos ou nascidos no Brasil.

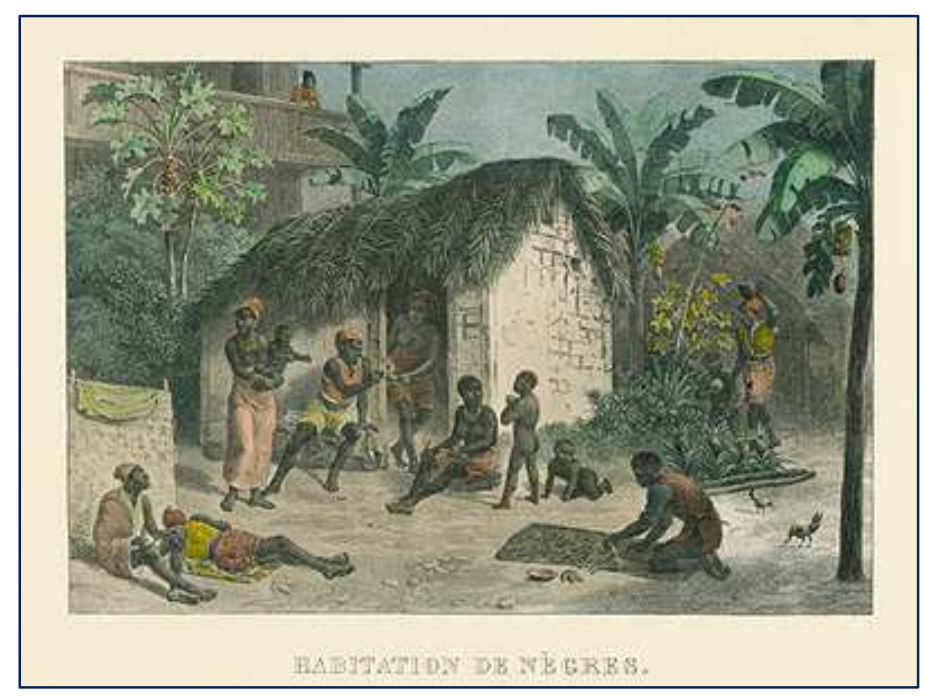

Figura 129: RUGENDAS, Johann Moritz. "Casa de Negros", $1835^{648}$.

648 RUGENDAS, Johann Moritz. “Casa de Negros", 1835. Fonte: Aguillar, Nelson (Org.). Mostra do redescobrimento: negro de corpo e alma. São Paulo: Associação Brasil 500 Anos Artes Visuais, 2000. 
Vemos na gravura de Johann Moritz Rugendas (1802, Augsburgo, Alemanha - 1858, Weilheim an der Teck, Alemanha) como as posições corporais africanas de assentar no chão com as pernas cruzadas, mas projetadas para a frente (sublinhado em vermelho na figura 122 elaborada por Hewes), diferentemente dos ameríndios. Também há o uso de se sentar sobre os joelhos e pés ao executar os trabalhos sobre esteiras também se efetuava na nova terra à qual precisavam se adaptar, no grande choque não só de civilizações materiais, mas também de coberturas vegetais. A minúcia do gravurista traz ainda outras informações importantes através da imagem, como o fato das sociabilidades e trabalhos diurnos desses indivíduos darem-se especialmente no espaço externo à pequena casa onde viviam, de perto observada pelos habitantes do sobrado que ocupa a porção superior da imagem, talvez propriedade de seu senhorio.

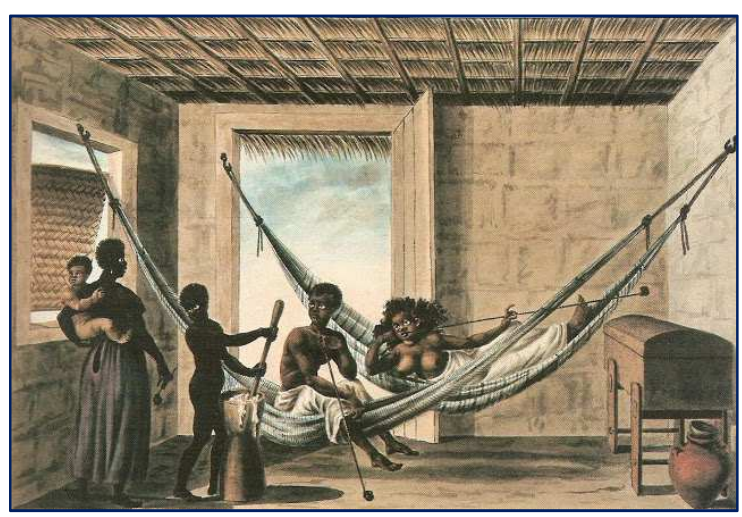

Figura 130: GUILLOBEL, Joaquim Cândido - "Interior de uma casa do baixo povo", c. $1820^{649}$.

Notemos também nesta imagem feita por Joaquim Cândido Guillobel (Lisboa, 1787 - Rio de Janeiro, 1859) de um interior doméstico de população negra e mestiça menos privilegiada o teto feito de caibros entrelaçado de pindoba, o chão de terra batida e as redes presas nas estruturas de madeira da casa de taipa de mão. Importante observar a presença do baú com apoio de pés, indício de que mesmo as populações mais pobres poderiam adquirir mobílias, e decerto eram de grande importância para elas guardarem os mais variados pertences da família ${ }^{650}$. Apesar

\footnotetext{
${ }^{649}$ GUILLOBEL, Joaquim Cândido - "Interior de uma casa do baixo povo", c.1820. Fonte: MOURA, Carlos Eugênio Marcondes de. A travessia da calunga grande: três séculos de imagens sobre o negro no Brasil (16371899). São Paulo: Editora da Universidade de São Paulo, 2000.

650 O baú com tampo abaloado não seria incomum que os próprios escravos pudessem ter semelhantes apetrechos, caso tivessem a confiança de seus senhores. Pelo relato do escravo cubano Juan Manzano, sabemos que sua família pode ajuntar peças de ouro e dinheiro para poder comprar a sua liberdade, sem que sua senhora o soubesse. A mesma não aceitara a aquisição e apropriou-se dos bens com tanto esforço guardados nestes móveis, que resguardavam a pouca privacidade dos escravos à vigilância de seus senhores.
} 
de se tratar de uma casa de pobres livres, pode-se aventar que elas possuíam escravos trabalhando para elas, marcados estes pela pele mais negra - indicação de que são escravos trazidos da África e não mestiços como as figuras deitadas na rede, retrato de que as hibridizações culturais ocorriam também entre os africanos e indígenas, trocas ainda a serem melhor compreendidas.

Assim colhemos elementos para compreender o grande choque cultural que significava aos povos ameríndios e africanos que foram submetidos em São Paulo a presença de mobiliário tão diverso daqueles presentes nas suas civilizações materiais próprias, e com usos e propósitos diferentes que decerto lhes confundiam as noções simbólicas e de status originais de seus grupos culturais originais.

Encontramos nas fontes iconográficas ainda semelhante diferenciação social pelo estatuto do assento, novamente vetorizada e conformada através da exuberância das formas do móvel em pinturas de viajantes estrangeiros na interação entre senhores e escravos.

Quanto aos móveis, são raríssimas as representações de negros assentados, possuindo ou utilizando algo que fosse próprio. Isto porque dentro da "economia da escassez" que caracteriza a Civilização Material europeia até a Revolução Industrial ${ }^{651}$, o patamar da escravaria era ainda mais privado de bens.

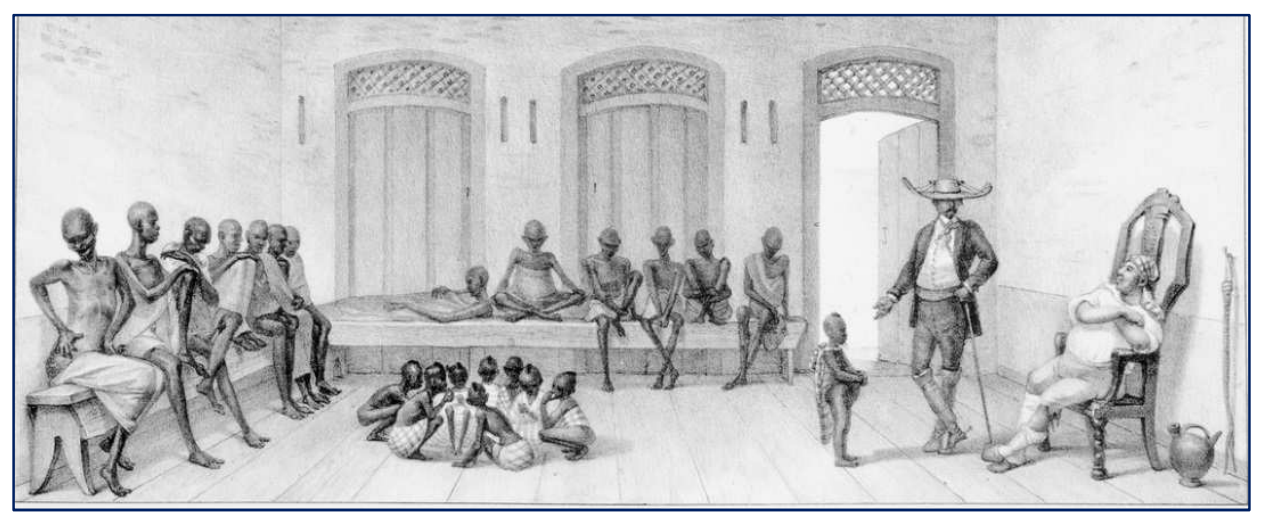

Figura 131: DEBRET, Jean-Baptiste. Mercado da rua do Valongo. $1835^{652}$

MANZANO, Juan Francisco. A autobiografia do poeta-escravo. Organização e tradução de Alex Castro. São Paulo: Hedra, 2015.

${ }^{651}$ SARTI, Rafaella. Casa e Família. Habitar, Comer e Vestir na Europa Moderna. Lisboa: Estampa, 2001. P. 15ss. ROCHE, Daniel. História das coisas banais: nascimento do consumo nas sociedades do século XVII ao XVIII, tradução de Ana Maria SCHERER, Rio de Janeiro, Rocco, 2000. P. 17.

652 DEBRET, Jean-Baptiste. Voyage pittoresque et historique au Brésil . Paris, Firmin Didot Freres, 1834-39. Disponível em: https://digital.bbm.usp.br/handle/bbm/3745. Acesso em: 20/02/2018. 
Notamos na figura anterior, também de Jean-Baptiste Debret, o vigia dos escravos assentado em uma cadeira de braços e alto encosto, que poderíamos atribuir a um estilo de transição entre as pernas torneadas em bolachas do XVII com encosto vazado em rocalha, inovação do $X \mathrm{VIII}{ }^{653}$. O porte físico robusto do vigia contrasta com a magreza dos escravos, sentados ou deitados em bancos coletivos, destacando-se a figura sentada com as pernas cruzadas sobre o próprio banco, bem como as crianças acocoradas no chão ao centro. Também contrastante à penúria dos escravos, vemos objetos elementares, mas muito significativos: ao seu lado o chicote pendurado na parede e uma jarra ao chão. A postura distintiva da personagem de pé se revela pelas suas roupas, bota com esporas, a cana e o largo chapéu, e a perna cruzada evidenciando as esporas da bota.

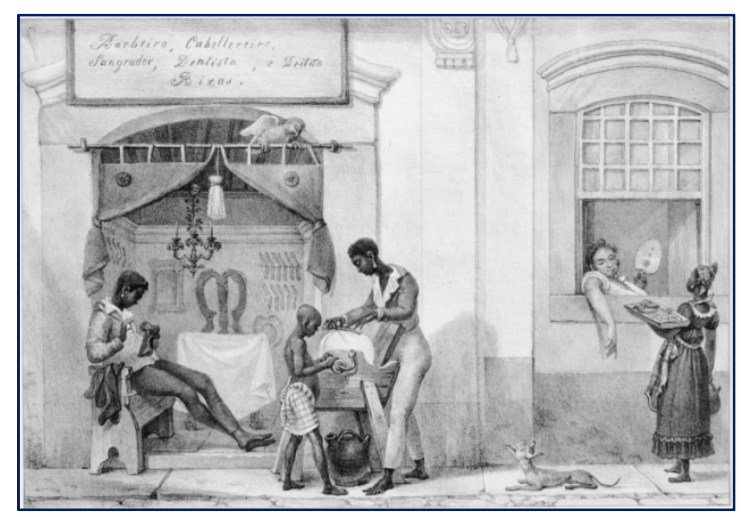

Figura 132: Debret, Jean-Baptiste. loja de barbeiro. $1835^{654}$.

Também na clássica ilustração de Debret de uma barbearia no Rio de Janeiro, vemos exemplo do poder simbólico dos móveis que não passou despercebido ao perspicaz pintor. $\mathrm{O}$ escravo barbeiro aguarda um próximo cliente sentado à porta em um banco sem encosto, ao passo em que ao fundo da loja vemos uma grande cadeira com influência inglesa ${ }^{655}$, com espaldar alto e tabela no espaldar recortada, e trabalhado em rocalha destinado ao cliente, mas interdito ao escravo, o qual se apresenta com boas roupas, diferente do pano do jovem amolador ambulante, mas igualmente descalço para marcar sua condição.

\footnotetext{
653 CANTI, Tilde. 0 móvel no Brasil: origens, evolução e características. Rio de Janeiro: Ed. Candido Guinle de Paula Machado, 1980, p. 193.

654 DEBRET, Jean-Baptiste. Voyage pittoresque et historique au Brésil . Paris, Firmin Didot Freres, 1834-39. Disponível em: https://digital.bbm.usp.br/handle/bbm/3690. Acesso em: 20/05/2018.

${ }^{655}$ CANTI, Tilde. 0 móvel no Brasil: origens, evolução e características. Rio de Janeiro: Ed. Candido Guinle de Paula Machado, 1980. Compare-se com a cadeira da Imagem n. 196, p. 243.
} 


\subsection{Por uma etnografia sobre o colonizador}

À parte a visão escravista dos portugueses inferiorizando as populações indígenas e africanas, temos também no Brasil a visão exotista de viajantes de outros países europeus e mesmo de novas levas de reinóis sobre a manutenção de práticas corporais herdadas de Portugal pelos colonos no Brasil. Como já observara Vânia Carneiro de Carvalho ${ }^{656}$, no Brasil até o século XIX, as mulheres sentavam-se "à maneira asiática", isto é, com as pernas cruzadas entre si e sobre os pés. Esta postura é classificada por Gordon Hewes de "turk-fashion" ou "tailor-fashion", como é conhecido na Inglaterra ${ }^{657}$. Tal forma de se assentar praticada especialmente entre as populações do Extremo Oriente, como notou também Siegfried Giedion ${ }^{658} \mathrm{e}$ também entre os árabes, com os quais esta tradição se perpetuou na Península Ibérica ${ }^{659}$. Tal prática de assento, que não necessita de móveis para ser realizado, pode lançar luz sobre as visões consolidadas sobre a "pobreza" das casas paulistas coloniais, como veremos adiante.

A seguir temos exemplo visual que permite compreender a vida doméstica paulista para além da análise quantitativa dos inventários, através da qual já contemplamos a diversidade e a qualidade de bens domésticos desde o começo do século XVIII e o adensamento ao longo do tempo, bem como a correlação da composição da riqueza com o cabedal de escravos e de terras.

\footnotetext{
${ }^{656}$ CARVALHO, Vânia Carneiro de. Gênero e artefato... Op. Cit. p. 198 ss.

${ }^{657}$ HEWES, Gordon. World distribution of certain Postural Habits. American Anthropologist, 1955. p. 231 ss.

${ }^{658}$ Apud CARVALHO, Vânia Carneiro de. Gênero e artefato: op. cit.. 2008.; p. 198 ss.

${ }^{659}$ CASCUDO, Câmara. Mouros, franceses e judeus: três presenças no Brasil. Editora Perspectiva, 1984. P. 2528.
} 


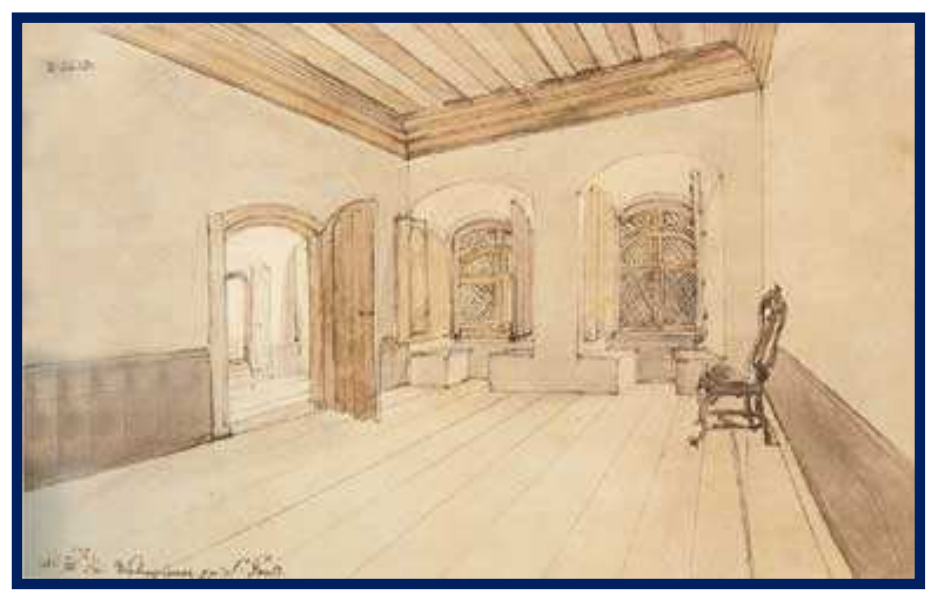

Figura 133: ENDER, Thomas. “Uma sala de estar em São Paulo”, $1817^{660}$.

Como observado por Maria Aparecida Borrego ${ }^{661}$, esta raríssima ilustração de Thomas Ender (1793, Viena, Áustria - 1875, idem) de um interior doméstico paulista em um primeiro olhar nos engana: a sala quase vazia, possuindo apenas uma cadeira seria prova concreta da pobreza paulista até o século XIX. Porém, atenta aos detalhes, a historiadora notou como esta é uma casa abastada, com ampla sala contando com piso de tábuas corridas, teto forrado e janelas com gelosias ${ }^{662}$. As conversadeiras, projeções da parede abaixo das janelas, revela que a cadeira não é o único artefato propiciador do ato de assentar, para além da possibilidade do assento no chão, ou sobre tapetes e esteiras que poderiam ser colocadas pelas mulheres nas ocasiões certas.

Olhando com maior atenção para a solitária cadeira, notamos a sua qualidade formal, com rocalha e pés de cabra, índice de distinção dentro do processo de mudanças dos aparatos domésticos durante este século, bastante semelhante à cadeira do estilo $D$. João $\vee$ que analisamos no primeiro capítulo. A sua posição na sala, de frente à porta, é mais um sinal de como este era um móvel de requinte, que simbolizava o status de seu rico proprietário ${ }^{663}$, decerto o único autorizado a usá-la e tanto por isso distinto no seu espaço social.

\footnotetext{
${ }^{660}$ ENDER, Thomas. “Uma sala de estar em São Paulo". 1817 apud. LAGO, P.C. do. Iconografia paulistana do século XIX. 2a ed. São Paulo: Capivara. 2003. P.36.

${ }^{661}$ BORREGO, Maria Aparecida de Menezes. Artefatos e práticas sociais em torno das refeições (São Paulo, séculos XVIII e XIX). Varia hist., Belo Horizonte, v. 32, n. 58, p. 101-137, Apr. 2016.

${ }^{662}$ Sinal de status tradicional como mostrado por MARINS, Paulo Cesar Garcez. Através da rótula: sociedade e arquitetura urbana no Brasil, sécs. XVII-XX. Tese de Doutorado. São Paulo, Dpto. De História da FFLCH-USP, 1999.

${ }^{663}$ Vânia Carneiro de Carvalho notou que o uso das cadeiras até quase a passagem para o século XX foi peremptoriamente utilizada pelos homens, dado o fato de serem individuais, caras, rígidas e ligadas ao poder institucional. As mulheres teriam, desta forma, permanecido por mais tempo assentadas no chão com esteiras
} 
Tal compreensão ainda é ainda pouco presente na historiografia sobre São Paulo, onde imperou as interpretações de "pobreza" e "vazio". Isto se deve em grande parte ao fato de que os historiadores do começo do século $X X$, pelas suas concepções sobre a história nacional não compreendiam a diversidade cultural em coexistência nas populações brasileiras, pouco incluindo o índio e o negro nas especificidades de suas práticas transplantadas na América. Também não aquilataram tais estudiosos a continuidade de práticas já consideradas arcaicas em Portugal. Estas são sensibilidades historiográficas que só viriam a se formar na segunda metade do século XX e se consolidar nos anos 1970, ainda que sobre o crivo do folclorismo dos "usos e costumes".

Por exemplo, Afonso Taunay em suas considerações sobre a civilização material paulista traçou comentários sobre os bens domésticos na sua Historia da Cidade de São Paulo 1735-1765, onde dedica um capítulo a falar das "casas pobres, anti-higiênicas e desconfortáveis" dos paulistas. Citando trechos do pioneiro historiador brasileiro Capistrano de $\mathrm{Abreu}^{664}$, descreve as casas, sua arquitetura e a vida doméstica da seguinte maneira ${ }^{665}$ :

Térreas, geralmente, raro possuindo mais de um piso, não é preciso insistir sobre a detestável planta das nossas casas coloniais. (...)

Nos diminutos cômodos apinhavam-se à noite, numa atmosfera de bafio os dormentes, adultos e crianças.

Às oito horas da manhã almoçava-se; ao meio dia, era o jantar. Sentavamse pais e filhos em torno da grande mesa, cercada de bancos de pau e às vezes de uma ou duas cadeiras.

Nas famílias menos abastadas não passava este traste de grande prancha estendida sobre cavaletes, e muitos dos convivas acocoravam-se no chão. Os alimentos molhados vinham em terrinas ou cuias; os alimentos secos em cestas; comia-se em pratinhos de Lisboa. Só os homens serviam-se de faca; mulheres e meninos comiam com a mão.

Ninguém à mesa conversava, comia-se a galope, devorava-se; o que motivaria a conhecida observação de um viajante: "os brasileiros só tem pressa quando comem".

e estrados, ou nas marquesas e canapés. CARVALHO, Vânia Carneiro. Gênero e artefato: o sistema doméstico na perspectiva da cultura material: São Paulo, 1870-1920. EdUSP, 2008. P. 201.

664 Taunay cita como "Breves traços da História do Brasil", que depois compuseram "Capítulos de História Colonial". ABREU, João Capistrano de. Capítulos de História Colonial (1500-1800). Brasília: Conselho Editorial do Senado Federal, 1998. Biblioteca Básica Brasileira. P. 218.

${ }^{665}$ TAUNAY, Affonso de E. História da cidade de São Paulo no século XVIII (1735-1765). São Paulo: Imprensa Oficial do Estado. Parte 2, vol.1. 1931. Pagina 109 ss. 
Notamos nessa expressiva passagem o forte tom de penúria com que a cidade é descrita, parte essencial no corpo da narrativa que tece sobre a história paulista de vila periférica até grande metrópole.

Devemos, primeiramente, considerar essas observações maneira menos generalista e depreciativa, particularizando os casos. Se a falta de espaço, insalubridade, interpolação dos usos dos espaços para diversas atividades e pessoas, bem como a posse reduzida de objetos se verificava entre as populações mais pobres ${ }^{666}$, denominar a planta das casas coloniais e a vida nelas como "detestável" decerto é compactar a um perfil único a variedade de situações e deixar de ver as particularidades das formas de vida praticadas pelos mais variados grupos, classes e estamentos, como pudemos conjeturar no capítulo anterior. Igualmente é deixar de lado a possibilidade de, através das práticas corporais e dos móveis presentes nas casas, compreender as formas de distinção social entre os grupos, mesmo entre os menos favorecidos. Afinal, também nos lares mais pobres havia cisões nas utilizações dos bens e dos espaços, que revelam importantes elementos para a compreensão das dinâmicas sociais como um todo ${ }^{667}$.

Paradoxalmente às noções da historiografia paulista do começo do século XX, Carl Friedrich Philipp von Martius (1794, Erlangen, Alemanha - 1868, Munique, Alemanha) considerou que a simplicidade das casas era sinal de menor influência dos gostos europeus do que em outras capitanias. Ao mesmo tempo o naturalista admira-se da conveniência, limpeza e da antiguidade dos móveis presentes nas salas $^{668}$ :

\footnotetext{
${ }^{666}$ Não começou com os historiadores brasileiros dos inícios do século XX a visão pejorativa sobre as casas coloniais, senão com os próprios viajantes europeus que relataram a nova fronteira aberta com a vinda da Corte. Por exemplo, o oficial da marinha britânica James Tuckey, em 1803 visitando o Rio de janeiro faz comparações com o rigor sanitário inglês e a interiorização das normas de "bom gosto", tecendo criticas até mesmo às casas mais ricas da cidade, que vê com desprezo, já que "a residência dos ricos conta com janelas envidraçadas, o que só contribui para intensificar a luz solar e tornar o calor insuportável" TUCKEY, James. apud: FRANÇA, Jean Marcel Carvalho. Outras Visões do Rio de Janeiro Colonial. Antologia de Textos (15821808). Rio de Janeiro: José Olympio Editora, 2000, p. 261. A respeito dos sobrados, há semelhante desprezo: "tem comumente dois andares altos e independentes do térreo. Esse é ocupado por uma loja ou por uma adega, em geral, muito suja, quente e insalubre. A escada que dá acesso aos andares superiores é inclinada e desprovida de luminosidade. O interior revela que a distribuição dos cômodos não levou em consideração nem a livre circulação do ar nem a beleza da perspectiva. A mobília aí encontrada, ainda que suntuosa, ofende os olhos acostumados à simplicidade elegante, pois peca pelo excesso de enfeites." Idem, ibidem.

667 Como mostrado para o contexto francês por ROCHE, Daniel. História das coisas banais: nascimento do consumo nas sociedades tradicionais (XVII-XIX). 2 ed. Trad. Telma Costa. Lisboa: Editorial Teorema, 1998.

${ }^{668}$ SPIX, J. e MARTIUS, C. Viagem pelo Brasil. 3 volumes. Tradução de Lúcia Furquim Lahmeyer. 3a edição. São Paulo: Edições Melhoramentos, 1976.p. 12.
} 
Entre os moradores de São Paulo, o gosto pelo luxo europeu nem de longe se desenvolveu tanto como entre os ricos baianos, pernambucanos e maranhenses. Cuida-se mais do asseio e do conforto na disposição da casa do que de elegância e suntuosidade, e, em vez do mobiliário leve americano e dos espelhos franceses daquelas províncias, encontram-se nas salas cadeiras pesadas, enfileiradas, que datam de longos decênios, e um espelho pequeno com sua moldura da manufatura de Nüremberg, no qual um alemão imaginará reconhecer um compatriota. Em vez das grandes lâmpadas de vidro ou castiçais com velas de cera, campeia no meio da mesa um lampião de latão, no qual se queima, em geral, azeite de mamona (Ricinus communis). No tom da sociedade, nota-se igualmente, ainda pouca influência da Europa.

A observação final, sobre a menor influência europeia na população, foi um grande argumento para a historiografia paulista reputar à cidade isolamento e rusticidade, sem compreender as idiossincrasias do cultivo de antigas práticas europeias e do hibridismo de aprendizados indígenas na vida cotidiana dos lares ${ }^{669}$.

Retornando à passagem anterior, vemos como Afonso Taunay considera o acocorar como uma prática improvisada dada a ausência de móveis. Não leva em consideração a postura costumeira das populações indígenas do Brasil, que no período colonial estavam em processo de amálgama com os elementos europeus, os quais, por sua vez, já traziam do Reino posturas corporais independentes de apoio mobiliar.

Assim, aquilo que Afonso Taunay considerara postura rústica em São Paulo, dada a pobreza e ausência de móveis, revela-se do ponto de vista antropológico repleto de riqueza cultural. A maneira como tais indivíduos se assentavam no período - tal qual os europeus em suas cortes repletas de cadeiras - também estava sujeita a ritualidades, hierarquias, divisões de gênero e idade, todas crivadas dos julgamentos e criticas sociais dentro dos seus grupos sociais.

Como pudemos observar no capítulo anterior, os inventários do começo dos Setecentos revelam diversos aparatos utilizados para o assento, mas não necessariamente mobiliares - com estruturas altas e pés - como os tapetes, estrados, alcatifas, almofadas e mesmo o alambel, sendo que estes três últimos

\footnotetext{
${ }^{669}$ Ademais, resta dúvida a respeito de quais casas teria Martius visitado em São Paulo, pois como mostramos nos capítulos anteriores através da análise dos inventários, a presença de mobiliário ligeiro e diversificado, em circularidade com a Europa, já se fazia presente na cidade à época da viagem do naturalista alemão. De fato, devemos compreender como as narrativas dos viajantes, por mais minuciosas, são sempre parciais à sua experiência. Cf. CRUZ, Ana L. R. B. As viagens são os viajantes: dimensões indentitárias dos viajantes naturalistas brasileiros do século XVIII. História. Questões e Debates, Curitiba, v. 19, n.36, 2003. p. 61-98.
} 
somem dos registros à proporção que os móveis de assento se tornam mais comuns.

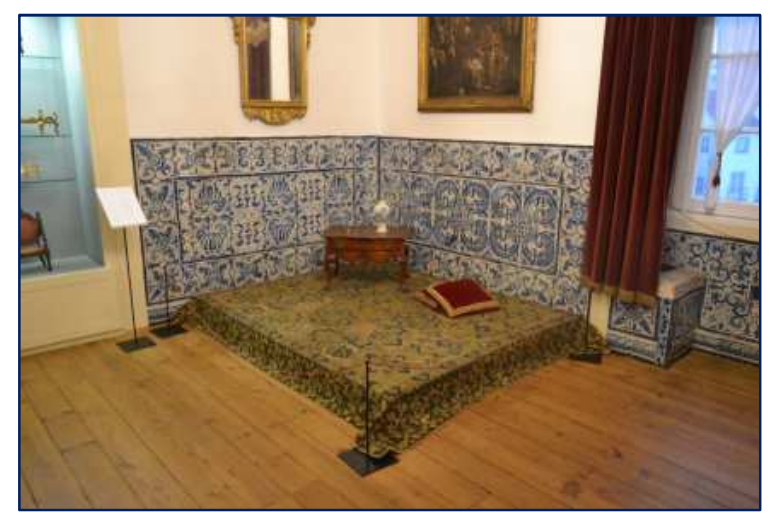

Figura 134: Sala no Palácio Azurara, Museu de Artes Decorativas de Lisboa. Fotografia do autor.

Podemos ver pela fotografia um exemplo de estrado coberto por tapete onde se assentavam as mulheres portuguesas, seguindo a influência mourisca, acompanhadas de almofadas e móveis de pequenas proporções, como esta mesinha de estrado. Note-se ainda a conversadeira ao pé da janela neste recinto no andar superior do Palácio Azurara, sede da FRESS.

Trabalho de expulsão da marca moura, houve esforço secular da historiografia portuguesa em anular, desvalorizando a presença islâmica no território português, que durara quase cinco séculos ${ }^{670}$. Isso, porém, não significa que 0 hábito de se assentar ao chão tenha desaparecido no Reino, como veremos mais adiante.

Até o avançar do século XIX ocorreu o combate às formas "arcaicas" de herança mourisca em São Paulo, como as rotulas e gelosias das janelas, como traçado por Paulo Garcez Marins ${ }^{671}$, bem como a proibição do uso das mantilhas pelas mulheres em São Paulo. A respeito destas, o Capitão-general Martim Lopes de Lobo Saldanha proibiu na cidade o uso das baetas em 17 de novembro de 1775, baseando-se na lei do reino de 20 de agosto de $1649^{672}$. Segundo o governante ${ }^{673}$ :

\footnotetext{
${ }^{670}$ OLIVEIRA, Raquel Salomé Sousa. A síntese mediterrânea na construção da identidade cultural. Tese de Mestrado - Feup-Faculdade de Engenheira da Universidade do Porto, 2003.p. 61.

${ }^{671}$ MARINS, Paulo Cesar Garcez. Através da rótula: sociedade e arquitetura urbana no Brasil, sécs. XVII-XX. Tese de Doutorado. São Paulo, Dpto. De História da FFLCH-USP, 1999.

${ }^{672}$ Segundo Nuto Santana, "havia também na corte de Madrid e por ter tratado de o abolir viu-se Carlos III obrigado a abafar alguns graves motins." SANT'ANNA, Nuto. Chapéus desabados. São Paulo histórico: Aspectos, Lendas, Costumes. Volume VI. SP: Dpto. de cultura. 1944. p. 193.

673 SANT'ANNA, Nuto. Chapéus desabados. São Paulo histórico: Aspectos, Lendas, Costumes. Volume VI. SP: Dpto. de cultura. 1944. p. 194.
} 
"Achei nesta cidade o inculto uso de andarem as mulheres livres rebuçadas em dois côvados de baeta preta assim como se cortavam nas lojas, e com chapéus desabados nas cabeças; e deste modo, com as caras todas tapadas, tanto nas ruas, como nas Igrejas, se precipitavam muitas a entrarem até de dia em casas de homens, onde não entrariam, se lhes não desse ousadia o bárbaro rebuço, de que também me constou usavam alguns criminosos para se encobrirem às Justiças, e alguns facinorosos para cometerem delitos, como algumas vezes tinha acontecido na Capitania (...)".

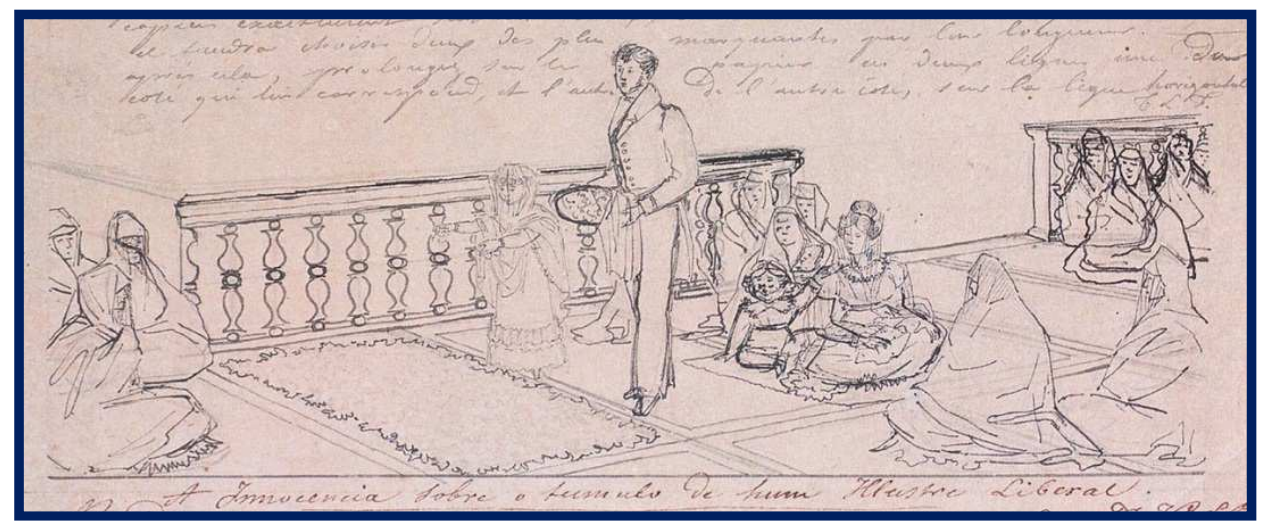

Figura 135: FLORENCE, Hercules "A inocência sobre o túmulo de um ilustre liberal", $1830^{674}$.

Exemplificação visual para a postura que o Capitão-general buscou combater em São Paulo, vemos nesta rara gravura de Hercule Florence (1804, Nice, França 1879, Campinas, São Paulo), representando mulheres de mantilha na nave da Igreja da Sé praticando a postura mourisca, também executado por uma senhora na parte central da imagem que utiliza vestido mais próximos aos usados na Europa no período.

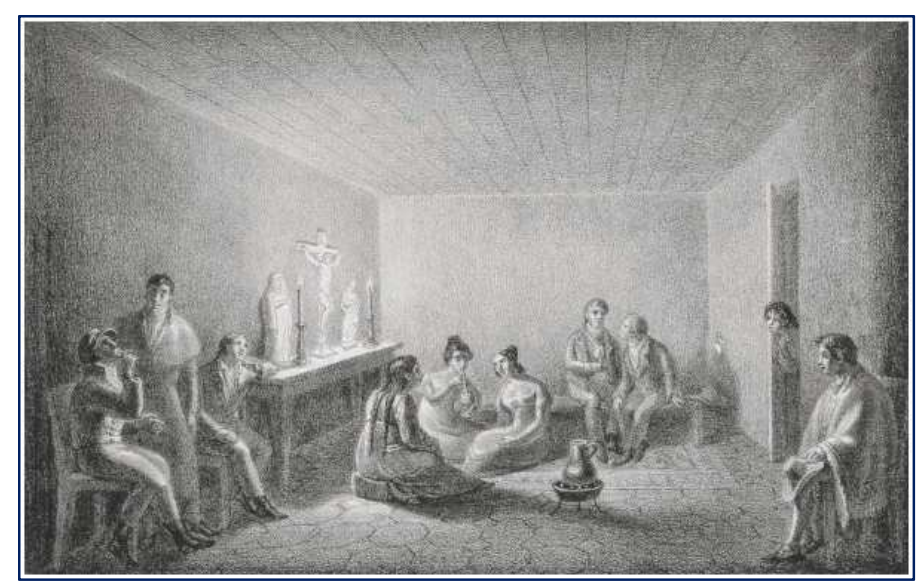

Figura 136: Tertulia and mate party. Gravura de Peter Schimdtmeyer, Travels into Chile..., $1824^{675}$.

\footnotetext{
${ }^{674}$ Apud: MARINS, Paulo César. A vida cotidiana dos paulistas: moradias, alimentação, indumentária. In: SETÚBAL, Alice (org.). Terra Paulista: histórias, arte, costumes, vol. 1. São Paulo: Imprensa Oficial; Cenpec, 2008. p. 89-190.
} 
Não era apenas em São Paulo que se dava este fenômeno de preservação secular de práticas corporais ibéricas. Apesar de ser gravura feita no Chile em 1824 a cena de sociabilidade doméstica na figura acima nos fornece grandes semelhanças com Piratininga, onde não encontramos congênere, a não ser a sala vazia pintada por Thomas Ender. A julgar pela gravura de Florence das mulheres paulistas na Igreja da Sé praticando das mesmas posturas do sentar "à oriental", notamos como se assemelham as práticas de assento de influência moura entre os povos ibéricos, perdurando até o avançar do século XIX. Constatamos, aliás, como as práticas de assento são divididas por gênero, com as mulheres sentadas ao chão, com as pernas dobradas, ainda que utilizem vestidos à moda europeia. Os homens se assentam em bancos e cadeiras encostados às paredes, bem como ao móvel de apoio, que poderia ser denominado de aparador ou banca ${ }^{676}$, comportando um crucifixo e imagens de santos, e servindo de fato com um núcleo de gravidade da sala, de onde se emite a luz das velas sobre os candelabros.

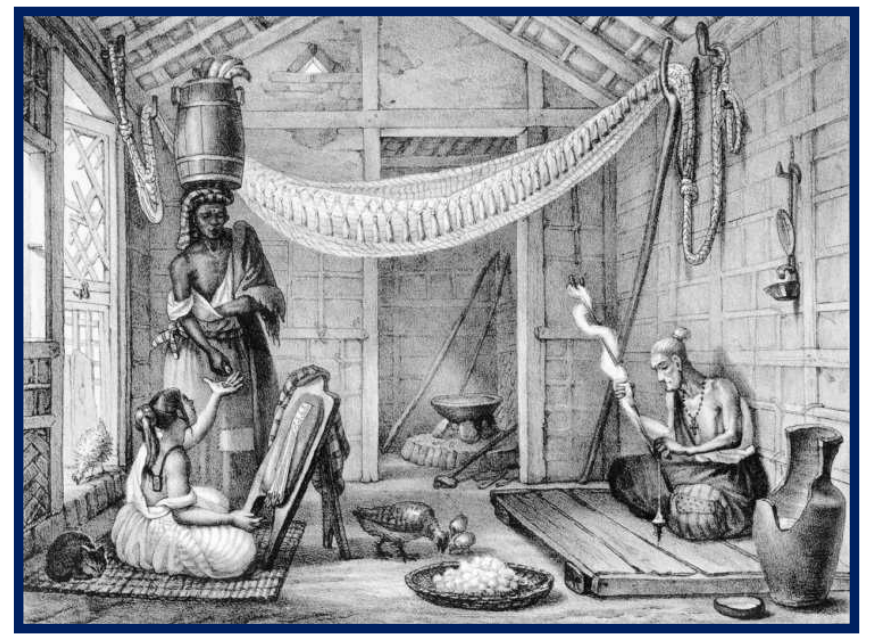

Figura 137: DEBRET, Jean Baptiste, "Família pobre em sua casa”, c. $1830^{677}$.

A iconografia dos viajantes franceses e ingleses no Rio de Janeiro revela ainda mulheres praticando tais posturas, não somente no chão, mas também se utilizando de aparatos como os estrados, esteiras e redes, e pode também servir por

\footnotetext{
${ }^{675}$ Extraído de MARTINEZ, Juan Manuel. El Mueble. Un espacio para habitar. Museu Histórico Nacional del Chile, 2012 p. 21.

${ }^{676}$ Flexor em seu estudo constata serem as bancas - que possuíam função decorativa - ornamentadas apenas em três lados para ficarem junto às paredes. Esses móveis também eram designados como mesas de encostar ou consoles, aparecendo em inventários mais raramente o termo "bufete de encosto" cf. BORREGO, Maria Aparecida de Menezes; FELIX, Rogério Ricciluca Matiello. Ambientes domésticos e dinâmicas sociais em São Paulo colonial. Rev. Hist. (São Paulo), São Paulo, n. 175, p. 91-132, dez. 2016. .

677 DEBRET, Jean-Baptiste. Voyage pittoresque et historique au Brésil . Paris, Firmin Didot Freres, 1834-39. Disponível em: https://www.bbm.usp.br/node/68. Acessado em: 20/05/2018.
} 
extinção ao contexto paulista, menos documentados visualmente que a capital da época.

A gravura de Debret, por exemplo, revela uma senhora sobre um estrado de tábuas e uma jovem sobre uma esteira de caibras amarrados, onde tece e recebe dinheiro de sua escrava de ganho. Neste cômodo simplório vemos como ocorrem a sobreposição de funções, com o trabalho, a recepção dos escravos, o momento de lazer, a criação de animais e a reserva de alimentos, além de ser também o espaço do descanso noturno, seja armando a rede pendurada, seja deitando-se no estrado, móvel de múltiplos usos.

Tendo-se, aliás, em conta a versatilidade de móveis para assento e descanso, a variedade de suportes para o sono e o grau de improviso, a própria existência de móveis de repouso nos inventários já é relevante, pois sinal de especialização do mobiliário e do aposento e dispêndio de capital em objetos para fins de maior conforto. Ter um estrado, uma arca grande, ou ainda catres de tábuas ou de cipó já significava não dormir no chão, ou em redes coletivas ao modo de alguns povos indígenas ${ }^{678}$.

Mesmo no momento do sono percebemos como a posição do corpo e o artefato e o espaço utilizado para o estágio diário de repouso também é elemento diferenciador, e de grande monta: notem-se os preguiceiros nos inventários como categoria de móvel especialmente voltado à distinção, bem como os catres e os leitos com dosséis, de grande requinte e proporcionadores de privacidade ${ }^{679}$.

\footnotetext{
${ }^{678}$ Apesar de ser recorrente a historiografia tratar os hábitos dos povos indígenas de maneira planificada, muito devido à indisponibilidade de fontes, no caso das formas de repouso o registro de Spix e Martius nos permite particularizá-los. Referindo-se em 1818 aos índios Camacans, em Ferradas, Bahia, escrevem: "Não se deitam em redes, porém num jirau de grades de madeira, que eles cobrem com folhas secas e peles de animais." SPIX, Johann Baptiste von e MARTIUS, Carl Friedrich Philippe von. Viagem pelo Brasil (1818-1819). Rio de Janeiro: Imprensa Nacional, 1938, vol. II, p. 344.

679 Como observou CARVALHO, Vânia Carneiro. Gênero e artefato: o sistema doméstico na perspectiva da cultura material: São Paulo, 1870-1920. EdUSP, 2008, p. 200 e também nós realizamos considerações BORREGO, Maria Aparecida de Menezes; FELIX, Rogério Ricciluca Matiello. Ambientes domésticos e dinâmicas sociais em São Paulo colonial. Rev. Hist. (São Paulo), São Paulo, n. 175, p. 91-132, dez. 2016.
} 


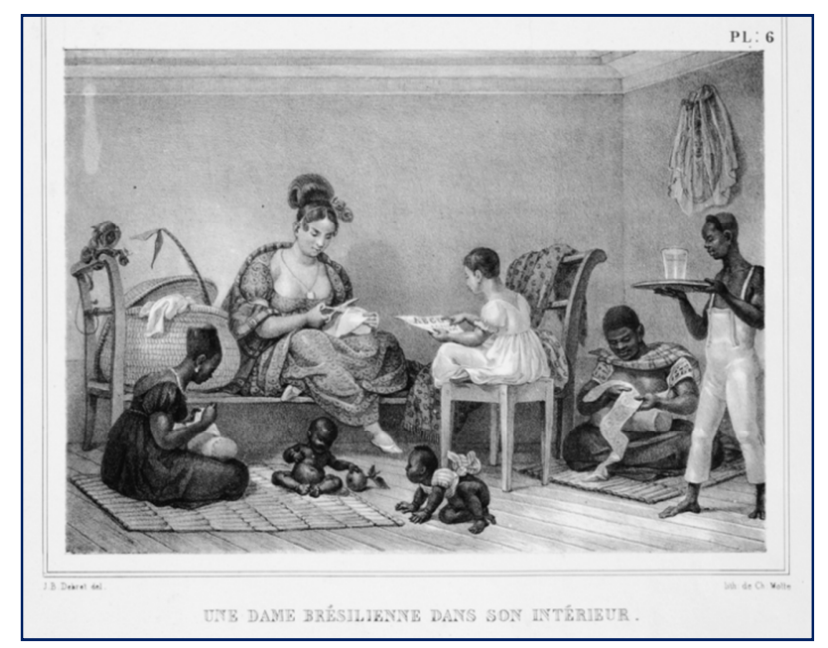

Figura 138: DEBRET, Jean-Baptiste. Voyage pittoresque et historique au Brésil. Une dame brésilienne dans son intérieur. C. $1830^{680}$.

Vemos nesta composição de Debret a hierarquia das formas de sentar na casa colonial: as escravas se assentam com as pernas cruzadas sobre esteiras, ao passo que a senhora e sua filha utilizam-se de móveis. Usam um pequeno banco sem encosto, e um canapé que as elevam do chão, mas ainda propiciam a mesma postura nas pernas e costas das escravas, técnicas do corpo na extensão em objetos às quais estavam as mulheres lusas acostumadas pela tradição mourisca e influência oriental. Pequena sutileza, mas evidência do porte "sedutor através do objeto" como identifica Hellman ${ }^{681}$ para a corte francesa, vemos que a senhora com delicadeza estica uma das pernas a diferenciando ainda mais de suas serviçais.

Para além das diferenças culturais e o simbolismo em cada cultura sobre a corporificação dos atos de sentar, devemos enfatizar a própria possibilidade de possuir e usar móveis, bem como o próprio espaço onde se usa, como fatores ativos na hierarquização da sociedade colonial.

Sabemos que em São Paulo as sociabilidades internas às casas se adensam principalmente a partir da segunda metade do século XVIII ${ }^{682}$, em uma rotatividade de práticas com as cortes europeias, onde estes fenômenos se iniciaram desde 0 século XVII. O "Século do Conforto" entre 1670 e 1765 foi o período no qual se

\footnotetext{
${ }^{680}$ DEBRET, Jean-Baptiste. Voyage pittoresque et historique au Brésil . Paris, Firmin Didot Freres, 1834-39. Disponível em: https://www.bbm.usp.br/node/68.

${ }^{681}$ HELLMAN, Mimi. Introduction In: KODA, Harold; BOLTON, Andrew (eds.). Dangerous Liaisons: Fashion and Furniture in the Eighteenth Century. New Haven: Yale Univ. Press, 2005.p 20.

${ }^{682}$ ALGRANTI, Leila M. "Famílias e vida doméstica". In: SOUZA, Laura de Mello (org.) História da vida privada no Brasil: cotidiano e vida privada na América portuguesa. São Paulo: Companhia das Letras, 1997, pp. 54-90. E CARVALHO, Vânia Carneiro. Gênero e artefato: o sistema doméstico na perspectiva da cultura material: São Paulo, 1870-1920. EdUSP, 2008.;
} 
formou uma mudança no modo de vida das elites francesas, mais especificamente as parisienses. Elas cada vez mais estavam preocupadas em rodear-se de aparatos relaxantes para o corpo, por exemplo, os tecidos das roupas, as formas e estofados da mobília, bem como sua disposição, e a praticar posturas corporais menos rígidas do que a sociedade de corte obrigava durante o alto Ancien Regime ${ }^{683}$.

Devemos recordar que até o século XVIII a população paulista privilegiava as ocasiões de sociabilidades especialmente nos espaços externos às casas $^{684}$. Na passagem do século XVIII para o XIX, houve mudanças nos padrões de interação social nas cidades com a procura cada vez maior de recintos fechados para formas de convivência em detrimento dos espaços abertos. A casa tornava-se cada vez mais um espaço de sociabilidades. Os interiores domésticos passam então a contar com novas salas de recepção destinadas a momentos de convívio com pessoas alheias ao núcleo familiar e, como decorrência deste fenômeno, o despojamento material gradualmente cede espaço à entrada de mais móveis nos aposentos, que eram confeccionados "não apenas para conter e suportar, mas ainda para serem vistos" 685 .

Ao aproximar os corpos, tal movimento tornou o campo de observação visual mais individualizado, obrigando a gestos e palavras mais regrados e atentos aos ditames de civilidade e bons costumes que provinham da Europa ${ }^{686}$.

Não obstante o conforto que deviam ostentar estava em jogo a rígida capacidade de expressar movimentos corporais bastante sutis e de aprendizado minucioso e repetitivo que eram verdadeiro "ócio trabalhoso", ou trabalho de lazer, como identifica Mimi Hellman para a corte francesa ${ }^{687}$. De maneira a publicizar esse lazer, o mobiliário precisava ser utilizado da maneira certa, e isso não era tão simples e obvio quanto parece. Para entender como os indivíduos da elite habitavam

\footnotetext{
683 DEJEAN, Joan. 0 século do conforto. Rio de Janeiro: Civilização Brasileira. 1ạed. 2012, p. 13.

${ }^{684}$ CARVALHO, Mônica Muniz Pinto de. A cidade de São Paulo no século XVIII. Uma sociabilidade constituída em torno de símbolos do poder. São Paulo, dissertação de mestrado - FFLCH-USP, 1994. ALGRANTI, Leila M. "Famílias e vida doméstica". In: SOUZA, Laura de Mello (org.) História da vida privada no Brasil: cotidiano e vida privada na América portuguesa. São Paulo: Companhia das Letras, 1997, pp. 54-90.

${ }^{685}$ SUANO, Marlene. Alfaias, apetrechos, tarecos, trecos: os móveis. In: MENESES, Ulpiano T. Bezerra de (org.). Como explorar um museu histórico. São Paulo: Museu Paulista/USP, 1992, p.16.

${ }^{686}$ MADUREIRA, Nuno Luís. Luxo e distinção: 1750-1830. Lisboa: Editorial Fragmentos, 1990, p. 76. Apud BORREGO, Maria Aparecida de Menezes; FELIX, Rogério Ricciluca Matiello. Ambientes domésticos e dinâmicas sociais em São Paulo colonial. Rev. Hist. (São Paulo), São Paulo, n. 175, p. 91-132, dez. 2016.

687 HELLMAN, Mimi. Introduction In: KODA, Harold; BOLTON, Andrew (eds.).Dangerous Liaisons: Fashion and Furniture in the Eighteenth Century. New Haven: Yale Univ. Press, 2005.
} 
seus ambientes elegantes, é necessário saber como lhes era esperado se conduzir a si mesmo e o que era necessário para obter uma persona social ideal.

Todas as técnicas do corpo, adquiridas com muita prática e esforço em executar os movimentos corporais e a ativação dos objetos de maneira respeitável e agradável aos índices de conduta moral daquela sociedade precisava ser conduzido de uma maneira que parecesse absolutamente "natural", como se as maneiras fossem inatas e não aprendidas. Já as condutas que traiam os esforços e estranhamente sugeriam a ausência de cultivação, como o exemplo da foto de Milton Guran do jovem indígena sentado na cadeira escolar de maneira inesperada, revela justamente um exemplo de ruído naquilo que seria o padrão de uso e seria jocoso aos acostumados com outras formas de uso daquele mesmo objeto.

E não foi somente para "selvagens" indígenas e africanos que a depreciação sobre a forma de sentar ocorreu.

Escreveu a viajante inglesa Isabel Burton (1831, Inglaterra - 1896, idem), em passagem por São Paulo em 1865, sobre a sua convivência com Domitila de Castro Canto e Mello (1797, São Paulo - 1867, idem), a Marquesa de Santos ${ }^{688:}$

We had one very curious character at Sao Paulo. It was the Marchesa de Santos. She was a beauty and a favourite in the time of the present Emperor's father, and led a very brilliant and stormy life. She got finally banished by his Empress (they say) to Santos, with a pension for life, and she lived in a small house a few doors from me. I used to see a great deal of her. She was quite grande dame, most sympathetic, most entertaining, full of stories of Rio and the Court, and the Imperial people, and the doings of that time. She had been obliged to adopt up-country habits, and the last time I saw her, she received me en intime in her own kitchen, where she sat on the floor, smoking, not a cigarette, but a pipe. She had beautiful black eyes, full of sympathy, and intelligence, and knowledge. She was a great bit of interest to me in that out-of-the-way place

Com esta inusitada passagem sobre a Marquesa de Santos - que como vimos anteriormente possuía entre seus bens até mesmo móveis importados feitos originalmente para a realeza francesa - prova-se como a prática de sentar ao chão nada tinha de correlação com a pobreza atribuída pelos historiadores da era

\footnotetext{
${ }^{688}$ BURTON, Isabel. The Life of Captain Sir Richard. F. Burton. London: Chapman and Hall. Vol. 1. 1893. P. 480. Disponível em: 207http://burtoniana.org/biography/1893-Isabel-Life/iburton-1893-life-vol1.pdf. Acessado em: 01/08/2017. Negrito nosso, itálicos originais.
} 
bandeirante, ou de "selvagem", como se atribuía aos indígenas. Era a expressão de um porte culturalmente transmitido pela população luso-americana que nos termos de sua economia simbólica carregava o peso da qualidade e distinção de quem o praticava.

Vale notar que as práticas que Isabel Burton considerara exóticos e "provincianas" ${ }^{689}$, como fumar não a cigarrilha com piteira, mas sim um cachimbo, foram, séculos antes, praticados pelas mulheres europeias como atributo de distinção apropriado das ricas orientais, cujas representações chegavam às suas casas nas preciosas porcelanas, como observou Timothy Brook. Aliás, prova das diferentes temporalidades das práticas entre as culturas, durante o século XIX as próprias chinesas passaram a considerar deselegante fumar em cachimbos compridos, que ficaram restritos aos homens e as classes inferiores, adotando como sinal de elegância o narguilé do mundo otomano e tempos depois o cigarro com piteira, símbolo de classe na Europa e utilizado com piteira especialmente pelas mulheres ${ }^{690}$.

Não podemos deixar de compreender, dentro dessas práticas corporais historicizadas, outra "camada estratigráfica": a emulação europeia das posturas corporais das mulheres do Extremo Oriente, como as indianas, japonesas e chinesas quando da chegada na Europa das novidades e bens orientais através das Grandes Navegações ${ }^{691}$. Para além dessa prática corporal ibério-moura de longa duração, pode ter havido diálogo com os costumes dos povos do Oriente, que tanto fascínio geraram nos europeus, alterando diversos hábitos, tecnologias e a cultura material europeia, como o costume de beber chá que foi absorvido com grande assiduidade.

Em outra passagem, ocorrida no Rio de janeiro em 1807, o próprio viajante inglês James Hardy Vaux (1783-1841) ${ }^{692}$ observara de maneira bastante intrigada o

\footnotetext{
${ }^{689}$ Segundo as observações e tradução de CARVALHO, Vânia Carneiro. Gênero e artefato: o sistema doméstico na perspectiva da cultura material: São Paulo, 1870-1920. EdUSP, 2008.

690 BROOK, Timothy. 0 chapéu de Vermeer. Rio de Janeiro: Record, 2012.78 p..146.

691 PINTO, Maria Helena Mendes, “Sentando-se em Goa”, Oceanos, no 19/20, 1994,

692 O falsário e batedor de carteiras James Hardy Vaux (1782-?) passou quase três meses no Rio de Janeiro (onde desembarcou a 22 de maio de 1807, ficando até 12 de agosto), terra que muito lhe agradou, após passar seis anos em exílio em uma colônia penal na Austrália. FRANÇA, Jean Marcel. Outras Visões sobre o Rio de Janeiro Colonial Rio de Janeiro: José Olympio Editora, 2000.
} 
fato de que as portuguesas possuíam boa qualidade de móveis, mas preferiam o chão ${ }^{693}$ :

Na rua em que estávamos estabelecidos residia, na companhia de três jovens, uma velha senhora. Frequentemente, eu a via na porta de sua simpática casa, entretida com uns carretéis dispostos sobre uma almofada (...) Essa senhora e suas acompanhantes ficavam sentadas no chão da sala de visitas, de pernas cursadas, em frente a uma porta de treliça, que permanecia sempre aberta para receber o ar fresco. (...) A senhora, numa certa tarde, convidou-me para entrar e sentar - obviamente não sentei no chão, pois a casa contava com cadeiras e com outras mobílias, todas elegantes, mas desprovidas de luxo (...).

Complementando este inusitado fenômeno da preferência à prática de assentar-se ao chão independente da posse de mobiliário, temos o relato de SaintHilaire em 1818, na localidade de São Pedro da Aldeia, região do Rio de janeiro ${ }^{694}$ :

Indo visitar o Capitão-mor da aldeia não achei sua casa melhor que a de seus administrados. Nela se via, na verdade, um banco e um par de tamboretes; mas o digno magistrado achava-se sentado no chão, com sua mulher, cada qual sobre uma toalha separada.

Esta passagem é ainda mais rara por evidenciar que também um homem e membro da elite praticava este hábito do assento ao chão, mesmo dispondo de móveis para seu uso. Entretanto, o viajante não nos fornece pistas para saber se a mesma postura corporal praticada pelas mulheres era repetida, ou se haveria diferenças de gênero também neste aspecto.

Afastando-nos da compreensão de isolamento, arcaísmo e "barbarização", o habito mourisco de sentar com as pernas cruzadas foi registrado pelas penas de diversos autores não só em São Paulo, bem como no próprio Reino, como se pode ver pela tela de Nicolas Delerive (1755, Lille, França - 1818, Lisboa, Portugal) abaixo:

\footnotetext{
${ }^{693}$ Complementa este viajante que "a senhora chamava-se dona Joaquina Roza de Làce [...] e era viúva de um oficial militar, que serviu à Coroa portuguesa. Dona Joaquina recebia uma pensão do governo que, somada ao salário de suas talentosas filhas, lhe permitia viver de uma maneira simples, mas distinta", evidenciando novamente que aquela família de camada intermediária sentava-se no chão mesmo possuindo móveis não por pobreza, mas por costume. FRANÇA, Jean Marcel. Outras Visões sobre o Rio de Janeiro Colonial. Rio de Janeiro: José Olympio Editora, 2000 P. 301.

${ }^{694}$ SAINT-HILAIRE, Auguste de. Viagem pelo Distrito dos Diamantes e Litoral do Brasil (1817-1818). São Paulo, Belo Horizonte, EDUSP/ Itatiaia Editora, 1974. p. 160.
} 


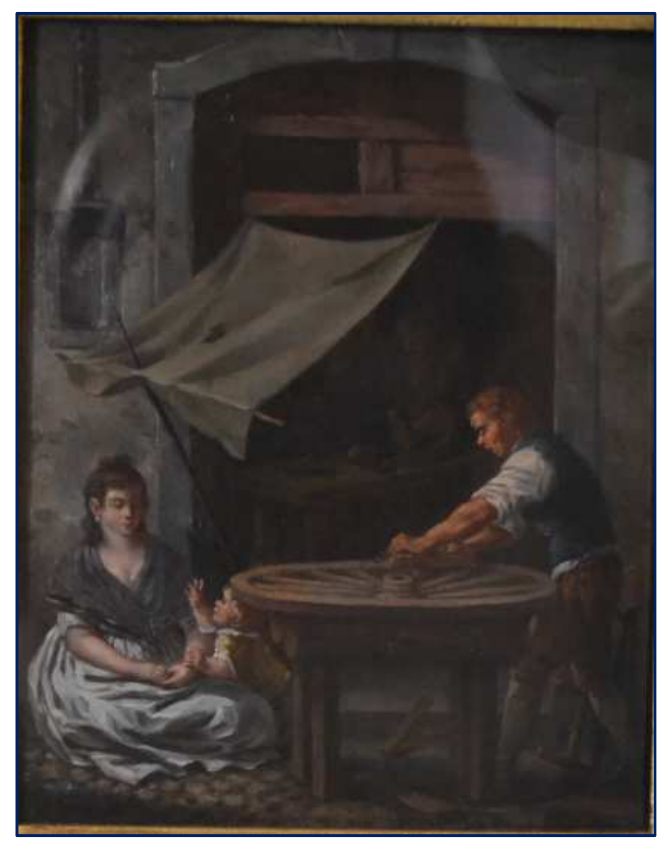

Figura 139: DELERIVE, Nicolas. O marceneiro de rodas de carroça. c. 1801. Foto do autor. Acervo do Museu de Artes Decorativas de Lisboa ${ }^{695}$.

Por fim, através do relato de viajantes de outras nações europeias temos o registro dessa prática de assentar, fato considerado bastante exótico especialmente pelos ingleses Thomas e Macro Cox, que serviam de argumento para inferiorizar, dentro do próprio mundo europeu, a nação portuguesa ${ }^{696}$.

(...) Os nobres são servidos no colo pelos seus escravos de joelhos. As mulheres ainda mantêm o costume dos mouros de se sentarem no chão, de pernas cruzadas, e recebem as suas visitas num estrado com uma esteira ou tapete turco sobre ele, não jantam com os maridos, mas comem no chão, sentadas sobre um bocado de cortiça.

Assim, nessas breves considerações - que certamente merecem maior aprofundamento - sobre as especificidades em São Paulo das técnicas do corpo e na sua extensão nos objetos, buscamos mostrar como este contexto entendido em sua riqueza cultural particular é também fragmento de uma História Global da civilização material portuguesa e não um mero provincianismo piratingano. No processo de diálogo, hibridização e atrito com diferentes grupos culturais, em especial os viajantes de outras nações europeias, vemos como também as práticas corporais portuguesas se revelam cheias de historicidade, com suas peculiaridades,

\footnotetext{
${ }^{695}$ Nicolas Delerive (1755-1818) Costumes e atividades de Lisboa, c. 1801. O marceneiro de rodas de carroça. (FRESS - Inv. 630). Foto do autor.

${ }^{696}$ COX, Macro; COX, Thomaz. Relação do Reino de Portugal. 1701. Lisboa: Biblioteca Nacional, 2007.
} 
seja mesmo o assentar do corpo, ainda que fossem consideradas pelos seus agentes proselitamente como civilizadas e normatizadas.

\subsection{O não-uso e a memória}

Uma última faceta do uso dos móveis que merece ser explorada se relaciona ainda a um dos estágios possíveis de sua vida social: a sua manutenção pelo usuário em prazo indefinido. Isto implica numa mudança na sua forma de ativação pelo corpo, interditando-se seu uso mais prático para que sirva principalmente em função da memória. Ao analisarmos muitos dos inventários consultados nos deparamos com peças descritas como "antigas", outras como "velhas", bem como aparecem aquelas "com seu uso". Ao mesmo tempo, estavam arroladas peças classificadas como "novas", de "pouco uso" ou ainda sem indicação temporal ${ }^{697}$.

Dos exemplares de mobiliário usados na São Paulo seiscentista remanescentes até a nossa época mais bem conservados e talvez os que possuem maior detalhamento de informações sobre a sua trajetória sejam as cadeiras há oito gerações pertencentes à Família Amaral Gurgel. Sobre elas fez um acuradíssimo trabalho genealógico Celso Maria de Mello Pupo, descendente desta antiga estirpe $^{698}$.

A família Amaral Gurgel estabeleceu-se em São Paulo em meados do século XVIII, sendo o patriarca da família o Ouvidor Interino Bento do Amaral da Silva. Ele nasceu no Rio de Janeiro em 1647 e a sua esposa, Escolástica de Godoy, em Santana de Parnaíba, filha de ricos fazendeiros na Vila de São Paulo ${ }^{699}$.

Figura abastada pelo trabalho nas Minas Gerais, informa-nos o inventário post-mortem do Ouvidor Bento do Amaral, de $1719^{700}$, vasto conjunto de mobiliário, de prataria, tecidos e roupas, além de imóveis e cabeças de gado. Na casa urbana do Ouvidor, situada na frente da Igreja Terceira do Carmo, destacavam-se dois conjuntos de 12 cadeiras, na época designados de tamboretes. Ambos os conjuntos

\footnotetext{
${ }^{697}$ Algo que Carlos Franco também observou em seu estudo sobre Lisboa, FRANCO, Carlos. O mobiliário das elites de Lisboa na segunda metade do século XVIII. Lisboa: Livros Horizonte, 2007.

698 PUPO, Celso Maria de Mello. As cadeiras do ouvidor. Revista do Instituto Histórico e Geográfico de São Paulo, v. 78, 1982, pp. 122.

${ }^{699}$ Idem, ibidem, p. 129

${ }^{700}$ APESP, inventário post-mortem, caixa 505. Apud. PUPO, Celso. Op. Cit. 1982.
} 
portavam no encosto o brasão da família, composto do símbolo leonino dos Gurgel, de origem francesa, e as luas crescentes dos lusitanos Amaral.

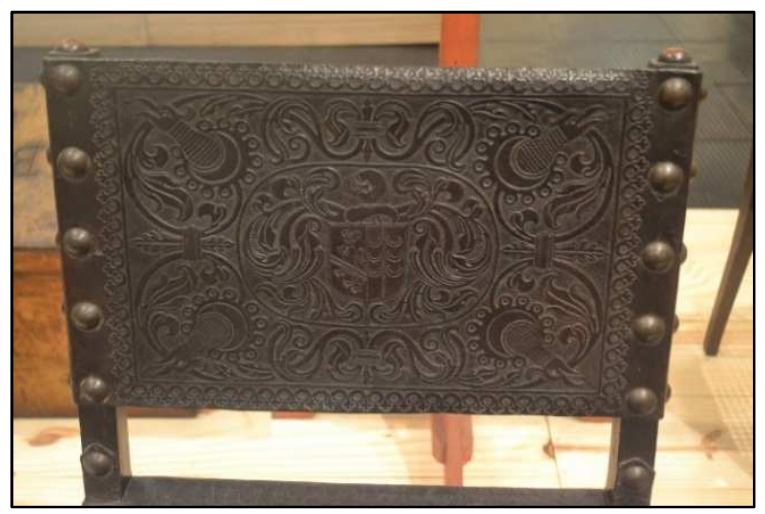

Figura 140: fotografia do espaldar da cadeira de sola pertencente à Família Amaral Gurgel, onde se pode ver o brasão. Exibido no MASP por ocasião da exposição "A Mão do Povo Brasileiro". Acervo Museu de Arte Sacra de São Paulo. Fotografia do autor.

O conjunto mais antigo, descrito no documento como "doze tamboretes feitos na terra com pregaria miúda e algum uso" cujo valor unitário era de $2 \$ 000$ réis, foi descrito como sendo feito em São Paulo. Já o conjunto mais novo, avaliado em $4 \$ 000$ réis, não era da terra, já que provinha da Bahia e possuía "pregaria e maçanetas douradas", mais uma indicação do consumo de peças importadas a outras capitanias revelando o enriquecimento das fortunas mineiras se consolidando na própria vila de São Paulo e refutando o seu isolacionismo ${ }^{701}$.

Para além da banalidade quotidiana da coexistência de peças adquiridas em momentos diferentes, ao fazermos uma análise pormenorizada dos itens e dos seus antigos possuidores, passamos a compreender fenômenos sociais ligados às formas de consumo e à distinção social. Assim, aquilo que acharíamos ser "trastes", peças estragadas ou imprestáveis, poderia ser justamente o contrário.

Podemos aventar que esta condição depende de dois fatores principais. Primeiro, a qualidade material do objeto. Esta se relaciona especialmente da lógica de sua produção. Como vimos, eram executados de maneira a durar o maior tempo possível, diferentemente da obsolescência moderna da sociedade de consumo efêmero $^{702}$. Segundo, a durabilidade da peça e sua manutenção por séculos dizem respeito à ativação da memória que se dá através dos objetos, e que estimula seus portadores a prezar pela sua integridade com todo cuidado.

\footnotetext{
701 PUPO, Celso Maria de Mello. As cadeiras do ouvidor. Revista do Instituto Histórico e Geográfico de São Paulo, v. 78, 1982, pp. 121-158.

${ }^{702}$ Cf. BAUDRILLARD, Jean. O sistema dos objetos. São Paulo: Perspectiva, 2004.
} 
Um dos processos antrópicos que são influenciados reflexivamente pelos objetos é a memória ${ }^{703}$ : ao visualizarmos, dispormos ou consumirmos as mais variadas coisas, estas acabam por nos oferecer lembranças de acionamentos anteriores em momentos específicos e dos indivíduos que os possuíam.

Tendo por base essas dimensões materiais da memória, diversos estudiosos dos mais variados ramos do saber buscam compreender as lógicas e variações entre as formas de uso dos objetos ao longo da história e nas mais variadas culturas, já que este é componente fundamental da vida humana.

O antropólogo Grant McCracken ao contemplar as características materiais que guardam os objetos antigos propôs como modelo explicativo uma Teoria da Pátina ${ }^{704}$, cujos pressupostos são:

1) Um objeto adquire pátina em proporção direta à sua idade.

2) A idade de um objeto é diretamente proporcional à duração de sua posse por parte de uma família (comprado novo).

3) A duração da posse familiar de um objeto representa a extensão de tempo durante a qual esta família gozou de um certo nível de renda discricionária e caprichosa.

4) A duração deste nível de renda representa a extensão de tempo durante a qual esta família desfrutou de um certo status social.

Fazendo análises comparativas entre relatos antropológicos de atuais guardiões familiares de móveis antigos - tal como a descendência Amaral Gurgel com os de consumidores comuns e de antiquários, McCracken conclui que podemos partir de características físicas comuns aos mais variados objetos, para pensarmos no que leva os indivíduos a conserva-los ou adquiri-los de segunda mão.

A característica comum em todas as peças é a presença de desgastes como descoramentos, amassados e rachaduras que são provas indeléveis do uso e antiguidade das peças. Tudo isso é agrupado sob o nome de pátina e foi utilizado como índice da antiguidade das peças do Ouvidor Amaral Gurgel pelo próprio Celso Pupo.

\footnotetext{
${ }^{703}$ CSIKSZENTMIHALYI, Mihaly, Why we need things, in LUBAR, S. and KINGERY W. (eds). History from Things, Washington: Smithsonian Institution Press, 1993, pp. 20-9.

704 MCCRACKEN, Grant. Cultura \& Consumo. RJ: Ed. Mauad, 2010. p. 58.
} 
Esses atributos revelam-se não só como qualidades de valor simbólico em sistemas de posse dentro de grupos familiares tradicionais, mas também de valor econômico em sistemas comerciais de antiquariato e de preservação museal.

Esse é um tipo de consumo que McCracken chama de curatorial, isto é, o objeto importa pela sua trajetória histórica singular e pela sua materialidade única. Ocorre o "não-uso" prático, ou corpóreo do objeto, para dar-se um uso simbólico, principalmente visual e expositivo, buscando-se evitar ao máximo o contato físico com o objeto de maneira a prolongar a sua conservação. Este é justamente o seu atributo semióforo - na acepção de Kristof Pomian ${ }^{705}$ - ou seja, o objeto perde em valor de uso e ganha valor simbólico ${ }^{706}$. Assim, as marcas do tempo na peça fazem a conexão entre a sua invisível trajetória diacrônica e a sua evocação mnemônica.

Neste esquema de consumo, o ato de possuir esses trastes velhos, não só é um sinal de status pela antiguidade da posse rara, mas também índice de pujança de seus conservadores, já que no rotineiro ato de manter as arcaicas peças, opera a necessidade de ter espaço nas residências para comportá-las, bem como dispor de conforto financeiro suficiente para dispor de peças novas para o uso corrente no dia a dia, signo de remota distinção e permitiria aos novos-ricos da terra ter o mesmo capital histórico que linhagens centenárias como, por exemplo, o da família Amaral Gurgel.

O caso das cadeiras do Ouvidor Bento do Amaral é o exemplo mais concreto que temos do consumo curatorial, como vemos pelo relato feito por Celso Pupo de sua memoria familiar sobre as peças de seus antepassados ${ }^{707}$ :

As pessoas grandes da casa ensinavam, e exigiam mesmo, respeitável cuidado ao móvel vetusto; tinha sido de avoengos e constituía venerável tradição da família; havia transcorrido vidas de vários possuidores, todos da mesa estirpe, para ali ser admirada em casa patriarcal.

Notamos no caso de Celso Pupo como as cadeiras ativam sua memória pessoal de infância e sua representação sobre o objeto - um móvel reservado na

\footnotetext{
705 POMIAN, Krzysztof. "Coleção". In: Enciclopédia Einaud. I. Memória - História. Porto: Imprensa Nacional. Casa da Moeda, 1984, p.51-86.

${ }^{706}$ Complementando a compreensão museológica de Ulpiano que nos propulsou na introdução, é justamente este ganho de valor simbólico que, quando reificado pelos museólogos nas exposições torna o objeto um fetiche de seu usuário. Cf. MENESES, Ulpiano B. de. Do teatro da memória... op. cit. 1994.

707 PUPO, Celso Maria de Mello. As cadeiras do ouvidor. Revista do Instituto Histórico e Geográfico de São Paulo, v. 78, 1982, pp. 121-158.
} 
casa, que não poderia sofrer uma ativação mecânica banal como outras cadeiras, já que era uma peça carregada pela sensibilidade semiófora.

Após passar gerações como relíquias domésticas, as cadeiras reminiscentes foram doadas ao Museu de Arte Sacra de São Paulo.

Desta forma, essas peças passaram da memória de um núcleo privado, para a esfera publica de observação. Neste processo de musealização, que poderia parecer mesmo uma quebra com a teoria da pátina, percebemos como se dá - ao contrário - o ápice da exteriorização do status de antiguidade da família doadora, uma verdadeira monumentalização da estirpe. Afinal, a distinção vetorizada pelos objetos domésticos patinados poderia ser agora operada através de sua visualização publica em um lugar de memoria coletiva, o museu.

Assim, para além da mera preservação da tradição familiar, o legado e exibição das peças levam a uma escrita da história da cidade e da nação através de tal memória familiar, a qual passa a ilustrar, por eleição, a memória geral da coletividade $^{708}$, pois as mobílias que nos sobraram em museus para estudar a vida material passada são na maioria de membros da elite.

Com esses exemplos apresentados buscamos compreender que muito mais do que um monte de "trastes velhos", como poderia entender um consumidor moderno envolto em lógicas de consumo massificado e descartável, as antigas peças de mobília arroladas nos inventários são artefatos cujo valor estava em ser vetores da ativação da memória e cuja serventia era a de serem estandartes da sólida manutenção de status de um grupo familiar ao longo do tempo, bem como passaporte dos quais poderiam se apropriar indivíduos em busca de símbolos de prestigio que lhes permitissem entrar em circuitos de poder e destaque, bem como perpetuar o seu status dentre a coletividade.

Retomando as observações iniciais sobre a teoria da cultura material podemos reforçar com nosso estudo especifico a compreensão de que os objetos são produto, mas também vetores das relações sociais e das ações corporais como pontuou Ulpiano Bezerra de Meneses ${ }^{709}$. A inter-relação dos corpos com o meio

\footnotetext{
708 Tal como observou Regina Abreu a respeito da doação em concordata das peças da família Calmon ao Museu Histórico Nacional, em uma estratégia de consagração da memoria de sua família associada à formação histórica do Brasil, cf. ABREU, Regina. A fabricação do imortal: Memória, História e Estratégias de Consagração no Brasil. Rio de Janeiro: Rocco. 1996.

709 MENESES, Ulpiano Bezerra de. Do teatro da memória ao laboratório da História: a exposição museológica e o conhecimento histórico. Anais do Museu Paulista, n.1 vo. 2. 1994, p. 17.
} 
físico e com o meio cultural é sempre um processo constante de adaptação, conformação e mudança, dentro das necessidades que tem a cada momento os indivíduos e os grupos culturais. a distancia temporal e cultural dos comentadores e estudiosos destas práticas levou muitas vezes a incompreensões sore o seu valor no contexto diacrônico, solidificando desta maneira visões depreciativas sobre este momento histórico da cidade de São Paulo, as quais buscamos desfraldar. 


\section{CONCLUSÃO - Um museu em peças}

De modo geral, não é a observação de fenômenos raros e escondidos que só são apresentáveis por meio de experimentos que serve para a descoberta das mais importantes verdades, mas a observação daqueles fenômenos que são evidentes e acessíveis a todos. Por isso a tarefa não é ver o que ninguém viu ainda, mas pensar aquilo que ninguém pensou a respeito daquilo que todo mundo vê. (grifos do autor).

SCHOPENHAUER, Arthur. Sobre a filosofia e seu método. São Paulo: Hedra, 2010. p. 156-157.

Partimos neste percurso de pesquisa do exame de alguns móveis presentes no Museu Paulista para, aos poucos, compreender através de seus detalhes, evidencias que nos informaram sobre sua produção e tecnologia, consumo e uso, permitindo, junto a interconexões complexas dos dados de diversos tipos de fontes e lugares, fazer uma história das dinâmicas sociais de São Paulo entre os séculos XVIII e XIX.

Evitando a tradicional historiação que primeiramente considera os remotos possuidores das peças como ilustração de suas vidas no Teatro da memória paulista, buscamos, pelo contrário, fazer do museu e suas peças verdadeiro Laboratório da História com a combinação de saberes e elementos interdisciplinares, com testes e experimentações de metodologias. Partimos, assim, do exame de peças em um museu para ajudar a entendê-lo como um museu em peças, evidenciando as várias camadas de discurso e historiografia que foram atribuídas à trajetória e a história de uma parte dos móveis de seu acervo, tal como vários outros historiadores realizaram com outros objetos e temáticas.

Inclusive devemos perceber estes artefatos, com uma mirada geral sobre sua própria condição museológica como uma seleção mínima do que restou, pelos mais variados motivos e maneiras, do substrato material da sociedade paulista passada. São permanências ativas da conservação, cobertos de restauros de várias épocas e com diferentes marcas de usos das mais variadas trajetórias pelas quais passaram desde seus usuários, aos herdeiros, compradores, até as instituições de guarda, que os escolheu, dispôs e recobriu de significações e propósitos diferentes ao longo das variadas gestões. 
Guiados pela proposta de Ulpiano de Meneses, partimos de exames formais e técnicos, entendendo-os como artefatos, e não somente levando em consideração os aspectos estéticos e estilísticos, como muitas vezes fez a História da Arte. Assim, os sinais de ferramentas e as configurações estruturais evidenciaram as tecnologias produtivas do período, evidenciando a coexistência de técnicas antigas de corte e preparação do móvel com a introdução de novas formas de fazer, especialmente dinâmicas no século XVIII. Com o olhar profundo sobre os objetos notamos como a história das coisas banais também não é uma linha reta de sucessivas descobertas e invenções, mas sim um relevo, variando em cada parte do mundo, com paralelismos e reinvenções, reproduções e adaptações.

Também os exames arqueométricos, com metodologias advindas das Ciências da Natureza, permitiram-nos reforçar o caráter laboratorial dos exames no museu, não de maneira a compreender a História de maneira cientificista, mas pelo contrário evidenciar como os objetos só possuem de próprios seus elementos físicoquímicos e mesmo estes são eivados de historicidade em sua escolha e combinação. Os exames de Física Aplicada e Dendrologia revelaram como os pigmentos e madeiras eram muitas vezes provindas de espaços externos à capitania de São Paulo, fornecendo assim importantes dados para compreender a ligações comerciais e a produção econômica interna colonial, área ainda sendo explorada pela historiografia recente. Foi na junção de varados tópicos já explorados por vários autores em seus ramos que buscamos dar a nossa contribuição aos estudos de mobiliário e à historiografia paulista e colonial.

Realizando meta-reflexão sobre a perspectiva empregada para o estudo, notamos como os estudos de cultura material de fato possuem um potencial enorme quando usados como disparadores das problemáticas e a serem trabalhadas, e revelam como através desse procedimento não necessariamente chegamos às mesmas conclusões feitas por estudiosos com outros olhares, como a historiografia paulista do começo do século XX. Nessa trajetória de análise documental pudemos reforçar a importância do uso de fontes materiais e textuais de maneira equilibrada, reconhecendo os potenciais e limites que nos oferecem cada uma delas em suas especificidades. Esta reflexão é bastante importante no nosso caso, pois como vimos o núcleo de fontes que usamos já possuía dados escritos a seu respeito, como as meticulosas fichas catalográficas do banco de dados do museu, mas que 
não por isso deixaram de ser problematizadas com o aporte de novos dados, principalmente os extraídos da materialidade dos mesmos artefatos.

Não havendo informações nem nas próprias peças, nem nas fichas catalográficas a respeito dos produtores destes móveis, partimos à busca de outras fontes que trouxessem dados sobre possíveis produtores de móveis em São Paulo, como os testamentos, inventários post-mortem, processos de casamento, livros de receita e despesa, censo populacionais, entre outros, mas tendo sempre em diálogo os artefatos.

Reforçando a importância de compreender a produção moveleira de maneira ampla, pudemos traçar as trajetórias de vida de alguns artífices que viveram em São Paulo, tendo nascido no reino ou na América. Notamos como eram bastante plurais as suas origens, trabalhos e posses. Evidenciou-se a flexibilidade dos ofícios mecânicos em São Paulo, a mais do que na Metrópole e em outras capitanias, como a historiografia já demonstrara. Sendo cidade tradicionalmente considerada esvaziada de artífices de qualidade, buscamos problematizar tal visão. Notando como a dinâmica dos movimentos da população paulista refletia-se também no exercício da produção moveleira, com artesãos intermitentes, deslocando-se por diversas regiões para além de São Paulo. Não obstante, também nesta capital se fixaram desde a primeira metade do século XVIII, evidência de que havia maior demanda pelo seu trabalho e as oportunidades de ascensão social estavam presentes, fosse através da diversificação de atividades, fosse através da aquisição de escravos.

Através desse setor produtivo específico dimensionamos em âmbito global como a presença da escravidão transformava a sociedade estamental do Antigo Regime transplantada, com os grupos de mais baixo estrato na Europa pelo "defeito mecânico" conseguindo ascender a condição de grupos intermediários, assentados sobre o trabalho de seus escravos domésticos.

Igualmente as características materiais dos móveis foram importantes para a compreensão do consumo moveleiro, e das formas e locais de aquisição onde se davam esses trâmites. Apreendemos o consumo especialmente através de fontes escritas como os testamentos e inventários post-mortem, que nos revelam o que os falecidos possuíam em suas casas e os valores de suas fortunas, mas não nos ativemos somente aos importantes dados quantitativos, que indicam as mutações no aumento do consumo e do incremento das casas. Vimos qualitativamente, por 
exemplo, como elementos construtivos dos móveis, como o gosto pelas formas de rocalha nas artes menores em florescimento no Século XVIII ou o uso de materiais como a palhinha que tornaram mais leves os móveis de assento, serviram como início do aumento do número de móveis nas casas paulistas e justamente da introdução de estilos de móveis arrojados e em diálogo com as tendências metropolitas. Evidência material de que os interiores domésticos estavam a comportar cada vez mais ocasiões de sociabilidades, nota-se ao tomar não só o móvel como produto, mas vetor das sociabilidades dos seus possuidores, especialmente as famílias de comerciantes com grandes quantidades de tais peças de mobiliário que recheavam suas propriedades urbanas. Importantes elementos para a recepção de convidados e para a multiplicação dos momentos festivos e de encontros, a formação da noção moderna de lar reforça-se nesse momento entre estes setores, que dão cada vez maior atenção, cuidado e dispêndio aos seus ambientes domésticos, refletindo-se e efetuando-se também na disposição dos cômodos, dos vários gêneros de móveis que se tornam mais numerosos e específicos. Igualmente refletem-se e efetuam-se tais mudanças no habitar através da estrutura das casas, onde as noções de conforto e privacidade ganham novos contornos acompanhando e tomando frente no processo de mutação das mentalidades e representações da época ${ }^{710}$.

Através do estudo dos poucos exemplares de móveis examinados, em metodologias que poderiam, e devem cada vez mais, ser aplicadas para as várias peças em outros museus, devemos compreender pelos remanescentes o que foi excluído nos processos históricos e, como apreciamos, o que é subliminar à materialidade, como os múltiplos usos na interface com os corpos. Fomos da materialidade secular conservada por ser símbolo das elites que a mantiveram para perpetuar seu status para os móveis já desmaterializados no tempo, principalmente os pertencentes àqueles que não os puderam manter e alvo de pouco interesse dos que elegiam quais peças eram dignas de conservação.

Realizando compreensão histórica aproximada da Antropologia sobre o uso dos móveis em sua interação com os corpos e a expressão de simbolismos subreptícios e com os móveis (re)produzidos, pudemos sintetizar a cadeia produtiva dos móveis e sua interligação com as dinâmicas sociais de São Paulo. Assim, a

\footnotetext{
${ }^{710}$ PINTO, Pedro da Costa. O móvel de assento português do século XVIII. Lisboa: Mediatexto, 2005.
} 
materialidade também nos levou ao imaterial das práticas corporais, que pudemos ver em parte em "negativo" nos objetos nas próprias características materiais das peças que indicam o sentar, o conforto, o manter, o transportar, o apoiar e a visualidade e status de todos esses processos na dinâmica cotidiana do usuário. Da interação corpo-objeto, vislumbramos mais sinais da distinção que (re)produziam as diferenças sociais da sociedade colonial. $E$ angariamos elementos para compreender mais formas de desenvolvimento interno da colônia, seja dos capitais econômicos, seja dos capitais simbólicos, que assumem facetas particulares mesmo em relação à matriz europeia que a informa com grande peso e continuadamente.

Retornando aos sinais evidentes nas características físicas das peças indicando a posição prevista aos corpos, notamos como ocorriam choques com as tradicionais técnicas do corpo na sua extensão em objetos. E isto não só com o acocorar ameríndio e o assentar ao chão africano, mas também com as formas tradicionais mouro-portuguesas, como o assentar de pernas cruzadas "à oriental" em relação às modernizações das novas ondas do processo civilizador europeu, como também com as de outros grupos culturais que compuseram, hibridamente, a população colonial. São práticas corporais ainda cobertas por forte depreciação e obscurecimento, que decerto merecem estudos mais aprofundados.

Se em diversos outros aspectos e dimensões da vida colonial, como o trabalho, a religiosidade e a exclusão social a historiografia evidenciou os contrastes e dominações entre as várias etnias e classes que compunham o Brasil, também as pudemos evidenciar na produção, aquisição, posse, uso e mesmo transporte dos móveis. Damo-nos conta que tais artefatos são também vetores da reprodução de hierarquias quando rompemos a barreira da aceitação banal sobre o uso cotidiano desses artefatos, e fazemos assim da História um inventário das diferenças, na clássica formulação de Paul Veyne ${ }^{711}$, vendo os contrastes no tempo e nas culturas, revestindo de historicidade o objeto comum.

Por isso tudo, móveis da terra não são apenas as peças de mobiliário na sua mudança de forma, uso e significado, também as pessoas que as fizeram, compraram e utilizaram, sejam elas brasileiras ou estrangeiras, estabelecidas em São Paulo ou de passagem, em ascensão ou declínio de status, exercendo uma profissão ou se ramificando por outras áreas, na sua fluidez e dinamicidade.

\footnotetext{
${ }^{711}$ VEYNE, Paul. O inventário das diferenças. História e Sociologia. Brasília: Editora Brasiliense, 1983.
} 
Realizado este percurso pela história através dos móveis pudemos desconstruir das visões tradicionais de história que, valendo-se destas peças como ilustrações, compuseram narrativas únicas de pobreza e depreciação sobre São Paulo e de sua vida laboriosa e econômica.

Havendo assim compreendido como estes móveis carregam em si vasta gama de informações de múltiplas épocas e qualidades, as quais pudemos explorar com a minúcia dos detalhes e da historiação hermenêutica e plural, usamo-las de guia para acessar outras documentações e cruzá-las, fazendo uma História de São Paulo por outros prismas, bem como estabelecendo referências e projeções para futuras análises com outros móveis e mesmo outros artefatos musealizados.

Manifestamos, por fim, a importância da aplicação desse esforço metodológico ${ }^{712}$ não só para a apreciação teórica e historiográfica, mas também nas suas aplicações para a efetuação de projetos educacionais. De tais e conteúdos podem se desdobrar propostas de atividades não só em museus, mas também em escolas. Gerando assim alternativas para o ensino formal ao se acessar os conteúdos curriculares através de tais metodologias e análises, e, aliás, não só trabalhar com a disciplina histórica, mas também em interface com os conteúdos de outras áreas do saber, como as Ciências da Natureza contempladas pela Arqueometria. E não somente no ensino escolar tradicional pode haver tal prisma, mas também pode se multiplicar em oficinas e em outros espaços de aprendizado, como ocorre na FRESS de Lisboa; em cursos profissionalizantes e mesmo em cursos superiores, que devem cada vez mais compreender a importância dos trabalhos manuais do "pensar com as mãos", tendo em consideração a sua função ética e das possibilidades da valorização e democratização do trabalho em nosso país. Para além do recontar e do reproduzir os artefatos históricos, cumpre recriá-los e com eles aprender, intercalando passado e presente.

\footnotetext{
712 Como já realizado pela própria equipe do Museu Paulista quando do advento da remodelação de seu projeto museológico como os guias: MENESES, Ulpiano T. Bezerra de (org.). Como explorar um museu histórico. São Paulo: Museu Paulista/USP, 1992; GUILHOTTI, Ana Cristina. A postura do olhar: coisas que guardamos na memória... In: OLIVEIRA, Cecília Helena Salles de. Museu Paulista: novas leituras. São Paulo: Museu Paulista, 1995; sobre as interfaces do ensino com objetos, ver também RAMOS, Francisco Régis Lopes. A insustentável leveza do tempo: os objetos da sociedade de consumo em aulas de história. Educ. rev., Belo Horizonte, n. 47, p. 179-196, Junho 2008.
} 


\section{REFERÊNCIAS DOCUMENTAIS}

\section{Fontes Manuscritas}

\section{1. Arquivo Público do Estado de São Paulo}

Inventários e Testamentos não publicados

\begin{tabular}{|c|c|c|}
\hline João Fernandes & 1717 & C00504 \\
\hline Manoel Pedroso Oliveira & 1742 & C00623 \\
\hline João do Prado de Siqueira & 1742 & C00733 \\
\hline Diogo de Toledo Lara & 1743 & C00643 \\
\hline $\begin{array}{l}\text { Manoel de Gois Cardoso e Isabel de } \\
\text { Almeida }\end{array}$ & 1744 & C00623 \\
\hline José de Lemos e Moraes & 1744 & C00658 \\
\hline Matias de Oliveira Lobo & 1745 & C00650 \\
\hline João Rodrigues Vaz & 1746 & C00659 + avulso \\
\hline Manoel José da Cunha & 1746 & C00651 \\
\hline João Francisco Lustosa & 1746 & C00667 \\
\hline Caterina Mendes Tenória & 1747 & C00658 \\
\hline Miguel de Oliveira & 1747 & C00652 \\
\hline José da Silva Góes & 1748 & C00659 \\
\hline José Casado Vilas Boas & 1749 & C00707 \\
\hline José do Prado da Cunha & 1749 & C00519 \\
\hline Izidora do Amaral & 1750 & C00670 \\
\hline Domingos Lobo de Oliveira & 1750 & C00643 \\
\hline Bartolomeu Bueno Cacunda & 1750 & C00707 \\
\hline Cornélio Rodrigues Arzão & 1750 & C00658 \\
\hline Francisco da Silva Coelho & 1750 & C00523 \\
\hline Nicolau Francisco Rosal & 1751 & C00641 \\
\hline Nicolau Francisco Rosal & 1751 & C00641 \\
\hline Agostinho Duarte do Rego & 1752 & C00528 \\
\hline Manoel Veloso & 1752 & C00528 \\
\hline André Alvares de Castro & 1752 & C00721 \\
\hline Mecia de Aguirra de Camargo & 1753 & C00650 \\
\hline Bartolomeu Correa Bueno & 1753 & C00707 \\
\hline Bento do Amaral da Silva & 1753 & C00645 \\
\hline Escolástica Veloso & 1753 & C00530 \\
\hline Manoel de Macedo & 1753 & C00531 e 705 \\
\hline Juliana Maciel & 1754 & C00623 \\
\hline Manoel Luis da Costa & 1755 & C00703 \\
\hline Manoel Gonçalves Sete & 1755 & C00653 \\
\hline José Barbosa de Lima & 1755 & C00686 \\
\hline Alexandre Monteiro de Sampaio & 1755 & C00703 \\
\hline
\end{tabular}




$\begin{array}{llr}\text { Domingos Barreto de Lima } & 1756 & \text { C00643 } \\ \text { Antonio Rodrigues Froes } & 1756 & \mathrm{C} 00634 \\ \text { Manoel Mendes de Almeida } & 1756 & \mathrm{C} 00532 \\ \text { Francisco Afonso Lima } & 1756 & \mathrm{C} 00690 \\ \text { Matias de Castro de Oliveira } & 1757 & \mathrm{C} 00650 \\ \text { Marcos Francisco } & 1758 & \mathrm{C} 00647 \\ \text { Maria Francisca Lustosa } & 1758 & \mathrm{C} 00689 \\ \text { Inacio Soares de Barros } & 1759 & \mathrm{C} 00670 \\ \text { Antonio Ribeiro Pires e Maria } & 1760 & \mathrm{C} 00634 \\ \text { Rodrigues Barbosa } & & \\ \text { Francisco Pinheiro de Sepeda } & 1760 & \mathrm{C} 00690 \\ \text { João Pinto Rodrigues } & 1761 & \mathrm{C} 00620 \\ \text { Luis Rodrigues Lisboa } & 1761 & \mathrm{C} 00538 \\ \text { José da Silva Ferrão } & 1762 & \mathrm{C} 00541 \\ \text { Aniceto Fernandes } & 1762 & \mathrm{C} 00540 \\ \text { Pedro da Silva Pontes } & 1763 & \mathrm{C} 00719 \\ \text { Antonio Barbosa de Lima } & 1764 & \mathrm{C} 00631 \\ \text { Ana de Oliveira Montes } & 1765 & \mathrm{C} 00664 \\ \text { Anna Maria } & 1765 & \mathrm{C} 00680 \\ \text { Domingos João Vilarinhos } & 1766 & \mathrm{C} 00544 \\ \text { Vicente Ferreira Neves } & 1766 & \mathrm{C} 00663 \\ \text { Manoel Rodrigues Ferreira } & 1768 & \mathrm{C} 00665 \\ \text { Inácia Maria Rodrigues } & 1768 & \mathrm{C} 00546 \\ \text { Bento de Oliveira Lima } & 1769 & \mathrm{C} 00668 \\ \text { José Rodrigues Pereira } & 1770 & \mathrm{C} 00686 \\ \text { José Pires de Almeida } & 1771 & \mathrm{C} 00737 \\ \text { João da Mota Liver } & 1771 & \mathrm{C} 00654 \\ \text { Manoel Francisco Domingues } & 1771 & \mathrm{C} 00652 \\ \text { Manuel Soares de Carvalho } & 1772 & \mathrm{C} 00549 \\ \text { Antonio da Costa Rodrigues } & 1773 & \mathrm{C} 00631 \\ \text { Manuel Antônio da Cruz } & 1775 & \mathrm{C} 00705 \\ \text { Francisco Coelho Aires } & 1776 & \mathrm{C} 00640 \\ \text { Rosa de Souza } & 1777 & \mathrm{C} 00680 \\ \text { José da Costa Vale } & 1780 & \mathrm{C} 00674 \\ \text { Francisco Pereira Mendes } & 1781 & \mathrm{COO} 664 \\ \text { Francisco Duarte do Rego } & 1782 & \mathrm{C} 00726 \\ \text { Manuel Rodrigues Jordão (alferes) } & 1786 & \\ \text { Modesto Antonio Coelho Neto } & 1803 & 201007000171 \text { - } \\ & & 1170 \\ \text { Rosa Maria do Rozario Pedrosa } & 1803 & 201007000541- \\ \text { Manoel Cardoso de Abreu } & & 1197 \\ \text { Ana Francisca Novaes } & & 201007000351- \\ & & 1631 \\ & & \end{array}$




\begin{tabular}{|c|c|c|}
\hline Ana Maria de Assumpção & 1806 & $\begin{array}{r}201006003837- \\
1587\end{array}$ \\
\hline Maria Josefa Mendes da Silva & 1806 & $\begin{array}{r}201007000452- \\
1175\end{array}$ \\
\hline Diogo José de Souza & 1811 & $\begin{array}{r}201007000516- \\
1894\end{array}$ \\
\hline Domingos Fernandes Lima & 1812 & $\begin{array}{r}201006003305- \\
1895\end{array}$ \\
\hline José Pinto Tavares & 1815 & $\begin{array}{r}201007000466- \\
1169\end{array}$ \\
\hline Luis Antonio de Sousa Queiroz - brig. & 1819 & 530 \\
\hline Bento Dias Vieira & 1823 & $\begin{array}{r}201007000202- \\
470\end{array}$ \\
\hline Diogo José da Silva & 1824 & $\begin{array}{r}201006003981- \\
1185\end{array}$ \\
\hline José Vaz de Carvalho & 1825 & $\begin{array}{r}201006003982- \\
981\end{array}$ \\
\hline Antonio José Vaz & 1825 & $\begin{array}{r}201006003973- \\
1203\end{array}$ \\
\hline Manoel Rodrigues Jordão - brig & 1828 & 229 \\
\hline Joaquim José dos Santos & 1828 & $\begin{array}{r}201006004032- \\
472\end{array}$ \\
\hline Antonio José Vieira Barbosa & 1831 & $\begin{array}{r}201006003416- \\
1091\end{array}$ \\
\hline $\begin{array}{l}\text { Joaquim Mariano Galvão de Moura } \\
\text { Lacerda }\end{array}$ & 1834 & \\
\hline Joaquim Dias Vieira & 1835 & $\begin{array}{r}201006003486- \\
307\end{array}$ \\
\hline João José de Alvarenga & 1836 & $\begin{array}{r}201007000260- \\
548\end{array}$ \\
\hline Pulqueria Maria de Barros & 1837 & $\begin{array}{r}201007000250- \\
609\end{array}$ \\
\hline Francisco Leandro Leme de Moraes & 1837 & $\begin{array}{r}201007000188- \\
285\end{array}$ \\
\hline Genebra de Barros Leite & 1838 & $\begin{array}{r}201007000804- \\
531\end{array}$ \\
\hline
\end{tabular}

\section{Maços de População}

Disponível em: http://www.arquivodoestado.sp.gov.br/viver/recenseando.php.

Anos referenciados: $1765,1767,1798,1807,1815,1818$. 


\subsection{Arquivo da Cúria Metropolitana de São Paulo}

\section{Livros manuscritos}

Livro da receita e despesa da Fábrica da Sé de $1^{\circ}$ de janeiro de 1748 a 18 de janeiro de 1817. Ordem: 02-03-042. 1768.

Livro ํo. 20, Inventário 1747-1876, Paroquia de № Sª de Assunção de São Paulo, Catedral da Sé P.. 8ss

\section{Dispensas e processos matrimoniais}

livro 260, Nicolau Francisco Rosal, 1748.

4-75-543, João da Mota Liver, 1761.

\subsection{Arquivo do Judiciário de São Paulo.}

\section{Inventários e Testamentos}

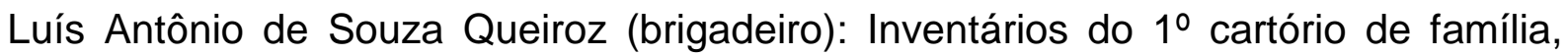
proc. 530-1819.

Manuel Rodrigues Jordão (brigadeiro): Inventários do $1^{0}$ cartório de família, proc. 229-1828.

\subsection{Arquivo Nacional da Torre do Tombo}

\section{Coleção Papéis do Brasil.}

Cleto, Marcelino Pereira ."Dicionário da capitania de São Paulo", vol. I. [microfilmado]. PT/TT/PBR/11.

\section{Registros da mercês}

Domingos António da Silva Mestre. Marceneiro da Casa Real, 1824. PT/TT/RGM/F/0019/143583

\section{Junta do Comércio}

Termos de licença para o estabelecimento de fábricas. "Livro $1^{\circ}$ dos termos de mestres fabricantes de nova invenção e outros". 1761 a 1796. PT/TT/JC/A-C/2/1.

"Livro $1^{\circ}$ dos termos de mestres fabricantes de nova invenção e outros" Datas de produção: 1761-03-03 / 1796-10-10. liv. 69. 
Inventários orfanológicos dos Feitos Findos (1500-1800).

Feliciano da Cruz (mestre do ofício de carpinteiro de móveis), 1799. PT/TT/IFF/006/0175/00006.

Úrsula da Silva (Cônjuge: Estêvão da Silva, entalhador), 1704 $\mathrm{PT} / \mathrm{TT} / \mathrm{IFF} / 020 / 0015 / 00010$

Helena da Cruz, (marido: Antônio Duarte, carpinteiro de seges), 1752 PT/TT/IFF/005/0010/00003

Francisco José de Paiva (marceneiro), 1823. PT/TT/IFF/006/0049/00003

\subsection{Arquivo Histórico Ultramarino - Projeto Resgate}

(Disponível em: http://www.cmd.unb.br/resgate.php)

Documentos manuscritos avulsos da Capitania de Mato Grosso CT-AHU-ACL-CU-010,CX 13, DOC 768

Documentos manuscritos avulsos da Capitania do Rio de Janeiro

Rio de Janeiro 1774, Julho, 27. Cota: 8374.

Rio de Janeiro 1758, Março, 13, ํo 5300.

Rio de Janeiro 1755, Setembro, 6, ㄲo 4914

\subsection{Arquivo Histórico Municipal de São Paulo}

AHMSP, Fundo Câmara Municipal, Série Documentos Avulsos, caixa 28

AHMSP, Fundo Câmara Municipal Série Documentos Avulsos, caixa 41.

AHMSP. Fundo Câmara Municipal. Série Receita e Despesa. Livro 1656, fl. 127.

AHMSP. Fundo Câmara Municipal. Série Receita e Despesa. Livro 314 fl. 74.

\subsection{Fontes textuais impressas e periódicos}

ANDRADA, Martim Francisco Ribeiro. Jornais de Viagem pela Capitania de São Paulo, 1803. CLETO, Marcelino Pereira et al. Roteiros e notícias de São Paulo colonial: 1751-1804. São Paulo: Governo do Estado de São Paulo, 1977, p. 191.

ANTONIL, André João. Cultura e Opulência do Brasil por suas drogas e minas etc [1711]. Introdução e comentário crítico de Andrée Mansuy Diniz 
Silva. Lisboa: Comissão Nacional para as Comemorações dos Descobrimentos Portugueses, 2001.

ARQUIVO PÚBLICO DO ESTADO DE SÃO PAULO. Documentos Interessantes para a História e Costumes de São Paulo. 95 vols. São Paulo: Tipografia Piratininga. Volumes referenciados: 16, 23, 32, 45, 46, 73.

ARQUIVO PÚBLICO DO ESTADO DE SÃO PAULO. Inventários e Testamentos publicados. 47 vols. S. Paulo: Publicação da Divisão do Arquivo Histórico. 1920-1999. Volumes referenciados: 23, 24, 25 e 26.

ARQUIVO PÚBLICO DO ESTADO DE SÃO PAULO. Registo Geral da Câmara Municipal de S. Paulo, São Paulo: Typographia Piratininga, vols. referenciados: $4,5,8$.

BIARD, François. Dois anos no Brasil. São Paulo: Cia. Ed. Nacional. 1945.

BURTON, Isabel. The Life of Captain Sir Richard. F. Burton. London: Chapman and Hall. Vol. 1. 1893. P. 480. Disponível em: 207http://burtoniana.org/biography/1893-Isabel-Life/iburton-1893-lifevol1.pdf. Acessado em: 01/08/2017.

CLETO, Marcelino Pereira. Dissertação a Respeito da Capitania de São Paulo, sua decadência e modo de restabelece-la. 1782. Em: CLETO, Marcelino Pereira et al. Roteiros e notícias de São Paulo colonial: 1751-1804. São Paulo: Governo do Estado de São Paulo, 1977.

COX, Macro; COX, Thomaz. Relação do Reino de Portugal. 1701. Lisboa: Biblioteca Nacional, 2007.

CUNHA, D. António Álvares da [1700-1791] a seu filho D. João Lourenço passando aos Estados da Índia. S.d. Publicado em CARVALHO, José Adriano de Freitas. Pais e Nobres. Cartas de instrução para educação de jovens nobres (Sécs. XVI-XVIII) Volume I. Porto: FLUP Ed, 2009 p. 170.

Diário da jornada, que fez o Exm. Senhor Dom Pedro (Conde de Assumar) desde o Rio de Janeiro até a Cidade de São Paulo, e desta até as Minas Ano de 1717. Revista do SPHAN, n. 3, 1939, p. 303

DIVISÃO DO ARQUIVO HISTÓRICO DO DEPARTAMENTO DE CULTURA DA PREFEITURA DO MUNICIPIO DE SÃO PAULO. Atas da Câmara Municipal de S. Paulo 1744-1748. São Paulo: Typographia Piratininga,. Volumes referenciados: 1, 5, 8, 9, 10, 12,15, 17, 21, 22, 23, 24, 40.

EWBANK, Thomas. Vida no Brasil. Belo Horizonte: Itatiaia; Edusp,1976.

FERREIRA, Alexandre Rodrigues. Viagem filosófica pelas capitanias do GrãoPará, Rio Negro, Mato Grosso e Cuiabá [1789]. Memórias antropológicas. Brasília, Conselho Federal de Cultura. 1974.

GONZAGA, Tomás, Antonio. Cartas chilenas (quinta). Disponível em: http://www.dominiopublico.gov.br/download/texto/ua000293.pdf. Acesso em: 20/05/2018.

LUCCOCK, John. Notas sobre o Rio de Janeiro e partes meridionais do Brasil (1808-1818). São Paulo, Belo Horizonte: Edusp/ Itatiaia Editora, 1975.

PIRES, P.e Vicente Ferreira. Viagem ao Reino do Daomé. 1800. In: LESSA, Clado Ribeiro de. Crônica de uma Embaixada Luso-Brasileira à Costa 
d'África em fins do século XVIII, incluindo o texto da Viagem de África em o Reino de Dahomé escrita pelo Padre Vicente Ferreira Pires no ano de 1800 e até o presente inédita. São Paulo: Companhia Editora Nacional (Brasiliana), 1957.

PISO, Guilherme. Historiae Naturalis Brasiliae. 1648. apud. MÉTRUX, alfred. A civilização material tupi-guarani. 1928. Campo Grande: Ed.Alvorada. 2012.

REVISTA DO INSTITUTO Histórico Geográfico Brasileiro. v. 6. Rio de Janeiro: IHGB e Imprensa Nacional. 1844. p. 236.

SALVADOR, Frei Vicente do. História do Brasil, 1500-1627 . São Paulo: Ed. Itatiaia. 1982, p. 187. Apud PREZIA, Benedito Antônio Genofre. Os Tupi de Piratininga: acolhida, resistência e colaboração. 2008. 407 f. Tese (Doutorado em Ciências Sociais) - Pontifícia Universidade Católica de São Paulo, São Paulo, 2008.

SPIX, J. e MARTIUS, C. Viagem pelo Brasil. 3 volumes. Tradução de Lúcia Furquim Lahmeyer. $3^{a}$ edição. São Paulo: Edições Melhoramentos, 1976.p. 12.

VASCONCELLOS, Ignacio da Piedade. Artefactos symmetriacos, e geometricos: advertidos, e descobertos pela industriosa perfeicão das artes, esculturaria, architectonica, e da pintura. Lisboa: 1733. Apud PEREIRA, Benjamim. Tecnologia Tradicional Portuguesa: Sistemas de serração de madeiras. Etnologia - 5. Instituto Nacional de Investigação Científica. Centro de estudos de Etnologia. 1990.

\section{Biblioteca Nacional Digital - Hemeroteca.}

Aviso no jornal Farol Paulistano, ํㅜㄹㄱ 19 de novembro de 1829, Aviso no jornal Farol Paulistano, n. 214. 16 de maio de 1829.

Disponível em: bndigital.bn.gov.br/hemeroteca-digital.

\subsection{Fontes Iconográficas}

"Interior de uma casa do baixo povo", c.1820. GUILLOBEL, Joaquim Cândido Fonte: MOURA, Carlos Eugênio Marcondes de. A travessia da calunga grande: três séculos de imagens sobre o negro no Brasil (1637-1899). São Paulo: Editora da Universidade de São Paulo, 2000.

"Casa das Índias em Monte Alegre". FERREIRA, Alexandre Rodrigues. Viagem filosófica pelas capitanias do Grão-Pará, Rio Negro, Mato Grosso e Cuiabá [1789]. Memórias antropológicas. Brasília, Conselho Federal de Cultura. 1971, p. 28 apud. MARTINS, Renata Maria de Almeida. Tintas da terra tintas do reino: arquitetura e arte nas Missões Jesuíticas do Grão-Pará (1653-1759). 2009. Tese de Doutorado. FAU-USP. P. 266. 
"Casa de Negros", RUGENDAS, Johann Moritz. 1835. Fonte: Aguillar, Nelson (Org.). Mostra do redescobrimento: negro de corpo e alma. São Paulo: Associação Brasil 500 Anos Artes Visuais, 2000.

"Ebenisterie-marqueterie". D'ALEMBERT, Jean le Rond; DIDEROT, Denis. Encyclopédie ou Dictionnaire raisonné des sciences, des arts et des métiers. vol. 4 (plates). Paris, 1769. Disponível em: https://quod.lib.umich.edu/d/did/did2222.0001.442/--cabinet-making-andmarquetry?rgn=main;view=fulltext;q1=frames. Acesso em 20/05/2018.

"Escola Kayapó, aldeia Djetuktire", GURAN, Milton. 1991 - fotografia em gelatina/prata tonalizada, $23,8 \times 30,3 \mathrm{~cm}$ (Acervo MASP).

"História do Chapeleiro António Joaquim Carneiro". REAL FÁBRICA de Louça, ao Rato .Lisboa,. 1790-1800. Exposto no Museu do Azulejo de Lisboa. Proveniente da Quinta do Chapeleiro, Póvoa de Santo Adrião. MNA, Inv. $227 \mathrm{f}$. Foto do autor.

"Menuisier en meubles". D'ALEMBERT, Jean le Rond; DIDEROT, Denis. Encyclopédie ou Dictionnaire raisonné des sciences, des arts et des métiers. vol. 7 (plates). Paris, 1769. Disponível em: https://quod.lib.umich.edu/d/did/did2222.0001.572/--art-of-the-cabinetmaker?rgn=main;view=fulltext; $q 1=$ cabinet-maker. $\quad$ Acessado em 20/05/2018.

"O marceneiro de rodas de carroça". DELERIVE, Nicolas (1755-1818). Constumes e atividades de Lisboa, c. 1801.. (FRESS - Inv. 630).

"Vista da cidade - palácio da sola." (detalhe). PINK, Edmund 1823. LAGO, P.C. do. Iconografia paulistana do século XIX. $2^{\underline{a}}$ ed. São Paulo: Capivara. 2003.p.62.

DEBRET, Jean-Baptiste. Voyage pittoresque et historique au Brésil . Paris, Firmin Didot Freres, 1834-39. Disponível em: https://www.bbm.usp.br/node/68. Acessado em: 20/05/2018.

\subsection{Fontes Tridimensionais}

\section{Acervo Museu Paulista}

Arca-cofre. RG 1-05-03-000-03242-00-00.

Cadeiras de palhinha RG 1-05-02-000-00072-00-00.

Cadeira de palhinha RG 1-05-02-000-05883-00-00.

Cadeira de sola. RG 1-05-02-000-00055-00-00

Cadeira de sola. RG 1-05-02-000-00057-00-00

Cadeira de sola. RG 1-05-02-000-00060-00-00.

Cadeira de sola. RG 1-05-02-000-00061-00-00

Cadeira de sola. RG 1-05-02-000-00117-00-00

Cadeira de sola. RG 1-05-02-000-00553-00-00. 
Cadeira de sola. RG 1-05-02-000-00559-00-00

Cadeira em rocalha. RG 1-05-02-000-00469-00-00

Leito. RG 1-05-04-000-03962-00-00.

Mesa Bufete RG 1-05-01-000-00116-00-00.

Mesa Console RG 1-05-01-000-00069-00-00

Disponível em: http://acervo.mp.usp.br/ObjetosV2.aspx\#

Acervo Museu do Oriente, Lisboa.

Cadeira de Braços. Mombaça, século XVII. ébano, osso, palhinha. Número de Inventário: FO/1350.

Acervo Museu de Artes Decorativas de Lisboa

Banca de Jogos, Século XVIII. S.r.

Estrado, Século XVII. S.r.

\section{Coleção Museu Casa do Anhanguera em Santana de Parnaíba}

Serrote de Armação ou de São José. S.d.

Coleção particular de Emanuel Araújo - Museu Afro Brasil

Plainas, século XVIII-XIX.

Enxó. S.d.

Serras de Braço, Século XIX.

Instituto do Patrimônio Histórico e Artístico Nacional - Minas Gerais

Macetes de madeira e verruma encontradas em Congonhas, atribuídas a Francisco Viera Servas (1720-1811).

\section{Museu Histórico Nacional - Brasil}

Urna funerária antropomorfa de cerâmica do povo Maracá, Sul do Amapá. c. 1000 d.C. Disponível em:

http://www.museunacional.ufrj.br/dir/exposicoes/arqueologia/arqueologiabrasileira/arqbra002.html. 
Metropolitan Museum of Art - Nova York

Banco de chefe. Cultura Chokwe de Angola. Sec. XIX-XX. Disponível em:

http://www.metmuseum.org/collection/the-collection-online/search/311078 


\section{BIBLIOGRAFIA}

A CATHEDRAL de São Paulo. São Paulo: [s.n], [1911]. Apud. RAMIREZ, Karen Niccoli; NETO, Henrique Lindenberg. De igreja de taipa a catedral: aspectos históricos e arquitetônicos da igreja matriz da cidade de São Paulo. Pós. Revista do Programa de Pós-Graduação em Arquitetura e Urbanismo da FAUUSP, v. 21, n. 35, p. 186-199, 2014.

ABREU, João Capistrano de. Capítulos de História Colonial (1500-1800). Brasília: Conselho Editorial do Senado Federal, 1998. Biblioteca Básica Brasileira. P. 218.

ABREU, Regina. A fabricação do imortal: Memória, História e Estratégias de Consagração no Brasil. Rio de Janeiro: Rocco. 1996

ADAMS, Douglas. Guia do Mochileiro das Galáxias. São Paulo: Sextante. 2004.

ALBERNAZ, Cássio. Da História política dos "grandes homens" a prosopografia das elites políticas: considerações historiográficas e metodológicas. São Paulo: ANPUH. Anais do XXVI Simpósio Nacional de História, 2011.

ALGRANTI, Leila M. "Famílias e vida doméstica". In: SOUZA, Laura de Mello (org.) História da vida privada no Brasil: cotidiano e vida privada na América portuguesa. São Paulo: Companhia das Letras, 1997, pp. 54-90.

AMARAL, Aracy. A hispanidade em São Paulo: da casa rural à capela de Santo Antônio. São Paulo: Livraria Nobel, 1981.

ANGELINI, Ivana; ARTIOLI, Gilberto. Scientific Methods and Cultural Heritage: An Introduction to the Application of Materials Science to Archaeometry and Conservation Science. Oxford: Oxford University Press. 2010.

ANTUNES, L. F. D. Alguns interiores domésticos nos inventários de mercadores lisboetas: uma avaliação do valor simbólico de objetos asiáticos. In: MENESES, A. de F de; OLIVERIRA E COSTA, J. P. (orgs.) O Reino, As Ilhas e o Mar Oceano: Estudos em Homenagem a Artur Teodoro de matos. Lisboa: Ponta Delgada, Vol.2, 2007.

APPADURAI, Arjun (org.). A vida social das coisas: as mercadorias sob uma perspectiva cultural. Niterói: Editora da Universidade Federal Fluminense, 2008.

APPOLONI, Carlos Roberto e SILVA, Wislley Dueli da. Pigmentos: propriedades físicas, químicas e o período histórico de utilização. Londrina: Publicação Técnica do Laboratório de Física Nuclear Aplicada, Volume 13, Número 1, $1^{\text {a }}$ Edição, Outubro de 2009. s.p. disponível em: www.uel.br/grupos/gfna/pigmentos2009.pdf. Acesso em: 20/05/2018.

ARAÚJO, Jeaneth. DIAS, Renato da Silva. Núcleos urbanos na capitania de Minas Gerais: artistas, oficiais mecânicos e vida cotidiana no termo de vila rica. Revista Mnemosine. Vol.6, n.1, jan/jun. 2015.

ARAÚJO, M. L. V. Os interiores domésticos após a expansão da economia exportadora paulista. Anais do Museu Paulista: História e Cultura Material, 12, 129-160. 2004

ARAÚJO, Maria Lucília Viveiros. Reflexões sobre a pesquisa historiográfica dos testamentos. 2005.

https://www.tjrs. 
jus.br/export/poder_judiciario/historia/memorial_do_poder_judiciario/memoria I_judiciario_gaucho/revista_justica_e_historia/issn_1676-

5834/v5n10/doc/9_Maria_Lucilia_Viveiros.pdf.

ARES, José Antonio. O Metal: Técnicas de conformação, forja e soldadura. Editorial Estampa, p. 71.

ASSUNÇÃO, P. Negócios Jesuíticos: O cotidiano da administração dos bens divinos. São. Paulo: Editora da Universidade de São Paulo, 2004.

AUSLANDER, Leora. Taste and Power: furnishing modern France. Berkley: University of Califórnia Press, 1996.

BACELLAR, Carlos de Almeida Prado. As famílias de povoadores em áreas de fronteira da Capitania de São Paulo na segunda metade do século XVIII. Revista Brasileira de Estudos de População, v. 34, n. 3, p. 549-566, 2017

BACELLAR, Carlos de Almeida Prado. Viver e sobreviver em uma vila colonial Sorocaba, séculos XVIII e XIX. São Paulo: Annablume/Fapesp, 2001. p. 101

BAQUAQUA, Mahommah Gardo; MOORE, Samuel. Biography of Mahommah G. Baquaqua, a Native of Zoogoo... Detroit: Tribune Office.1854. Disponível em: http://docsouth.unc.edu/neh/baquaqua/baquaqua.html. Acesso: 20/05/2018.

BARDI, Pietro Maria. Mestres, artífices, oficiais e aprendizes no Brasil. São Paulo: Banco Sudameris Brasil, 1981.

BARONE, Fran. A cross-cultural look at posture in eHRAF (electronic Human Relations Area Files Cultural), Yale: 13 de junho de 2015. Disponível em: hraf.yale.edu/a-cross-cultural-look-at-posture-in-ehraf/. Acessado em 01/08/2017.

BARREIRO, José Carlos. Imaginário e viajantes no Brasil do Século XIX: cultura e cotidiano, tradição e resistência. São Paulo: Editora UNESP, 2002.

BARRETO, Cristina. Bancos indígenas do Brasil. São Paulo: BEI, 2017.

BARROS, Daisy Ribeiro de Moraes. Um século dos ofícios mecânicos na Vila de São Paulo. Dissertação de Mestado: FFLCH-USP, 1982, p.97.

BARROS, Maria Paes de. No Tempo de Dantes, 1946. In MOURA, Carlos Eugênio Marcondes. (Org.). Vida cotidiana em São Paulo no século XIX: memórias, depoimentos, evocações. São Paulo: Ateliê Editorial, 1998.

BASTOS, Celina; SOUSA, Maria da Conceição Borges - Mobiliário: artes plásticas e artes decorativas. Lisboa: IPM, 2004

BASTOS, Rodrigo Almeida. O urbanismo conveniente luso-brasileiro na formação de povoações em Minas Gerais no século XVIII. An. mus. paul. 2012, vol.20, n.1, pp.201-230.

BATISTA, Eduardo Luis Araújo de Oliveira. Iconografia tropical: motivos locais na arte colonial brasileira. An. mus. paul., São Paulo , v. 25, n. 1, p. 359401, Apr. 2017.

BAUDRILLARD, Jean. O sistema dos objetos. São Paulo: Perspectiva, 2004.

BERNAL, Rocio Astrid; VALENT, Adelina; PISSARRA, José. Wood identification of 18th century furniture: interpreting wood naming inventoires. International Journal of Conservation Science, v. 2, n. 3, 2011. 
BERTELLI, Luiz Gonzaga. A construção de São Paulo e seus artífices: notas biográficas. São Paulo: Engenho Editora Técnica. 2016. pg 36.

BEUNZA, José María Imízcoz. Introducción. CASADO, I.; RODRÍGUEZ, J.; VEGA, D. Redes Sociales y económicas en el mundo bajomedieval. Valladolid: Castilla Ed. 2011.

BEUNZA, José María Imízcoz. Redes, grupos, classes. Uma perspectiva desde el análisis relacional. MOLINA PUCHE, S. ; IRIGOYEN LÓPEZ, A. (Eds.). Territorios distantes, comportamientos similares. Familias, redes y reproducción social en la Monarquía Hispánica (siglos XIV-XIX). Murcia: Editium. 2008.

BLAJ, llana. A trama das tensões: o processo de mercantilização de São Paulo colonial (1681-1721). São Paulo : Humanitas/FFLCH/USP : Fapesp, 2002;

BLUTEAU, Raphael. Vocabulario portuguez \& latino: aulico, anatomico, architectonico... Coimbra: Collegio das Artes da Companhia de Jesus, 17121728, 10 vol.. Disponível em: http://dicionarios.bbm.usp.br/pt-br/dicionario/1. Acessado em 20/05/2018.

BORREGO, Maria Aparecida de Menezes. A teia mercantil: negócios e poderes em São Paulo colonial (1711-1765). São Paulo: Alameda/ Fapesp, 2010.

BORREGO, Maria Aparecida De Menezes. Artefatos da casa em exposição: o espaço doméstico colonial paulista em acervos do Museu Paulista/USP. 2012. In: ASENSIO, MOREIRA, ASENJO \& CASTRO (Eds.). SIAM. Series Iberoamericanas de Museología. Vol. 7. 2012.

BORREGO, Maria Aparecida de Menezes. Artefatos e práticas sociais em torno das refeições (São Paulo, séculos XVIII e XIX). Varia hist., Belo Horizonte, v. 32, n. 58, p. 101-137, Apr. 2016

BORREGO, Maria Aparecida de Menezes. Laços familiares e aspectos materiais da dinâmica mercantil na cidade de São Paulo (séculos XVIII e XIX). An. mus. paul., São Paulo, v. 18, n. 1, p. 11-41, Junho 2010

BORREGO, Maria Aparecida de Menezes. Projeto de Pesquisa Jovem Pesquisador FAPESP - Espaço Doméstico e Cultura Material em São Paulo Colonial a partir do estudo de acervos do Museu Paulista/USP. Não Publicado. 2010.

BORREGO, Maria Aparecida de Menezes; FELIX, Rogério Ricciluca Matiello. Ambientes domésticos e dinâmicas sociais em São Paulo colonial. Rev. Hist. (São Paulo), São Paulo, n. 175, p. 91-132, dez. 2016.

BOTELHO, Nilza. Serpentinas e cadeirinhas de arruar. Anais do Museu histórico Nacional. Rio de janeiro, IX: 445-72, 1943.

BOTELHO, Nilza. Serpentinas e cadeirinhas de arruar. Rio de janeiro, Anais do Museu histórico Nacional. IX: 445-72, 1943

BOUCARD, Daniel. Dictionnaire des outils et instruments pour la plupart des métiers. Paris: Éd. JC Godefroy, 2006.

BOURDIEU, Pierre. A distinção: crítica social do julgamento. São. Paulo: Edusp; Porto Alegre, RS: Zouk, 2007.

BOWETT, Andam. Furniture woods in London and Provincial Furniture, 1700-1800. Londres: Regional Furniture, Vol. XXII, 2008. Disponível em: 
https://regionalfurnituresociety.files.wordpress.com/2013/02/furniture-woods-

in-london-and-provincial-furniture-1700-1800-adam-bowett.pdf

BRANDÃO, Angela. Anotações para uma história do mobiliário brasileiro do século XVIII. Revista CPC (USP), vol. 9, 2009-2010, p. 42-64.

BRANDÃO, Angela. Antônio Francisco Lisboa e um ebanismo de jacarandá. Belo Horizonte: IX colóquio luso-brasileiro de História da Arte. 2014. Disponível em: http://www.forumpatrimonio.com.br/aleijadinho/artigos/pdf/9.pdf. Acesso em: 20/05/2018.

BRANDÃO, Angela. Antônio Francisco Lisboa e um ebanismo de jacarandá. Belo Horizonte: IX colóquio luso-brasileiro de História da Arte. 2014. Disponível em: http://www.forumpatrimonio.com.br/aleijadinho/artigos/pdf/9.pdf. Acesso em: 20/05/2018.

BRANDÃO, Angela. Das pontes aos castiçais: a produção de mobiliário artístico em Minas Gerais do século XVIII e os ofícios mecânicos. Revista Científica/FAP , v. 4, n. 2. Curitiba: jul./dez. 2009, pp. 50-66.

BRANDÃO, Angela. Inventários como Fontes para a História da Arte e do Mobiliário Brasileiro. Cultura Visual, n. 13, p. 11-23, 2010.

BRANDÃO, Angela. Móveis em miniatura: a demonstração de um saber fazer. An. mus. paul., São Paulo, v. 25, n. 1, p. 169-197, Abr. 2017 . Disponível em: $\quad$ http://www.scielo.br/scielo.php?script=sci_arttext\&pid=S010147142017000100169\&lng=en\&nrm=iso $>$. Acessado em: 01/02/2018.

BRAUDEL, Fernand. Civilização material, economia e capitalismo - séculos XVXVIII. São Paulo: Martins Fontes, 1995 (vol.2: As estruturas do cotidiano)

BREFE, A. C. F. O., Museu Paulista: Affonso de Taunay e a memória nacional, 1917-1945. São Paulo, Editora UNESP, Museu Paulista, 2005.

BRUNO, Ernani da Silva. História e tradições da cidade de São Paulo. São Paulo: Hucitec, 1991 (volume 1: Arraial de sertanistas, 1554-1828).

BRUNO, Ernani da Silva. O equipamento da casa bandeirista segundo os antigos inventários e testamentos. São Paulo: Departamento do Patrimônio Histórico, 1977.

BUENO, Beatriz Piccolotto Siqueira. Do borrão às aguadas: os engenheiros militares e a representação da Capitania de São Paulo. An. mus. paul., São Paulo , v. 17, n. 2, p. 111-153, Dec. 2009

BUENO, Beatriz Piccolotto Siqueira. Sistema de produção da arquitetura na cidade colonial brasileira: mestres de ofício," riscos" e" traças". Anais do Museu Paulista: História e Cultura Material, v. 20, n. 1, p. 321-361, 2012.

BUENO, Beatriz Piccolotto Siqueira. Tecido urbano e mercado imobiliário em São Paulo: metodologia de estudo com base na Décima Urbana de 1809. An. mus. paul., São Paulo, v. 13, n. 1, p. 59-97, June 2005.

CABRAL, Diogo de Carvalho. Na Presença da Floresta:, Mata Atlântica e História Colonial. Rio de Janeiro: Garamond/FAPERJ, 2014. 
CAMPOS, Eudes. Ecos paulistanos da vinda da Família Real para o Brasil. In: Informativo do Arquivo Histórico Municipal. São Paulo: PMSP/SMC/DPH, março/abril de 2008.2 Disponível em: http://www.arquiamigos.org.br/info/info17/i-inter.htm. Acesso em: 20/05/2018. CAMPOS, Eudes. Os móveis franceses da Marquesa de Santos. In: Informativo do Arquivo Histórico Municipal. São Paulo: PMSP/SMC/DPH, março/abril de 2008. Disponível em: http://www.arquiamigos.org.br/info/info17/i-inter.htm. Acesso em: 20/05/2018.

CANCLINI, Néstor Garcia. Culturas híbridas: estratégias para entrar e sair da modernidade. Trad. de Ana Regina Lessa, Heloísa Pezza Cintrão. 4. ed. São Paulo: Edusp, 2003., p. 19

CANTI, Tilde. O móvel no Brasil: origens, evolução e características. Rio de Janeiro: Ed. Candido Guinle de Paula Machado, 1980, p. 249.

CAPOTE, R.; LOPEZ, E.; MAINEGRA, E. WinQXAS Manual (Quantitative X'Ray Analysis System for Windows) Version 1.2. Austria: IAEA, 2000.

CARDIM, Fernão. Tratados da terra e gente do Brasil. Belo Horizonte: Itatiaia; São Paulo: Edusp, 1980. p. 173 apud VILARDAGA, Jose Carlos. São Paulo na órbita do Império dos Felipes: conexões castelhanas de uma vila da América Portuguesa durante a União Ibérica (1580-1640). 2010. Tese (Doutorado em História Social) - Faculdade de Filosofia, Letras e Ciências Humanas, Universidade de São Paulo, São Paulo, 2011.

CARVALHO, Francismar Alex Lopes de. Viajantes, mareantes e fronteiriços: relações interculturais no movimento das monções - séculos XVIII. Mestrado em História - Universidade Estadual de Maringá, Paraná, 2006.

CARVALHO, Mônica Muniz Pinto de. A cidade de São Paulo no século XVIII. Uma sociabilidade constituída em torno de símbolos do poder. São Paulo, dissertação de mestrado - FFLCH-USP, 1994.

CARVALHO, Paula Carolina de Andrade. O Museu Sertório: uma coleção particular em São Paulo no final do século XIX (primeiro acervo do Museu Paulista). An. mus. paul., São Paulo, v. 22, n. 2, p. 105-152, Dec. 2014

CARVALHO, Vânia Carneiro. Gênero e artefato: o sistema doméstico na perspectiva da cultura material: São Paulo, 1870-1920. EdUSP, 2008.

CASCUDO, Câmara. Mouros, franceses e judeus: três presenças no Brasil. Editora Perspectiva, 1984. P. 25-28.

CASTELLANO, Alfredo; MARTINI, Marco; SIBILIA, Emanuela. Elementi di archeometria. Metodi fisici per i beni culturali. Milão: EGEA. 2007

CAVENAGHI, Airton José. O território paulista na iconografia oitocentista: mapas, desenhos e fotografias. análise de uma herança cotidiana. An. mus. paul., São Paulo, v. 14, n. 1, p. 195-241, Junho 2006;

CIANCIARULO, Adriana Quilici Barreto. Materiais usados como pigmento no período colonial brasileiro. Tese de Mestrado em História da Ciência - PUC-SP. 2014

CONSTITUIÇÕES Primeiras do Arcebispado da Bahia. 1707. São Paulo: Tipografia 2 de Dezembro, 1853, p. 265 ss. 
COSTA, Lúcio. Notas sobre a evolução do mobiliário luso-brasileiro. Revista do SPHAN.n‥3 1939.

CRUZ, Ana L. R. B. As viagens são os viajantes: dimensões indentitárias dos viajantes naturalistas brasileiros do século XVIII.. História. Questões e Debates, Curitiba, v. 19, n.36, p. 61-98, 2003.

CRUZ, João António. A proveniência dos pigmentos utilizados em pintura em Portugal antes da invenção dos tubos de tintas: problemas e perspectivas. SERRÃO, Vítor et al., As Preparações na Pintura Portuguesa. Séculos XV e XVI. Lisboa: Faculdade de Letras da Universidade de Lisboa, 2013. pp.297-306

CSIKSZENTMIHALYI, Mihaly, Why we need things, in LUBAR, S. and KINGERY W. (eds). History from Things, Washington: Smithsonian Institution Press, 1993, pp. 20-9.

CUNHA JUNIOR, Henrique Antunes. Arte e tecnologia africana no tempo do escravismo criminoso. Revista Espaço Acadêmico - Uem. v. 14, n. 166, 2015.

DE CERTEAU, M. A invenção do cotidiano: 1. artes de fazer. Petrópolis: Vozes, 2001

DEAN, Warren. A ferro e fogo: a História e a devastação da Mata Atlântica brasileira. São Paulo: Cia das Letras, 1997, p. 180.

DEBRET, Jean Baptiste. Voyage pittoresque et historique au Brésil. Paris: Firmin Didot Frères, $1835 . \quad$ Disponível em: http://www.brasiliana.usp.br/bbd/handle/1918/624520069.

DEJEAN, Joan. O século do conforto. Rio de Janeiro: Civilização Brasileira, 2012;

DIAS, Maria Odila Leite da Silva. Hermenêutica do Quotidiano na Historiografia Contemporânea. Projeto História: Trabalhos da Memória. São Paulo: Educ, n. 17, nov. 1998.

DORTIER, J. Dicionário de Ciências Humanas. São Paulo: Martins Fontes. 2011

DOUCLEFF, Michaeleen. Lost Posture: Why some indigenous cultures may not have back pain. 2015. http://wshu.org/post/lost-posture-why-indigenouscultures-dont-have-back-pain\#stream/0. Acesso em: 20/05/2018.

DOUGLAS, Mary, ISHERWOOD, Baron. $\mathbf{O}$ mundo dos bens: para uma antropologia do consumo. Rio de Janeiro: Editora UFRJ, 2004.

ELIAS, Norbert, O Processo Civilizador. 2 vol. Rio de Janeiro: Jorge Zahar Editor. 1994.

ELLIS Jr., Alfredo; ELLIS, Myriam. A economia paulista no século XVIII. São Paulo: Boletim da Civilização Brasileira, n.11, 1950.

ESTADO DE MINAS. Restauradores descobrem ferramentas do século 18 em igreja de Congonhas. 27/12/2016. Disponível em: https://www.em.com.br/app/noticia/gerais/2016/12/27/interna gerais,835414/ restauradores-descobrem-ferramentas-do-seculo-18-em-igreja-decongonha.shtml. Acesso em: 20/5/2018.

FACTUM, Ana Beatriz Simon. Joalheria escrava baiana: a construção histórica do design de jóias brasileiro. 2009. Tese (Doutorado em Design e Arquitetura) Faculdade de Arquitetura e Urbanismo, Universidade de São Paulo, São Paulo, 2009. P. 87. 
FARSHAM, William. Woodwork joints; how they are set out, how made and where used; with four hundred and thirty illustrations and a complete index of eleven hundred references. Philadelphia and London: J. B. Lippincott company, 1921. Disponível em https://archive.org/details/woodworkjointsho00fair. Acessado em 03 out. 2016.

FELLET, J. Antes dos portugueses, SP teve floresta tropical, Cerrado e miniPantanal. BBC Brasil, Brasilia, 24 de fevereiro de 2018. Disponível em: http://www.bbc.com/portuguese/geral-43148025. Acessado em: 24 de fevereiro de 2018.

FERNANDES, Antônia Terra de Calazans. Memórias de ofício. Tese de doutorado em História Social, Faculdade de Filosofia, Letras e Ciências Humanas, Universidade de São Paulo, São Paulo, 1997.

FICHER, Sylvia ; MACEDO, D. M. . Três vinholas no Brasil do século 19. In: 4 Projetar, 2009, São Paulo. Projeto como investigação: antologia. São Paulo: Alter Market, 2009. v. 1. p. 1-20.

FILHO, Alexandre Melo Morais, Festas e tradições populares do Brasil, Rio de Janeiro, Secretaria Municipal de Cultura, DGDI, 1994, p. 296. Apud TRINDADE, Pedro Moraes. Do lado de cá da Kalunga: Os africanos Angolas em Salvador - 1800-1864. Salvador: Dissertação de Mestrado UFBA, 2008, p. 58.

FLEMING, E. McClung. Artifact Study: A proposed Model. Chicago: University of Chicago Press Winterthur Portfolio, Vol. 9, 1974

FLEXOR, Maria Helena Ochi. O Trabalho Livre em São Paulo - Século XVIII. Tese de Doutorado - São Paulo: FFLCH/USP, 1984.

FLEXOR, Maria Helena Ochi. Mobiliário baiano. Brasília, DF: Iphan / Programa Monumenta, 2009.

FLEXOR, Maria Helena Ochi. Ofícios, Manufaturas e Comércio. In Szmrecsányi, Tamás. História Econômica do Período Colonial. 1993. pp. 175

FLEXOR, Maria Helena Ochi. Os núcleos urbanos planejados do século XVIII : Porto Seguro e São Paulo. Bahia: Salvador Universidade Federal da Bahia, Centro de Estudos Baianos, 1989.

FORTY, Adrian. Objetos de desejo. Design e sociedade desde 1750. São Paulo: Cosac \& Naif, 2007.

FRANÇA, Jean Marcel Carvalho. Outras Visões do Rio de Janeiro Colonial. Antologia de Textos (1582-1808). Rio de Janeiro: José Olympio Editora, 2000, p.

FRANCO, Carlos. O mobiliário das elites de Lisboa na segunda metade do século XVIII. Lisboa: Livros Horizonte, 2007, p. 77.

FREIRE, Fernanda Castro. Mobiliário, vol. 1. Lisboa: Fundação Ricardo do Espírito Santo Silva, 1994.

FREYRE, Gilberto. Casa-Grande \& Senzala. São Paulo: Global, 2006.

GINZBURG, Carlo. Olhos de madeira: nove reflexões sobre a distância. São Paulo: Companhia das Letras, 2001.

GINZBURG, Carlo. Mitos, emblemas, sinais: morfologia e história. $2^{a}$ ed., São Paulo: Companhia das Letras, 2012, p. 178. 
GOELDI, Emílio A.. Sobre o uso dos machados de pedra de índios sul-americanos, especialmente amazônicos, atualmente existentes. Boletim do Museu Paraense Emílio Goeldi. Ciênc. Humanas., Belém , v. 4, n. 1, p. 131133, Apr. 2009. (original: 1906)

GONÇALVES, José Reginaldo Santos. "Teorias antropológicas e objetos materiais". Antropologia dos Objetos: coleções, museus e patrimônios. Rio de Janeiro: IPHAN / DEMU, Col. Museu, Memória e Cidadania. 2007, P. 20.

GOODMAN, Dena; NORBERG, Kathryn. Furnishing the Eighteenth Century: What Furniture Can Tell Us about the European and American Past. New York and London: Routledge Taylor \& Francis Group, 2007 pp. 155-65.

GOULÃO, Maria José. "La Puerta Falsa de América". A influência artística Portuguesa na região na Região do Rio da Prata no período colonial. 1 vol. Tese de Doutoramento na Faculdade de Letras da Universidade de Coimbra, 2005.

GOULÃO, Maria José. A encomenda a entalhadores portugueses nas missões franciscanas do Paraguai no século XVIII. FERREIRA-ALVES, Natália. (coord.). A Encomenda. O Artista. A Obra. CEPESE: 2010, p. 435.

GUEDES, Roberto. Ofício mecânicos e mobilidade social: Rio de Janeiro e São Paulo (sécs. XVII-XIX). Topoi, v. 7, n. 13, jul.-dez. 2006, pp. 379-423.

GUERRA, José Wilton e SIMÕES, Renata (orgs.). Equipamentos - Equipamentos, Usos e Costumes da Casa Brasileira, Marlene Milan Acayaba (organizadora da coleção). Vol. 5, São Paulo, MCB, EDUSP, 2001.

GUILHOTTI, Ana Cristina. A postura do olhar: coisas que guardamos na memória...In: OLIVEIRA, Cecília Helena Salles de. Museu Paulista: novas leituras. São Paulo: Museu Paulista, 1995

HAMEISTER, Martha Daisson. O Continente do Rio Grande de São Pedro: os homens, suas redes de relações e suas mercadorias semoventes (c.1727c.1763). Dissertação (Mestrado em História) - Universidade Federal do Rio de Janeiro, Rio de Janeiro, 2002.

HELLMAN, Mimi. "Furniture, sociability, and the work of leisure in eighteenth-century France." Eighteenth-Century Studies n. 32. V.4. 1999.

HELLMAN, Mimi. Introduction In: KODA, Harold; BOLTON, Andrew (eds.).Dangerous Liaisons: Fashion and Furniture in the Eighteenth Century. New Haven: Yale Univ. Press, 2005.

HENRIQUES, João Maria, A "caixa de Açúcar", in Das Artes e da História da Madeira, 1950, vol. I, no.4, pp.28-29.

HEWES, Gordon. World distribution of certain Postural Habits. American Anthropologist, 1955. p. 231 ss.

HODGKINSON, Ralph, Tools of the woodworker. S.I.: American Association for State and Local history. Technical Leaflet, $\mathrm{n}-119.1979$.

HOLANDA, S. B. de. Raízes do Brasil. São Paulo: Cia das Letras, 2009.

HOLANDA, Sérgio Buarque de (org.). História Geral da Civilização Brasileira: O Brasil monárquico - O Processo de Emancipação. 1.ed. São Paulo: Difel, 1962. t.II, v1.,

HOLANDA, Sérgio Buarque de. Monções e Capítulos da expansão paulista. Organização de Laura de Mello e Souza e André Sekkel de Cerqueira. Notas de André Sekkel de Cerqueira. São Paulo: Companhia das Letras, 2014. 
HOLANDA, Sérgio Buarque de. Movimentos da população em São Paulo no século XVIII. Revista do Instituto de Estudos Brasileiros. v. I, 55-111, 1966.

IHERING, Herman von. Os machados de pedra dos índios do Brasil e o seu emprego nas derrubadas de mato. Revista do Instituto Histórico e Geográfico de São Paulo, São Paulo, v.12, 1907.

INGOLD, Tim. Trazendo as coisas de volta à vida: emaranhados criativos num mundo de materiais. Horiz. antropol., Porto Alegre , v. 18, n. 37, p. 2544, June 2012.

JOYCE, Ernest; PETERS, Alan. Encyclopedia of Furniture Making. Ed.1. Nova York: Sterling Publishing Company, Inc., 2000. P. 208.

KATINSKY, Julio Roberto. "O ofício da carpintaria no Brasil: justificação para uma investigação sistemática." Revista de História 34.70 (1967).

KOK, Glória. A presença indígena nas capelas da capitania de São Vicente (século XVII). Espaço Ameríndio, v. 5, n. 2, p. 45, 2011.

KOSMINSKY, Doris Clara. $O$ olhar inocente é cego: a construção da cultura visual moderna. 2008. Tese (Doutorado)-Pontifícia Universidade Católica do Rio de Janeiro, Departamento de artes \& design, 2008.

KUZNESOF, Elizabeth Anne. Household economy and urban development: São Paulo: 1765 to 1836. Berkeley, University of California, 1976.

LANDGRAF, Fernando et al. Notas sobre a história da metalurgia no Brasil (15001850). In: MOTOYAMA, Shozo; (org.). Preludio para uma historia: ciência e tecnologia no Brasil. São Paulo: Edusp, 2004.

LEITE, José Roberto Teixeira. As raízes na África Negra da siderurgia brasileira. Arte, adorno, design e tecnologia no tempo da escravidão. (Catálogo de exposição) curador Emanoel Araújo. São Paulo: Museu Afro Brasil, 2013.

LEITE, Serafim. Artes e ofícios dos Jesuítas no Brasil, 1549-1760. Lisboa: Edições Brotéria, 1953.

LEMOS, C. A. C. . Notas sobre a cultura material e o cotidiano em São Paulo dos tempos coloniais. In: Paula Porta. (Org.). Historia da Cidade de São Paulo. 1ed.São Paulo: Paz e Terra, 2004, v. 1, p. 179-189.

LISBOA, M. G. P. ; GONÇALVES, C. A. O. . O adorno como objeto simbólico de um habitus de classe. In: INTERCOM, 2011, Recife-PE. INTERCOM NACIONAL 2011, 2011.

LORIGA, Sabina. O pequeno "x" da História: da biografia à História. Belo Horizonte: Autêntica, 2011

LUNA, Francisco Vidal, e KLEIN, Herbert. Evolução da sociedade e economia escravista de São Paulo, de 1750 a 1850. São Paulo: Edusp, 2006

LYONS, Richard. Restoring Antique Furniture. A Complete Guide. Mineola, New York: Dover Publications, Inc. 1990.

MACHADO, Alcântara. Vida e morte do bandeirante. Belo Horizonte: Itatiaia; São Paulo: Edusp, 1980.

MADUREIRA, Nuno Luis. Cidade: Espaço e Quotidiano. Lisboa 1740-1830. Lisboa: Livros Horizonte, 1992;

MADUREIRA, Nuno Luís. Lisboa: Luxo e distinção: 1750-1830. Lisboa: Editorial Fragmentos, 1990. 
MANZANO, Juan Francisco. A autobiografia do poeta-escravo.Organização e tradução de Alex Castro. São Paulo: Hedra, 2015.

MARANHO, Milena Fernandes. A opulência relativizada: significados econômicos e sociais dos níveis de vida dos habitantes da região do Planalto de Piratininga, 1648-1682. Campinas, UNICAMP, 1999 (dissertação de mestrado).

MARCHIORI, J. N. C.; SCHULZE-HOFER, M. C. O uso da madeira nas reduções jesuítico-guarani do Rio Grande. IPHAN, 2008.

MARCílIO, Maria Luiza. A cidade de São Paulo. Povoamento e população. 1750-1850. São Paulo: Pioneira/Edusp, 1974.

MARCÍLIO, Maria Luiza. Crescimento demográfico e evolução agrária paulista 1700-1836. São Paulo: Hucitec/Edusp, 2000.

MARCONDES, Renato Leite. Formação da rede regional de abastecimento do Rio de Janeiro: a presença dos negociantes de gado (1801-1811). Topoi, Rio de Janeiro, mar. 2001, pp. 41-71.

MARINS, Paulo Cesar Garcez. Através da rótula: sociedade e arquitetura urbana no Brasil, sécs. XVII-XX. Tese de Doutorado. São Paulo, Dpto. De História da FFLCH-USP, 1999.

MARINS, Paulo Cesar Garcez. Vida cotidiana entre os paulistas: moradias, alimentação, indumentária. In: SETUBAL, Maria Alice (org.). Terra paulista: histórias, arte, costumes. São Paulo: C. Imesp, 2004.

MARTINEZ, Juan Manuel. EI Mueble. Un espacio para habitar. Museu Histórico Nacional del Chile, 2012.

MARTINEZ, Paulo Henrique (org.). História ambiental paulista: temas, fontes e métodos, vol. 1. São Paulo: Senac, 2007, p. 51-69.

MARTINS, Eline Matos. Conservação de Ocotea catharinensis, 0 . odorifera e 0 . porosa: espécies de Lauraceae ameaçadas de extinção. (tese). Rio de Janeiro, RJ: Escola Nacional de Botânica Tropical, 2013.

MARTINS, Monica de Souza. Entre a cruz e o capital: as corporações de ofícios no Rio de Janeiro após a chegada da família real (1808-1824). Rio de Janeiro: Garamond, Prefeitura do Rio de Janeiro, 2009.

MARTINS, Renata Maria de Almeida. Tintas da terra tintas do reino: arquitetura e arte nas Missões Jesuíticas do Grão-Pará (1653-1759). 2009. Tese (Doutorado em História e Fundamentos da Arquitetura e do Urbanismo) Faculdade de Arquitetura e Urbanismo, Universidade de São Paulo, São Paulo, 2009.

MATUCK, Rubens. Instrumentos Manuais de Carpintaria e Marcenaria (catálogo de exposição). São Paulo: Prefeitura do Município de São Paulo: Secretaria Municipal de Cultura. 1982

MAUSS, Marcel. Sociologia e Antropologia. São Paulo: Cosac \& Naify. 2003.

MAYER, Ralph. NAZARETH, Christine (trad). Manual do artista: de técnicas e materiais. São Paulo: Martins Fontes, 2 ed., 1999. P. 42.

MAYUMI, Lia. Taipa, canela-preta e concreto. São Paulo: Romano Guerra Editora, 2008.

MCCRACKEN, Grant. Cultura e consumo. Rio de Janeiro: Mauad, 2003. 
MCKENDRICK, Neil. "The Consumer Revolution of Eighteenth-Century England." In MCKENDRICK Neil, BREWER John e PLUMB J. H. (eds.), The Birth of a Consumer Society: The Commercialization of Eighteenth Century England. Bloomington: Indiana University Press, 1982. P. 9-33.

MCNEIL, Ian (Ed.). An encyclopedia of the history of technology. Routledge, 2002.

MENESES, José Newton Coelho. Artes fabris \& ofícios banais: o controle dos ofícios mecânicos pelas câmaras de Lisboa e das vilas de Minas Gerais (1750-1808). Belo Horizonte: Fino Traço, 2013.

MENESES, José Newton Coelho. O Continente Rústico. Abastecimento alimentar nas Minas Gerais setecentistas. Diamantina: Maria Fumaça, 2000.

MENESES, Ulpiano Bezerra de. Do teatro da memória ao laboratório da História: a exposição museológica e o conhecimento histórico. Anais do Museu Paulista, n.1 vo. 2. 1994 , p. 17.

MENESES, Ulpiano Bezerra de. Fontes Visuais, Cultura Visual, História Visual. Balanço provisório, propostas cautelares. Revista Brasileira de História. V. 23. N. 45, p. 11-36. 2003, p. 29.

MENESES, Ulpiano Bezerra de. O Objeto Material Como Documento reprodução de aula ministrada no curso Patrimônio cultural: políticas e perspectivas. IAB/CONDEPHAAT, 1980

MENESES, Ulpiano Toledo Bezerra de. A cultura material no estudo das sociedades antigas. Revista de História, n. 115, São Paulo, 1983, p.103-117.

MÉTRAUX, Alfred. A civilização material tupi-guarani. 1928. Campo Grande: Ed.Alvorada. 2012.

MEUVRET, Jean. FRÉGNAC, Claude. Les Ébénistes due XVIIlâ siecle francais. Paris, Hachette, Collection Connaissance des arts. "Grands artisans d'autrefois". 1963;

MIRANDA, Maria José de Andrade Casimiro; PIGOZZO, Raphael Jaquier Bossler. Most common timbers in Brazilian wood historical artefacts. Pro Ligno, v. 9, n. 4, p. 312-318, dez., 2013.

MONTEIRO, John Manuel. Negros da terra. Bandeirantes e índios nas origens de São Paulo. São Paulo: Companhia das Letras, 1994.

MONTEIRO, John Manuel. Negros da terra. Bandeirantes e índios nas origens de São Paulo. São Paulo: Companhia das Letras, 1994.

MORESI, Claudina M. D. "Materiais usados na decoração de esculturas em madeira policromada no período colonial em Minas Gerais." Revista Imagem Brasileira, 1 de 2007: 79-82.

MOURA, Clóvis. Dicionário da escravidão negra no Brasil, São Paulo, SP, Brasil: Edusp, 2004.

MOUTINHO, Stella Rodrigo Octavio; PRADO, Rúbia Braz Bueno do.; LONDRES, Ruth Rodrigo Octavio. Dicionário de artes decorativas e decoração de interiores. Rio de Janeiro: Lexikon. 2011

MUSEU PAULISTA. Collectanea de Mappas da Cartographia Paulista Antiga. (Cartas de 1612 a 1837, acompanhadas de breves comentários por Affonso D'EscragnolleTaunay). São Paulo: Cia Melhoramentos de São Paulo, 1922. 
NAZZARI, Muriel. Oliveira, Lólio Lourenço de (trad). O desaparecimento do dote: mulheres, famílias e mudança social em São Paulo, Brasil, 1600-1900. São Paulo: Companhia das Letras, 2001, p. 119.

NORMAN, Don. The design of everyday things: Revised and expanded edition. Nova York: Basic Books, 2013. P. 46.

OLIVAL, Fernanda. Os lugares e espaços do privado nos grupos populares e intermédios. In: MONTEIRO, Nuno Gonçalo. História da vida privada em Portugal, vol. 2. Lisboa: Círculo de Leitores, 2011.

OLIVEIRA, C. H. L. S. . Ferramentas: dimensões históricas e sociais. In: ABREU, Adilson Avansi de. (Org.). Quantos anos faz o Brasil?. 1a.ed.São Paulo: Editora do Universidade de São Paulo, 2000, v. , p. 18-19

OLIVEIRA, Maria Luiza Ferreira de. Entre a casa e o armazém: relações sociais e experiência da urbanização, São Paulo, 1850-1900. São Paulo: Alameda, 2005. P. 95.

OLIVEIRA, Raquel Salomé Sousa. A síntese mediterrânea na construção da identidade cultural. Tese de Mestrado - Feup-Faculdade de Engenheira da Universidade do Porto, 2003.

ORTMANN, Adalberto. História da antiga capela da Orde Terceira da Penitenciária de São Francisco em São Paulo. Rio de Janeiro: Ministério da Educção e Saúde/DPHAN, 1951

OSORIO, Helen. O Império Português no Sul da América: estancieiros, lavradores e comerciantes. Porto Alegre: Editora da UFRGS, 2007;

PAIXÃO, Giselle Marques Leite. Sistema descritivo para acervos de mobiliário, contendo 923 vocábulos e 638 ilustrações. BARBUY, Heloisa (org.). Instrumento para catalogação produzido para o Serviço de Objetos do Museu Paulista-USP. São Paulo: MP-USP, 1999.

PEREIRA, Andréa Franco. Madeiras brasileiras. Guia de combinação e substituição. São Paulo: Blucher, 2013. P. 103.

PEREIRA, Benjamim. Tecnologia Tradicional Portuguesa: Sistemas de serração de madeiras. Etnologia - 5. Instituto Nacional de Investigação Científica. Centro de estudos de Etnologia. 1990.

PEREIRA, Danielle Manoel dos Santos. A pintura ilusionista no Meio Norte de Minas Gerais -Diamantina e Serro - e em São Paulo - Mogi das Cruzes (Brasil); 2012; Dissertação (Mestrado em Mestrado em Artes Visuais) - Instituto de Artes da UNESP. 2012.

PEREIRA, Danielle Manoel dos Santos. Autoria da Pinturas llusionistas do Estado de São Paulo: São Paulo, Itu e Mogi das Cruzes (Brasil). 2017. Tese (Doutorado em ARTES) - UNESP. 2017.

PEREIRA, Franklin. O couro lavrado no mobiliário artístico de Portugal. Lisboa: Lello Editores. 2000, P. 164ss.

PESAVENTO, Fábio. Novas perspectivas sobre o comércio de anil no Rio de Janeiro colonial: 1749-1820. Revista de História Econômica e de Economia Regional Aplicada, v. 1, n. 1, p. 1-19, 2006. 
PINTO, Augusto Cardoso. NASCIMENTO, J. F. da Silva (org). Cadeiras portuguesas. Lisboa, [Edição dos Autores], 1952. P. 106.,

PINTO, Maria Helena Mendes. "Sentando-se em Goa", Lisboa: Oceanos, no 19/20, 1994.

PINTO, Maria Helena Mendes. Os Móveis e o seu Tempo: Mobiliário Português do Museu Nacional de Arte Antiga, Séculos XV-XIX. Lisboa: Instituto Português do Patrimônio Cultural, 1987.

PINTO, Pedro da Costa. O móvel de assento português do século XVIII. Lisboa: Media-texto, 2005.

POINTON, Marcia. History of Art: A Student's Handbook. 4 ed. London: Routledge, 1994.

POLLETI, Daniel Nogueira. Relatório de Iniciação Científica - Fapesp, 2011.

POMIAN, Krzysztof. "Coleção". In: Enciclopédia Einaud. I. Memória - História. Porto: Imprensa Nacional. Casa da Moeda, 1984, p.51-86

POMIAN, Krzysztof. "Coleções" In: Enciclopédia Einaudi, vol.1. Memória/História. Porto: Imprensa Nacional/Casa da Moeda: 51-86, 1984.

POULIOT, Bruno P., MASS, Jennifer, KAPLAN, Lara. Using XRF for the identification of Chrome tanning in leather. American Institute for Conservation $\mathbf{4 3} 3^{\text {rd }}$ Annual Meeting. 2015. Disponível em: <http://www.conservationus.org/docs/default-source/annualmeeting/2015am poster 92.pdf?sfvrsn=2> Acessado em: 03 Out. 2016

PREZIA, Benedito Antônio Genofre. Os Tupi de Piratininga: acolhida, resistência e colaboração. 2008. 407 f. Tese (Doutorado em Ciências Sociais) - Pontifícia Universidade Católica de São Paulo, São Paulo, 2008.

PUPO, Celso Maria de Mello. As cadeiras do ouvidor. Revista do Instituto Histórico e Geográfico de São Paulo, v. 78, 1982, pp. 121-158.

QUEIRÓZ, Suely Robles Reis de. Escravidão negra em São Paulo: um estudo de Tensões provocadas pelo Escravismo no Século XIX. Rio de Janeiro: Instituto Nacional do Livro/Jose Olympio. 1977, p. xiii. Documentos Brasileiros, 176.

RABELLO, Elizabeth Darwiche. Os ofícios mecânicos e artesanais em São Paulo na segunda metade do século XVIII. Revista de História, n. 112, 1977, p. 575588.

RAMINELLI, Ronald. Ciência e colonização: viagem filosófica de Alexandre Rodrigues Ferreira. Revista Tempo, v. 6, p. 157-182, 1998.

RAMOS, Francisco Régis Lopes. A insustentável leveza do tempo: os objetos da sociedade de consumo em aulas de história. Educ. rev., Belo Horizonte, n. 47, p. 179-196, June 2008

REDE, M. História a partir das coisas: tendências recentes nos estudos de cultura material. Anais do Museu Paulista. v. 4, p. 165-82, jan./dez. 1996.

REIS Filho, Nestor Goulart. O caminho do Anhanguera. São Paulo: Via das Artes, 2014, pp. 30-1. 
REIS, Lysie. "Os Homens Rudes e muito Honrados Mesteres", Revista da Faculdade de Letras: Ciências e Técnicas do Património, vol IV, Porto, (2005). 235-259.

REIS. Lysie. A liberdade que veio do ofício: práticas sociais e cultura dos artífices na Bahia do século XIX. Salvador: EDUFBA. 2012, p. 172

RIBA, M. T. L.; MIRÓ, E. P. O couro: as técnicas para criar objectos de couro explicadas com rigor e clareza. Lisboa: Editorial Estampa, 2007.

RICE, Charles, The Emergence of the Interior: Architecture, Modernity, Domesticity. Oxford: Routledge, 2007.

ROCHE, Daniel. História das coisas banais: nascimento do consumo nas sociedades tradicionais (XVII-XIX). Rio de janeiro: Rocco, 2000

RODRIGUES, José Wasth. Descrições de mobiliário. São Paulo: Museu Paulista, 1948. Datilografado e rubricado.

RODRIGUES, José Wasth. Mobiliário. As Artes plásticas no Brasil. Coleção brasileira de ouro. Rio de Janeiro: Ed. de Ouro, 1968. P.92.

SÁ, José António de, Compendio de Observações que foram o plano da Viagem Politica, e Filosófica, que se deve fazer dentro da Pátria, Lisboa, Officina de Francisco Borges de Sousa, 1783, p. 47 Apud RAMINELLI, Ronald. Ciência e colonização: viagem filosófica de Alexandre Rodrigues Ferreira. Revista Tempo, v. 6, p. 157-182, 1998.

SAINT-HILAIRE, Auguste de. Viagem ao Rio Grande do Sul (1820-1821). São Paulo, Belo Horizonte: Edusp/ Itatiaia Editora, 1974.

SAINT-HILAIRE, Auguste de. Viagem pelo Distrito dos Diamantes e Litoral do Brasil (1817-1818). São Paulo, Belo Horizonte, EDUSP/ Itatiaia Editora, 1974. p. 160

SAINT-HILAIRE. Auguste de. Viagem à Província de São Paulo e resumos das viagens ao Brasil, província Cisplatina e Missões do Paraguay. Tradução e notas de Rubens Borba de Morais. São Paulo: Martins Editora/EDUSP, 1972. p. 180ss.

SANDÃO, Arthur de. 0 móvel Pintado Português. Barcelos: Companhia Editora do Minho, 1966.

SANT'ANNA, Nuto. Chapéus desabados. São Paulo histórico: Aspectos, Lendas, Costumes. Volume VI. São Paulo: Dpto. de cultura. 1944. p. 193,.

SANT'ANNA, Nuto. Metrópole (Histórias da cidade de São Paulo de Piratininga e São Bernardo do campo em tempos de El-Rei, o Cardeal Dom Henrique, da Dinastia de Avis). São Paulo: Departamento de Cultura, v.1,1953.

SANT'ANNA, Nuto. São Paulo Histórico. Vol. VI. São Paulo: Dpto. De Cultura de S. Paulo. 1944. P. 30.

SANTI, Maria Angélica. Mobiliário no Brasil: origens da produção e da industrialização. São Paulo: SENAC, 2013. P. 99

SANTOS, Amália Cristóvão dos. Em obras: os trabalhadores da cidade de São Paulo entre 1775 e 1809. 2013. Dissertação (Mestrado em História e Fundamentos da Arquitetura e do Urbanismo) - Faculdade de Arquitetura e Urbanismo, Universidade de São Paulo, São Paulo, 2013. 
SANTOS, Noronha. Um litígio entre marceneiros e entalhadores no Rio de Janeiro. Revista do Sphan, no 06, 1942, p. 295-317.

SARMENTO, Therezinha de Moraes. Um preguiceiro no Museu Histórico Nacional. Anais do Museu Histórico Nacional, vol. XXI. Rio de Janeiro, MEC, pp.4352. 1969 , p. 47.

SARTI, Rafaella. Casa e Família. Habitar, Comer e Vestir na Europa Moderna. Lisboa: Estampa, 2001.

SCARATO, Luciane Cristina. Caminhos e descaminhos do ouro nas Minas Gerais: administração, territorialidade e cotidiano (1733 - 1783). Dissertação de mestrado. Universidade Estadual de Campinas. Campinas/ SP. 2009.

SCHOPENHAUER, Arthur. Sobre a filosofia e seu método. São Paulo: Hedra, 2010.

SCHUNK, R. Arte Colonial e Imperial da cidade de Santana de Parnaíba. 1. ed. Osasco: MB Gráfica, 2015.

SENNETT, Richard. 0 artífice. Rio de Janeiro: Record, 2012

SODRE, Nelson Werneck. Formação Histórica do Brasil. São Paulo: Brasiliense. 1962. p. 119.

SOUZA, Laura de Mello; Formas provisórias de existência: a vida cotidiana nos caminhos, nas fronteiras e nas fortificações. In: SOUZA, Laura de Mello (Org.). História da vida privada no Brasil: cotidiano e vida privada na América portuguesa, 1. São Paulo: Companhia das Letras, 1997, p 41ss.

SPIX, Johann Baptiste von \& MARTIUS, Carl Friedrich Philippe von. Travels in Brazil (1818-1820), vol. II. Londres: Longman, 1824.

STOBART, Jon. Selling (through) politeness: advertising provincial shops in eighteenth-century England. Cultural and Social History, v. 5, n. 3, p. 309328, 2008.

STYLES, J., \& VICKERY, A. Gender, taste, and material culture in Britain and North America, 1700-1830. New Haven. Yale Univ. Press. 2006.

SUANO, Marlene. Alfaias, apetrechos, tarecos, trecos: os móveis. In: MENESES, Ulpiano T. Bezerra de (org.). Como explorar um museu histórico. São Paulo: Museu Paulista/USP, 1992, p.16.

SYLOS, Honório de. São Paulo e seus caminhos. Editora McGraw-Hill do Brasil, 1976.

TAUNAY, Affonso de E. História da cidade de São Paulo no século XVIII (17111720). São Paulo: Imprensa Oficial do Estado, 1931, t.1.

TAUNAY, Affonso de E. História da cidade de São Paulo no século XVIII (17351765). São Paulo: Imprensa Oficial do Estado. Parte 2, vol.1, capítulo XI. 1931.

TAUNAY, Affonso de E. São Paulo nos primeiros anos (1554-1601): Ensaio de reconstituição social. Tours: Imprenta de Arrault et cia. 1920., p. 66.;

TAUNAY, Afonso. Guia da Secção Histórica do Museu Paulista. São Paulo: Imprensa oficial do estado. 1937

THOMAS, Keith. 0 Homem e o Mundo Natural: mudanças de atitude em relação às plantas e aos animais (1500-1800). São Paulo: Companhia das Letras, 1988. 
THOMPSON, E. P. Costumes em comum. São Paulo: Companhia das Letras, 1998.

TORRÃO FILHO, Amílcar. Paradigma do caos ou cidade da conversão? São Paulo na administração do Morgado de Mateus. São Paulo: Annablume, 2010.

TRINDADE, Jaelson Bitran. O fantasma de Debret. Revista de História. Rio de Janeiro: Biblioteca Nacional, 7 jan. 2008.

VASCONCELLOS, Ignacio da Piedade. Artefactos symmetriacos, e geometricos: advertidos, e descobertos pela industriosa perfeicão das artes, esculturaria, architectonica, e da pintura. Lisboa: 1733.

VEYNE, Paul. O inventário das diferenças. História e Sociologia. Brasília: Editora Brasiliense, 1983.

VILARDAGA, José Carlos. Imagens em trânsito: as virgens de Luján e Sumampa e os circuitos coloniais na América Meridional na primeira metade do século XVII. Anais do Museu Paulista: História e Cultura Material, v. 23, n. 2, p. 43-67, 2015.

VILARDAGA, José Carlos. Na bagagem dos peruleros: mercadoria de contrabando e o caminho proibido de São Paulo ao Paraguai na primeira metade do século XVII. An. mus. paul., São Paulo , v. 25, n. 1, p. 127147, Abr. 2017

VILARDAGA, Jose Carlos. São Paulo na órbita do Império dos Felipes: conexões castelhanas de uma vila da América Portuguesa durante a União Ibérica (1580-1640). FFLCH/USP - Tese de Doutorado. 2010.

WARNIER, Jean-Pierre. Construire la culture matérielle.L'homme qui pensait avec ses doigts. Paris: Presses Universitaires de France, 1999, p. 21-35

WARNIER, Jean-Pierre. Retorno a Mauss (tradução de Christian Pierre Kasper). In: WARNIER, Jean-Pierre. Construire la culture matérielle.L'homme qui pensait avec ses doigts. Paris: Presses Universitaires de France, 1999, p. 21-35.

Disponível

em:

https://aforcadascoisas.files.wordpress.com/2011/07/warnier-retorno-amauss.pdf. Acesso em: 20/05/2018.

WEATHERILL, Lorna. Consumer behavior and material culture in Britain, 16601760. Londres: Psychology Press, 1988

WELSH, Peter. Woodworking Tools, 1600-1900. Washington: Library of Congress. 2008.

WILLIAMS, Don. "Reading Tool Marks;" The Chronicle (Journal of the Early American Industries Association), Setembro de 2008.

ZANETTINI, P. E. Maloqueiros e seus palácios de barro: o cotidiano doméstico na Casa Bandeirista. 2005. Tese (Doutorado em Arqueologia) - Museu de Arqueologia e Etnologia, Universidade de São Paulo, São Paulo, 2006.

ZEQUINI, Anicleide. Arqueologia de uma fábrica de ferro: morro de Araçoiaba séculos XVI-XVIII. 2006. Tese (Doutorado em Arqueologia) - Museu de Arqueologia e Etnologia, Universidade de São Paulo, São Paulo, 2007. 